\title{
Politie en de nieuwe internationale informatiemarkt : grensregionale politiele gegevensuitwisseling en digitale expertise
}

Citation for published version (APA):

Verbeek, J. P. G. M. (2004). Politie en de nieuwe internationale informatiemarkt : grensregionale politiele gegevensuitwisseling en digitale expertise. [Doctoral Thesis, Maastricht University]. Sdu Uitgevers. https://doi.org/10.26481/dis.20040526jv

Document status and date:

Published: 01/01/2004

DOI:

10.26481/dis.20040526jv

Document Version:

Publisher's PDF, also known as Version of record

Please check the document version of this publication:

- A submitted manuscript is the version of the article upon submission and before peer-review. There can be important differences between the submitted version and the official published version of record.

People interested in the research are advised to contact the author for the final version of the publication, or visit the DOI to the publisher's website.

- The final author version and the galley proof are versions of the publication after peer review.

- The final published version features the final layout of the paper including the volume, issue and page numbers.

Link to publication

\footnotetext{
General rights rights.

- You may freely distribute the URL identifying the publication in the public portal. please follow below link for the End User Agreement:

www.umlib.nl/taverne-license

Take down policy

If you believe that this document breaches copyright please contact us at:

repository@maastrichtuniversity.nl

providing details and we will investigate your claim.
}

Copyright and moral rights for the publications made accessible in the public portal are retained by the authors and/or other copyright owners and it is a condition of accessing publications that users recognise and abide by the legal requirements associated with these

- Users may download and print one copy of any publication from the public portal for the purpose of private study or research.

- You may not further distribute the material or use it for any profit-making activity or commercial gain

If the publication is distributed under the terms of Article 25fa of the Dutch Copyright Act, indicated by the "Taverne" license above, 
Politie en de Nieuwe Internationale Informatiemarkt

Grensregionale politiele gegevensuitwisseling en digitale expertise 
Voor mijn ouders

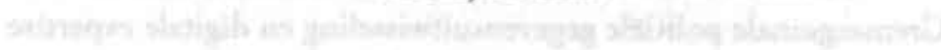




\title{
POLITIE EN DE NIEUWE INTERNATIONALE INFORMATIEMARKT
}

\author{
GRENSREGIONALE POLITIËLE GEGEVENSUITWISSELING \\ EN DIGITALE EXPERTISE
}

\section{PROEFSCHRIFT}

ter verkrijging van de graad van doctor aan de Universiteit Maastricht, op gezag van de Rector Magnificus, Prof. mr. G.P.M.F. Mols, volgens het besluit van het College van Decanen, in het openbaar te verdedigen op woensdag 26 mei 2004 om 16.00 uur

door

Johan Peter Gerard Marie Verbeek 
Promotores: Prof. dr. H.J. van den Herik

Prof. mr. Th. A. de Roos

Beoordelingscommissie:

Prof. mr. M.G. Faure (voorzitter)

Prof. mr. Y. Buruma (Katholieke Universiteit Nijmegen)

Prof. mr. A.H. Klip

Prof. mr. E. Prakken

Prof. mr. A.H.J. Schmidt (Universiteit Leiden)

2004 J.P.G.M. Verbeek

Omslagontwerp: Villa Y, Den Haag

Zetwerk: www.az-gsb.nl

STIS Dissertation Series No. 2004-08

The research reported in this thesis has been carried out under the auspices of SIKS, the Dutch Research School for Information and Knowledge Systems.

Van deze studie is een handelseditie verschenen bij Sdu Uitgevers bv onder ISBN: 9054094249

Niets uit deze uitgave mag worden verveelvoudigd en/of openbaar worden gemaakt door middel van druk, fotokopie, microfilm of op welke andere wijae dan ook zonder voorafgaande schriftelijke toestemming van de auteur. Het gebruik van cijfen en/ of tekst als toelichting of ondersteuning bij artikelen, boeken en scripties is toegestaan, mits de bron duidelijk wordt vermeld.

Copyright reserved. Subject to the exceptions provided for by law, no part of this publication may be reproduced and/or published in print, by photocopying, on microfilm or in any other way without the prior written consent of the copyright owner; the same applies to whole or partial adaptations. The use of figures and/or text for explanation of support by articles, books, and essays is allowed, provided that the source is well mentioned. 


\section{Inhoud}

Voorwoord

Lijst van afkortingen

1 Opzet van het onderzoek

1.1 Aanleiding tot het onderzoek 22

1.2 Historische achtergrond $\quad 24$

$\begin{array}{lll}1.3 & \text { Probleemstelling } & 33\end{array}$

1.3.1 Hoofdvraag 33

$\begin{array}{lll}\text { 1.3.2 Drie aanvullende onderzoeksvragen } & 34\end{array}$

1.4 Afbakening onderzoeksdomein 34

$\begin{array}{lll}1.5 & \text { Plan van aanpak } & 36\end{array}$

2 Grensregionale politiële gegevensuitwisseling in de praktijk $\quad 39$

2.1 Traditionele grensregionale gegevensuitwisseling 40

2.1.1 Informele samenwerking $\quad 41$

2.1.2 De IRC's $\quad 42$

2.1.3 Communicatielijnen $\quad 44$

$\begin{array}{lll}2.1 .4 & \text { Obstakels voor samenwerking } & 47\end{array}$

2.1.5 Communicatiemiddelen $\quad 48$

2.1.6 Vastlegging en afhandeling $\quad 48$

2.1.7 Verschil in organisatie $\quad 49$

2.1.8 Verschil in automatisering 55

$\begin{array}{lll}2.2 & \text { Naar een geautomatiseerde grensregionale communicatie } & 57\end{array}$

$\begin{array}{lll}2.2 .1 & \text { PALMA } & 57\end{array}$

2.2.2 EMMI 57

2.2.3 Verworvenheden van PALMA en EMMI 58

$\begin{array}{ll}\text { 2.2.4 Nieuwe mogelijkheden } & 58\end{array}$ 
3 Het PALMA-concept

3.1 Twee soorten communicatie $\quad 62$

3.2 De PALMA-software $\quad 62$

3.2.1 Het PALMA-Intranet 63

3.2.2 De PALMA-omgeving 63

$\begin{array}{ll}\text { 3.2.3 De informatie-uitwisseling } & 67\end{array}$

3.2.4 Informatie-uitwisseling via de PALMA-software $\quad 69$

3.2.5 Het ontwerp van PALMA 69

3.2.6 De PALMA Protocol Server 71

3.2.7 Het PALMA Protocol 72

3.2.8 De PALMA-formulieren nojuationeran nat 73

3.2.9 Registratic van de gegevensuitwisseling $\quad 74$

3.2.10 Het vertalen van berichten 75

3.2.11 Koppeling van gegevens $\quad 76$

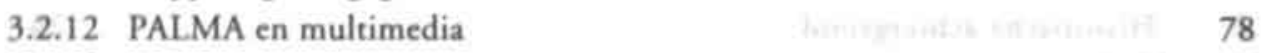

$\begin{array}{lll}3.2 .13 \text { Samenvatting } & 80\end{array}$

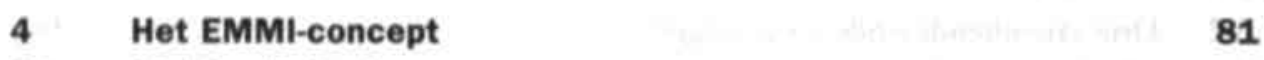

4.1 Multimediakiosk $\quad 82$

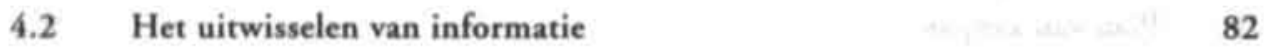

$\begin{array}{lll}4.3 & \text { Het koppelen van databases } & 83\end{array}$

4.4 De toekomst van EMMI $\quad 84$

4.4.1 Integratie met nationale netwerken $\quad 84$

4.4.2 Geautomatiseerde toegang tot nationale netwerken $\quad 85$

$\begin{array}{ll}\text { 4.4.3 Rechtstreekse toegang van de gebruiker } & 85\end{array}$

$\begin{array}{ll}\text { 4.4.4 Het gebruik van protocolgegevens } & 86\end{array}$

$\begin{array}{lll}4.4 .5 & \text { Blauwdruk } & 86\end{array}$

$\begin{array}{lll}\text { 4.4.6 Koppeling nog niet legitiem } & 87\end{array}$

$\begin{array}{ll}\text { 4.4.7 Overige mogelijkheden EMMI } & 87\end{array}$

$\begin{array}{lll}4.5 & \text { Vier niveaus grensoverschrijdende bevraging } & 89\end{array}$

4.6 Actuele stand van zaken EMMI 90

$\begin{array}{ll}\text { 4.6.1 Nieuwe functionaliteiten van PALMA } & 90\end{array}$

$\begin{array}{lll}\text { 4.6.2 EMMII Kiosk } & 91\end{array}$

$5 \quad$ Politiële gegevensuitwisseling volgens het VEU 93

\begin{tabular}{ll}
5.1 & Kader kleine rechtshulp \\
\hline
\end{tabular}

$\begin{array}{ll}5.2 & \text { Kader SUO en VEU }\end{array}$

$\begin{array}{lll}5.2 .1 & \text { Verstrekking op verzoek } & 100\end{array}$

$\begin{array}{lll}5.2 .2 & \text { Verstrekking zonder verzoek } & 103\end{array}$ 
5.3 Persoonsgegevens internationaal beschermd

5.3.1 Het Databeschermingsverdrag

5.3.2 Aanbeveling $R$ (87) 15

5.3.3 EU-richtlijnen

5.3.4 Constituties en artikel 8 EVRM

5.3.5 Politiēle gegevensbescherming in de SUO

5.4 Nederlandse uitvoeringswetgeving Schengen $\quad 126$

5.4.1 Artikel 552i Sv way 127

$\begin{array}{lll}5.4 .2 & \text { Richtlijn inzake toepassing artikel } 552 \mathrm{i} \mathrm{Sv} & 132\end{array}$

5.4.3 Wet en Besluit politieregisters en de Wbp $\quad 134$

5.5 Convenanten en Akkoorden $\quad 155$

$\begin{array}{ll}5.5 .1 & \text { Nederlandse grensakkoorden } \\ 5.5 .2 & 155\end{array}$

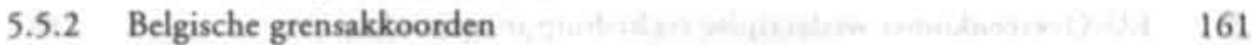

$\begin{array}{ll}5.5 .3 \text { Duitse grensakkoorden } & 162\end{array}$

$\begin{array}{ll}\text { 5.5.4 Benelux-grensakkoorden } & 166\end{array}$

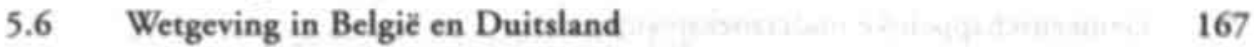

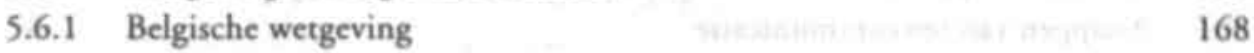

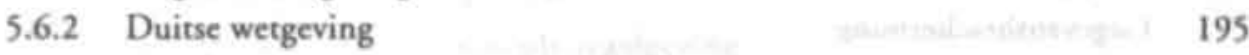

$\begin{array}{ll}\text { 5.6.3 Conclusies omgaan met zachte gegevens } & 209\end{array}$

6 Koppelen van gegevens en rechtstreekse toegang 213

$\begin{array}{lll}\text { 6.1 Koppeling en de bijbehorende technieken } & 213\end{array}$

$\begin{array}{ll}\text { 6.1.1 Computer matching } & 214\end{array}$

$\begin{array}{ll}\text { 6.1.2 Computer-assisted front-end verification } & 214\end{array}$

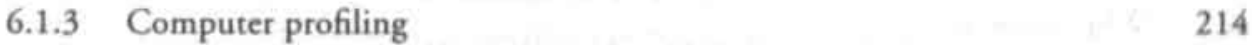

$\begin{array}{lll}6.1 .4 & \text { Integratie van bestanden } & 215\end{array}$

$\begin{array}{ll}6.1 .5 & \text { Combinaties } \\ 6.6 & 215\end{array}$

6.1.6 Knowledge Discovery in Databases 216

6.2 Koppeling en de Nederlandse juridische visie 216

$\begin{array}{ll}\text { 6.2.1 Het begrip 'persoonsgegeven' } & 217\end{array}$

6.2.2 Koppeling in de WPolr en het BPolr 219

6.2.3 Commentaar op de wet $\quad 222$

6.2.4 Nadere regels omtrent koppeling $\quad 222$

6.2.5 Commentaar op nadere regels 225

6.2.6 Datamining in juridische zin $\quad 226$

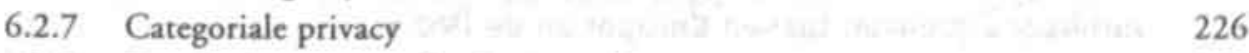

6.2.8 Conclusies en aanvullende opmerkingen $\quad 227$

$\begin{array}{lll}6.3 & \text { Rechtstreekse geautomatiseerde toegang } & 229\end{array}$

$\begin{array}{ll}\text { 6.3.1 De protocolplicht } & 229\end{array}$

$\begin{array}{ll}\text { 6.3.2 Mogelijke verstrekkingen } & 232\end{array}$ 
6.4 Twee wegen van verstrekkingen $\quad 232$

6.4.1 De weg via de WPolr $\quad 232$

6.4.2 De weg via de Wbp

$\begin{array}{ll}\text { 6.4.3 Hergebruik van protocolgegevens } & 237\end{array}$

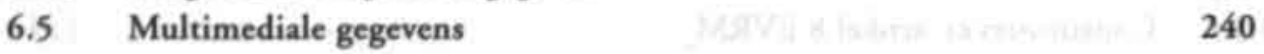

6.6 Voorgenomen herziening WPolr 241

7 Digitale expertise in internationaal perspectief $\quad 243$

$\begin{array}{ll}7.1 & \text { Internationale grensoverschrijdende bevoegdheden }\end{array}$

7.2 Het Cybercrimeverdrag 244

7.2.1 Doel van het Cybercrimeverdrag 244

$\begin{array}{ll}\text { 7.2.2 Inhoud van het Cybercrimeverdrag } & 245\end{array}$

7.3 EU-Overeenkomst wederzijdse rechtshulp in strafzaken 249

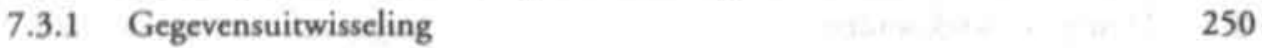

7.3.2 Grensoverschrijdende videoconferentic en telefoonconferentie $\quad 251$

$\begin{array}{lll}7.3 .3 & \text { Gemeenschappelijke onderzoeksteams } & 251\end{array}$

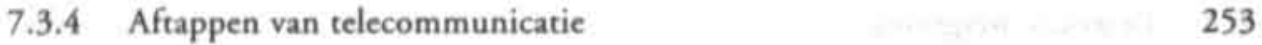

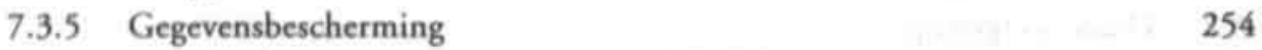

7.3.6 Nederlandse uitvoeringswetgeving EU-RHO 255

7.4 EMMI en directe toegang 256

7.5 Directe toegang en de Raad van Europa $\quad 258$

$\begin{array}{ll}7.6 & \text { Directe toegang in het Nederlandse recht }\end{array}$

7.6.1 Geen directe toegang voor het OM 259

$\begin{array}{ll}\text { 7.6.2 Bepaald omschreven doel } & 261\end{array}$

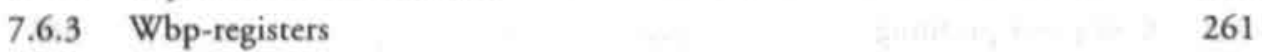

7.7 Rechtstreekse toegang in België en Duitsland 261

\begin{tabular}{ll}
7.8 & Conclusies: regelen directe toegang \\
\hline
\end{tabular}

$\begin{array}{lll}7.8 .1 & \text { Raad van Europa } & 263\end{array}$

$\begin{array}{lll}7.8 .2 & \text { Europese Unie } & 264\end{array}$

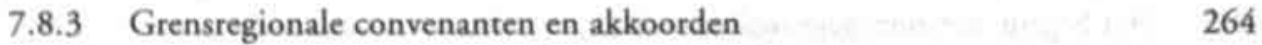

$\begin{array}{ll}7.8 .4 & \text { Regeling in het nationale recht }\end{array}$

$\begin{array}{ll}7.8 .5 & \text { Juridische haalbaarheid van automatisering } 265\end{array}$

7.8.6 Invloed ontwerp-kaderbesluit Europees bewijsverkrijgingsbevel $\quad 268$

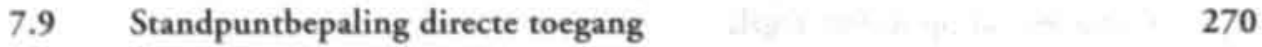

8 Juridische grenzen tussen Europol en de IRC's 273

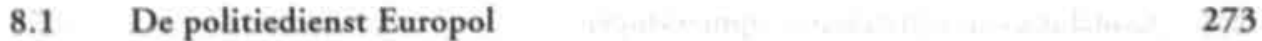

$\begin{array}{ll}8.1 .1 & \text { Juridische basis Europol } \\ 8.1 .2 & 273\end{array}$

$\begin{array}{ll}\text { 8.1.2 Het Europolmandaat } & 275\end{array}$

$\begin{array}{ll}\text { 8.1.3 Het beheer van Europol } & 280\end{array}$

$\begin{array}{ll}\text { 8.1.4 Toezicht op werkzaamheden Europol } & 281\end{array}$ 
8.2 Informatic-uitwisseling in het kader van Europol

8.2.1 De juridische structuur van informatie-uitwisseling

8.2.2 Gegevensbescherming in het kader van Europol

8.2.3 Bescherming bij informatieverwerking

8.3 Conclusies Europol versus IRC's

9 Conclusies: de techniek aan juridische banden

9.1 Juridische mogelijkheden voor gegevensuitwisseling 296

9.1.1 Is koppeling verboden of toegestaan? 298

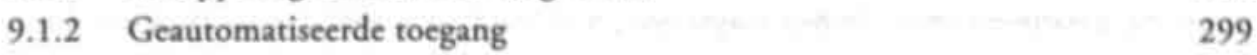

9.2 Juridische eisen aan gegevensuitwisseling 300

$\begin{array}{ll}9.2 .1 & \text { Internationale juridische eisen } \\ 901\end{array}$

9.2.2 Internationale gegevensbeschermingsbepalingen $\quad 302$

9.3 Technische mogelijkheden voor juridische eisen $\quad 302$

9.3.1 Koppeling van gegevens $\quad 303$

$\begin{array}{ll}\text { 9.3.2 Rechtstreekse geautomatiseerde toegang } & 304\end{array}$

9.4 Samenwerking van organisaties $\quad 305$

9.5 Legitimiteit binnen bestaande regelgeving 306

9.6 Betrouwbaarheid van gebruik en gebruiker 308

$\begin{array}{ll}\text { 9.6.1 Juridische randvoorwaarden } & 308\end{array}$

9.6.2 Beginselen van behoorlijk ICT-gebruik 309

9.7 Conclusies eerste aanvullende onderzoeksvraag 311

9.8 Conclusies tweede aanvullende onderzoeksvraag 313

9.9 Conclusies derde aanvullende onderzoeksvraag 314

9.10 Standpuntbepaling ten aanzien van het juridische kader 315

9.11 Op weg naar een EMMI-beheersorganisatie 321

9.12 Pro of contra invoering directe toegang? 324

$\begin{array}{ll}\text { Summary } & 331\end{array}$

Appendix A: De Duitse politiēle organisatiestructuur $\quad 339$

Appendix B: Duitse politieregisters $\quad 341$

Appendix C: Lijst zelfstandige politiële gegevensuitwisseling België $\quad 343$

Appendix D: Het OIPG-register $\quad \mathbf{3 4 7}$

Appendix E: Huidige softwareonderdelen van PALMA 349 
Referenties 


\section{Voorwoord}

Voor u ligt de dissertatic 'Politie en de Nieuwe Internationale Informatiemarkt'. De titel duidt erop dat sinds 1996 in de Europese grensregio's een nieuwe samenwerkingsmarkt tussen politiediensten is ontstaan door de automatisering van de informatie-uitwisseling met buitenlandse politiediensten. Er ontstond namelijk een behoefte aan snelle grensoverschrijdende informatie-uitwisseling voor het dagelijkse operationele politiewerk 'op straat', zoals ordehandhaving, verkeerstoezicht en de kleinere criminaliteit. De reden daarvan is de enorme migratie van burgers in een Europa zonder binnengrenzen. Burgers uit andere Europese landen veroorzaken in het buitenland een deel van de dagelijkse politiezorg, waaronder de zorg voor verkeersongevallen, verkeersovertredingen, vechtpartijen, diefstallen, handel in drugs et cetera.

Zoals blijkt uit de ondertitel, Grensregionale politiele gegevensuitwisseling en digitale expertise, gaat het in de eerste plaats om politiële gegevensuitwisseling in de grensregio's van de EU. Meer in het bijzonder betreft het de ontwikkeling van een normatief kader voor een grensoverschrijdende koppeling van multimediale politiēle databases in het belang van de internationale informatieve politiesamenwerking in de grensregio's. We hebben een inventarisatie gemaakt van de bestaande en wenselijke juridische normering voor de koppeling van politiële netwerken en het grensoverschrijdend gebruik van multimediale databases. In het onderzoek is zowel een technologische als een juridische component aanwezig. Voor de technische component geldt dat de beschikbare techniek door een juridische bril is bekeken en getoetst aan de bestaande en gewenste normering. Voor de juridische component zijn de bestaande juridische normen getoetst op hun innerlijke consistentie en compatibiliteit met de huidige praktijk van de internationale politiële gegevensuitwisseling. Daarbij ligt de nadruk op het gebruik van allerlei moderne communicatietechnieken.

Blijkens de ondertitel gaat het in de tweede plaats om digitale expertise in de grensregio's. Dit betreft een aanverwant onderzoeksdomein van grensoverschrijdende opsporing door politiediensten in computernetwerken op basis van internationale regels die zijn neergelegd in het Cybercrimeverdrag van de Raad van Europa en de EU-Overeenkomst betreffende de wederzijdse rechtshulp in strafzaken. De onderzoeksdomeinen van de informatieve politiesamenwerking en de grensregionale digitale expertise, die mij 
beide na aan het hart liggen, kunnen leren van elkaars oplossingen voor moeilijke internationaal-rechtelijke vraagstukken.

Op deze plaats wil ik allereerst mijn dank uitspreken aan beide promotores, Jaap van den Herik (hoogleraar informatica en directeur van IKAT aan de Universiteit Maastricht en bijzonder hoogleraar juridische informatica aan de Universiteit Leiden) en Theo de Roos (hoogleraar straf- en strafprocesrecht aan de Universiteit Leiden). De multidisciplinaire samenwerking heeft de onderzoeksas Leiden-Maastricht verstevigd. Jaap en Theo zijn gedurende dit onderzoek steeds mijn grote inspiratiebronnen geweest, Jaap vanuit het domein van de (rechts) informatica en Theo vanuit het domein van het (internationale) straf- en strafprocesrecht. Jaap, dank je voor je gedrevenheid, je steun en je hulp in de schrijfkunst. Theo, dank je voor onze samenwerking op het juridische internationaal strafrechtelijke en privacyrechtelijke vlak. Jouw grote kennis en rustgevende aanwezigheid zijn voor mij een lichtbaken geweest in de juridische duisternis die heerste in het door ons onderzochte onderzoeksdomein.

Verder wil ik heel graag de leden van de beoordelingscommissie hartelijk bedanken, met name prof. mr. M.G. Faure (hoogleraar vergelijkend en internationaal milieurecht bij het onderzoeksinstituut METRO, Faculteit der Rechtsgeleerdheid van de Universiteit Maastricht), prof. mr. Y. Buruma (hoogleraar strafrecht en strafprocesrecht, sectie Strafrecht, Faculteit der Rechtsgeleerdheid van de Katholieke Universiteit Nijmegen), prof. mr. A.H. Klip (hoogleraar grensoverschrijdende aspecten van strafrecht, capaciteitsgroep Strafrecht en Criminologie, Faculteit der Rechtsgeleerdheid van de Universiteit Maastricht), prof. mr. E. Prakken (hoogleraar straf- en strafprocesrecht, capaciteitsgroep Strafrecht en Criminologie, Faculteit der Rechtsgeleerdheid van de Universiteit Maastricht) en prof. mr. A.H.J. Schmidt (hoogleraar recht en informatica, eLaw@Leiden, Faculteit der Rechtsgeleerdheid van de Universiteit Leiden).

Voorts wil ik graag de volgende personen dank zeggen voor hun medewerking: $\mathrm{H}$. Mostert (voormalig korpschef van de regiopolitie Limburg-Zuid), G. Oomens en C. Timmermans (penvoerders van het EMMI-project, politieregio Limburg-Zuid), L. Plugge en J. Donkers (de ontwerpers van het PALMA-concept en het EMMI-concept, IKAT),

A. Geus (voormalig Hoofd van het toenmalige Informatic en Coördinatie Centrum (ICC) Maastricht en thans Hoofd van de infodesk Heerlen, regiopolitie Limburg-Zuid), H. de Heus (voormalig Coördinator Internationale Samenwerking/Euregionale Zaken, regiopolitic Limburg-Zuid), B. van Montfort (ICT-adviseur politieregio Limburg-Zuid en adviseur van de ICT-Service Coöperatie (ISC) Politie, Justitie en Veiligheid), W. Velings (korpschef politieregio Limburg-Zuid), M. van Amelsvoort (hoofd Internationaal Rechtshulp Centrum (IRC) Zuid, politieregio Limburg-Zuid), W. van de Vrede (hoofd IRC Noord, voorzitter landelijk hoofdenoverleg IRC's en lid van de Werkgroep Internationaal van de Gebruikersgroep Landelijke OpsporingsSystemen (GLOS) van de 
Coöperatie Informatiemanagement Politic (CIP), C. van Gestel (coördinator Internationale Samenwerking/Euregionale Zaken, regiopolitie Limburg-Zuid), R. Mokroz (coördinator Internationale Samenwerking/Euregionale Zaken, Polizeiprisidium Aachen), V. Reilly (project officer bij het Directoraat-Generaal Informatic van de Europese Commissie), E. Schreuders (onderzoeker Centrum voor Recht, Bestuur en Informatisering. Universiteit van Tilburg) en alle medewerkers van de IRC's van Nederland, Belgiè, Duitsland en Frankrijk.

In het bijzonder bedank ik alle collega's van de capaciteitsgroep Informatica en het onderzoeksinstituut IKAT voor de bijzonder prettige werksfeer waarin dit proefschrift tot stand is gekomen. Jullie zijn een geweldige steun en inspiratiebron.

Ten slotte dank ik mijn ouders voor hun toegewijde steun en geduld.

Joop Verbeek, 30 januari 2004. 



\section{Lijst van afkortingen ${ }^{1}$}

Aae

aant.

$A P B$

ACOG

AID

AIK

AIVD

amvb

ANG

ANITA

APA

APD

AP-ERV

APSD

ARI

art.

AZRG

Bbrp

BDSG

BGBI

BGS

BKA

BKAG

BNP

BNPS

BPolr

BPS

B.S.
Ars Aequi

aantekening

Algemeen Politieblad

AdviesCommissie Open Grenzen

Algemene Inspectiedienst

arrondissementele informatickruispunt (B)

Algemene Inlichtingen- en Veiligheidsdienst

algemene maatregel van bestuur

algemene nationale gegevensbank (B)

Administrative Normative Information Transaction Agents

Autonome politionele afhandeling (B)

Algemene politiedienst (basispolitie)

Aanvullend Protocol ERV

Algemene Politie Steundienst (B)

Afdeling Recherche Informatie

artikel(en)

Gesetz über das Ausländerzentralregister (D)

Besluit beheer regionale politiekorpsen

Bundesdatenschutzgesetz (D)

Bundesgesetzblatt (D)

Bundes Grenzschutz (D)

Bundeskriminalamt (D)

Gesetz über die Einrichtung eines Bundeskriminalamtes (D)

Bruto Nationaal Product

Belgisch-Nederlandse Politiéle Samenwerking

Besluit politieregisters

Bedrijfs Processen Systeem

Belgisch Staatsblad (B)

1. Bij het samenstellen van deze lijst is de volgende systematiek toegepast. Woorden van buitenlandse herkomst zijn gecursiveerd, evenals afkortingen die een 'staande verwijzing' betreffen. Instellingen, wetgeving en dergelijke van Belgie zijn aangeduid met een B, en van Duitsland met een D. 


$\begin{array}{ll}\text { BUV } & \text { Benelux uitleverings- en rechtshulpverdrag } \\ \text { BverfG } & \text { Bundesverfassungggericht (D) } \\ \text { BverfGE } & \text { Bundesverfassungsgericht - Entscheidungen (D) } \\ \text { BW } & \text { Burgerlijk Wetboek } \\ \text { BZK } & \text { (Ministerie van) Binnenlandse Zaken en Koninkrijksrelaties } \\ \text { CBP } & \text { College bescherming persoonsgegevens } \\ \text { CBPL } & \text { Commissie voor de Bescherming van de Persoonlijke Levenssfeer (B) } \\ \text { CGI } & \text { Commissariaat-Generaal, directie voor het beleid inzake Internatio- } \\ & \text { nale politiële samenwerking (B) } \\ \text { CGI } & \text { Common Gateway Interface } \\ \text { CID } & \text { Criminele Inlichtingendienst } \\ \text { CIE } & \text { Criminele Inlichtingeneenheid } \\ \text { CIP } & \text { Coöperatie Informatiemanagement Politie } \\ \text { CJIB } & \text { Centraal Justitieel Incasso Bureau } \\ \text { CPB } & \text { Coördinerend Politie Beraad } \\ \text { CSIS } & \text { Centraal Schengen Informatie Systeem } \\ \text { dCRI } & \text { divisie Centrale Recherche Informatic } \\ \text { DD } & \text { Delikt \& Delinkwent } \\ \text { DIN } & \text { Dienst Internationale Netwerken } \\ \text { dI. } & \text { deel } \\ \text { DNPS } & \text { Duits-Nederlandse Politiële Samenwerking } \\ \text { DNS } & \text { Domain Name Server } \\ \text { DSB } & \text { Directie van de nationale gegevensbank (B) } \\ \text { DSG NRW } & \text { Datenschutzgesetz Nordrhein-Westfalen (D) } \\ \text { DST } & \text { Directie van de Telematica (B) } \\ \text { DVS } & \text { Digitaal Voorlichting Systeem } \\ \text { ECD } & \text { Economische Controledienst } \\ \text { EDE } & \text { Europol-Drugseenheid } \\ \text { EG } & \text { Europese Gemeenschap } \\ \text { EHRM } & \text { Europese Hof voor de Rechten van de Mens } \\ \text { ELO } & \text { Europol Liaison Officer (Europol-verbindingsofficier) } \\ \text { EMMI } & \text { Euregionale MultiMediale Informatie-uitwisseling } \\ \text { EMMII Kiosk } & \text { EMMI Kiosk 2000 } \\ \text { EO } & \text { Europol-Overeenkomst } \\ \text { ERV } & \text { Europees rechtshulpverdrag (Europees verdrag aangaande de weder- } \\ \text { Estof } & \text { zerimple transfer of files } \\ \text { ETS } & \text { EU } \\ \text { EU-RHO } & \end{array}$


EVRM

EWDD

FIOD

GBA

GG

GGD

GLOS

GPRS

GROS

GSM

GVBl

GVG

GVNRW

$\mathrm{Gw}$

GWb

HKD

HKS

HR

HTML

HTTP

HvJEG

ICC

I.C.PO.

ICT

IIS

Interpol

IPS

IRC

IRG

IRIC

IRP

ISC

ISDN

ISLP

ITeR

ITO

IVBPR

JBZ

jo.

Jur
Europees Verdrag tot bescherming van de Rechten van de Mens en de fundamentele vrijheden

Europees Waarnemingscentrum voor Drugs en Drugsverslaving

Fiscale Inlichtingen- en Opsporingsdienst

Gemeentelijke Basisadministratie

Grundgesetz (D)

Gemeentelijke Geneeskundige Dienst

Gebruikersgroep Landelijke OpsporingsSystemen

Genenal Packet Radio System

grensoverschrijdende politiesamenwerking

Global System for Mobile Communication

Gesetz- und Verontnungsblat (D)

Gerichtsverfassungsgesetz (D)

Gesetz- und Verwaltungsblatt Nondrhein-Westfalen (D)

Grondwet

Gerechtelijk Wetboek (B)

Herkenningsdienst

herkenningsdienstsysteem

Hoge Raad

HyperText Markup Language

Hyper Text Transfer Protocol

Europese Hof van Justitic

Informatie en Coördinatic Centrum

The International Criminal Police Organization

informatie- en communicatietechnologie

Internet Information Server

De Internationale Organisatie van Criminele Politic

Afdeling internationale politiesamenwerking (B)

Internationaal Rechtshulp Centrum

Gesetz über die internationale Rechtshilfe in Strafsachen (D)

Institute for Research on Intercultunal Cooperation (D)

Internationale rechtshulp politic

ICT-Service Coöperatie Politic, Justitic en Veiligheid

Integnated Service Digital Network

Informatiesysteem Lokale Politie (B)

Nationaal Programma voor Informatietechnologie en Recht

Informatic en Communicatic Technologie Organisatic

Internationaal Verdrag inzake burgerrechten en politieke rechten

Justitie en Binnenlandse Zaken

juncto

jurisprudentie van het Europese Hof van Justitie 
$\mathrm{KB}$

KDD

KLPD

KMAR

Kripo

KUL

LKA

LIEM

L-IRC

LSOP

LUC

LURIS

MATRIKS

MEPolG

METRO

MMIV

m.nt.

MOT

MS

MvA

MvT

NAW

NCID

NDSG

NdsGefAG

Nds. GVBl

NdsVerf

NJ

NORMA

NPI

nr.

NSIS

NvT

OECD

OESO

OIPG

$\mathrm{OM}$

OOV
Koninklijk Besluit

Knowledge Discovery in Databases

Korps Landelijke Politiediensten

Koninklijke Marechaussee

Kriminalpolizei (D)

Katholieke Universiteit Leuven

Landeskriminalame (D)

Landelijke Implementatic EMmi

Landelijk Internationaal Rechtshulp Centrum

Landelijk Selectie- en Opleidingsinstituut

Limburgs Universitair Centrum

Landelijk Uniform Registratiesysteem voor Internationale rechtshulp in Strafzaken

MAastrichts Technologisch Research Instituut voor Kennis en Systemen

Musterentuurf eines Polizeigesetzes (D)

Maastrichts Europees Instituut voor Transnationaal Rechts-

wetenschappelijk Onderzoek

MultiMediale Informatie Voorziening

met noot

Melding ongebruikelijke transacties

Microsoft

Memorie van Antwoord

Memoric van Toelichting

Naam Adres Woonplaats

Nationale Criminele Inlichtingendienst

Niedersächsische Datenscbutzgesetz (D)

Niedersächsisches Gefabrenabuvehrgesetz (D)

Niedersächsisches Gesetz- und Verondnungsblatt (D)

Verfassung Niedersachsen (D)

Nederlandse Jurisprudentie

NORmering Multimediale Aanvragen

Nederlands Politie Instituut

nummer(s)

Nationaal Schengen Informatie Systeem

Nota van Toelichting

Onganisation for Economic Co-openation and Development

Organisatie voor Economische Samenwerking en Ontwikkeling

Operationeel InvalsPunt in Grensgebieden (B)

Openbaar Ministerie

Openbare Orde en Veiligheid 


\begin{tabular}{|c|c|}
\hline Ov] & Officier van Justitie \\
\hline p. & 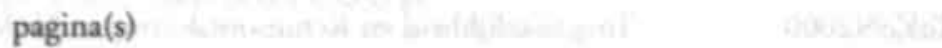 \\
\hline PALMA & Politieverbindingen Aken Luik MAastricht \\
\hline par. & 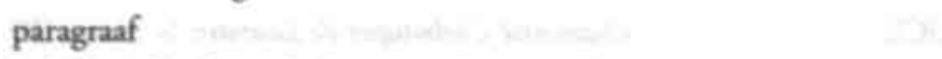 \\
\hline $\mathrm{PbEG}$ & Publikatieblad van de Europese Gemeenschap \\
\hline PILZ & Politic Intranet Limburg Zuid \\
\hline PIOS & Personen, Institutionen, Objekte, Sachen (D) \\
\hline POC & Politic Opleidingscentrum \\
\hline PODACS & POlitie DAtaCommunicatie Systeem \\
\hline PolDOVNW & $\begin{array}{l}\text { Verondnung über die Zulasoung der Datenübermittlung von der Polieei } \\
\text { und ausländiscbe Polizeibebönden (D) }\end{array}$ \\
\hline PolGNRW & Nontrhein-westfalisches Polizeigesetz (D) \\
\hline Polw & 10 \\
\hline PPS & PALMA Protocol Server \\
\hline Pres. & President \\
\hline PVD & Politie Verbindings Dienst \\
\hline $\mathbf{R b}$. & Rechtbank \\
\hline RC & Rechter-Commissaris \\
\hline RCIE & Regionale Criminele Inlichtingeneenheid \\
\hline red. & redactie \\
\hline RIB & Recherche Informatiebureau \\
\hline RID & Regionale Inlichtingendienst \\
\hline \multirow[t]{2}{*}{ RiVASt } & Richtlinien für den Verkehr mit dem Ausland in stnafrechtlichen \\
\hline & Angelegenheiten (D) \\
\hline RVST & Regionale VerbindungsSTelle (D) \\
\hline RWTH & Rheinisch-Westfalische Technische Hochschule (D) \\
\hline Schupo & Schutzpolizei (D) \\
\hline SIRENE & Supplementary Information Request at the National Entry \\
\hline SIS & Schengen Informatic Systeem \\
\hline SOFI-nummer & Sociaal-Fiscaal-nummer \\
\hline Spooldir & Spool directory \\
\hline SPUDOK & Spurendokumentationssystem (D) \\
\hline SQL & Structured Query Language \\
\hline StA & Staatsanwalt (D) \\
\hline Stb. & Staatsblad \\
\hline Stert. & Staatscourant \\
\hline $\mathrm{StPO}$ & Strafprozeßordnung (D) \\
\hline SUO & Schengen Uitvoeringsovereenkomst \\
\hline Sv & Wetboek van Strafvordering \\
\hline$T \not C$ & Tekst en Commentaar \\
\hline TCP/IP & Transmission Control Protocol/Internet Protocol \\
\hline
\end{tabular}


TECS

ToKeN2000

Trb.

UCL

URL

VB

VerfNRW

Vgl.

VEU

Viclas

Wbp

WDO

WPA

WPolr

WPR

WVP

WvSv

WWW

XML

XSL.

zwacri-register
The Europol Computer System

Toegankelijkheid en Kennisontsluiting in Nederland 2000

Tractatenblad

Universite Catholique de Louvain-la-Neuve (B)

Uniform Resource Locator

Visual Basic

Verfassung für das Land Nordrhein-Westfalen (D)

Vergelijk

Verdrag betreffende de Europese Unie

Violent Criminal Linkage Analysis System (B)

Wet bescherming persoonsgegevens

Wereld Douane Organisatie

Wet op het politieambt (B)

Wet politieregisters

Wet persoonsregistraties

Wet Verwerking Persoonsgegevens (B)

Het Wetboek van Strafvordering

World Wide Web

Extensible Markup Language

Extensible Stylesheet Language

register zware criminaliteit 


\section{Opzet van het onderzoek}

Deze dissertatie beoogt inzicht te verschaffen in de ontwikkeling van de geautomatiseerde grensoverschrijdende uitwisseling van politiele gegevens, in het bijzonder in de Europese grensregio's van Nederland, Belgiê en Duitsland. Het onderzoek legt de nadruk op de vraag hoe koppeling en rechtstreekse geautomatiseerde toegang tot nationale databases en netwerken in de praktijk moeten plaatsvinden om ze in juridisch opzicht rechtmatig te doen zijn. Verder houdt het onderzoek zich bezig met het onderscheid tussen 'harde' en 'zachte' gegevens in Nederland, Belgič en Duitsland, alsmede met het verschil tussen Europol en de Internationale Rechtshulp Centra (IRC's). Ten slotte wordt ook andacht besteed aan de digitale expertise van de politic en de daarbij behorende opsporingsbevoegdheden in internationaal verband. Dit onderzoeksdomein vertoont raakvlakken met het domein van de informatieve politiesamenwerking. Beide domeinen kunnen van elkaar leren en worden in dit proefschrift met elkaar geconfronteerd.

De dissertatie vormt een geactualiseerde uitwerking en aanvulling van eerder onderzoek op het terrein van de grensregionale informatieve politiesamenwerking. ${ }^{2}$ Het belicht de technologische, juridische en organisatorische aspecten ervan.

In dit eerste hoofdstuk vertellen wij érst iets over de aanleiding tot het onderzoek (sectie 1.1). Vervolgens geven we in sectie 1.2 een uitvoerig overzicht van de historische ontwikkeling van de geautomatiseerde grensregionale politiële gegevensuitwisseling. Hoe belangwekkend ook, het overzicht straalt kortheid en bondigheid uit. De geschetste ontwikkeling roept op tot een duidelijke juridische probleemstelling: wat zijn de voorwaarden waaronder grensregionale informatie-uitwisseling mag plaatsvinden? Sectie 1.3 beschrijft de probleemstelling aan de hand van de hoofdvraag van het onderzoek, die vervolgens wordt geconcretiseerd in twee deelvragen en drie aanvullende onderzoeksvragen. In sectie 1.4 bakenen wij ons onderzoeksdomein af. Sectie 1.5 geeft het plan van anpak.

2. Verbeek, Van den Herik, Plugge $\&$ De Roos 1999 (zie voor een bespreking Koen \& Schmidt 2003); Verbeek, Claus, Van den Eshof \& Van den Herik 2002; en Ver. beek, Claus \& Van den Herik 2003. Zie ook Van Dorp, Verbeek \& Van den Herik 2001 en Donkers, Verbeek, Van den Herik, Van der Krogt, Boers, Spronck \& Wiesman 2001. 


\subsection{Aanleiding tot het onderzoek}

Het Europese Unieverdrag van Maastricht, ${ }^{3}$ het Akkoord van Schengen en de Schengen Uitvoeringsovereenkomst (SUO) hebben bewerkstelligd dat de Europese binnengrenzen van de EG (thans EU) in 1992 zijn opengegaan. Sinds die tijd is de zorg voor criminaliteitsbeheersing en voor handhaving van de Openbare Orde en Veiligheid (OOV) in Europa geintensiveerd. Dat bleek hard nodig, want er was sprake van een toenemende internationalisering van de criminaliteit. ${ }^{4}$ De openstelling van de grenzen had natuurlijk ook haar weerslag op de werkzaamheden van de politiekorpsen van de Europese lidstaten. Om hun taak in een verenigd Europa naar behoren te vervullen, ontstond er een grote behoefte aan internationale uitwisseling van gegevens binnen de Euregio's.

Het concept Euregio is een nieuw concept en voegt als zodanig een dimensie toe aan de internationale opsporing. Een voorbeeld van een Euregio is de Euregio Maas en Rijn, met als Euregionale grensgebieden Nederlands Limburg, Noordrijn-Westfalen, Belgisch Limburg en Luik. In een Euregio laat zich de behoefte aan snelle gegevensuitwisseling met het buitenland duidelijk gevoelen. Daar is de relevantie van gegevensuitwisseling vaak nog groter dan de gegevensuitwisseling met collegae in het eigen land. Immers bij opsporing is de geografische verbondenheid van een streek met een andere streek veel belangrijker dan een nationale verbondenheid. Kortom, de traditionele politiële communicatic- en uitwisselingsmiddelen waren in het begin van de jaren negentig duidelijk aan een update toe om de strijd tegen de - al dan niet georganiseerde en/of zware - criminaliteit het hoofd te bieden.

Een kernvraag daarbij is: welke bevoegdheden hebben buitenlandse opsporingsambtenaren met betrekking tot nationale (politiële) databases, en welke rechten en plichten hebben de betrokken landen in het kader van de grensregionale informatieve politiesamenwerking? Uit de ontwikkelingen blijkt dat alle betrokken politiepartners een grote behoefte hebben aan het kunnen bevragen van multimediale databases via een internationaal politieel Intranet. Technisch is dit heel goed mogelijk door een directe toepassing van diverse Internetconcepten. Het gebruik van deze technische mogelijkheden is echter onderworpen aan de nationale en internationale wet- en regelgeving. Door de enorme mogelijkheden van de informatie- en communicatietechnologie (ICT) worden juristen gedwongen de onduidelijke en vooral ingewikkelde juridische normering

3. Voorafgegaan door het EEG-Verdrag.

4. De Hert \& Vanderborght 1996, p. 7-8. Zij wijzen erop dat in november 1994 een interministeriele conferentie aan dit onderwerp werd gewijd: de Ministerięle wereldconferentie over georganiseerde misdaad. Zie verder: Busch 1995 en LEVI 1993, p. 1, 3 en 57-77. Verschillende andere auteurs wijzen eveneens op de relatie tussen het wegvallen van persoonscontroles, de toename van de internationale mobiliteit en de toename van de internationale criminaliteit: zie bijvoorbeeld Bruinsma 1998, Bovenkerk \& Yesilgöz 1998 en Janssen \& Koning 1998. 
expliciet te maken. Hierbij speelt EMMI een belangrijke rol. EMMI staat voor Euregionale MultiMediale Informatie-uitwisseling. De implementatie van de huidige EMMIomgeving, die gebruikt wordt voor een geautomatiseerde grensregionale gegevensuitwisseling, verdraagt zich weliswaar met de internationale en nationale wet- en regelgeving. maar de door de politie gewenste orngeving doet dit nog niet. De wens van de politie is een koppeling van nationale politienetwerken aan de EMMI-omgeving, waardoor grensoverschrijdend raadplegen van politiēle databases mogelijk is. Deze wens werpt ingewikkelde juridische vragen op. Om EMMI in alle politieregio's langs de Nederlandse grens op de voorgestelde wijze te laten functioneren, is het noodzakelijk om duidelijke juridische normen ter zake - voor zover die er nog niet zijn - en heldere formele procedures op te stellen. Verbetering en verlichting van de politiele taakuitoefening langs de Europese binnengrenzen zijn afhankelijk van wat juridisch is toegestaan.

In de praktijk van alle dag vormt multimediale database sharing een veelbelovend hulpmiddel voor het opsporen van daders van diverse strafbare feiten. Dit gebeurt dan aan de hand van daderprofielen en de uitwisseling van allerlei gegevens uit documenten, zoals paspoorten, rijbewijzen en kentekenregistraties. Zolang het echter niet duidelijk is waaraan politie en justitie zich in juridisch opzicht hebben te houden, is controle op het (illegaal) gebruik van multimediale databases moeilijk.

In de loop van 2001 is in Nederland de administratieve afhandeling van alle inkomende en uitgaande internationale rechtshulpverzoeken, zowel politieel als justiticel, georganiseerd in acht IRC's en één Landelijk IRC (L-IRC) als centrale autoriteit. In Nederland is een IRC op dit moment (januari 2004) een samenwerkingsverband tussen het Openbaar Ministerie (OM) en de politie; in enkele gevallen strekt de samenwerking zich ook uit tot de Koninklijke Marechaussee (KMÁR). Deze organisatiestructuur, die politieel ook in België, Duitsland en Frankrijk bestaat, beoogt te bewerkstelligen dat rechtshulpverzoeken sneller worden afgedaan. Voor het buitenland is via deze organisatie direct duidelijk wie aanspreekpunt is voor een rechtshulpverzoek. Alle verzoeken om rechtshulp die op grond van een verdrag of overeenkomst rechtstreeks aan een rechterlijke autoriteit of aan de politie kunnen worden gezonden, dienen aan het betreffende (L-)IRC te worden gezonden.

Om een goed overzicht te hebben van de stand van zaken met betrekking tot de uitvoering van een rechtshulpverzoek zijn alle Nederlandse IRC's aangesloten op een landelijk computersysteem waarin alle rechtshulpverzoeken, zowel justitieel als politieel worden ingevoerd en opgeslagen. Dit computersysteem heet LURIS, hetgeen staat voor Landelijk Uniform Registratiesysteem voor Internationale rechtshulp in Strafzaken. Het is cen registratiesysteem, dat de verantwoordelijke autoriteiten, met name het College van Procureurs-Generaal, in staat stelt vragen over de stand van zaken met betrekking tot de uitvoering van rechtshulpverzoeken rechtstreeks aan het betreffende IRC te stellen. Voor de 
daadwerkelijke verzending naar het buitenland en de ontvangst vanuit het buitenland van de politiële rechtshulpverzoeken wordt het computernetwerk EMMI gebruikt. Het bestaat uit twee hoofdonderdelen, te weten PALMA en EMMI Kiosk. Beide onderdelen hebben een eigen ontstaansgeschiedenis. PALMA staat voor Politieverbindingen Aachen Liège MAastricht en is bedoeld voor de uitwisseling van persoonsgegevens met het buitenland. Het is uitgegroeid tot een groot verbindingsnetwerk, met veel meer steden dan de oorspronkelijke drie. De EMMI Kiosk is bedoeld voor de publicatie van allerlei andere soorten informatie die bestemd is voor de buitenlandse partners en die gecommuniceerd wordt via websites. Het gaat hierbij om de websites die in de internationale EMMI-omgeving beschikbaar zijn voor de medewerkers van de IRC's. Zo weet men van elkaar wat er in de grensregio's op het gebied van criminaliteit gaande is. De juridische en organisatorische aspecten van EMMI vormen de concrete aanleiding van dit onderzoek. Ruwweg gesproken gaat het om de juridische vraag: wat mag er wel en wat mag er niet uitgewisseld worden aan gegevens, en welke voorwaarden spelen daarbij een rol? Een gedetailleerde opzet van de onderzoeksvragen wordt gegeven in sectie 1.3.

In Nederland is ieder arrondissementsparket van het $\mathrm{OM}$ en elke politie-instantie gekoppeld aan één van de acht IRC's. Een rechtshulpverzoek dient aan dat IRC te worden verzonden, waarvoor het bestemd is. Meestal is dat duidelijk; soms niet. Indien onbekend is welk parket of welke politieregio competent is ten aanzien van het verzoek, dan kan het rechtshulpverzoek worden gezonden aan het L-IRC, een samenwerkingsverband tussen het Landelijk Parket en het Korps Landelijke Politiediensten (KLPD).

Het EMMI-concept maakt het technisch mogelijk dat de EMMI-omgeving wordt gekoppeld aan de nationale politienetwerken van de betrokken landen: Nederland, Belgiè en Duitsland. Tot op heden is dit echter niet gebeurd omdat de koppeling stuit op politieke en juridische bezwaren in de drie landen. Alleen in Nederland heeft het Ministerie van Binnenlandse Zaken toestemming gegeven voor een uitzonderlijk experiment met een fysieke koppeling tussen de EMMI-omgeving en het nationale politienetwerk.

\subsection{Historische achtergrond}

In deze sectie schetsen wij de historische achtergrond van het computernetwerk EMMI, dat gebruikt wordt voor de grensregionale politiēle gegevensuitwisseling tussen Nederland, België, Duitsland en Frankrijk.

In 1992 verzocht de toenmalige korpschef van de politieregio Limburg-Zuid, de heer $\mathrm{H}$. Mostert, aan de voorzitter van de capaciteitsgroep Informatica (die haar onderzoek thans verenigt in het Instituut voor Kennis en Agent Technologie, IKAT) van de Universiteit Maastricht, Prof. Dr. H.J. van den Herik, de mogelijkheid te onderzoeken om binnen de regio een geautomatiseerd systeem van informatievoorziening te realiseren. De voor- 
naamste doelstelling was op dat moment om te komen tot een deugdelijke informaticvoorziening tussen de districtsbureaus van de politieregio Limburg-Zuid.

\section{MMIV en DVS}

De capaciteitsgroep Informatica voerde daarop een haalbaarheidsstudie uit voor een zogenaamde MultiMediale $e^{5}$ Informatie Voorziening (MMIV). ${ }^{6}$ Op basis daarvan werd in december 1995 een pilotproject DVS (Digitaal Voorlichting Systeem) binnen het district Maastricht opgezet. De gebruikte techniek voor het DVS was afkomstig van het wereldomspannende computernetwerk Internet. ${ }^{7}$ DVS bleek goed bruikbaar en werd in juli 1996 ingevoerd in de gehele politieregio Limburg-Zuid. Het systeem was uitsluitend bedoeld voor interne voorlichting - met name via actuele berichtgeving - van de politie in de regio Limburg-Zuid. Het DVS-systeem was hiermee het eerste in de praktijk geĩmplementeerde Intranet." De term 'Intranet' houdt in dat de Internetfunctionaliteit wordt toegepast binnen een gesloten netwerkomgeving, in dit geval het regiokorps. Het computernetwerk is in tegenstelling tot het Internet niet openbaar toegankelijk.

\section{PILZ}

DVS werd in 1997 opgewaardeerd tot een netwerk dat alle politie-informatie omvatte en kreeg de naam Politie Intranet Limburg Zuid (PILZ). Deze opwaardering was niet van technische aard. Het betrof dus een inhoudelijke verbreding. Via dit Intranet werden vervolgens ook alle overige informatiebronnen, waaronder multimediale databases maar bijvoorbeeld ook hand- en wetboeken, ontsloten.

\section{InterRegioNet-project}

In kringen van de Nederlandse, Belgische en Duitse politie ontstond belangstelling voor dit nieuwe medium. In Nederland leidde dit tot het zogenaamde InterRegioNet-project, waarmee bij middel van proef binnen een aantal regio's, te weten Utrecht, Gelderland, Brabant en Zuid-Limburg, ook een Intranet werd gerealiseerd.' Deze Intranetten zijn allemaal met elkaar verbonden, tenzij er technische maatregelen waren getroffen die gegevensverkeer met andere regio's niet mogelijk maakten. In dit proefproject werd de World Wide Web (WWW)-functionaliteit als mogelijke toepassing binnen de politieorganisatic als interregionaal informatic- en communicatie-instrument nader onderzocht.

5. Multimedia houdt een integratie van teksten, video, geluid, foto's, platjes, ingescande documenten emzovoorts in.

6. Van den Herik, Bakker \& Schoo 1993.

7. Van den Herik, van der Meulen \& Schijf 1994; Derey 1997.

8. De term zelf werd destijds geintroduceerd door L..A. Plugge.

9. Van Montfort 1997. 


\section{Politie IntraNet}

De resultaten van het InterRegioNet-project waren erg positief en deed het Platform voor de Politiële Informatievoorziening (Ppi) besluiten tot de implementatie van een bovenregionaal Intranet, het zogenaamde Politie IntraNet. ${ }^{10}$ Hiertoe is het project Implementatie Politie Intranet in het leven geroepen. De projectgroep Politie IntraNet heeft de implementatie verzorgd van Politie IntraNet in de politickorpsen en in aan de politie gelieerde landelijke organisaties, zoals het Nederlands Politie Instituut (NPI), het Landelijk Selectie- en Opleidingsinstituut Politie (LSOP), de Informatie en Communicatie Technologie Organisatie ITO en het Politie Adviescentrum In-pact.

\section{PALMA}

In de Euregio Aken-Luik-Maastricht heeft de belangstelling voor DVS geleid tot het PALMA-project, dat in februari 1995 van start is gegaan. Het PALMA-project is mogelijk gemaakt door de inspanning en financiering van het toenmalige PTT-Telecom.

PALMA is een samenwerkingsverband tussen:

- de politie in de regio's Limburg-Zuid, Aken en Eupen;

- de Universiteit Maastricht;

- de Rheinisch-Westfalische Technische Hochschule (RWTH) Aachen;

- de Université de Liegge;

- het Limburgs Universitair Centrum (LUC) te Diepenbeek; en

- PTT-Telecom.

Via een onderzoeks- en pilotproject is met PALMA een structurele oplossing gevonden voor een beveiligde communicatie en informatie-uitwisseling tussen de politiekorpsen in de Euregio Aken-Luik-Maastricht; dit alles geschiedde binnen het raamwerk van het Akkoord van Schengen en de SUO. In juni 1996 werd het zogenaamde PALMA-systeem in gebruik genomen, waarmee de Euregionale gegevensuitwisseling in de genoemde Euregio duidelijk verbeterd werd en beter beveiligd was dan tot dan toe het geval was. Binnen PALMA worden op een formuliergebaseerde wijze elektronische politiële rechtshulpverzoeken verzonden en ontvangen tussen de betrokken grensregionale IRC's van Nederland, België, Duitsland en Frankrijk. Hierbij worden persoonsgegevens uitgewisseld in overeenstemming met de Europese verdragswetgeving en de nationale wet- en regelgeving van de betrokken landen. Deze grensregionale politiële rechtshulp wordt ook geregistreerd op de door de Schengenwetgeving voorgeschreven wijze.

10. Van Montfort 1997. 


\section{PALMA PC-PC}

Deze eerste fase van PALMA is in maart 1997 gevolgd door een tweede fase." Daarin werd de PALMA-software voorzien van nieuwe multimediafaciliteiten voor het versturen van gedigitaliseerde documenten. Dit betreft bijvoorbeeld ingescande documenten van vingerafdrukken en pasfoto's. De gebruikers van de toenmalige Informatie en Coördinatie Centra (ICC's) in Aken, Mönchengladbach, Eupen, Genk en Maastricht zijn nauw bij dit project betrokken geweest. De systeemuitbreiding was in november 1997 gereed.

\section{EMMI}

De resultaten van het PALMA-project zijn vervolgens tocgepast in het Europese EMMIproject. ${ }^{12}$ EMMI is de afkorting die gehanteerd wordt voor het op 1 januari 1996 gestarte project EMML. Het is voor vijftig procent gefinancierd doot de EU in het kader van het zogenaamde $4 \mathrm{th}$ Framework Programme (Telematics Applications for the Administrations Sector). In dit project is een geintegreerde geautomatisecrde omgeving ontwikkeld voor de Euregionale uitwisseling van politiële gegevens tussen Nederland, Belgiě en Duitsland. Hiertoe zijn in eerste instantie in de Euregio Aken-Luik-Maastricht de belangrijkste ICC's van de politie via een beveiligd Private Network met elkaar verbonden.

\section{Twee technische EMMI-trajecten}

Het EMMI-project is verdeeld in twee technische trajecten. Het eerste traject betreft multimedia communicatie. Het tweede traject behelst de zogenaamde multimediakiosk. De doelstellingen van het eerste traject waren het ontwerpen, ontwikkelen, implementeren, testen en evalueren van een geautomatiseerde omgeving bestaande uit soft- en hardware voor de uitwisseling van informatie via (1) video-conferencingtools met de mogelijkheid om applicaties te delen, èn via (2) formuliergebaseerde, beveiligde elektronische post (e-mail).

De doelstellingen van het tweede traject waren het ontwerpen, ontwikkelen, implementeren, testen en evalueren van een geautomatiseerde omgeving bestaande uit soft- en hardware voor het ontsluiten ('publiceren') van informatic (gegevens en nieuws). Die informatie wordt toegankelijk gemaakt via een kiosk, die gebaseerd is op het model van het WWW. In de EMMI Kiosk wordt alle mogelijk informatie uitgewisseld met de grensregionale buitenlandse politiepartners, met uitzondering van persoonsgegevens. Die worden via PALMA verzonden.

11. PC-PC Fase II project PALMA \& Multimedia; Van den Herik, Plugge, Mathijsen, Donkers, van den Bosch \& Klinkers 1997.

12. Plugge 1997. 
De volgende instanties namen deel in het EMMI-project:

- de Duitse Kreispolizei Mönchengladbach;

- de Duitse Kreispolizei Aachen;

- de Belgische Rijkswacht Eupen en Genk/Maaseik;

- de Belgische Algemene Politie Steundienst (APSD);

- de Nederlandse Regiopolitie Limburg-Zuid;

- de Nederlandse Regiopolitie Limburg-Noord;

- het Nederlandse PTT-Telecom; en

- de universiteiten van Maastricht, Aken, Luik en Diepenbeek.

\section{Uitbreiding EMMI}

De directe doelstelling van het EMMI-project is het vergroten en stimuleren van de samenwerking tussen de politic in aangrenzende politieregio's van de drie betrokken landen in een Euregionale situatie. De verder gelegen doelstelling van het EMMI-project is het op langere termijn stimuleren van de politie in andere Euregio's om een eigen vervolg aan dit project te geven. Zo is sinds 1999 ook Frankrijk betrokken bij EMMI.

De gebruikers, de leden van de ICC's (thans IRC's), staan in het EMMI-project centraal. Aan de hand van gebruikerseisen en -wensen zijn de genoemde nieuwe functionaliteiten ontwikkeld, aangepast en geìmplementeerd. Het gaat daarbij om het routinematig uitwisselen van multimediale politiële gegevens binnen het kader van het Akkoord van Schengen en de SUO. De EMMI-omgeving geeft de gebruikers van de betrokken IRC's toegang tot de bovengenoemde multimediakiosk, de PALMA-software en video conferencing (die uiteindelijk niet clientgebaseerd per werkplek geïmplementeerd werd, maar een algemene mogelijkheid tot videoconferencing tussen de betrokken EMMI-servers mogelijk maakt). Vooral de eerste twee onderdelen lenen zich voor het indirect bevragen van wederzijdse (multimediale) databases. Op die manier kan een gemeenschappelijke geografisch gedistribueerde vraagbaak ontstaan voor diverse politierelevante onderwerpen. De behoefte aan een dergelijke vraagbaak is bij alle betrokken politiepartners erg groot. Op elk gewenst moment kunnen politiediensten in de Euregio's elkaar dan van informatie voorzien over met name actuele gebeurtenissen.

\section{LIEM}

In mei 1998 is het LIEM-project van start gegaan. LIEM staat voor Landelijke Implementatie EMmi. Dankzij een subsidieregeling van het Ministerie van Binnenlandse Zaken van 6 januari 1998, genaamd 'Financiële bijdrage grensoverschrijdende politiële samenwerking', is het EMMI-concept uitgebreid. Alle twaalf Nederlandse grensregio's, alsmede de toenmalige divisies Centrale Recherche Informatiedienst (dCRI) en Mobiliteit van het KLPD zijn op het EMMI-netwerk aangesloten. 


\section{NORMA (Politie en Intranet) en NORMA+}

De Afdeling Internationale Politiesamenwerking van het Ministerie van Binnenlandse Zaken en Koninkrijksrelaties verleende in 2000 ter versterking van de activiteiten van de AdviesCommissie Open Grenzen (ACOG) een gerichte subsidie om onderzoek te doen naar de in Belgiě en Duitsland bestaande juridische normering voor de koppeling van političle netwerken en het grensoverschrijdend gebruik van multimediale databases. IKAT kreeg opdracht tot de uirvoering van dit onderzoek NORMA+, ${ }^{13}$ als vervolg op het door haar reeds in 1999 uitgevoerde onderzoek NORMA (NORmering Multimediale Aanvragen), gepubliceerd als deel 19 in de Nederlandse ITeR-reeks, onder de titel 'Politie en Intranet. ${ }^{14}$ Dit laatste onderzoek is gepubliceerd in opdracht van het Nederlandse Nationaal Programma voor Informatietechnologie en Recht (ITeR) en vormt de basis voor het juridische en organisatorische onderzoek betreffende de grensregionale politiële gegevensuitwisseling. De subsidie werd verleend in het kader van de grensoverschrijdende politiesamenwerking (GROS). Tijdens de opeenvolgende projecten NORMA en NORMA+ is onderzoek gedaan naar de juridische normering van netwerkkoppeling en het grensoverschrijdend gebruik van multimediale databases op een internationaal politieel Intranet, zoals EMMI, vanuit Nederlands, Belgisch en Duits perspectief.

\section{Reright}

In februari 2000 kreeg het IKAT van de Universiteit Maastricht de opdracht van het Ministerie van Binnenlandse Zaken om een fundamenteel nieuw ontwerp voor het PALMA-systeem te maken. Een inventarisatie van het huidige PALMA-systeem bracht namelijk aan het licht dat er door het dubbele gebruik van PALMA, te weten als pilotproject en als groeisysteem, vier problemen waren ontstaan. Deze problemen liggen op het gebied van stabiliteit, capaciteit, functionaliteit en beheersbaarheid. Het ontwerp. dat in juni 2001 werd opgeleverd door middel van het rapport Reright's ('opnieuw goed'), bevat de nieuwste Intranettechnieken, oplossingen voor nieuwe gebruikerswensen en de mogelijkheid om direct nieuwe (verwachte) (kennis)technologische ontwikkelingen op te nemen.

\section{Euro-Info}

In mei 2001 heeft IKAT het rapport Euro-Info ${ }^{16}$ opgeleverd aan het Nederlandse Ministerie van Binnenlandse Zaken en Koninkrijksrelaties en de regiopolitie Limburg-Zuid. Dit onderzoek betreft cen inventarisatie en een analyse van de huidige en gewenste politiële informatie-uitwisseling met Belgiē en Duitsland. Het bevat een overzicht van de

13. Verbeek, Claus, Van den Eshof \& Van den Herik 2002.

14. Verbeek, Van den Herik, Plugge \& De Roos 1999.

15. Donkers, Verbeek, Van den Herik, Van der Krogt, Boers, Spronck \& Wiesman 2001.

16. Van Dorp, Verbeek \& Van den Herik 2001. 
binnenlandse en buitenlandse politiēle aanspreekpunten en een inventarisatie van het relevante juridische kader en de daaruit voortvloeiende beperkingen voor de informatieuitwisseling met het buitenland. Tevens wordt een overzicht gegeven van de belangrijkste Nederlandse informatiesystemen die worden ingezet voor de informatie-uitwisseling. De grensoverschrijdende problematiek wordt uitvoerig toegelicht.

\section{Overgang naar acht Nederlandse IRC's}

Op grond van een richtijin van het College van Procureurs-Generaal kent Nederland sinds 2001 een landelijk dekkend netwerk van acht bovenregionale arrondissementale ICC's en één landelijk (L-)ICC, de Dienst Internationale Netwerken (DIN) van het KLPD. De ICC's, die in 2002 omgedoopt werden tot IRC's, behandelen alle politiële en justitiele rechtshulpverzoeken. Het zijn samenwerkingsverbanden van regionale politiekorpsen en arrondissementen van het OM. Bij het IRC-Noord, het IRC-Zuid-West en het IRC-Limburg neemt ook de KMAR aan dit samenwerkingsverband deel, vooralsnog op informele basis.

De via de IRC's uitgewisselde gegevens betreffen meestal zogenaamde bulkgegevens ter ondersteuning van het dagelijkse operationele werk op straat. Het gaat vooral om gegevens over kentekens, rijbewijzen, naamsverificaties, signaleringen, voertuigen, antecedenten van personen en vreemdelingen. Het aantal gegevensaanvragen varieert van enige duizenden tot enige tienduizenden per contactpunt per jaar. Het aantal groeit nog steeds. De politieregio Limburg-Zuid verwerkt zo'n dertigduizend aanvragen per jaar. De acht bovenregionale IRC's zijn: het IRC-Noord, het IRC-Amsterdam/Utrecht, het IRCOost, het IRC-Limburg, het IRC-Den Haag, het IRC-Haarlem/Alkmaar, het IRC-Zuid West en het IRC-Rotterdam/Dordrecht.

\section{EMMII Kiosk}

In de tweede helft van 2002 heeft IKAT het project EMMII Kiosk (EMMI Kiosk 2002) uitgevoerd. Dit project heeft het onderdeel Kiosk van EMMI aanzienlijk gemoderniseerd en eenvoudiger in het gebruik gemaakt. Het project is uitgevoerd in samenwerking met de Regiopolitie Limburg-Zuid, de Kreispolizei Aachen en de Federale politie van Eupen en Genk. Het project is gefinancierd door de Euregio Maas-Rijn, de Nederlandse provincie Limburg, de Regiopolitie Limburg-Zuid, de Kreispolizei Aachen en de Federale politie van Eupen en Genk.

De informatie die op een Kiosk wordt gepubliceerd wordt slechts incidenteel door een IRC zelf gegenereerd. Meestal is de informatie afkomstig van het regionale of nationale politiçle Intranet. Dit Intranet is voor de EMMI-partners vanzelfsprekend niet benaderbaar, waardoor het kopiëren van informatie nodig is. Daarnaast wordt een deel van de informatie die door een IRC op een Kiosk is gepubliceerd, om dezelfde reden door IRC's van andere EMMI-partners gekopieerd en gepubliceerd op hun Intranet. 
In de oorspronkelijke opzet van de Kiosk werden de websites in de EMMI-kiosk opgemaakt en aangepast met behulp van de tool FrontPage van Microsoft. Deze tool vereist een technisch niveau van de gebruiker dat helaas niet altijd haalbaar is in de IRC's. Verder vroeg het kopiëren van informatie van en naar het Intranet te veel handelingen. Er was dus behoefte aan cen eenvoudigere en snellere manier om informatie op de Kiosk te publiceren en om informatie van en naar de Intranetten te kopiëren. De Intranetten staan niet in verbinding met het EMMI-netwerk. Dit houdt in dat gebruikers van het Intranet niet automatisch toegang hebben tot het EMMI-netwerk en dus ook geen toegang hebben tot de informatie die zich op het andere Intranet bevindt.

Om ervoor te zorgen dat de gebruikers van het ene netwerk toch op de hoogte kunnen worden gesteld van informatie (niet zijnde persoonsgegevens) dat op een ander netwerk staat, worden kiosken gebruikt. Een kiosk vormt dan een tussenstation voor een Intranet en het EMMI-netwerk. De oplossing van EMMII Kiosk voorziet zowel kiosken op de Intranetten (bijvoorbeeld de kiosk op het PILZ) als op het EMMI-netwerk (bijvoorbeeld de kiosk van het IRC-Limburg). Op de kiosken van het EMMI-netwerk staan berichten die zijn samengesteld uit informatie van het aangrenzende Intranet. Het betreft alle informatie die relevant is voor de EMMI-partners. Zo staan er op de kiosk van het IRC Limburg berichten die hun oorsprong hebben in websites die op het PILZ staan. Een kiosk op het Intranet bevat daarentegen berichten die afkomstig zijn uit kiosken op het EMMI-netwerk en die relevant zijn voor de gebruikers van het Intranet. De kiosk op het PIL Z kan berichten bevatten die van een Duitse kiosk op het EMM1-netwerk gekopieerd zijn en die interessant zijn voor de gebruikers van het PILZ. Derhalve vindt er op adequate wijze verspreiding van informatie over de grens plaats. Nu kunnen berichten die hun oorsprong hebben op het Nederlandse (regionale) Intranet eindigen in een kiosk op het Duitse Intranet, en andersom.

\section{Overname eigendom EMMI door BZK en nieuwbouw EMMI}

Midden 2002 is EMMI door de Nederlandse Coöperatie Informatiemanagement Politic (CIP), die de vraag van alle Nederlandse regionale politietegio's coördineert, bestempeld tot landelijk politiesysteem. Op 23 juni 2003 is door het Ministerie van Binnenlandse Zaken en Koninkrijksrelaties (BZK) het formele besluit genomen om de eigendom van EMMI over te nemen, althans het beheer ervan. Formeel ligt de eigendom van het EMMI-concept bij de oorspronkelijke, hierboven genoemde, EMMI-partners. Het beheer van EMMI komt door de beslissing van BZK te liggen bij de ITO van de Nederlandse politie, een agentschap van BZK. De intentie is om nog in 2003 tot een nieuwbouw van de EMMI-omgeving te komen, waarbij de huidige functionaliteit van EMMI wordt behouden, maar in een nog moderner jasje wordt gestoken. De nieuwste ontwerptechnieken zullen daarvoor worden toegepast. Ook wordt in dit kader een technische koppeling gerealiseerd tussen PALMA en het Nederlandse LURIS. 


\section{EMMI derde traject}

In het Europese onderzoek EMMI derde traject, dat is gefinancierd door het DirectoraatGeneraal Informatie van de Europese Commissie en uitgevoerd door IKAT, staat het zogeheten derde en laatste traject van het EMMI-project centraal. Het onderzoek ziet op 'Further Legal Research on Trans-border Communication Standardization. ${ }^{17}$ Het betreft vier juridische en organisatorische vraagstukken die nog niet beantwoord zijn in de juridische onderzoeken 'Politie en Intranet' en 'NORMA+': (1) de al dan niet wenselijkheid van verdragswetgeving aangaande de rechtstreekse geautomatiseerde toegang tot (politięle) databases op een internationaal Intranet zoals EMMI; (2) de wijze waarop in het kader van de grensregionale politiële gegevensuitwisseling met zachte gegevens dient te worden omgegaan; (3) de afgrenzing van de werkzaamheden van Europol ten opzichte van de werkzaamheden van de IRC's; en (4) de samenwerking en de gegevensuitwisseling met de veiligheidspartners in grensregionaal verband.

\section{De toekomst van EMMI}

EMMI voorziet in een relatief nieuwe 'samenwerkingsmarkt': de politiële en justitiële behoefte aan snelle grensoverschrijdende informatie-uitwisseling voor het 'gewone' werk, zijnde voornamelijk ordehandhaving, verkeerstoezicht en de zogenoemde kleinere criminaliteit. Het is een aanvulling op de samenwerkingsverbanden Europol, dat vooral op het gebied van de georganiseerde misdaad werkzaam is, en Interpol, dat een wereldwijd netwerk is, maar in de grensregionale praktijk niet echt geschikt is gebleken voor de genoemde 'nieuwe informatiemarkt, ${ }^{18}$ EMMI wordt thans gebruikt door twintig (grensregionale) politiekorpsen in vier landen: Nederland, België, Duitsland en Frankrijk. Er bestaat interesse voor deze informatieve samenwerkingsvorm in Luxemburg, Denemarken, Polen, Hongarije, Slovenië en Oostenrijk. Het streven is erop gericht om te komen tot een internationale beheersorganisatie onder auspiciën van het Nederlandse Ministerie van BZK. Alle betrokken landen zullen erin participeren en de beheers-, ontwikkelingsen uitbreidingsactiviteiten zullen centraal aangestuurd worden.

Hoewel EMMI primair ontwikkeld is voor een snelle elektronische communicatic en gegevensuitwisseling tussen politiepartners in het grensgebied, is de omgeving technisch gesproken perfect toepasbaar voor alle Europese politiekorpsen en aanverwante organisaties, zoals de partners die instaan voor de OOV. De toepassing van EMMI is geen technisch probleem meer, maar een juridisch en organisatorisch vraagstuk.

17. EMMI Technical Annex, October 1999; Verbeek, Claus \& Van den Herik 2003.

18. De Heus 2000 en 2002. 


\subsection{Probleemstelling}

Hieronder behandelen wij de hoofdvraag van het onderzoek in subsectie 1.3.1. Vervolgens worden in subsectie 1.3.2 drie aanvullende onderzoeksvragen geformuleerd. De aanvullende onderzoeksvragen vallen binnen het kader van de hoofdvraag. $\mathrm{Zij}$ hebben evenwel betrekking op heel specifieke deelonderwerpen van de hoofdvraag en worden daarom afzonderlijk behandeld.

\subsubsection{Hoofduraag}

De concrete hoofdvraag die dit onderzoek beoogt te beantwoorden, is verwoord in de volgende probleemstelling:

"Kan er een juridisch kader worden ontwikkeld dat een beveiligde koppeling tussen nationale politienetwerken mogelijk maakt in het kader van de Europese grensrogionale informatieve samenwerking?"

Deze hoofdvraag wordt beantwoord in de hoofdstukken 5 en 6.

Met betrekking tot de probleemstelling laten zich twee deelvragen formuleren. De eerste deelvraag luidt:

"Voldoet de bestaande nationale en internationale wet- en regelgeving aan de voorwaarden die gesteld worden aan een adequate geautomatiseerde (multimediale) politiële gegevensuitwisseling?"

Bij de beantwoording van deze vraag in de hoofdstukken 5 en 6 dient een evenwicht gevonden te worden tussen de juridische mogelijkheden en eisen op het terrein van de uitwisseling van politiële gegevens enerzijds, en de technische mogelijkheden en beperkingen om te kunnen voldoen aan de juridische normen anderzijds. Voor de beantwoording van deze vraag dient onderzocht te worden:

1. hoe het EMMI-concept ingepast kan worden binnen de bestaande wet- en regelgeving, en

2. op welke gebieden nadere regulering noodzakelijk is, wil het EMMI-concept zonder wettelijke belemmeringen geïmplementeerd kunnen worden in de Europese grensregio's.

Een nauwe afstemming tussen de technische randvoorwaarden en de juridische normering is daarvoor onontbeerlijk. De tweede deelvraag, die beantwoord wordt in hoofdstuk 5, luidt derhalve: 
"Welke technische randvoorwaarden en juridische waarborgen zijn vereist voor de betrouwbaarheid van gebruik en gebruiker, als ook ten aanzien van de bescherming van de persoonlijke levenssfeer, in het bijzonder wanneer het om gevoelige (persoons) gegevens gaat?"

\subsubsection{Drie aanvullende onderzoeksuragen}

Wij komen hieronder tot een formulering van drie aanvullende concrete onderzoeksvragen.

De eerste aanvullende onderzoeksvraag, die beantwoord wordt in hoofdstuk 5, luidt als volgt.

"Hoe worden zachte politiële gegevens in de Nederlandse, Belgische en Duitse rechtsorde juridisch beschermd en hoe dient ermee omgegaan te worden in het kader van de grensregionale politiele gegevensuitwisseling?"

De tweede aanvullende onderzoeksvraag, die beantwoord wordt in hoofdstuk 7, luidt als volgt.

"Welke juridische keuze dienen de Raad van Europa en de Europese Unie te maken met betrekking tot het vraagstuk van de rechtstreekse geautomatiseerde grensoverschrijdende toegang van buitenlandse opsporingsambtenaren tot nationale (politiële) databases en computernetwerken, mede in het licht van de internationale juridische ontwikkelingen betreffende digitale expertise?"

De derde aanvullende onderzoeksvraag, die beantwoord wordt in hoofdstuk 8, luidt als volgt.

"Waar liggen de juridische grenzen tussen de werkzaamheden van Europol en de werkzaambeden van de IRC's?"

\subsection{Afbakening onderzoeksdomein}

EMMI wenst zich uitdrukkelijk in het kader van het Verdrag van Amsterdam en het Akkoord van Schengen en de SUO te manifesteren. Daarom ligt de nadruk in dit onderzoek op de juridische implicaties van het Schengenregime (dat thans valt onder het Verdrag van Amsterdam) voor de geautomatiseerde politiële uitwisseling van gegevens in het grensgebied.

De SUO regelt de grensoverschrijdende politiële samenwerking op formele wijze. $\mathrm{Zij}$ biedt een wettelijk kader voor grensoverschrijdende samenwerking. Tot 1995 bestond zo'n wetrelijk kader eigenlijk niet. Wel waren er diverse ad hoc afspraken en overeen- 
komsten. In dit onderzoek zal uitdrukkelijk aandacht worden besteed aan de SUO zelf, alsmede aan de nationale uitvoeringswetgeving van de betrokken landen ter zake. Men moet hierbij voor Nederland denken aan Boek IV, Titel X Sv, met name artikel $552 i$ lid 2 Sv betreffende de politiële uitwisseling van inlichtingen zonder de toepassing van dwangmiddelen. Van grote invloed voor de praktijk is de richtlijn van 23 novembet 1994 van het College van Procureurs-Generaal inzake de toepassing van artikel 552i Sv.

Bijzondere aandacht zal worden besteed aan de positionering van de politiele rechtshulp binnen de traditionele internationale kleine rechtshulp in strafzaken. De bepalingen van de SUO houden namelijk een vernieuwing in van het rechtshulpconcept, in die zin dat zij voor het eerst een uitdrukkelijke rechtsbasis voor politiële rechtshulp bieden. Verder bespreken we de van kracht zijnde bilaterale overeenkomsten tussen Nederland en Belgie en tussen Nederland en Duitsland ter zake van de grensoverschrijdende politiele uitwisseling van gegevens.

Ook de privacywetgeving ter zake wordt onder de loep genomen. Voor Nederland is deze wetgeving voornamelijk neergelegd in de Wet politieregisters (met name artikel 18 lid 1 WPolr), het Besluit politieregisters (met name artikel 13 BPolr) en aanvullend in de Wet bescherming persoonsregistraties (Wbp).

Wij staan ook stil bij internationale teksten die voor de bescherming van persoonsgegevens als leidend moeten worden gezien. We noemen in dit verband de Conventie nr. 108 van 28 januari 1981 van de Raad van Europa (het Databeschermingsverdrag), de Aanbeveling R (87) 15 van de Raad van Europa over de bescherming van persoonsgegevens in de politiële sector, en de EU-privacyrichtlijnen 95/46/EG en 2002/58/EG. De laatste is een nieuwe Europese richtlijn inzake privacy en elektronische communicatic, die richtlijn 97/66/EG (de zogenaamde ISDN-richtlijn) vervangt. Verder zijn natuurlijk de nationale Constituties en artikel 8 van het Europees Verdrag tot bescherming van de Rechten van de Mens en de fundamentele vrijheden (EVRM) leidend voor ons onderzoek. Ten slotte maken wij ook een kort uitstapje naar (1) het Cybercrimeverdrag van de Raad van Europa ${ }^{19}$ uit 2001, het eerste internationale verdrag dat betrekking heeft op strafbare feiten die gepleegd zijn via het Internet of andere computernetwerken, zowel publick als privaat en (2) de EU-Overeenkomst betreffende de wederzijdse rechtshulp in strafzaken van 2000 . Uit deze verdragswetgeving lichten wij enige relevante regelingen omtrent digitale politiële expertise in een internationale opsporingsomgeving. Dit domein is mede leerzaam voor de juridische keuzes die voor de toekomst van de internationale informatieve politiesamenwerking gemaakt dienen te worden.

19. Convention on Cybercrime, Cowncil of Europe, European Treary Series (ETS), no, 185. November 23, 2001. 
De praktijksituatie beschrijven wij aan de hand van de op dit moment binnen de IRC's gehanteerde wijze van uitwisseling van gegevens met het buitenland. Tevens geven we aan op welke rechtsbasis dit geschiedt. De (juridische) organisatiestructuur van de internationale kleine rechtshulp in strafzaken wordt hierbij ook besproken. Om de praktijksituatie goed te kunnen begrijpen, laten we een technisch-functionele beschrijving van het PALMA-concept en van het EMMI-concept aan de juridische verhandeling voorafgaan.

De internationale regelgeving voor de politiële samenwerking verwijst vaak naar de nationale wetgeving. Daarom wordt eveneens aandacht besteed aan de in Beigië en Duitsland geldende nationale wetgeving ter zake van de uitwisseling van politiële gegevens met het buitenland. Een complicerende factor is dat er verschillende regelgevingen van toepassing zijn in de drie betrokken landen.

Het is van belang op te merken dat er bij politièle gegevensuitwisseling sprake is van een gelaagdheid van de internationale en nationale wet- en regelgeving. Dit wil zeggen dat er verschillende lagen van wet- en regelgeving tegelijkertijd van toepassing zijn, terwijl er niet per definitie een onderlinge voorrang tussen de toepasselijke normen bestaat. ${ }^{20}$ Daarom ontkomen wij in dit onderzoek niet aan een brede uiteenzetting van de toepasselijke lagen van wet- en regelgeving. De toepasselijke norm is niet altijd eenvoudig te vinden. Eigenlijk zou de toepasselijke wet- en regelgeving over de lagen heen moeten worden gelegd om in een specifiek geval de precieze toepasselijke norm te vinden. De verschillende lagen van wet- en regelgeving moeten al dan niet tegelijkertijd worden toegepast. Deze noodgedwongen gecompliceerdheid is nu eenmaal eigen aan de onderzochte materie.

\subsection{Plan van aanpak}

In hoofdstuk 2 contrasteren wij de traditionele wijze en de huidige wijze waarop in de grensregionale politiële praktijk gegevens grensoverschrijdend worden uitgewisseld. De daarbij betrokken organisaties en instellingen worden besproken. In hoofdstuk 3 wordt het PALMA-concept beschreven en in hoofdstuk 4 het EMMI-concept.

$\mathrm{Na}$ de beschrijving van de praktijksituatic wordt in hoofdstuk 5 de beantwoording van de hoofdvraag van het onderzoek aangevat. Het hoofdstuk begint met een uitwerking van de juridische structuur van kleine rechtshulp in Nederland, met een onderverdeling in justitiële en politiële rechtshulp. Op deze laatste vorm van rechtshulp zal vervolgens

20. Er is dus geen sprake van gelede normstelling. Daarbij is namelijk wel per definitic een onderlinge voorrang van de toepasselijke normen aanwezig. Bij gelede normstelling zijn de verschillende lagen hiërarchisch aflopend. 
nader worden ingegaan. De internationale teksten ter zake van de politiêle uitwisseling van gegevens alsmede de verschillende nationale wetgevingen van Nederland, Belgiê en Duitsland worden besproken. Wij gaan daarbij tevens uitdrukkelijk in op de wijze waarop in grensregionaal verband dient te worden omgegaan met zachte politicle gegevens. Dit ter beantwoording van de eerste aanvullende onderzoeksvraag (zie in het bijzonder subsectie 5.6.3). Zachte gegevens zijn in dit verband gegevens die nog niet zijn bevestigd en die nog niet mogen worden gebruikt voor de bewijsvoering.

In hoofdstuk 6 gaan wij verder met de beantwoording van de hoofdvraag van het onderzoek. Het hoofdstuk beschrijft daartoe de Nederlandse visie op het koppelen van gegevens. Het blijkt dat de wetgever slechts uit is gegaan van het eenvoudig koppelen van databases. Moderne technieken geven echter anleiding tot diverse andere manieren om informatic op het spoor te komen. Juridisch gezien zijn hier nog veel obstakels aanwezig.

Hoofdstuk 7 voert ons in het domein van de digitale expertise van de politie die opsporing verricht over de fysieke landsgrenzen en de grenzen van cyberspace heen. Wij behandelen het Cybercrimeverdrag uit 2001 en de EU-Overeenkomst betreffende de wederzijdse rechtshulp in strafzaken uit 2000 . Wij proberen ter beantwoording van de tweede aanvullende onderzoeksvraag uit dit aangrenzend onderzoeksdomein iets te leren in verband met de noodzaak (of in ieder geval de wens van bepaalde Europese politiediensten) tot het in het leven roepen van een adequate regeling voor het centrale vraagstuk van de directe grensoverschrijdende toegang van buitenlandse politicambtenaren tot nationale computernetwerken, -bestanden en databases.

Ten slotte onderzoeken wij in hoofdstuk 8 , ter beantwoording van de derde aanvullende onderzoeksvraag de juridische grenzen die bestaan tussen de werkzaamheden van Europol en de werkzaamheden van de IRC's.

In hoofdstuk 9 geven wij de conclusies van het onderzoek. In onze conclusies formuleren wij een synthese van de bestaande praktijk en de juridische normering. Uit de conclusies komt duidelijk naar voren wat de relevante juridische kaders zijn, wat de daaruit voortvloeiende juridische problemen zijn, en wat daarvan de organisatorische implicaties voor de betrokken politiediensten zijn. De conclusies beantwoorden in essentie de vraag: "Wat is zowel juridisch deugdelijk als technisch goed te realiseren?" De juridische dimensie houdt een zorgvuldige afweging in van het recht op de persoonlijke levenssfeer van de burger ten opzichte van het belang van een geautomatiseerde opsporing in de grensgebieden. 



\section{Grensregionale politiële gegevensuitwisseling in de praktijk}

Het verkrijgen van politiele gegevens uit het buitenland verloopt traditioneel op formele wijze via met name het kader van Interpol. ${ }^{21}$ In Nederland fungeert de DIN van het KLPD als Nationaal Bureau voor Interpol ${ }^{22}$ en als nationale cenheid voor Europol. De verdragsrechtelijke kaders voor de zogenaamde kleine rechtshulp in strafzaken zijn niet rechtstreeks op deze gegevensuitwisseling van toepassing. Genoemde kaders geven geen duidelijke regeling voor de grensoverschrijdende gegevensuitwisseling tussen politiediensten onderling. Zij zien in beginsel slechts op de justitiële rechtshulp tussen justitiële instanties (Ministeries, het $\mathrm{OM}$, et cetera, al naargelang de invulling die de betreffende verdragsstaat hieraan geeft).

De op 26 maart 1995 in werking getreden SUO is het eerste tastbare juridische instrument voor de politiële gegevensuitwisseling. Het is de belangrijkste verdragsrechtelijke basis voor politiële samenwerking tussen aanvankelijk zeven Europese lidstaten: Nederland, Belgiè, Duitsland, Luxemburg, Frankrijk, Spanje en Portugal. Op grond van het Verdrag van Amsterdam met bijbehorend Protocol tot opneming van het Schengenacquis in het kader van de Europese Unie, behoort de SUO sinds 1 mei 1999 tot het zogenoemde 'acquis communautaire' (de communautaire verworvenheden) van de EU. De SUO geldt sindsdien tussen de volgende dertien Europese lidstaten: Nederland, Belgiě, Duitsland, Luxemburg, Frankrijk, Spanje, Portugal, Denemarken, Griekenland, Italië, Oostenrijk, Finland en Zweden. In 2000 zijn ook het Verenigd Koninkrijk en Noord-Ierland tot het samenwerkingsverband toegetreden en in 2002 lerland (zie sectie 5.2). De juridische Schengeneisen ten aanzien van de politiële gegevensuitwisseling bouwen voort op het Databeschermingsverdrag van de Raad van Europa uit 1981 alsmede op Aanbeveling R (87) 15 van de Raad van Europa uit 1987.

21. De Internationale Organisatie van Criminele Politie (I.C.P.O.-Interpol).

22. De IRC's handelen de gegevensuitwisseling rechtstreeks met de Nationale Bureaus van Interpol af, met afschrift aan de DIN. 
De verschillende nationale wetgevingen voor de politieregisters en de bescherming van persoonsgegevens blijken bij de uitwisseling van heel groot juridisch en praktisch belang te zijn. Wij komen hierop terug in hoofdstuk 5 . Uit de wet- en regelgeving volgt direct de officiële procedure. De hoofdregel is dat de politie voor informatic uit het buitenland contact opneemt met de instantie die de informatie op landelijk niveau (in Duitsland eventueel op Bondsstaatsniveau) beheert. Deze procedure werkt vertragend, alleen al omdat er geen vierentwintig-uurs bereikbaarheid bestaat. Voor het geven van informatie aan het buitenland gelden analoge regels. Gegevensuitwisseling in de grensgebieden is echter op een specifieke andere wijze geregeld (zie hoofdstuk 5).

Dit hoofdstuk geeft een overzicht van de manier waarop in de politiële praktijk van de Europese grensregio's gegevens worden uitgewisseld met het buitenland. Daarbij worden en passant diverse organisaties en instellingen besproken. Wij beginnen met een bespreking van de situatie tot 1996 waarin nog geen sprake was van geautomatiseerde gegevensuitwisseling. Zo'n traditionele grensregionale gegevensuitwisseling geldt overigens op dit moment nog voor heel wat grensregio's en Euregio's in Europa (zie sectie 2.1). Als opmaat voor een uitgebreide bespreking van het PALMA- en EMMI-concept, beschrijven we resultaten van de nieuwe ontwikkelingen kort. Wij leggen vooral de nadruk op de voordelen die cen geautomatiseerde grensregionale communicatie- en informatievoorziening oplevert (zie sectie 2.2).

\subsection{Traditionele grensregionale gegevensuitwisseling}

Gegevensuitwisseling is de meest voorkomende vorm van politiële samenwerking. ${ }^{23} \mathrm{De}$ gegevens die de verschillende politiediensten binnen Nederland, Belgiě en Duitsland in verband met grensoverschrijdende samenwerking uitwisselen, hebben van oudsher hoofdzakelijk betrekking op personen (achtergrondinformatie en vermissingen) ${ }^{24}$ en voertuigen (tenaamstelling van kentekens). In de grensregio's worden hoofdzakelijk gegevens uitgewisseld die in verband staan met het 'gewone politiewerk': ordehandhaving, verkeerstoezicht en de zogeheten 'kleinere' criminaliteit. ${ }^{25}$ Deze informatie-uitwisseling vond tot 1996 op een niet-adequate en ongestructureerde wijze plaats. In deze sectie behandelen wij de traditionele gegevensuitwisseling in de Europese grensregio's zoals die

23. Andere vormen van samenwerking zijn grensoverschrijdende achtervolging en observatic. Uit vraaggesprekken met politiediensten van de betrokken landen in de Euregio Mass-Rijn bleck reeds in 1993 dat gegevensuitwisseling het meest voorkomt. Het onderzock werd uitgevoerd door het Instinute for Reseanch on Intercultwnal Coopenation (IRIC) en het Maastrichts Europees Instituut voor Transnationaal Rechtswetenschappelijk Onderzock (METRO) in Duirsland en Nederland, en door de Universite Catbolique de Lownain-L-Newte (UCL) en de Katholieke Universiteit Leuven (KUL) in Beigiē; Hofstede, Twuyver, Kapp, de Vries, Faure, Claus, $\$$ van der Wel 1993, p. 16 en 22.

24. Hofstede, Twuyver, Kapp, de Vries, Faure, Claus, \& van der Wel 1993, p. 15.

25. Van Dorp, Verbeek \& Van den Herik 2001. 
plaatsvond tot 1996, het jaar waarin de grensregionale gegevensuitwisseling geautomatiseerd werd. Tot die tijd vond de grensregionale gegevensuitwisseling hoofdzakelijk plaats via telefoon en fax. Er vond bijna geen registratie plaats van de informatie-uitwisseling. Enkel in Maastricht was sinds 1994 een registratiedatabase in gebruik. In subsectie 2.1.1 behandelen wij de informele samenwerking. Subsectic 2.1.2 bespreekt de organisaticstructuur van de IRC's. Subsectie 2.1.3 geeft de officiële en officieuze communicatielijnen weer die binnen de grensregionale gegevensuitwisseling in Europa bestaan. In subsectie 2.1.4 geven wij enige obstakels aan voor de informatieve politiesamenwerking. Subsectie 2.1 .5 behandelt de traditionele communicatiemiddelen voor de grensregionale politiele gegevensuitwisseling. In subsectie 2.1 .6 bespreken wij hoe traditioneel de vastlegging en de afhandeling van de grensregionale gegevensuitwisseling plaatsvindt. Subsectie 2.1 .7 geeft aan dat verschillen in de Europese politicorganisaties een complicerende factor zijn voor een goede informatieve politiesamenwerking. In subsectie 2.1.8 wijzen wij er ten slotte op dat ook het verschil in automatisering tussen de Europese politieorganisaties de informatieve politiesamenwerking in de grensregio's aanzienlijk bemoeilijkt(e).

\subsubsection{Informele samenwerking}

De politiēle samenwerking vindt in de praktijk over het algemeen nog op een weinig gestructureerde manier plaats. De gegevensuitwisseling blijkt vooral op de lagere niveaus binnen de politieorganisaties plaats te vinden. ${ }^{26}$ De formele weg wordt vanwege het gebleken tijdrovende en ondoorzichtige karakter door de politiekorpsen als niet bevredigend ervaren. Veel uitwisselingen vinden als gevolg daarvan plaats via informele persoonlijke contacten met collegae in het buitenland. Het principe van wederkerigheid staat centraal: als $x$ gegevens verschaft aan $y$, doet $y$ dat aan $x$. Verder geldt het principe dat men nooit iets 'eist' van een buitenlandse collega wat hij of zij redelijkerwijs niet mag doen, omdat hij of zij bestraft zou kunnen worden. Als gegevens officieel gebruikt gaan worden, vermeldt men elkaar soms niet als bron. Men weet niet goed wanneer men toestemming nodig heeft van het OM voor de gegevensuitwisseling. Vaak wordt ook spontaan informatie verstrekt aan buitenlandse collega's zonder dat zij daarom hebben gevraagd. Het betreft dan bijvoorbeeld waarschuwingen dat bepaalde individuen de grens dreigen te passeren en de signalering van verdachte personen. De officiële weg wordt wel bewandeld in ongewone (zwaardere) gevallen en ook achteraf, als gegevens officieel gebruikt gaan worden. Het algemene beeld is dat er weinig controle plaatsvindt op de gegevensuitwisseling. ${ }^{27} \mathrm{De}$ informele wijze van infor-

26. Hofstede, Twuyver, Kapp, de Vries, Faure, Claus, \& van der Wel 1993, p. 22.

27. Hofstede, Twuyver, Kapp, de Vries, Faure, Claus, \& van der Wel 1993, p. 23 en 24. De Parlementaire Enquetrecommissie Van Traa constateerde in 1996 hetaelfde; Enquettecommisie opsporingsmethoden 1996, p. 292-302 en p. 458. In de praktijk wordt geen adequate controle uitgeoefend door de nationale gegevensbeschermingrautoriteiten. 
matievergaring heeft, nog los van de vraag of de informele contacten juridisch door de beugel kunnen, de volgende nadelen.

- De grensoverschrijdende gegevensuitwisseling staat of valt met het kennen of gekend worden en is daarmee niet structureel. Men is afhankelijk van de aanwezigheid van de betreffende contactpersoon in het buitenland. Zijn afwezigheid kan een politieel onderzoek aanzienlijk vertragen.

- De uitwisselingen worden niet als zodanig geregistreerd. Derhalve zijn zij oncontroleerbaar en tevens in strijd met de SUO, zoals zal blijken in hoofdstuk 5.

Dat de politic zijn toevlucht neemt tot zo'n informeel circuit, geeft aan dat zij onvoldoende op de hoogte is - of in ieder geval was - van de mogelijkheid van het direct aan elkaar doorgeven van bepaalde gegevens. Dit is juridisch namelijk toegestaan op basis van afspraken tussen verschillende nationale politiediensten, zoals zal blijken in hoofdstuk 5. De kennis van de regels voor internationale gegevensuitwisseling is mager. ${ }^{2 s}$ Dit kan een verklaring zijn voor de vermeende onduidelijkheid van de regels. De betreffende politieambtenaren zeggen vaak niet meer te weten dan dat zij de instantie moeten inschakelen die de gegevens op landelijk niveau beheert: in België is dit het Commissariaat-Generaal, directie voor het beleid inzake Internationale politiēle samenwerking (CGI) van de Federale Politie te Brussel, in Duitsland het Bundeskriminalamt (BKA) te Wiesbaden of het Landeskriminalamt (LKA) en in Nederland de DIN te Zoetermeer. Wellicht dat de klachten over het gebrek aan duidelijke regels afnemen als de kennis van de bestaande regels toeneemt. Het is evenwel zo dat de regelingen omtrent internationale politiële gegevensuitwisseling erg complex zijn, omdat de nationale en internationale wetgever een geheel sluitend systeem heeft willen maken waarin de privacy van de burger op adequate wijze wordt beschermd.

\subsubsection{De IRC's}

Om aan de registratie-eis van de SUO te voldoen, zijn in Nederland, België en Duitsland voorzieningen getroffen om de Euregionale - en in de nabije toekomst ook van de Europese - politiële gegevensuitwisseling vast te leggen. Dit gebeurt met behulp van de daarvoor opgezette (grensregionale) IRC's: het IRC in Nederland, het Operationeel InvalsPunt in Grensgebieden (OIPG) in België en de Regionale VerbindungsSTelle (RVST) in Duitsland. De uitwisseling tussen deze IRC's is formeel van aard en vindt plaats binnen het officiële wettelijke kader. Tussen de IRC's stromen gegevens heen en weer. Er zijn

28. Hofstede, Twuyver, Kapp, de Vries, Faure, Claus, \& van der Wel 1993. p. 25. Exemplarisch is in dit verband ook de opmerking van een medewerker van het Nederlandse Ministerie van Justitie tijjdens dit onderzoek, dat "men weleens in het Duitse wetboek van strafrecht kijkt", maar verder alleen contact heeft met de Staatsanuvalt (StA). Men heeft blijkbaar niet echt cen idee hoe de wetgeving er an de andere kant van de grens uitriet. 
twee soorten van gegevensaanvragen te onderscheiden, namelijk (1) binnenlandse aanvragen van buitenlandse gegevens en (2) buitenlandse aanvragen van binnenlandse gegevens. Belangrijk hierbij is dat, in overeenstemming met de regelgeving, slechts vragen die uit het grensgebied komen in behandeling worden genomen.

\section{De IRC's hebben van oudsher vier functies:}

1. een helpdesk-functie;

2. de coördinatie van operationele samenwerkingsacties;

3. de coördinatic van (grensoverschrijdende) opleidingen; ${ }^{29}$

4. management-ondersteuning.

De IRC's hebben met elkaar afgesproken dat het verstrekkende IRC de controle op de juistheid en de rechtmatigheid van de verstrekking verricht. Het ontvangende IRC behoeft geen rechtmatigheidscontrole meer uit te voeren. Het buitenland meldt niet waarvoor de verstrekte gegevens gebruikt zijn en wat het resultaat van het gebruik is geweest. Wettelijk gezien zou dit wel dienen te gebeuren (zie hoofdstuk 5).

Bij de regionale politiële informatievoorziening in Nederland zijn behalve de IRC's ook nog andere instanties betrokken:

- de Regionale Criminele Inlichtingeneenheid (RCIE);

- het Recherche Informatiebureau (RIB); het RIB valt onder de divisie Regionale Recherche en is gevestigd bij de DIN; het vervangt de oude ARI's, de Afdelingen Recherche Informatie;

- de Regionale Informatiedesks; deze zijn vaak ondergebracht bij de afdelingen georganiseerde criminaliteit van de recherche en ondersteunen de bestrijding van de georganiseerde criminaliteit.

Tussen het IRC, de RCIE en het RIB komt een functionele integratie tot stand. Men wil komen tot eén regionale infodesk die als aanspreekpunt fungeert. Op districtsniveau is dit al gerealiseerd.

Op grond van een richtlijn van de Procureurs-Generaal, kent Nederland sinds 2001 een landelijk dekkend netwerk van acht bovenregionale arrondissementale IRC's en tén landelijk L-IRC, de DIN. De IRC's behandelen alle politiele en justitiële rechtshulpverzoeken. Het zijn samenwerkingsverbanden van regionale politiekorpsen en arrondissementen van het OM. Bij het IRC-Noord, het IRC-Zuid-West en het IRC-Limburg neemt ook de KMAR aan dit samenwerkingsverband deel, vooralsnog op informele basis.

29. Hierbij is het Politie Opleidingscentrum (POC) betrokken. 
Doordat de Nederlandse IRC's nog in ontwikkeling zijn en regionaal zijn opgebouwd bestaan er verschillen in taken en taakinvulling tussen de IRC's. Door het College van Procureurs-Generaal en de Raad van Hoofdcommissarissen zijn initiatieven genomen om de IRC's uniform te laten functioneren. De IRC-structuur zal worden aangepast aan de organisatie van de nieuwe Nederlandse landelijke en (boven)regionale recherche. Het L-IRC en de IRC's zullen gezamenlijk functioneren als nationaal loket voor internationale rechtshulpverzoeken. De geherdefinieerde taken van de huidige regionale IRC's zijn:

- registratie van rechtshulpverzoeken in LURIS, het landelijk uniform registratiesysteem voor inkomende rechtshulpverzoeken;

- coördinatic (en voortgangsbewaking) op de uitvoering van rechtshulpverzoeken; en - toezicht op de kwaliteit van de afdoening van rechtshulpverzoeken.

\subsubsection{Communicatielijnen}

Tijdens het PALMA-project (zie subsectic 2.2.1) is een kleinschalige inventarisatie verricht van de officiële en officieuze communicatielijnen die reeds bestonden tussen de diverse bij het project betrokken IRC's. Tevens zijn toen enkele knelpunten bij de Euregionale gegevensuitwisseling in kaart gebracht. De officieuze communicatielijnen onttrekken zich verder aan registratic en (dus) aan controle achteraf.

\section{Officiële communicatielijnen}

De IRC's spelen een rol bij de volgende officiële communicatielijnen.

- Een individuele politieambtenaar doet een gegevensaanvraag aan het eigen IRC over nationaal beschikbare informatie.

- Een individuele politieambtenaar doet een gegevensaanvraag aan het eigen IRC over in het buitenland (hoofdzakelijk België en Duitsland) beschikbare informatie.

- Een buitenlands IRC doet een gegevensaanvraag aan een Nederlands IRC.

- Een Nederlands IRC doet cen gegevensaanvraag aan een buitenlands IRC.

- De IRC's maken gebruik van officiële informatiebronnen.

De bestaande officiële communicatielijnen waarmee de IRC's te maken hebben zijn aanschouwelijk weergegeven in Figuur 1. De figuur wordt rechts afgegrensd door _ _ _; dit geeft de Europese buitengrenzen aan. De informatie-uitwisseling met niet-Europese grensregio's geschiedt via de Interpolkanalen. In de figuur zien we de nationale Europese grenzen aangegeven met _. - . . . Alleen de IRC's communiceren met elkaar over de grenzen heen. De hoofdcommunicatie en -gegevensuitwisseling (aangegeven met dikke zware pijlen) verloopt van de aanvrager in een politickorps via twee IRC's naar de beantwoorder en terug. De IRC's beschikken over diverse informatiebronnen waaruit zij kunnen putten voor de beantwoording van een informatieaanvraag uit het buitenland (de lijnen daar naartoe zijn aangegeven met _... .... . Het betreft nationale databanken, onder welke het Nationaal Schengen Informatiesysteem (NSIS), evenals persoonlijke informatiebronnen en externe organisaties. De internationale gegevensuitwisseling wordt gere- 
gistreerd in een handmatig of geautomatiseerd gevoerd archief of in een zogeheten registratiedatabase. Een IRC is verplicht zonodig andere autoriteiten, onder welke het $O M$ of bepaalde gerechtelijke autoriteiten, om autorisatie te verzoeken voor bepaalde gegevensverstrekkingen aan het buitenland. Deze relatie is aangegeven met dunne zwarte pijlen.

Het gebruik van deze officièle communicatielijnen kent de volgende regels.

- Wanneer de aangevraagde gegevens vallen onder een speciaal wettelijk regime, wordt er autorisatie gevraagd aan de betreffende bevoegde instantic.

- De contacten met Interpol verlopen via de DIN.

- Bevraging van het NSIS en diverse nationale databanken behoort tot de mogelijkheden.

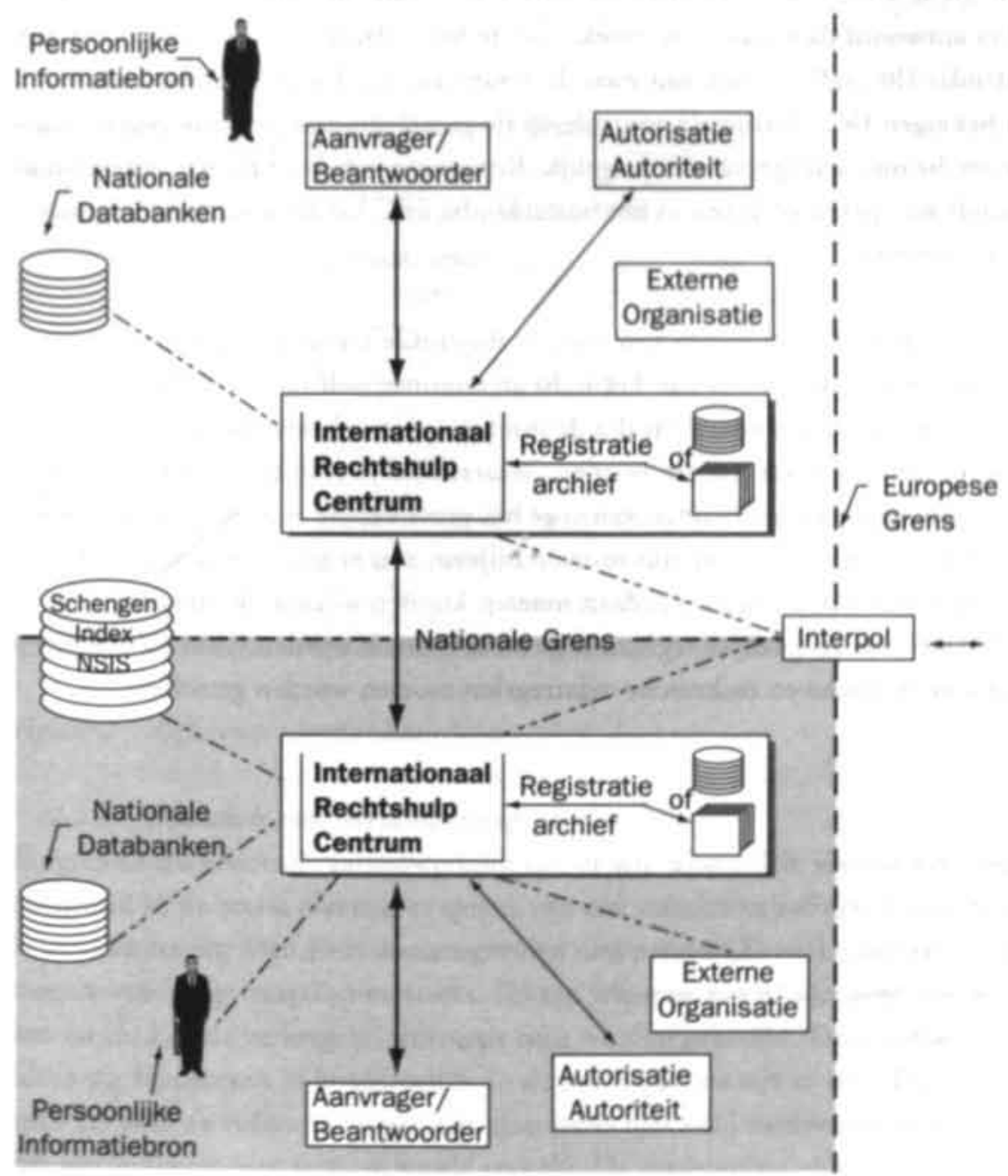

Figuur I Officièle communicatielijnen 


\section{Officieuze communicatielijnen}

Verder zijn de volgende officieuze communicatielijnen aangetroffen.

- Informatieverschaffing uit officieuze informatiebronnen.

- Informatieverschaffing door raadpleging van externe organisaties.

- Een aanvrager wendt zich niet tot het IRC van het eigen land, maar stelt de vraag direct aan een IRC of een collega in het buitenland.

De officieuze communicatielijnen zijn in Figuur 2 in beeld gebracht. In de praktijk werd voór de automatisering van de IRC's vaak rechtstreeks, dus zonder tussenkomst van het eigen IRC, contact opgenomen door de aanvrager aan de ene zijde van de grens met (1) een buitenlandse persoonlijke informatiebron, bijvoorbeeld een collega aan de andere zijde van de grens of met (2) een buitenlands IRC. De beantwoorder van de informatievraag gaf het antwoord dan vaak rechtstreeks aan de buitenlandse informatiebron of aan het buitenlandse IRC (afhankelijk van waar de vraag vandaan kwam), zonder tussenkomst van het eigen IRC. Nationale controle op de grensregionale politiële gegevensuitwisseling is in die omstandigheid niet mogelijk. Registratic van de officieuze gegevensuitwisseling vindt niet plaats of alleen in het buitenlandse IRC bij de beantwoording van het informatieverzoek.

De officieuze persoonlijke contacten zijn voor de dagelijkse samenwerking van groot belang. Zij onttrekken zich echter aan het zicht en daarmee ook aan controle achteraf. De politiepartners zijn het er over eens dat de huidige informele communicatielijnen in de nabije toekomst vermeden moeten worden. Waarschijnlijk zullen de informele contacten echter niet helemaal verdwijnen vanwege het grote belang voor de praktijk. Hoewel de informele contacten dus beperkt moeten blijven, zou er in voorkomende uitzonderlijke gevallen toch een beroep op gedaan moeten kunnen worden. Er zou van die contacten dan wel een deugdelijke registratie gevoerd moeten worden. Voor zo'n registratie zullen organisatorische en technische maatregelen moeten worden getroffen. 


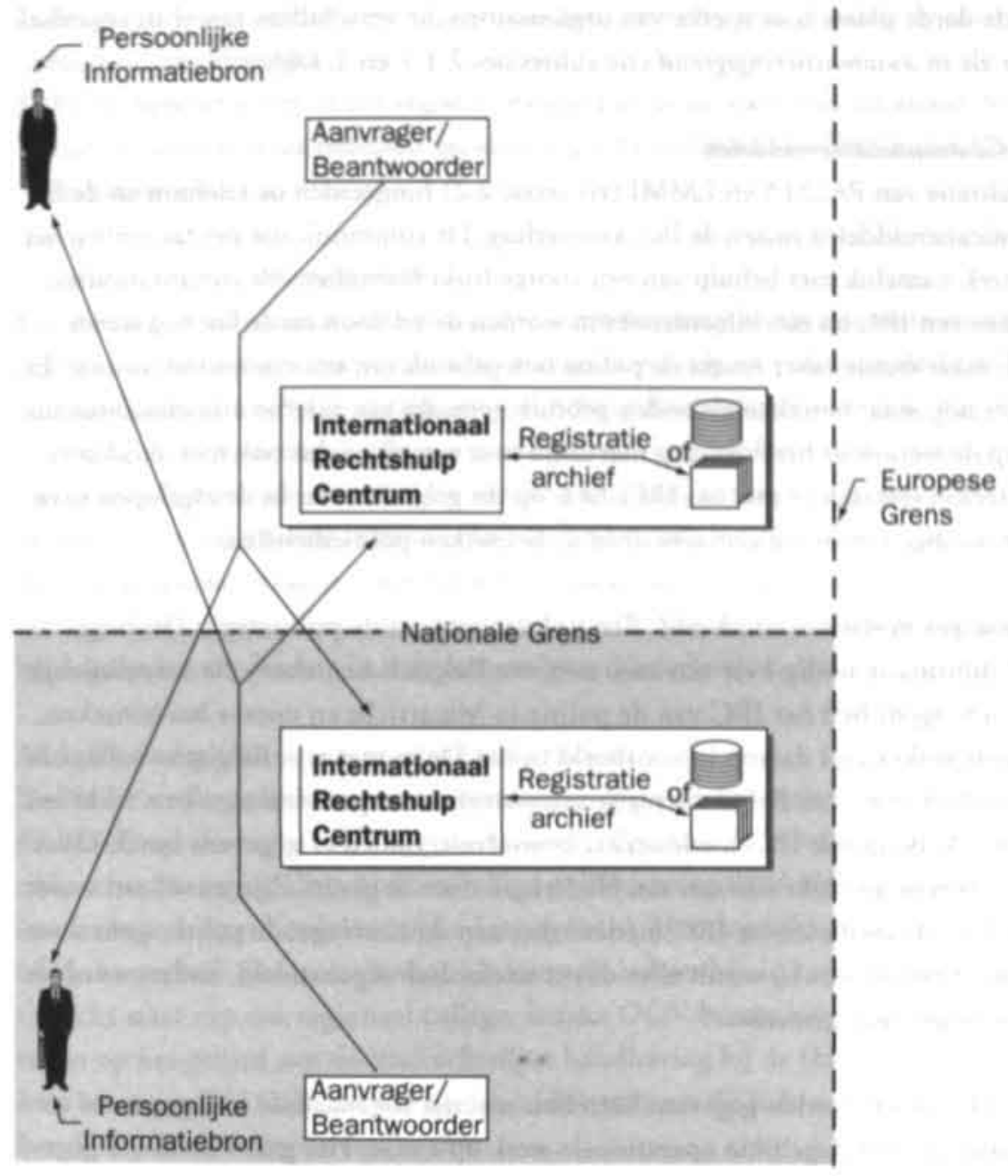

Figuur 2 Officieuze communicatielijnen

\subsubsection{Obstakels voor samenwerking}

Bij grensoverschrijdende samenwerking zijn er ten minste drie klassen van mogelijke obstakels. In de eerste plaats is er sprake van een verschil in politiek en wetgeving in de betrokken staten. Men weet dientengevolge niet precies (1) welke gegevens wel of niet mogen worden gevraagd en verstrekt, (2) aan wie men wel of niet gegevens mag verstrekken en (3) hoe de verkregen informatie mag worden gebruikt. Deze obstakels worden uitvoerig beschreven in hoofdstuk 5 . In de tweede plaats zijn er obstakels die voortkomen uit taal-en cultuurbarrieres. Uit interviews met IRC-medewerkers blijkt echter dat het taalprobleem niet zo sterk wordt gevoeld. De medewerkers blijken elkaars taal in voldoende mate te beheersen, met name binnen het domein van hun werk (zie subsectie 
2.1.5). In de derde plaats is er sprake van organisatorische verschillen, zowel in organisatiestructuur als in automatiseringsgraad (zie subsecties 2.1.7 en 2.1.8).

\subsubsection{Communicatiemiddelen}

Vò̀r de realisatie van PALMA en EMMI (zie sectie 2.2) fungeerden de telefoon en de fax als communicatiemiddelen tussen de IRC's onderling. De communicatie per fax verliep het meest formeel, namelijk met behulp van een voorgedrukt formulier. Als communicatiemiddel tussen een IRC en een informatiebron worden de telefoon en de fax nog steeds gehanteerd, maar steeds vaker maakt de politie ook gebruik van een computerterminal. Er wordt echter nog maar betrekkelijk zelden gebruik gemaakt van interne e-mailfaciliteiten. De agent op de werkvloer beschikt nog niet altijd over e-mail en dus ook niet altijd over een rechtstreekse verbinding met het IRC. Er is op dit gebied echter in de afgelopen twee jaar wel een aardige inhaalslag gemaakt door de betrokken politiediensten.

Ter illustratie geven wij een voorbeeld. Een politieagent uit de politieregio LimburgZuid heeft informatie nodig over een auto met een Belgisch kenteken, die vermoedelijk gestolen is. De agent belt het IRC van de politie in Maastricht en noemt het kenteken. De IRC-medewerker belt daarop bijvoorbeeld in het Duits met zijn Belgische collega in Eupen. Deze logt in op het Belgische registratiesysteem voor gestolen auto's en zoekt het nummer op. De Belgische IRC-medewerker beoordeelt, indien er gegevens beschikbaar zijn, of de gegevens geschikt zijn om aan Nederland door te geven. Zijn antwoord wordt vervolgens door de Nederlandse IRC-medewerker aan de aanvragende politieagent doorgegeven. Als er grote haast is, wordt alles direct telefonisch afgehandeld, anders wordt er van fax of post gebruik gemaakt.

De via de IRC's uitgewisselde gegevens betreffen meestal zogenaamde bulkgegevens ter ondersteuning van het dagelijkse operationele werk op straat. Het gaat vooral om gegevens over kentekens, rijbewijzen, naamsverificaties, signaleringen, voertuigen, antecedenten van personen en vreemdelingen. Het aantal gegevensaanvragen varieert van enige duizenden tot enige tienduizenden per contactpunt per jaar. Het aantal groeit nog steeds. Het IRC-Limburg te Maastricht verwerkt zo'n dertigduizend aanvragen per jaar.

\subsubsection{Vastlegging en afhandeling}

Elke gegevensuitwisseling wordt in principe gearchiveerd. In Duitsland gebeurt dat deels nog met behulp van een papieren archief, maar in België en Nederland wordt reeds met een elektronisch databestand gewerkt.

Tenzij reeds bekend is waar een gegeven zich bevindt, wordt bij de afhandeling van een gegevensaanvraag standaard de volgende zoekvolgorde toegepast.

1. Er wordt nagegaan of de gegevens al eerder zijn opgevraagd door het registratiearchief te raadplegen. 
2. Als de gegevens niet in het registratiearchief aanwezig zijn, worden de nationale databanken geraadpleegd.

3. Als de gegevens niet in het registratiearchief en in de nationale databanken te vinden zijn, worden externe bronnen geraadpleegd, bijvoorbeeld de Kamer van Koophandel en Fabricken.

\subsubsection{Verschil in onganisatie}

Een complicerende factor voor een goede samenwerking bij de internationale politièle gegevensuitwisseling is het verschil in de manier waarop de politie in de betrokken landen georganiseerd is. ${ }^{30}$ De organisatie- en bevoegdhedenstructuren zijn uitermate verschillend en vormen nogal eens een obstakel voor een goede communicatic. Men weet niet goed wie men aan de overzijde van de grens kan, moet en mag aanspreken. Het bestaan van verschillende instanties in én land maakt het niet eenvoudig om een adequate gegevensaanvraag te doen. Ook is het lang niet altijd zeker dat een antwoord wordt verkregen. Wij geven hieronder een kort overzicht van de verschillende organisatie- en bevocgdhedenstructuren van achtereenvolgens Nederland, Belgiě en Duitsland.

\section{Nederlandse onganisatie- en bevocgdhedenstructuur}

De Nederlandse politicorganisatie bestaat uit 25 relatief autonome politieregio's en het KLPD. De politieregio's zijn opgedeeld in de Algemene Politiedienst (APD) en de recherche. De regiopolitie heeft volledige politiebevoegdheid binnen de eigen regio en (onder beperkingen) ook landelijke bevoegdheid. Het dagelijks gezag en beheer berust bij de korpschef. Daarnaast berust het centrale beheer bij de korpsbeheerder die onder toezicht staat van een regionaal college. Inzake OOV berust het gezag bij de burgemeester en op het gebied van de strafrechtelijke handhaving bij de (Hoofd)OvJ. Het opperbeheer berust wat de OOV betreft bij het Ministerie van BZK en wat strafvorderlijke taken betreft bij het Ministerie van Justitie.

\section{Belgische organisatie- en bevoegdhedenstructuur}

België kent sinds 2002 een lokale en federale politie, met een vrij grote mate van centrale leiding. Op het lokale politieniveau worden de basisfuncties vervuld. Dit zijn niet alleen de uniformdiensten ${ }^{31}$ maar ook de relatief eenvoudige rechercheonderzoeken. Daarnaast dient de lokale politie in een aantal gevallen ook ondersteuning te verlenen aan opdrachten van federale aard. België is opgedeeld in 196 politiezones. De provincie Limburg bestaat uit 12 zones. ${ }^{32}$ Een voorbeeld is de zone HaZoDi. Dit staat voor Hasselt-Zonhoven-Diest. In vergelijking met de Nederlandse politieregio's zijn deze zones kleinscha-

30. Bevers \& Joubert, 1994, p. 39-58 en 84-94.

31. Wat in Nederland onder de APD zou vallen.

32. Zie het $K B$ van 27 december 2000 , houdende de indeling van het grondgebied van de provincie Limburg in politiezones, Belgisch Staatsblad (B.S.) 251, 30 december 2000. 
liger. Dit komt het contact met de bevolking ten goede. Overigens is reeds vanuit meerdere hoeken aangevoerd dat deze kleinschaligheid relatief duur is. Het ligt dan ook in de lijn der verwachting dat een aantal van deze zones vroeg of laat zullen worden samengevoegd. ${ }^{39}$

Op het federale niveau neemt de politie de specialistische onderzoeken en bepaalde specificke onderwerpen zoals computercriminaliteit, financiële, economische en georganiseerde criminaliteit voor haar rekening. Verder zorgt de federale politie ook voor het inzetten van bijzondere opsporingsmethoden (zoals pseudokoop), het beheer van informanten en operationele misdrijfanalyse. De opdrachten van de zogeheten bestuurlijke politie (zie hierna) vallen ook onder de taken van de federale politie, evenwel niet exclusief. Zoals de lokale politic in bepaalde zaken de federale politie ondersteunt, dient ook het landelijke apparaat de lokale politie te helpen indien dit nodig is. Hierbij gaat het dan met name om bijzondere onderzoeken.

Om te voorkomen dat de politiediensten op de twee niveaus uit elkaar groeien, wordt er een zogeheten 'performante functionele band' geschapen. Ondanks hun uiteenlopende takenpakket behouden de diensten een aantal gemeenschappelijke instellingen, zoals gezamenlijke selectic en opleiding en het beheer van informatie en informatica. Het is duidelijk dat de architecten van de reorganisatie een splitsing zoals voorheen ${ }^{34}$ wilden voorkomen. De band blijkt ook uit de onderlinge afhankelijkheid tussen de niveaus. Zo dient de lokale politic in bepaalde gevallen bijstand te verlenen aan de federale politie en vice versa.

Naast de verschillende niveaus van politie kan ook een indeling worden gemaakt naar politietaken. De Belgische Wet op het Politieambt (WPA) ${ }^{35}$ maakt een onderscheid naar gerechtelijke en bestuurlijke politie. Het eerste artikel van de wet maakt dit al duidelijk. ${ }^{36}$ Een nadere toelichting is te vinden in artikel 14 WPA, dat uitlegt dat de bestuurlijke politie toeziet op 'de handhaving van de openbare orde, met inbegrip van de naleving van de politiewetten en -verordeningen'. Ook de bijstand aan personen in gevaar valt onder de taken van de bestuurlijke politie. De bestuurlijke taken hebben dus eerder

33. Zie Fijnaut, De Ruyver \& Goossens 1999, p. 40.

34. Toen werden bijvoorbeeld de Rijkswachtofficieren op de Koninklijke Militaire School opgeleid, terwijl het kader van de andere diensten op "gewone" politiescholen werd opgeleid. Tot in de jaren negentig viel de Rijkswacht trouwens niet onder Binnenlandse Zaken, maar onder Defensic.

35. Wet van 5 augustus 1992 op het Politieambt, B.S., 22 december 1992, zoals in werking getreden op 1 januari 2003.

36. Het artikel maakt het verschil expliciet door het volgende te stellen: "Bij het vervullen van hun opdrachten van bestuurlijke of gerechtelijke politie, waken de politiediensten over de naleving en dragen zij bij tor bescherming van de individuele rechten en vrijheden, evenals tot de democratische ontwikkeling van de maatschappij." 
betrekking op de openbare veiligheid en de preventie van misdrijven. De burgemeester van een gemeente heeft namelijk ook de taak van bestuurlijke politie, omdat hij of zij verantwoordelijk is voor de openbare rust, veiligheid en gezondheid in de gemeente. In het kader hiervan dienen de lokale politiechefs en andere relevante ambtenaren de burgemeester alle noodzakelijke inlichtingen te verschaffen. ${ }^{37}$ De taken van de gerechtelijke politie zijn opgesomd in artikel 15 WPA: opsporing en bewijsverzameling van misdrijven, opsporing van gezochte personen en goederen en verslaglegging van opdrachten en inlichtingen alvorens deze informatie door te geven aan de bevoegde overheden.

\section{Duitse organisatie- en bevoegdhedenstructuur}

Duitsland kent als federale staat politie die onder verantwoordelijkheid valt van de Bundes Staat - in het kader van de gegevensuitwisseling met name het BKA ${ }^{34}$ en de Bundes Grenzschutz $(B G S)^{39}$ - en cen politie die onder verantwoordelijkheid valt van de afzonderlijke Länder (deelstaten). ${ }^{40}$ In de praktijk blijkt dat zowel de Länder-politie als de BGS zich bezighouden met Euregionale gegevensuitwisseling. Vanwege Duitse competentieperikelen tussen de RVST en de BGS nam de BGS aanvankelijk echter niet deel aan het EMMI-project. Er is evenwel sprake van een toenemende interesse voor EMMI bij de BGS.

Artikel 30 Grundgesetz (GG) stelt: "Die Ausibung der staatlichen Befugnisse und die erfullung der staatlichen Aufgaben ist Sache der Lander, soweit dieses Grundgesetz keine andere Regelung trifft oder zulaßt." De politiezorg berust dus primair op het niveau van de respectieve deelstaten, waarbij dit grondwetsartikel tevens bepaalt dat een afwijking hiervan

37. Zie artikel $5 / 2$ lid 2 WPA.

38. Het BKA verieent ondersteuning van de strafvorderingstaak van de Landeskriminalämter en heeft een executieve taak bij misdrijven op bondsniveau. Organisatie, beheer en taakuitvoering staan onder direct toezicht van de Minister van Binnenlandse Zaken.

39. De BGS heeft als hoofdtaken grensbewaking en paspoortcontrole. Het dagelijks gezag en beheer berusten bij de Inspecteur der BGS. Het opperbeheer berust bij het Ministerie van Binnenlandse Zaken.

40. Op deelstaatniveau bevindt zich de Volleugspolizei ('executieve politie'), die doorgaans is opgesplitst in de Schutzpolizei (Schupo), Kriminalpolizei (Kripo) en Berritschaftupolizei. Dexe 'executieve politie' heeft volledige politiebevoegdheid, in principe slechts binnen de deelstaat van de aanstelling. Het dagelijks gerag en beheer berusten achtereenvolgens bij de Leiter der Schupo en de Leiter der Kripo onder toezicht van de Polizeipräsident als Kreispolizeibehörde. Deze staan onder toezicht van de Rogienungupnitsident als Landerpolizeibehönde. Die valt op zijn beurt direct onder de Minister van Binnenlandse Zaken, bij wiens ministerie ook het opperbeheer berust. Verder heeft elke deelstaat een LKA met ondersteunende en executieve taken op bovenlokal niveau, vergelijkbas met het BKA. Het LKA is in principe slechts bevoegd binnen de eigen deelstaat. Het dagelijks gerag en beheer berusten bij de ditecteur van het LKA, onder toezicht van de Regierungspralsident. Het opperbeheer berust bij het Ministerie van Binnenlandse Zaken. 
slechts bij of krachtens de grondwet is toegelaten. Een dergelijke afwijkende regeling is te vinden in $\$ 73 \mathrm{GG}$.

Ingevolge de voormelde grondwetsartikelen heeft de Bondsstaat geen eigen wetgevende bevoegdheid op het gebied van het politierecht. Een uitzondering hierop vormen de bevoegdheden die voortvloeien uit $\$ 73$ GG. Op basis hiervan heeft de Bondsstaat namelijk wetgevende bevoegdheid ten aanzien van politiediensten die bevoegd zijn met betrekking tot:

- douane en grensbewaking (\$ 73 sub 5 GG);

- luchtverkeer ( $\$ 73$ sub 6 GG);

- spoorwegen (\$73 sub 6a GG);

- samenwerking op het gebied van de strafrechtelijke handhaving van de rechtsorde ( $\$ 73$ sub 10, onder a GG) de bescherming van het staatsbestel ( $\$ 73$ sub 10 , onder b GG), bescherming tegen activiteiten die de belangen van de Bondsstaat in gevaar brengen ( $\$ 73$ sub 10, onder $\mathrm{C}$ GG);

- de Bundeskriminalpolizei ( $\$ 73$ sub 10 GG jo. $\$ 87$ lid 1 GG); en

- de internationale misdaadbestrijding ( $\$ 73$ sub 10 , onder a-c, GG).4t

Op basis van $\$ 73$ sub $10 \mathrm{GG}$ is het BKA opgericht. De kerntaak van het BKA is de ondersteuning van de politiediensten in de respectieve deelstaten en de hiervoor opgesomde politiediensten op bondsniveau. Deze ondersteuning betreft de voorkoming en vervolging van strafbare feiten die een deelstaatoverstijgend karakter hebben. Hiervan is sprake als het betreffende misdrijf van zodanig ernstige aard is dat meerdere deelstaten getroffen worden, of als aan het betreffende misdrijf een grensoverschrijdend aspect kleeft.

De Bondsrepubliek Duitsland kent een uitgebreide politieorganisatie. De variaties in taakstelling hebben hun gevolgen voor de variaties binnen de organisatie en voor de verschillende bevoegdheden. Slechts op deelstaatniveau wordt qua taakstelling onderscheid gemaakt tussen preventic en repressie. Daarmee wordt tevens binnen de politieorganisatie een organisatorische splitsing aangebracht. Het maken van een onderscheid op basis van taken heeft gevolgen voor de bevoegdheden die de verschillende delen van de politieorganisatic ter beschikking staan.

In Duitsland is de politietaak de laatste tijd aan verandering onderhevig geweest, evenals in Belgiê en Nederland. Het betreft hier met name een uitbreiding op het niveau van de preventic, in Nederland ook wel betiteld als het proactieve optreden. Ondanks de nieuwe

41. Voor een meer uitgebreide beschrijving, zie: Knemeyer 2000 , hoofdstuk 2 . 
Nederlandse terminologie blijft de politietaak in feite te verdelen naar preventie en repressie.

Ten aanzien van preventie als generaal begrip heeft de politie in beginsel een secundaire taak: de politie is bevoegd, voorzover geen andere dienst bevoegd is. Als geen andere dienst is aangewezen als bevoegd, dan treedt de politie op het betreffende terrein op. Wat de politie zelf betreft, is de primaire taak van preventieve aard. Dit politieoptreden wordt gekenschetst door de term 'Gefabrenabwehr'. De invulling van de reikwijdte van dit begrip is van belang voor het concretiseren van de taakstelling van de politie. Die invulling kent twee varianten:

1. de enge uitleg en

2. de brede uitleg.

Degenen die de enge uitleg hanteren zijn de mening toegedaan dat pas sprake is van Gefahrenabwehr op het moment dat een concreet gevaar aanwijsbaar is. Van cen concreet gevaar is sprake als een naar tijd en plaats beperkte situatie met voldoende waarschijnlijkheid een beschadiging zal opleveren van de rechrsgoederen openbare orde en openbare veiligheid, mits de gebeurtenissen niet zullen worden onderbroken. Een gevolg hiervan is dat bijvoorbeeld het surveilleren, het enkele 'aanwezig zijn' of het verstrekken van publieksvoorlichting geen deel uitmaakt van de politietaak zoals die omschreven is in de politiewetten. De vervulling van de politietaak kent met deze interpretatie slechts reactief optreden.

Bij toepassing van de brede uitleg wordt in een veel vroeger stadium aangenomen dat sprake is van Gefahr, met als gevolg dat de politiewet veel eerder van toepassing is. De brede uitleg omvat zowel het concrete gevaar zoals hiervoor omschreven, alsook het abstracte gevaar en het algemene gevaar. Bij het laatste soort gevaar behoeft zelfs niet eens het vermoeden van een concreet gevaar te bestaan, omdat het een feit van algemene bekendheid is dat bij een bepaalde levenswijze een zeker gevaar kan ontstaan. Bij deze invulling van het begrip Gefahrenabwehr, vallen het surveilleren, het enkele 'aanwezig zijn' of het verstrekken van publieksvoorlichting wel degelijk onder de taakstelling van de politie zoals die geformuleerd is in de respectieve politiewetten. De vervulling van de politietaak kent met deze interpretatie zowel het reactief optreden, alsook het preventief en pro-actief optreden.

De invulling van het begrip Gefahrenabwehr is van beslissend belang om te bepalen of de toegekende bevoegdheden wel of niet mogen worden gebruikt. De grens van de toepassingsmogelijkheden van politiële bevoegdheden wordt immers gevormd door de taakstelling. Aangezien de taakstelling van de Duitse politie primair Gefahrenabwehr is, bepaalt de invulling van het begrip Gefahrenabwehr vanaf welk moment de politièle bevoegdheden, dus ook de bevoegdheden met betrekking tot de informatichuishouding, toegepast mogen worden. 


\section{De algemene politietaak wordt in beginsel slechts uitgevoerd door de Schutzpolizei} (SchuPo), de geüniformeerde dienst. Deze taakstelling is vrij algemeen geformuleerd in de respectieve politiewetten. Een specifieke wettelijke grondslag wordt pas geëist, op het moment dat het preventieve handelen binnen de rechtssfeer van het individu treedt. Een simpel 'pas op, anders val je', valt wel onder preventief optreden, maar behoeft geen wettelijke grondslag.

Bij de uitvoering van de Duitse politietaak geldt het positief legaliteitsbeginsel. Dit beginsel houdt in dat er altijd een wettelijke plicht tot optreden bestaat. Het principe is evenwel niet al te stringent. De politie treedt slechts op, indien de autoriteit die eigenlijk bevoegd is niet tijdig kan ingrijpen. Dit betekent dat de politie regelmatig een afweging moet maken met betrekking tot de vraag of er wel of niet wordt ingegrepen. Indien de situatie de politie dwingt tot direct optreden op een terrein dat eigenlijk onder de competentie van een Ordnungsbehörde valt, dan moet die Ordnungsbehörde daarover wel ten spoedigste ingelicht worden. ${ }^{42}$ Met betrekking tot de Gefahrenabwehr die met uitsluiting van andere diensten binnen de taakstelling van de politie valt, is het de taak van de politie om op te treden. De hier relevante politiewetten spreken dus niet van 'de plicht' tot optreden. Ten aanzien van de Gefahrenabwehr geldt dan ook het opportuniteitsbeginsel. ${ }^{43}$

Het preventieve politiële optreden is het uitgangspunt. Alle bevoegdheden die de politie in de politiewet van de betreffende deelstaat krijgt toebedeeld, zijn slechts toe te passen ten behoeve van dat preventieve optreden. De omschrijving van de politietaak met de bijbehorende bevoegdheden zoals die te vinden zijn in de respectieve politiewetten, is restrictief bedoeld. Overige taken van de politie waarbij binnen de rechtssfeer van de burger wordt getreden, behoeven een specifieke wettelijke grondslag. De overgang van de politiewet naar een andere specifieke wet, is gebaseerd op een zogenaamde 'brugbepaling'. De basistekst van de politiewetten in zowel Noordrijn-Westfalen als Nedersaksen is te vinden in het Musterentwurfeines Polizeigesetzes (MEPolG). ${ }^{44}$ Deze modelwet geeft als

42. Zie $\$ 1$ lid 1 Nontrhein-wertfalisches Polizeigesetz (PolGNRW) van 24 februari 1990, GVNRW p. 70, zoals laatstelijk gewijzigd door het Gesetz van 9 mei 2000. GVNRW p. 452. Zie ook \$1 lid I Nieulenächsisches Gefahrenabuehrgesetz (NdsGefAG); Wet van 17 november 1981, Nds. GVBl, p. 347, laatstelijk gewijzigd bij wet van 25 okrober $2001, N d s . G V B l$, p. 664 . Bij vergelijking van de hier toepasselijke politiewetten is overigens wel een nuanceverschil te zien. In Nedersaksen wordt meer nadruk gelegd op een samenwerking tussen politie en overige publieke autoriteiten die met name tot uitdrukking komt in cen voortdurend wederzijds informeren. In Noordrijn-Westfalen ligt de nadruk meer op de scheiding der bevoegdheden en daardoor op het pas informeren indien een concrete situatie daarom vraagt.

43. Knemeyer 2000 , p. 36.

44. Dit modelontwerp is van bondswege vastgesteld en vormt voor alle deelstaten een leidraad, De verschillende bepalingen worden veelal woordelijk overgenomen. 
tekst: "Die Polizei hat ferner die Aufgaben zu erfillen, die ibr durch andere Rechtsworschrif. ten ubertnagen sind." Zonder een dergelijke brugbepaling zou de politie qua bevoegdheidstoepassing niet buiten de politiewet kunnen treden.

De ontdekking van een gepleegd strafbaar feit heeft een aantal gevolgen. Allereerst een organisatorisch gevolg: de SchuPo schakelt de Kriminalpolizei (KriPo) in. Ten tweede is er een juridisch gevolg. De rechtsgrond die de politiewet van de betreffende deelstaat biedt, is niet meer toereikend. De betreffende politiewet betreft immers slechts het preventieve optreden. De juridische basis voor politieel handelen is nu te vinden in het Duitse Wetboek van Strafvordering (Strafprozeßondmung, ${ }^{46}$ StPO). ${ }^{47}$

Teneinde buiten de politiewet te kunnen treden en op basis van een andere wet te kunnen handelen, maakt de politie gebruik van de hiervoor vermelde brugbepaling. In geval van repressief optreden, leidt deze brugbepaling naar $\$ 163$ StPO. Daadwerkelijk repressief optreden en daarmee een toepassen van de bevoegdheden zoals vermeld in de StPO kan eerst plaatsvinden als, conform $\$ 152$ lid 2 StPO, sprake is van een Anfangsvendacht, een redelijk vermoeden van schuld. Pas op dat moment wordt de toegang tot strafvorderlijke bevoegdheden geopend, zoals bedoeld in $\$ 163 \mathrm{StPO}$.

Echter, met het overschakelen naar de StPO wordt de politiewet verlaten. Dit heeft uiteraard gevolg voor de ter beschikking staande bevoegdheden. Indien gehandeld wordt op basis van de politiewet, staan de daarin vermelde bevoegdheden ter beschikking. Met het verlaten van de politiewet als juridische grondslag van het handelen verlaat de politie ook de betreffende bevoegdheden en staan slechts die bevoegdheden ter beschikking die zijn vermeld in de bijzondere wet op basis waarvan de politie dan optreedt. Zie voor de Duitse politiële organisatiestructuur nader Appendix A.

\subsubsection{Verschil in automatisering}

Er is zoals gezegd ook sprake van een uiteenlopende graad van automatisering in de verschillende landen. Wij lichten dit verschil in automatisering hieronder nader toe voor respectievelijk België en Duitsland.

45. Deze brugbepaling is voor Noordrijn-Westalen te vinden in $\$ 1$ lid 4 PolGNRW en voor Nedersaksen in $\$ 1$ lid 5 NdsGefAG. Beide wetten volgen het MEPolG woordelijk.

46. Wet van 12 september 1950; $B G B l 1950,455,512,629$; latstelijk gewijzigd bij wet van 25 juni 2001, BGBI2001, 1206.

47. De brugbepaling, zoals geformuleerd in de respectieve politiewetten, leidt niet alleen naar $\$ 163$ StPO waarop de bevoegdheid tot repressief optreden is gebaseerd, mar naar elke lex specialis waarin de politie genoemd staat als de tot optreden bevoegde dienst. Dus ook naar die wetten warin de politie genoemd staat als bevoegd tot preventief optreden of als ondersteunende dienst voor andete handhavingrautoriteiten. 


\section{Automatiseringsgraad in België}

Met de invoering van een eenheidspolitie werden in Belgiě ook de databases van de drie grote politiediensten samengevoegd. ${ }^{48}$ Aan dit aspect is bij de politiehervorming grote aandacht besteed. Uiteindelijk is besloten om alle politie-informatic onder te brengen bij de federale politie. ${ }^{9} \mathrm{Om}$ de lokale politie niet al te afhankelijk te maken van de federale politie, is besloten om de dienst die deze gegevensbank beheert onder het gezag te stellen van zowel een federale als een lokale politieambtenaar.

\section{Automatiseringsgraad in Duitsland}

In Duitsland wordt de archivering van de uitgewisselde gegevens nog veelal met de hand gedaan.

Het huidige Bundeskriminalamtgesetz ${ }^{30}$ (BKAG) geeft een formele regeling aangaande het voeren van een persoonsregistratie in $\$ 7$ tot en met $\$ 13$ BKAG. In de zogenoemde Zentralstelle registreert het BKA:

- de kenmerken van diegenen die, terecht of onterecht, als verdachte in een strafprocedure betrokken zijn geweest;

- de modus operandi die gehanteerd is bij gepleegde strafbare feiten met een koppeling naar de daarbij behorende personen;

- de gegevens van vermiste personen en zaken; en

- voor zover het de grote steden betreft, de geografische gegevens van gepleegde strafbare feiten ten behoeve van het herkennen van risicogebieden.

De gegevens die worden geregistreerd spruiten voort uit eigen onderzoek door het BKA of worden op verzoek verstrekt door de politiediensten van de respectieve deelstaten. De gegevens die de verschillende politieorganisaties hebben verzameld in het kader van strafrechtelijke onderzoeken zijn voor de politie beschikbaar via het INPOL-systeem. ${ }^{51}$ Enige tijd is het de bedoeling geweest om alle INPOL-systemen centraal op te slaan bij het BKA, ${ }^{32}$ maar dit is uiteindelijk niet doorgegaan. Een belangrijke belemmering was de verscheidenheid aan systemen en de onwil van de politiediensten van de deelstaten om hun eigen (dure) systeem op te geven. Zie voor enkele voorhanden zijnde (politie)registers in Duitsland Appendix B.

48. Zie artikel 44/4 WPA. Er wordt hier gesproken over een "algemene nationale gegevensbank".

49. Dit hangt vermoedelijk samen met de "ondersteunende functic" van de federale politie, waartoe ook het beheer van de informatie wordt gerekend.

50. Gesetz über das Bundeskriminalams und die Zusammenarbeit des Bundes und der Länder in kriminalpolizerilichen Angelogenheiren, BGBI 1 1997, 1650; laatstelijk gewijzigd bij artikel 2 Wet van 11 december 200113510.

51. INPOL. staat voor: Informationsystem Polizei.

52. Zie hierover de bijdrage van Herold aan Baümler 1999, p. 333. 
In geen van de bij EMMI betrokken landen verloopt de registratie van de vragen en antwoorden bij politiële gegevensuitwisseling helemaal automatisch. In alle landen worden de gegevens handmatig ingevoerd. De communicatie tussen de politiekorpsen aan weerszijden van de grens verliep tot 1996 alleen via meldkamers of 'krakkemikkige' verbindingen die door de korpsen zelf tot stand waren gebracht. Soms werden over en weer mobilofoons uitgewisseld. Het moge duidelijk zijn dat de technische middelen in het begin van de jaren negentig aan een update toe waren.

\subsection{Naar een geautomatiseerde grensreglonale communicatie}

Aangezien de traditionele grensregionale gegevensuitwisseling te slecht voorzag in een effectieve, snelle en gestructureerde informatie-uitwisseling voor de nieuwe informatieve samenwerkingsmarkt voor het gewone politiewerk, werd de behoefte gevoeld aan een automatisering van deze informatic-uitwisseling. Dit gebeurde in door PALMA (subsectie 2.2.1) en EMMI (subsectie 2.2.2). In subsectie 2.2.3 bespreken wij de verworvenheden van PALMA en EMMI en in subsectie 2.2.4 de nieuwe mogelijkheden van deze technologische infrastructuur.

\subsubsection{PALMA}

In februari 1995 besloten de korpschef van de politieregio Limburg-Zuid, Mostert, en de voorzitter van de capaciteitsgroep Informatica van de Universiteit Maastricht, Van den Herik, het PALMA-project te ontwikkelen. Het ambitieuze project was mogelijk geworden door inspanning en financiering van PTT-Telecom (thans KPN Telecom). PALMA moest zich ontwikkelen tot een hecht samenwerkingsverband tussen de verschillende universiteiten en politiepartners in de Furegio Maas-Rijn en het toenmalige PTTTelecom. Door onderzoek en een pilotstudie is metterdaad een structurele oplossing gevonden voor een beveiligde gegevensuitwisseling tussen de politiekorpsen in de Euregio Aken-Luik-Maastricht. In maart 1997 kreeg het project een vervolg met het PC-PC Fase II project getiteld PALMA \& Multimedia. In dit project werden multimediafaciliteiten ontwikkeld voor het versturen van gedigitaliseerde documenten. $W_{i j}$ komen in hoofdstuk 3 uitgebreid op deze projecten terug.

\subsubsection{EMMI}

Op 1 januari 1996 ging met financiële steun van de EU het EMMI-project van start. Tijdens dit project is een beveiligd Private Network gecreëerd voor de uitwisseling van politiële gegevens tussen de IRC's in de Euregio Maas-Rijn. Het EMMI-project heeft de resultaten van PALMA geimplementeerd en verder uitgewerkt. Aldus zijn twee manieren van geautomatiseerde communicatie ontwikkeld. In de eerste plaats worden persoons- en voertuiggegevens (dit zijn ook persoonsgegevens) uitgewisseld via gestandaardiseerde eiektronische formulieren. In de tweede plaats wordt alle mogelijke (andere) niet persoonsgebonden informatie uitgewisseld via elektronische publicatie op een website. We komen in hoofdstuk 4 uitgebreid op het EMMI-project terug. 


\subsubsection{Verworvenheden van PALMA en EMMI}

De belangrijkste verworvenheden van het PALMA- en het EMMI-project zijn als volgt te typeren.

- PALMA heeft een tot dan toe onbestaand organisatiemodel voor Euregionale samenwerking tussen politieorganisaties, universiteiten en het bedrijfsleven gerealiseerd. Aldus is een platform voor Euregionale samenwerking ontstaan. Tevens is inzicht verkregen in nieuwe telematicamogelijkheden op verschillende niveaus binnen de politieorganisaties.

- Er is een trend gezet voor een verdere ontwikkeling van telematica binnen de Europese politieorganisaties, waarbij de te gebruiken infrastructuur op elkaar kan worden afgestemd. Dit gaat gepaard met een uitstralingseffect naar andere organisaties, zoals brandweer, GGD," gemeenten, provincies, Ministerie van Justitie en Ministerie van Binnenlandse Zaken (en Koninkrijksrelaties). Verder is er een uitstraling binnen de politieorganisaties zelf om het PALMA- en EMMI-concept ook intern toe te passen.

- Er is afstemming bereikt tussen de politicorganisaties omtrent de met het buitenland uit te wisselen gegevens.

- Uitbreiding van PALMA en EMMI is gemakkelijk realiseerbaar omdat aan de invoering van de nieuwe technieken en middelen een groeimodel ten grondslag ligt.

\subsubsection{Nieuwe mogelijkheden}

Op juridisch en sociaal vlak zijn de politieorganisaties door het organisatiemodel van het PALMA-project en de te implementeren nieuwe technieken in staat meer kennis te vergaren over elkaars beperkingen, beslisprocedures, verantwoordelijkheden, wetgeving et cetera.

De in de projecten PALMA en EMMI ontwikkelde software heeft de IRC's een informatietechnologisch instrumentarium gegeven dat in staat is om de genoemde complexe factoren bij de politiële gegevensuitwisseling het hoofd te bieden. Omdat alle betrokken politieorganisaties gebruik maakten van de IRC's kon de focus op 'communicatisering' bij de IRC's worden gelegd. Zo wil de EMMI-omgeving bewerkstelligen dat de gebruikers vanaf de eigen werkplek een aanvraag kunnen sturen aan het eigen IRC of een vraag direct kunnen doorsturen naar het betreffende buitenlandse IRC. Met behulp van de PALMA-software kan in alle betrokken landen de registratie van de gegevensverstrekking volledig worden geautomatiseerd. Het bestaan van verschillende instanties is voor het EMMI-netwerk geen probleem. $\mathrm{Zij}$ kunnen overal worden gepresenteerd als een eenheid.

53. Thans wordt in de Euregio Aken-Luik-Maastricht ook in het ziekenhuiswezen aan grensoverschrijdende samenwerking gewerkt, waarbij tevens via 'contracten' de wetgevingen van de verschillende landen op elkaat worden afgestemd. 
Het automatiseringsniveau is door het EMMI-project in de verschillende landen naar elkaar toegegroeid en zelfs op elkaar afgestemd. De EMMI-omgeving leidt daarenboven tot vereenvoudiging en vermindering van het aantal handelingen dat in het kader van de SUO vereist is (zie hoofdstuk 5). Er is sprake van een betere toegangsbeveiliging door het gebruik van wachtwoorden en geautomatiseerde autorisaties. De beantwoording van de aanvragen kan beter worden gepland door het aangeven van de mate van urgentie. Doordat de telefoon en de fax niet langer doorlopend zijn bezet, is de bereikbaarheid van de IRC's verbeterd. Ook het genereren van managementinformatie is aanzienlijk eenvoudiger geworden.

Een belangrijke ontwikkeling die voortspruit uit een pilot bij het oorspronkelijke IRC Limburg-Zuid is de 'vooruitgeschoven post' van het OM. Bij het IRC Limburg-Zuid werden vanaf 1998 medewerkers van het OM gedetacheerd die bij binnengekomen rechtshulpverzoeken direct kunnen beoordelen of het verzoek door het $\mathrm{OM}$ dient te worden afgehandeld dan wel zelfstandig door de politie kan worden afgehandeld. Deze mensen van het parket zijn door de Officier van Justitie (OvJ) gemandateerd om documenten met bewijskracht te verstrekken aan het buitenland. Alle justitiële rechtshulpverzoeken en de antwoorden daarop worden nog per traditionele post naar het buitenland verzonden. De buitenlandse justitiele rechtshulpverzoeken gaan voortaan als volgt: $\mathrm{OvJ}$ per adres IRC Limburg. De snelheid en de kwaliteit van de afdoening is aldus enorm verbeterd. De afdoening is teruggebracht van drie maanden naar drie weken. De mensen van het parket die gedetacheerd zijn bij het IRC behandelen jaarlijks zo'n 5500 justitiele rechtshulpverzoeken. Daarvan levert het merendeel feitelijk werk op voor de politie. ${ }^{54}$

Wij merken verder op dat de in sectie 2.1 sangehaalde individuele contacten toch via de EMMI-omgeving in stand gehouden kunnen worden. Bij EMMI is men namelijk verzekerd van registratie en van controle achteraf.

In mei 1998 ging in Nederland de Landelijke Implementatic EMmi van start. Dankzij een subsidieregeling van het toenmalige Ministerie van Binnenlandse Zaken van 6 januari $1998^{55}$ werden tussen die datum en mei 2000 alle twalf Nederlandse grensregio's, alsmede de toenmalige dCRI (thans DIN) op het EMMI-netwerk aangesloten. Ook enkele Belgische, Duitse en zelfs Franse partners zijn bij het project betrokken om EMMI ook in het buitenland te verspreiden.

54. Het gat voornamelijk om verkeersovertredingen die Nederlanders in het buitenland hebben gepleegd. Alleen al voor Belgie behelst dit zo'n 3500 aanvragen per jar. De betrokken Nederlanders moeten voor die overtredingen in Nederland worden verhoord door de regiopolitie.

55. 'Financiele bijdrage grensoverschrijdende poliriele samenwerking' genaamd. 
In februari $2000 \mathrm{kreeg}$ het IKAT van de Universiteit Maastricht de opdracht van het Ministerie van BZK om een fundamenteel nieuw ontwerp voor het PALMA-systeem te maken. Een inventarisatie van het huidige PALMA-systeem bracht namelijk aan het licht dat er door het dubbele gebruik van PALMA, te weten als pilotproject en als groeisysteem, vier problemen waren ontstaan. Deze problemen liggen op het gebied van stabiliteit, capaciteit, functionaliteit en beheersbaarheid. Het ontwerp, dat in juni 2001 werd opgeleverd, bevat de nieuwste Intranettechnieken, oplossingen voor nieuwe gebruikerswensen en de mogelijkheid om direct nieuwe (verwachte) (kennis)technologische ontwikkelingen op te nemen. ${ }^{56}$ Ook dient een koppeling van de nieuwe PALMA-software met LURIS gerealiseerd te worden. Vooralsnog worden door de ITO evenwel geen nieuwe functionaliteiten voor EMMI ontwikkeld. Er wordt wel gewerkt aan een herontwikkeling van de softwareomgeving, gebaseerd op dezelfde functionaliteit, maar in een state of the art technologisch jasje. ${ }^{57}$

EMMI voorziet aldus in een nieuwe 'samenwerkingsmarkt': de markt van de behoefte aan snelle grensoverschrijdende informatie-uitwisseling voor het 'gewone' politiewerk, dat is voornamelijk ordehandhaving, verkeerstoezicht en de zogenoemde kleinere criminaliteit. Het is een aanvulling op de samenwerkingsverbanden Europol, dat vooral op het gebied van de georganiseerde misdaad werkzaam is, en Interpol, dat een wereldwijd netwerk is, maar in de grensregionale praktijk niet echt geschikt is gebleken voor de genoemde 'nieuwe internationale informatiemarkt. ${ }^{58}$ EMMI wordt op dit moment (januari 2004) gebruikt door twintig (grensregionale) politiekorpsen in vier landen: Nederland, België, Duitsland en Frankrijk. Er bestaat interesse voor deze informatieve samenwerkingsvorm in Luxemburg, Denemarken, Polen, Hongarije, Slovenië en Oostenrijk. Er dient een internationale beheersorganisatie voor EMMI te worden opgericht onder auspiciën van het Nederlandse Ministerie van BZK, waarin de betrokken landen zullen participeren en waarin de beheers-, ontwikkelings- en uitbreidingsactiviteiten centraal aangestuurd zullen worden (zie hoofdstuk 10).

Hoewel EMMI primair ontwikkeld is voor een snelle elektronische communicatic en gegevensuitwisseling tussen politiepartners in het grensgebied, is de omgeving technisch gesproken perfect toepasbaar voor alle Europese politiekorpsen en aanverwante organisaties in de OOV-keten. ${ }^{99}$ De toepassing van EMMI is geen technisch probleem meer, maar een juridisch en organisatorisch vraagstuk, dat het hoofdonderwerp vormt van deze dissertatie.

56. Donkers, Verbeek, Van den Herik, Van der Krogt, Boers, Spronck \& Wiesman 2001.

57. Aangezien de precieze details van deze nieuwe EMMI-omgeving nog niet bekend zijn, laten wij deze ontwikkeling hier verder buiten beschouwing. Er verandert. zoals gezegd, niets aan de functionaliteit.

58. De Heus 2000 en 2002.

59. Verbeek, Claus \& Van den Herik 2003, hoofdstuk 5, p. 131-150. 


\section{Het PALMA-concept}

In dit hoofdstuk beschrijven wij het PALMA-concept. Dit concept richt zich op drie doelstellingen, te weten: (1) het ontwikkelen van een hecht samenwerkingsverband tussen politie, universiteiten en bedrijfsleven in de diverse grensregio's; (2) het bereiken van doelstelling (1) via het model van groeikernen zowel organisatorisch gezien als met het oog op de software; en (3) het ontwikkelen van een beveiligde communicaticomgeving waarbinnen de politie snel relevante gegevens kan uitwisselen voor het handhaven van de rechtsorde en de OOV. De nadruk valt op de beschrijving van de PALMA-software, dat is de in het PALMA-project ontwikkelde omgeving voor een beveiligde gegevensuitwisseling tussen de politiekorpsen in de Euregio Aken-Luik-Maastricht. De in het PC-PC Fase II project PALMA \& Multimedia ontwikkelde multimediafaciliteiten voor het versturen van gedigitaliseerde documenten in de PALMA-omgeving komen ook aan bod.

Het belangrijkste resultaat van het PALMA-project is de PALMA-omgeving. Deze omgeving is als basis gebruikt voor het EMMI-project. PALMA is aanleiding geweest voor het ontwikkelen van twee wijzen van geautomatiseerde communicatie: ten eerste het uitwisselen van persoonsgegevens (met als prominert onderdeel voertuiggegevens) en ten tweede het uitwisselen van alle mogelijke andere informatie. Beide communicatiemogelijkheden zijn geỉncorporeerd in één EMMI-omgeving (zie nader hoofdstuk 4). ${ }^{60}$

De PALMA-software wordt gebruikt voor het uitwisselen van persoonsgegevens via gestandaardiseerde elektronische formulieren. Het uitwisselen van andere informatic gebeurt via elektronische publicatie en vindt plaats in de EMMI-omgeving. Wij maken in sectie 3.1 onderscheid tussen twee soorten communicatie en in sectie 3.2 beschrijven wij de PALMA-software.

60. Voor de goede orde zij hier vermeld dat de in de hoofdstukken 3 en 4 besproken software PALMA en EMMI niet als onderdeel van dit promotieonderzoek is geproduceerd, maar dat het product een van de onderwerpen van dit onderzoek is. Voor nadere details over PALMA en EMMI en hun historische achtergronden zie Donkers, Verbeek, Van den Herik, Van der Krogt, Boers, Spronck \& Wiesman 2001. Het ontwerp van PALMA en EMMI is (voor het overgrote deel) van de hand van Jeroen Donkers, in nauwe samenwerking met Leo Plugge. 


\subsection{Twee soorten communicatie}

Wij onderscheiden twee soorten communicatie.

1. Multimediacommunicatie

Multimediacommunicatie vindt plaats tussen twee of meer personen of instanties.

Wij beschrijven in sectie 3.2 de software en hardware die nodig is voor de uitwisseling van gegevens via een formuliergebaseerde, beveiligde e-mailfunctie. Tevens worde de mogelijkheid tot video conferencing als communicatiemiddel aangeboden.

2. Multimediakiosk

De multimediakiosk wordt gekenmerkt door 'publicatie' van informatie met behulp van de WWW-technologie ten behoeve van de IRC's. Dit publiceren houdt in het beschikbaar stellen van gegevens op een server, alsmede het elektronisch 'ophalen' van deze gegevens via een browser door de gebruiker.

De multimediakiosk is te vergelijken met het publiceren van informatie in een intern magazine. Er wordt informatie ontsloten door en voor de IRC-medewerkers, aan weerszijden van de grens. Degene die de informatie beschikbaar stelt, weet wel aan welke groep de informatie beschikbaar gesteld wordt, maar weet niet wie welke informatie ophaalt en op welk tijdstip. De kiosk staat tegenover de formuliergebaseerde e-mail van de multimediacommunicatic. Daar ziịn genoemde gegevens wel bekend. Via de multimediakiosk wordt alle mogelijke informatie verspreid: van de tijden waarop men bereikbaar is tot dagjournaals en bepaalde operationele informatie, zoals een lijstje van gezochte criminelen.

\subsection{De PALMA-software}

In deze sectic behandelen wij eerst het PALMA-Intranet (subsectie 3.2.1) en de PALMAomgeving (subsectic 3.2.2). Daarna bespreken wij de informatie-uitwisseling via PALMA (subsecties 3.2.3 en 3.2.4). Vervolgens verschaffen wij inzicht in het oorspronkelijke PALMA-ontwerp (subsectie 3.2.5), de oorspronkelijke PALMA Protocol Server (subsectic 3.2.6) en het PALMA Protocol (subsectie 3.2.7). In subsectie 3.2.8 bespreken wij de PALMA-formulieren. Subsectie 3.2.9 behandelt de registratie van de gegevensuitwisseling. In subsectie 3.2.10 gaat het om de wijze waarop bepaalde onderdelen van de PALMA-formulieren vertaald worden voor de verzending naar het buitenland. Wij onderzoeken in subsectie 3.2.11 vervolgens de vraag of gegevens in de EMMI-omgeving technisch gekoppeld kunnen en mogen worden. In subsectie 3.2.12 behandelen wij enkele multimediale uitbreidingen van de PALMA-software. Subsectie 3.2.13 geeft een samenvatting van hoe door middel van een IRC een informatie-aanvraag aan een buitenlandse politiedienst plaatsvindt in de grensregio's tussen Nederland, België en Duitsland. Wij maken in deze subsectic ook enkele afrondende opmerkingen omtrent de bij PALMA gebruikte Internet-technieken. 


\subsubsection{Het PALMA-Intranet}

In het kader van het PALMA-project is in 1996 een structurele oplossing gevonden voor een beveiligde communicatie tussen de politiekorpsen in de Euregio Aken-Luik-Maastricht. Het PALMA-systeem heeft de Euregionale gegevensuitwisseling in deze regio aanzienlijk verbeterd. Vervolgens heeft er integratie plaatsgevonden van de PALMA-software in het Europese EMMI-project. Die integratie stond van tevoren al vast. Niet alleen de software, maar de gehele infrastructuur werd op elkaar afgestemd, waarbij er in de confguratie van de hardware rekening mee werd gehouden dat de groep gebruikers in het EMMI-project driemaal zo groot zou zijn als in het PALMA-project. De ontwikkelde PALMA-software vormt nu een autonoom onderdeel van de EMMI-omgeving en is in zekere zin het belangrijkste bestanddeel. Immers, hiermee worden gevoelige (persoons)gegevens uitgewisseld. De PALMA-software functioneert binnen een besloten computernetwerk, het PALMA-Intranet. De term 'Intranet' staat voor een besloten netwerkomgeving waarbinnen de Internetfunctionaliteit wordt toegepast. Het computernetwerk is besloten omdat het in tegenstelling tot het Internet niet openbaar toegankelijk is. Het is slechts toegankelijk voor IRC-medewerkers.

\subsubsection{De PALMA-omgeving}

De specificatic van de PALMA-omgeving wordt vooral bepaald door het doel van PALMA, namelijk het uitwisselen van gevoelige gegevens. Derhalve worden er eisen gesteld aan de gebruikers, die dan ook als zodanig gedefinieerd dienen te worden. De PALMA-omgeving zelf wordt bepaald door de infrastructuur en door de computerconfiguraties die met elkaar verbonden zijn (zie Figuur 3 ). Wij merken nog op dat de huidige PALMA-omgeving onder het EMMI-netwerk valt.

ALMA-Intranet informatic op te vragen in het buitenland via het IRC.

Hieronder noemen wij vier actoren die bij het opvragen van informatie een rol spelen.

Informatiecentra of contactpunten:

IRC-medewerkers:
Centra waartussen informatie wordt uitgewisseld. Iedere politieregio dient zich te wenden tot een dergelijk IRC, oorspronkelijk ICC genoemd. De centra zijn bedoeld voor uitwisseling tussen landen, niet binnen een land.

Een medewerker van een Nederlands IRC die bevoegd is contact op te nemen met buitenlandse centra om informatie op te vragen over personen, voertuigen en dergelijke binnen het kader van het Verdrag van Amsterdam en de SUO.

Buitenlandse partner: Een medewerker, zoals de IRC-medewerker, maar nu aangesteld bij een informatiecentrum van een buitenlandse politieorganisatic.

Gebruiker:
Een medewerker van de politie die bevoegd is informatie op te vragen via het IRC bij buitenlandse partners. 


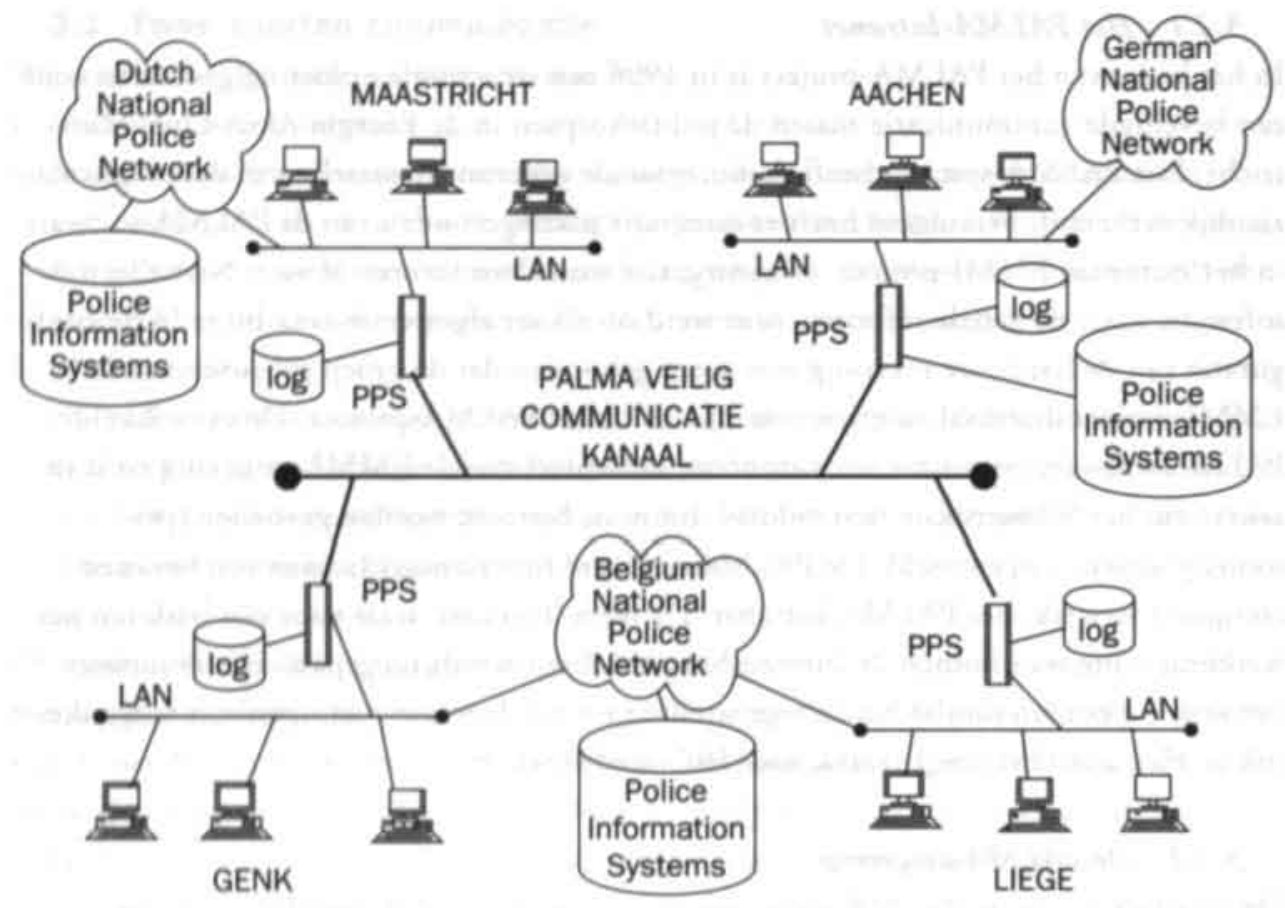

Figuur 3 Opbouw van het oorspronkelijke PALMA-Netwerk uit 1996 (voor afkortingen zie tekst)

Het doel van de applicatie is: de politiële gebruiker op de werkvloer de mogelijkheid bieden om door middel van het PALMA-Intranet informatie op te vragen in het buitenland via het IRC.

Hieronder noemen wij vier actoren die bij het opvragen van informatie een rol spelen.

Informatiecentra of contactpunten:

IRC-medewerkers:
Centra waartussen informatie wordt uitgewisseld. Iedere politieregio dient zich te wenden tot een dergelijk IRC, oorspronkelijk ICC genoemd. De centra zijn bedoeld voor uitwisseling tussen landen, niet binnen een land.

Een medewerker van een Nederlands IRC die bevoegd is contact op te nemen met buitenlandse centra om informatie op te vragen over personen, voertuigen en dergelijke binnen het kader van het Verdrag van Amsterdam en de SUO.

Buitenlandse partner: Een medewerker, zoals de IRC-medewerker, maar nu aangesteld bij een informatiecentrum van een buitenlandse politicorganisatie.

Gebruiker: Een medewerker van de politie die bevoegd is informatie op te vragen via het IRC bij buitenlandse partners. 
Hieronder noemen wij de zeven belangrijkste elementen uit de infrastructuur die voor de uitwisseling van de gevoelige informatie van belang is.

EMMI-netwerk: $\quad$ Een Intranetwerk gebaseerd op Internetprotocollen, bestaande uit 20 locaties, verspreid over 3 landen, gebruikmakend van een besloten ISDN-netwerk.

EMMI-server: $\quad$ Een computer waarop programma's draaien die gebruikt worden binnen het EMMI-netwerk. Nederland beschikt over een centrale EMMI-server bij de ITO in Driebergen. De buitenlandse politieregio's hebben thans nog eigen EMMI-servers.

PALMA: Eén van de programma's die draaien op de EMMI-servers. PALMA is een serverapplicatie die zorg draagt voor de verzending, ontvangst en omzetting van berichten tussen Informatiecentra.

PALMA-formulieren: Een PALMA-formulier is een elektronisch HTML-document (HTML staat voor HyperText Markup Language) met daarin informatievelden en coderingen die de informatievelden identificeren voor PALMA.

PALMA-aanvraag De inhoudelijke velden en de meta-informatic van de aanvraag zoals 'doel' en een deel voor het verloop van een bericht (bron/bestemming, positie in het protocol). De laatstgenoemde velden zijn te beschouwen als de 'header' van een bericht. Een aanvraag omvat het hele traject van invullen van een formulier, opsturen, beantwoorden en het lezen van een aanvraag. In dit traject van een aanvraag worden op verschillende momenten berichten (zie hierna) tussen twee servers gestuurd (of eigenlijk tussen twee Estof-programma's; zie subsectie 3.2.6). Het versturen van die berichten gaat buiten de gebruiker om (dat kan bijvoorbeeld door de server meerdere keren gebeuren als de communicatic niet helemaal goed verloopt). De gebruiker doet een aanvraag en wacht op antwoord.

PALMA-bericht: $\quad$ Een PALMA-bericht is gestructureerd als een Microsoft Windows .ini bestand. Dat wil zeggen dat de informatie is verdeeld in secties en dat er per sectie een aantal regels zijn met de vorm 'veldnaam =veldinhoud".

Van de velden in een bericht is een deel voorbestemd voor de PALMA-aanvraag.

Een modernere aanpak van de berichten zou zijn om de XML-standaard te gebruiken in plaats van de ini standaard. XML staat voor Extensible Markup Language. 
PODACS-netwerk: Het interne landelijke computernetwerk van de politie, thans PolitieNet geheten. PODACS stond voor POlitie DAtaCommunicatie Systeem

PILZ:

Politie Intranet Limburg Zuid.

De configuratie van het oorspronkelijke EMMI-computernetwerk en de daarmee verbonden EMMI-omgeving is gegeven in Figuur 4.

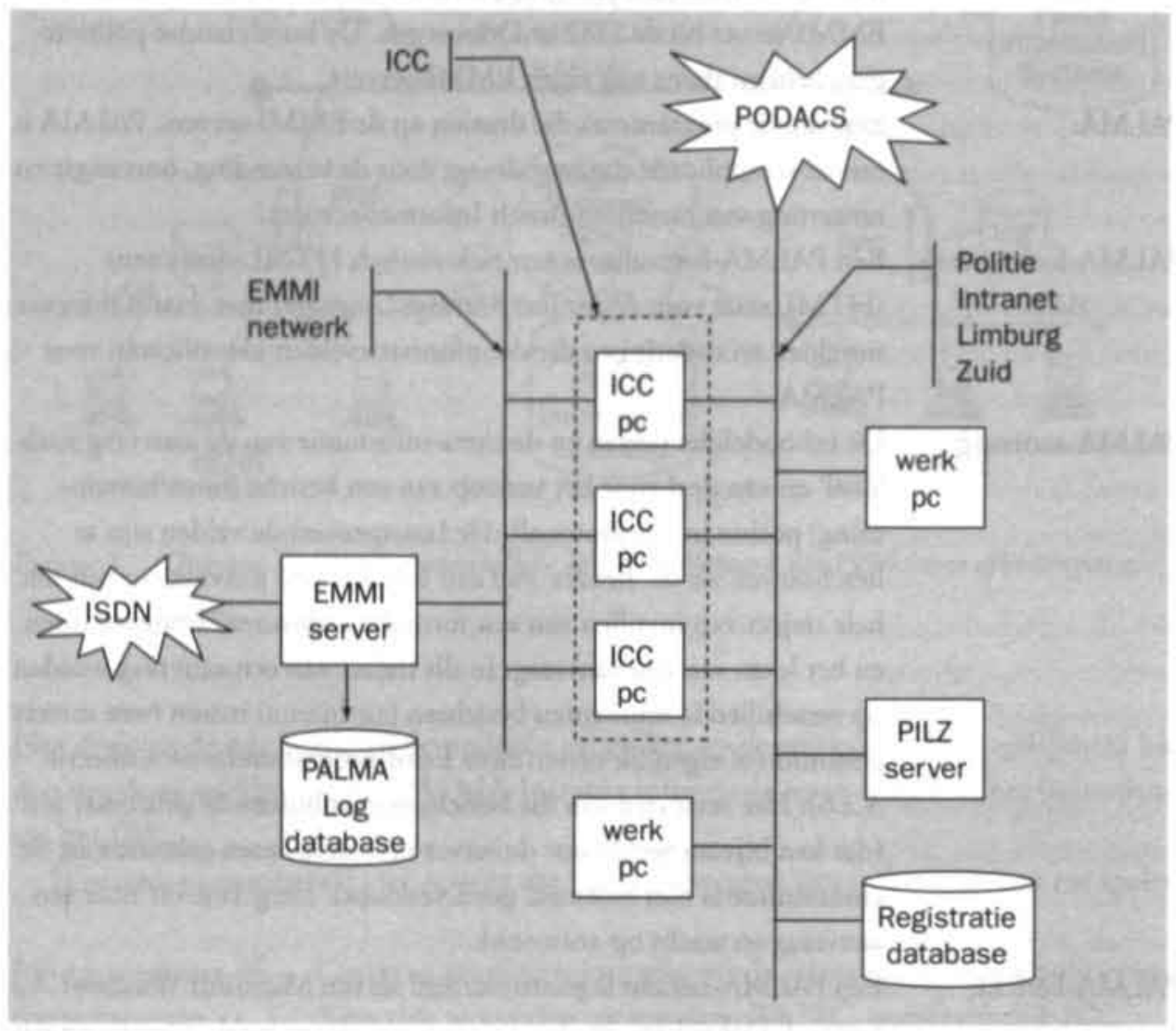

Figuur 4 Het oorspronkelijke EMMI-netwerk en de oorspronkelijke EMMI-omgeving

In Figuur 4 zien we de oorspronkelijke configuratie van het EMMI-netwerk ten opzichte van het PODACS-netwerk (thans PolitieNet) en PILZ. Het ICC (thans IRC) vormt daarin de waterscheiding tussen het binnenlandse en buitenlandse netwerk. IRC-medewerkers hebben toegang tot beide netwerken, terwijl de gebruikers van PolitieNet niet naar het EMMI-netwerk kunnen en vice versa. 


\subsubsection{De informatie-uirwisseling}

IRC-medewerkers kunnen berichten lezen en versturen via het EMMI-netwerk, maar zij kunnen ook berichten lezen en versturen op het PolitieNet. De configuratie van Figuur 4 biedt de mogelijkheid dat gebruikers op het PolitieNet een informatieaanvraagformulier van het EMMI-netwerk opvragen via de PILZ-server, het formulier invullen en terugsturen naar de PILZ-server. Het wordt dan gedeponeerd in een postbus voor de IRC-medewerkers. Het informatieaanvraagformulier bevat naast de gebruikelijke gegevens het e-mailadres van de afzender (de aanvrager/gebruiker).

Een IRC-medewerker kan het informatieaanvraagformulier openen en beoordelen op geschiktheid om te versturen naar het buitenland. Indien geschikt bevonden, wordt het bericht op de reguliere manier gepost op de EMMI-server in een postbus. Als het bericht ongeschikt wordt bevonden, gaat het antwoord per e-mail naar de afzender retour, eventueel voorzien van de reden van afwijzing.

Een antwoord op een aanvraag komt op de reguliere manier binnen bij de IRC-medewerkers. Als het antwoord akkoord wordt bevonden, stuurt de IRC-medewerker het per e-mail naar de gebruiker (de afzender die de oorspronkelijke aanvraag had ingediend). Deze procedure betekent dat het e-mailadres van de gebruiker (de originele aanvrager) gedurende de hele PALMA-aanvraag-antwoord-procedure meegestuurd moet worden, om er voor te zorgen dat het antwoord uiteindelijk weer op de juiste plek terug komt.

Om de gedachten nader te bepalen, geven wij hieronder in 19 stappen aan hoe de informatie-uitwisseling tussen een gebruiker die aangesloten is op PILZ en een gebruiker in het buitenland kan plaatsvinden. De stappen z:jn gegeven in de vorm van een algoritme dat door politiemedewerkers gehanteerd wordt. Daarom is het niet geschreven in de vorm van een programma met twee procedures 'afwijzen' en 'toewijzen'. We merken verder nog op dat 'de gebruiker op de werkvloer' op dit moment (januari 2004) meestal nog niet de beschikking heeft over een e-mailverbinding met het eigen IRC. De stappen die betrekking hebben op de verbinding van de gebruiker met het eigen IRC vinden momenteel (januari 2004) nog vaak telefonisch en per fax plaats. Hetzelfde geldt voor het geven van een antwoord door een IRC-medewerker aan een gebruiker. De te onderscheiden stappen zijn als volgt. ${ }^{61}$

1. De gebruiker vraagt via PILZ de pagina op waarop hij of zij aangeeft informatie in het buitenland aan te willen vragen.

2. De gebruiker geeft op die pagina tevens aan aan welk land en aan welke instantie hij of zij informatie vraagt, en welke informatie hij of zij wenst te ontvangen (via het kiezen van informatievelden).

61. Verbeck, Van den Herik, Plugge \& De Roos 1999, p. 34-35. 
3. De gebruiker krijgt een pagina voor zich waarin alle bekende gegevens staan ingevuld en waarin lege velden bestemd zijn voor de gewenste informatie (dit kan ook het controleren van de informatie inhouden).

4. $\mathrm{Na}$ invulling van nog ontbrekende bekende informatie klikt de gebruiker op de knop Versturen.

5. Het bericht gaat terug naar de PILZ-server, waar het wordt opgeslagen in een postbus voor de IRC-medewerkers.

6. De IRC-medewerkers zien in hun browser of er interne aanvragen zijn binnengekomen.

7. Als dat zo is, dan openen ze zo'n bericht en beoordelen ze de inhoud. Die beoordeling leidt tot één van de volgende twee mogelijkheden:

a. Afwijzen (ga verder met stap 8)

b. Toewijzen (ga verder met stap 12).

\section{Het bericht wordt afgewezen.}

9. De IRC-medewerker drukt op de knop Afwijzen. Het bericht verdwijnt en de IRCmedewerker krijgt de gelegenheid om een reden op te geven.

10.De IRC-medewerker drukt daarna op de knop Verzenden.

11. Het bericht wordt per e-mail naar de afzender (de gebruiker) geretourneerd. STOP

\section{Het bericht wordt toegewezen.}

13. De IRC-medewerker bepaalt waar het bericht naar toe moet in het land waar de aanvraag naar toe gestuurd moet worden.

14.De IRC-medewerker drukt op de knop Verzenden.

15. Het bericht komt op de reguliere manier in de PALMA postbus.

16. Het antwoord komt op de reguliere manier aan in de PALMA-postbus (zie subsectie 3.2.6).

17. De IRC-medewerkers zien in hun browser of er externe berichten (antwoorden of aanvragen) zijn binnengekomen.

18. De IRC-medewerker opent het (antwoord-)bericht en stuurt het door naar de gebruiker (de originele aanvrager) door op de knop Verzenden te klikken.

19. Het bericht wordt nu verder per e-mail verzonden naar de gebruiker. STOP

De stappen 1 tot en met 12 zijn in de meeste gevallen nog niet geautomatiseerd. $\mathrm{Zij}$ verlopen zelfs in 2004 nog telefonisch en per fax. De stappen 13 tot en met 17 en het eerste deel van stap 18 geven de huidige werking weer van het geïmplementeerde PALMAIntranet. We merken op dat het laatste deel van stap 18, namelijk het doorsturen van het antwoord door een IRC-medewerker aan de gebruiker, thans ook nog meestal telefonisch of per fax verloopt. Stap 19 is veelal ook nog niet geautomatiseerd. 


\subsubsection{Informatie-uitwisseling via de PALMA-sofruane?}

Het PALMA-systeem maakt gebruik van een reeks definitiebestanden waarin de precieze werking van het systeem vastligt. Het systeem is generiek. De definitiebestanden zijn na een korte instructie door de gebruikers, met name de systeembeheerders, zelf aan te passen.

De ontwerpers hebben er rekening mee gehouden dat de registratie van de uitgewisselde gegevens conform de - in hoofdstuk 5 te behandelen - Schengen-eisen dient te geschieden. Het PALMA-systeem maakt het mogelijk om ook officieuze gegevensuitwisselingen via het vervaardigde computernetwerk te laten verlopen, zodat registratie en daardoor controle achteraf voor alle gegevensuitwisselingen verzekerd zijn. Daarnaast gebruiken de politiepartners de registratie voor managementdoeleinden om de kwaliteit en kwantiteit van de gegevensuitwisseling te beoordelen.

Verder is door alle politiepartners geëist dat er een fysieke scheiding blijft bestaan tussen het EMMI-netwerk en de nationale politienerwerken en politiedatabanken. Die eis berust op wettelijke en politieke gronden die, zoals zal blijken in hoofdstuk 5, onderlinge verbindingen in beginsel verbieden. Dit brengt belangrijke beperkingen met zich mee voor de internationale gegevensuitwisseling.

\subsubsection{Het ontwerp van PALMA}

Het ontwerp van het PALMA-systeem is onder meer gebaseerd op de Internet-standaard HTTP, HyperText Transfer Protocol. Die biedt de gebruiker en de IRC-medewerker - hierna voor het gemak gezamenlijk aangeduid als gebruiker - de mogelijkheid om op eenvoudige wijze teksten, afbeeldingen, geluid, videobeelden en dergelijke door te geven. Het PALMAsysteem kan dankzij de gehanteerde technologie ook gemakkelijk geïntegreerd worden met andere bestaande en toekomstige informatie- en communicatiesystemen.

De verbinding met het buitenland wordt gerealiseerd door een router. De router is verbonden met de EMMI-server, de computer waarin de PALMA-gegevens zijn opgeslagen. Tevens is de router verbonden met de werkstations van de IRC-medewerkers (voor video conferencing) en met een ISDN-lijn naar het buitenland. $\mathrm{Er}$ is een aantal ISDN-lijnen tussen de IRC's aangelegd. Zij vormen samen het EMMI-netwerk. Ieder buitenlands deelnemend IRC heeft een eigen EMMI-server met als bestanddeel de PALMA Protocol Server (zie subsectie 3.2.6). ledere PPS registreert alle internationale communicatie die via de EMMI-server verloopt in een registratie- of logbestand, de PALMA-logdatabase.

62. Voor een conceprueel technische beschrijving zie Van den Herik, Plugge, Donkers 8 Berghmans 1996 en in het bijzonder Donkers, Verbeek, Van den Herik, Van der Krogt, Boers, Spronck \& Wiesman 2001. 
We merken op dat alleen de communicatic die via de PALMA-software verloopt, wordt geregistreerd. De via de multimediakiosk beschikbaar gestelde gegevens worden niet geregistreerd in de lokale PALMA-logdatabase.

De WWW-technologie berust oorspronkelijk op het client-server-model. Enerzijds draaien er programma's op computers die server worden genoemd: een WWW-server kan gegevens opslaan en verstrekken. Anderzijds draaien er programma's op de computer van de gebruiker, die client wordt genoemd. De termen 'server' en 'client' staan hier dus voor de met elkaar communicerende computers. We merken echter op dat de programma's die de communicatie tussen de client-computer en de server-computer mogelijk maken ook 'client' respectievelijk 'server' worden genoemd.

Een WWW-client verleent de gebruiker toegang tot de gegevens die bij een WWW-server zijn opgeslagen, nadat contact is gemaakt met de WWW-server via het betreffende netwerk (zie Figuur 5). De WWW-client wordt ook wel 'browser' of 'viewer' genoemd. We hebben het dan over het programma dat op de client-computer draait en de gebruiker toegang verleent tot de gegevens die bij een WWW-server zijn opgeslagen. De WWW-client presenteert de gegevens aan de gebruiker en vormt de eigenlijke gebruikersomgeving. De WWW-server start op vraag van de WWW-client een bepaald programma op, verzamelt de resultaten van dat programma en stuurt die resultaten terug naar de client. De presentatie gebeurt in de vorm van pagina's die bij de PALMA-software de vorm hebben van een invulformulier. Een gebruiker vult de velden in dit formulier in en drukt op de verzendknop. Het formulier wordt vervolgens naar de plaatselijke server gezonden, vanwaaruit het naar de bestemmingsserver elders kan worden doorgezonden.

Bij de bovenstaande beschrijving past een relativerende opmerking. In de moderne informaticaterminologie is de combinatie van een HTTP-server/browser geen goed voorbeeld voor een client-serversysteem, hoewel dat met het woord 'server' wel zo lijkt te zijn. Het wordt in ieder geval niet meer zo genoemd. Een zogenoemd three-tier client-serversysteem kan weliswaar van een HTTP-server gebruik maken. De echte server staat achter de web-server, in ons geval de PPS-server en/of de SQL-server. Deze laatste verzorgt momenteel de dataopslag (SQL staat voor Structured Query Language). De term 'clientserver aanpak' heeft eigenlijk meer te maken met intensieve taken zoals een database. Daarbij is er een centrale machine die de database bevat en alle queries op de database uitvoert. De client stuurt alleen een kleine aanvraag en krijgt alleen het antwoord van de server terug. Afhankelijk van het feit of er tussen de client en server nog en webserver zit wordt gesproken over two-tier of three-tier architectuur. Bij PALMA hebben we een three-tier architectuur met de volgende rollen:

- gebruikers-PC: 'client'

- webserver: 'portal'63 
- PPS (zie subsectie 3.2.6): 'business logic' (de 'workflow')

- SQL-server: 'storage' (de gegevensopslag in de logdatabase)

- Estof (zie subsectic 3.2.6): 'communication' (de communicatic)

\subsubsection{De PALMA Protocol Server}

De PALMA Protocol Server (PPS) maakt de Euregionale en grensregionale communicatie mogelijk. De term 'server' staat hier niet voor een computer, maar voor een computerprogramma. Het programma PPS is speciaal voor PALMA geschreven. Het wordt door een WWW-server (ook een programma) geactiveerd op verzoek van een WWWclient (zie Figuur 5, die evenwel de verouderde oorspronkelijke situatie weergeeft, zie nader hoofdstuk 4 voor de huidige werking). De PPS vormt het centrale onderdeel van de PALMA-software. Het programma voorziet de WWW-server desgewenst van gegevens die de server vervolgens kan doorsturen naar een client.

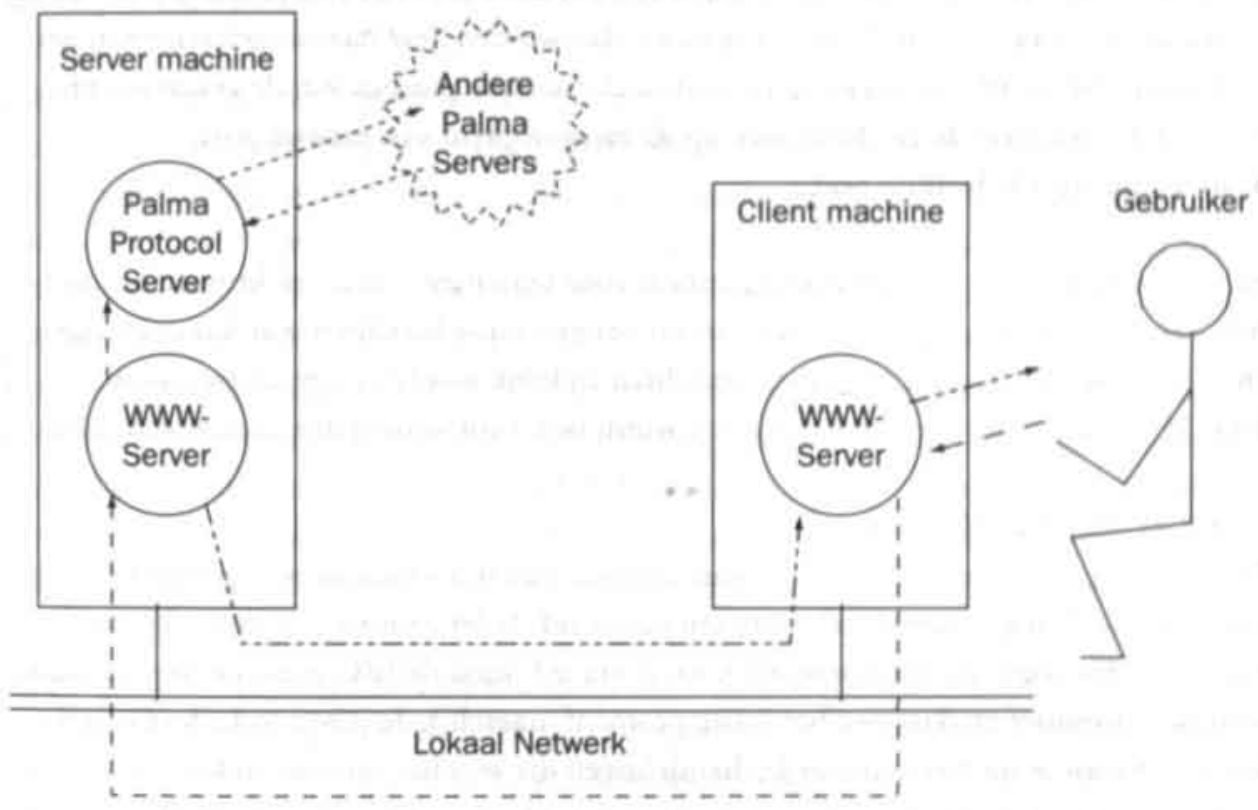

Figuur 5 Oorspronkelijke PPS

63. In het algemeen worden de volgende eigenschappen toegeschreven aan een portal. Het betreft een startpagina, in de vorm van een unieke URL. (Uniform Resource Locator) voot elke gebruiker binnen een organisarie, waarin kunnen zijn opgenomen (1) links naar interne of externe WWW-sites (sites die informatic aanbieden) en (2) links naar bestaande applicaties (transactieverwerkende systemen). De sites en applicaties zijn met tén muisklik oproepbaar. De gebruiker behoeft maar ten keer in te loggen. Hij of zij kan zijn of hast startpagina naar eigen smaak inrichten (items toevoegen of verwijderen), echter wel binnen de in het portaal vastgelegde toegangsregels (autorisatic). 
Het verzenden van berichten via de PPS gebeurde in het oorspronkelijk ontwerp door de volgende acht punten af te werken:

1. een verzender stuurt een bericht van de client (browser) naar de eigen servermachine en specifiek naar de daarvan onderdeel uitmakende PPS;

2. de PPS plaatst het te verzenden bericht in een zogeheten Spool directory (Spooldir);

3. het programma Estof, ${ }^{64}$ dat speciaal voor PALMA is ontwikkeld, controleert iedere tien seconden of et een bericht in de Spooldir staat; als er éen of meer berichten in de Spooldir staan, dan wordt het bericht geopend en wordt gekeken naar het adres van de geadresseerde, naar het adres van de afzender en naar het onderwerp van het bericht;

4. het programma Estof van de verzender verstuurt het bericht naar het programma Estof van de ontvanger;

5. Estof ontvangt het bericht en schrijft het weg in een directory waarin alle ingekomen berichten worden geplaatst;

6. Estof controleert iedere tien seconden of er een nieuw bericht in de directory staat; als er één of meer berichten in de directory staan, dan worden deze daaruit gelezen en in het formaat van de PPS weggeschreven in de elektronische postbus van de geadresseerde;

7. de PPS attendeert de geadresseerde op de aanwezigheid van nieuwe post;

8. de geadresseerde leest de post.

Er zijn derhalve twee soorten opslagplaatsen voor berichten: (1) de elektronische 'postbus' van een PALMA-organisatie waarin binnengekomen berichten worden opgeslagen en (2) de Spooldir waarin uitgaande berichten tijdelijk worden opgeslagen totdat ESTOF ze kan versturen. Deze directory wordt ook voor andere doeleinden gebruikt.

\subsubsection{Het PALMA Protocol}

Het PALMA-systeem werkt met een vast patroon van informatieaanvraag en informaticverstrekking. Dit patroon wordt protocol genoemd. Ieder protocol is een reeks van formulieren. Als gegevens moeten worden aangevraagd, kiest de IRC-medewerker het juiste aanvraagformulier en daarmee het juiste protocol, namelijk de juiste reeks formulieren. De verschillende (geautomatiseerde) handelingen die worden verricht tijdens het proces van de informatieaanvraag en de informatieverstrekking worden aangeduid met de term job. Een job begint op het moment dat een IRC-medewerker een aanvraagformulier invult en eindigt op het moment dat het antwoord wordt geaccepteerd. De drie tussenliggende stappen zijn:

1. het ontvangen van een zogeheten reactieformulier door het buitenlandse IRC,

2. het invullen ervan, en

3. het versturen van het ingevulde formulier naar het vragende IRC.

64. Estof staat voor Extremely simple tnansfer of files. Estof gebruikt als netwerkprotocol TCP/IP (Thansmission Control Protorol/Internet Protocol). 
Het buitenlandse IRC werkt dus niet met het oorspronkelijke aanvraagformulier, maar met een reactieformulier dat in de eigen landstaal is opgesteld. Zowel het aanvraagformulier als het reactieformulier bevatten invulvelden. Het antwoordformulier presenteert de gegevens, zoals aangeleverd door de beantwoorder. Het bevat geen invulvelden meer. Iedere job krijgt een unieke identificatiecode, waardoor achteraf nagegaan kan worden wat er precies met een bepaalde aanvraag is gebeurd.

De overeengekomen standaard voor de afhandeling van berichten, als het ware de 'workflow', via PALMA-servers is het zogeheten PALMA Protocol. Door dit PALMA Protocol worden berichten gemaakt en gelezen met behulp van een interface waarmee ook informatiebronnen kunnen worden geraadpleegd, namelijk via browsersoftware. ${ }^{65}$ Alle post wordt geadresseerd aan het betreffende IRC en niet aan een persoon. Op deze manier wordt voorkomen dat berichten onbeantwoord blijven, omdat een bepaalde persoon afwezig is. De PPS biedt dan ook geen mogelijkheid voor privé-post.

De beveiliging van het gegevensverkeer is verzekerd door een versleuteling (encryptie) van de uit te wisselen berichten. De betreffende sleutel is berichtafhankelijk. Versleuteling van de berichten vindt plaats vóór de plaatsing in de Spooldir. Ontsleuteling (decryptie) vindt plaats vindt plaats direct bij ontvangst door Estof. Tot op heden werd voor zover bekend door geen van de politiepartners encryptie toegepast op hun nationale politienerwerken. De gebruikte ISDN-lijnen voorzien in een extra beveiliging door zogeheten nummeridentificatie. Alleen de nummers die voorgeprogrammeerd zijn om een verbinding mee tot stand te brengen, worden toegelaten. Contact met andere nummers is daardoor uitgesloten. Verder zijn de ISDN-routers ook nog voorzien van wachtwoorden. Aldus worden alleen verbindingen met geautoriseerde IRC's geaccepteerd. Het communicatiekanaal is ook alleen maar toegankelijk voor de EMMI-software.

\subsubsection{De PALMA-formulieren}

Een PALMA-aanvraag is per definitie gestructureerd in de vorm van formulieren. Het PALMA Protocol maakt gebruik van drie soorten formulieren: een aanvraagformulier, een reactieformulier en een antwoordformulier int. Nieuwe formulieren kunnen op eenvoudige wijze worden toegevoegd. Dit is in het hierna te beschijven PALMA II-project reeds gebeurd. Daarbij is een zogeheten mededelingenformulier aan de PALMA-software toegevoegd, met de mogelijkheid om bestanden te versturen. De gebruikersomgeving van het PALMA-systeem is gemakkelijk aan te passen aan de specifieke eisen van de

65. Als browser wordt Microsoft Explorer gebruikt omdat Microsoft de gekozen software-standaard is. Als besturingsysteem voor EMMI wordt Windows gebruikt. Dit besturingssysteem biedt een goede stabiliteit en goede beveiligingsmogebijkheden. 
gebruikers. Naast de tekst in de gestrucureerde velden (vergelijk Appendix G) kan ook vrije tekst worden verstuurd.

De formulieren worden in HTML gespecificeerd in zogeheten formulierscripts. Bij het schrijven van de formulierscripts door de ontwikkelaars van de PALMA-software werden op de juiste plekken verwijzingen naar de in te vullen gegevens opgenomen, zodat de PPS op die plekken een invulveld of een presentatieveld van het juiste type voor bepaalde gegevens kan neerzetten. De formulierscripts zijn preciezer geformuleerd opgesteld in een speciaal ontworpen uitbreiding op HTML. In de toekomst kan de XML-standaard hiervoor worden gebruikt. De PPS maakt van deze scripts en de informatie uit een bericht pas een HTML-pagina. De op dit moment ontwikkelde en geaccordeerde formulieren betreffen in hoofdzaak voertuig-en persoonsgegevens. Zij zijn opgesteld aan de hand van bestaande papieren formulieren.

\subsubsection{Registratie van de gegevensuitwisseling}

Het is belangrijk dat alle gegevensuitwisselingen worden gearchiveerd. In een geautomatiseerd archief wordt bijgehouden wanneer het betreffende bericht is verstuurd en ontvangen, van welke instantie het afkomstig is en door wie het bericht behandeld is. Bovendien wordt de complete inhoud van het bericht opgeslagen. ${ }^{66}$

Terwille van de archieffunctie wordt op de EMMI-server een logging bijgehouden. Dit gebeurde oorspronkelijk in een Microsoft Access-database, maar thans op een Microsoft SQL-server. Microsoft Access is het softwarepakket dat nog wel voor de lokale PALMAregistratiedatabase wordt gebruikt. De centrale database wordt PALMA-logdatabase genoemd. Alleen de gegevensuitwisseling die via de PALMA-software verloopt, wordt in de PALMA-logdatabase geregistreerd. De informatie die wordt gepubliceerd in de EMMI-omgeving wordt niet in de PALMA-logdatabase geregistreerd. Voor de PALMAlogdatabase van de EMMI-server is geen gebruikersinterface ontworpen om de loggegevens in leesbare vorm te presenteren of om ze te wissen. Wel kunnen bepaalde velden door de IRC-medewerkers door een druk op de knop worden overgebracht naar een zogeheten registratiedatabase. De registratiedatabase maakt onderdeel uit van het lokale

66. Het bericht zelf wordt daarnaast ook als bestand bewaard op de harde schijf van de EMMI-server, totdat het wordt gewist. Dit wissen van het eigenlijke bericht gebeurt standaard nadat bet bericht is gelezen. 
politienetwerk; in Maastricht is dat PILZ: Alleen voor die registratiedatabase is een gebruikersinterface ontworpen die het mogelijk maakt de inhoud ervan toegankelijk te maken voor degenen die er toegang toe hebben, met name de IRC-medewerkers en de RCIE. In de registratiedatabase worden door de IRC-medewerkers verder met de hand ook alle gegevens ingevoerd over gegevensuirwisselingen via de fax en de telefoon. De IRC-medewerkers kunnen met behulp van het softwareprogramma Microsoft Access vanuit de registratiedatabase bepaalde statistische gegevens bijhouden. Er is een aantal standaardbevragingen of -queries gemaakt voor specifieke vragen die steeds terugkomen. Zo kan over een bepaalde periode bijgehouden worden hoeveel berichten verstuurd zijn en wanneer zij verstuurd zijn, of bepaalde berichten al cerder verstuurd zijn, en hoeveel aanvragen er vanuit een land zijn binnengekomen. Aldus functioneert de logging ook als een controle- en waarschuwingssysteem. Vanuit managementsperspectief is op deze manier kwaliteitsbewaking mogelijk van het proces van de internationale politiële gegevensuitwisseling. Hieraan was, zoals is gebleken in hoofdstuk 2, een grote behoefte ontstaan.

\subsubsection{Het vertalen van berichten}

Het systeem is verder op verzoek van de politiepartners in zekere zin meertalig van opzet; de toevoeging 'in zekere zin' geeft aan dat een vertaling van vrije tekst vooralsnog niet tot de mogelijkheden behoort. Een bericht wordt, omdat er met sjablonen of templates gewerkt wordt, in de vorm van een bestand verzonden. Alleen de inhoud van het formulier wordt verzonden, niet de formulieren zelf. Zodoende zijn de formulieren taalonafhankelijk te houden. Elk land gebruikt zijn eigen sjablonen in de eigen taal. Daarnaast

67. De PALMA-logdatabase van de EMMI-server bevat in een logtabel de volgende gegevens: het nummer van het bericht, de datum, het tijdstip van de logging, en (als voornamste onderdeel) de inhoud van het hele bericht in de vorm van een Access memoveld. Het bericht in het memoveld is verdeeld in velden, zoals naam. telefoonnummer en paspoortnummer. In deze vorm zijn de gegevens echter niet goed te interpreteren door de gebruikers. Dese velden kunnen worden overgebracht naar de registratiedatabase. Dit gebeurt na een opdracht daartoe door een IRC-medewerker om bijvoorbeeld alle vandaag binnengekomen reconds (bestanden met alle gegevens omtrent cen bepaalde gegevensuitwisseling) te kopièren naar de registratiedatabase. Aan de registratiedatabase wordt verder nog informatie toegevoegd over bijvoorbeeld de plaats waar de informatie is gevonden en wie een verzock om informatie heeft afgehandeld. In de PALMA-logdatabases van de beide bij de verzending en ontvangat van een bericht betrokken EMMI-servers worden op de volgende momenten aantekeningen gemaakt: ten eerste nadat de verzender op de verzendknop heeft gedrukt om het ingevulde aanvraagformulier te verzenden; ten tweede nadat degene die het bericht wil beantwoorden het 'aanvraagbericht' in zijn mailbox heeft geopend; ten derde op het moment wasop de beantwoorder zijn reactieformulier terugaendt naar de anvrager; ten vierde op het moment wasop de aanvrager het 'antwoordbericht' opent; ten slotte op het moment waarop de aanvrager het bericht wist. Deze momenten worden ook aangegeven in de PALMA. logdatabase. De eerste, vierde en vijfde aantekening worden gemaakt door de EMMI-server aan de zijde van de aanvrager. De tweede en derde antekening worden gemaakr door de EMMI-server aan de zijde van de beantwoorder. 
worden veel voorkomende begrippen uit de inhoudsvelden, zoals het doel van de aanvraag en de urgentie ervan, door middel van tabellen automatisch vertaald in de landstaal, met Engels als intermediaire taal. Op die manier is voor elke PPS slechts één vertaaltabel noodzakelijk, die steeds als brontaal het Engels heeft en als doeltaal de plaatselijke taal. De PPS zoekt, voordat het betreffende formulier wordt getoond, de bijbehorende vertaling in de tabel op en vult die in op het formulier. Vrije tekst kan echter nog niet geautomatiseerd vertaald worden. Geautomatiseerd vertalen wordt door IRCmedewerkers ook niet als een essentiële voorwaarde naar voren gebracht, omdat zij, zoals gezegd in het vorige hoofdstuk, de verschillende talen afdoende beheersen om hun werk te doen. Wel zou in de toekomst, bij een mogelijke toename van het aantal deelnemende landen aan EMMI en daarmee dus van het aantal mogelijke talen, een vorm van semiautomatische vertaling noodzakelijk kunnen zijn. Volledig automatisch vertalen, zal - naar men op dit moment moet aannemen - niet mogelijk zijn, omdat dit tot (ernstige) fouten zou kunnen leiden, die incorrecte handelingen tot gevolg kunnen hebben en dat is in de wereld van politie en justitie absoluut onwenselijk.

\subsubsection{Koppeling van gegevens}

Op grond van het voorgaande zal duidelijk zijn dat de gegevens die bij de gegevensuitwisseling worden gebruikt, in drie groepen onderverdeeld kunnen worden, namelijk:

1. gegevens die de aanvrager invult in het aanvraagformulier;

2. gegevens die de beantwoorder invult of anpast ${ }^{68}$ in het reactieformulier;

3. gegevens die het PALMA-systeem automatisch genereert.

Onder de laatste groep vallen de gegevens die niet over de inhoud van het bericht maar over het bericht zelf gaan: het gebruikte protocol, de identificatiecode van de job, de naam van de aanvrager en de beantwoorder, hun organisatie, het tijdstip van de aanvraag en van de beantwoording, et cetera. Een deel van deze gegevens worden gepresenteerd in de verschillende formulieren.

Wat de koppeling van het EMMI-netwerk aan de verschillende nationale politiële netwerken betreft, geldt dat, in verband met de eisen van de SUO en de nationale wetgevingen daaromtrent, geen directe koppeling is gerealiseerd in Belgiè en Duitsland. Een koppeling werd politiek en juridisch op voorhand door deze politiepartners niet haalbaar geacht in verband met privacyaspecten, die in in hoofdstuk 5 besproken worden. Nederland heeft in 1996 met toestemming van het toenmalige Ministerie van Binnenlandse Zaken gekozen voor een indirecte koppeling. Dit houdt in dat, hoewel er wel degelijk

68. In het reactieformulier worden de gegevens uit groep 1 namelijk gepresenteerd aan de buitenlandse IRC-medewerker. Deze gegevens kunnen daarna gewijzigd of aangevuld worden door de beantwoorder. 
een fysicke koppeling tussen beide netwerken bestaat, er geen geautomatiseerde routing van gegevens van het ene naar het andere netwerk plaatsvindt.

In Nederland beschikt elk werkstation in het IRC ${ }^{69}$ over twee netwerkkaarten: én voot de verbinding met de EMMI-server en één voor de verbinding met het regionet PILZ. In Belgiê en Duitsland is er geen directe verbinding met het regionet, In Duitsland wordt alles nog handmatig gearchiveerd en 's avonds in kasten opgeslagen. De Belgische en Duitse politiediensten gebruikten EMMI in de beginperiode dan ook bijna alleen voor foto's, rijbewijzen en vingerafdrukken (weliswaar niet goed genoeg voor identificatic, maar wel goed genoeg om eventueel een daadwerkelijke aanvraag te versturen).

Wat er doorgegeven wordt aan de gebruiker op de werkvloer wordt bepaald door de mens, namelijk door de IRC-medewerkers. Er is dus sprake van een door mensen gecontroleerde firewall (informatiefilter). Anderen dan IRC-medewerkers kunnen niet 'over de muur kijken' van het EMMI-netwerk. Zij hebben geen rechtstreekse toegang tot de EMMl-omgeving. Slechts via de IRC-medewerkers kunnen zij aan informatie uit de EMMI-omgeving komen. De lokale netwerken in de aan het EMMI-project deelnemende politiebureaus zijn op een of andere manier ook weer verbonden met de nationale politiële netwerken, in Nederland met het PolitieNet. In die nationale netwerken zijn centrale politiële informatiesystemen aanwezig, zoals het kentekenregistratiesysteem en het herkenningsdienstsysteem (HKS) voor de herkenning van verdachten. Deze informatiesystemen zijn niet vrij toegankelijk voor buitenlandse politieorganisaties. Het merendeel van de internationaal uitgewisselde gegevens is echter wel afkomstig uit deze systemen. Om gegevens vanuit de nationale politielle databanken via de daarvoor bestaande formulieren in de EMMI-server te brengen, moet er door de IRC-medewerkers met behulp van het Microsoft Windows-besturingssysteem elektronisch geknipt en geplakt worden. Er is geen mogelijkheid gecreëerd om rechtstreeks op geautomatiseerde wijze gegevens uit een nationale databank in de PALMA-formulieren in te vullen. Het toenmalige Nederlandse Ministerie van Binnenlandse Zaken is met deze proefopstelling van EMMI akkoord gegaan. Er is derhalve geen directe koppeling tussen het nationale politienetwerk en het EMMI-netwerk voor andere dan de IRC-medewerkers. De IRCmedewerkers bepalen welke gegevens van de EMMI-omgeving naar het nationale politienetwerk gekopieerd worden voor voeding van de registratiedatabase en voor beantwoording van de vragen van en aan de medewerkers op de werkvloer. Omgekeerd bepalen de IRC-medewerkers ook welke gegevens van de nationale politiële databanken gekopieerd worden naar de EMMI-server en dus welke gegevens het buitenland vanuit die nationale

69. In het IRC Limburg zijn ex op dit moment (januari 2004) viet workstations operationed. 
databanken verkrijgt. Een IRC-medewerker draagt in dezen dus een grote verantwoordelijkheid.

De RCIE heeft geen rechtstreekse toegang tot de EMMI-omgeving. Zij beschikt namelijk niet over een werkstation binnen de EMMI-omgeving. Wel beschikt zij over een werkstation op het regionet PILZ. Via het werkstation op PILZ heeft de RCIE toegang tot de registratiedatabase. Het $\mathrm{OM}$ heeft feitelijk op dit moment nog geen rechtstreekse geautomatiseerde toegang tot de EMMI-omgeving, maar zou dat in de toekomst wel willen. Technisch kan dit heel eenvoudig gerealiseerd worden, op dezelfde manier als dit voor de RCIE is gebeurd. De registratiedatabase moet niet verward worden met de PALMA-logdatabase van het EMMI-netwerk. Tot de PALMA-logdatabase hebben de RCIE en het OM geen toegang.

Het is van belang dat tot op dit moment slechts een deel van de gegevensuitwisseling volledig geautomatiseerd is, namelijk alleen de communicatie die plaatsvindt tussen de verschillende IRC's. De communicatic tussen een politiële medewerker op de werkvloer en het IRC is nog niet volledig geautomatiseerd. In de toekomst zal elke agent op de werkvloer via reguliere e-mail een gegevensaanvraag kunnen versturen naar het IRC. Het IRC zal dan ook via e-mail een antwoord kunnen geven (voor de beoogde werking, zie subsectie 3.2.3).

\subsubsection{PALMA en multimedia}

In februari 1997 kreeg de onderzoeksafdeling van MATRIKS-informatica ${ }^{70}$ van de Universiteit Maastricht de opdracht van de Regiopolitic Limburg-Zuid om PALMA uit te breiden met multimediafaciliteiten, dat wil zeggen de mogelijkheid tot het versturen van gedigitaliseerde documenten. In het daartoe opgestarte project PALMA \& Multimedia ${ }^{71}$ is de PALMA-software uitgebreid met de mogelijkheid om allerlei digitale bestanden te versturen. Gedigitaliseerde documenten van bijvoorbeeld vingerafdrukken, voertuigbewijzen en foto's kunnen dankzij deze uitbreiding samen met berichten via het PALMA-Intranet worden verzonden. Naast gescande documenten kunnen ook tekstdocumenten en spreadsheetbestanden worden verstuurd. Deze uitbreiding heeft een multimediale functionaliteit aan PALMA toegevoegd.

Voor de uitbreiding is er tevens onderzoek verricht naar de benodigde hardware, de mogelijke bestandsformaten en de geschikte software. Voorts zijn de specifieke kenmerken van de te versturen documenten onderzocht alsmede hoe en met welke hardware

70. MATRIKS staat voor MAastrichts Technologisch Research Instituut voor Kennis en Systemen.

71. Van den Herik, Plugge, Mathijsen, Donkers, van den Bosch \& Klinkers 1997. 
deze het beste gescand kunnen worden, met inachtneming van de eisen van reproductic. Verder is aandacht besteed aan de wijze waarop de te verzenden multimediale bestanden het beste (tijdelijk) opgeslagen kunnen worden. Het opslaan van de bestanden gebeurt op een zo compact mogelijke wijze met behoud van de vereiste kwaliteit. Op basis van het onderzoek zijn ten slotte specificaties opgesteld van de manier waarop de verschillende documenten het beste gescand en opgeslagen kunnen worden.

Het versturen van de bestanden gebeurt als volgt. De te versturen documenten worden door de IRC-medewerkers in een data-directory geplaatst. Daarna 'pakt' de IRC-medewerker een elektronisch PALMA-mededelingenformulier dat speciaal voor dit doel ontwikkeld is. Op dat moment wordt gekeken welke bestanden er in de data-directory staan. ${ }^{72}$ Deze bestanden worden in een overzicht onderaan het mededelingenformulier geplaatst. De IRC-medewerker kan dan 'aankruisen' welke bestanden hij of zij wil verzenden. ${ }^{73}$ De te verzenden bestanden kunnen worden voorzien van een omschrijving ter verduidelijking van de ontvanger. Daarna wordt het formulier verzonden. Na het verzenden worden de bestanden in de data-directory automatisch gewist. Dit is gedaan om te voorkomen dat er een steeds grotere lijst met bestanden ter verzending gepresenteerd wordt.

De ontvangen bestanden van een ander IRC zijn ook weer gekoppeld aan een mededelingenbericht. De IRC-medewerker kan de bestanden bekijken door op de bestandsnaam te klikken. Door het klikken wordt de bijbehorende applicatie opgestart.

In de PALMA-logdatabase en uiteindelijk in de registratiedatabase is de naam van het verzonden bestand terug te vinden, samen met andere kenmerken van de gegevensuitwisseling, zoals de afzender, de ontvanger, het tijdstip van verzending en de gedane mededeling.

Technisch gesproken zijn er bij PALMA twee manieren om documenten klaar te zetten om mee te sturen: een via een zogeheten HTTP-upload en een via een locale-netwerk link (datadirectory). De upload-manier is de modernere en wordt in Nederland toegepast (zie nader subsectie 4.6.1).

72. Dit gebeurt door het in subsectie 3.2 .6 besproken programma Estof dat special hiervoor werd ontwikkeld door de capaciteitsgroep Informatica van de Universiteit Masstricht. Estof zorgt daarnast ook, zoals we gezien hebben, voor het verzenden en ontvangen van de PALMA-berichten zelf.

73. Standaard worden alle bestanden ter verzending geselecteerd. Bestanden die niet verzonden moeten worden, dienen dus als zodanig te worden gekenmerkt. 


\subsubsection{Samenvatting}

Op dit moment ziet de gegevensuitwisseling via PALMA in de EMMI-omgeving er in het in hoofdstuk 2 aangehaalde voorbeeld als volgt uit. De politieagent belt het IRC in Maastricht en noemt het kenteken van een aangetroffen Belgische auto. De betreffende IRC-medewerker start via de PALMA-software een nieuwe gegevensaanvraag door het opvragen van een aanvraagformulier. In dit Nederlandstalige aanvraagformulier vult hij of zij het kenteken in en verstuurt het formulier al dan niet met een urgentievermelding naar een collega in Eupen. In het OIPG in Eupen wordt het bericht ontvangen. De Belgische IRC-medewerker leest het Duitstalige formulier, vult de ontbrekende informatic in en stuurt het terug naar het IRC in Maastricht. De IRC-medewerker in Maastricht ontvangt een bericht van antwoord, opent dit bericht door middel van het daartoe bestemde antwoordformulier en vertelt via telefoon of fax - op dit moment meestal nog niet via e-mail of computerterminal - aan de aanvragende agent wat er op het Nederlandstalige formulier staat. Ondertussen heeft de PALMA-software op de beschreven wijze zowel in Eupen als in Maastricht de aanvraag en beantwoording van de gegevensaanvraag al geregistreerd.

Bij het ontwerp van PAL.MA is vooral aansluiting gezocht bij beproefde Internet-technieken. Dit is ook gebeurd bij de voorafgaande politieprojecten zoals DVS. In 1995 en 1996 was dat allerminst vanzelfsprekend voor de politie. Enkele redenen hiervoor waren:

- veel software was gratis;

- de software was open, alle standaarden waren bekend en broncodes waren beschikbaar;

- de software werd veel gebruikt en er was dus veel ervaring mee;

- er waren veel hulpmiddelen te vinden;

- er vonden veel ontwikkelingen plaats;

- de HTML-standaard van dat moment bood veel flexibiliteit om de gebruikersomgeving te maken zonder dat lokaal veel software nodig was.

De Internet-technieken die bij aanvang van PALMA werden gebruikt waren:

- het TCP/IP protocol voor netwerkcommunicatie (zonder Domain Name Server (DNS) weliswaar);

- het HTTP-protocol voor communicatie tussen webbrowsers en webservers; en

- het CGI-protocol (CGI staat voor Common Gateway Interface) voor communicatie tussen de PPS en de webserver.

Bij het ontwerpen van de gebruikersomgeving is gebruik gemaakt van HTML, maar wel op een uitgebreide manier. In PALMA worden zogeheten 'templates' gebruikt die door de PALMA-server met behulp van de berichtinhoud in HTML worden omgezet. Een vergelijkbare, maar modernere manier hiervoor is het gebruik van XML/XSL (XSL staat voor Extensible Stylesheet Language). 


\section{Het EMMI-concept}

In dit hoofdstuk behandelen wij het EMMI-concept. Analoog aan het PALMA-concept heeft EMMI tot doel: (1) het ontwikkelen van een hecht samenwerkingsverband tussen politie, universiteiten en telecommunicatiebedrijven, in dit verband is het blikveld gericht op geheel Europa: (2) het bereiken van doelstelling (1) via groeikernen, zowel organisatorisch, als politieel, alsook softwarematig gezien; en (3) het ontwikkelen van een beveiligde communicaticomgeving, waarbinnen de politie zowel gebruik kan maken van gewone informatiediensten als van kioskdiensten. Kortom, EMMI is cen omgeving waarin meerdere diensten zijn ondergebracht. Voorbeelden hiervan zijn het verzenden van multimediale bestanden (file transfer) en de in hoofdstuk 3 beschreven PALMA-software. Andere voorbeelden zijn de multimediakiosk en video conferencing. Daarnaast is er nog de mogelijkheid van het koppelen van databases. Figuur 6 geeft een visueel beeld van hoe de EMMI-omgeving er uitziet.

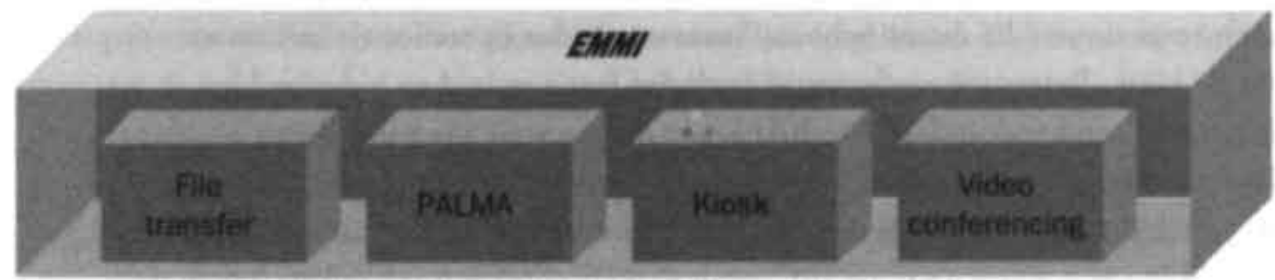

Figuur 6 De EMMI-omgeving

De volgende politieorganisaties beschikken over EMMI (stand van zaken januari 2004): het IRC-Noord te Assen, het IRC-Oost te Enschede, het IRC-Limburg te Maastricht, het IRC-Zuid-West te Breda, het IRC-Rotterdam-Dordrecht van de politieregio Rotterdam-Rijnmond, het IRC-Haaglanden te Rotterdam, het IRC-Haarlem-Alkmaar te Haarlem, het IRC-Amsterdam-Utrecht te Amsterdam, het L-IRC te Zoetermeer, het OIPG Genk, het OIPG Antwerpen, de RVST Eupen, de CGI te Brussel, de RVST Aachen (Noordrijn-Westfalen), de RVST Mönchengladbach (Noordrijn-Westfalen), de RVST Lingen (Nedersaksen), de RVST Münster (Noordrijn-Westfalen), de Gendarmerie Lille (Lille Securite Public), de Nederlandse vestiging van het L-IRC te Lille en ten slotte de Nederlandse ambassade te Parijs (Politie-attache). 
In dit hoofdstuk worden aanvullingen belicht op de in hoofdstuk 3 reeds besproken mogelijkheden van PALMA. Daarnaast beschrijven wij een aantal andere mogelijkheden van de EMMI-omgeving, te weten: de multimediakiosk (in sectie 4.1), het uitwisselen van informatie (in sectie 4.2), het koppelen van databases (in sectie 4.3), de toekomst van EMMI (in sectic 4.4), vier niveaus van grensoverschrijdende bevraging (in sectie 4.5), en de actuele stand van zaken EMMI (in sectie 4.6). De hoofdstukken 3 en 4 vormen tezamen de opmaat voor de juridische hoofdstukken 5 en 6.

\subsection{Multimediakiosk}

De multimediakiosk is een elektronisch publicatiemiddel voor het 'publiceren' van informatie ten behoeve van de IRC's. Publiceren houdt het beschikbaar stellen van informatie op de EMMI-server in, alsmede het elektronisch 'ophalen' van de informatie via een brotuser door de gebruiker. Het begrip kiosk is ontleend aan het dagelijks spraakgebruik waar kiosk ook gezien wordt als een doorgeefluik van informatic. Wij zien bij de vergelijking af van de betalingsaspecten.

De multimediakiosk is een vervolgontwikkeling van het regionale digitale voorlichtingssysteem DVS van de politieregio Limburg-Zuid. Iedere politiepartner in het EMMI-project voorziet de eigen multimediakiosk van informatie. De multimediakiosk heeft een aantal standaardrubrieken. Dit zijn onder andere 'hot news' (operationele gegevens), gezochte en vermiste personen, procedures/voorschriften, dagrapporten, organogrammen en personen die dienst hebben. Soms wordt dus operationele informatie verspreid via de kiosk. Belangrijke informatie, inclusief foto's, geluid en videobeelden, is met een browser in een handomdraai beschikbaar te maken voor alle aangesloten politiepartners. In de toekomst zouden technisch gesproken op die manier de nationale databanken van de verschillende landen, met de browser van de multimediakiosk als interface beschikbaar gesteld kunnen worden aan de IRC-medewerkers en/of aan gebruikers 'op de werkvloer'.

\subsection{Het uitwisselen van informatie}

Wij weten nu dat het uitwisselen van informatie via de EMMI-omgeving uit twee componenten bestaat. Allereerst is er de mogelijkheid om via de PALMA-formulieren persoonsgegevens waaronder voertuiggegevens uit te wisselen. De tweede component betreft het publiceren van alle mogelijke soorten informatie via de multimediakiosk. Van de uitwisseling via de PALMA-formulieren wordt een volledig geautomatiseerde registratie gevoerd. Bij de uitwisseling via de multimediakiosk is dat op het eerste gezicht niet nodig, omdat deze informatie binnen het EMMI-Intranet vrij opvraagbaar is en dus meestal ook achteraf te controleren is.

Vooruitlopend op het juridische hoofdstuk 5 stellen wij nu reeds vast dat via de multimediakiosk geen persoonsgegevens mogen worden verspreid. Een direct gevolg van deze vaststelling is een helder onderscheid tussen de twee componenten voor de uitwisseling 
van informatie via de EMMI-omgeving. Veel uitwisselingen van persoonsgegevens, die juridisch sterk beschermd zijn, moeten (voorlopig) voorbehouden blijven aan de PALMA-formulieren. Registratie en dus ook controle achteraf zijn hierdoor te allen tijde verzekerd. Voor de uitwisseling van alle niet-persoonsgebonden informatie kan de multimediakiosk goede diensten bewijzen.

\subsection{Het koppelen van databases}

Het koppelen van databases en computersystemen is een fenomeen waarvoor zowel binnen als buiten de overheid de belangstelling groeit, ook bij de politie. De informatica biedt zeer goede mogelijkheden voor het leggen van verbanden die een mens anders niet legt. Buiten de overheid worden via koppeling van databases bijvoorbeeld analyses uitgevoerd op gegevens en worden er profielen van mensen gemaakt voor marketingdoeleinden. Binnen de overheid probeert men onder andere fraude op te sporen via het koppelen van bijvoorbeeld belastingregistraties en sociale zekerheidsregistraties.

Hoe het koppelen van bestanden technisch in zijn werk gaat, wordt beschreven in hoofdstuk 6, waarin de koppelingsproblematiek in juridische zin wordt behandeld. De essentic van koppelen is het systematisch vergelijken van verschillende verzamelingen van persoonsgegevens. Om dit mogelijk te maken is feitelijk vaak een koppeling zowel van systemen als van programmatuur vereist. Het begrip 'koppeling' ziet juridisch op het treffen van technische en organisatorische voorzieningen, waardoor verzamelingen van persoonsgegevens systematisch met elkaar kunnen worden vergeleken. Zo kan nieuwe informatie worden gegenereerd over een vooraf onbepaalde groep van personen.

Het juridische koppelingsbegrip is dus iets geheel anders dan de zogeheten directe toegang tot systemen en bestanden. Hierover worden overigens in juridische zin ook belangrijke constateringen gedaan en wel in de hoofdstukken 5 en 7. Zo is het niet vanzelfsprekend dat aan buitenlandse politieambtenaren directe toegang verleend mag worden tot de Nederlandse systemen en bestanden. Zoals in hoofdstuk 5 zal blijken, zijn buitenlandse politicambtenaren in beginsel niet bevoegd tot een dergelijke rechtstreekse geautomatiseerde toegang. Evenmin is het vanzelfsprekend dat het OM directe toegang tot de politiegegevens heeft. De mogelijkheid en bevoegdheid tot directe (on line) toegang tot gegevens en systemen is overigens vereist alvorens men over kan gaan tot koppeling van systemen en bestanden.

Bij de IRC's van de politie is echter een duidelijke behoefte ontstaan aan mogelijkheden voor directe toegang tot gegevensbestanden voor buitenlandse politieambtenaren. De mogelijkheid van koppeling van bestanden, in de juridische zin van het woord, is wellicht ook wenselijk in de toekomst. Deze twee zaken zijn essentieel als het gaat over grensoverschrijdende politiële informatie-uitwisseling. 
De behoefte van de IRC's aan directe toegang van buitenlandse politieambtenaren tot databases wordt ingegeven door de toegenomen werkdruk van de IRC's sinds de effectuering van de politiële informatieve samenwerking in de grensgebieden. Een aanzienlijk deel van de informatieverzoeken betreft bulkinformatie, zoals kentekenbevragingen. Voor de doorgifte van dit soort informatie zou rechtstreekse bevraging van dergelijke bestanden door buitenlandse politieambtenaren heel welkom zijn. In de praktijk is er met dit doel bijvoorbeeld al een rechtstreekse verbinding gerealiseerd tussen het Nederlandse CJIB (Centraal Justitieel Incasso Bureau) en de Duitse Rijksdienst voor het wegverkeer voor strafbare feiten die via administratieve weg worden afgehandeld, de zogenaamde Mulderfeiten. Dergelijke informatiestromen behoeven dan niet meer via de Nederlandse en Duitse politiediensten te verlopen. Zulke rechtstreekse verbindingen leveren een vermindering van de werklast op. Het voorbeeld betreft verificatievragen uit een openbaar register. De IRC's willen duidelijkheid omtrent de vraag of ook voor andere registraties een soortgelijke rechtstreekse verbinding tot de mogelijkheden behoort. Hierop zal in de hoofdstukken 5 en 6 een antwoord worden geformuleerd.

In het verieden is een voorstel van de Nederlandse noordelijke politiegrensregio's om Duitse politieambtenaren rechtstreeks toegang tot het Nederlandse HKS te verschaffen op juridische gronden afgewezen (zie sectie 7.6). Dit is een duidelijk voorbeeld van het feit dat de huidige stand van de techniek een verdergaande informatie-uitwisseling mogelijk maakt dan momenteel juridisch is toegestaan (zie verder hoofdstukken 5, 6 en 7).

\subsection{De toekomst van EMMI}

In deze sectie behandelen wij enkele aspecten die in de toekomst technologisch gerealiseerd zouden kunnen worden binnen de EMMI-omgeving, maar die vooralsnog op juridische obstakels stuiten. Het gaat om de volgende aspecten: de integratie met nationale politienetwerken (subsectie 4.4.1), geautomatiseerde toegang tot nationale politienetwerken (subsectic 4.4.2), rechtstreekse toegang van de gebruiker (subsectie 4.4.3), het gebruik van zogeheten protocolgegevens (subsectie 4.4.4), een EMMI-blauwdruk (subsectie 4.4.5), de constatering dat koppeling nog niet legitiem is (subsectie 4.4.6), alsmede overige mogelijkheden binnen de EMMI-omgeving (subsectie 4.4.7).

\subsubsection{Integratie met nationale netwerken}

De EMMI-omgeving zou technisch gesproken geïntegreerd kunnen worden met alle nationale netwerken waarmee EMMI verbonden is. Op die manier kan veel dubbel werk worden voorkomen. De technologische architectuur is daar klaar voor. Zoals het vaak gaat in de wereld van de ICT: als men ziet dat iets mogelijk is, wil men het ook gerealiseerd zien. Of dat ook gebeurt, hangt echter af van de wettelijke belemmeringen, die in de hoofdstukken 5 en 6 aan de orde komen. Zo is het met het PALMA-systeem technisch mogelijk om de communicatie van en naar het eigen IRC over te slaan. De politiële medewerker op de werkvloer zou dan zelf rechtstreeks de vraag kunnen stellen aan 
het buitenlandse IRC met behulp van een PALMA-formulier. De rol van het IRC zou dan kunnen worden beperkt tot het beantwoorden van aanvragen uit het buitenland. Het is echter de vraag of dit vanuit juridisch (controle-)oogpunt wenselijk is te achten. Hierop wordt nader ingegaan in hoofdstuk $5 \mathrm{en}$ in hoofdstuk 7.

\subsubsection{Geautomatiseerde toegang tot nationale netwerken}

Men zou de PPS zelf ook geautomatiseerde toegang kunnen geven tot de nationale politięle informatiesystemen. Die kan dan gegevens geheel automatisch ophalen uit de nationale databank. De IRC-medewerker behoeft het versturen van die gegevens dan alleen maar te bevestigen en ze eventueel aan te vullen met gegevens die niet met het programma opgezocht kunnen worden. Met andere woorden, hetgeen nu een IRC-medewerker doet, kan eigenlijk ook door een programma gedaan worden, vooral voor veel voorkomende aanvragen. Het programma ziet bijvoorbeeld dat er voertuiggegevens moeten worden opgezocht en zoekt die op in het kentekenregister. Tevens ziet het programma dat er persoonsgegevens moeten worden opgezocht en zoekt die op in de Gemeentelijke Basisadministratie (GBA). Andere gegevens, voor het opzoeken waarvan het programma door de IRC-medewerkers niet geautoriseerd is, kunnen dan alsnog handmatig worden opgezocht en worden toegevoegd in het reactieformulier. Controle van het gehele proces is achteraf nog steeds verzekerd met behulp van de registratiedatabase. De werklast van de IRC-medewerker bij het opzoeken in de nationale databanken kan dan verminderd worden. Tevens wordt vierentwintiguursbevraging voor veel gevraagde gegevens mogelijk met controle achteraf. Het programma zou dan bijvoorbeeld een Nederlands programma zijn waarin Nederland bepaalt welke gegevens en databanken wel en niet op deze geautomatiseerde manier te bevragen zijn. Als extra controle wordt er nog een menselijke controle aan toegevoegd. Het is duidelijk dat, als de invoering van zo'n systeem wenselijk geacht wordt, de wetgeving aangepast moet worden.

\subsubsection{Rechtstreekse toegang van de gebruiker}

De capaciteitsgroep Informatica van de Universiteit Maastricht heeft in het project 'PALMA op de werkplek' in 1999 de technische mogelijkheid in PALMA ingebouwd om 'de agent op de werkvloer', met gebruikmaking van een formulier dat hij of zij in bijvoorbeeld PILZ opvraagt, via e-mail een vraag te laten stellen aan het eigen IRC. Een IRC-medewerker heeft via de netwerkkaart in zijn IRC-PC een verbinding met bijvoorbeeld PILZ. Hij of zij kan dan met behulp van zijn/haar browser zien of er berichten van agenten zijn binnengekomen. Tevens kan hij of zij dan bij een uit het buitenland binnengekomen bericht aan de betreffende agent per reguliere e-mail een antwoord sturen. De beoogde werking is beschreven in subsectie 3.2.3. Deze functionaliteit is echter in de meeste gevallen nog niet doorgevoerd. 


\subsubsection{Het gebruik van protocolgegevens}

In de PALMA-logdatabase en in de registratiedatabase die aan de lokale politiële Intranetten hangt, wordt meer geregistreerd dan door de Schengen-uitvoeringswetgeving en door de WPolr en het BPolr wordt vereist (zie de hoofdstukken 5 en 6). De gegevens die geregistreerd (moeten) worden, noemen we overigens protocolgegevens (zie hierover hoofdstuk 6). Het is niet vereist dat de hele inhoud van het uitgewisselde bericht wordt geregistreerd. De IRC-medewerkers zouden, nu dat echter wel gebeurt, de in de registratiedatabase geregistreerde vragen en antwoorden gaarne natrekken en hergebruiken, op een gecontroleerde manier. Technisch gesproken is dat tot op zekere hoogte mogelijk. De registratiedatabase is technisch geschikt gemaakt voor het systematisch opzoeken van informatie, waaronder gehele berichten. Ook is de registratiedatabase geschikt gemaakt om alle PALMA-berichten op te slaan. Dit gebeurt op het moment dat IRC-medewerkers die berichten vanuit de PALMA-logdatabase van de EMMI-server 'met een druk op de $\mathrm{knop}^{174}$ naar de registratiedatabase doorsturen. Het up-to-date houden van de registratiedatabase - in de zin van het steeds aanvullen van de laatste NAW-gegevens et cetera - is echter, vooral voor de handmatig ingevoerde gegevens over uitwisselingen via telefoon en fax, die overal vandaan kunnen komen, technisch niet goed realiseerbaar. Zoals zal blijken is een dergelijk hergebruik van gegevens juridisch eigenlijk niet geoorloofd. Men zal de gegevens in principe steeds opnieuw moeten opvragen, ook al omdat de registratiedatabase om technische redenen bijna niet up-to-date te houden is. Anders zouden fouten in de beoordeling gemaakt kunnen worden.

\subsubsection{Blauwdruk}

De EMMI-omgeving zou als blauwdruk kunnen fungeren voor een Europees PolitieDatanetwerk en, nog algemener geformuleerd, als standaard voor gegevensuitwisseling van de meest uiteenlopende aard binnen en tussen de verschillende overheidsinstellingen. Veel van de uitgewisselde gegevens hebben namelijk een vooraf bepaalde structuur, die in elektronische formulieren kan worden gestructureerd. IRC's en andere Informaticcentra zouden in de toekomst kunnen fungeren als echte Europese informatieknooppunten, waar de gegevensuitwisseling zowel inhoudelijk als technisch wordt bewaakt.

Binnen afzienbare tijd moeten er dan echter wel wettelijke mogelijkheden komen om een verbinding tot stand te mogen brengen tussen de politiekorpsen van de Europese lidstaten. Zoals het er nu voorstaat, hebben de bij EMMI betrokken politiepartners de noodzaak gesignaleerd tot de opheffing van de wettelijke belemmeringen voor het koppelen van de nationale politiële netwerken. Het creëren van de wettelijke mogelijkheid tot koppeling van de nationale netwerken is in hoge mate afhankelijk van het vertrouwen

74. Omdat er geen rechtstreekse koppeling mag zijn tussen de EMMI-omgeving en het nationale netwerk (zie hoofdstukken 5 en 6 ). 
van de betrokken overheden in de technische mogelijkheden om een beveiligde verbinding tot stand te brengen. In het PALMA-project is gebleken dat zo'n afgeschermde verbinding technisch mogelijk is.

Wellicht dat in de toekomst de nationale Intranetten ingezet kunnen worden voor geautomatiseerde grensoverschrijdende gegevensuitwisseling. Vervolgens moet er ook aandacht komen voor de niet-grensregio's. Die zouden eveneens graag gebruik maken van het EMMI-concept, maar op basis van de huidige regelgeving lijkt dat niet mogelijk. Zoals gezegd, de IRC's wisselen via EMMI in overeenstemming met de wet- en regelgeving in principe alleen gegevens uit met de aangrenzende buitenlandse regio's. De politie in de grensregio's ervaart als belangrijk knelpunt dat hun IRC's door politicambtenaren in niet-grenspolitieregio's oneigenlijk worden benaderd voor het verkrijgen van informatic. De officiële weg leidt via de DIN en door directe benadering van de IRC's wordt die vermeden. De vraag wordt hierdoor actueel of in de toekomst ook de niet-politiegrensregio's aangesloten moeten of mogen worden op het EMMI-netwerk. Wij komen hierop terug in hoofdstuk 9 bij het formuleren van onze conclusies.

\subsubsection{Koppeling nog niet legitiem}

Aangezien wettelijk en politiek nog geen koppeling mogelijk is tussen de nationale politiële netwerken, zou op het eerste gezicht de volgende technische oplossing denkbaar zijn: er komt een verbinding tussen het EMMI-netwerk en Europol door het plaatsen van een PALMA-server bij ten minste één Europolbureau. Bepaalde informatic, die dan door Europol wordt verzameld en doorgegeven, wordt vervolgens ook door de IRC's gebruikt en vice versa. Een fysieke koppeling tussen Europol en de EMMI-omgeving is evenwel juridisch niet toegestaan. Op grond van artikel 6 lid 2 EO mogen de door Europol beheerde geautomatiseerde gegevensbestanden onder geen beding worden verbonden met andere systemen voor geautomatiseerde gegevensverwerking, met uitzondering van het systeem voor geautomatiseerde gegevensverwerking van de nationale eenheden. Een rechtstreekse verbinding met bijvoorbeeld PALMA/EMMI is dus op grond van deze bepaling uit den boze (zie hoofdstuk 8 ).

\subsubsection{Overige mogelijkbeden EMMI}

EMMI heeft op diverse gebieden, zoals justitie, brandweer en GGD, mensen geïnspireerd tot het initiëren van plannen die elementen aan EMMI ontlenen. Wij noemen hieronder drie voorbeelden.

1. Het Nederlandse Ministerie van Justitie heeft een eigen justitieel Intranet opgezet en een verbinding met het nationale politienetwerk gemaakt. Ook hierbij doen zich vragen voor van directe toegang tot en koppeling van gegevensbestanden. ${ }^{75}$

75. Deze vragen vallen evenwel buiten het bestek van dit proefschrift. 
2. Intussen bestaat bij andere OOV-partners belangstelling voor het EMMI-concept. ${ }^{76}$

3. Bij nieuwe binnenlandse netwerkpartners is een beveiligde verbinding noodzakelijk, die kwalitatief even hoogstaand is als de beveiliging van de verbinding met het buitenland. Voor de politie kan iedere poort naar buiten een potentieel lek van informatie betekenen. Beveiligde verbindingen zouden bijvoorbeeld ook tussen de politie en het publiek met behulp van de PALMA-software tot stand gebracht kunnen worden.

\section{Toekomstige uitbreidingsmodules in PALMA}

Om de medewerkers van de IRC's in staat te stellen hun controletaak ten aanzien van een rechtmatige internationale gegevensuitwisseling nog gemakkelijker te laten verlopen, kan een nieuwe versie van PALMA worden voorzien van een uitbreidingsmodule voor toekomstige kennistechnologische toepassingen. Die kennistechnologische toepassingen kunnen in de tockomst het voldoen aan de databeschermingsbepalingen faciliteren. $\mathrm{Te}$ denken valt hierbij aan de inzet van softwareagenten. ${ }^{77} \mathrm{Er}$ kan ook worden gewerkt met waarschuwingsmodules die bijvoorbeeld in beeld brengen wanneer een bepaalde wettelijke termijn verstrijkt of die aangeven dat er van wettelijke of absolute weigeringsgronden voor het verlenen van (zelfstandige) politiële rechtshulp sprake is.

\section{Video conferencing}

Op vraag van met name de Belgische politiepartners is de EMMI-omgeving voorzien van video conferencing-faciliteiten met gebruikmaking van het TCP/IP-protocol over de aanwezige ISDN-verbindingen. Hiermee kon een life videoverbinding (in real-time) met een ander IRC tot stand worden gebracht. Sinds het LIEM-project, waarbij er in Nederland een centrale EMMI-server in Driebergen is gekomen, is video conferencing echter feitelijk niet meer mogelijk, aangezien in Nederland alleen het IRC Limburg beschikt over een ISDN-lijn. De functionaliteit is in de toekomst wel weer nieuw leven in te blazen, eventueel via het Internet. Dankzij op computers aangesloten videocamera's kunnen de IRC's dan weer visueel contact met elkaar hebben. Ook is de mogelijkheid gecreëerd videobeelden met relevante informatie, die in het ene land zijn opgenomen, door het IRC in het andere land op te vragen. $\mathrm{Zij}$ kunnen ook gedownload worden om zodoende de beelden later te bekijken (time-shifted). De Microsoft-Explorer browser fungeert ook hiervoor als interface. In de toekomst zal er voor dit videomateriaal een bewaarplaats moeten komen. Het bewaren kan gecentraliseerd gebeuren maar ook gedistribueerd. Het videomateriaal zal gecodeerd worden bewaard. Geautoriseerde gebruikers kunnen dit videomateriaal dan via hun browsers bekijken.

76. Zie voor de jurisiche aspecten dienaangaande Verbeek, Claus $\&$ Van den Herik 2003, hoofdstuk 5. Deze aspecten vallen buiten het bestek van dit proefschrift.

77. Soortgelijke werkzaamheden worden reeds verricht in het kader van het Nederlandse ToKeN2000-project ANITA (Administnative Normative Information Thansaction Agenss). 
Video conferencing zou in de toekomst ook ingezet kunnen worden voor gezamenlijke acties en gezamenlijke onderzoeksteams in de grensregio's, grensoverschrijdende achtervolgingen, direct overleg bij calamiteiten, et cetera. Mobiele video conferencing via een videocamera die aangesloten is op bijvoorbeeld een notebook dat voorzien is van een modem met GSM- of GPRS-aansluiting, is technisch ook realiseerbaar.

\subsection{Vier niveaus grensoverschrijdende bevraging}

In de volgende hoofdstukken wordt duidelijk welke technische mogelijkheden die EMMI in zich heeft juridisch zijn toegestaan. De ontwerpers van EMMI hebben al rekening gehouden met de in de Schengenwetgeving en de nationale wet- en regelgeving gestelde eisen, vooral die tot de registratie van de gegevensuitwisseling en het zogenaamde 'verbod van koppeling. ${ }^{\text {"78 }}$

Het zwaartepunt van dit onderzoek is gelegen in het feit dat met het EMMI-concept veel meer mogelijk is dan tot nog toe in de EMMI-omgeving is gerealiseerd. Dat die mogelijkheden nog niet zijn toegepast, heeft veel te maken met (veronderstelde) wettelijke en politieke belemmeringen.

Er zijn vier niveaus te onderscheiden waarop grensoverschrijdende bevraging van (multimediale) databases kan plaatsvinden.

niveau 1: Het uitwisselen van informatie geschiedt volgens de huidige stand van zaken, die juridisch is toegestaan (zie hoofdstukken 5 en 6): zowel in het aanvragende als in het verstrekkende land overleggen speciaal daarvoor aangestelde politiefunctionarissen of en welke gegevens worden uitgewisseld, eventueel na inschakeling van het OM. Het zoeken in de nationale databases gebeurt uitsluitend door de IRCmedewerkers van het verstrekkende land zelf, alsmede door de agent op de werkvloer die hiervoor is benaderd door de IRC-medewerkers.

niveau 2: Het zoeken in de nationale databases wordt uitgevoerd door computerprogramma's in het informatieverstrekkende IRC. Op de uitkomst van die geautomatiseerde zoekactie vindt controle plaats door de daarvoor aangestelde IRC-medewerkers. Daarna worden de gegevens al dan niet verzonden naar het buitenlandse IRC.

niveau 3: Het wordt de IRC-medewerker mogelijk gemaakt om via computerprogramma's rechtstreeks te zoeken in buitenlandse databases en de gevonden informatie op te halen. Controle kan achteraf plaatsvinden door de inhoud van de registratiedatabase na te trekken.

78. We zullen zien dat er juridisch gesproken geen koppelingsverbod bestaat, maar een verbod van rechtstreekse geautomatiseerde toegang voot buitenlandse politieambenaren en voor het OM (zie subsectie 5.4.3). 
niveau 4: Politieambtenaren mogen 'op de werkvloer', bijvoorbeeld via de brouser van de multimedia-kiosk, rechtstreeks in de buitenlandse databases kijken en de gegevens ophalen, zonder dat er nog sprake is van enige vorm van firewall.

\subsection{Actuele stand van zaken EMMI}

In deze sectie beschrijven wij hoe de situatie momenteel is wat de functionaliteit van PALMA en EMMI betreft. We bekijken enkele nieuwe functionaliteiten van PALMA in subsectie 4.6.1. In subsectie 4.6.2 bespreken wij de nieuwe EMMII Kiosk. Appendix E bevat een lijst van de huidige softwareonderdelen van PALMA. In Appendix F tonen wij een overzicht van de huidige netwerksituatie van EMMI /PALMA. Appendix G toont de inhoud van de PALMA-registratiedatabase.

\subsubsection{Nieuwe functionaliteiten van PALMA}

In PALMA zijn ten opzichte van de beschrijving uit hoofdstuk 3 verschillende aanpassingen en aanvullingen aangebracht. Hieronder bespreken wij vijf nieuwe functionaliteiten.

\section{PALMA Administrator}

Om de mogelijkheid te hebben om op afstand (remote) bepaalde aanpassingen te doen aan het PALMA-systeem is het programma PALMA Administrator ontwikkeld. Dit programma is uitsluitend bedoeld voor het onderhoud van de software en niet voor de gebruikers. PALMA Administrator biedt de mogelijkheid om: nieuwe gebruikers op te voeren of te wijzigen, nieuwe organisaties op te voeren of te wijzigen, (secties uit) inifiles te bekijken en/of te wijzigen, en in principe directories en files te maken, te wijzigen of te verwijderen.

\section{Uploader}

Oorspronkelijk konden er bij het mededelingenformulier in PALMA alleen bestanden uit een specifieke data-directory (die van te voren was klaargezet) worden verstuurd. Nu kunnen er via de WWW-browser in een apart scherm verschillende bestanden uit willekeurige directories worden geselecteerd die door middel van het programma 'uploader' naar de ontvanger worden verzonden.

\section{Pop-up scherm bij nieuwe mail}

Indien er een nieuw mailbericht arriveert wordt et nu naast het ophogen van de 'mailteller' in het scherm van het PALMA-hoofdmenu ook een extra schermpje getoond (witte letters in rode achtergrond) met het aantal nog niet behandelde binnengekomen berichten. Tevens wordt er een geluidssignaal gegeven. De bedoeling hiervan is de gebruiker duidelijker te attenderen op het binnenkomen van een nieuw bericht dan alleen via het ophogen van de teller. 


\section{Autopalma}

Deze nieuwe functionaliteit dient ervoor om informatie van de PALMA-logdatabase automatisch in de registratiedatabase te plaatsen. Het maakt niet uit of de logdatabase cen SQL-server is of een MS-Access bestand.

\section{PALMA op de Werkplek}

Deze nieuwe functionaliteit, die zoals gezegd nog niet breed geïmplementeerd is, maakt het politieambtenaren mogelijk 'op de werkplek' hun informatievraag aan hun eigen IRC te stellen via e-mailfaciliteiten.

\subsubsection{EMMII Kiosk}

In de tweede helft van 2002 heeft IKAT het onderdeel Kiosk van EMMI aanzienlijk gemoderniseerd en eenvoudiger in het gebruik gemaakt. De informatie die op cen Kiosk wordt gepubliceerd wordt slechts incidenteel door een IRC zelf gegenereerd. Meestal is de informatie afkomstig van het regionale of nationale politiële Intranet. Dit Intranet is voor de EMMI-partners vanzelfsprekend niet benaderbaar, waardoor het kopiëren van informatie nodig is. Daarnaast wordt een deel van de informatie die door een IRC op een Kiosk is gepubliceerd, om dezelfde reden door IRC's van andere EMMI-partners gekopieerd en gepubliceerd op hun Intranet.

In de oorspronkelijke opzet van de Kiosk werden de websites in de EMMI-kiosk opgemaakt en aangepast met behulp van de tool FrontPage van Microsoft. Deze tool vereist een technisch niveau van de gebruiker dat helaas niet altijd haalbaar is in de IRC's. Verder vroeg het kopiëren van informatie van en naar het Intranet te veel handelingen. Er was dus behoefte aan een eenvoudigere en snellere manier om informatie op de Kiosk te publiceren en om informatie van en naar de Intranetten te kopiëren. De Intranetten staan niet in verbinding met het EMMI-netwerk. Dit houdt in dat gebruikers van het Intranet niet automatisch toegang hebben tot het EMMI-netwerk en dus ook geen toegang hebben tot de informatie die zich op het andere Intranet bevindt.

Om ervoor te zorgen dat de gebruikers van het ene netwerk toch op de hoogte kunnen worden gesteld van informatie (niet zijnde persoonsgegevens) dat op een ander netwerk staat, worden kiosken gebruikt. Een kiosk vormt dan een tussenstation voor een Intranet en het EMMI-netwerk. De oplossing van EMMII Kiosk voorziet zowel kiosken op de Intranetten (bijvoorbeeld de kiosk op het PILZ) als op het EMMI-netwerk (bijvoorbeeld de kiosk van het IRC-Limburg). Op de kiosken van het EMMI-netwerk staan berichten die zijn samengesteld uit informatie van het aangrenzende Intranet. Het betreft alle informatie die relevant is voor de EMMI-partners. Zo staan er bijvoorbeeld op de kiosk van het IRC Limburg berichten die hun oorsprong hebben in websites die op het PILZ staan. Een kiosk op het Intranet bevat daarentegen berichten die afkomstig zijn uit kiosken op het EMMI-netwerk en die relevant zijn voor de gebruikers van het Intranet. Zo 
kan de kiosk op het PILZ berichten bevatten die van een Duitse kiosk op het EMMInetwerk gekopieerd zijn en die interessant zijn voor de gebruikers van het PILZ. Derhalve vindt er op adequate wijze verspreiding van informatie over de grens plaats. Nu kunnen berichten die hun oorsprong hebben op het Nederlandse (regionale) Intranet eindigen in een kiosk op het Duitse Intranet, en andersom. 


\section{Politiële gegevensuitwisseling volgens het}

\section{VEU}

In dit hoofdstuk behandelen wij het juridische kader voor de informatieve politiesamenwerking in de grensregio's tussen Nederland, België en Duitsland. Sectie 5.1 behandelt het kader van de kleine rechtshulp. In sectie 5.2 bespreken wij het kader van de SUO en het VEU. Sectie 5.3 gaat uitgebreid in op de juridische bescherming van persoonsgegevens in het internationale recht. In sectie 5.4 behandelen wij de Nederlandse Schengenuitvoeringswetgeving. Sectie 5.5 geeft een overzicht van de relevante convenanten en akkoorden die gelden voor de grensregionale politiële gegevensuitwisseling tussen Nederland, België en Duitsland. In sectie 5.6 passeert ten slotte de Belgische en Duitse nationale wetgeving ten aanzien van de informatieve politiesamenwerking de revue.

\subsection{Kader kleine rechtshulp ${ }^{79}$}

De politiële gegevensuitwisseling (ook genoemd de informatieve politiesamenwerking) over de grenzen heen vindt plaats in het kader van de zogeheten kleine rechtshulp. Kleine rechtshulp betreft de strafprocessuele ondersteuning in Nederland van een in een ander land plaatsvindend opsporingsonderzoek, of strafvorderlijk vooronderzoek, of ook onderzoek ter terechtzitting of tenuitvoerlegging van straf of boete. ${ }^{80}$ Kleine rechtshulp wordt verleend door functionarissen van justitie en/of politie van de ene staat aan de andere staat. Dit gebeurt op verzoek van buitenlandse autoriteiten van de andere staat. De kleine rechtshulp is een onderdeel van het internationale strafrecht. Internationaal strafrecht houdt zich bezig met de internationale aspecten van het nationale strafrecht. Het internationale strafrecht is ontwikkeld op het snijvlak van strafrecht en volkenrecht. ${ }^{81}$ Er gelden hier zowel strafrechtelijke als volkenrechtelijke normen. Verdragen zijn de belangrijkste bronnen van het internationale strafrecht, vooral omdat sommige rechtshulpfiguren slechts mogelijk zijn op basis van een verdrag (bijvoorbeeld de uitleve-

79. Zie hieromtrent nader Klip, Swart \& Van der Wilt, par. III.1 (losbladig) en Sjöcrona \& Orie 2002, alsmede Koers 2001. Zie over het internationaal strafrecht in Belgiē: Vermeulen, Vander Beken \& De Ruyer 1998 en Thomas 1998. Zie ook Vermeulen 1999. Voor Duitsland zie Grürzner \& Pötz (losbladig) en Mokroz 2001.

80. $T \not C S v$ (Sjöcrona/De Groot), aant. 1 bij de eerste afdeling van Titel $X$ Sv.

81. Buruma 1994, p. 1. 
ring en de overname van strafexecutie). Ook voor de politiële gegevensuitwisseling zijn verdragen van groot belang (zie de secties 5.2 en 5.3). Verder spelen het nationale strafvorderingsrecht en het nationale gegevensbeschermingsrecht (het recht op de informationele privacy) op dit terrein een prominente rol. De verdragen verwijzen dikwijls naar het nationale recht voor de precieze uitvoering van de verdragswetgeving (zie sectie 5.4).

Het internationale strafrecht zoekt de juiste balans tussen de rechten en plichten van staat A, van staat $B$ en van de betrokken verdachte/veroordeelde. In de eerste plaats behelst internationaal strafrecht het zogenoemde strafmachts- of jurisdictierecht. Het gaat hierbij om de reikwijdte die de nationale wetgever geeft aan de gelding van de nationale materiele normen en de grenzen die het volkenrecht aan die reikwijdte stelt.

In de tweede plaats heeft het internationale strafrecht betrekking op interstatelijke strafprocesrechtelijke samenwerking, de zogenaamde internationale rechtshulp. Deze internationale rechtshulp wordt traditioneel ingedeeld in primaire rechtshulp en secundaire rechtshulp. Onder de primaire rechtshulp vallen de overdracht en overname van strafvervolging alsmede de overdracht en overname van de tenuitvoerlegging van buitenlandse strafvonnissen. Het belangrijkste kenmerk van de primaire rechtshulp is dat de staat die de rechtshulp verleent een essentieel onderdeel van een buitenlands strafproces overneemt. Onder de secundaire rechtshulp vallen de uitlevering en de genoemde kleine rechtshulp, waaronder zoals gezegd de politiële gegevensuitwisseling valt. Het belangrijkste kenmerk van de secundaire rechtshulp is dat de staat die de rechtshulp verleent een vreemde staat ondersteuning geeft bij het voeren van diens strafproces. ${ }^{82}$ De kleine rechtshulp bestaat uit de traditionele justitiële rechtshulp en de politiële rechtshulp. De politiële gegevensuitwisseling valt onder de subcategorie politiële rechtshulp van de categorie kleine rechtshulp. De overdracht en overname van strafvervolging, de overdracht en overname van de tenuitvoerlegging van buitenlandse strafvonnissen alsmede de uitlevering worden ook wel aangeduid als de 'grote' of 'grotere' rechtshulp. De term 'kleine' rechtshulp suggereert dat deze vorm van internationale rechtshulp minder ingrijpend is dan de grotere rechtshulpvormen. Deze suggestie is echter onjuist. Door middel van kleine rechtshulp kunnen namelijk bewijsmiddelen worden overgedragen aan het buitenland. Dit bepaalt inhoudelijk het strafproces in het buitenland en is dus wel degelijk erg ingrijpend..$^{83}$

Op het verlenen van kleine rechtshulp of strafprocessuele bijstand door Nederlandse functionarissen van justitie en/of politie aan en op verzoek van buitenlandse autoriteiten zijn de artikelen $552 h-552 q$ Sv van toepassing. Deze strafvorderlijke bepalingen zien uit-

82. Kamensukten II, 1990/1991, 22 083, nt. 3, p. 6 (MvT; 'Plukze internationaal').

83. Buruma 1994, p. 20. Zie ook het ontwerp-kaderbesluit Europees bewijsverkrijgingsbevel, dat wordt besproken in subsectie 7.8.6. 
sluitend op Nederland als aangezochte staat. De positie van Nederland als verzoekende staat is naar Nederlands recht niet wettelijk geregeld. Voor de positie van Nederland als verzoekende staat zijn de rechtshulpverdragen en/of de nationale wetgeving van de door Nederland aangezochte staat bepalend. Op de nationale wetgeving van de door Nederland aangezochte staat wordt daarom ingegaan in sectie 5.6. Voor het gebruiken van door het buitenland verleende kleine rechtshulp gelden de regels van de Nederlandse strafvordering. ${ }^{\text {st }}$

Op de (zelfstandige) politiële rechtshulp, waar dit onderzock zich op toespitst, ziet met name artikel $552 i$ lid $2 \mathrm{~Sv}$ en de daarbij behorende Richtlijn wederzijdse rechtshulp (zie subsecties 5.4.1 en 5.4.2). De politiële samenwerking heeft verder aanvullend vorm gekregen in de WPolr en het BPolr (zie subsectie 5.4.3). De SUO voorziet sinds 26 maart 1995 op verdragsrechtelijk vlak in een belangrijke rechtsbasis voor politiele samenwerking tussen in eerste instantie Nederland, Belgie,, Duitsland, Luxemburg, Frankrijk, Spanje en Portugal. De politiēle gegevensuitwisseling is voornamelijk geregeld in de artikelen 39 en 46 SUO alsmede in de artikelen 126-129 SUO (zie sectie 5.2 en subsectie 5.3.5). Politiële rechtshulp, waaronder de informatieve samenwerking, kan blijkens artikel $552 i$ lid $2 \mathrm{~Sv}$ echter ook buiten verdrag plaatsvinden (zie subsectie 5.4.1). Bij 'verdragsloze' aanvragen zijn de criteria voor de beoordeling van de verzoeken op grond van artikel $552 k$ lid $2 \mathrm{~Sv}$ enkel gelegen in de artikelen $552 h-552 q \mathrm{~Sv}$. De artikelen $552 n$ $5520 \mathrm{~Sv}$ verhelderen om welke vormen van rechtshulp het kan gaan: globaal gezegd zijn dat slechts die gevallen waarin geen dwangmiddelen behoeven te worden toegepast of waarin de rechter-commissaris (RC) niet behoeft te worden ingeschakeld. ${ }^{55}$ Politiële gegevensuitwisseling waarvoor geen toepassing van dwangmiddelen nodig is en/of geen $\mathrm{RC}$ behoeft te worden ingeschakeld, kan derhalve ook buiten verdrag plaatsvinden (zie verder subsectie 5.4.1).

Traditioneel ging in de rechtshulpverdragen, zoals het Europees rechtshulpverdrag (ERV) ${ }^{86}$ het Benelux uitleverings- en rechtshulpverdrag (BUV), ${ }^{87}$ en het Verdrag van Wittem, ${ }^{88}$ de meeste aandacht uit naar de samenwerking tussen rechters en justitiële

84. HR 4 november $1986, N J 1987,812$.

85. $T \partial C S_{v}$ (Sjöcrona/De Groot), ant. 1d bij de eerste afdeling van Titel X Sv.

86. Europees Verdrag aangaande de wederzijdse rechtshulp in straftaken: Straatsburg. 20 april 1959, Trb. 1965, 10 met aanvullend protocol van 17 maart 1978, Trb. 1979.

87. Verdrag tussen het Koninkrijk der Nederlanden, het Koninkrijk Belgiê en het Groothertogdom Luxemburg aangaande de uitlevering en de rechtshulp in strafza. ken; Brussel, 27 juni 1962, Trb. 1962, 97 en Trb. 1974, 161.

88. Verdrag van 30 augustus 1979, Trb. 1979, 143, behorende bij het ERV voor de relatic Nederland/Bondsrepublick Duitsland (de arrikel III lid 1 en XII lid 2 zijn vervallen per 6 juni 1991 omdat toen tussen de twee verdragspartijen het aanvullend protocol in werking trad (Tr6. 1992, 38)). 
autoriteiten. Zij hadden voornamelijk betrekking op de vervolgings- en berechtingsfase en niet op de opsporingsfase. Over politiële samenwerking, waaronder de gegevensuitwisseling valt, is in de rechtshulpverdragen niet rechtstreeks iets terug te vinden. Men wilde de politiēle praktijk niet aan strakke verdragsregels onderwerpen. ${ }^{89}$ De laatste decennia heeft echter juist de internationale samenwerking tussen politieambtenaren en hun optreden buiten de eigen landsgrenzen enorm aan belang gewonnen. ${ }^{90}$ Het bleef daarbij voor de politie onduidelijk wat zij wel en niet mocht doen in het kader van de internationale politiële samenwerking. De SUO heeft in deze leemte van politiële bevoegdheden voorzien en heeft voor de politiële samenwerking de nodige normering aangegeven. Sinds de inwerkingtreding per 1 november 1993 van het Europese Unieverdrag van Maastricht, waarin in artikel K1 ook een onderscheid werd gemaakt tussen justitiêle en politiële samenwerking, biedt de Raad van Ministers van Justitie en Binnenlandse Zaken van de Unie een formele basis voor politiële en justitiële samenwerking. Dit heeft geleid tot een verzelfstandiging van de politiële samenwerking ten opzichte van de justitiēle samenwerking. De politiële samenwerking wordt ook wel aangeduid met de term 'internationale opsporing'. ${ }^{11}$ De artikelen 39-47 SUO zijn bedoeld te komen tot een intensivering van de politiesamenwerking.

Ten slotte merken we op dat degene op wie de kleine rechtshulp betrekking heeft een drietal rechtsmiddelen tot zijn beschikking heeft. Ten eerste is in artikel $552 p$ Sv de beklagregeling van artikel $552 a$ Sv van overeenkomstige toepassing verklaard op het verlenen van kleine rechtshulp. ${ }^{92}$ Ten tweede kan tegen een (dreigende) verlening van kleine rechtshulp alsmede tegen een weigering van rechtshulp een kort geding worden aangespannen. Ten derde kan een belanghebbende, na uitputting van de eventuele nationale rechtsmiddelen, bij het Europese Hof voor de Rechten van de Mens in Straatsburg klagen over de wijze waarop Nederland handelingen van rechtshulp heeft verleend.

89. De opstellers van het ERV hebben de redactic overwogen van een verdragsbepaling die aan de politicle overheden van de verdragsstaten de mogelijkheid zou bieden onderling eenvoudige inlichtingen over een strafzaak uit te wisselen. Deze bepaling werd later uit de verdragstekst weggelaten, omdat het weinig opportuun geacht werd de soepele politiele praktijk (zie hoofdstuk 2) an een strakke verdragsrechtelijke regeling te onderwerpen; Thomas 1980.

90. Buruma 1994, p. 1-2.

91. Buruma 1994, p. 21-22. De term 'internationale opsporing' wordt gebruikt als descriptief begrip waarmee gecoördineerde activiteiten door opsporingsambtenaren uit diverse landen worden aangeduid.

92. Art. $552 a$ Sv heeft betrekking op het beklag van belanghebbenden over inbeslagneming, het gebruik van inbeslaggenomen voorwerpen, het uitblijven van een last tot teruggave of over de kennisneming of het gebruik van gegevens. 


\subsection{Kader SUO en VEU}

Op 26 maart 1995 is de SUO'3 in werking getreden. ${ }^{94}$ Hiermee heeft de politièle samenwerking, waaronder de informatie-uitwisseling, een verdragsbasis gekregen. Thans is de rechtsgrondslag voor de informatieve politiesamenwerking te vinden in Titel VI van het Verdrag betreffende de Europese Unie (VEU) ${ }^{95}$ aangaande de politiele en strafrechtelijke samenwerking. Dit is zogeheten Eerde Pijler van de EU: ${ }^{\%}$ de intergouvernementele samenwerking op het gebied van politic en strafrecht. De Derde Pijler is ingevoerd door het Verdrag van Maastricht, dat op 1 november 1993 in werking trad. Hij zag oorspronkelijk op de samenwerking op het gebied van justitie en binnenlandse zaken, doch is onder het Verdrag van Amsterdam beperkt tot politiële en strafrechtelijke samenwerking (artikel 29-42 VEU).

Onder het Verdrag van Amsterdam, dat op 1 mei 1999 in werking is getreden, werd de Schengensamenwerking in het zogenoemde acquis (de verworvenheden) van de EU geïntegreerd. Dit is hoofdzakelijk geregeld in het 'Protocol tot opneming van het Schengenacquis in het kader van de Europese Unie." ${ }^{97}$ De lidstaten zijn gemachtigd om de Schengensamenwerking voort te zetten met gebruikmaking van het juridische en institutionele kader van de EU. Daartoe zijn de rechtsbases in het EU-recht van de bestaande juridisch bindende Schengenregelingen door de Raad van de EU vastgelegd. ${ }^{98}$ De SUO-regels met

93. Uitvoeringsovereenkomst Schengen, Overeenkomst ter uitvoering van het op 14 juni 1985 te Schengen gesloten Akkoord betreffende de geleidelijke afschaffing van de controles an de gemeenschappelijke grenzen; Schengen, 19 juni 1990, Trb. $1990,145$.

94. Trb, 1995, 75.

95. Verdrag betreffende de Europese Unie, Trb. 1992, 74; in Trb. 1998, 12 is de geconsolideerde versie van het verdrag opgenomen, na doorvoering van de wijzigingen uit het Verdrag van Amsterdam en in PbEG 2002/C 325/5, 24 december 2002 de geconsolideerde versie na doorvoering van de wijzigingen uit het Verdrag van Nice.

96. De Eerste Pijler omvat de drie gemeenschappen EG, EGKS en Eurotom (zie de artikelen 8-10 VEU). De Tweede Pijler omvat het Gemeenschappelijk Buitenlands. en Veiligheidsbeleid (Titel V VEU). De EU draagt zorg voor de overkoepeling van het geheel van de betrekkingen tussen de Europese lidstaten.

97. Dit protocol heeft het karakter van cen verdrag en is ook mede getatificeerd in het kader van de goedkeuring van het Verdrag van Amsterdam op nationaal niveau. Het wordt genoemd onder II. B. 2 van de Slotakte van het Verdrag van Amsterdam. PbEG L. 239, 22 september 2000 bevat het gehele Schengen-acquis.

98. Zie Besluit 1999/435/EG van de Raad van 20 mei 1999, PbEG L 176/1 van 10 juli 1999. Hierin wordt het Schengen-acquis gepreciseerd. Zie verder Besluit $1999 /$ 436/EG van de Raad van 20 mei 1999. PbEG L 176/17 van 10 juli 1999. Hierin wordt per Schengenbepaling de rechtsgrondslag in het EU-recht angegeven. 
betrekking tot de informatieve politiesamenwerking gelden daarom thans rechtstreeks voor alle vijftien Europese lidstaten."

Op grond van artikel $29 \mathrm{VEU}$ wil de EU komen tot een ruimte van vrijheid, veiligheid en rechtvaardigheid. ${ }^{100}$ Deze doelstelling wordt onder meer verwezenlijkt door het voorkomen en bestrijden van al dan niet georganiseerde criminaliteit, met name terrorisme, mensenhandel en misdrijven tegen kinderen, illegale drugshandel en illegale wapenhandel, corruptie en fraude, door middel van een nauwere samenwerking tussen politiediensten, douaneautoriteiten en andere bevoegde autoriteiten in de lidstaten, zowel rechtstreeks als via de Europese Politiedienst (Europol), in overeenstemming met de artikelen 30 en 32 VEU. Op grond van artikel 30 lid 1 VEU omvat gezamenlijk optreden op het gebied van politièle samenwerking:

a. operationele samenwerking tussen de bevoegde autoriteiten, met inbegrip van de politie, de douane en andere gespecialiseerde instanties van de lidstaten die belast zijn met

99. Her Verenigd Koninkrijk en lerland namen oorspronkelijk een uitzonderingspositie in, omdat zij tot dan toe buiten de Schengensamenwerking waren gebleven. Beide lidstaten hebben evenwel de Raad van de EU verzocht (beperkt) mee te mogen doen aan de Schengensamenwerking. De Raad heeft op beide verzoeken positief beslist. Derhalve valt de informatieve politiesamenwerking met deze EUlidstaten ook onder de SUO-regels. Zie hieromtrent (1) Besluit van de Raad van 29 mei 2000 betreffende het verzoek van het Verenigd Koninkrijk van Groot-Britanniè en Noord-lerland deel te mogen nemen aan enkele van de bepalingen van het Schengen-acquis (2000/365/EG), PbEG L 131/43 van 1 juni 2000 en (2) Besluit van de Raad van 28 februari 2002 betreffende het verzoek van Ierland deel te mogen nemen aan bepalingen van het Schengen-acquis (2002/192/EG), PbEG L. 164/20 van 7 maart 2002. De juridische basis van beide besluiten is artikel 4 van het voornoemde Schengen Protocol. De positic van de Republiek IJsland en het Koninkrijk Noorwegen is geregeld in Besluit 1999/437/EG van de Raad van 17 mei 1999 inzake bepaalde toepassingsbepalingen van de door de Raad van de Europese Unic, de Republiek IJsland en het Koninkrijk Noorwegen gesloten Overeenkomst inzake de wijze waarop deze twee staten worden betrokken bij de uitvoering, de toepassing en de ontwikkeling van het Schengen-acquis, PbEG L 176/31 van 10 juli 1999. De informatieve politiesamenwerking met deze twee staten valt derhalve ook onder de SUO.

100. Drie belangrijke politicke EU-documenten die deze ruimte van vrijheid, veiligheid en rechtvaardigheid willen bewerkstelligen zijn: (1) het Weense Actieplan van de Raad en Commissie over hoe de bepalingen van het Verdrag van Amsterdam inzake de totstandbrenging van een ruimte van vrijheid, veiligheid en rechtvaardigheid het best kunnen worden uitgevoerd, PbEG C 19/1 van 23 januari 1999; (2) de Conclusies van de Europese Raad van 15 en 16 oktober 1999 in Tampere (Finland). Prosidency Conclusions, Secretariaat-Generaal van de Europese Commissie, Brussel, 16 oktober 1999, kenmerk SI (1999) 800, SN 200/99; en (3) het zogenoemde Scorebord, waarmee voortdurend kan worden toegezien op de vorderingen bij de uitvoering van de nodige maatregelen respectievelijk op de inachtneming van het tijdschema dat met het Verdrag van Amsterdam, het Weense Actieplan en de Condusies van Tampere is vastgesteld met betrekking tot de totstandbrenging van een ruimte van vrijheid, veiligheid en rechtvaardigheid. Een bijgewerkte versie van het Scorebord wordt eenmaal per voorzitterschap ten behoeve van het Europees Parlement en de Raad opgesteld en gepubliceerd als mededeling. 
wetshandhaving met betrekking tot het voorkomen, opsporen en onderzoeken van strafbare feiten;

b. de verzameling, opslag, verwerking, analyse en uitwisseling van relevante informatic, met inbegrip van informatie over meldingen van verdachte financiële transacties waarover instanties die belast zijn met wetshandhaving beschikken, met name via Europol, onder voorbehoud van passende bepalingen inzake de bescherming van persoonsgegevens;

c. samenwerking en gezamenlijke initiatieven inzake de opleiding, de uitwisseling van verbindingsfunctionarissen, detacheringen, het gebruik van apparatuur en het forensisch onderzoek;

d. de gezamenlijke beoordeling van bepaalde onderzoekstechnieken in verband met het opsporen van ernstige vormen van georganiseerde criminaliteit.

De Raad van de EU bepaalt op grond van artikel 32 VEU onder welke voorwaarden en met welke beperkingen de in de artikel $30 \mathrm{VEU}$ bedoelde bevoegde autoriteiten op het grondgebied van een andere lidstaat mogen optreden in overleg met en met instemming van de autoriteiten van die staat. Artikel 33 VEU stelt dat Titel VI VEU de uitoefening van de verantwoordelijkheden van de lidstaten ten aanzien van de handhaving van de openbare orde en de bescherming van de binnenlandse veiligheid onverlet laat. Dit betekent dus dat de nationale wetgeving leidend blijft op deze terreinen. Artikel 34 lid 1 bepaalt dat op de in Titel VI VEU genoemde gebieden tussen de lidstaten wederzijdse informatie-uitwisseling en onderling overleg plaats dient te vinden in de Raad van de EU, teneinde hun optreden te coördineren. De lidsraten dienen met dat doel een samenwerking tussen hun bevoegde overheidsdiensten tot stand te brengen. Op grond van art 34 lid 2 VEU dient de Raad van de EU maatregelen te nemen en samenwerking te bevorderen, in een passende vorm en volgens passende procedures zoals bepaald in Titel VI. Op grond van artikel 34 lid 2, eerste alinea, tweede zin VEU heeft de Europese Commissie in de Derde Pijler een algemeen recht van initiatief verworven naast de lidstaten.

De politiële gegevensuitwisseling is in de SUO, voor zover voor dit onderzoek van belang, geregeld in de artikelen 39 en 46. ${ }^{101}$ Artikel 39 SUO handelt over de verstrekking van politiële gegevens na een daartoe strekkend verzoek van een andere Schengenstaat. Dit noemen we de verstrekking op verzoek. Artikel 46 SUO heeft betrekking op de verstrekking van politiële gegevens aan een andere Schengenstaat zonder een daartoe strekkend verzoek. Dit is de verstrekking zonder verzoek. Beide artikelen worden hieronder 
uitvoerig besproken (subsecties 5.2.1 en 5.2.2). Artikel 47 handelt daarnaast over contactambtenaren die bij politiediensten van een andere Schengenstaat kunnen worden gedetacheerd. Ook met en via deze contactambtenaren kunnen gegevens uitgewisseld worden. Omdat dit informatiekanaal niet rechtstreeks van belang is voor dit onderzoek, laten we de contactambtenaren onbesproken.

In subsectic 5.2.1 bespreken wij de verstrekking op verzoek en in subsectie 5.2.2 de verstrekking zonder verzoek.

\subsubsection{Verstrekking op verzoek}

\section{Artikel 39 lid I SUO}

In artikel 39 lid 1 SUO verbinden de Schengenstaten zich ertoe dat hun politiediensten elkaar wederzijds bijstand verlenen. Het doel van die bijstand is de voorkoming en opsporing van strafbare feiten. Het gaat dus zowel om preventieve als om repressieve doeleinden. Het proactief optreden is nieuw ten opzichte van het traditionele kleine rechtshulprecht, waarbij het moest gaan om een reeds aanhangige strafzaak. ${ }^{102}$ De politiediensten mogen elkaar alleen bijstand verlenen voor zover:

1. het doen of behandelen van een verzoek naar nationaal recht niet aan de justitiële autoriteiten is voorbehouden, en

2. voor het inwilligen van het verzoek door de aangezochte Schengenstaat geen dwangmiddelen behoeven te worden toegepast.

Wat onder justitiële autoriteiten moet worden verstaan, staat niet in het artikel. Hiervoor dient teruggegrepen te worden op artikel 24 ERV met de daarbij door de betrokken staten afgelegde verklaringen, aangezien de SUO voortbouwt op het ERV. Voor Nederland wordt onder 'justitiële autoriteiten' verstaan de staande magistratuur (het $\mathrm{OM}$ ) en de zittende magistratuur (de RC of een andere rechter). Ook een bevoegde ambtenaar van justitie kan eronder vallen.

In de gevallen waarbij dwangmiddelen moeten worden toegepast of waarbij het doen of behandelen van een verzoek om gegevens naar nationaal recht (voor Nederland het WvSv, de WPolr en het BPolr) is voorbehouden aan het OM, een ambtenaar van justitie, de RC of een andere rechter, mogen politiediensten van verschillende Schengenstaten gegevens niet rechtstreeks met elkaar uitwisselen op verzoek. De gegevensuitwisseling met de andere Schengenstaat is dan voorbehouden aan het OM of een rechter. In alle andere gevallen mogen de politiediensten van verschillende Schengenstaten wel rechtstreeks gegevens met elkaar uitwisselen op verzoek. In die gevallen van rechtstreekse poli- 
tiēle gegevensuitwisseling moet volgens artikel 39 lid 1 SUO het nationale recht in acht worden genomen. Verder moet de uitwisseling binnen de grenzen van de politiële bevoegdheden blijven. In Nederland dienen met name artikel 552i Sv en artikel 13 BPolr in acht te worden genomen. Wanneer de aangezochte politieautoriteiten niet bevoegd zijn tot de afdoening van een verzoek, moeten zij dit verzoek aan de wel bevoegde autoriteiten doorzenden.

\section{Artikel 39 lid 2 SUO}

Het tweede lid van artikel 39 SUO bepaalt dat 'schriftelijke' informatie die krachtens de zojuist beschreven systematiek van artikel 39 lid 1 SUO wordt verstrekt door de verzoekende Schengenstaat slechts met toestemming van de bevoegde justitiële autoriteiten van de aangezochte Schengenstaat als bewijsmiddel voor het ten laste gelegde feit kan worden gebruikt. Voor de aanwending van de verstrekte gegevens als bewijsmiddel in strafzaken is dus de toestemming van de aangezochte staat vereist. In Nederland beslist de Ov] uit wiens arrondissement de verstrekte gegevens afkomstig zijn over de vraag of aan het buitenland verstrekte informatie krachtens artikel 39 lid $2 \mathrm{SUO}$ als bewijsmiddel gebruikt mag worden. ${ }^{103}$ Hoewel artikel 39 lid 2 SUO spreekt over 'schriftelijke' informatie, is het niet aannemelijk dat de Schengenstaten dit artikel niet op geautomatiseerde gegevens van toepassing achten. Wil de informatie in een strafrechtelijke procedure aangewend worden, dan zal trouwens meestal een uitdraai van de verstrekte geautomatiseerde gegevens gemaakt moeten worden. Veel bewijsstelsels verbinden immers aan strafrechtelijk bewijs de eis van schriftelijkheid. Dan is de te gebruiken informatie dus hoe dan ook schriftelijk. Het door ons gesignaleerde puat van de schriftelijkheid is dus een theoretisch punt. In ieder geval zal de toestemming van de aangezochte Schengenstaat gevraagd moeten worden alvorens de verstrekte gegevens als bewijs in een strafzaak mogen worden gebruikt.

\section{Artikel 39 lid 3 SUO}

Het derde lid van artikel 39 SUO geeft uitsluitsel over de vraag tussen welke autoriteiten de politiële gegevens moeten worden uitgewisseld. De hoofdregel is dat de gegevensverzoeken en de antwoorden daarop moeten worden uitgewisseld tussen de met de internationale politiesamenwerking belaste centrale autoriteiten van de verschillende Schengenlanden. In Nederland is de DIN van het KLPD de centrale autoriteit (als opvolger van de dCRI), in België het CGI van de Federale Politie (de opvolger van de APSD), en in Duitsland het LKA voor gegevens voor preventie en het BKA voor gegevens voor de strafvervolging. 
In die gevallen echter waarin een verzoek om gegevens niet tijdig kan worden gedaan, kunnen verzoeken door de politieautoriteiten van de verzoekende Schengenstaat rechtstreeks aan de bevoegde politieautoriteiten van de aangezochte Schengenstaat worden toegezonden. De bevoegde politie-autoriteiten van het aangezochte Schengenland kunnen dan ook rechtstreeks antwoord geven op dit verzoek. Bij spoed kunnen gegevens dus rechtstreeks tussen de betrokken politiediensten van de verschillende Schengenlanden worden uitgewisseld. In deze gevallen moet de verzoekende politieautoriteit wel zo spoedig mogelijk de in de aangezochte Schengenstaat met de internationale samenwerking belaste autoriteit in kennis stellen van haar rechtstreekse verzoek. Bij spoed mag dus wel rechtstreeks om gegevens worden verzocht door politiediensten, maar dan moet de centrale autoriteit van het aangezochte land hiervan op de hoogte worden gebracht.

\section{Artikel 39 lid 4 en 5 SUO}

Voor de grensregionale politiēle gegevensuitwisseling is het vierde lid van artikel 39 SUO van heel groot belang. Artikel 39 lid 4 SUO bepaalt namelijk dat de samenwerking in de grensgebieden nader kan worden geregeld in afspraken tussen de bevoegde Ministers van de Schengenlanden. Zoals we zullen zien in sectie 5.5 is van de mogelijkheid die artikel 39 lid 4 SUO biedt gebruik gemaakt in de Euregio Maas-Rijn. In deze Euregio zijn namelijk allerlei bilaterale Convenanten en Akkoorden van toepassing tussen voornamelijk Nederland en België, en Nederland en Duitsland. Die akkoorden regelen specifiek voor de Euregio Maas-Rijn de rechtstreekse politiële gegevensuitwisseling in de grensregio's. Die afspraken gaan verder dan de zojuist besproken procedure van gegevensuitwisseling. Met name de spoedeisendheid van rechtstreekse gegevensuitwisseling tussen betrokken politiediensten en de tussenkomst van de centrale autoriteiten is in deze akkoorden niet langer vereist voor de gegevensuitwisseling in de Euregio. Volgens artikel 39 lid 5 SUO mogen die bilaterale akkoorden tussen aan elkaar grenzende Schengenlanden ook verder gaan. Artikel 39 lid 5 SUO voegt er nog aan toe dat de Schengenlanden elkaar mededeling moeten doen van deze akkoorden.

Vanuit juridisch oogpunt kunnen wij concluderen dat alle categorieën informatie die wettelijk mogen worden uitgewisseld tussen de politiële grenspartners ook daadwerkelijk in de praktijk worden uitgewisseld. ${ }^{104}$ Daarbij wordt in het bijzonder acht geslagen op drie regelingen voor de informatie-uitwisseling met respectievelijk België en Duitsland: 1. het convenant ten behoeve van de verstrekking van informatie uit een politieregister, convenant tussen de korpsbeheerders van de politieregio's Zeeland, Midden- en WestBrabant, Brabant Zuid-Oost, Limburg-Noord en Limburg-Zuid en de Beheerders van de OIPG's te Gent, Antwerpen, Turnhout, Genk en Eupen, met bijbehorende werkinstructic, Gent, 24 oktober 2000; 
2. het convenant ten behoeve van de verstrekking van informatie uit een politieregister, convenant tussen de korpsbeheerders van de politieregio's Limburg-Noord en Limburg-Zuid en de beheerders van de Verbindungsstellen Aachen en Mönchen-Gladbach, 31 januari 2001; en

3. het decreet Gem. RdErlaß d. Justizministeriums (9350-III A. 19) u. d. Innenministeriums - IV A I-1431/3.0, Nordrhein-Westfalen (Diüsseldorf), 10 maart 1999, in afwachting van een convenant met alle Duitse politiegrensregio's.

In de convenanten en het genoemde decreet is geregeld dat de internationale informaticuitwisseling in de grensregio's mag geschieden via zogenoemde IRC's, die speciaal voor dit doel zijn opgericht. Zo mogen Nederlandse IRC's met de aangrenzende Belgische OIPG's en Verbindungsstellen, alsmede met de aangrenzende Duitse RVST's rechtstreeks op verzoek en spontaan (zie subsectie 5.2.2) gegevens met elkaar uitwisselen. De agenten en rechercheurs in het veld (op de werkvloer) dienen de IRC's in te schakelen om een politieel rechtshulpverzoek te doen aan het buitenland.

\subsubsection{Verstrekking zonder verzoek}

\section{Artikel 46 lid 1 SUO}

Volgens het eerste lid van artikel 46 SUO kan ieder Schengenland met inachtneming van haar nationale recht in individuele gevallen zonder een daartoe strekkend verzoek informatie meedelen aan een betrokken Schengenland. De informatic kan worden uitgewisseld voor de volgende doeleinden:

- ter verlening van bijstand bij de bestrijding van toekomstige strafbare feiten;

- ter voorkoming van strafbare feiten; of

- ter afwending van een gevaar voor de OOV.

Met het oog hierop moet de informatie voor de ontvangende Schengenstaat van belang kunnen zijn. Deze zogenaamde spontane gegevensuitwisseling kan dus in ieder geval voor preventieve doeleinden plaatsvinden, maar ook voor repressieve doeleinden. Of onder die repressieve doeleinden ook de opsporing van reeds gepleegde strafbare feiten valt, is uit de tekst van artikel 46 lid 1 SUO niet duidelijk op te maken. De tekst spreekt namelijk van de bestrijding van toekomstige strafbare feiten en niet van reeds gepleegde strafbare feiten. Men mag echter aannemen dat de Schengenstaten ook hiervoor de spontane gegevensuitwisseling mogelijk hebben willen maken. Het spontane en proactieve optreden van politieambtenaren is nieuw ten opzichte van het traditionele kleine rechtshulprecht, waarbij het moest gaan om gevraagde hulp en een reeds aanhangige strafzaak. ${ }^{105}$ 


\section{Artikel 46 lid 2 SUO}

Het tweede lid van artikel 46 SUO geeft uitsluitsel over de vraag tussen welke autoriteiten spontaan politiële gegevens dienen te worden uitgewisseld. Hoofdregel is de tussenkomst van de centrale instantie (de DIN van het KLPD, CGI, LKA of BKA). In de grensgebieden echter geschiedt de spontane gegevensuitwisseling onder de voorwaarden zoals vastgelegd in de in artikel 39 lid 4 SUO genoemde akkoorden. Daarnaast bestaat er op de hoofdregel een uitzondering voor bijzonder spoedeisende gevallen. In bijzonder spoedeisende gevallen kan, onder voorbehoud van afwijkende bepalingen van het nationale recht, de spontane gegevensuitwisseling rechtstreeks tussen de betrokken politiediensten plaatsvinden. De centrale instantie van het verstrekkende Schengenland moet hiervan wel zo spoedig mogelijk in kennis worden gesteld.

\subsection{Persoonsgegevens internationaal beschermd}

In het begin van de jaren tachtig besteedden verschillende internationale fora aandacht aan de eerbiediging van het privé-leven bij het verzamelen, opslaan en gebruik van persoonsgegevens. Dit wordt de zogenaamde informationele privacy genoemd. Er werden verschillende gegevensbeschermingsbeginselen geïntroduceerd. Eén van de basisprincipes is het beginsel dat persoonsgegevens slechts gebruikt mogen worden voor het doel dat reeds gedefinieerd moet zijn voordat de verzameling van die gegevens begint. Verwerking voor andere doeleinden kan het use limitation-principe schenden. Het internationaal economisch forum van de OESO (Organisatie voor Economische Samenwerking en Ontwikkeling) deed in 1980 een voorstel om, op grond van een aantal nieuw te formuleren internationale spelregels, het economisch belang van de vrije omgang met informatie te verzoenen met de privacyrechten van de geregistreerden. ${ }^{106}$ Eén jaar later legde de Raad van Europa haar lidstaten het Verdrag van Straatsburg tot bescherming van personen ten opzichte van de geautomatiseerde verwerking van persoonsgegevens voor (zie subsectie 5.3.1 over dit Databeschermingsverdrag). De teksten van de OESO en de Raad van Europa liepen parallel. De OESO had aan de uitwerking van het verdrag meegewerkt. Het Databeschermingsverdrag bevatte dan ook een clausule die het verdrag openstelde voor alle OESO-richtlijnen. De OESO-richtlijnen waren een niet-bindend rechtsinstrument dat vooral was gericht op multinationals, die verzocht werden zich vrijwillig te conformeren aan de richtlijnen. ${ }^{107}$ De Raad van Europa wilde de dreiging van de opkomst van databanken aanpakken om de eerbiediging van de persoonlijke levenssfeer af te dwingen. Via een bindend rechtsinstrument wilde de Raad zowel in de publieke als de private sector plichten opleggen aan de houders van bestanden en rechten geven aan degenen op wie de gegevens betrekking hebben. Bovendien moest een bindend verdrag

106. OECD.Gwidelines Governing stoe Protection of Privacy and Transbonder Data Flows of

Persenal Dasa van 23 september 1980.

107. De Hert \& Vanderborght 1996, p. 481. 
verhinderen dat de lidstaten met gegevensbeschermingswetgeving hun gebied in de naam van privacy zouden afsluiten voor Europese landen zonder wetgeving op dit gebied. Hierdoor zou elke internationale gegevensstroom onmogelijk worden. En dat zou ten koste gaan van de in artikel 10 EVRM neergelegde vrijheid inlichtingen te ontvangen 'ongeacht grenzen. ${ }^{\text {'10 }}$

Wij bespreken in deze sectie achtereenvolgens: het Databeschermingsverdrag van 1981 (subsectie 5.3.1), de Aanbeveling R (87)15 uit 1987 (subsectie 5.3.2), de EU-richtlijnen uit 1995 en 2002 (subsectie 5.3.3), de Constituties en artikel 8 EVRM uit 1950 (subsectie 5.3.4) en de politiële gegevensbescherming in de SUO (subsectie 5.3.5).

\subsubsection{Het Databeschermingsverdrag}

Alle Schengenlanden hebben destijds het Databeschermingsverdrag ${ }^{109}$ van 28 januari 1981 van de Raad van Europa ondertekend. Het verdrag werd door Nederland geratificeerd op 24 augustus 1993 en het trad in werking voor Nederland op 1 december 1993. België ratificeerde het verdrag op 28 mei 1993 en het trad voor België in werking op 1 september 1993. Duitland ratificeerde het verdrag op 19 juni 1985 en het trad voor Duitsland in werking op 1 oktober 1985 . Het verdrag wilde personen beschermen tegen eventuele negatieve effecten van de automatische verwerking van persoonsgegevens. Het verdrag trad op 1 oktober 1985 in werking tussen vijf staten (Spanje, Zweden, Noorwegen, Duitsland en Frankrijk) en heeft een bindend effect. Het is echter niet self-executing. Dit betekent dat de burgers de door het Databeschermingsverdrag toegekende rechten niet rechtstreeks aan het verdrag kunnen ontlenen. Artikel 4 Databeschermingsverdrag schrijft voor dat elke verdragspartij in zijn nationale recht de noodzakelijke maatregelen moet treffen teneinde de in het verdrag vervatte principes uit te voeren. Hieronder beschrijven we een aantal relevante artikelen uit het Databeschermingsverdrag.

In artikel 2 sub a van het verdrag wordt het begrip persoonsgegeven ('personal data') omschreven als "any information relating to an identified or identifiable individual". Het onderdeel 'any information relating to' in de definitie van 'personal data' in het Databeschermingsverdrag ziet op alle gegevens die informatie over een bepaalde persoon kunnen verschaffen. Beschermd worden natuurlijke personen, maar de lidstaten kunnen door een verklaring ook rechtspersonen in de bescherming betrekken (artikel 3 lid 2 sub

108. De Hert \& Vanderborght 1996, p. 481.

109. Verdrag tot bescherming van personen met betrekking tot de geautomatiseerde verwerking van persoonsgegevens, Straatsburg 28 januari 1981, Trb. 1988, 7. 
b). Het verdrag biedt daarnaast ook bescherming aan vreemdelingen ongeacht de plaats van de verwerking ${ }^{110}$ van de gegevens (artikel 1).

Het Databeschermingsverdrag ziet verder op geautomatiseerde gegevensbestanden en geautomatiseerde verwerkingen (artikel 3 lid 1), maar door een verklaring kunnen ook niet-automatisch bewerkte persoonsbestanden onder het toepassingsdomein van het verdrag gebracht worden (artikel 3 lid 2 sub c). Het verdrag moet toegepast worden in zowel de private als de publieke sector en derhalve ook in de politiële sector. Politiële gegevensuitwisseling valt dus onder het verdrag. Artikel 5 Databeschermingsverdrag bepaalt dat de gegevens rechtmatig verzameld moeten worden en enkel mogen worden opgeslagen voor specifieke en gerechtvaardigde doeleinden. De gegevens mogen niet worden gebruikt op een wijze die onverenigbaar is met die doeleinden. Dit wordt het beginsel van verenigbaar gebruik of het doelbindingsbeginsel genoemd. Bovendien moeten de gegevens relevant, adequaat, nodig voor het doel en accuraat zijn. De gegevens mogen ook niet langer worden bewaard dan nodig is voor het doel waarvoor ze werden opgeslagen. Artikel 6 verbiedt in beginsel de verwerking van gegevens betreffende ras, politieke overtuiging, godsdienstige of andere levensbeschouwingen, gezondheid, seksueel gedrag en strafrechtelijke veroordelingen. Als de nationale wetgeving echter in passende waarborgen voorziet, mogen dergelijke gegevens wel worden verwerkt. Artikel 7 heeft betrekking op gegevensbeveiliging en roept de lidstaten op om passende veiligheidsmaatregelen te nemen om in geautomatiseerde bestanden opgeslagen persoonsgegevens te beschermen tegen toevallige of ongeoorloofde vernieling, toevallig verlies alsmede tegen ongeoorloofde toegang, wijziging of verstrekking. Het betreft dus maatregelen tegen menselijke en niet-menselijke factoren. Artikel 8 verleent aan eenieder de volgende individuele rechten:

- de mogelijkheid om het bestaan van een geautomatiseerd bestand te achterhalen, alsmede de bedoeling ervan, de identiteit en het adres van de verantwoordelijke;

- de mogelijkheid om met redelijke tussenpozen en zonder overdreven vertraging of kosten te achterhalen of persoonsgegevens over hem of haar in het bestand zijn opgeslagen, onder mededeling van die gegevens in een begrijpelijke vorm;

- een recht op verbetering wanneer er sprake is van onjuiste gegevens of op vernietiging wanneer de gegevens in strijd met de privacyregelgeving in een land zijn opgenomen;

- een recht op beroep indien een verzoek tot kennisgeving of mededeling van gegevens of een verzoek tot verbetering of uitwissing niet wordt beantwoord.

110. Art. 2 sub c Databeschermingsverdrag verstaat onder "automatische verwerking" de volgende geheel of gedeeltelijk door middel van geautomatiseerde proceddes uitgevoerde bewerkingen: gegevens opslaan, logische en/of rekenkundige bewerkingen op die gegevens uitvoeren: het wijzigen, wissen, opvragen en verstrekken van die gegevens. 
Artikel 9 Databeschermingsverdrag laat uitzonderingen toe op artikel 6 tot en met 8. Uitzonderingen zijn echter alleen toegestaan als ze bij wet bepaald zijn en noodzakelijk zijn in een democratische samenleving voor de bescherming van de veiligheid van de staat, de openbare veiligheid, de monetaire belangen van de staat, de bestrijding van de criminaliteit, de bescherming van de betrokkene zelf of voor de rechten en vrijheden van derden (vergelijk artikel 8 lid 2 EVRM; subsectie 5.3.4).

Artikel 12 Databeschermingsverdrag heeft betrekking op internationale gegevensstromen. Het uitgangspunt van de regeling is dat er vrij gegevensverkeer moet bestaan tussen lidstaten van het verdrag en met staten die een gelijkwaardige bescherming kunnen garanderen. Er kan een uitzondering worden gemaakt voor bepaalde categorieën van gegevens waarvoor de nationale wetgeving een speciale behandeling voorschrijft. Ook kan er een uitzondering worden gemaakt voor de gegevensuitvoer naar landen die geen partij zijn bij het verdrag via een staat die wel partij is.

De lidstaten hebben zich er verder toe verbonden elkaar in te lichten over hun rechtstoestand. Tevens hebben zij zich ertoe verbonden in onderlinge administratieve en gerechtelijke hulp te voorzien (artikel 13 lid 1 en 3 ). De verdragsstaten moeten ook hulp verlenen aan personen die in het buitenland wonen of er wensen te ageren wanneer zij inlichtingen vragen over hun gegevens of wanneer zij de verbetering of vernietiging van de gegevens wensen (artikel 14 lid 1). Daartoe moeten de lidstaten controleorganen of rechterlijke instanties instellen (artikel 14 lid 2).

Het Databeschermingsverdrag is dus weliswaar van toepassing op de verwerking van persoonsgegevens door politiediensten, maar er wordt niets specifieks gezegd over Europese politiesamenwerking.

\subsubsection{Aanbeveling $R(87) 15$}

De Raad van Europa beperkte zich wat de politiële gegevensbescherming betreft niet tot het in de vorige subsectie besproken Databeschermingsverdrag. Het Comité van Ministers van de Raad van Europa nam op 17 september 1987 Aanbeveling R (87) 15 aan betreffende het gebruik van persoonsgegevens op het terrein van de politic." "In deze aanbeveling zijn niet-bindende doch wel gezaghebbende aanbevelingen gericht tot de lidstaten van de Raad van Europa, waarin de basisbeginselen van het Databeschermingsverdrag (subsectie 5.3.1) verder zijn uitgewerkt. De aanbeveling dient als een leidraad voor zowel wetgeving als zelfregulering. Het Comité van Ministers wijst op artikel 8 EVRM ter bescherming van de persoonlijke levenssfeer (zie subsectie 5.3.4) alsmede op 
artikel 9 Databeschermingsverdrag, waarin de uitzonderingsmogelijkheden op de basisbeginselen voor de bescherming van persoonsgegevens staan opgesomd. De Aanbeveling $R$ (87) 15 wil duidelijkheid verschaffen over welke afwijkingen toegestaan zijn voor de politiële sector. Her Comité van Ministers heeft daarbij een evenwicht gevonden tussen enerzijds het belang dat de samenleving heeft bij het voorkomen en bestrijden van de misdaad en handhaving van de openbare orde, en anderzijds de belangen en het recht op het privé-leven van het individu.

Aanbeveling R (87) 15 bevat acht fundamentele beginselen. De beginselen zijn van toepassing op het verzamelen, opslaan, gebruiken en verstrekken van persoonsgegevens voor politiedoeleinden, die automatisch worden verwerkt. 'Voor politiedoeleinden' houdt alle taken in die politie-instanties moeten uitoefenen om misdaad te voorkomen en te bestrijden en om de openbare orde te handhaven. Onder 'persoonsgegevens' wordt verstaan enige informatie over een geidentificeerde of identificeerbare persoon. Een persoon wordt volgens de aanbeveling niet als identificeerbaar beschouwd wanneer het vaststellen van zijn identiteit onredelijk veel tijd, kosten en mankracht vergt. Een lidstaat kan de beginselen mede van toepassing verklaren op persoonsgegevens die niet automatisch worden verwerkt. Daarenboven dient verwerking van gegevens met de hand niet te gebeuren met het oogmerk de beginselen van de aanbeveling te ontlopen. Ook voor staatsveiligheidsdoeleinden kunnen de beginselen leidend zijn. De beginselen van de aanbeveling zijn verwerkt in de nationale wetgeving, voor Nederland in de WPolr en het BPolr. In de SUO wordt ook naar de aanbeveling verwezen (zie subsectie 5.3.5). Elke Schengenstaat heeft de nodige maatregelen moeten nemen om een niveau van bescherming te verwezenlijken dat de beginselen van Aanbeveling R (87) 15 in acht neemt. Hieronder bespreken wij in het kort de acht beginselen.

Het eerste beginsel zegt dat elke lidstaat een onafhankelijke controleautoriteit buiten de politiële sector moet hebben die vooraf geraadpleegd moet worden telkens wanneer de invoering van automatische verwerkingsmethoden vragen opwerpt over de toepassing van de aanbevelingen; in Nederland oefent het College bescherming persoonsgegevens (CBP) deze taak uit. Het eerste beginsel stelt verder dat nieuwe technische middelen voor gegevensverwerking pas mogen worden ingevoerd als alle redelijke maatregelen zijn genomen om te bevorderen dat het gebruik van die middelen geschiedt in de geest van de bestaande gegevensbeschermingswetgeving. Elk permanent geautomatiseerd bestand moet ter kennis worden gebracht van de controleautoriteit. Concreet houdt dit dus in dat voor de implementatie van bijvoorbeeld de EMMI-omgeving vooraf overleg gevoerd dient te worden met de nationale controleautoriteiten om na te gaan of aan alle wettelijke eisen wordt voldaan. Dit overleg is succesvol gevoerd in het EMMI-traject.

Het tweede beginsel bepaalt dat geen persoonsgegevens mogen worden verzameld voor politiedoeleinden, tenzij dit noodzakelijk is voor de preventie van een reëel gevaar of het 
bestrijden van een specifiek misdrijf. Uitzonderingen hierop moeten in een aparte nationale wet worden geregeld. De persoon van wie gegevens worden opgeslagen moet daarvan op de hoogte worden gebracht zodra dit de politieactiviteiten niet meer schaadt. Gegevens over ras, religie, seksueel gedrag, politieke overtuiging of lidmaatschap van een wettelijk toegelaten vereniging mag in geen enkel geval worden geregistreerd, tenzij dat absoluut noodzakelijk is in het kader van een bijzonder onderzoek.

Het derde beginsel benadrukt dat het opslaan van gegevens voor politiedoeleinden zoveel mogelijk moet worden beperkt tot accurate gegevens en gegevens die nodig zijn om politie-instanties in staat te stellen hun wettelijke taken binnen het kader van de nationale wetgeving uit te voeren. Ook moeten de verplichtingen die voortvloeien uit het internationale recht, waaronder de gegevensuitwisseling met het buitenland, kunnen worden nagekomen. De verschillende soorten gegevens die worden opgeslagen, moeten zoveel mogelijk worden onderscheiden naar hun mate van precisie of betrouwbaarheid. In het bijzonder dienen gegevens gebaseerd op feiten gescheiden te worden van gegevens berustend op meningen of persoonlijke beoordelingen. Administratieve gegevens ten slotte mogen niet worden behandeld volgens de regels voor politiegegevens.

Het vierde beginsel bepaalt dat persoonsgegevens alleen voor politiedoeleinden mogen worden gebruikt.

Het vijfde beginsel brengt hierop enige nuancering aan in de zin dat ook voor de verstrekking aan andere overheidsdiensten en aan particulieren normen worden aanbevolen. We laten dit aspect hier verder buiten beschouwing, omdat het in dit onderzoek alleen gaat om de uitwisseling van gegevens tussen politiediensten van verschillende landen. Wat dit betreft zegt het vijfde beginsel dan ook dat het verstrekken van politiegegevens aan buitenlandse instanties beperkt dient te blijven tot politie-instanties. Verstrekking aan andere buitenlandse instanties blijkt dus niet mogelijk. Bovendien is het verstrekken van politiegegevens aan buitenlandse politie-instanties slechts toelaatbaar in twee gevallen:

1. wanneer er duidelijke wettelijke bepalingen dienaangaande bestaan in het nationale of internationale recht (voor Nederland artikel 13 BPolr; zie subsectie 5.4.3);

2. wanneer de verstrekking noodzakelijk is om een ernstig en onmiddellijk gevaar af te wenden of een ernstig misdrijf onder het gewone recht te bestrijden.

Bij de doorgifte aan het buitenland moeten in beide gevallen de nationale regels voor bescherming van de persoon onaangetast blijven. De doorgifte van gegevens aan het buitenland mag dus niet gepaard gaan met een vermindering aan gegevensbescherming. Als de gegevens worden doorgegeven aan landen met een vergelijkbaar gegevensbeschermingsniveau (zoals België, Duitsland en Frankrijk) wordt aan deze eis voldaan. Wanneer de gegevens echter worden doorgegeven aan landen zonder adequate gegevens- 
bescherming, zullen ad hoc afspraken gemaakt moeten worden over de na te leven voorwaarden.

Het vijfde beginsel zegt vervolgens dat verzoeken tot het verstrekken van gegevens in beginsel dienen aan te geven wie de verzoekende instantie of persoon is, welke redenen deze voor het verzoek heeft en wat met de gegevens wordt beoogd. Voor zover mogelijk dient uiterlijk ten tijde van de verstrekking de deugdelijkheid van de gegevens te worden geverifieerd. Zo mogelijk dienen bij elke verstrekking rechterlijke uitspraken en besluiten tot ontslag van rechtsvervolging te worden opgegeven. Tevens dienen gegevens die berusten op opinies of persoonlijke beoordelingen vór de verstrekking aan de bron te worden gecontroleerd. Daarbij dient de mate van nauwkeurigheid en betrouwbaarheid van de gegevens te worden aangegeven. Wanneer wordt geconstateerd dat gegevens niet langer juist zijn of up-to-date zijn, mogen zij niet worden verstrekt. Indien toch niet langer juiste of niet bijgewerkte gegevens verstrekt zijn, dient de verstrekkende instantie zoveel mogelijk alle ontvangers erop attent te maken dat de gegevens niet langer aan de werkelijkheid beantwoorden.

Een heel belangrijke eis van het vijfde beginsel is dat gegevens die verstrekt zijn aan buitenlandse instanties (of aan overheidslichamen en particulieren) voor geen ander doel gebruikt mogen worden dan aangegeven in het verzoek om inlichtingen. Gebruik van de gegevens voor andere doeleinden moet afhankelijk worden gesteld van goedkeuring door de verstrekkende instantie. Dit wordt de eis van doelbinding of beperkt gebruik genoemd.

Van cruciaal belang voor het onderhavige onderzoek is dat het vijfde beginsel van de aanbeveling ook een normering aanlegt voor de koppeling van bestanden en de directe toegang tot bestanden. In één van de twee volgende gevallen mag een bestand gekoppeld worden aan een ander bestand dat een ander doel dient:

1. de controleautoriteit (voor Nederland het CBP) heeft in verband met een onderzoek naar een bepaald strafbaar feit machtiging gegeven;

2. de koppeling geschiedt op grond van een uitdrukkelijk wettelijk voorschrift (in Nederland neergelegd in de WPolr en het BPolr; zie sectie 6.2).

Directe (on line) toegang tot een bestand is volgens het vijfde beginsel slechts toegestaan in overeenstemming met nationale wetgeving die de beginselen 1 tot en met 6 van Aanbeveling R (87) 15 respecteert (zie sectie 6.3; de uitwerking hiervan in Nederland vindt men met name in artikel $17 \mathrm{BPolr})$.

Het zesde beginsel formuleert aanbevelingen voor de openbaarheid van politiebestanden, het recht van toegang tot de eigen gegevens voor de betrokkene, het recht van verbetering en de mogelijkheid van beroep bij een weigering daarvan. De toepassing van de 
algemene regels van het Databeschermingsverdrag zou alleen beperkt mogen worden als dat onontbeerlijk is voor de vervulling van de politietaak, of noodzakelijk is voor de bescherming van de betrokkene of van de rechten en vrijheden van derden. In elk geval moet weigering van toegang of verbetering schriftelijk worden gemotiveerd. Aan de betrokkene moet bovendien de mogelijkheid worden geboden tegen een weigering beroep in te stellen bij de nationale controleautoriteit.

Het sevende beginsel bepaalt dat de nodige maatregelen moeten worden genomen om de gegevens die niet meer nodig zijn voor het doel waarvoor zij werden opgeslagen, te verwijderen. Het is echter wel van belang om de gegevens te kunnen bewaren voor de afronding van een onderzoek, na een onherroepelijke rechterlijke uitspraak, voor rechrsherstel, na veroordelingen waaraan voldaan is en na het toekennen van amnestie. Het gaat hierbij zowel om gegevens als de leeftijd van de betrokken persoon als om specifieke categorieën gegevens. In overleg met de controleautoriteit of in overeenstemming met het nationale recht moeten regels worden opgesteld voor de bewaartermijnen van verschillende soorten persoonsgegevens en voor een regelmatige controle op de deugdelijkheid van die gegevens.

Het achtste beginsel ten slotte handelt over de beveiliging van de gegevens. De beheerder van de gegevens dient alle mogelijke maatregelen te nemen om een behoorlijke fysieke en softwarebeveiliging van de gegevens te garanderen. Ongeoorloofde veranderingen, toegang of verstrekkingen moeten worden voorkomen. Daarbij moet rekening worden gehouden met de verschillende kenmerken en de inhoud van de bestanden.

\subsubsection{EU-richtlijnen}

De toepasselijkheid van het recht van de EU in het kader van de politiële rechtshulp is enigszins gecompliceerd, omdat de EU een eigen rechtsorde kent. De EU-richtlijnen kunnen door belanghebbenden tegen de nationale overheid worden ingeroepen, ook in strafzaken, mits de door de richtlijn opgelegde verplichtingen voldoende nauwkeurig en precies zijn. De rechter moet dan bepalen of de nationale overheid binnen de grenzen van bijvoorbeeld de richtlijn is gebleven. ${ }^{112}$ De Europese privacyrichtlijnen sluiten echter het domein van de politie en het strafrecht van hun toepassingsgebied uit. Zij zijn dan ook niet van toepassing op de politiële gegevensuitwisseling. Om de gedachten te bepalen, behandelen wij de relevante privacyrichtlijnen hieronder in het kort. 


\section{De algemene privacyrichtlijn}

De Europese algemene privacyrichtlijn 113 omschrijft persoonsgegevens als alle informatie betreffende een geïdentificeerde of identificeerbare natuurlijke persoon. De regels van deze richtlijn dienden vóór 24 oktober 1998 geïmplementeerd worden in de wetgeving van de lidstaten van de EU. In Nederland is de richtlijn uiteindelijk geïmplementeerd door de invoering van de Wet bescherming persoonsgegevens (Wbp) ${ }^{114}$ die de Wet persoonsregistraties (WPR) heeft vervangen. In de richtlijn staat niet langer het begrip persoonsregistratie centraal maar het begrip 'verwerken'."15

De Europese privacyrichtlijn is echter niet van toepassing op politiële gegevensuitwisseling. Ingevolge artikel 3 lid 2 van de richtlijn is zij niet van toepassing verklaard op de verwerking van persoonsgegevens die met het oog op de uitoefening van niet binnen het Gemeenschapsrecht vallende activiteiten geschiedt. Hieronder vallen activiteiten als bedoeld in de titels V en VI (waarin de politiële en strafrechtelijke samenwerking is geregeld). De richtlijn heeft in ieder geval geen betrekking op verwerkingen die betrekking hebben op de openbare veiligheid, defensie, de veiligheid van de staat en activiteiten van de staat op strafrechtelijk gebied.

\section{De richtlijn betreffende pricacy en elektronische communicatie}

De ISDN-richtlijn ${ }^{116}$ vormde tot 2002 een aanvulling op de algemene privacyrichtlijn uit 1995. $\mathrm{Zij}$ beantwoordde aan de specifieke eisen en aan de technische mogelijkheden van telecommunicatienetwerken, met name van digitale netwerken (vaste of mobiele). De ontwikkeling daarvan hangt ten dele af van de vraag of de gebruikers ervan verzekerd kunnen zijn dat deze diensten geen inbreuk maken op hun persoonlijke levenssfeer.

Behalve de fundamentele rechten van natuurlijke personen, beoogde de richtlijn ook de rechtmatige belangen van rechtspersonen te beschermen. De bepalingen van de richtlijn hadden betrekking op: de veiligheid van de diensten en de netwerken, het vertrouwelijk

113. Richtlijn van de Europese Unie van 24 oktober 1995 betreffende de bescherming van natuurlijke personen in verband met de verwerking van persoonsgegevens en betreffende het vrije verkeer van die gegevens, PbEG L. 281, 23 november 1995.

114. Wet van 6 juli 2000, houdende regels inzake de bescherming van persoonsgegevens (Wet bescherming persoonsgegevens), Stb. 2000, 302; in werking getreden op 1 september 2001; laatstelijk gewijzigd bij wet van 7 februari 2002, Stb. 2002, 148.

115. Verwerken is in artikel 2 van de richelijn omschreven als elke bewerking of elk geheel van bewerkingen met betrekking tot persoonsgegevens, al dan niet uitgevoerd met behulp van geautomatiseerde procédés, zoals het verzamelen, vastleggen, ordenen, bewaren, uitwerken, wijzigen, opvragen, raadplegen, gebruiken, verstrekken door middel van doorzending, verspreiding of enige andere vorm van terbeschikkingstelling, samenbrengen, met elkaar in verband brengen, alsmede het afschermen, uitwissen of vernietigen van gegevens.

116. Richtlijn 97/66/EG (oud) van het Europese Parlement en de Raad van 15 december 1997 betreffende de verwerking van persoonsgegevens en de bescherming van de persoonlijke levenssfeer in de telecommunicatiesector, PbEG L. 24, 30 januari 1998. 
karakter van de oproepen, de gegevens over het telefoonverkeer en de facturatie, het recht om niet-gedetailleerde rekeningen te ontvangen, de weergave van de identificatie van de oproepende en verbonden lijnen alsmede een beperking van deze mogelijkheid, het automatisch oproepsysteem, de gegevens in telefoonboeken en de ongevraagde oproepen met het oog op direct marketing. De uiterste datum waarop de richtlijn door de lidstaten in nationaal recht moet worden omgezet, was dezelfde als die voor de algemene richtlijn, te weten 24 oktober $1998 .{ }^{117} \mathrm{De}$ ISDN-richtlijn wordt in Nederland geimplementeerd in de nieuwe Telecommunicatiewet, die binnenkort van kracht wordt. ${ }^{118}$

De ISDN-richtlijn was echter evenmin als de algemene privacyrichtlijn van toepassing op de politiële gegevensuitwisseling. Artikel 1 lid 3 van de richtlijn bepaalde namelijk dat de richtlijn niet van toepassing is op activiteiten die niet onder het Gemeenschapsrecht vallen, zoals de activiteiten waarin wordt voorzien door de titels V en VI (waarin de politiële samenwerking is geregeld) van het VEU. Het artikellid bepaalt verder dat de richtlijn in geen geval van toepassing is op activiteiten die verband houden met de openbare veiligheid, defensie, staatsveiligheid en de activiteiten van de staat op strafrechtelijk gebied.

De ISDN-richtlijn is in 2002 vervangen door de Richtlijn betreffende privacy en elektronische communicatie. ${ }^{119}$ Deze laatste richtlijn is evenmin als de algemene privacyrichtlijn van toepassing op vraagstukken met betrekking tot de bescherming van fundamentele rechten en vrijheden van niet onder het Gemeenschapsrecht vallende activiteiten. De richtlijn is dus niet van toepassing op activiteiten uit de Derde Pijler, waaronder de informatieve politiesamenwerking valt. ${ }^{120} \mathrm{Zij}$ verandert niets aan het bestaande evenwicht tussen het recht van personen op hun persoonlijke levenssfeer en de mogelijkheid voor de lidstaten om de in artikel 15 lid 1 van de richtlijn bedoelde maatregelen te nemen, die nodig zijn voor de bescherming van de openbare veiligheid, defensie, staatsveiligheid en de wetshandhaving op strafrechrelijk gebied. Bijgevolg doet de richtlijn geen afbreuk aan de mogelijkheid voor de lidstaten om wettelijk toegestane interceptie van elektronische communicatie uit te voeren of andere maatregelen vast te stellen, wanneer dat voor één van voornoemde doeleinden noodzakelijk is. De richtlijn is onder meer van belang met het oog op het erin neergelegde principe dat bepaalde soor-

117. Om rekening te houden met de in sommige lidstaten noodzakelijke bijzondere procedures, was deze termijn wat de bepalingen over het vertrouwelijke karakter van de oproepen betreft, vastgesteld op 24 oktober 2000.

118. Kamerstukken 1997/1998, 25533.

119. Richtlijn 2002/58/EG van het Europees Parlement en de Raad van 12 juli 2002 betreffende de verwerking van persoonsgegevens en de bescherming van de persoonlijke levenssfeer in de sector elektronische communicatie, PbEG L 201/37 van 31 juli 2002.

120. Zie overweging 11 en artikel 1 lid 3 van Richtlijn 2002/58/EG. 
ten gegevens, waaronder persoonsgegevens, die berusten bij bepaalde type houders niet mogen worden bewaard en vernietigd dienen te worden als er niet langer een zakelijke reden is voor het bewaren van de gegevens. De lidstaten kunnen echter wetgeving aannemen om te voorzien in uitzonderingen in het belang van een goede rechtsbedeling. Zo is in 2002 in de Derde Pijler van de EU voorgesteld om een algemene bewaarplicht van 1 jaar of meer in te voeren voor verkeersgegevens ${ }^{121}$ in het belang van de opsporing. Het betrof een verzoek van de Verenigde Staten naar aanleiding van 11 september 2001.

Deze bewaarplicht zou dienen te gelden voor telefoon, fax, e-mail en kortweg al het overige gebruik van Internet. Hierop is kritiek gekomen van onder meer de nationale controleautoriteiten. Een dergelijke bewaarplicht vormt een onrechtmatige inbreuk op artikel 8 EVRM (zie subsectie 5.3.4). Bovendien is een bewaarplicht op grond van artikel 15 lid 1 van de richtlijn alleen toegestaan voor een beperkte periode en wanneer dat in een democratische samenleving noodzakelijk, passend en evenredig is. ${ }^{122}$

\subsubsection{Constituties en artikel 8 EVRM}

\section{Invloed nationale constituties}

De internationale politiële gegevensuitwisseling wordt beïnvloed door in de nationale constituties en in het EVRM ${ }^{123}$ neergelegde grondrechten en mensenrechten ${ }^{124}$. Zo vinden we in het recht betreffende de internationale politiële gegevensuitwisseling grondrechten terug als het discriminatieverbod van artikel $1 \mathrm{Gw}$ (zie subsectie 5.4.2) en het recht op eerbiediging van de persoonlijke levenssfeer van artikel $10 \mathrm{Gw}$. Artikel 10 lid 2 Gw bepaalt expliciet dat de wet regels moet stellen ter bescherming van de persoonlijke levenssfeer in verband met het vastleggen en verstrekken van persoonsgegevens. Dit is gebeurd in de Wbp en de WPolr (subsectie 5.4.3). Op grond van artikel 10 lid $3 \mathrm{Gw}$ dient de wet ook regels te stellen inzake de aanspraken van personen op kennisneming van over hen vastgelegde gegevens en van het gebruik dat daarvan wordt gemaakt, alsmede op verbetering van zodanige gegevens. Ook deze regels zijn expliciet neergelegd in de Wbp en de WPolr, alsmede in het Reglement internationale rechtshulp politie (zie subsectie 5.4.3),

121. Deze gegevens geven informatic over tijdstip, duur en plaats van de communicatic, over aansluitingen, et cetera.

122. Zie hierover ook Opinion 4/2001 van de artikel 29 Working Party, de werkgroep die de Commissie, de Raad en het Europees Parlement op grond van artikel 29 en 30 van de algemene privacyrichtlijn en artikel 15 lid 3 van Richtijn 2002/58/EG adviseert over de uitvoering van de privacyrichtlijnen.

123. Verdrag van 4 november 1950, Trb. 1990, 156.

124. Zie omtrent de relatie mensenrechten en strafvordering Brants, Mevis \& Prakken 2001. 


\section{Verbouding nationaal recht en vendragsrecht}

In Nederland maakt het internationale recht deel uit van het nationale recht. Nederland heeft een gematigd monistisch stelsel, hetgeen betekent dat het internationale recht in beginsel directe werking heeft. Het internationale recht behoeft in principe niet te worden getransformeerd door een nationaalrechtelijke procedure. Er is dus niet noodzakelijkerwijs uitvoeringswetgeving vereist. Dit is in tegenstelling tot bijvoorbeeld Duitsland, dat een dualistisch stelsel kent. In een dualistisch stelsel moet het internationale recht via zogenaamde transformatiewetgeving in nationaal recht worden omgezet. In Nederland hebben verdragen een ieder verbindende werking als ze naar hun inhoud ieder kunnen binden (artikel $93 \mathrm{Gw}$ ). Dat is zoals gezegd voor het Databeschermingsverdrag niet helemaal het geval. Het Databeschermingsverdrag heeft echter wel verbindend effect (zie subsectie 5.3.1). In geval van botsing tussen volkenrecht en nationaal recht beschouwt Nederland verdragen en besluiten van volkenrechtelijke organisaties, zoals Aanbeveling $R$ (87) 15 (zie subsectie 5.3.2) als van hoger orde dan zijn eigen wetgeving (artikel 94 Gw).

In de Nederlandse rechtsorde wordt ervan uitgegaan dat de op een verdrag gebaseerde volkenrechtelijke plicht tot rechtshulp voorrang heeft boven de nationale wetgeving (bijvoorbeeld de artikelen 39 en 46 SUO). ${ }^{125}$ De nationale wetgeving kan echter wel als beoordelingsmaatstaf fungeren, bijvoorbeeld bij de interpretatie van het verdrag of als het verdrag uitdrukkelijk verwijst naar de nationale wetgeving, zoals het geval is bij de artikelen 39 en 46 SUO. ${ }^{126}$

\section{Invloed artikel 8 EVRM}

Vanwege de werking van artikel $94 \mathrm{Gw}$ is de invloed van het EVRM op het Nederlandse strafprocesrecht en op het Nederlandse gegevensbeschermingsrecht (het recht op de informationele privacy) groot. Op het gebied van de politiële gegevensuitwisseling laat zich de invloed van artikel 8 EVRM gevoelen. In artikel 8 lid 1 EVRM is het recht van eenieder op respect voor zijn privé-leven neergelegd. Het verstrekken van gegevens uit

125. Hetzelfde geldt voor in een rechtshulpverdrag opgenomen imperatieve weigeringsgronden. In een dergelijk geval doet het er niet toe of de nationale wet rechtshulp toestaat. De rechtshulp moet dan verleend worden.

126. Buruma 1994 , p. 3-4. Ook kan een rechtshulpverdrag door middel van een facultatieve clausule een rechtshulpbeslissing 'ter discretie stellen' van de om rechtshulp verzochte staat. Dit betekent dat in het verdrag de staat onder bepaalde omstandig. heden is ontslagen van zijn plicht om rechtshulp te verlenen, maar de staat mág die rechtshulp wel verlenen. Het verdrag geeft dan verlof om de wet toe te passen. Als in zo'n geval de wet (onder omstandigheden) het verlenen van rechtshulp verbiedt, mag de rechtshulp niet verleend worden. Wanneer de nationale wet echter eveneens een facultatieve clausule bevat of helemaal geen bepaling ter zake, dan staat het de nationale autoriteiten vrij al dan niet rechtshulp te verlenen. Zie omtrent facultatieve en imperatieve weigeringsgronden met betrekking tot de internationale politiële gegevensuitwisseling subsectie 5.4.2. 
een politieregister zal in het merendeel van de gevallen een inbreuk maken op dit recht. $\mathrm{De}$ (politiele) overheid mag ingevolge artikel 8 lid 2 EVRM geen inbreuk maken op het recht op de privacy van personen, tenzij een dergelijke inbreuk bij de wet is voorzien en in een democratische samenleving noodzakelijk is in het belang van onder meer de openbare veiligheid en het voorkomen van wanordelijkheden en strafbare feiten. Op grond van deze beperkingsclausule is in de WPolr en de Wbp wetgeving tot stand gebracht met betrekking tot de informationele privacy (zie subsectie 5.4.3). De regeling voor het verstrekken van de gegevens en de concrete verstrekkingen zelf moeten voldoen aan de voorwaarden van artikel 8 lid 2 EVRM. Het Europese Hof voor de Rechten van de Mens (EHRM) stelt in haar jurisprudentic een aantal stringente eisen aan beperking van het recht op privacy. ${ }^{12}$ Het Hof eist niet enkel het bestaan van een rechtsregel, maar ziet ook toe op de kwaliteit van het nationale recht ter zake. Het nationale recht dient voldoende bescherming te bieden tegen ongerechtvaardigde inmenging door de overheid in de vrijheidsrechten van de burger. Dit geldt in het bijzonder wanneer het overheidsoptreden in het geheim of buiten kennis van de betrokkenen plaatsvindt en schadelijke of onomkeerbare consequenties kan hebben. ${ }^{128}$ Het nationale recht dient verder voldoende toegankelijk en kenbaar te zijn voor de burger. De normen dienen precies te zijn geformuleerd. Er worden met andere woorden eisen van toegankelijkheid, inzichtelijkheid en duidelijkheid gesteld. Het verstrekken van persoonsgegevens uit een politieregister zal vervolgens op grond van het noodzakelijkheidsvereiste van artikel 8 lid 2 EVRM moeten worden gerechtvaardigd door een pressing social need. Dit begrip wordt ingevuld door de beginselen van proportionaliteit en subsidiariteit. Het proportionaliteitsvereiste houdt in dat naarmate de inbreuk op de privacy groter is, bijvoorbeeld doordat het gevoelige gegevens betreft over ras et cetera, het belang van de gegevensverstrekking meer moet worden aangetoond. Het subsidiariteitsvereiste houdt in dat duidelijk moet zijn dat andere, minder in de persoonlijke levenssfeer van de burger ingrijpende maatregelen redelijkerwijs niet mogelijk of onvoldoende doeltreffend zouden zijn. Aan de nationale autoriteiten wordt bij de beoordeling van het noodzakelijkheidsvereiste een 'margin of appreciation' gelaten. Het EHRM acht in dit verband de praktijk en de rechtsopvattingen in de overige landen van de Raad van Europa in belangrijke mate medebepalend voor de vraag wat in een democratische samenleving noodzakelijk kan worden geacht. Naast artikel 8 EVRM is ook artikel 17 van het Internationaal Verdrag inzake burgerrechten en politieke rechten (IVBPR) rechtstreeks van toepassing binnen de Nederlandse rechtsorde. Dit privacyartikel stelt voor politieregisters geen striktere eisen dan artikel 8 EVRM. ${ }^{129}$

127. Zie bijvoorbeeld de volgende uitspraken: EHRM 26 april 1979, NJ 1980, 146 (Sunday Times); EHRM 2 augustus 1984, NJ 1988, 534 (Malone); en EHRM 26 maart 1987, NJCM 1988, 148 (Leander).

128. EHRM 24 april 1990, NJ 1991, 523 alsmede Series A, ar. 176 a en 1766 (Kruslin en Hüvig).

129. Schreuders 1995, p. 11. 


\subsubsection{Politiële gegevensbescherming in de SUO}

De Schengenpartners hebben in de loop der jaren een complex systeem ontwikkeld voor de bescherming van persoonsgegevens. ${ }^{130} \mathrm{Er}$ moet maar liefst onderscheid gemaakt worden tussen vijf verschillende beschermingsregimes:

1. uitwisseling van gegevens in het kader van het Schengen Informatie Systeem (SIS);

2. uitwisseling van gegevens in het kader van de behandeling van asielverzoeken;

3. uitwisseling van gegevens in het kader van de internationale samenwerking in strafrechtelijke procedures;

4. overige gevallen van uitwisseling van persoonsgegevens; en

5. uitwisseling van gegevens in het kader van de politiële samenwerking.

De informatiekanalen die genoemd zijn in (1) tot en met (3) hebben verspreid over het verdrag een ad hoc gegevensbescherming gekregen. De artikelen 126 tot en met 128 SUO willen daarnaast een algemeen kader opleggen voor de gegevensbescherming van de overige acht informatiekanalen, die in punt ad (4) genoemd worden. ${ }^{131}$ Punt (5), de uitwisseling van gegevens in het kader van de politiële samenwerking, maakt onderdeel uit van deze acht informatiekanalen, waarvoor het algemene kader geldt. Voor deze politięle informatieve samenwerking gelden bovendien bijkomende bepalingen, namelijk de artikelen 129 en 130 SUO. De vijf soorten van informatiekanalen met hun afzonderlijke beschermingsregimes passeren hieronder de revue.

\section{Ad (1) Schengen is bekend geworden bij het grote publiek vanwege het SIS}

Het SIS wordt in dit onderzoek verder niet behandeld. ${ }^{132}$ We vermelden slechts enige punten die duidelijk maken dat het SIS verschilt van het PALMA- en EMMI-systeem. Het SIS bevat verzoeken van Schengenstaten om ten aanzien van een bepaalde persoon of een bepaald voorwerp een specifieke, in de SUO omschreven actie te ondernemen. Het SIS bestaat uit een systeem van aparte, indentieke bestanden die naast de nationale opsporingsregisters bestaan. In deze bestanden zijn de verzoeken opgenomen die een Schengenstaat heeft gericht aan alle andere Schengenstaten. In het SIS mogen volgens artikel 94 SUO alleen gegevens worden opgenomen die noodzakelijk zijn voor de volgende doeleinden: aanhouding met het doel van uitlevering (artikel 95 SUO), weigering van toegang van bepaalde vreemdelingen (artikel 96 SUO), opsporen van vermiste personen of bepaalde tegen zichzelf te beschermen personen (artikel 97 SUO), opsporen van getuigen of bepaalde procespartijen (artikel $98 \mathrm{SUO}$ ), onopvallend volgen van bepaalde personen en voertuigen (artikel 99 SUO) en het opsporen van voorwerpen nodig voor beslag of als bewijsmiddel in een strafprocedure (artikel $100 \mathrm{SUO}$ ). ${ }^{133} \mathrm{Er}$ worden voor

130. Dumortier 1992, p. 140.

131. De Hert \& Vanderborght 1996, p. 558-559.

132. Zie over het SIS in de praktijk Vermaas 1998.

133. De Hert \& Vanderborght 1996, p. 544. 
die doeleinden gegevens in het SIS opgenomen van personen, van voertuigen en van andere voorwerpen (bijvoorbeeld gestolen caravans, vuurwapens, blanco formulieren, identiteitsdocumenten en bankbiljetten). ${ }^{14}$ Personen, voertuigen en andere voorwerpen worden door een Schengenland gesignaleerd. Een signalering in het SIS moet men zien als een verzoek van de signalerende Schengenstaat aan de andere Schengenstaten om een actie te ondernemen als er een hit (een positieve controle) is. Ingevolge artikel 93 SUO dient het SIS met het voorgaande drie doeleinden: handhaving van de OOV op het grondgebied van de Schengenlanden; de staatsveiligheid van de Schengenlanden alsmede de handhaving van de bepalingen inzake het personenverkeer van de SUO. Een apart hoofdstuk in de SUO heeft betrekking op de gegevensbescherming met betrekking tot het SIS. Het betreft de artikelen 102-118 SUO. Het SIS bestaat uit een centraal systeem CSIS voor alle Schengenlanden en een nationale Schengendatabank NSIS in elke Schengenstaat. ${ }^{13}$ De belangrijkste functie van het CSIS is het waarborgen van de integriteit van de gegevens. Het CSIS ziet erop toe dat alle nationale SIS-bestanden te allen tijde identiek blijven. Elke wijziging van het SIS moet daarom via het CSIS verlopen. ${ }^{136}$ Dit systeem wordt bovendien aangevuld met het zogenaamde SIRENE-netwerk, dat uit vertegenwoordigers van politie, douane en justitie bestaat. In de Schengenstaten zelf verlopen alle wijzigingen via de nationale SIRENE. SIRENE staat voor Supplementary Information REquest at the National Entry. Het systeem heeft met andere woorden betrekking op aanvullende informatie die bij binnenkomst in een land vereist is. Raadplegingen blijven altijd beperkt tot het NSIS. De bevoegde ambtenaren kunnen op dezelfde terminal zowel de nationale informatiesystemen als het NSIS bevragen. Ditzelfde geldt voor de IRC-medewerkers. Bij een hit moeten de ambtenaren onmiddellijk de nationale SIRENE waarschuwen, hetgeen meestal telefonisch gebeurt. Schengenstaten mogen voor deze waarschuwing ook een geautomatiseerde oplossing uitwerken, die in de bevraging van het NSIS kan worden geïntegreerd. De zogenaamde gemeenschappelijke Schengencontroleautoriteit waakte over de rechtmatige werking van het CSIS (artikel 115 SUO oud). Zij was samengesteld uit vertegenwoordigers van alle nationale controleautoriteiten, twee van elke nationale controleautoriteit. ${ }^{137}$ Met de inwerkingtreding van het Verdrag van Amsterdam is de Schengencontroleautoriteit opgegaan in het

134. Dumortier 1992, p. 146.

135. Zie hierover: Dumortier 1992, p. 142-145.

136. Mogelijke wijzigingen zijn: invoeren, veranderen of verwijderen van signaleringen in het SIS.

137. In Nederland is de nationale controleautoriteit het Cbp, in Belgie de Commissie voor de Bescherming van de Persoonlijke Levenssfeer (CBPL), en in Duitsland een aparte Datenschutzbeatufinager. 
Schengen-secretariaat van het secretariaat-generaal van de Europese Raad. ${ }^{138}$ De lidstaten hebben in 1999 besloten het contract voor het SIRENE-netwerk niet te verlengen waardoor het op 23 augustus 2001 is verstreken. Het netwerk is op die datum vervangen door een nieuwe communicatie-infrastructuur SISNET die zich op termijn zou moeten omvormen tot een 'Europees informatiesysteem', dat eveneens gegevens over de immigratie bevat. De plaatsvervangend secretaris-generaal van de Raad is bij besluit van 17 december 1999 gemachtigd de contracten met betrekking tot de installatie en de werking van SISNET te sluiten en te beheren. ${ }^{139}$ Het SIS is momenteel operationeel voor 13 lidstaten alsmede voor twee andere staten, namelijk Noorwegen en IJsland. Het systeem beschikt evenwel niet over voldoende capaciteit om te kunnen functioneren voor alle lidstaten die de Unie na de uitbreiding in mei $2004 \mathrm{zal}$ tellen. ${ }^{140}$

\section{Ad (2) Artikel 38 SUO bevat een aparte gegevensbeschermingsregeling voor asielverzoeken}

Deze regeling luidt vrijwel identiek aan die in de Europese Asielzoekersovereenkomst. ${ }^{141}$ De regeling valt buiten het bestek van dit onderzoek.

138. Sinds 1 september 2001 is er in de EU sprake van één secretariaat voor alle bestaande gemeenschappelijke controleorganen voor gegevensbescherming. De rechtsbasis hiervoor is het Besluit van de Raad van 17 oktober 2000 tot oprichting van een secretariaat voor de gemeenschappelijke controleorganen voot gegevensbescherming ingesteld bij de Overeenkomst tot oprichting van de Europese politicdienst (Europol-Overeenkomst), de Overeenkomst inzake het gebruik van informatica op douanegebied en de Overeenkomst ter uitvoering van het te Schengen gesloten akkoord betreffende de geleidelijke afschaffing van de controles aan de gemeenschappelijke grenzen (Schengen-Overeenkomst), PbEG L 271 van 24 september 2000. Vanaf 1 september 2001 is Besluit 1999/438/EEG inzake de gemeenschappelijke controleautoriteit, ingesteld bij artikel $115 \mathrm{SUO}$ ingetrokken. 139. PbEG L 337 van 30 december 1999.

140 . Om het gebruik van het systeem door de toekomstige lidstaten mogelijk te maken en om met de laatste ontwikkelingen op het gebied van de informatietechnologieěn rekening te houden, hebben het Koninkrijk België en het Koninkrijk Zweden twee nieuwe initiatieven voorgelegd met het oog op de goedkeuring van:

- Verordening (EG) nr. 2424/2001 betreffende de ontwikkeling van het SIS van de tweede generatie gebaseerd op artikel 66 van het Verdrag tot oprichting van de Europese Gemeenschap;

- Besluir 2001/886/JBZ van de Raad betreffende de ontwikkeling van het SIS van de tweede generatic gebaseerd op de artikelen 30,31 en 34 van het Verdrag betreffende de Europese Unie.

Dit onderscheid kan worden verklaard door het feit dat het SIS bedoeld is ter verbetering van de politiēle en justitiële samenwerking in strafzaken (welke materie valt onder Titel VI VEU), alsook het beleid inzake visa, immigratie en vrij verkeer van personen (welke materie valt onder Titel IV van het Verdrag tot oprichting van de Europese Gemeenschap): PbEG C 328 van 13 december 2001.

141. Overeenkomst van 15 juni 1990, neergelegd in artikel 15 van de Convention Determining the State Responsibility for Examining Applications Lodged in One of the Member States of the European Communities, ondertekend te Dublin op 15 juni 1990. 
Ad (3) In het kader van de Schengensamenwerking bestaan op het vlak van de witwisseling van gegevens in het kader van de internationale samenwerking in strafrechtelijke procedures geen specifieke bepalingen

De SUO bevat bepalingen over de volgende traditionele onderdelen van de internationale justitiële rechtshulp: wederzijdse rechtshulp in strafzaken, toepassing van het ne bis in idem-beginsel, uitlevering en overdracht van tenuitvoerlegging van strafvonnissen. In de artikelen 126 tot 130 SUO worden deze onderdelen van de internationale justitiële rechtshulp echter grotendeels uitgezonderd van gegevensbescherming. De enige voorwaarde van de SUO om gegevens in het kader van de internationale samenwerking in strafrechtelijke procedures uit te wisselen, is dat de Schengenstaten in hun nationale wetgeving een niveau van gegevensbescherming moeten bieden dat ten minste gelijk is aan het niveau van het Databeschermingsverdrag van de Raad van Europa (artikel 126 lid 1 en 4 SUO). ${ }^{142}$ Enkele van de beginselen uit het Databeschermingsverdrag werden bovendien opgenomen in de Schengenbepalingen met betrekking tot de justitiële rechtshulp. ${ }^{143}$

Ad (4) De acht overige informatiekanalen worden hieronder slechts ter informatie opgesomd 1. Gegevensuitwisseling met de overige Schengenstaten naar aanleiding van een uitzonderlijke visumverstrekking door een Schengenland (artikel 16 SUO).

2. Gegevensuitwisseling met de overige Schengenstaten naar aanleiding van een uitzonderlijke verblijfstitelverstrekking door een Schengenland (artikel 25 SUO).

3. Gegevensuitwisseling met een of meerdere Schengenstaten naar aanleiding van de raadpleging van centrale autoriteiten over de behandeling van een visumaanvraag (artikel 17 SUO).

4. Gegevensuitwisseling met een derde staat naar aanleiding van het terugsturen van een vreemdeling.

5. Gegevensuitwisseling met een Schengenpartij naar aanleiding van tips over illegale vreemdelingenhandel met betrekking tot dat land (artikel 27 SUO).

6. Gegevensuitwisseling over genomen maatregelen in de strijd tegen de handel in verdovende middelen (artikel 76 SUO).

7. Gegevensuitwisseling over het verwerven van vuurwapens door particulieren (artikel 91 SUO).

142. Dumortier 1992, p. 170-171: De Hert \& Vanderborght 1996, p. 557-558.

143. Zo bepaalt artikel 50 lid 3 SUO dat de rechtshulpgegevens slechts mogen worden gebruikt voor andere doeleinden dan de rechrshulp in strafzaken, voor zover de gegevensaanleverende partij darmee vooraf heeft ingestemd. Artikel 57 lid 3 SUO vereist dat voorafgaande aan de gegevensuitwisseling met betrekking tot het $\mathrm{me}$ bis in idem-beginsel de autoriteiten aangeduid worden die deze gegevens mogen vragen of ontvangen. De verzocken tot uitlevering kunnen op Schengenniveau via het SIS worden 'geseind', Dan is de specifieke gegevensbescherming voor het SIS van toepassing. 
8. Gegevensuirwisseling mogelijk gemaakt in het kader van de politiële samenwerking (artikel 39-47 SUO).

Ad (5) Voor de gegevensbescherming met betrekking tot de uitwisseling van gegevens in het kader van de politiële samenwerking gelden de artikelen 126 tot en met 130 SUO

Deze complexe gegevensbeschermingsregeling bespreken we in het kader van dit onderzock uitvoerig.

\section{Gegevensbescherming bij politiële samenwerking}

Uit de eerste twee leden van artikel 126 SUO blijkt dat de Schengenstaten, alvorens zij mochten starten met de geautomatiseerde uitwisseling van gegevens in de zin van (4) en (5), een nationale wetgeving moesten hebben die tenminste het gegevensbeschermingsniveau haalde van het Databeschermingsverdrag.

Op de geautomatiseerde verwerking van persoonsgegevens die worden verstrekt, zijn de volgende zes bepalingen van toepassing (artikel 126 lid 3 SUO).

1. De verstrekte persoonsgegevens mogen door de ontvangende Schengenstaat niet gebruikt worden voor andere doeleinden dan die welke de SUO heeft omschreven. Politiële gegevensuitwisseling mag dus alleen plaatsvinden binnen de bepalingen van de artikelen 39 en 46 SUO. Gebruik voor andere doeleinden is slechts mogelijk na voorafgaande toestemming door de verstrekkende Schengenstaat, overeenkomstig het recht van de ontvangende Schengenstaat. De toestemming kan worden verleend voor zover dit op grond van het nationale recht van de verstrekkende Schengenstaat is toegestaan.

2. De verstrekte persoonsgegevens mogen alleen worden gebruikt door diensten, instanties en gerechtelijke autoriteiten die bij de voor de verstrekking (onder 1) bedoelde doeleinden een taak of functie hebben. Wat de politiële gegevensuitwisseling betreft, mogen de verstrekte gegevens dus alleen worden gebruikt door in dat kader bevoegde personen.

3. De Schengenstaat die de persoonsgegevens verstrekt, ziet erop toe dat de gegevens juist zijn. Wanneer blijkt dat onjuiste gegevens zijn verstrekt of dat de gegevens niet hadden mogen worden verstrekt, wordt dit de ontvangende Schengenstaat onmiddellijk meegedeeld. De ontvangende Schengenstaat kan ook een verzoek indienen om na te gaan of de gegevens juist en rechtmatig verstrekt zijn. Als de gegevens inderdaad onjuist zijn of onrechtmatig werden verstrekt, moet de ontvangende partij overgaan tot verbetering of vernietiging van de betreffende persoonsgegevens, danwel vermelden dat de persoonsgegevens onjuist zijn of onrechtmatig zijn verstrekt.

4. De ontvangende Schengenstaat is aansprakelijk voor het gebruik van de ontvangen gegevens, ook al waren de gegevens onjuist of onrechtmatig verstrekt. Als de gegevens onjuist of onrechtmatig zijn verstrekt, is er evenwel een mogelijkheid tot het instellen van een regresvordering op de verstrekkende staat na een door de ontvangende staat 
uitbetaalde schadevergoeding. De verstrekkende staat moet dan het volledige bedrag aan betaalde schadevergoeding terugbetalen aan de ontvangende staat.

5. Van de verstrekking en de ontvangst van persoonsgegevens dient in de registratic waaruit zij worden verstrekt en waarin zij worden opgenomen aantekening te worden gehouden.

6. De gemeenschappelijke Schengencontroleautoriteit is bevoegd advies uit te brengen over de toepassings- en interpretatiemoeilijkheden van artikel 126 SUO.

De Schengengegevensbescherming voor de genoemde acht overige informatiekanalen, waaronder de politiële informatieve samenwerking, is absoluut, in de zin dat alle vormen van informatieverwerking en -verstrekking erdoor bestreken worden. Het in subsectie

\subsection{1 behandelde Databeschermingsverdrag heeft daarentegen alleen betrekking op} geautomatiseerde gegevens. Naast de besproken volledig geautomatiseerde verwerking en verstrekking (artikel 126 SUO) vallen onder de Schengengegevensbescherming ook de verwerking en verstrekking van persoonsgegevens uit niet-geautomatiseerde doch gestructureerde bestanden (artikel 127 lid 1 SUO). Ten slotte vallen onder de bescherming ook de verwerking en verstrekking van losse (niet-geautomatiseerde) ongestructureerde persoonsgegevens, die niet in een registratie zijn opgeslagen (artikel I 27 fid 2 SUO). ${ }^{144}$ Aldus ontstaat een complex onderscheid tussen drie groepen gegevens.

- Groep 1: persoonsgegevens die volledig geautomatiseerd worden verwerkt (artikel 126 SUO).

- Groep 2: persoonsgegevens uit niet-geautomatiseerde persoonsregistraties (artikel 127 lid 1 SUO).

- Groep 3: losse, niet-gestructureerde persoonsgegevens die niet in een registratie zijn opgeslagen (artikel 127 lid 2 SUO). Hierbij kan worden gedacht aan losse inlichtingen, een (robot)foto of een ad hoc opgestelde persoonsbeschrijving. ${ }^{145}$

De gegevensbeschermingsregimes voor persoonsgegevens uit de groepen 2 en 3 worden hieronder besproken. Groep 1 is hierboven reeds besproken. Daarvoor geldt de regeling van artikel 126 SUO.

Voor de gegevens uit groep 2 geldt het volgende. Ingevolge artikel 127 lid 1 SUO is de regeling van artikel 126, dus de hele zojuist besproken regeling, ook van toepassing op het verstrekken uit en het opnemen in een niet-geautomatiseerde persoonsregistratie. Voor geautomatiseerde persoonsgegevens en niet-geautomatiseerde doch gestructureerde persoonsgegevens geldt dus dezelfde regeling, namelijk die van artikel 126 SUO.

144. Dumortier 1992, p. 165-166; De Hert \& Vanderborght 1996, p. 559-560.

145. De gegevensbescherming voor gegevens uit groep 3 is er gekomen op initiatief van Duitsland: Dumortier 1992, p. 166. 
Voor gegevens uit groep 3 geldt het volgende. Op de verstrekking van losse, niet-gestructureerde persoonsgegevens zijn ingevolge artikel 127 lid 2 SUO in de eerste plaats de bepalingen van artikel 126 lid 3 SUO van toepassing, met uitzondering van bepaling e, de registratieplicht (zie hierboven). Bovendien zijn de drie onderstaande bepalingen van toepassing.

1. Van de verstrekking en de ontvangst van losse gegevens wordt bij die gegevens aantekening gehouden. Deze verplichting geldt niet indien, gelet op het gebruik van de gegevens, aantekening niet nodig is. Dit geldt in het bijzonder wanneer de gegevens niet of slechts kortstondig worden gebruikt. (Deze bepaling vervangt bepaling $\mathrm{e}$ van artikel 126 lid 3 SUO.)

2. Het gebruik van verstrekte losse gegevens krijgt bij de ontvangende Schengenstaat ten minste de bescherming die op grond van het recht van het ontvangende Schengenland geldt voor het gebruik van gegevens van gelijke aard.

3. De beslissing of en onder welke voorwaarden aan een verzoek van een belanghebbende tot kennisneming van losse gegevens wordt voldaan, wordt door de Schengenstaat waarbij het verzoek is ingediend, genomen in overeenstemming met haar nationale wetgeving.

Ingevolge artikel 128 lid 1 SUO is een onafhankelijke nationale controleautoriteit belast met onafhankelijk toezicht op de naleving van de op basis van de artikelen 126 en 127 in nationale wetgeving gestelde uitvoeringsvoorschriften. In Nederland geschiedt dit toezicht door het CBP, in België door de CBPL, en in Duitsland door een aparte Datenschutzbeauftragte. (artikel 128 lid 2 SUO). Het toezicht geldt voor de drie genoemde groepen van persoonsgegevens. Artikel 128 lid 2 SUO herhaalt expliciet dat het toezicht ook op gegevens die niet in registraties zijn opgeslagen van toepassing is, dus op gegevens van groep 3. De privacycommissies in de Schengenlanden zijn derhalve bevoegd om al het Schengengegevensverkeer te toetsen aan de gegevensbeschermingsregels, zelfs al gaat het om een losse mededeling. Daarmee wordt de nationale bevoegdheid van de privacycommissies aanzienlijk uitgebreid. In de nationale wetgevingen van de Schengenlanden strekt de controlebevoegdheid zich namelijk alleen uit over de geautomatiseerde gegevens en de niet-geautomatiseerde doch gestructureerde gegevens (de groepen 1 en 2 dus), maar niet over de losse gegevens. ${ }^{146}$

Zoals gezegd, gelden voor de politiële informatieve samenwerking (artikel 39, 46 en 47 SUO) bovenop de besproken regeling nog enkele bijkomende bepalingen, namelijk de bepalingen van de artikelen 129 en 130 SUO. Over artikel 130 SUO kunnen we kort zijn, omdat het ziet op de in dit onderzoek niet erg relevante contactambtenaren. Artikel 130 
stelt dat de artikelen 126 en 127 SUO van toepassing zijn op de drie genoemde groepen gegevens die uitgewisseld worden door contactambtenaren, doch alleen bij de doorgifte van informatie aan de thuisbasis. Artikel 129 SUO ziet op de in sectie 5.2 besproken gegevensverstrekking op verzoek (artikel 39 SUO) en op de spontane gegevensverstrekking (artikel 46 SUO). Deze aanvullende regeling wordt hieronder besproken.

Ingevolge artikel 129 SUO geldt dat voor de verstrekking van persoonsgegevens op grond van de artikelen 39 en 46 SUO, naast de besproken regeling van de artikelen 126 en 127 SUO, voor de drie genoemde groepen gegevens twee aanvullende regels gelden.

1. Er moet een niveau van gegevensbescherming verwezenlijkt zijn waarbij de beginselen van de in subsectie 5.3.2 besproken aanbeveling $R$ (87) 15 in acht zijn genomen. Voor Nederland is bijvoorbeeld in de WPolr en het BPolr aan die eis voldaan. Eén van de kernbepalingen in de aanbeveling verbiedt disproportionele gegevensdoorgifte of doorgifte van gegevens die niet noodzakelijk zijn voor de voorkoming van een reëel gevaar of de opsporing van een specifiek misdrijf.

2. Op de spontane verstrekking op grond van artikel 46 SUO zijn de volgende aanvullende gegevensbeschermingsbepalingen van toepassing:

3. De ontvangende Schengenstaat mag de verstrekte gegevens uitsluitend voor de door het verstrekkende Schengenland bepaalde doeleinden gebruiken. De ontvangende staat dient daarbij de door de verstrekkende staat gestelde voorwaarden in acht te nemen. Dit is het zogenaamde doelbindingsprincipe.

4. De gegevens mogen uitsluitend aan politiediensten worden verstrekt. Doorgeleiding van de verstrekte gegevens aan andere diensten is slechts mogelijk na voorafgaande toestemming van de verstrekkende Schengenstaat.

5. Het ontvangende Schengenland informeert de verstrekkende Schengenstaat desgevraagd over het gebruik van de verstrekte gegevens en het op grond daarvan bereikte resultaat.

\section{Schengen Handleiding samenwerking en politiële handhaving openbare orde en veiligheid} In een ontwerpbesluit van 24 juli $1997^{147}$ heeft het Uitvoerend Comité van Schengen te Lissabon een concepttekst goedgekeurd voor een Schengen Handleiding over de samenwerking en politiële handhaving inzake de openbare orde en veiligheid. Het uitvoerend Comité van Schengen had tot taak op de correcte toepassing van de SUO toe te zien en aanvullende regelingen te treffen (artikel 132 SUO oud). Met de inwerkingtreding van het Verdrag van Amsterdam heeft de Raad de plaats ingenomen van het Uitvoerend Comité dat door de Schengenakkoorden is opgericht. ${ }^{148}$ Op 1 mei 1999 heeft de Raad de

147. Strrt. 1997, 113, p. 12.

148. Op grond van artikel 2 "Protocol tot opneming van het Schengen-acquis in het kader van de Europese Unie". 
wijze vastgesteld waarop het Schengen-secretariaat in het secretariaat-generaal van de Raad moest worden opgenomen, en met name de modaliteiten betreffende het personeel van het Schengen-secretariaat. ${ }^{149}$ Daarna werden nieuwe werkgroepen opgericht om de Raad bij het beheer ervan te steunen.

De Schengen Handleiding heeft tot doel de samenwerking op het gebied van de handhaving van de OOV tussen de Schengenstaten te bevorderen. Het is gericht op de afwending van (dreigende) verstoringen van de OOV, die cen of meerdere Schengenstaten kunnen treffen. De Schengenstaten kunnen de inhoud van deze Handleiding in hun nationale instructies en handboeken opnemen.

De samenwerking als bedoeld in de Schengen Handleiding vindt haar grondslag in artikel $46 \mathrm{SUO}$. Zij betreft onder meer gebeurtenissen waarbij grote aantallen mensen zich verzamelen en waarbij het politie-optreden primair gericht is op het handhaven van de OOV, en op het voorkomen van strafbare feiten. Voorbeelden hiervan zijn sportwedstrijden, rockconcerten, betogingen en wegblokkades. Het gaat in het algemeen om activiteiten van concentraties van personen die een gevaar voor de OOV kunnen vormen. Deze vorm van samenwerking is niet beperkt tot aangrenzende Schengenstaten, maar kan ook plaatsvinden tussen Schengenstaten die niet aan elkaar grenzen, alsmede tussen een Schengenstaat en een 'transit Schengenstaat'.

De Schengen Handleiding bevat een specifiek hoofdstuk over de informatie-uitwisseling in voornoemde gevallen. In beginsel dient de informatie-uitwisseling te geschieden door tussenkomst van de centrale instanties, die elkaar gevraagd en ongevraagd informatic verstrekken. De instanties komen in actie wanneer zich bepaalde feiten voordoen of wanneer groepen van personen van enige omvang die de OOV (kunnen) bedreigen, zich door of naar andere Schengenstaten verplaatsen. De informatie dient in een zo vroeg mogelijk stadium te worden verstrekt. Onder voorbehoud van afwijkende bepalingen van het nationale recht kan de informatie-uitwisseling in spoedeisende gevallen rechtstreeks tussen de betrokken politiediensten geschieden. De centrale instantie dient hiervan zo spoedig mogelijk in kennis te worden gesteld. Dit is in overeenstemming met artikel 46 lid 2 SUO.

Omtrent de inhoud van de informatic zegt de Schengen Handleiding het volgende: (1) de informatie die Schengenstaten elkaar verstrekken dient vertrouwelijk te worden behandeld; (2) de informatie mag uitsluitend worden gebruikt voor het doel waarvoor zij is verstrekt; en (3) de verstrekte informatie dient zoveel mogelijk gegevens te bevatten over: 
- de aard van de gebeurtenis of het evenement;

- de groep personen:

- aantal

- aard en samenstelling van de groep (drijfveren, gewelddadigheid, kans op ongeregeldheden);

- verzamelplaatsen en -tijdstippen;

- routes en halteplaatsen;

- middelen en vervoer:

- overige relevante informatie;

- betrouwbaarheid van de informatic.

Voorts dient de informatic met inachtneming van de nationale gegevensbeschermingsregels verstrekt te worden.

Bij de informatie-uitwisseling kan gebruik worden gemaakt van communicatiemiddelen zoals de telefoon, fax, e-mail en radiocommunicatic, maar ook van andere communicatiemiddelen. Detachering en uitwisseling van ad hoc contactambtenaren behoren ook tot de mogelijkheden voor het verstrekken van inlichtingen.

Voor de informatieverstrekking in het kader van de samenwerking en politiële handhaving inzake de OOV is het OM niet verantwoordelijk. Dit behoort tot de verantwoordelijkheid van de burgemeester/korpsbeheerder. In een strafrechtelijk onderzoek dienen op een dergelijke manier verkregen gegevens ook als zodanig verantwoord te worden. ${ }^{150} \mathrm{De}$ Schengen Handleiding wijst uitdrukkelijk op deze mogelijkheid. Daarom is een dergelijke wijze van informatieverkrijging rechtmatig.

\subsection{Nederlandse uitvoeringswetgeving Schengen}

In deze sectie bespreken wij de Nederlandse Schengen-uitvoeringswetgeving. Subsectie 5.4.1 behandelt artikel $552 i$ Sv en subsectie 5.4.2 de richtlijn inzake de toepassing van dit artikel. In subsectie 5.4.3 gaan wij ten slotte in op de (uitvoerings)regelingen van de WPolr, het BPolr en de Wbp. 


\subsubsection{Artikel 552i Sv}

Vooruitlopend op de inwerkingtreding van de SUO is de Nederlandse nationale wetgeving al in 1993 gewijzigd. ${ }^{151}$ Wat de politiële gegevensuitwisseling betreft is toen artikel $552 i$ Sv gewijzigd. De nieuwe wetgeving is al op 31 december 1993 van kracht geworden, dus ruim vóór de inwerkingtreding van de SUO.

Artikel $552 i$ Sv bepaalt wat er met een buitenlands verzoek om kleine rechtshulp moet gebeuren. De hoofdregel is verwoord in artikel $552 i$ lid 1 Sv: het rechtshulpverzoek moet in handen van de $\mathrm{OvJ}$ worden gesteld. ${ }^{152}$ Hieruit volgt, in samenhang met artikel $552 j$ $\mathrm{Sv}^{153}$ de centrale positie van de rechtshulpofficier bij het al dan niet gevolg geven aan een verzoek tot kleine rechtshulp. ${ }^{154}$

De wijzigingen in artikel $552 i \mathrm{~Sv}$ betreffen de leden 2 en 3 van het toenmalige artikel. In artikel $552 i$ lid $2 \mathrm{~Sv}$ is, in overeenstemming met artikel 39 lid 1 SUO, vastgelegd dat, indien het buitenland uitsluitend om inlichtingen vraagt en voor het verkrijgen van die inlichtingen geen dwangmiddelen nodig zijn, de kleine rechtshulpverzoeken niet doorgezonden behoeven te worden naar de OvJ. Deze bepaling is een uitzondering op het beginsel dat de Ovj steeds de centrale rechtshulpautoriteit is in het kleine internationale rechtshulpverkeer. De politie kan voortaan een rechtshulpverzoek zelfstandig afhandelen voor zover het verzoek slechts strekt tot het verkrijgen van inlichtingen en de prestatie waarop het verzoek betrekking heeft geen toepassing van dwangmiddelen onderstelt. De politic is dan niet verplicht rechtshulpverzoeken door te zenden naar het OM. Onder het begrip 'dwangmiddel' wordt verstaan: datgene wat door het WvSv en door bijzondere

151. Wet van 24 februari 1993 tot wijziging van de Vreemdelingenwet, het Wetboek van Strafrecht, het Wetboek van Strafvordering en de Uitleveringswet met het oog op de uitvoering van de op 19 juni 1990 te Schengen tot stand gekomen Overeenkomst ter uitvoering van het tussen de regeringen van de Staten van de Benelux Economische Unie, de Bondsrepubliek Duitsland en de Franse Republiek op 14 juni 1985 te Schengen gesloten Akkoord betreffende de geleidelijke afschaffing van de controle aan de gemeenschappelijke grenzen; St6. 1993, 141.

152. Art. $552 i$ lid 1 Sv luidt: "Het verzoek wordt, zo het niet tot een officier van justitie is gericht, door de geadresseerde onverwijld doorgezonden aan de officier van justitie in het arrondissement waarin de gevraagde handeling moet worden verricht, of waarin het verzoek is ontvangen, dan wel aan de officier van justitie bij het landelijk parket." Deze regeling sluit aan bij artikel 15 lid 2 ERV.

153. Art. 552 $j$ Sv luidt: "De officier van justitie die het verzoek heeft ontvangen, beslist onverwijld omtrent het daaraan te geven gevolg. Indien handelingen in meer dan éen arrondissement moeten worden verricht, is in elk van die arrondissementen de officier van justitie tot het in behandeling nemen van het gehele verzoek bevoegd. De officier van justitie die het gehele verzoek in behandeling heeft genomen roept voor de uitvoering ervan 20 nodig de tussenkomst in van het openbare ministeric in andere rechtsgebieden. In het belang van een spoedige en doelmatige afdoening kan hij het verzoek overdragen aan zijn ambtgenoot in een ander arrondissement."

154. $T \& C S_{v}$ (Sjöcrona/De Groot), aant. 2 bij artikel $552 i \mathrm{~Sv}$. 
strafwetten uitdrukkelijk als dwangmiddel wordt aangemerkt. ${ }^{155}$ Fysieke geweldsuitoefening of lijfsdwang is hiervoor niet per definitie nodig. Het opnemen van telecommunicatieverkeer (artikel $126 \mathrm{~m} \mathrm{~Sv}$ ) is bijvoorbeeld ook een dwangmiddel. Artikel $552 i$ lid 2 Sv maakt sinds 1 februari 2000, de datum van inwerkingtreding van de Wet bijzondere opsporingsbevoegdheden, ${ }^{156}$ de zelfstandige afdoening van informatieverzoeken door de politie mogelijk indien sprake is van: inlichtingen waarvoor geen dwangmiddelen, bijzondere opsporingsbevoegdheden artikel $126 \mathrm{~g}-126 \mathrm{ua}$ Sv), bijstand aan de opsporing door burgers (artikel 126v-126z Sv), verkennend onderzoek (artikel $126 \mathrm{gg} \mathrm{Sy}$ ) of doorlating (artikel 126ff Sv) nodig zijn. In alle andere gevallen geschiedt afhandeling door het $\mathrm{OM}$. Het $\mathrm{OM}$ is altijd verantwoordelijk.

Het derde lid van artikel $552 i \mathrm{~Sv}$ is, bij amendement van Van Traa, vervangen door twee nieuwe leden 3 en $4 .{ }^{157}$ Artikel $552 i$ lid 3 Sv bepaalt dat voortaan van elke 'inwilliging' van een verzoek tot kleine rechtshulp aantekening moet worden gehouden in een register. Het model van dit register is op grond van deze bepaling vastgesteld door de Minister van Justitic. ${ }^{158}$ In de aantekening moeten in ieder geval de aard van het verzoek, de hoedanigheid van de verzoeker en het gevolg dat aan het verzoek is gegeven, worden opgenomen. In het model voor het register specificeert de Minister van Justitie deze opsomming in het derde lid van artikel $552 i \mathrm{~Sv}$ als volgt. Het register moet in ieder geval de volgende gegevens bevatten:

a. de datum waarop het verzoek is gedaan;

b. de aard van het verzoek;

c. de naam van de verdachte over wie het verzoek is gedaan;

d. de verzoeker;

e. de hoedanigheid van de verzoeker;

$f$. de behandelend ambtenaar van politic en de regio waar deze werkzaam is;

g. het gevolg dat aan het verzoek is gegeven;

h. de reden voor afwijzing van het verzoek;

i. de datum van verstrekking;

j. de omschrijving van de verstrekte gegevens;

k. eventuele bijzonderheden over het verzoek.

De in subsectie 5.4.2 te bespreken Richtlijn wederzijdse rechtshulp bepaalt nader dat ook in het geval rechtshulp niet werd of kon worden verleend daarvan onder opgaaf van

155. Kamerrakken II, 1991/1992, 22 142, nr. 6, p. 28 (MvA).

156. Wet van 27 mei 1999, Stb. 1999, 245.

157. Kamerstukken II, 1991/1992, 22 142, nr. 17 (gewijzigd amendement van het lid Van Traa).

158. Besluit van 28 december 1993, Stcrt. 1993, 252. De regeling is in werking getre den per 1 januari 1994. 
redenen melding dient te worden gemaakt. De registratieplicht geldt dus niet enkel bij inwilliging van een verzoek tor kleine rechtshulp.

De in artikel $552 i$ lid $3 \mathrm{~Sv}$ geregelde registratieplicht is niet geheel in overeenstemming met het bepaalde in artikel 126 lid 3 sub e SUO: "Van de verstrekking en de ontvangst van persoonsgegevens dient in de registratie waaruit zij worden verstrekt en waarin zij worden opgenomen aantekening te worden gehouden." In artikel $552 i$ lid 3 Sv staat dat van elke inwilliging van een verzock tot kleine rechtshulp aantekening moet worden gehouden 'in een register'. Dat is niet hetzelfde als aantekening houden in het register waaruit de gegevens worden verstrekt en in het register waarin de gegevens worden opgenomen. Het Nederlandse WvSv loopt wat dit betreft dus enigszins uit de pas met de SUO. Eigenlijk dient de zwaardere Schengeneis toegepast te worden. Dit gebeurt in de praktijk evenwel niet.

Het vierde lid van artikel $552 i$ Sv bepaalt dat bij de afdoening van een verzoek tot kleine rechtshulp de bevoegde politiële autoriteit de door de OvJ gegeven algemene en bijzondere aanwijzingen in acht moet nemen. Als algemene aanwijzing geldt de Richtlijn wederzijdse rechtshulp. Deze richtlijn vermeldt dat bijzondere aanwijzingen aan de politie in voorkomende gevallen in de praktijk op basis van concrete verzoeken en gegevens zullen worden ontwikkeld.

Volgens de toelichting van Van Traa bij zijn amendement ${ }^{159}$ strekt het nieuwe derde lid van artikel $552 i \mathrm{~Sv}$ ertoe een verslaglegging van de politiële rechtshulp in te voeren. Het nieuwe vierde lid beoogt volgens Van Traa mogelijkheden te scheppen tot nadere normering van de bevoegdheidsuitoefening door andere autoriteiten dan de OvJ. De door de OvJ te geven algemene aanwijzingen kunnen volgens Van Traa bijvoorbeeld betrekking hebben op gevallen waarvoor geldt:

1. in Nederland is het strafbare feit waar het over gaat niet strafbaar gesteld;

2. hetzelfde feit is geseponeerd; of

3. een zelfde soort feit zou worden geseponeerd; of

4. de kans bestaat dat een Nederlander als gevolg van de verstrekte informatie in het buitenland wordt gearresteerd waar zijn berechting in Nederland de voorkeur zou verdienen. De nadere normering van de bevoegdheidsuitoefening is door het College van Procureurs-Generaal ter hand genomen met de in subsectie 5.4.2 te behandelen Richtlijn wederzijdse rechtshulp. 
Artikel $552 i$ lid 2 Sv bevat de nationaalrechtelijke grondslag voor interstatelijke samenwerking tussen politiediensten, de politiële rechtshulp. Zoals besproken in de subsecties 5.2.1 en 5.2.2 dient krachtens de artikelen 39 en 46 SUO het nationale recht in acht te worden genomen. Dit nationale recht betreft Boek IV, Titel X, afdeling 1 (Internationale rechtshulp, algemene bepalingen) van het WvSv (de artikel $552 h-552 q \mathrm{~Sv}$ ) alsmede de in subsectie 5.4 .3 te bespreken wetgeving inzake de politieregisters. ${ }^{160}$ Het basisartikel voor de politiële rechtshulp is dus artikel $552 i$ lid 2 Sv. De politie mag ingevolge dit artikellid slechts 'inlichtingen' verstrekken die zonder dwangmiddelen kunnen worden verkregen. Wat houdt deze bevoegdheid concreet in? Blijkens de wetsgeschiedenis ${ }^{161}$ mogen in principe slechts inlichtingen die het resultaat zijn van eerdere rechtmatige opsporings- of controlehandelingen, of inlichtingen die algemeen toegankelijk zijn (bijvoorbeeld uit telefoonboeken, registers burgelijke stand, kentekenregistratie) worden verstrekt. De praktijk is echter wel eens anders. ${ }^{162}$ De Richtlijn wederzijdse rechtshulp (zie subsectie 5.4.2) gaat ervan uit dat opsporingshandelingen worden verricht om te voldoen aan een verzoek tot politiële rechtshulp. Als de inlichtingen met toepassing van andere opsporingshandelingen kunnen worden verzameld, kan de politie zelfstandig uitvoering geven aan het verzock. Het OM is echter ook dan verantwoordelijk. Opmerkelijk is in dit opzicht ook de stelling van de Minister van Justitie dat op grond van artikel $552 i$ lid 2 Sv Nederlandse politieambtenaren onder omstandigheden bevoegd zijn om zonder tussenkomst van de RC personen te horen. De voorwaarden voor dit horen van personen zijn: - dat uit het buitenlandse rechtshulpverzoek blijkt dat geen behoefte bestaat aan het horen van een getuige onder ede en

- dat de betrokken persoon bereid is verklaringen af te leggen. ${ }^{163}$

Wat de politie in ieder geval niet mag, is overgaan tot andere opsporingshandelingen dan waartoe het Nederlandse recht haar - geheel los van het verzoek - al bevoegd maakte. ${ }^{164}$ De politie mag ook niet overgaan tot het gebruik van controlebevoegdheden met het oogmerk om daarmee aan het rechtshulpverzoek te voldoen. ${ }^{165}$

De zelfstandige afdoening van rechtshulpverzoeken door de politie in de zin van artikel $552 i \mathrm{~Sv}$ is niet beperkt tot verzoeken om rechtshulp gedaan in het kader van de SUO.

160. $T \propto C S v$ (Sjöcrona/De Groot), aant. 3 bij artikel 552i Sv en aant. 7 bij artikel $552 h \mathrm{~Sv}$.

161. Kamenstukten II, 1991/1992, 22 142, nr. 6, p. 27 (MvA) en nr. 8, p. 11 (Nota naar aanleiding van het cindverslag).

162. Zie het rapport 'Inzake opsporing' van de Parlementaire Enquêtecommissie van Traa, bijlage V, hoofdstuk 10; Kamerstukken II, 1995/1996, 24 072, nr. 14, p. 422454.

163. Kamerstukten II, 1991/1992, 22 142, nr. 6. p. 26 (MvA).

164. Kamentukten II, 1991/1992, 22 142, ne. 8, p. 11 (Nota naar aanleiding van het eindverslag). In gelijke zin Rb. Utrecht 16 juni 1987, NJ 1987, 922.

165. Kamenstukken II, 1991/1992, 22 142, nr. 6, p. 27 (MvA) en nr. 8, p. 11 (Nota naar aanleiding van het eindverslag). 
Volgens de Minister van Justitie kan de zelfstandige afdoening door de politie ook zonder verdragsbasis plaatsvinden, omdat er bij dergelijk 'klein rechtshulpverkeer' slechts sprake is van het uitwisselen van inlichtingen. Er is geen sprake van het gebruik van penal enforcement power. De rechtsbescherming van de vervolgde is volgens de Minister niet in het geding. ${ }^{166}$ Klein rechtshulpverkeer, waarbij geen dwangmiddelen behoeven te worden gebruikt, kon trouwens op basis van artikel $552 k$ lid $1 \mathrm{~Sv}$ al buiten verdragsbasis plaatsvinden.

In de wetsgeschiedenis wordt ten slotte benadrukt dat artikel 552i Sv de Nederlandse politie niet de bevoegdheid verleent tot het verrichten van bewijsvergaringshandelingen in het buitenland. Voor de bewijsvergaring in het buitenland door Nederlandse opsporingsambtenaren in het buitenland geldt volgens de Minister van Justitie als uitgangspunt dat de Nederlandse overheid geen strafvordering in het buitenland mag plegen anders dan op basis van toestemming van de territorialiteitsstaat en met inachtneming van het recht ter plaatse. ${ }^{167}$ Indien in het kader van grensoverschrijdend politieoptreden onrechtmatigheden hebben plaatsgevonden, kan de rechter de onrechtmatigheden sanctioneren op grond van artikel $359 a$ Sv. ${ }^{168}$ De rechter kan vier dingen doen:

1. een lagere straf opleggen, indien het door het betreffende verzuim veroorzaakte nadeel langs deze weg kan worden gecompenseerd (artikel $359 a$ lid 1 sub a Sv);

2 . het bewijs dat verkregen is als gevolg van het verzuim uitsluiten van het bewijs (artikel $359 a$ lid 1 sub b Sv);

3. het OM niet-ontvankelijk verklaren, indien door het verzuim geen sprake kan zijn van een behandeling van de zaak die aan de beginselen van een behoorlijke procesorde voldoet (artikel 359a lid 1 sub c Sv);

4. constateren dat er een verzuim heeft plaatsgevonden, zonder daar consequenties aan te verbinden. ${ }^{169}$

Op grond van artikel $359 a$ lid 2 Sv dient de Nederlandse rechter bij zijn beslissing rekening te houden met het belang dat het geschonden voorschrift dient, met de ernst van het verzuim, alsmede met het nadeel dat door het verzuim wordt veroorzaakt.

166. Kamerstukken II, 1991/1992, 22 142, nr. 6, p. 27 (MvA).

167. Kamerstukken II, 1991/1992, 22 142, nr. 8, p. 10 (Nota naar aanleiding van het eindverslag).

168. Zie HR 6 april 1999, NJ 1999, 565 en Rb. Utrecht 18 april 2001, LJN-nummer AB1866. Zie met betrekking tot onrechtmatig verkregen bewijs Nijboer 2000.

169. Zie HR 22 september 1998, NJ 1999, 104; alsmede Buruma 2002. 


\subsubsection{Richtlijn inzake toepassing artikel 552i Sv}

Van groot belang voor de Nederlandse praktijk van de informatieve politiesamenwerking is de richtlijn van het College van Procureurs-Generaal inzake de toepassing van artikel $552 i \mathrm{~Sv}$ (Richtlijn wederzijdse rechtshulp). ${ }^{170}$ Het college stelde in november 1994 vast dat informatic-uitwisseling met buitenlandse opsporings- en vervolgingsinstanties vanwege de internationalisering van de misdaad onmisbaar is bij de opsporing en vervolging van personen van wie vermoed wordt dat zij betrokken zijn bij grensoverschrijdende criminele activiteiten. Tegelijkertijd constateerde het college een wezenlijk gebrek aan normering bij de informatie-uitwisseling. Het vond vooral dat onduidelijkheid bestond over de reikwijdte van de politiebevoegdheden. Het doel van de Richtlijn wederzijdse rechtshulp is daarom aan te geven in welke gevallen de politie zelfstandig uitvoering kan geven aan rechtshulpverzoeken en dus informatie kan verstrekken, in welke gevallen de tussenkomst van het $O M$ vereist is en in welke specifieke gevallen niet mag worden samengewerkt.

Het College van Procureurs-Generaal stelt in de eerste plaats vast dat de informatieverstrekking op verzoek van een buitenlandse autoriteit wordt beheerst door de in subsectie 5.4.1 aangehaalde titel X van Boek IV WvSv. De spontane informatieverstrekking is, voor zover die uit politieregisters geschiedt, geregeld in artikel 13 lid $1 \mathrm{BPolr}$, dat wij in subsectic 5.4 .3 bespreken. Spontane bijstand kan volgens het college alleen worden verleend onder de voorwaarden die ook voor een rechtshulpverzoek gelden. Dit betekent onder meer dat, voordat door politiesamenwerking spontaan verstrekte gegevens een bewijsbestemming kunnen krijgen, deze gegevens alsnog op grond van een rechtshulpverzoek dienen te worden verstrekt.

Het verstrekken van de informatie mag volgens het college niet zonder meer afspringen op het feit dat de verstrekking betrekking heeft op een Nederlandse ingezetene. Dit geldt ook indien de informatieverstrekking betrekking heeft op een Nederlandse ingezetene en het niet uitgesloten moet worden geacht dat deze op grond van de verstrekte informatie in het buitenland wordt aangehouden met het oog op vervolging en berechting aldaar. Informatic kan worden verstrekt indien dat in het belang is van een effectieve criminaliteitsbestrijding.

170. Richtlijn wederzijdse rechtshulp: Richtlijn van 23 november 1994, Stcrt. 242, inzake de toepassing van artikel $552 i \mathrm{WvSv}$ door het $\mathrm{OM}$ en de informatieverstrekking door de politie in her kader van de wederzijdse rechtshulp in strafzaken, vastgesteld door de vergadering van Procureurs-Generaal. De geldigheid van de richtlijn is verlengd tot 31 december 2004; Secr. 2000, 43. 


\section{Bevoegdhedenverdeling tussen het $O M$ en de politie}

De politie is zoals gezegd niet langer verplicht om rechtshulpverzoeken door te zenden aan het $\mathrm{OM}$ als om informatie wordt gevraagd die zij met toepassing van opsporingshandelingen kan verzamelen. Het OM blijft echter verantwoordelijk voor de in het kader van de internationale rechtshulp door de politie te verrichten handelingen. Bovendien blijven de wettelijke absolute en relatieve weigeringsgronden van kracht die ook voor de justitiële rechtshulp gelden (artikel $552 k, 552 l$ en $552 \mathrm{~m} \mathrm{~Sv}$ ). Het zou immers inconsequent zijn als de politie in de gevallen die aanleiding geven tot het weigeren van (traditionele) justitiële rechtshulp wel informatie zou kunnen verstrekken aan het buitenland in het kader van de politiele rechtshulp.

In de hieronder aangegeven gevallen moet het $\mathrm{OM}$ toestemming verlenen alvorens de politie tot uitvoering van een verzoek kan overgegaan. De rechtshulpverzoeken moeten dan ter verdere beoordeling onverwijld door de ontvangende politie-instantie aan de bevoegde OvJ worden doorgezonden. De politie moet een rechtshulpverzoek - en hetzelfde geldt voor een voorgenomen spontane verstrekking - doorzenden aan het $\mathrm{OM}$ indien:

1. gevraagd wordt om de toepassing van dwangmiddelen;

2. het rechtshulpverzoek niet op een verdrag is gebaseerd, danwel het toepasselijk verdrag niet tot inwilliging verplicht, en de afdoening van het verzoek mogelijk in strijd komt met een wettelijk voorschrift (met name artikel 13 BPolr; zie subsectie 5.4.3) of met een aanwijzing van de Minister van Justitie (artikel $552 k \mathrm{~Sv}$ );

3. bij de politie het vermoeden rijst dat het verzoek is gedaan met het oog op een van de gronden genoemd in artikel $552 l$ lid 1 onder $a$ Sv (discriminatoire vervolging);

4. het verlenen van rechtshulp in strijd zou komen met de in artikel $552 l$ lid 1 onder $b$ en $c$ genoemde weigeringsgronden ( $n$ e bis in idem en vervolging in Nederland ter zake van dezelfde feiten); indien in Nederland vervolging ter zake van dezelfde feiten plaatsvindt, kunnen door het $\mathrm{OM}$ in overleg met het Ministerie van Justitie, afdeling Internationale Rechtshulp, voorwaarden worden gesteld aan het gebruik van de gegevens;

5. om rechtshulp wordt gevraagd ten behoeve van een onderzoek naar politicke delicten, ongeacht of het verzoek afkomstig is van een staat die partij is bij het Europees Verdrag tot bestrijding van het terrorisme of bij de Overeenkomst betreffende de toepassing van dat verdrag (artikel $552 \mathrm{~m}$ lid $1 \mathrm{~Sv}$ );

6. om rechtshulp wordt gevraagd ten behoeve van een onderzoek naar strafbare feiten met betrekking tot retributies, belastingen, douane, deviezen, of daarmee verband houdende feiten (artikel $552 \mathrm{~m}$ lid $3 \mathrm{~Sv}$ );

7. het voor het verkrijgen van inlichtingen noodzakelijk dan wel wenselijk is dat:

a. personen en/of objecten worden geobserveerd,

b. een gecontroleerde aflevering wordt begeleid, 
c. in het kader van een buitenlands opsporingsonderzoek het optreden op Nederlands grondgebied van informanten of infiltranten wordt toegestaan, bevorderd dan wel begeleid, (dir zijn de algemene aanwijzingen in de zin van artikel $552 i$ lid $4 \mathrm{~Sv}$ aan de politie en de DIN van het KLPD vanwege het OM);

8. het lokale OM daartoe ingevolge artikel $552 i$ lid $4 \mathrm{~Sv}$ bijzondere aanwijzingen geeft aan de politie en de DIN van het KLPD; het lokale OM heeft op grond van deze bepaling de mogelijkheid om op het punt van de doorzendplicht van rechtshulpverzoeken door de politie aan het OM een eigen beleid te ontwikkelen; hierbij kan worden gedacht aan het maken van afspraken met de politie omtrent de vraag wie in welke gevallen de in artikel 13 lid 5 BPolr en in artikel 39 lid 2 SUO voorziene toestemming verleent; in artikel 39 lid 2 gaat het zoals gezegd om de toestemming voor het gebruik van de verstrekte gegevens als bewijsmiddel; in artikel 13 lid 5 van het BPolr, dat in subsectie 5.4.3 wordt besproken, gaat het om de toestemming van de beheerder van het politieregister voor het gebruik van de gegevens door het buitenland voor een ander doel dan waarvoor ze zijn verstrekt.

De centrale autoriteit die moet worden ingeschakeld bij de toepassing van de genoemde opsporingsmethoden is de landelijke OvJ van de DIN van het KLPD. Hij of zij ziet bijvoorbeeld toe op de (internationale) infiltratieacties.

De situatie waarin de Nederlandse rechter gebruik maakt van bewijsmateriaal dat door een buitenlandse opsporingsinstantie is verkregen, is niet apart in de wet geregeld.

\subsubsection{Wet en Besluit politieregisters en de Wbp}

De registratie en het gebruik van niet persoonsgebonden gegevens is in Nederland niet verboden en derhalve niet geregeld. De opslag en het gebruik van persoonsgegevens is wel geregeld ter bescherming van de zogenaamde informationele persoonlijke levenssfeer. De opslag en het gebruik van persoonsgegevens door particulieren, het bedrijfsleven en de overheid is geregeld in de Wbp. Ten dienste van de uitvoering van de in artikel 2 Politiewet $1993^{171}$ omschreven politietaak ${ }^{172}$ dienen persoonsgegevens opgeslagen te worden in een politieregister. Op een dergelijk register is de Wbp blijkens artikel 2 lid 2 sub c

171. Wet van 9 december 1993 tot vaststelling van een nieuwe Politiewet, zoals laatstelijk gewijzigd bij Wet van 23 januari 2003, Stb. 52 en 60.

172. Art. 2 Politiewet 1993 luidt: "De politie heeft tot taak in ondergeschiktheid an het bevoegde gezag en in overeenstemming met de geldende rechtsregels te zorgen voor de daadwerkelijke handhaving van de rechtsorde en het verlenen van hulp aan hen die deze behoeven." Deze definitie bakent de algemene politietaak af tegen bijvoorbeeld uirvoerende of toezichthoudende taken die ingevolge bijzondere wetten in formele en materiele zin aan de politie zijn opgedragen. Waar deze wetten echter de overtreding van bepaalde voorschriften strafbaar stellen, gaat het om een strafbaar feit dat zich niet onderscheidt van andere strafbare feiten. De opsporing hiervan behoort tot de algemene politietaak. 
Wbp niet van toepassing. Op een politieregister is namelijk een speciale wet van toepassing, de Wet politieregisters (WPolr) ${ }^{173}$ alsmede het daarbij behorende Besluit politieregisters (BPolr). ${ }^{174}$ Een politieregister is een samenhangende verzameling van op verschillende personen betrekking hebbende persoonsgegevens die (a) langs geautomatiseerde weg wordt gevoerd of met het oog op een doeltreffende raadpleging van die gegevens systematisch is aangelegd, en die (b) is aangelegd ten dienste van de uitvoering van de politietaak (artikel 1 sub c WPolr). De WPolr is slechts van toepassing als de persoonsgegevens zijn opgeslagen in een persoonsregistratie. Dat wil zeggen dat de persoonsgegevens op een systematische wijze moeten zijn verzameld, hetgeen bijna altijd het geval is als dit geautomatiseerd gebeurt. De algemene politietaak omschreven in de Politiewet 1993 ziet op de reguliere politie, onder omstandigheden aangevuld met de Koninklijke marechaussee.

Wij behandelen in deze subsectie achtereenvolgens het begrip persoonsgegevens, registraties onder de $\mathrm{Wbp}$, politieregisters, de internationale verstrekking van gegevens uit een politieregister, artikel $13 \mathrm{BPolr}$, spontane inlichtingen, contactambtenaren, de verstrekking van tijdelijke en zachte gegevens, informatie omtrent onverdachte personen, de bijzondere politieregisters, de vraag welke politiedienst welke register dient te voeren, de opslagtermijnen die gelden voor zachte gegevens, de internationale uitwisseling van CIEgegevens, de vraag welke gegevens mogen worden verstrekt, het verbod van rechtstreekse toegang voor buitenlandse politieambtenaren en voor het OM en ten slotte het Het Reglement Internationale rechtshulp politie.

\section{Persoonsgegevens}

Bij persoonsgegevens gaat het niet alleen om gegevens die een persoon identificeren, maar om alle gegevens die met een bepaalde persoon in verband kunnen worden gebracht (zie subsectie 5.3.1). Men kan hierbij volgens de Minister van Justitie denken aan: ${ }^{175}$ volledige personalia; adresgegevens, telefoonnummer; geboortegegevens, nationaliteit en spreektaal; soort, plaats en tijd van het strafbare feit of het incident; voertuiggegevens; risico-aanduiding (bijvoorbeeld vuurwapengevaarlijk); eventuele politiecontacten; weergave van afgelegde verklaringen; en dactyloscopische gegevens, signalement, gegevens over werkwijze en foto's. De via de PALMA-formulieren uitgewisselde voertuig-

173. Wer van 21 juni 1990, houdende regels ter bescherming van de persoonlijke levenssfeer in verband met politieregisters, zoals laatstelijk gewijzigd bij Wet van 20 juni 2002, Stb. 674.

174. Besluit van 14 februari 1991, houdende bepalingen ter uitvoering van de Wet politieregisters, zoals laatstelijk gewijzigd bij Besluit van 14 oktober 2002, Stb. 2002. 514.

175. Deze opsomming is ontleend an de opsomming van de Minister van Justitie in bijlage 1 bij het Benelux Drugsconvenant van 21 december 1993: Convenant tussen Politie-autoriteiten van de BENELUX-staten in de grensregio MAASTRICHT betreffende de as MAASTRICHT-LUIK-LUXEMBURG. 
gegevens, plaatjes, foto's en videomateriaal zijn dus ook persoonsgegevens. Al deze gegevens kunnen immers met een bepaalde persoon in verband worden gebracht.

\section{Registraties onder de Wbp}

Op het verstrekken van gegevens die geen politiegegevens zijn, is de Wb van toepassing. In de Wbp zijn geen nadere voorwaarden genoemd voor internationale verstrekking aan politieambtenaren of andere personen. Een buitenlandse politieambtenaar wordt wat de verstrekking uit cen persoonsregistratie waarop de Wbp van toepassing is, betreft, derhalve gelijkgesteld met een Nederlandse politieambtenaar. Alle gegevens die vallen onder Wbp zijn dus juridisch gesproken vrij opvraagbaar.

Voorbeelden van registraties die vallen onder de Wbp, waaruit dus 'vrij verstrekt' mag worden, zijn: het bevolkingsregister, registers met telefoonnummers, het kentekenregister te Veendam, het rijbewijzenregister bij de gemeenten, het register van de burgerlijke stand en het handelsregister bij de Kamer van Koophandel. De Nederlandse politie beschikt zelf ook over persoonsregistraties in het kader van de Wb. Deze registraties zijn niet aangelegd voor de uitvoering van de politietaak, als bedoeld in de Politiewet 1993, maar veeleer voor andere dan aan de politie opgedragen, bestuurlijke taken. Voorbeelden zijn: de horeca-administratie, de jachtwetadministratie, de vreemdelingenadministratie, de klachtenafhandelingsadministratie, de vuurwapenwetadministratie en de beheer- en opslag-administratie.

\section{Politieregisters}

$\mathrm{Bij}$ de politieregisters gaat het onder meer om de volgende registers:

- herkenningsdienstregistratie (een verzameling van alle bekende en onbekende daders van misdrijven);

- dag- en nachtrapportenregisters (een verzameling van alle incidenten waarmee de politie geconfronteerd wordt);

- bedrijfsprocessensystemen (BPS): een verzameling van alle incidenten inclusief processen-verbaal, inbeslaggenomen goederen, gestolen voertuigen et cetera; kenmerk van dit systeem is dat met de eenmalige invoer van de naam van een persoon alle formulieren met betrekking tot die persoon gelijktijdig worden gepresenteerd;

- bekeuringenregistratie;

- criminele inlichtingendienstregister;

- ontzeggingen rijbevocgdheidregister;

- gestolen voertuigregister;

- inbeslaggenomen goederenregister.

\section{Internationale verstrekking van gegevens uit een politieregister}

De WPolr kent een zogenaamd gesloten verstrekkingsregime: politiegegevens mogen alleen aan in de wet of bijbehorende nadere regelgeving met name genoemde personen 
en instanties worden verstrekt. ${ }^{176}$ Voor verstrekking aan buitenlandse politieambtenaren dient daarbij aan enkele bijzondere voorwaarden te worden voldaan.

Op grond van artikel 18 lid 1 WPolr zijn in artikel 13 BPolr regels gesteld voor de verstrekking van gegevens uit een politieregister aan politieautoriteiten in andere landen. Tevens zijn op grond van artikel 18 lid 1 WPolr in artikel 13 BPolr voorwaarden gesteld an het gebruik van de verstrekte gegevens door buitenlandse politieautoriteiten. De in artikel 13 BPolr gestelde regels vormen bijzondere bepalingen ten opzichte van de artikelen $552 h-552 q$ Sv. ${ }^{177}$ Blijkens artikel $552 h$ lid 1 Sv zijn de artikelen $552 h-552 q$ Sv namelijk slechts van toepassing voor zover in de afdoening van een rechtshulpverzoek niet is voorzien in het bepaalde bij of krachtens andere wetten. In casu is voor de verstrekking van gegevens uit een politieregister aan buitenlandse politieautoriteiten dus de regeling van artikel 13 BPolr bepalend. Volgens de MvT bij de WPolr ${ }^{178}$ zijn de artikelen $552 \mathrm{~h}$ $552 q \mathrm{~Sv}$ in dit opzicht slechts aanvullend. ${ }^{179}$

De verhouding tussen artikel $552 i$ lid 2 Sv en artikel 13 BPolr is blijkens de Nederlandse goedkeuringswet van de SUO de volgende. ${ }^{180}$ Wanneer de politie gegevens uit een politieregister moet verstrekken, moet zij eerst nagaan of het verzoek binnen de grenzen van artikel $552 i$ lid $2 \mathrm{~Sv}$ valt. Vervolgens moet de politie nagaan of het verzoek ingevolge de artikelen $552 h-552 q \mathrm{~Sv}$, vooral met het oog op de weigeringsgronden, kan worden ingewilligd. Als het verzoek kan worden ingewilligd en dit zou leiden tot verstrekking van gegevens uit een politieregister, dient de politie na te gaan of artikel 13 BPolr een dergelijke verstrekking toestaat.

176. Het gesloten verstrekkingsregime lijkt op het eerste gezicht in strijd met het beginsel van verenigbaar gebruik van artikel 5 van het Databeschermingsverdrag (vergelijk subsectie 5.3.1). Dit beginsel houdt in dat de gegevens niet mogen worden gebruikt op een wijze die onverenigbaar is met de doeleinden waarvoor zij zijn opgeslagen. De Nederlandse wetgever is echter van mening dat van strijdigheid geen sprake is omdat het gesloten verstrekkingsregime binnen de uitzonderingsregel van artikel 9 lid 2 sub a van het Databeschermingsverdrag valt: de beteugeling van strafbare feiten en de openbare veiligheid; Kamerstukken II, 1988/1989, 19 589 , nr. 6, p. 4 (MvA).

177. Een ander voorbeeld van dergelijke bijzondere bepalingen wordt gevormd door artikel 4 jo. Artikel 6 van het Besluit registratie buitenlandse strafbladen. Hierin is de verstrekking van uittreksels uir het strafregister of van inlichtingen die daarop betrekking hebben geregeld (vergelijk artikel 13 ERV en 36 BUV). Ook de uitwisseling van mededelingen omtrent veroordelingen wordt erdoor beheerst (vergelijk artikel 22 ERV, XII Wittem, 4 Aanvullend Protocol ERV en 43 BUV).

178. Kamerstukken II, 1985/1986, 19589 , nr. 3, artikelsgewijze toelichting bij artikel 18 lid 1 WPolr.

179. De in artikel 13 BPolr gestelde regels kunnen echrer geen afbreuk doen aan de verplichringen van Nederland ingevolge de rechtshulpverdragen.

180. Kamerstukken II, 1991/1992, 22 140, nr. 12, p. 84 (MvA). 
Wij zullen hieronder artikel 13 BPolr eerst in het algemeen bespreken. Daarna besteden we speciale aandacht aan de regeling voor de grensgebieden (artikel 13 lid 2 en 7 BPolr).

\section{Artikel 13 BPolr}

Artikel 13 lid 1 sub a BPolr stelt dat gegevens door Nederland kunnen worden verstrekt aan politieautoriteiten in een ander land indien dit noodzakelijk is voor de goede uitvoering van de politietaak in Nederland (zie hierboven). Het gaat hier om de internationale politiële samenwerking ten behoeve van Nederland. Het noodzakelijkheidsvereiste geeft volgens de Nota van Toelichting $(\mathrm{NvT})^{1 / 1}$ bij het BPolr aan dat een afweging van belangen moet plaatsvinden. De privacybelangen van de geregistreerde moeten worden afgewogen tegen de goede uitvoering van de politietaak in Nederland. Deze afweging is voorbehouden aan de Nederlandse politic.

Op grond van artikel 13 lid 1 sub b BPolr kunnen door de Nederlandse politie ook uit eigen beweging of naar aanleiding van een algemeen verzoek gegevens worden verstrekt ten behoeve van buitenlandse politieautoriteiten. ${ }^{162}$ De verstrekking is dan echter beperkt tot gevallen waarin sprake is van een misdrijf waardoor de rechtsorde in het betreffende land ernstig is geschokt of waarin sprake is van een ernstig en dreigend gevaar. Artikel 13 lid 1 sub b BPolr is een uitwerking van het vijfde beginsel van Aanbeveling R (87) 15 van de Raad van Europa (zie subsectie 5.3.2).

Artikel 13 lid 1 sub c zegt ten slotte dat internationale verstrekking van gegevens aan buitenlandse politicautoriteiten ook mogelijk is voor de goede uitvoering van de politietaak in het buitenland. Hiertoe moet dan wel een (niet algemeen) verzoek zijn gedaan door de betreffende buitenlandse politieautoriteiten en wel met betrekking tot een bepaald (concreet aangeduid) geval of een bepaalde persoon (al dan niet met naam aangeduid). ${ }^{183}$ Wie de buitenlandse politieautoriteiten zijn, zal, gelet op de diversiteit van de politieorganisaties en hun bevoegdheden (vergelijk subsectie 2.2.4), niet altijd duidelijk zijn. Ingevolge Aanbeveling R (87) 15 is beslissend of de betrokken politie-instanties een taak vervullen die vergelijkbaar is met de taak van de Nederlandse politie. De aanbeveling verstaat onder politieautoriteiten: iedere buitenlandse overheidsinstantie die formeel is belast met het voorkomen en bestrijden van criminaliteit en het handhaven van de openbare orde. In twijfelgevallen kunnen het Ministerie van Binnenlandse Zaken en het Ministerie van Justitic geraadpleegd worden. Tot zover de algemene regeling voor de internationale verstrekking aan buitenlandse politieautoriteiten. Artikel 13 lid 4 BPolr bepaalt ten aanzien van deze algemene verstrekkingsregeling dat rekening moet worden 
gehouden met de mate waarin waarborgen in het andere land aanwezig zijn. Het gaat dan om waarborgen voor een juist gebruik van de verstrekte gegevens en voor de bescherming van de persoonlijke levenssfeer. De DIN van het KLPD beschikt over de nodige kennis om dit na te gaan. Deze norm komt overeen met die van artikel 12 Databeschermingsverdrag waarin het niveau van de rechtsbescherming als criterium voor de vraag of gegevens zullen worden overgedragen, is neergelegd (zie subsectie 5.3.1).

\section{Spontane inlichtingen}

Een in verband met ons onderzoek cruciale regeling is de bijzondere regeling, neergelegd in artikel 13 lid 2 BPolr, voor de politiële samenwerking en gegevensuitwisseling in de grensgebieden. Deze regeling sluit grotendeels aan bij de regeling van artikel $46 \mathrm{SUO}$ (zie subsectie 5.2.2) en is voor de praktijk in de Euregio's van groot belang. De bijzondere regeling maakt het mogelijk dat in de grensgebieden gegevens ook spontaan, zonder een verzoek als bedoeld in artikel 13 lid 1 sub c, aan de buitenlandse autoriteiten kunnen worden verstrekt. De overige verstrekkingsmogelijkheden van de algemene regeling blijven natuurlijk ook mogelijk, met inachtneming van de noodzakelijkheidseis. De aanvullende toets van artikel 13 lid 4 BPolr is ten aanzien van België en Duitsland hoe dan ook niet nodig, omdat deze landen een afdoende gegevensbeschermingsniveau hebben. In beginsel kunnen voor elk feit (misdrijf of overtreding) gegevens worden verstrekt.

Artikel 13 lid 5 BPolr schrijft - zowel voor de algemene verstrekkingsregeling als voor de bijzondere regeling voor de grensgebieden - voor dat een verstrekking alleen mag plaatsvinden onder de voorwaarde dat het gegeven niet zonder aanvullende toestemming kan worden gebruikt voor een ander doel dan waarvoor het is verstrekt. Wanneer bijvoorbeeld een gegeven wordt verstrekt voor de opsporing van een bepaald delict en degene aan wie het is verstrekt wil hetzelfde gegeven later gebruiken voor de opsporing van een geheel ander delict, dan is hiervoor aanvullende toestemming van de korpsbeheerder, in zijn functie van beheerder van het politieregister, nodig. In wezen komt dit neer op een hernieuwd - namelijk voor een ander doel - ter beschikking stellen van het gegeven. De toestemming is daarom ook slechts mogelijk indien het gebruik van de betreffende gegevens voor het nieuwe doel noodzakelijk is voor de goede uitvoering van de politietaak in het betreffende land. ${ }^{184} \mathrm{Als}$ een ander land verzoekt om al verstrekte gegevens te mogen gebruiken als bewijs in een strafzaak, dan moet de procedure van artikel $552 \mathrm{~h} \mathrm{~Sv}$ en volgende gevolgd worden. Hierover moet het $\mathrm{OM}$ beslissen naar aanleiding van een door de buitenlandse staat gedaan rechtshulpverzoek ter zake (zie subsectie 5.4.2). In artikel 13 lid 5 BPolr is dus het specialiteitsbeginsel opgenomen: het beginsel dat de verstrekte gegevens in principe niet voor een ander doel gebruikt mogen worden dan waarvoor ze verstrekt zijn. Dit beginsel is ook in artikel 126 SUO opgenomen (zie subsectie 5.3.5).

184. Stb. 1991, 56, p. 27 (NvT). 
Als het gaat om gevoelige gegevens moet ingevolge artikel 13 lid $6 \mathrm{BPolr}-$ zowel wat de algemene verstrekkingsregeling als de bijzondere regeling voor de grensgebieden betreft extra worden getoetst of de verstrekking onvermijdelijk is. De verstrekking moet onvermijdelijk zijn met het oog op een juiste beantwoording van een door een buitenlandse politieautoriteit gestelde vraag. Tevens is bij de verstrekking van gevoelige gegevens de vermelding van een betrouwbaarheidsindicatie voorgeschreven: er moet aangegeven worden in hoeverre het gegeven betrouwbaar is. Gevoelige gegevens zijn ingevolge artikel 5 lid 1 WPolr persoonsgegevens over godsdienst of levensovertuiging, ras, politieke gezindheid, seksualiteit, intiem levensgedrag, medische of psychologische kenmerken.

Op grond van artikel 13 lid 7 BPolr dient de verstrekking van gegevens aan buitenlandse politieautoriteiten in beginsel plaats te vinden door tussenkomst van het KLPD (de DIN). De verstrekking kan echter op grond van dit artikellid ook plaatsvinden overeenkomstig afspraken met politieautoriteiten in het buitenland. De Minister van Justitic moet hiermee instemmen als het gaat om gegevens uit een register dat is aangelegd voor de uitvoering van een taak onder het gezag van de $\mathrm{OvJ}$, zoals de registratiedatabase van de IRC's. ${ }^{1 \text { 's }}$ In de Euregio Maas-Rijn zijn dergelijke afspraken gemaakt. Zij passeren de revue in sectie 5.5. De afspraken zijn gemaakt op basis van een modelregeling voor de politiegrensregio's van de Raad van Hoofdcommissarissen van 1993 (zie sectie 5.5). De voormalige dCRI was volgens een richtlijn uit 1961 alleengerechtigd tot het inwinnen en verstrekken van politiële inlichtingen uit en aan het buitenland. Een uitzondering hierop vormt dus het rechtstreekse contact tussen politieautoriteiten in de grensgebieden voor de bestrijding van de grenscriminaliteit. ${ }^{186}$

Ingevolge artikel 13 lid 8 BPolr ${ }^{187}$ mogen in het geheel geen gegevens worden verstrekt: - wanneer een vermoeden bestaat dat de gegevens worden gebruikt voor een onderzoek dat is ingesteld met het oogmerk van een discriminatoire vervolging of bestraffing;

- wegens strijd met het ne bis in idem-beginsel;

- voor een onderzoek naar feiten waarvoor reeds in Nederland wordt vervolgd; en

- wanneer het verzoek in verband met een onderzoek naar strafbare feiten met betrekking tot belastingen, retributies of douane wordt gedaan.

185. De burgemeester moet hiermee instemmen als het gat om gegevens uit cen register dat is aangelegd voor de uitvoering van een taak onder het gezag van de burgemeester.

186. Buruma 1994, p. 31.

187. Deze regeling staat in verband met verdragsrechtelijke bepalingen, zoals artikel 22 lid 2 sub b BUV (het internationale ne bis in idem-beginsel). 


\section{Contactambtenaren}

Het tiende en elfde lid van artikel 13 BPolr zien op bijzondere regelingen voor buitenlandse contactambtenaren die in Nederland zijn gestationeerd, respectievelijk Nederlandse contactambtenaren die in het buitenland zijn gestationeerd. In afwijking van de genoemde bepalingen van artikel 13 BPolr kunnen met de buitenlandse staat die de contactambtenaar heeft uitgezonden ad hoc afspraken worden gemaakt. Een buitenlandse contactambtenaar kan echter nooit voor verdergaande gegevensverstrekking in aanmerking komen dan een Nederlandse politieambtenaar. Een in het buitenland gestationeerde Nederlandse contactambtenaar kan op gelijke voet gegevens ontvangen als wanneer hij of zij in Nederland zou zijn. Deze ambtenaar blijft echter bij de verstrekking aan buitenlandse politieautoriteiten gebonden aan de Nederlandse wet- en regelgeving.

\section{Verstrekking tijdelijke en zachte gegevens}

Artikel 13 BPolr bepaalt ten slotte in het twaalfde en laatste lid dat de artikelen 11 en 12 BPolr over de verstrekking uit politieregisters ook bij internationale verstrekking van toepassing zijn. ${ }^{188}$ Een gevolg hiervan is dat voor verstrekking uit tijdelijke of voorlopige registers toestemming van het OM nodig is, omdat verstrekking alleen ter 'verrijking' van het doel van deze registers mogelijk is (artikel 13 lid 12 jo. Artikel 12 BPolr).

Wij merken op dat er op grond van artikel 13 BPolr geen plicht bestaat tot verstrekken. De Nederlandse politie wordt slechts een bevoegdheid toegekend. De gegevens kunnen maar moeten niet worden verstrekt. De politie dient in een concreet geval te beoordelen of de verstrekking opportuun en verantwoord is. De bevoegdheid tot verstrekken wordt begrensd door het doel waarvoor de ontvanger de gegevens kan verkrijgen of nodig heeft. ${ }^{189}$

In de volgende vijf paragrafen behandelen wij het vrij recent (in 1999) herziene Nederlandse wettelijk regime ten aanzien van de omgang met zachte politiële gegevens en de uitwisseling daarvan met het buitenland. De paragrafen hebben betrekking op (1) de regeling aangaande informatie over onverdachte personen, (2) de bijzondere politieregisters, waarin zachte gegevens geregistreerd kunnen worden, (3) de vraag welke politiedienst welk register voert, (4) de opslagtermijnen die gelden voor zachte gegevens, en (5) de regeling voor de internationale uitwisseling van CIE-gegevens.

\section{Informatie omtrent onverdachte personen}

De door de politie verkregen informatie kan een onverdachte persoon betreffen. Als dit het geval is dan is de regeling van artikel 5 a WPolr van toepassing. De aanhef van het

188. Dit geldt zowel voor de bijzondere regeling voor de grensgebieden als voor de algemene verstrekkingsregeling.

189. Vergelijk Schreuders 1995, p. 9. 
eerste lid van artikel 5a WPolr stelt dat, indien informatie omtrent onverdachte personen geregistreerd zal worden in een register dat is aangelegd voor de strafrechtelijke handhaving van de rechtsorde, dat dan slechts kan geschieden:

a. overeenkomstig $\$ 3 \mathrm{a}$ WPolr (deze paragraaf betreft de bijzondere politieregisters); of

b. in een register dat is opgezet in het kader van de Wet melding ongebruikelijke transacries; of

c. voor een duur van niet meer dan vier maanden.

Juist omdat het een registratie van onverdachte personen betreft, heeft de Nederlandse wetgever de toepasselijke regels strenger gemaakt dan gebruikelijk. Het gaat dan ook om personen die volkomen onverdacht zijn. De wet stelt niet als eis dat zij onverdacht zijn ten aanzien van betrokkenheid bij een specifiek strafbaar feit waarover informatie is verkregen.

Ten aanzien van onverdachte personen waarvan de gegevens geregistreerd zullen worden in een politieregister dat is aangelegd voor de strafrechtelijke handhaving van de rechtsorde, geeft artikel 5a WPolr dus een heldere regeling. Op grond van artikel 5a lid 1 aanhef en onder $c$ mogen onverdachte personen geregistreerd worden gedurende een termijn van maximaal vier maanden. Er geldt geen beperking ten aanzien van het type register waarin die onverdachte persoon geregistreerd mag worden. De termijn van vier maanden dient benut te worden voor nader onderzoek. Indien dit onderzoek verder niets oplevert dan moet het gegeven worden verwijderd. Verdere opslag van de betreffende gegevens mag enkel en alleen ten behoeve van de afhandeling van klachten, de verantwoording van de verrichtingen naar aanleiding van de opgenomen gegevens of voor beleidsinformatie die niet tot individuele natuurlijke personen herleidbaar is. Operationeel gebruik van die gegevens is na die vier maanden dus absoluut uitgesloten. Gedurende de termijn van vier maanden geldt geen beperking ten aanzien van het type register waarin de gegevens terecht dienen te komen.

De bovenstaande basisregeling kent twee uitzonderingen. De maximumtermijn van vier maanden geldt niet indien de onverdachte wordt geregistreerd in:

1. een register als bedoeld in $\$ 3$ a WPolr (artikel 5 a lid 1 aanhef en onder a WPolr); of

2 , in een register bedoeld in artikel 4 Wet melding ongebruikelijke transacties ${ }^{190}$ (Wet MOT). 


\section{De bijzondere politieregisters}

Paragraaf 3a WPolr handelt over de bijzondere politieregisters en is opgenomen via een aparte wijzigingswet. ${ }^{191}$ In die paragraaf staan bepalingen met betrekking tot de tijdelijke registers (artikel 13 WPolr), de registers zware criminaliteit (artikel 13a WPolr) en de voorlopige registers (artikel 13b WPolr). In elk van deze drie bijzondere registers kunnen onverdachte personen terechtkomen. In welk type bijzonder politieregister geregistreerd zal worden, is afhankelijk van het doel van de betreffende registratie.

De definitie van een tijdelijk register is terug te vinden in artikel 1 lid 1 onder $j$ WPolr. ${ }^{192}$ Een tijdelijk register wordt aangelegd ten behoeve van de uitvoering van de politietaak in een bepaald geval of in geval van een verkennend onderzoek als bedoeld in artikel $126 \mathrm{gg}$ Sv. Een verkennend onderzoek is gericht op een verzameling personen. Een dergelijk onderzoek wordt opgestart indien uit feiten of omstandigheden aanwijzingen voortvlocien dat misdrijven zoals omschreven in artikel 67 lid $1 \mathrm{~Sv}$ worden beraamd of gepleegd die, gezien hun aard of de samenhang met andere misdrijven die in die verzamelingen van personen worden beraamd of gepleegd, een ernstige inbreuk op de rechtsorde opleveren. Een dergelijk verkennend onderzoek kan worden bevolen door de OvJ.

De definitie van een voorlopig register is terug te vinden in artikel 1 lid 1 onder 1 WPolr. Ook dit register wordt aangelegd ten behoeve van de politietaak, maar dan slechts voor zover het betreft de vaststelling of een geregistreerde in samenhang met andere gegevens kan worden opgenomen in een register zware criminaliteit (zwacri-register). Het voorlopig register is de vervanger van het voorheen gevoerde ' 'grijze-veldregister'. Het is per definitie het voorportaal van een zwacri-register en is wat dit betreft van een duidelijk ander karakter dan een tijdelijk register dat veel algemener bruikbaar is.

Een register zware criminaliteit is ingevolge artikel 1 lid 1 sub $\mathrm{k}$ een politieregister dat is aangelegd met het oog op de uitvoering van de politietaak, voor zover het betreft:

$1^{\circ}$ misdrijven als omschreven in artikel $67 \mathrm{lid} 1 \mathrm{~Sv}$, die in georganiseerd verband worden beraamd of gepleegd en gezien hun aard of de samenhang met andere misdrijven die in het georganiseerd verband worden beraamd of gepleegd, een ernstige inbreuk op de rechtsorde opleveren of

$2^{\circ}$ misdrijven waarop naar de wettelijke omschrijving een gevangenisstraf van acht jaar of meer is gesteld;

191. Wet van 27 mei 1999 tot wijziging van de Wet politieregisters, houdende nadere regels voor bijzondere politieregisters ten behoeve van de politie, Koninklijke marechaussee en daartoe aangewezen diensten van publiekrechtelijke lichamen die met de opsporing van strafbare feiten zijn belast (bijzondere politieregisters), Stb. 1999, 244.

192. Hier is de eerste letter $j$ bedoeld. Wegens een slordigheidje van de wetgever komt onder artikel 1 lid 1 WPolr tweemaal de letter $j$ als anduiding voor. 
a. niet langer noodzakelijk zijn voor het doel van het register dan wel

b. na verloop van vijf jaar na datum van de laatste opname van gegevens die blijk geven van de noodzaak tot registratie van betrokkene met het oog op het doel van het register.

De termijn van vijf jaren is een harde termijn. De voorloper van de CIE-regeling, de CID-regeling $1995,{ }^{196}$ kende aan het gedetineerd worden van een geregistreerde persoon wel een opschortende werking toe met betrekking tot de termijn van vijf jaren. Met invoering van de nieuwe CIE-regeling is deze opschortende werking vervallen. Enkel het toevoegen van een gegeven dat noodzakelijk is met het oog op het doel van het register heeft nu het effect van een opnieuw aanvangen van de termijn van vijf jaren.

\section{Internationale uitwisseling van CIE-gegevens}

Voor de verstrekking van CIE-informatie aan het buitenland is de toestemming van de (landelijke) CIE-OvJ nodig. Voor de verstrekking van informatie uit de tijdelijke registers is ook de tussenkomst van het OM vereist. De tussenkomst van de NCIE (Nationale Criminele Inlichtingeneenheid) is tevens vereist voor de verstrekking van CIE-informatie. Dit geldt op basis van artikel 13 lid 12 BPolr en artikel 8 Regeling criminele inlichtingen eenheden van 5 oktober 2000. De politie kan de verstrekking van dergelijke gegevens dus niet zelfstandig afhandelen. Artikel 13 lid 1 van de oude CID-regeling 1995 bepaalde echter dat over de verstrekking van CID-informatie aan buitenlandse politieinstanties ook afspraken kunnen worden gemaakt voor zover de Minister van Justitie deze afspraken overeenkomstig artikel 13 BPolr heeft goedgekeurd. Indien de verstrekking van CID-informatie niet gebeurde door tussenkomst van de Nationale Criminele Inlichtingendienst (NCID) moest van de verstrekking afschrift worden gezonden aan de NCID (art. 13 lid 3 CID-regeling 1995). De nieuwe CIE-regeling van 5 oktober 2000 kent een dergelijke regeling niet, zodat voor de internationale uitwisseling van gegevens uit een tijdelijk register alsmede uit de CIE-registers toestemming van de CIE-OvJ en tussenkomst van de NCIE vereist is.

\section{Welke gegevens mogen worden verstrekt?}

$\mathrm{Bij}$ internationale verstrekkingen is geen beperking van het soort gegevens gesteld. Afhankelijk van de omstandigheden kunnen alle soorten gegevens worden verstrekt. In de praktijk blijkt bij Belgische en Duitse politie-instanties voornamelijk behoefte te bestaan aan operationele informatie. ${ }^{197}$

196. Regeling van 31 maart 1995, Stcrt. 1995, 74: in werking getreden 15 april 1995; vervallen per 1 november 2000. CID stond voot Criminele Inlichtingen Dienst.

197. Zie Van Dorp, Verbeek \& Van den Herik 2001; dit blijkt ook uit een inventarisatie in het kader van het Benelux Drugsconvenant van 21 december 1993: Convenant tussen Politie-autoriteiten van de BENELUX-staten in de grensregio MAASTRICHT betreffende de as MAASTRICHT-LUIK-LUXEMBURG. 


\section{Verbod rechtstreekse toegang voor buitenlandse politieambtenaren en voor het $O M$}

Van heel groot belang in verband met dit onderzoek is ten slotte artikel 17 BPolr. Hierin is bepaald dat rechtstreekse verstrekking uit een politieregister, dat wil zeggen verstrekking zonder menselijke tussenkomst, langs geautomatiseerde weg alleen is toegestaan aan personen die daartoe een schriftelijke autorisatie hebben gekregen. Deze autorisatie mag op grond van artikel 17 lid 1 BPolr alleen worden verleend aan bepaalde Nederlandse politieambtenaren belast met opsporingstaken. ${ }^{198}$ Belgische of Duitse politieambtenaren zijn derhalve nooit bevoegd tot het raadplegen van de Nederlandse politieregisters zonder tussenkomst van een Nederlandse geautoriseerde persoon. De beheerder van het politieregister moet op grond van artikel 17 lid 4 BPolr de nodige voorzieningen van technische en organisatorische aard treffen om te voorkomen dat ongeautoriseerde verstrekkingen plaatsvinden. Het is deze bepaling die de grondslag vormt voor de beschreven praktijk van de Nederlandse IRC's. Een Nederlands IRC mag op grond van deze bepaling niet via een on-lineverbinding rechtstreeks toegang tot Nederlandse politieregisters verlenen aan buitenlandse politiediensten en dat doet zij dan ook niet. Elke gegevensverstrekking geschiedt via de tussenkomst van een IRC-medewerker. Zoals nog zal blijken is deze belemmering voor de IRC's veel lastiger dan de juridische koppelingsproblematiek die besproken wordt in hoofdstuk 6. Artikel 17 BPolr is een echt juridisch knelpunt voor de praktijk van de IRC's.

De autorisatie tot rechtstreekse toegang langs geautomatiseerde weg mag evenmin als aan buitenlandse politieambtenaren aan het $\mathrm{OM}$ worden gegeven. Het $\mathrm{OM}$ valt namelijk niet in de categorie personen waaraan op grond van artikel 17 lid 1 BPolr rechtstreeks (on line) verstrekt mag worden langs geautomatiseerde weg. De personen aan wie rechtstreeks langs geautomatiseerde weg verstrekt mag worden, moeten namelijk deel uitmaken van de reguliere politie of de Koninklijke marechaussee. ${ }^{199} \mathrm{On}$-lineconsultatie is een uitzondering op het uitgangspunt van de menselijke verstrekking en is alleen bedoeld voor de meest voorkomende verstrekkingen en dus niet voor de verstrekking aan het OM.

Aan het OM mogen dus op grond van artikel 17 lid 1 BPolr uit de registratiedatabase geen gegevens langs geautomatiseerde weg worden verstrekt. De gegevens mogen ter controle van de naleving van artikel $552 i$ lid $2 \mathrm{~Sv}$ of voor de uitvoering van de aan het OM opgedragen rechtshulptaak, slechts 'op verzoek' aan het OM worden verstrekt op grond

198. Het betreft de personen genoemd in artikel 14 sub a en b WPolr en artikel 14 lid 1 sub a BPolr.

199. Ook opsporingsambtenaren van bijzondere opsporingsdiensten zoals de Fiscale Inlichtingen- en Opsporingsdienst FIOD (in de zin van artikel 14 sub c WPolr) mogen op grond van artikel 17 lid 1 BPolr niet geautoriseerd worden tot rechtstreekse geautomatiseerde toegang. 
van artikel 15 lid 1 WPolr. ${ }^{200}$ Dat wil zeggen dat een on-lineverbinding met de registratiedatabase, zoals men die in de toekomst ten behoeve van het $\mathrm{OM}$ in gebruik wil stellen, op dit moment wettelijk niet is toegestaan. Politiële gegevens mogen slechts incidenteel op verzoek van het OM ter controle van de naleving van artikel $552 i$ lid 2 en 3 Sv uit de registratiedatabase worden verstrekt. Het is niet de bedoeling dat het OM continu over alle met het buitenland uitgewisselde persoonsgegevens beschikt. Dit is in de praktijk niet te ondervangen door de betreffende functionaris van het $\mathrm{OM}$ ter uitoefening van de controlefunctie een zogenaamde commissie (toelating) van onbezoldigd opsporingsambtenaar te geven via de Procureur-Generaal. Dan zou de OM-functionaris immers een buitengewoon opsporingsambtenaar zijn in de zin van artikel 142 lid 1 sub a Sv. ${ }^{201}$ Dit zijn opsporingsambtenaren in de zin van artikel 14 sub $\mathrm{c}$ WPolr. Hieraan kan op grond van artikel 17 lid 1 BPolr ook niet rechtstreeks langs geautomatiseerde weg uit de registratiedatabase worden verstrekt. Hier manifesteert zich dus een juridisch obstakel als het $\mathrm{OM}$ in de toekomst rechtstreekse toegang wil krijgen tot de politiële gegevens die zich in de registratiedatabase bevinden. Het periodiek, bijvoorbeeld wekelijks, aan het $\mathrm{OM}$ verstrekken van de integrale inhoud van de registratiedatabase is op grond van artikel 15 WPolr ook niet mogelijk. Een dergelijke afspraak treedt aanzienlijk buiten de mogelijkheden en grenzen van de voorwaarde 'op verzoek'. ${ }^{202}$ Het verbod voor het OM om rechtstreeks toegang te krijgen tot de registers van de politie is moeilijk te rijmen met de hiërarchische relatie OM-politie en mede daarom dient de wetgever in de toekomst de ratio van dit verbod te heroverwegen.

De autorisatie tot rechtstreekse geautomatiseerde toegang aan bevoegden, waaronder de RCIE, kan slechts worden gegeven voor een bepaald omschreven doel. Daarbij wordt ervan uitgegaan dat de terminals waar vanaf politieregisters kunnen worden geraadpleegd door de beheerder ingevolge artikel 7 lid 2 WPolr afdoende beveiligd zijn tegen

200. Uit een politieregister worden "op hun verzoek" gegevens verstrekt aan leden van het $\mathrm{OM}$, voorzover zij deze behoeven:

1) in verband met hun gezag en zeggenschap over de politie (...): artikel 15 lid 1 sub a sub 1 WPolr; hieronder valt de controle door het $O M$ op grond van artiket $552 i$ lid 2 en $3 \mathrm{~Sv}$; of

2) voor de uitvoering van andere bij of krachtens wet opgedragen taken: artikel 15 lid 1 sub a sub 2 WPolr; hieronder valt in het algemeen de rechtshulptaak van het OM.

201. Op basis van een op naam gestelde akte ("een individuele aanwijzing") kan opsporingsbevoegdheid worden verleend aan een zogenaamde buitengewone opsporingsambtenaat. De akte wordt verleend door de Minister van Justitie of de ProcureurGeneraal. Zie verder het Besluit buitengewoon opsporingsambtenaar van 11 november 1994, St6. 825, dat op grond van artikel 442 lid 4 Sv nadere regels stelt.

202. Vergelijk Schreuders 1995, p. 9, met verwijzing naar het Jaarverslag van de Registratiekamer 1992-1993, p. 24. 
raadpleging door onbevoegden. ${ }^{203}$ Ingevolge artikel 17 lid 5 BPolr dient van iedere verstrekking langs geautomatiseerde weg aantekening te worden gehouden. ${ }^{204}$

\section{Het Reglement Internationale rechtshulp politie}

Art. 9 WPolr verplicht de korpsbeheerder voor elk politieregister een privacyreglement op te stellen. Zo ook voor het register dat is ingericht voor de politiële rechtshulp: de registratiedatabase of in juridische termen het politieregister Internationale rechtshulp politie (register IRP). Na overleg met het bevoegd gezag dat verantwoordelijk is voor de politietaak waarvoor het register is aangelegd - in casu met het OM dat verantwoordelijk is voor de politiële rechtshulptaak - wordt een dergelijk reglement vastgesteld. Daarna wordt het reglement bekendgemaakt en voor eenieder ter inzage gelegd. Een exemplaar van het privacyreglement wordt dan naar het CBP gezonden. Als het privacyreglement bepalingen bevat over de opname van gevoelige gegevens of over de beperking van het recht op inzage van de burger - zoals in casu - danwel over koppeling met andere registers, wordt via een zogenaamde hoorprocedure het reglement eerst getoetst door het CBP. Voor het vaststellen van de reglementen kan op grond van artikel 12 WPolr gebruik worden gemaakt van modelreglementen. Zo is er voor de politiële rechtshulp een Modelreglement Internationale rechtshulp politie opgesteld. ${ }^{205}$ Hiervan maken de regiokorpsen gebruik bij het opstellen van hun eigen Reglement Internationale rechtshulp politie (Reglement IRP). Deze reglementen wijken niet af van het Modelreglement. Ingevolge artikel 10 lid 4 WPolr regelt het reglement de verstrekking van gegevens uit het register, daaronder begrepen de rechtstreekse toegang met het oog op raadpleging van persoonsgegevens. Belangrijk is dat dit volgens dezelfde bepaling dient te gebeuren met inachtneming van het bij of krachtens de artikelen 14 tot en met 19 en 27 WPolr bepaalde. Dit betekent dat bijvoorbeeld de regeling van artikel 17 BPolr voor de rechtstreekse geautomatiseerde toegang tot politieregisters ook in het Reglement IRP in acht genomen moet worden. Aan buitenlandse politiediensten en aan het OM mag dus geen rechtstreekse geautomatiseerde toegang worden verleend in het Reglement IRP. Dit is dan ook niet gebeurd, zoals uit het hiernavolgende blijkt.

203. Stb. 1991, 56, p. 31 (NvT).

204. Een uitzondering op deze vastleggingsplicht is ingevolge artikel 17 lid 6 en 7 BPolr mogelijk indien naar het oordeel van de Minister van Justitie of de Minister van Binnenlandse Zaken (naargelang het taken onder het gezag van de OvJ respectievelijk de burgemeester betreft) vergelijkbare waarborgen anderszins aanwezig zijn om het verstrekkingenregime te handhaven. Hierbij wordt blijkens de NvT gedacht aan kleine systemen op posten waar slechts enkele politicambtenaren rechtstreeks langs geautomatiseerde weg van de opgeslagen gegevens kennis kunnen nemen (Stb. 1991, 56, p. 32; NvT).

205. Stcrt. 1994, 133. 


\section{Het Reglement IRP artikelsgewijs bekeken}

Het Reglement IRP duidt de korpschef van het betreffende regionaal politiekorps aan als zogenaamde registerbeheerder. De korpschef is dus degene die onder verantwoordelijkheid van de korpsbeheerder (de wettelijke beheerder van het register volgens artikel 1 sub f sub $1^{\circ}$ ) is belast met de zeggenschap over het register (conform artikel 10 lid 2 sub h WPolr). Een 'gegeven' wordt in overeenstemming met artikel 1 sub $i$ WPolr jo. Artikel 1 WPR (oud) omschreven als een gegeven dat herleidbaar is tot een identificeerbare natuurlijke persoon. Het 'verstrekken van gegevens uit het register' wordt in overeenstemming met artikel 1 sub $\mathrm{h}$ WPolr omschreven als "het bekend maken of ter beschikking stellen van gegevens, voor zover zulks geheel of grotendeels steunt op gegevens die in het register zijn opgenomen, of die door verwerking daarvan, al dan niet in verband met andere gegevens, zijn verkregen." Onder 'gegevensbeheer' verstaat het reglement "de verantwoordelijkheid voor de juistheid van de ingevoerde gegevens, alsmede voor het bewaren, verwijderen en verstrekken van gegevens".

De artikel 2 en 3 van het Reglement IRP hebben betrekking op het doel en de werking van het register IRP. Het register heeft volgens artikel 2 lid 1 van het reglement tot doel het overeenkomstig artikel $552 i$ lid $3 \mathrm{~Sv}$ vastleggen van gegevens betreffende verzoeken als bedoeld in artikel $552 i$ lid $2 \mathrm{~Sv}$ (politiële rechtshulpverzoeken) ten behoeve van controle door in het bijzonder het OM. Ingevolge artikel 2 lid 2 van het reglement kunnen gegevens uit het register gebruikt worden ten behoeve van de interne bedrijfsstatistiek, interne bedrijfsvoering en interne ontwikkeling van beleid voor de uitvoering van de politietaak. Artikel 3 lid 1 bepaalt dat het register deels geautomatiseerd en deels handmatig kan worden gevoerd. In een bijlage is aangegeven op welke bureaus of afdelingen van de territoriale en functionele onderdelen van het korps het register wordt gevoerd of rechtstreeks toegankelijk is. In de Nederlandse regiokorpsen wordt het register gevoerd bij de IRC's. De bijlage maakt deel uit van het Reglement IRP.

Art. 4 van het reglement handelt over het beheer van het register. De korpschef is als registerbeheerder belast met de zeggenschap over het register. Hij draagt zorg voor de naleving van de WPolr, het BPolr en het reglement. Hij dient daartoe onder meer voorzieningen van technische en organisatorische aard te treffen ter beveiliging van het register tegen verlies of antasting van gegevens en tegen onbevoegde kennisneming, wijziging of verstrekking daarvan. Tevens moet hij maatregelen treffen ter bevordering van de juistheid en volledigheid van de in het register opgenomen gegevens. (art. 4 lid 1) De korpschef wijst bij besluit de functionarissen aan die belast zijn met de dagelijkse leiding over het gegevensbeheer alsmede met de opname van een aanduiding omtrent de betrouwbaarheid betreffende de gevoelige gegevens conform artikel 3 lid 3 BPolr (de IRC-medewerkers) (art. 4 lid 2 en 3). 
De artikel 5 tot en met 7 van het Reglement IRP gaan over de inhoud van het register IRP. Ingevolge artikel 5 worden in het register IRP gegevens opgenomen over de volgende vier categorieën van personen:

a. verdachten met betrekking tot wie een verzoek als bedoeld in artikel $552 i$ lid $2 \mathrm{~Sv}$ is gedaan;

b. overige betrokkenen, zoals getuigen en slachtoffers;

c. verzoekers; en

d. ambtenaren van politie.

Over de categorieën a en b mogen ingevolge artikel 6 lid 1 Reglement IRP ten hoogste de volgende soorten van gegevens worden opgenomen: ${ }^{206}$

a. volledige personalia en geboortegegevens;

b. de datum van het verzoek;

c. de aard van het verzoek;

d. het gevolg dat aan het verzoek is gegeven;

c. de redenen voor afwijzing;

f. de datum van verstrekking;

g. de omschrijving van de verstrekte gegevens; en

h. eventuele bijzonderheden over het verzoek.

In overeenstemming met artikel 5 lid 2 WPolr jo. Artikel 3 lid 2 BPolr mogen over de categorieën a en b ook bepaalde gevoelige gegevens worden opgenomen in het register IRP. Volgens artikel 7 lid 1 Reglement IRP mogen over deze personen gegevens worden opgenomen betreffende hun ras voor zover dit onvermijdelijk is:

a. met het oog op hun identificatie;

b. voor de juiste beoordeling van een strafbaar feit en dit gegeven het slachtoffer of de motieven van de dader van het feit betreft.

Volgens artikel 7 lid 2 Reglement IRP mogen over deze personen ook gegevens worden opgenomen over hun medische en psychologische kenmerken voor zover dit onvermijdelijk is:

a. met het oog op hun identificatie;

b. voor de juiste beoordeling van een strafbaar feit en dit gegeven het slachtoffer of de motieven van de dader van dat feit betreft;

c. ter afwering van dreigend gevaar voor leven of gezondheid van (buitenlandse) politieambtenaren en overige bij de directe uitoefening van hun taak betrokkenen. 
Volgens artikel 7 lid 3 Reglement IRP ten slotte mogen over deze personen ook gegevens worden opgenomen over hun godsdienst of levensovertuiging, politieke gezindheid, seksualiteit en intiem levensgedrag voorzover dit onvermijdelijk is voor de juiste beoordeling van een strafbaar feit en dit gegeven het slachtoffer of de motieven van de dader van dat feit betreft.

Omtrent de categorie c mogen ingevolge artikel 6 lid 2 Reglement IRP ten hoogste de volgende soorten van gegevens worden opgenomen:
a. volledige personalia;
b. hoedanigheid waarin het verzoek is gedaan;
c. de datum van het verzoek; en
d. eventuele bijzonderheden over het verzoek.

Omtrent de categoric d mogen ingevolge artikel 6 lid 3 Reglement IRP ten hoogste de volgende soorten gegevens worden opgenomen:

a. volledige personalia;

b. dienstnummer, organisatie-aanduiding, rang, functie; en

c. eventuele bijzonderheden over het verzoek.

Overeenkomstig artikel 10 lid 2 sub c, d en g WPolr regelt het Reglement IPR in artikel 8 de verwijdering en vernietiging van de gegevens in het register IRP. Op grond van artikel 8 lid 1 Reglement IPR moeten de gegevens uit het register worden verwijderd wanneer deze niet meer noodzakelijk zijn voor het doel van het register, controle van de politiële rechtshulp door het OM (art. 2 Reglement IPR). De gegevens moeten 'zodra mogelijk' vernietigd worden. De gegevens moeten ingevolge artikel 8 lid 2 van het reglement in ieder geval uit het register worden verwijderd na afloop van het tiende jaar na het jaar van het politiële rechtshulpverzoek. Over de vernietiging van spontaan verstrekte gegevens vermeldt het tweede lid niets. Artikel 8 lid 3 Reglement IRP bevat ten slotte nog een ontsnappingsbepaling. Indien noodzakelijk voor het doel van het register kan de registerbeheerder in bijzondere gevallen bij besluit afwijken van de termijn van tien jaar.

Art. 9 Reglement IRP bepaalt nog maar eens dat de verstrekking van gegevens plaatsvindt in overeenstemming met de WPolr en het BPolr.

Art. 10 Reglement IRP bepaalt dat alleen personen die daartoe overeenkomstig de WPolr en het BPolr door de registerbeheerder geautoriseerd zijn rechtstreekse toegang tot het register IRP hebben. De autorisatie moet aangeven voor welk doel de rechtstreekse toegang wordt verleend. Het betreffende besluit moet bij het reglement worden gevoegd. Deze regeling is in overeenstemming met artikel 17 BPolr. Indien de autorisaties geautomatiseerd zijn, wordt op verzoek inzage gegeven in de autorisaties. 
Art. 11 Reglement IRP bepaalt vervolgens in het eerste lid dat van iedere verstrekking die rechtstreeks langs geautomatiseerde weg plaatsvindt, overeenkomstig de WPolr en het BPolr aantekening moet worden gehouden. Deze regeling is in lijn met artikel 17 lid 5 BPolr. Van iedere verstrekking die niet langs geautomatiseerde weg geschiedt, moet overeenkomstig de WPolr en het BPolr ook aantekening worden gehouden, tenzij overeenkomstig het doel wordt verstrekt aan vaste gebruikers (art. 11 lid 2 Reglement IRP). Deze regeling is overeenkomstig artikel 16 lid 2 BPolr. Het Reglement IRP onderscheidt een categorie zogeheten vaste gebruikers. Het houden van aantekening, de protocolplicht, is niet van toepassing op de verstrekking aan deze groep. De term 'vaste gebruiker' heeft niets te maken met het al dan niet verlenen van rechtstreekse geautomatiseerde toegang aan een persoon. Artikel 11 lid 3 Reglement IRP bepaalt wie deze vaste gebruikers van het register IPR zijn. Dit zijn in de eerste plaats de personen die geautoriseerd zijn tot rechtstreekse toegang. Hieronder valt bijvoorbeeld de RCIE, die ingevolge artikel 17 lid 1 geautoriseerd is tot rechtstreekse toegang langs geautomatiseerde weg. In de praktijk is de RCIE, zoals gezegd, inderdaad daartoe geautoriseerd. In de tweede plaats zijn ingevolge artikel 11 lid 3 Reglement IRP ook de leden van het OM vaste gebruikers van het register IRP in het kader van de controle van politiële rechtshulpverzocken (art. $552 i$ lid $2 \mathrm{~Sv}$ ). Van een verstrekking aan het $\mathrm{OM}$ of aan de RCIE behoeft bijgevolg geen aantekening gehouden te worden als die verstrekking niet rechtstreeks langs geautomatiseerde weg is gedaan. Een verstrekking aan het OM mag, zoals gezegd, niet langs geautomatiseerde weg plaatsvinden op grond van artikel 17 lid 1 BPolr. Bijgevolg behoeft van een verstrekking uit het register IRP (de registratiedatabase) aan het OM in het geheel geen aantekening te worden gehouden.

Art. 12 en 13 Reglement IRP betreffen de rechten van dé geregistreerde. Artikel 12 ziet op het verzoek tot kennisneming. Ingevolge artikel 12 lid 1 kan een geregistreerde aan de registerbeheerder conform artikel 20 WPolr verzoeken hem mee te delen:

a. of hij in het register voorkomt;

b. welke gegevens over hem in het register zijn opgenomen;

c. van wie of van welke instanties de in het register over hem opgenomen gegevens zijn verkregen;

d. aan wie of aan welke instanties gegevens over hem zijn verstrekt.

Een verzoek tot kennisneming dient op grond van artikel 12 lid 2 Reglement IRP schriftelijk gericht te worden aan de registerbeheerder, ter attentie van de privacyfunctionaris. De privacyfunctionaris is de persoon die bij het regiokorps is aangesteld om de naleving van de privacyreglementen te controleren. Aan een verzoek zijn tien gulden (dit bedrag is nog in oude munt gesteld) administratiekosten verbonden. Een verzoek tot kennisneming wordt ten aanzien van minderjarigen die de leeftijd van zestien jaar nog niet hebben bereikt en ten aanzien van onder curatele gestelden gedaan door hun wettelijke vertegenwoordigers (art. 12 lid 3). Ook kan een verzoek tot kennisneming ingevolge artikel 
12 lid 4 worden gedaan namens de betrokkene door diens advocaat of procureur, na overlegging van een bijzondere daartoe strekkende schriftelijke machtiging. Op gelijke wijze kan het ingevolge artikel 12 lid 5 door een ander worden gedaan. In dat geval vindt verstrekking aan een dergelijke gemachtigde niet plaats indien aangenomen kan worden dat deze mede een zelfstandig belang heeft bij de te verstrekken gegevens, of indien tegen hem ernstige bezwaren bestaan. Ingevolge artikel 12 lid 6 moet op een verzoek tot kennisneming binnen vier weken nadat het verzoek ontvankelijk is, worden beslist. De registerbeheerder draagt op grond van artikel 12 lid 7 Reglement IRP zorg voor een deugdelijke vaststelling van de identiteit van de verzoeker. De behandelend functionaris kan verlangen dat de verzoeker hem bescheiden toont waaruit zijn identiteit blijkt alsmede die van degene namens wie hij optreedt. Artikel 12 lid 9 ten slotte bepaalt dat in geen geval mededelingen in antwoord op een verzoek tot kennisneming in schriftelijke vorm worden gedaan.

Het Reglement IRP zegt niets over mogelijke weigeringsgronden. Ingevolge artikel 21 lid 1 WPolr kan een kennisgeving echter worden geweigerd voor zover dit noodzakelijk is voor de goede uitvoering van de politietaak. Verder kan kennisgeving achterwege blijven indien gewichtige belangen van derden daartoe noodzaken. Deze weigeringsgronden gelden ingevolge artikel 21 lid 2 WPolr niet voor persoonsgegevens die op verzoek van de geregistreerde zijn opgenomen. Op grond van artikel 20 lid 3 WPolr zou het Reglement IRP eigenlijk iets over deze weigeringsgronden moeten bepalen. Omtrent dergelijke bepalingen moet het CBP vooraf worden gehoord.

Art. 13 Reglement IRP betreft verzoeken tot verbetering, aanvulling en verwijdering van gegevens. Ingevolge artikel 13 lid 1 kan een geregistreerde aan wie conform artikel 20 WPolr kennisneming is verleend, aan de registerbeheerder conform artikel 22 WPolr verzoeken bepaalde gegevens over hem a) te verbeteren, b) aan te vullen, of c) te verwijderen.

Op grond van artikel 13 lid 2 dient een correctieverzoek schriftelijk gericht te worden aan de registerbeheerder ter attentie van de privacyfunctionaris. In het verzoek dient de gewenste verbetering, aanvulling of verwijdering aangegeven te worden. Ingevolge artikel 13 leden 3 tot en met 5 kan een correctieverzoek, onder dezelfde voorwaarden die voor het verzoek tot kennisneming gelden (zie hierboven), gedaan worden door wettelijke vertegenwoordigers van minderjarigen en onder curatele gestelden; door de advocaat of procureur van de betrokkene; en door anderen namens de betrokkene. Ingevolge artikel 13 lid 6 Reglement IRP ten slotte moet binnen acht weken nadat het verzoek is ontvangen schriftelijk worden beslist op een correctieverzoek. Een weigering moet worden gemotiveerd. 
In het Reglement IRP wordt geen melding gemaakt van beroepsmogelijkheden. Indien de registerbeheerder echter niet aan cen verzoek tot kennisneming, verbetering, aanvulling en verwijdering van gegevens voldoet, kan de betrokkene zich ingevolge artikel 23 lid 1 WPolr tot de arrondissementsrechtbank wenden. Hij kan daar een schriftelijk verzoek indienen om de beheerder te bevelen alsnog aan zijn verzoek te voldoen. De procedure hiervoor is neergelegd in artikel 23 lid 2 WPolr. Het CBP kan op grond van artikel 23 lid 3 WPolr bemiddelen of adviseren. Ook kan de rechtbank op grond van artikel 23 lid 4 WPolr had advies van het CBP inwinnen.

Art. 14 Reglement IRP ten slotte bepaalt dat het reglement voor eenieder ter inzage moet liggen op het hoofdbureau van de politieregio en de bureaus waar het register IRP wordt gevoerd of rechtstreeks toegankelijk is, in casu het IRC.

\subsection{Convenanten en Akkoorden}

In deze sectie bespreken wij de convenanten en akkoorden die van toepassing zijn op de grensregionale politiële gegevensuitwisseling tussen Nederland, België en Duitsland. Subsectie 5.5.1 behandelt de Nederlandse grensakkoorden, subsectie 5.5.2 de Belgische grensakkoorden en subsectie 5.5.3 de Duitse grensakkoorden. De Benelux-grensakkoorden worden besproken in subsectie 5.5.4.

\subsubsection{Nederlandse grensakkoorden}

Op grond van artikel 13 lid 7 BPolr kan de verstrekking van politiegegevens rechtstreeks aan buitenlandse politie-autoriteiten plaatsvinden. Dit geldt zowel voor het spontane als het verzochte verstrekken van de gegevens. Hierover moeten dan met de betreffende buitenlandse politieautoriteiten wel afspraken zijn gemaakt die goedgekeurd zijn door de Minister van Justitie respectievelijk de Minister van Binnenlandse Zaken (zie subsectie 5.4.3). Sinds juli 1993 zijn er voor de regiopolitiekorpsen goedgekeurde modelafspraken (in de vorm van convenanten) te verkrijgen bij het Coördinerend Politie Beraad (CPB), thans de Raad van Hoofdcommissarissen. Deze modelafspraken zijn opgesteld door de toenmalige Werkgroep Privacyreglement Grensregio's van de Beleidsadviesgroep Open Grenzen van het CPB. De modelafspraken zijn volgens de Werkgroep bedoeld voor politiële gegevensverstrekking die in beginsel geen relatie heeft met een concrete strafzaak en derhalve geen betrekking heeft op justitiële rechtshulp. Op basis van de modelafspraken kunnen de regiokorpsen zelf afspraken opstellen. Deze afspraken moeten vervolgens apart ter goedkeuring worden voorgelegd voordat zij in werking treden. $\mathrm{Zij}$ worden ondertekend door de verantwoordelijke ministers van de betrokken landen. Het CPB beveelt aan om het maken van de afspraak met de buitenlandse politieautoriteit voor te behouden aan de beheerder van het politieregister (volgens artikel 1 sub f WPolr is dat de korpsbeheerder en niet de korpschef) danwel de door mandaatstelling daarvoor verantwoordelijke politiechef (de korpschef). 
In de zogeheten convenanten staan geen bepalingen over de vraag welke gegevens het buitenland aan Nederland verstrekt. Hierover zullen nadere afspraken met het buitenland moeten worden gemaakt, waarbij de betreffende nationale bepalingen van de buitenlandse onderhandelingspartner (België of Duitsland) richtsnoer moeten zijn. Dit eenrichtingverkeerseffect van de convenanten correspondeert met het feit dat artikel $552 i$ Sv niet van toepassing is op Nederlandse verzoeken om buitenlandse rechtshulp.

Zoals gebleken is in subsectie 5.4.3 spreekt artikel 13 BPolr over 'andere landen' als buitenland zonder daarin enige restrictie aan te brengen, bijvoorbeeld alleen Europese landen. Wel wordt aan de grensgebieden afzonderlijk aandacht besteed. De Werkgroep van het CPB heeft echter ook een onderscheid aangebracht in internationale verstrekkingen om een en ander in goede banen te leiden. Zij maakt een onderscheid tussen:

a. verstrekkingen van Nederland aan België en Duitsland (grensgebied);

b. verstrekkingen van Nederland aan overige Schengenlanden;

c. verstrekkingen van Nederland aan landen die geen partij zijn bij de SUO.

De Werkgroep heeft in de eerste plaats een modelafspraak of convenant ontworpen voor de verstrekkingen onder a voorzover die niet via de dCRI (thans de DIN) verlopen. Deze modelafspraak is niet alleen gebaseerd op het zevende lid, maar ook op het tweede lid (met betrekking tot de grensgebieden) van artikel 13 BPolr. Daarom is in de tweede plaats een enigszins aangepaste modelafspraak gemaakt voor de verstrekking van Nederland aan de overige Schengenlanden (categorie b). Voor categorie c is geen modelafspraak ontworpen. Internationale gegevensverstrekking aan niet-Schengenlanden leent zich naar het oordeel van de Werkgroep minder voor een algemene regeling. Volgens de Werkgroep moet verstrekking aan dergelijke landen in beginsel door tussenkomst van de dCRI (thans de DIN) geschieden. Afhankelijk van de situatie kan worden besloten een afspraak met de betrokken buitenlandse politieautoriteiten te maken. Volgens de Werkgroep zal echter ook bij verstrekkingen in categorie c de modelregeling voor de categorie $\mathrm{b}$ het uitgangspunt moeten vormen. Daarmee wordt een meer eenduidig verstrekkingenregime mogelijk. De Werkgroep merkt de modelafspraak aan als een 'in de grensgebieden nader geregelde samenwerking' in de zin van artikel 39 lid 4 en artikel 46 lid 2 SUO (vergelijk subsecties 5.2.1 en 5.2.2), voor zover het gaat om het verstrekken uit Nederlandse politieregisters.

Wij lopen kort even de artikelen van de modelconvenanten voor de categorieën a en b door. Alleen artikel 1 lid 1 is voor beide categorieèn afwijkend. Artikel 1 lid 2 en de overige artikel 2 tot en met 5 zijn gelijkluidend.

Art. 1 lid 1 van het modelconvenant voor categorie a bepaalt, in lijn met artikel 13 lid 1 en 2 BPolr, dat gegevens uit een politieregister aan de ontvanger kunnen worden verstrekt indien dit noodzakelijk is: 
a. voor de goede uitvoering van de politietaak in Nederland;

b. voor de goede uitvoering van de politietaak in het ontvangende land.

Onderdeel $\mathrm{b}$ betreft volgens de toelichting op het convenant de verstrekking ten behoeve van de buitenlandse politieautoriteiten door de Nederlandse politie uit eigen beweging of naar aanleiding van een algemeen verzoek. Onder deze omschrijving verstaat de Werkgroep ook het bepaalde in artikel 13 lid 1 sub b BPolr. De omschrijving "ter voorkoming van een ernstig en dreigend gevaar of ter opsporing van een misdrijf waardoor de rechtsorde in dat land ernstig is geschokt" wordt geacht altijd plaats te vinden in het kader van de goede uitvoering van de politietaak in dat land. Deze regeling geldt dus met name voor de Euregio's in de grensgebieden met België en Duitsland. Voor de gegevensverstrekking aan andere Schengenlanden zijn gewoon de drie gronden van artikel 1 lid 1 BPolr in artikel 1 van het convenant voor de categorie b opgenomen (vergelijk subsectic 5.4.3).

Het tweede lid van artikel 1 bepaalt dat de ontvanger de verstrekker desgevraagd informeert over het gebruik van de verstrekte gegevens. Deze bepaling is toegevoegd om na de verstrekking te kunnen controleren of de gegevens voor het doel gebruikt zijn waarvoor ze zijn verstrekt. De buitenlandse politieautoriteit (de ontvanger) is dan op grond van het convenant verplicht hierover mededelingen te doen.

In artikel 2 lid 1 van de convenanten is het bepaalde in artikel 13 lid 5 BPolr neergelegd (vergelijk subsectie 5.4.3). Artikel 2 lid 2 voegt hieraan toe dat de verstrekte gegevens alleen mogen worden gebruikt door politieautoriteiten die in het kader van voor de verstrekking (onder artikel 1) bedoelde doeleinden een taak of functie hebben (vergelijk subsectie 5.4.3). Doorgeleiding van de verstrekte gegevens aan andere diensten mag slechts plaatsvinden na voorafgaande toestemming van de verstrekker (de korpsbeheerder).

In artikel 3 lid 1 is artikel 13 lid 6 BPolr neergelegd (vergelijk subsectie 5.4.3). Het tweede lid voegt hieraan toe dat gegevens uit een grijze veld-register (thans voorlopig register) slechts mogen worden verstrekt met toestemming van een door de beheerder van dat register (de korpsbeheerder) aangewezen persoon. Een grijze veld-register was vóór de invoering van de Wet bijzondere politieregisters een register dat is aangelegd met het oog op de vaststelling of een geregistreerde in samenhang met andere gegevens kan worden aangemerkt als een CID-subject ${ }^{207}$ (art. 1 BPolr oud). Door de vraagstelling uit het buitenland in samenhang met andere gegevens kan dit het geval zijn. De informatie

207. Een CID-subject was een persoon die als verdachte betrokken is of naar redelijkerwijs kan worden vermoed als verdachte betrokken zal worden bij misdrijven met het oog waarop een CID-register is aangelegd (tekst conform artikel 1 sub c BPolr oud). 
over de betreffende persoon kan het beeld vollediger maken. Dit is de reden waarom de Werkgroep het wenselijk acht ook informatie uit dit register te laten verstrekken. Wij merken op dat in deze regeling dus rechtstreekse verstrekking van gegevens uit het voorlopig register (uiterst gevoelige en nog vrij onbetrouwbare informatie) mogelijk wordt na toestemming van een bepaalde daarvoor aangestelde persoon. Dit is niet geheel overeenkomstig de regeling van artikel 13 lid 12 BPolr en artikel 8 Regeling criminele inlichtingen eenheden van 5 oktober 2000, die de tussenkomst van de NCIE en de CIE-OvJ vereist. De door de Werkgroep getroffen regeling is echter niet in strijd met artikel 13 lid 7 BPolt, dat rechtstreekse verstrekking toestaat als daarover afspraken met de politieautoriteiten in het buitenland zijn gemaakt. Artikel 3 lid 1 van het modelconvenant zou onzes inziens echter bij voorkeur in overeenstemming moeten worden gebracht met artikel 13 lid 12 BPolr en artikel 8 Regeling criminele inlichtingen eenheden van 5 oktober 2000 . De Werkgroep kon natuurlijk in 1992 nog geen rekening houden met de CID-regeling uit 1995 en de genoemde huidige regeling.

Overeenkomstig onder meer de richtlijn inzake de toepassing van artikel $552 i$ Sv en artikel 39 lid 2 SUO bepaalt artikel 4 van de modelconvenanten dat de verstrekte persoonsgegevens door de ontvanger slechts met toestemming van de bevoegde Nederlandse justitiele autoriteiten als bewijsmiddel in een strafzaak mogen worden aangewend (vergelijk subsecties 5.2.1 en 5.4.2).

Art. 5 ten slotte bepaalt dat van een verstrekking in de registratie waaruit de gegevens worden verstrekt aantekening dient te worden gehouden. Indien de persoonsgegevens verstrekt zijn uit een niet-geautomatiseerde persoonsregistratie geldt deze verplichting op grond van het convenant niet wanneer de gegevens niet of slechts kortstondig worden gebruikt. Deze regeling is in overeenstemming met de regeling van artikel 126 lid 3 sub e SUO: "Van de verstrekking en de ontvangst van persoonsgegevens dient in de registratie waaruit zij worden verstrekt en waarin zij worden opgenomen aantekening te worden gehouden." Dat ook in de registratie waarin de gegevens worden opgenomen aantekening moet worden gehouden, is een verplichting waaraan het buitenland moet voldoen. Dat de registratieplicht echter niet geldt indien de persoonsgegevens zijn verstrekt uit een niet-geautomatiseerde persoonsregistratie als de gegevens niet of slechts kortstondig worden gebruikt, is niet geheel in overeenstemming met de regeling van artikel 127 lid 1 SUO. Voor niet-geautomatiseerde doch gestructureerde gegevens geldt namelijk dezelfde registratieplicht als voor geautomatiseerde gegevens. Alleen voor losse gegevens geldt op grond van artikel 127 lid 2 SUO dat van de verstrekking en de ontvangst bij die gegevens in beginsel aantekening wordt gehouden. Deze verplichting geldt niet indien, gelet op het gebruik van de gegevens, aantekening niet nodig is. Dit geldt in het bijzonder wanneer de gegevens niet of slechts kortstondig worden gebruikt (zie subsectie 5.3.5). De regel die geldt voor de losse gegevens is door de Werkgroep dus op alle niet-geautomatiseerde gegevens van toepassing verklaard. Dit is niet in overeenstemming met artikel 
127 lid 1 SUO. Op grond van artikel 39 lid 4 en artikel 46 lid 2 SUO kunnen echter voor de grensgebieden afwijkende afspraken worden gemaakt. De in artikel 5 neergelegde regeling is er daar een van. Het is echter de vraag of deze afwijking wel wenselijk is.

Op basis van het modelconvenant van categorie a (verstrekkingen in het grensgebied van Nederland aan Belgie of Duitsland) zijn in april 1997 drie convenanten gesloten. ${ }^{208} \mathrm{Het}$ eerste convenant is gesloten tussen de korpsbeheerder van de Nederlandse politieregio Limburg-Zuid en de beheerder van het OIPG in het Belgische Genk. Het tweede convenant is gesloten tussen de korpschef van de Nederlandse politieregio Limburg-Zuid en de beheerder van het IRC in Eupen. ${ }^{209}$ Het derde convenant is gesloten tussen de korpschef van de Nederlandse politieregio Limburg-Zuid en de Polizeipräsident van Aken. Bij de eerste twee convenanten is een werkinstructie gevoegd die heel gedetailleerd de Belgische wetgeving en richtlijnen weergeeft (zie hiervoor subsectie 5.6.1). De werkinstructie besteedt in het bijzonder aandacht aan de toetsing van de legitimiteit van de informatic-uitwisseling en de verplichte registratic. Degene die informatie opvraagt, moet zijn vraag stellen aan het eigen IRC of OIPG opdat het betreffende IRC of OIPG controle op de legitimiteit van de informatievrager kan uitoefenen en de verplichte registratie onder een uniek nummer uitvoert. Zowel inkomende als uitgaande informatievragen moeten worden geregistreerd, mede ten behoeve van het verwerven van managementinformatie. Indien de aanvraag om informatie afkomstig is van buiten het grensgebied, moet de informatie worden aangevraagd en verstrekt via de dCRI (thans de DIN) respectievelijk de APSD-Afdeling Internationale Politiesamenwerking (thans het CGI). Volgens de werkinstructie zijn informatie-uitwisselingscontacten tussen politiediensten in het aangeduide grensgebied zonder tussenkomst van de IRC's of OIPG's toegestaan in concrete opsporingsonderzoeken of samenwerkingsverbanden. Daarbij moet ten behoeve van de informatiehuishouding zowel in Nederland als in België een werkdossier/register worden aangelegd en bijgehouden. In voorkomende gevallen moeten de aldus rechtstreeks uitgewisselde gegevens zowel in Nederland als in België meegedeeld worden aan de IRC's respectievelijk OIPG's, voor zover deze mededeling een goede afwikkeling van het onderzoek niet schaadt of niet strijdig is met het 'embargo'-karakter van de informatie.

Ingevolge de werkinstructie bij de eerste twee convenanten kan informatie van België naar Nederland zelfstandig door de politie worden verstrekt, zonder tussenkomst van de Procureur des Konings of de Onderzoeksrechter, onder de volgende voorwaarden: ${ }^{210}$

208. Verder heeft ook de regiopolitie Midden- en West-Brabant een convenant gesloten met de politic van Antwerpen en Turnhout. De convenanten worden normaal gesproken gepubliceerd in de Staatscourant.

209. Vereinbarung für die Obermittlung von Informationen aus dem Polizeirgister.

210. Ook de wettelijke gevallen waarin niet zelfstandig door de Belgische politie verstrekt kan worden, worden aangegeven. Zie hierover subsectie 5.6.1. 
- De meegedeelde gegevens moeten noodzakelijk zijn voor de opsporing en vervolging van strafbare feiten of ter afwending van een gevaar voor de openbare orde en openbare veiligheid.

- Persoonsgegevens over ras, etnische afstamming, seksueel gedrag, politieke, levensbeschouwelijke of godsdienstige overtuiging en activiteiten, medische geschiedenis en lidmaatschap van een vakbond of ziekenfonds mogen niet meegedeeld worden.

- De verstrekte informatie mag uitsluitend worden gebruikt voor politiêle doeleinden. Schriftelijke informatie kan slechts met toestemming van de gerechtelijke overheden van het verstrekkende land als bewijsmiddel in strafzaken aangewend worden. Schriftelijke verstrekking moet uitdrukkelijk worden vermeld door de verstrekkende politiedienst.

- De politiedienst die via de OIPG's informatie verstrekt, blijft eerstgerechtigde ${ }^{211}$ tot die informatie. Doorgeleiding van de verstrekte gegevens aan een andere dan de oorspronkelijke politiedienst noodzaakt tot de toestemming van de initiële informatieverstrekker.

- De OIPG's moeten aantekening houden van de verstrekking en de ontvangst van schriftelijk en mondeling verstrekte gegevens. Indien het om persoonsgegevens gaat die zijn verstrekt uit een niet-geautomatiseerde persoonsregistratie, geldt deze verplichting niet wanneer de gegevens niet of slechts kortstondig worden gebruikt. ${ }^{212}$

- De verstrekkende politiedienst moet erop toe zien dat de persoonsgegevens juist zijn. De dienst moet ervoor zorgen dat onjuiste of onrechtmatig verstrekte gegevens onmiddellijk ter verbetering of ter vernietiging worden meegedeeld aan de ontvangende politiedienst.

- De informatieverstrekking is slechts mogelijk wanneer voor de verkrijging ervan geen dwangmiddelen nodig zijn.

In alle gevallen die afwijken van de genoemde punten, moet de informatie worden verstrekt door tussenkomst van de Procureur des Konings of de Onderzoeksrechter.

211. De werkinstructic gebruikt de term "eigenaar" van de informatic. Het gebruik van dergelijke privaatrechtelijke begrippen in dit verband lijkt ons niet juist.

212. Dat de registratieplicht niet geldt indien de persoonsgegevens zijn verstrekt uit een niet-geautomatiseerde persoonsregistratie en de gegevens niet of slechts kortstondig worden gebruikt, is zoals gezegd niet geheel in overeenstemming met de regeling van artikel 127 lid I SUO. Voor niet-geautomatiseerde doch gestructureerde gegevens geldt dezelfde registratieplicht als voor geautomatiseerde gegevens. Alleen voor losse gegevens geldt op grond van artikel 127 lid 2 SUO dat van de verstrekking en de ontrangst bij die gegevens in beginsel aantekening wordt gehouden. Deze verplichting geldt niet indien, gelet op het gebruik van de gegevens, antekening niet nodig is. Dit geldt in het bijzonder wanneer de gegevens niet of slechts kortstondig worden gebruikt. 
De drie convenanten golden voor twee jaar en konden tussentijds door een van beide partijen worden beëindigd. Zij zijn inmiddels vervangen door twee nieuwe convenanten met gelijkluidende inhoud, doch van onbeperkte duur en met meerdere grenspartners. Het betreft:

1. het Convenant ten behoeve van de verstrekking van informatie uit een politieregister, convenant tussen de korpsbeheerders van de politieregio's Zeeland, Midden- en WestBrabant, Brabant Zuid-Oost, Limburg-Noord en Limburg-Zuid en de Beheerders van de OIPG's te Gent, Antwerpen, Turnhout, Genk en Eupen, met bijbehorende werkinstructie, Gent, 24 oktober 2000; en

2. het Convenant ten behoeve van de verstrekking van informatie uit een politieregister, convenant tussen de korpsbeheerders van de politieregio's Limburg-Noord en Limburg-Zuid en de beheerders van de Verbindungsstellen Aachen en Mönchen-Gladbach, januari 2001.

De inhoud van de convenanten is woordelijk gelijk aan die van het besproken modelconvenant, zij het dat bij de convenanten met Belgiě een werkinstructie is gevoegd. Deze werkinstructie zal in het internationale recht vermoedelijk op gelijke hoogte staan met het convenant zelf, omdat de instructie als bijlage is toegevoegd en er dus onlosmakelijk mee is verbonden.

Tussen Nederland en België is verder een Belgisch-Nederlands Politieel Grensakkoord uit 1949 van toepassing. Dit akkoord regelt de spontane informatieverstrekking tussen de toenmalige Belgische Rijkswacht, de Nederlandse regiopolitie en de Koninklijke marechaussee inzake verdachten die in de grensstreek verblijf houden dan wel rondtrekken.

\subsubsection{Belgische grensakkoorden}

De spontane informatie-uitwisseling tussen de politiediensten aan de Belgisch-Duitse grens is geregeld in een bilateraal akkoord van 26 januari 1960 over de dienstbetrekkingen tussen de Belgische en de Duitse politiële overheden in de grensstreek. Volgens dit akkoord is spontane informatie-uitwisseling mogelijk als de informatie ten behoeve van de dienst is. De verzochte uitwisseling tussen België en Duitsland is er niet in geregeld. In het Akkoord wordt melding gemaakt van een gemeenschappelijke communicatiedienst voor het grensgebied. Tevens wordt melding gemaakt van de mogelijkheid van informatie-uitwisseling tussen politieautoriteiten over criminelen die hun woon- of verblijfplaats in de grensstreek hebben. Verder is tussen België en Nederland het in subsectie 5.5.1 genoemde Belgisch-Nederlands Politieel Grensakkoord uit 1949 van toepassing. Ook vindt in België informationele politiesamenwerking plaats op grond van een ministerieel akkoord van 4 juli 1994. Zie hierover subsectie 5.6.1. Ten slotte bestaat er een Overeenkomst ter uitvoering van de SUO tussen Duitsland en België van 27 maart 2000. Zie hierover subsectie 5.5.3. 


\subsubsection{Duitse grensakkoorden}

Speciale grensakkoorden van Duitse origine in de zin van artikel 39 lid 4 en artikel 46 SUO waren er tot voor enige jaren nog niet. Pogingen om te komen tot een regeling voor Nedersaksen, Noordrijn-Westfalen en alle betrokken Nederlandse grensregio's zijn mislukt, omdat nog niet iedereen de noodzaak van dergelijke grensregionale convenanten inzag. In Duitsland werkten Nedersaksen en Noordrijn-Westfalen afzonderlijk nieuwe regelingen uit. In Noordrijn-Westfalen is verder de - in subsectie 5.6.2 te behandelen ministeriêle verordening van kracht op basis van artikel 27 lid 2 PolGNRW. De verordening vergemakkelijkt de uitwisseling van gegevens in de grensregio's, in het bijzonder met de Polizeipräsidium-gebieden langs de grens en met de grens-Kreisen en hun autoriteiten (art. 1 en 2 PolDUVNW). ${ }^{213}$ De spontane informatie-uitwisseling tussen de politiediensten aan de Belgisch-Duitse grens is geregeld in het in subsectie 5.5.2 genoemde bilateraal akkoord van 26 januari 1960 over de dienstbetrekkingen tussen de Belgische en de Duitse politielle overheden in de grensstreek. Er zijn ook twee recentere Duitse grensakkoorden van kracht. Hieronder bespreken wij de eerst de Ministerielle overeenkomst tussen Nederland en Duitsland uit 1997 en daarna de Overeenkomst ter uitvoering van de SUO van 27 maart 2000 tussen Duitsland en Belgiè.

\section{Ministeriële overeenkomst tussen Nederland en Duitsland}

Op 1 februari 1997 is voorts een Ministeriële overeenkomst tussen Nederland en Duitsland in werking getreden betreffende de politiële samenwerking in de grensgebieden. ${ }^{214}$ De overeenkomst werd op 17 april 1996 te Den Haag gesloten. $\mathrm{Zij}$ is (mede) gesloten in het kader van artikel 39 lid 4 SUO. Het betreft dus een overeenkomst met nadere afspraken voor de grensgebieden tussen de bevoegde Ministers van Nederland en Duitsland. Op departementaal niveau is de overeenkomst tot stand gekomen in het kader van het zogenaamde Nederlands-Duitse 'Delegationsgespräch'. Hierin zijn de Nederlandse ministeries van Justitie en Binnenlandse Zaken vertegenwoordigd, evenals de betrokken ministeries van Nedersaksen en Noordrijn-Westfalen. Artikel 18 van de overeenkomst opent de mogelijkheid tot een nadere of meer concrete invulling van de in de overeenkomst neergelegde afspraken. De bevoegde instanties, voornamelijk de IRC's, kunnen daartoe concrete voorstellen doen over de uitvoering of over mogelijke verbeteringen. Onder meer moet volgens artikel 18 lid 2 van de overeenkomst de vastlegging van structuren voor het verstrekken van informatie nog worden geregeld.

213. Verondmung über die Zulasung der Datenübermintung ven der Polieci und ausländische Polieribebànden (PolDOVNW), 22 oktober 1994, GVNRW, 11 november 1994. p. 109, zoals laatstelijk gewijzigd bij verordening van 7 januari 1998. GVNRW, p. 109.

214. Overeenkomst tussen de Minister van Binnenlandse Zaken en de Minister van Justitic van Nederland en het Bondsministerie van Binnenlandse Zaken van de Bondsrepublick Duitsland inzake politiele samenwerking in het grensgebied tussen Nederland en de Bondsrepubliek Duitsland. 
De Ministeriële overeenkomst beoogt de 'politiële samenwerking en de samenwerking tussen de grenspolitiediensten in de grensgebieden' te intensiveren en uit te breiden. Hieronder bespreken wij de artikelen die van belang zijn voor de informatieve politiële samenwerking in de grensgebieden. Artikel 1 stelt vast welke gebieden in Nederland en Duitsland vallen onder het begrip 'grensgebied' in de zin van artikel 39 lid 4 SUO. In Nederland zijn dat de werkingsgebieden die bepaald zijn door het bevoegd gezag $^{215}$ van de politieregio's Groningen, Drenthe, IJsselland, Twente, Noord- en Oost-Gelderland, Gelderland-Midden, Gelderland-Zuid, Brabant-Noord, Limburg-Noord en LimburgZuid. De omvang van het werkingsgebied is afhankelijk van het onderwerp van de te maken samenwerkingsafspraken. Voor de Bondsrepubliek Duitsland hebben we het in Noordrijn-Westfalen over de 'Kreise' Borken, Coesfeld, Steinfurt, Kleve, Wesel, Viersen, Heinsberg, Aken en Düren, alsmede de 'kreisfreic' steden Münster, Krefeld, Mönchengladbach en Aken. In Nedersaksen gaat het over de 'Landkreise' Aurich, Leer, Emsland en Grafschaft Bentheim, alsmede de 'kreisfreie' stad Emden.

Art. 2 van de Ministeriële overeenkomst gaat over de aanduiding van contactpunten van de politie. Blijkens artikel 2 lid 3 moeten deze contactpunten, waarmee zeer waarschijnlijk voornamelijk de IRC's worden bedoeld, zorgen voor de uitwisseling van informatie in de gevallen "die niet via rechtstreekse communicatie tussen de bevoegde autoriteiten aan weerszijden van de grens kunnen worden afgehandeld". Dit is een nogal wonderlijke taakomschrijving omdat nog niet vastligt óf gegevens en zo ja welke rechtstreeks kunnen worden uitgewisseld tussen 'de bevoegde autoriteiten ${ }^{216}$ aan weerszijden van de grens. De IRC's hebben onzes inziens nu juist een controlefunctie te vervullen in eigenlijk alle internationale politiële gegevensuitwisselingen die niet verlopen via de centraal bevoegde autoriteiten (de DIN, het BKA en de LKA's). De politie op de werkvloer zou eigenlijk niet meer rechtstreeks gegevens uit mogen wisselen met het buitenland zonder het eigen IRC daarin te kennen. Misschien bedoelt de overeenkomst dat als er geen persoonsgegevens in het spel zijn rechtstreekse communicatie mogelijk is tussen de bevoegde autoriteiten aan weerszijden van de grens. Dit blijkt echter niet uit de tekst van artikel 2 lid 3. Kortom, de tekst van het derde lid is niet erg duidelijk.

Blijkens artikel 2 lid 1 sub b zijn de contactpunten van de politie in Nederland de door het bevoegd gezag (zie hierboven) van de genoemde politieregio's bepaalde instanties. Hoogstwaarschijnlijk worden hiermee de IRC's bedoeld. Ingevolge artikel 2 lid 1 sub a

215. In de zin van hoofdstuk IV van de Politiewet 1993. Voor de handhaving van de openbare orde en de hulpverleningstaak betekent dit de burgemeester; voor de strafrechtelijke handhaving van de rechtsorde, dan wel taken ten dienste van justitie is het in beginsel de Ovj.

216. Dit begrip wordt niet nader gespecificeerd. Het is onduidelijk welke autoriteiten precies bedoeld worden. 
zijn de contactpunten van de politie in de Bondsrepubliek Duitsland voor NoordrijnWestfalen: de 'Polizeipräsidien' Aken, Krefeld, Mönchengladbach en Münster. ${ }^{217}$ Waarschijnlijk zijn voornamelijk de RVST's van deze 'Polizeipräsidien' bedoeld. Artikel 2 lid 2 voegt nog toe dat wat de contactpunten voor de grens- en spoorwegpolitie betreft ook een taak kan zijn weggelegd voor het KLPD en voor de KMAR, maar dan wel uitsluitend in verband met hun taken op het gebied van het vreemdelingentoezicht. In de Bondsrepubliek Duitsland zijn de contactpunten voor de grens- en spoorwegpolitie het 'Grenzschutz- und Bahnpolizeiamt' Hannover, het 'Grenzschutzamt' Keulen en het 'Bahnpolizeiamt' Keulen.

Art. 3 van de Ministeriële overeenkomst bepaalt dat in aangelegenheden die betrekking hebben op het grensgebied gebruik kan worden gemaakt van rechtstreekse politiecontacten tussen de LKA's in Noordrijn-Westfalen en Nedersaksen en de dCRI (thans de DIN).

Art. 4 lid 1 bepaalt dat de in de artikelen 2 en 3 genoemde instanties (de contactpunten, de LKA's en de dCRI; thans de DIN) rechtstreeks samen moeten werken ter bestrijding van de gevaren voor de OOV. Deze instanties moeten elkaar in het kader van hun samenwerking bij de bestrijding van de criminaliteit op grond van artikel 4 lid 2 rechtstreeks de informatie meedelen die voor het grensgebied van belang is. Bij gevallen die van hoger of supraregionaal belang zijn, moeten op grond van artikel 4 lid 3 van de overeenkomst de nationale centrale instanties (BKA, DIN, 'Landelijk Coördinatiecentrum') worden geìnformeerd. Artikel 4 lid 4 zegt, in overeenstemming met de Duitse wetgeving (zie subsectie 5.6.2), dat de gevallen waarin de oorspronkelijke bevoegdheid ligt bij het BKA van rechtstreekse politiecontacten zijn uitgezonderd. De verstrekking van gegevens moet op grond van artikel 4 lid 5 plaatsvinden met inachtneming van de nationale, communautaire en de internationale wettelijke regels die van toepassing zijn op de bescherming van persoonsgegevens, alsmede met inachtneming van de bepalingen van de SUO.

Op grond van artikel 10 lid 1 van de Ministeriële overeenkomst moeten de bevoegde instanties contactpersonen aanwijzen. De contactpersonen moeten zo mogelijk vreemde talen spreken. $\mathrm{Zij}$ moeten ook informatie uitwisselen over hun organisatie en hun telecommunicatieaansluitingen. De informatie moet regelmatig bijgewerkt worden. De bevoegde instanties moeten er op grond van artikel 10 lid 2 naar streven de technische voorwaarden te scheppen voor een efficiënte samenwerking. Als voorbeelden worden genoemd: telefoon, telefax, telex- en radioverbindingen. EMMI zou in dit rijtje zeker niet misstaan.

217. Alsmede voor Nedersaksen de 'Polizeiinspektion Emsland' in Lingen. 
Art. 11 bepaalt dat in het kader van opleiding en bijscholing ook informatie moet worden uirgewisseld, met intensieve aandacht voor grensoverschrijdende problemen en oefeningen. De bevoegde instanties kunnen ambtenaren uitwisselen die zich in het buurland op de hoogte stellen van de structuren, bevoegdheden en werkwijzen van de politie aldaar. Op grond van artikel 13 moeten de bevoegde instanties ook informatic uitwisselen over uitrusting en nieuwe technieken teneinde compatibiliteit te bereiken. Ook hier valt te denken aan EMMI.

Art. 14 schrijft voor dat er een grenshandboek voor de politie moet komen met informatie voor het in het grensgebied werkende politiepersoneel. Artikel 17 van de Ministeriële overeenkomst vermeldt ten slotte nog dat op alle niveaus gezamenlijk dienstoverleg kan worden gepleegd.

\section{Overeenkomst ter uitvoering van de SUO van 27 maart 2000 tussen Duitsland en België} Op 27 maart 2000 werd in Brussel ter uitvoering van de SUO een overeenkomst tussen Duitsland en Belgiě ondertekend. ${ }^{218}$ Op grond van artikel 2 II van de overeenkomst ziet de voorziene samenwerking vooral op (1) de informatie-uitwisseling, met inbegrip van de uitwisseling van persoonsgegevens; (2) de coördinatie van politie-inzet in de grensgebieden; en (3) de samenwerking op het gebied van opleidingen en verdere ontwikkeling.

In artikel 3 van de overeenkomst worden de RVST's opgesomd die de informatie-uitwisseling met het oog op de voorkoming en opsporing van strafbare feiten alsmede de algemene Gefahrenabwehr (preventie; zie subsectie 2.1.7) in het grensgebied tot taak hebben. Het gaat om de volgende Duitse RVST's: het Polizeipräsidium Trier (Rheinland-Pfalz), het Polizeipräsidium Aken (Nordrhein-Westfalen) en het Bundesgrenzschutzamt van respectievelijk Kleve, Keulen en Saarbrücken. In België verricht de RVST Eupen van de federale politie de genoemde taken.

Art. 8 van de overeenkomst regelt welke informatie de RVST's rechtstreeks, dus zonder inschakeling van de centrale autoriteiten, mogen uitwisselen in het kader van artikel 39 SUO. Deze regeling is speciaal gericht op het politiële rechtshulpverkeer in strafvorderingszaken. De volgende informatie mag worden uitgewisseld: vaststellingen van houders en bestuurders; navragen van rijbewijzen; vaststellingen van woon- en verblijfplaats; de vaststelling van de houders van telecommunicatieaansluitingen, voor zover het daarbij gaat om publieke aansluitingen; informatie die betrokkenen vrijwillig aan de politie geven; identiteitsonderzoeken; informatie over de herkomst van zaken, in het bijzonder betreffende wapens en motorvoertuigen (navraag bij de verkoper); de vaststelling van

\footnotetext{
218. Abkommen zwischen der Regierung der Bundesrepublik Deutschland und der Regierung des Königsreichs Belgien über die Zusammenarbeit der Polizeibehörden und Zollverwaltungen in den Grenzgebieten, Brussel, 27 maart 2000.
} 
sporen; informatie uit politiële processen-verbaal en informatiesystemen. Het gaat bij deze informatie-uitwisseling om uitwisseling in concrete afzonderlijke gevallen. Daarnaast voorziet artikel 7 II van de overeenkomst in de uitwisseling van strategische en tactische informatie door de leiders van een politie-inzet.

Op grond van artikel 5 van de overeenkomst is de uitwisseling van verbindingsofficieren mogelijk bij bijzondere politie-inzet met een grensoverschrijdend bereik. Om bijzondere redenen is op grond van artikel 4 IV een inrichting van gezamenlijke politieposten mogelijk voor een bepaalde termijn. Indien daaraan behoefte bestaat, mogen Duitsland en Belgiê op grond van artikel $4 \mathrm{I}$ van de overeenkomst voor aangelegenheden van de grenspolitie een gemeenschappelijk bezet verbindingskantoor hebben. In de overige artikelen van de Duits-Belgische overeenkomst worden details over grensoverschrijdende observatic en achtervolging geregeld.

\subsubsection{Benelux-grensakkoorden}

Ten slotte maken we nog melding van twee akkoorden die in Benelux-verband tot stand zijn gekomen. Ook in deze akkoorden wordt iets gezegd over informatieve politiesamenwerking.

In de eerste plaats gaat het om een zogenaamd Benelux Drugsconvenant dat op grond van artikel 39 lid 4 SUO is gesloten. ${ }^{219}$ Dit convenant kwam tot stand na een 'Besluit van de ministers in de Benelux van 21 december 1993 in het kader van de strijd tegen de drugs'. In dit Besluit staat dat de Ministers van Justitie van België, Nederland en Luxemburg, alsmede de Minister van Binnenlandse Zaken van België overeenkomen om de 'politie-informatie-uitwisseling' ter uitvoering van de nationale wetten te regelen in de grensregio Limburg-Zuid, België en Luxemburg. Men wil op die manier komen tot een gezamenlijke aanpak van het drugstoerisme op de lijn Maastricht-Luik-Luxemburg. In het kader van de verbetering van de politiële samenwerking hebben de partijen zich tot het volgende verplicht.

- De politieautoriteiten in de regio Limburg-Zuid dragen op eigen gezag of op verzoek alle nuttige informatie over aan de Belgische en Luxemburgse politieautoriteiten over strafbare feiten en politiële inlichtingen betreffende de Opiumwet en aan druggebruik gerelateerde criminaliteit. Het gaat daarbij nadrukkelijk om strafbare feiten die zijn gepleegd in de politieregio Limburg-Zuid door Belgische of Luxemburgse ingezetenen.

- De politieautoriteiten in Belgiè en Luxemburg informeren de regiopolitie LimburgZuid over 'belastende verklaringen' van de in België en Luxemburg verhoorde personen in verband met drugs of hieraan gerelateerde delicten met betrekking tot deze regio.

219. Benelux Drugsconvenant van februari 1994: Convenant tussen Politie-autoriteiten van de BENELUX-staten in de grensregio MAASTRICHT betreffende de as MAASTRICHT-LUIK-LUXEMBURG. 
In verband met genoemde verplichtingen moeten afspraken gemakt worden over onder andere het vergaren van bewijsmateriaal, "zoals uitwisseling van fotomateriaal over coffeeshops en dealerspanden".

Het convenant heeft slechts betrekking op de verstrekking uit een politieregister van gegevens met betrekking tot de opiumwetgeving en de drugsgerelateerde criminaliteit door de regiopolitie Limburg-Zuid aan Belgische en Luxemburgse politieautoriteiten. Verstrekking van deze gegevens is mogelijk onder vrijwel dezelfde voorwaarden als genoemd in het Nederlandse modelconvenant van de categorie a (zie subsectie 5.5.1). Artikel 5 van het modelconvenant, betreffende de registratie, is in het Benelux Drugsconvenant echter vervangen door de volgende tekst: "Met inachtneming van de nationale regelgeving dient registratie te worden gehouden van de verstrekte gegevens in de daartoe voorziene registers."

In de tweede plaats is op 4 juni 1996 een Benelux Overeenkomst gesloten. ${ }^{220}$ Dit is een Ministeriële overeenkomst tussen Nederland, België en Luxemburg inzake samenwerking op het terrein van politie, justitie en immigratie, voornamelijk in de grensgebieden. De overeenkomst is (mede) gebaseerd op artikel 39 lid 4 SUO. Zij beoogt de samenwerking op de genoemde beleidsterreinen met België en Luxemburg te structureren. Daartoe voorziet de overeenkomst in een structuur van een trilateraal ministersoverleg. Hieraan is een ambtelijk overleg gekoppeld. In dit ambtelijk overleg zitten vertegenwoordigers van de ministeries van Binnenlandse Zaken en Justitie, de politie, het OM en de immigratiediensten. Onder de prioriteiten die bij voorrang moeten worden geregeld, vallen het technisch en inhoudelijk optimaliseren van de gegevensuitwisseling en de niet-operationele informatie-uitwisseling. In het kader van deze overeenkomst moet met name de Belgisch-Nederlandse Politiële Samenwerking (BNPS) verder gestalte krijgen. Dit is tevens een stimulans voor de zogeheten Duits-Nederlandse Politiële Samenwerking (DNPS). In beide gremia spelen de IRC's een belangrijke voortrekkersrol.

\subsection{Wetgeving in België en Duitsland 221}

In deze sectie worden de Belgische en Duitse wet- en regelgeving besproken met betrekking tot de internationale uitwisseling van politiële gegevens in de respectievelijke subsecties 5.6.1 en 5.6.2. Wat Duitsland betreft, besteden wij bijzondere aandacht aan de wetgeving van de deelstaten Noordrijn-Westfalen en Nedersaksen, omdat de politie van

220. Memorandum van overeenstemming inzake de samenwerking op het terrein van politie, justitie en immigratic tussen de ministers van Justitic van Belgiè, Nederland en Luxemburg, de ministers van Binnenlandse Zaken van Belgiě en Nederland en de minister van de Force Publique van Luxemburg.

221. Zie hieromtrent mede Joubert \& Bevers 1996, p. 443-511; zie ook Hofstede, Twuyver, Kapp, de Vries, Faure, Claus, \& van der Wel 1993, p. 17-22; alsmede De Hert \& Vanderborght 1996, p. 589-621. 
deze deelstaten participeert in de EMMI-omgeving. In subsectie 5.6.3 formuleren wij ten slotte onze conclusies omtrent het omgaan met zachte gegevens bij de grenstegionale politièle gegevensuitwisseling tussen Nederland, Belgiẽ en Duitsland (ter beantwoording van de eerste aanvullende onderzoeksvraag van deze dissertatie).

\subsubsection{Belgische wetgeving}

In deze subsectie behandelen wij de Belgische wetgeving met betrekking tot de informatieve politiesamenwerking. $\mathrm{Na}$ een inleiding in deze paragraaf in het Belgische gegevensbeschermingsrecht, gaan wij achtereenvolgens in op (1) uitzonderingen op gegevensuitwisseling door de Belgische politie en (2) het Belgisch wettelijk kader in ontwikkeling.

Het recht op eerbiediging van het privé-leven is neergelegd in artikel 22 van de Belgische gecoördineerde Grondwet van 1994. Dit artikel luidt: "Ieder heeft recht op eerbiediging van zijn privé-leven en zijn gezinsleven, behoudens in de gevallen en onder de voorwaarden door de wet bepaald." In de Belgische privacywet (WVP) ${ }^{22}$ moeten de politiediensten het stellen met slechts een paar regels. De gevallen waarin aan politiële gegevensverwerking mag worden gedaan, zijn geconcretiseerd in de artikelen 44/1 tot en met 44/11 van de WPA. Zowel het recht met betrekking tot de verwerking van persoonsgegevens als het recht met betrekking tot de gerechtelijke en politiële activiteit vormen dus in België de vindplaatsen voor juridische regels voor politiegegevens. ${ }^{223}$

Het vijfde beginsel van Aanbeveling R (87) 15 van de Raad van Europa (zie subsectie 5.3.2) heeft gedeeltelijk als basis gediend voor de bepalingen over het doorgeven van persoonsgegevens aan buitenlandse politiediensten in het zogenaamde achtste Koninklijk Besluit (KB) bij de Belgische privacywet.

Het wettelijke kader dat de Belgische wetgever heeft gecreëerd voor de internationale informatieve politiesamenwerking kan worden gekarakteriseerd als gematigd gedetailleerd. De bestaande regelingen zijn bijna allemaal erg recent. De meeste regelingen zijn geïnspireerd door of zelfs 'opgelegd door' de SUO. Voordat de SUO het licht zag, kende België slechts één wettelijke bepaling over internationale justitiële samenwerking, namelijk het toenmalige artikel 11 van het Gerechtelijk Wetboek (GWb).224 Daarin werd bepaald dat de Belgische gerechtelijke autoriteiten bevoegd zijn informatie, rechtshulp en opsporing te verzoeken aan buitenlandse gerechtelijke autoriteiten. Het Belgisch

222. Wet van 8 december 1992 tot bescherming van de persoonlijke levenssfeer ten opzichte van de verwerking van persoonsgegevens (Wet Verwerking Persoonsgegevens), B.S., 30 december 1993, Deze wet is aangepast door een KB van 11 december 1998 en een KB van 13 februari 2001. Dit eerste KB is een uitwerking van Europese Richtlijn 95/46/CE van 24 oktober 1995.

223. De Hert \& Vanderbonght 1996, p. 473.

224. Gerechtelijk Wetboek van 10 oktober 1967, B.S., 31 oktober 1967. 
straf-en strafprocesrecht schenken geen aandacht aan de politiële gegevensuitwisseling. In de WPA en in het Koninklijk Besluit ter installatie van de toenmalige APSD ${ }^{225}$ staan echter wel enkele algemene bepalingen ter zake. Meer gedetailleerde bepalingen omtrent de verwerking en de uitwisseling van informatie in het algemeen staan in de WVP en een aantal daarop gebaseerde besluiten. In beginsel is de WVP van toepassing op elke verwerking van persoonsgegevens die in Belgiè plaatsvindt. Het maakt daarbij niet uit of deze gegevens door de overheid of door particulieren worden verwerkt. De wet zelf herhaalt in artikel 2 WVP nogmaals dat iedere natuurlijke persoon recht heeft op bescherming van zijn fundamentele rechten en vrijheden en zijn persoonlijke levenssfeer. De WVP is niet enkel van toepassing op de verwerking en opslag van geautomatiseerde persoonsgegevens, maar ook op handmatig aangelegde registers en documentatic. Ten slotte staan er ook bepalingen over de uitwisseling van informatie in de Circulaire betreffende speciale politietechnieken en in de zogenoemde Schengencirculaire. ${ }^{226}$

Art. 3 sub 3 WVP bevat de beginselen van proportionaliteit en subsidiariteit door te stellen dat de persoongegevens 'toereikend, terzake en niet overmatig' dienen te zijn en 'uitgaande van de doeleinden waarvoor zij worden verkregen of waarvoor zij verder worden verwerkt'.

Het zogeheten 'finaliteitsbeginsel' betekent in België hetzelfde als de uitdrukking 'doelbindingsprincipe' in Nederland. ${ }^{27}$ Het houdt in dat de houder van een bestand enkel gegevens mag inzamelen en verwerken voor duidelijk omschreven, wettelijke doeleinden. In de wet is dit principe uitgewerkt in artikel 4 sub 2 van de WVP. In concreto betekent het dat de houder van een bestand een welomschreven doel van zijn verwerking dient vast te stellen. De strekking van het finaliteitsbeginsel is niet absoluut te noemen. Zo heeft de Privacycommisie (zie hierna) in haar Viclas-advies ${ }^{228}$ toegegeven dat misdaadanalyse vaak de verzameling van gegevens behelst waarvan uiteindelijk slechts een klein gedeelte relevant zal zijn. Hierbij passen enkele observaties. Allereerst behelst misdaadanalyse veel meer dan enkel Viclas ${ }^{229}$ en ten tweede geeft de CBPL in het advies ook aan

225. KB van 11 juli 1994 over de algemene politiesteundienst, B.S., 30 juli 1994.

226. Respectievelijk van 24 april 1990 (kenmerk 7/SDP/690/MN NIX/RB6/6) en 16 maart 1995, B.S., 28 maart 1995.

227. Vermoedelijk is dit een gallicisme, afgeleid van het woord "finalite", wat doel of doelgerichtheid betekent. Het woord 'finaliteit' komt niet voor in het Van Dale woordenboek.

228. Viclas staat voor Violent Criminal Linkage Analysis System. Het registreert kenmerken van dader en slachtoffer, om de mogelijke verbanden met andere misdrijven inzichtelijk te maken. Zie advies $15 / 99$ van de CBPL.

229. Viclas wordt gebruikt ten behoeve van de zogeheten specifieke daderanalyse, wat algemeen tot de misdaadanalyse wordt gerekend. Er zijn nog andere vormen van misdaadanalyse, bijvoorbeeld een strategische studie of een analyse van de verklaringen van getuigen en verdachten. 
dat de wettelijke basis voor Viclas eigenlijk onvoldoende is en roept zij de regering op om met een oplossing te komen voor dit geconstateerde manco.

Het principe van legaliteit dat in Belgiè ook wel 'wettigheidscriterium' of 'wettigheidsvereiste' wordt genoemd, staat expliciet vermeld in artikel 5 WVP Elke verwerking door de overheid dient een specifieke wettelijke basis te hebben en dient overeen te komen met de bevoegdheden van het desbetreffende orgaan. Artikel 5 sub e WVP spreekt over verwerkingen die noodzakelijk zijn voor de vervulling van een taak van openbaar belang. Hieronder valt ook de politie- en justitietaak. Het beginsel is in overeenstemming met het grondwetsartikel 22 dat stelt dat elke inbreuk op de persoonlijke levenssfeer een basis in de wet moet hebben. Uit artikel 2 WVP volgt dat het privé-leven moet worden gerespecteerd bij de verwerking van gegevens. De WVP geeft echter geen verdere precisering van methoden die het mogelijk maken persoonsgegevens te verzamelen zonder schending van de privacy. De wetgever heeft in de oorspronkelijke WVP ook aandacht besteed aan de grensoverschrijdende informatievoorziening. Artikel 22 WVP (oud) bepaalde namelijk dat internationate gegevensuitwisselingen plaats moeten vinden volgens specificaties die in Koninklijke Besluiten zijn uitgewerkt. Deze bepaling heeft geleid tot vier Koninklijke Besluiten ter zake, waarvan er één, het zogenaamde KB nr. $8,{ }^{230}$ ziet op de internationale uitwisseling van politiegegevens.

Art. 5 sub 1 WVP stelt in de cerste plaats dat de gegevens eerlijk en rechtmatig dienen te worden verwerkt. Sub 4 van hetzelfde artikel benadrukt dat de verwerking van de persoongegevens nauwkeurig dient te zijn en de gegevens indien nodig bijgewerkt dienen te worden. Deze twee onderdelen vormen samen het zorgvuldigheidsbeginsel.

Er dient ingevolge artikel 17 WVP een aangifte van de betreffende verwerking te worden gedaan bij de CBPL. Deze Belgische nationale controleautoriteit voert een controle uit op de gestelde voorwaarden. De CBPL speelt ook een rol bij het realiseren van de rechten van burgers (gegevenssubjecten) ten aanzien van politieregisters. In het algemeen garanderen de artikelen 9-15bis WVP het recht van een gegevenssubject op kennisgeving, toegang, controle en verbetering van de informatie die over hem of haar is opgeslagen. Wat de politieregisters betreft, wordt aan de CBPL de zorg toevertrouwd voor de belangen van het gegevenssubject via een systeem van indirecte toegang, controle en verbetering.

De Belgische wetgeving maakt wat het soort informatie betreft geen onderscheid tussen harde en zachte informatie. Er wordt wel een wettelijk onderscheid gemaakt tussen 
gerechtelijke en bestuurlijke politietaken. Bestuurlijke informatie wordt verzameld met het doel om de openbare orde te bewaken (bijvoorbeeld het voorkomen van rellen) of om misdrijven te voorkomen. Bij gerechtelijke informatie gaat het om gegevens die verzameld en verwerkt worden teneinde daders van concrete misdrijven op te sporen en uiteindelijk ook te vervolgen. Het doel van de politieactie en niet de aard van de politiedienst is van belang. Het is dus onjuist om te stellen dat bijvoorbeeld enkel de federale politie gezien moet worden als bestuurlijke politie. In de praktijk is het onderscheid tussen gerechtelijke en bestuurlijke politie moeilijk te handhaven. Indien bijvoorbeeld inzicht nodig is in een dierenrechtendemonstratie die uit de hand zou kunnen lopen, kan het nodig zijn om de gerechtelijke gegevens van bekende gewelddadige activisten op te vragen. Hieruit blijkt dat het verschil tussen bestuurlijke en gerechtelijke informatie vanuit een theoretisch standpunt interessant is, maar in de praktijk moeilijker te handhaven is. Men kan zich ook vragen stellen naar het belang van zo'n onderscheid. Immers, uit de verscheidene bepalingen van de WPA blijkt dat de verschillende instanties, zowel bestuurlijk als gerechtelijk, een onderlinge informatieplicht hebben indien zij wederzijds interessante informatie onder zich houden. ${ }^{231}$ Deze plicht is benadrukt door zelfs een straf te stellen op het achterhouden van informatie. ${ }^{232} \mathrm{Het}$ is duidelijk dat men debacles zoals de zaak-Dutroux ${ }^{233}$ in de toekomst wil vermijden.

De vraag laat zich stellen in hoeverre het onderscheid tussen de twee soorten informatic dan wel van belang is. Het meest opvallende verschil betreft de verantwoordelijkheid over de gegevens. Artikel 44/3 WPA stelt dat de inlichtingen en gegevens van bestuurlijke politie worden ingewonnen onder het gezag van de Minister van Binnenlandse zaken. Hetzelfde artikel stelt tevens dat de inlichtingen van gerechtelijke politie vallen onder de verantwoordelijkheid van de Minister van Justitie. Een ander verschil betreft de uitwisseling van informatie met buitenlandse politiediensten.

Voor de verwerking van de gegevens is het onderscheid niet van belang. Artikel $44 / 1$ WPA, dat over de verwerking gaat, spreekt over beide soorten informatic en geeft aan dat de politiediensten bevoegd zijn om persoonlijke gegevens te verzamelen en te bewerken. Het tweede lid stelt dat die diensten wat persoonlijke gegevens betreft eerst het advies van de CBPL moeten inwinnen.

231. Zie hiervoor onder andere artikel 44/5 WPA.

232. Zie artikel 44/11 WPA. Op dit achterhouden van informatic staat voor de politieambtenaar een straf van maximaal zes maanden.

233. Uit de onderzoeken van de Commissic Dutroux is gebleken dat meerdere politieinstanties met onderzoek naar Marc Dutroux bezig waren, maar de informatic onderling niet deelden omdat elke dienst zelf een grote slag wilde slaan. 
In de praktijk blijkt de politie echter wel een onderscheid tussen harde en zachte informatie te maken. In het algemeen kunnen Belgische politieregisters allerlei soorten informatie bevatten over gebeurtenissen, groepen van personen en individuen. Er zijn echter enige restricties wat de subjecten betreft van wie informatie mag worden verwerkt. De restricties staan voornamelijk in de artikelen 6-8 WVP. Deze bepalingen verbieden in beginsel de verwerking van gevoelige gegevens over het individu, zoals raciale of etnische afkomst, de politieke opvattingen, de godsdienstige of levensbeschouwelijke overtuiging, seksueel gedrag of het lidmaatschap van een vakvereniging. Tevens is in beginsel de verwerking verboden van medische gegevens, gegevens over strafrechtelijke veroordelingen, verdenkingen en andere gerechtelijke informatie. Uitzonderingen op deze regel kunnen worden gemaakt door de wet en moeten worden beperkt tot in de wet genoemde doeleinden. De uitzonderingen staan voornamelijk in de zogenoemde KB's nr. 7 en 8 . Op grond van een van deze uitzonderingen mag de politie dergelijke gevoelige gegevens verzamelen zolang als dit nodig is voor de politietaak als omschreven in artikel 39 WPA (oud) in het bijzonder. In de MvT op de artikelen 6-8 WVP voegde de Belgische regering hieraan toe dat het verzamelen van gevoelige gegevens niet mogelijk is om de enkele reden dat zij gevoelig zijn. ${ }^{234}$ Het verzamelen van gevoelige gegevens is alleen rechtmatig als daarmee een concreet belang wordt gediend.

Wanneer de verwerkte gegevens, zelfs occasioneel, bestemd zijn om naar het buitenland te worden doorgezonden, dient op grond van artikel 17 par. 6 WVP, ongeacht de gebruikte gegevensdrager, in de aangifte aan de CBPL te worden vermeld:

$1^{\circ}$ de categorieèn van gegevens die worden doorgezonden; en $2^{\circ}$ voor elke categorie van gegevens, het land van bestemming.

Bepaalde landen kunnen of moeten echter anders behandeld worden dan andere. Zoals bij elke andere vorm van gegevensverwerking, is de internationale uitwisseling van de gegevens genoemd in de artikelen 6-8 WVP gebonden aan bepaalde beperkingen. De gegevens die genoemd worden in artikel 6 WVP - betreffende religie, etnische afkomst et cetera - mogen alleen verwerkt en uitgewisseld worden op basis van

1. een wettelijke verplichting in België, of

2. het feit dat het ontvangende land het Databeschermingsverdrag heeft ondertekend en gegevensbeschermingsregels kent die gelijkwaardig zijn aan die van België.

De uitwisseling mag enkel plaatsvinden door politiemensen die met name genoemd zijn op een lijst die toegankelijk is voor de CBPL (art. $8 \mathrm{~KB}$ nr. 7). Volgens KB nr. 8 is de grensoverschrijdende verstrekking van justitiële en politiële gegevens alleen toegestaan op basis van een intergouvernementeel akkoord - zoals de SUO - of binnen het kader 
van een internationale organisatie voor politiële samenwerking, zoals Interpol (art. 1 par. $2 \mathrm{~KB} \mathrm{nr} .8$ ). De uitwisseling van gegevens met of de verstrekking van gegevens aan landen zonder een afdoende gegevensbeschermingsregime is niet uitgesloten, maar artikel 1 par. $2 \mathrm{~KB}$ nr. 8 onderwerpt zulke gegevensuitwisseling aan strengere voorwaarden en beperkingen. Zonder adequate gegevensbescherming in het ontvangende land kan er slechts informatie uitgewisseld worden bij een ernstig en dreigend gevaar of met het oog op de bestraffing van een misdaad of wanbedrijf. Ook kan er informatic worden uitgewisseld als dit noodzakelijk is voor de uitvoering van de politiële opdrachten van de Belgische politiële instanties of van de buitenlandse overheden of diensten met gelijkgestelde opdrachten van gemeen recht. De Belgische politiedienst of openbare overheid mag dus alleen informatie uitwisselen met overheden en politiediensten die actief zijn op het terrein van de preventie, de opsporing en bestraffing van misdrijven. Het moet daarbij gaan om misdrijven die het Belgisch strafrecht ook kent, met uitsluiting van politieke misdaden en wanbedrijven, drukpersmisdrijven en opiniedelicten. Bovendien zijn de categorieën van informatic die aan zulke landen mogen worden verstrekt ook teruggebracht. Er is geen uitwisseling mogelijk van gegevens over geschillen voorgelegd aan hoven, rechtbanken en administratieve gerechten; verzoeken tot betaling van een geldsom met het oog op het verval van de strafvordering voor sommige misdrijven; ontzettingen uit de ouderlijke macht en maatregelen van opvoedingsbijstand; de voorwaardelijke invrijheidsstelling; wegzendingen uit leger, politie of uit de dienst gewetensbezwaarden; maatregelen met betrekking tot geesteszieken op grond van de wet betreffende de bescherming van de persoon van de geesteszieke en alle andere door de Koning bepaalde maatregelen of sancties die betreffende een persoon zijn uitgesproken. Wel mogelijk is de mededeling van gegevens over veroordelingen, terbeschikkingstellingen, verdachte misdrijven et cetera. Ten slotte dient het nationaal bureau dat is belast met de internationale politiële samenwerking (met name de toenmalige APSD; thans het CGI) op grond van artikel 4 par. 4 van $\mathrm{KB}$ nr. 8 gedurende zes maanden de naam van de verzoeker en de reden van het verzoek te bewaren als het om landen met een ongelijkwaardige gegevensbescherming gaat. Een lijst van landen die een gelijkwaardige of anderszins afdoende gegevensbescherming bieden, zal worden neergelegd in een KB. Ongetwijfeld zullen Nederland en Duitsland hieronder vallen omdat zij over rechtswaarborgen beschikken die gelijkwaardig zijn aan die van België. Genoemde beperkingen in de gegevensuitwisseling gelden dan ook niet ten aanzien van Nederland en Duitsland.

De aangezochte Belgische politiedienst dient de wettelijkheid van het verzoek te beoordelen alvorens hij de informatie meedeelt. Dit vereiste vloeit voort uit het doelbindingsof finaliteitsprincipe. De Schengencirculaire bepaalt dat de informatie niet voor andere doeleinden mag worden gebruikt dan waarvoor zij is verstrekt. Het doel waarvoor om informatie is verzocht moet conform de doeleinden zijn waarvoor de verzochte informatie werd ingewonnen. Om dit te bewerkstelligen, zal de verzoekende staat de redenen 
moeten specificeren waarom zij bepaalde informatie nodig heeft. Het verzoek zal dan wellicht ook iets moeten zeggen over de context van het betreffende onderzoek.

Soms is de Belgische politie onbevoegd om zelfstandig een buitenlands verzoek om informatie te beantwoorden. $\mathrm{Zij}$ is dan verplicht het verzoek door te zenden aan de justitiële autoriteiten. De Schengencirculaire van de Belgische Ministers van Justitie en Binnenlandse Zaken verwijst naar artikel 39 SUO. Het doorzenden moet in ieder geval gebeuren als het verzoek het gebruik van dwangmiddelen betreft of als dergelijke middelen nodig zijn om de verzochte informatie te verkrijgen.

\section{Uitzonderingen op internationale gegevensuitwisseling door de Belgische politie}

De Schengencirculaire besteedt eigenlijk geen aandacht aan de verzoeken die door de justitie̋le autoriteiten moeten worden afgehandeld in plaats van door de politie. $\mathrm{Zij}$ bepaalt enkel, in aansluiting bij artikel $39 \mathrm{SUO}$, dat de politie onbevoegd is verzoeken te beantwoorden betreffende of te maken hebbende met een exclusieve bevoegdheid van de justitiële autoriteiten. De omstandigheden waaronder dit het geval is, worden in de Belgische wetgeving verder niet uitgewerkt. Er wordt in de wetgeving echter geen enkele expliciete uitzondering gemaakt op de informationele politiële samenwerking. Uit het algemene wettelijke systeem van het Belgische internationale strafrecht kunnen echter een aantal weigeringsgronden worden afgeleid voor het aan buitenlandse politiediensten verstrekken van politiële gegevens. De weigeringsgronden zijn: het politieke of fiscale karakter van het delict (in verband met artikel 2 ERV), de omstandigheid dat het beantwoorden van het verzoek in strijd met de Belgische openbare orde zou zijn, en het risico dat de doodstraf zou worden opgelegd of uitgevoerd op basis van de verstrekte informatie. Verder is het internationale non bis in idem-beginsel als facultatieve weigeringsgrond voor rechtshulp erkend. Dit staat in verband met artikel 22 lid 2 sub b BUV. Een verzoek om informatie kan, doch niet moet, vanwege het feit dat iemand al berecht is voor een dergelijk feit worden geweigerd. Andere Belgische voorbehouden op het verlenen van kleine rechtshulp hebben betrekking op de angst voor een discriminatoire vervolging en de schending van de mensenrechten, alsmede op de vervolging van een persoon die in België voor dezelfde feiten wordt vervolgd. Er is geen speciale uitzondering voor de internationale uitwisseling van 'zachte informatie', aangezien dergelijke gegevens geen aparte status hebben in de Belgische wetgeving. Op grond van de nr. 3.5.1-3.5.5 van de Circulaire betreffende speciale politietechnieken kan echter worden afgeleid dat informatie die is aangeleverd door politie-informanten slechts met toestemming van de Nationale Magistraat mag worden uitgewisseld.

Als de politie een buitenlands verzoek om informatie ontvangt, waarop een of meer van de genoemde weigeringsgronden van toepassing zijn, zal in de praktijk de APSD-divisie voor internationale politiesamenwerking (thans het CGI) moeten beslissen of en hoe het verzoek moet worden doorgeleid naar de justitiële autoriteiten. De Schengencirculaire 
bepaalt dat in dat geval de Nationale Magistraat belast is met de internationale politiesamenwerking en de kleine rechtshulp. In het geval van grensoverschrijdende criminaliteit tussen buurstaten zijn echter ook de Procureurs des Konings bevoegd.

In de navolgende paragrafen onderzocken wij nader het geldende Belgisch recht aangaande het omgaan met zachte en harde gegevens door de Belgische politiediensten alsmede de uitwisseling daarvan met het buitenland. Allereerst komen wij tot de vaststelling dat het Belgisch wettelijk kader sterk in ontwikkeling is. Er is nog veel uitvoeringswetgeving noodzakelijk, zeker op het gebied van het omgaan met zachte gegevens. De volgende paragraaf behandelt de artikelen $44 / 1$ tot en met 44/11 van de Belgische Wet op het politieambt (WPA), waarin recentelijk het politiële informatiebeheer is geregeld. Daarna gaan wij in op de begrippen doelbinding en concreet belang, die van belang zijn in het kader van de verwerking en het inwinnen van gegevens door de politicdiensten. In de volgende paragraaf wordt het onderscheid behandeld tussen harde en zachte politiële gegevens naar geldend Belgisch recht. Daarna bespreken wij de belangrijke omzendbrief inzake internationale politiesamenwerking met een gerechtelijke finaliteit, die de juridische basis vormt voor de uitwisseling van gegevens met het buitenland. In de daaropvolgende paragraaf komen wij tot de vaststelling dat er twee categorieen gegevens worden gehanteerd in het kader van de informatie-uitwisseling met het buitenland, afhankelijk van de vraag of er voorafgaandelijke toestemming van de Belgische rechterlijke autoriteiten nodig is voor de uitwisseling. Daarna behandelen wij de Belgische bevoegdheidsverdeling bij de afhandeling van rechtshulpverzoeken. Deze bevoegdheidsverdeling is afhankelijk van de vraag of er sprake is van een nieuw onderzoek of van een lopend onderzoek. In de volgende paragraaf bespreken wij de registratie van de politiële rechtshulp en de controle op de internationale politiële gegevensuitwisseling. Vervolgens bespreken wij het Protocolakkoord OIPG's. Daarna volgt een behandeling van de verhouding tussen de Belgische politie, het $\mathrm{OM}$, het zogeheten controleorgaan en rechtstreekse geautomatiseerde toegang. Ten slotte gaan wij in op de problematiek van de koppeling van gegevens en bestanden in het Belgische recht.

\section{Belgisch wettelijk kader in ontwikkeling}

De Belgische (lokale en federale) politiediensten hebben de opdracht om enerzijds de veiligheid van de burgers te helpen waarborgen en om anderzijds de democratische werking van de rechtsstaat te helpen verzekeren. Voor het vervullen van deze opdracht, waarin zowel een gerechtelijke (recherche naar Nederlandse begrippen) als een bestuurlijke dimensie (OOV naar Nederlandse begrippen) terug te vinden is, dienen de politiediensten in staat te zijn de nodige inlichtingen en persoonsgegevens in te winnen, te verwerken en uit te wisselen. Dit dient te verlopen met respect voor de fundamentele rechten en vrijheden van elke burger, meer in het bijzonder met respect voor de bescherming van de persoonlijke levenssfeer. Om deze twee op zichzelf tegengestelde belangen, namelijk enerzijds de 'plicht' van de politiediensten om inlichtingen en persoonsgege- 
vens, die het privé-leven kunnen aantasten, in te winnen, te verwerken en uit te wisselen, en anderzijds het recht van elke burger op de eerbiediging van zijn of haar privé-leven, met elkaar te verzoenen, werd door de Belgische wetgever een wettelijk kader gecreëerd. De krachtlijnen van dit wettelijke kader zijn terug te vinden in de artikelen 44/1 tot en met 44/11 van de Belgische Wet op het politieambt (WPA) van 5 augustus 1992, die daartoe recentelijk werd gewijzigd. ${ }^{235} \mathrm{De}$ Wet op de geïntegreerde politie van 7 december $1998,{ }^{236}$ waardoor de Belgische politie werd gestructureerd op twee niveaus, namelijk het federale en het lokale niveau, vervangt het oude artikel 39 WPA door de nieuwe Onderafdeling 3 'Het informatiebeheer' die de artikelen 44/1 tot en met 44/11 omvat. Deze artikelen maken deel uit van Hoofdstuk IV 'Opdrachten van de politiediensten', Afdeling 1 'De opdrachten van de politiediensten en het vervullen van die opdrachten'. Zij werden van kracht op 1 januari 2001. In afwachting van uitvoeringsbesluiten voor de verfijning van deze artikelen, werd door de Belgische Ministers van Justitie en Binnenlandse Zaken op 14 juni 2002 een dwingende omzendbrief ${ }^{37}$ uitgevaardigd, waarin de 'spelregels' van de Belgische politiële informatiehuishouding werden bepaald. De implementering van de richtlijnen die hierin zijn neergelegd is momenteel in alle geledingen van de Belgische geintegreerde politie gestructureerd op twee niveaus, aangevat.

De artikel 44/1 tot en met 44/11 WPA zijn thans de belangrijkste referentieteksten voor de inzameling en de verwerking van politiële informatie door de Belgische politiediensten. Een aantal koninklijke en ministeriële besluiten moeten in de toekomst nog de verschillende opdrachten en verantwoordelijkheden ter zake nader vastleggen. Een interministeriële werkgroep, 'werkgroep $44^{\prime}$ genoemd, bereidt deze teksten voor. De koninklijke en ministeriële besluiten waren in januari 2004 nog niet gereed.

Genoemde omzendbrief van 14 juni 2002 voorziet in richtlijnen om de overgangsperiode te dekken tot de inwerkingtreding van de definitieve wettelijke teksten.

\section{Art. 44/1 tot en met 44/11 WPA}

Het belangwekkendste artikel is wel artikel 44/4 WPA. Dit artikel ziet op de verwerking van de gegevens en inlichtingen, die ingezameld zijn door de politiediensten op basis van artikel 44/1 WPA, in één algemene nationale gegevensbank (ANG). Er is in België sinds de invoering in 2002 in beginsel sprake van één algemene nationale gegevensbank voor alle politiediensten en voor alle soorten politiële gegevens.

235. De regeling is in werking getreden op 1 januari 2003.

236. Wet tot organisatie van een geïntegreerde politiedienst, gestructureerd op twee niveaus, van 7 december 1998, zoals bijgewerkt tot 23 mei 2003, B.S. 5 januari 1999.

237. Gemeenschappelijke richtlijn MFO-3 van de Ministers van Justitie en van Binnenlandse Zaken betreffende het informatiebeheer inzake gerechtelijke en bestuurlijke politie, Brussel, 14 juni 2002, in werking getreden op 18 juni 2002. 
Op basis van artikel 44/1 WPA mogen de politiediensten persoonlijke gegevens en inlichtingen over gebeurtenissen, groeperingen en personen die een concreet belang vertonen voor de uitoefening van de opdrachten van gerechtelijke politie ${ }^{238}$ (te vergelijken met 'recherche' in Nederland) en bestuurlijke politie (te vergelijken met politiediensten aangaande $\mathrm{OOV}$ in Nederland), inzamelen en verwerken. Indien de inhoud van de informatie deze drempel van een concreet belang bereikt, dient de informatie te worden geregistreerd. In het tegengestelde geval mag de informatie niet worden geregistreerd. Op grond van artikel 44/1 WPA mogen ook gevoelige gegevens worden verzameld en verwerkt. ${ }^{239}$ De gegevens en inlichtingen mogen enkel worden medegedeeld aan de politieoverheden en politiediensten, waaronder begrepen de buitenlandse politiediensten, an de inlichtingen- en veiligheidsdiensten en aan de algemene inspectie van de federale politie en van de lokale politie, die ze nodig hebben voor de uitoefening van hun opdrachten. $\mathrm{Zij}$ mogen eveneens medegedeeld worden aan internationale organisaties voor politiële samenwerking, zoals Europol.

Op grond van artikel 44/2 WPA dienen de inzameling, de verwerking en de overdracht van informatie overeenkomstig de wetgeving op de bescherming van de persoonlijke levenssfeer te gebeuren. De inlichtingen en gegevens dienen in rechtstreeks verband te staan met de bestaansreden van het gegevensbestand en dienen beperkt te blijven tot de vereisten die eruit voortvloeien. Dit is te vergelijken met het Nederlandse doelbindingsprincipe.

Art. 44/3 WPA ziet op de toezichthoudende autoriteit ten aanzien van het inwinnen en verwerken van politiële gegevens. De inlichtingen van de bestuurlijke politie worden ingewonnen en verwerkt onder het gezag van de Ministér van Binnenlandse Zaken en de

238. Opdrachten van gerechtelijke politie worden uitgeoefend overeenkomstig artikel 28 bis, 28ter, 55 en 56 Sv. Artikel 28bis Sv ziet op de opsporing en de daartoe behorende zogeheten proactieve recherche. Hieronder wordt in België op grond van artikel 28 bis $\$ 2$ verstaan: "met het doel te komen tot het vervolgen van daders van misdrijven, het opsporen, het verzamelen, registreren en verwerken van gegevens en inlichtingen op grond van een redelijk vermoeden van te plegen of reeds gepleegde maar nog niet aan het licht gebrachte strafbare feiten, en die worden of zouden worden gepleegd in het kader van een criminele organisatie, zoals gedefinieerd door de wet, of misdaden of wanbedrijven als bedoeld in artikel 90 ter, $\$ \$ 2,3$ en 4, uitmaken of zouden uitmaken." Uit de aard van deze proactieve recherche zullen met name in deze fase van opsporing zachte gegevens worden ingewonnen en verwerkt. De proactieve recherche is in werking getreden op 21 mei 2002. Artikel 28ter Sv ziet op de procedures ten aanzien van de Procureur des Konings, te vergelijken met de Nederlandse Officier van Justitic. Artikel 55 Sv beeft betrekking op het gerechtelijk onderzoek en artikel $56 \mathrm{~Sv}$ op de onderzoeksrechter, te vergelijken met de Nederlandse Rechter-Commissaris.

239. Zoals bedoeld in artikel 6 van de Wet van 8 december 1992 tot bescherming van de persoonlijke levenssfeer ten opzichte van de verwerking van persoonsgegevens, B.S. 30 december 1993. 
inlichtingen van gerechtelijke politie onder het gezag van de Minister van Justitie, onverminderd de eigen bevoegdheden van de gerechtelijke overheden.

Art. 44/4 WPA heeft, zoals gezegd, betrekking op de ene algemene nationale gegevensbank. In de algemene nationale gegevensbank zijn meerdere indexsystemen vervat. De Belgische politiediensten dienen hun inlichtingen ambtshalve en rechtstreeks over te maken aan deze algemene nationale gegevensbank, die wordt beheerd binnen een algemene directie die belast is met de ondersteuning en onder toezicht staat van een controleorgaan, zoals geregeld in artikel 44/7 WPA. De Ministers van Binnenlandse Zaken en van Justitie dienen de categorieën van inlichtingen en gegevens te bepalen die geen toezending vereisen. Er dient nog uitvoeringswetgeving te worden vastgesteld, waarin de voorwaarden worden vastgelegd waaronder de algemene nationale gegevensbank en elk van de indexsystemen toegankelijk en bevraagbaar zijn door de bevoegde gerechtelijke overheden alsmede door de politiediensten.

Op grond van artikel 44/5 WPA hebben de Belgische politiediensten een informaticplicht ten aanzien van de gerechtelijke en bestuurlijke autoriteiten, elk voor de gegevens die hen betreffen. Ingevolge artikel 44/6 WPA dient de gerechtelijke informatie aan de gerechtelijke autoriteiten te worden meegedeeld. Dit dient overeenkomstig de procedures van het Belgische Wetboek van Strafvordering te geschieden (art. 28bis, 28ter, 55 en $56 \mathrm{~Sv})$.

Art. 44/7 WPA roept een controleorgaan in het leven, geleid door een federaal magistraat, dat is belast met de controle op de naleving van de toegangsregels tot de algemene nationale gegevensbank en het zenden van de gegevens naar deze gegevensbank. Het controleorgaan staat onder het gezag van de Ministers van Binnenlandse Zaken en van Justitie. Het controleorgaan beschikt hiertoe over een onbeperkte toegang tot de informatie en de lokalen waar de ambtenaren hun taken uitvoeren. Artikel 44/7 WPA bepaalt verder dat de politiediensten in bijzondere omstandigheden andere gegevensbanken kunnen oprichten dan de algemene nationale gegevensbank, na voorafgaande aanmelding aan het controleorgaan. Normaal gesproken dienen alle gegevens uit deze andere gegevensbanken ook medegedeeld te worden aan de algemene nationale gegevensbank, behoudens een akkoord van het controleorgaan tot niet-mededeling. In uitvoeringswetgeving dient de toegang tot en de bevraagbaarheid door de bevoegde overheden en de politiediensten nader geregeld te worden. Het controleorgaan oefent ook met betrekking tot de andere gegevensbanken haar controlebevoegdheden uit.

Art. 44/8 WPA ziet op het uitstellen van de toezending van informatie naar de algemene nationale gegevensbank, met andere woorden op een tijdelijk embargo op bepaalde informatie. Het toezenden van informatie kan enkel door de bevoegde magistraat en in een akkoord met de federale Procureur bij (hoge) uitzondering worden uitgesteld, in 
geval van gevaar voor de uitoefening van de strafprocedure of voor de veiligheid van een persoon. In artikel 44/9 WPA is een bijzonder statuut voorzien voor de beheerders van de algemene nationale gegevensbank om hun onafhankelijkheid en hun neutraliteit te waarborgen. Artikel 44/10 vermeldt dat de uitvoeringsprincipes aangaande het informatiebeheer uiteindelijk bij Koninklijk Besluit dienen te worden vastgelegd, in beginsel na advies van de Belgische gegevensbeschermingsautoriteit, zijnde de CBPL. Dit is dus nog niet gebeurd. Artikel 44/11 WPA sanctioneert in uitzonderlijke gevallen ten slotte het achterhouden en niet doorzenden van informatic naar de algemene nationale gegevensbank. Dit kan evenwel strafrechtelijk worden bestraft.

\section{Doelbinding en concreet belang}

Het concrete belang voor de uitoefening van de opdrachten van de gerechtelijke en bestuurlijke politie bij het inwinnen en verwerken van politiële gegevens uit artikel 44/1 WPA is gebonden aan het wettelijk gerechtvaardigde karakter van de inhoud, van de vorm en van de exploitatietermijnen van de gegevens bij elke stap van de informatieverwerking in het raam van de uitoefening van wel bepaalde opdrachten van gerechtelijke of bestuurlijke politie. Het principe van dit begrip berust met andere woorden op de doelstellingen waarvoor de politiële informatie wordt verwerkt. Dit is te vergelijken met het Nederlandse doelbindingsbeginsel. Deze doelstellingen zijn zelf gebaseerd op de informatiebehoeften in het raam van de uitvoering van de opdrachten van gerechtelijke en bestuurlijke politie, met name:

- hulp bij de controle van personen, vervoermiddelen of voorwerpen tegenover dewelke een politiële, gerechtelijke of bestuurlijke maatregel moet worden genomen;

- hulp bij het beheer van evenementen van bestuurlijke politie: gebruik voor operationele doeleinden, voor doeleinden van informatie van de bevoegde autoriteiten (bestuurlijke, gerechtelijke, militaire) en van beheer in het raam van de veiligheidsplannen;

- hulp bij het gerechtelijk opsporingswerk of het administratief onderzoek;

- hulp bij het beheer, in het kader van de beleidsontwikkeling met betrekking tot de nationale of lokale veiligheidsplannen.

Het begrip 'concreet belang' kan worden verzekerd door achteraf genomen maatregelen waardoor niet om het even welke informatie geregistreerd wordt en blijft. Het betreft hier aangepaste zogeheten ventilatietermijnen van de informatie (gelimiteerde opslagtermijnen), bijzondere maatregelen voor toegang tot de informatie, een strikte controle van de kwaliteit en relevantie van de gegevens door de Directie van de nationale gegevensbank, het Controleorgaan of de CBPL. Dit alles dient dus nog zijn wetttelijke verankering te krijgen in Koninklijke Besluiten ter uitvoering van de WPA. 


\section{Het onderscheid tussen harde en zachte politiële informatie naar geldend Belgisch recht}

Het onderscheid tussen harde en zachte informatic is in België niet zuiver te maken. Het zou cenvoudig zijn om aan te nemen dat alles wat in een proces-verbaal of politiecomputer is opgenomen, beschouwd kan worden als harde informatie. De gedachtegang is als volgt. Zowel aan de input in de computers als aan de processen-verbaal worden eisen van nauwkeurigheid en zorgvuldigheid gesteld, die zouden moeten leiden tot harde informatie. Daarnaast verplicht artikel 40 WPA elke politieambtenaar om van alle klachten, aangiften, inlichtingen en vaststellingen proces-verbaal op te maken en deze naar het $O M$ door te sturen. ${ }^{240}$ Toch is deze bepaling minder absoluut dan het lijkt. Allereerst zal een politieman geen proces-verbaal opmaken van dubieuze informatic of informatie die de informant in gevaar kan brengen. Verder bestaat er in de praktijk de mogelijkheid tot een vertrouwelijk verslag, waarbij de Procureur wel in kennis wordt gesteld van de belangrijke informatie, maar die informatie minder openbaar is dan bij een 'gewoon' procesverbaal. ${ }^{241}$ Het is onduidelijk in hoeverre dit toelaatbaar is in het licht van artikel 40 WPA, dat immers duidelijk spreekt over een proces-verbaal. Een formele interpretatie van dit artikel laat niet toe dat men een verslag in vrije vorm opstelt. Zo kan dus van zachte informatic toch een registratic worden opgemaakt, bij gebrek aan een nationaal formeel register van zachte informatie. Enkele politiezones en -diensten hebben de afgelopen jaren hun eigen CIE-achtige ${ }^{242}$ systeem opgezet. Zo was in Leuven een eigen variant van het zogenoemde Multisys-programma in gebruik, terwijl de Gentse politie het programma RBS ${ }^{243}$ gebruikte. De politiehervorming heeft echter aan deze wildgroei van systemen een eind gemaakt. Artikel 44/4 WPA stelt onomwonden dat er een algemene nationale gegevensbank bestaat waarin persoonlijke gegevens kunnen worden opgeslagen.

In de omzendbrief van 14 juni 2002 worden enkele sprekende voorbeelden gegeven die het op redelijk concrete wijze mogelijk maken om bestanddelen van het concrete politiële belang beter af te bakenen. Volgens de omzendbrief kan ervan worden uitgegaan dat informatie die in processen-verbaal wordt opgenomen een concreet belang inhoudt. De opsteller beschrijft immers de informatie en de vaststellingen betreffende de gebeurtenis waarvan hij kennis heeft genomen, alsook de onderzoeksdaden die hij ter zake stelt. Dat is 'harde' concrete informatie. Dit geldt niet voor het verhoor dat de woorden van een

240. Vroeger was bij de Rijkswacht met name het systeem POLIS in gebruik.

241. Een mogelijkheid hierbij is het artikel 44/8 WPA, op basis waarvan een Procureur bepaalde informatic onder zich kan houden indien het doorgeven van de informatic de "uitoefening van strafvordering of de veiligheid van een persoon in gevaar kan brengen".

242. CIE staat voor de (Nederlandse) Criminele Inlichtingen Eenheid.

243. Het is ons niet bekend of dit hetzelfde is als het Recherche Basissysteem zoals dat in bepaalde regio's in Nederland in gebruik is, of dat de gelijkheid in naam slechts roevallig is. 
derde persoon weergeeft. Er dient een grondige beoordeling te worden uitgevoerd alvorens de inlichtingen van het verhoor in de algemene nationale gegevensbank mogen worden geregistreerd. De discussie gaat dus veeleer over de informatie die niet in een procesverbaal is opgenomen. Met deze constatering zijn wij aangeland bij de kern van ons onderzoek, namelijk de informatic betreffende niet-concrete feiten, zoals dit in Belgie̋ wordt aangeduid, of de in het Nederlands zogeheten 'zachte' informatie. Zachte informatie mag ook worden geregistreerd evenals harde feiten. Op grond van geldend Belgisch recht is de politieambtenaar de essentiële filter die oordeelt of de informatie waarvan hij of zij kennis heeft genomen, voldoende belangrijk is om in een zogeheten informatierapport te worden geregistreerd en te worden meegedeeld aan het zogenoemde arrondissementele informatiekruispunt (AIK), de voorloper van de ANG, en de algemene nationale gegevensbank ANG. In het basisdocument dient een duidelijke motivering vermeld te worden op basis waarvan bepaalde entiteiten met een criminele context kunnen worden verbonden.

De informatie-inzameling verbonden met het aan het licht komen van een gebeurtenis, met het oog op het nemen van maatregelen door de bestuurlijke overheid, vormt een laatste voorbeeld van een concreet belang.

Met in het achterhoofd dit onderscheid tussen harde en zachte informatie en de informatie-inzameling met het oog op het nemen van maatregelen door de bestuurlijke overheid, geven wij thans enkele voorbeelden van informatie die een concreet belang vertonen voor de uitoefening van de politieopdrachten. $\mathrm{Zij}$ worden eveneens ter verduidelijking genoemd in de omzendbrief van 14 juni 2002. Het betreft de volgende voorbeelden: - het plegen van een hold-up in een bankinstelling: dit is concrete informatie van de gerechtelijke politie;

- de door een tipgever verstrekte informatie van plannen om een diefstal gewapenderhand te plegen in een apotheek: dit is niet-concrete informatie van de gerechtelijke politie;

- het aankondigen van de organisatie van een betoging in Brussel gedurende een Europese top; dit is concrete informatie van de bestuurlijke politie (OOV);

- de informatie dat hooligans een voetbalwedstrijd willen verstoren door het aanvallen van de supporters van de tegenpartij; dit betreft niet-concrete informatie van de bestuurlijke politie.

De bovenstaande voorbeelden geven heel goed het onderscheid aan tussen zachte en harde informatie. Beide soorten informatie kunnen een concreet belang vertegenwoordigen voor de opdrachten van de gerechtelijke politie (recherche naar Nederlandse begrippen) of de bestuurlijke politie (OOV naar Nederlandse begrippen). 
De algemene nationale gegevensbank is een conceptueel model dat zich op de twee niveaus van de geïntegreerde politie situeert: het lokale niveau (de lokale politie) en het federale niveau (de federale politie met zijn federale en gedeconcentreerde diensten). Er is slechts één algemene nationale gegevensbank met zowel concrete als niet-concrete bestuurlijke en gerechtelijke informatie. $\mathrm{E} r$ bestaat een absolute informatieplicht voor alle betrokken politieambtenaren (behalve in enkele uitzonderingsgevallen) en er is een maximale en gestructureerde doorstroming van de informatic. De informatiebehoeften dienen in het dagelijks werk van de politieambtenaar te worden geïntegreerd. De toegang tot de informatie door bevoegde overheden en politiediensten dient te worden gemoduleerd naar gelang de aard van de informatic. Dit dient te gebeuren door het invoeren van gebruikscodes en/of evaluatieroosters. Er dient te worden voorzien in een maximale toegankelijkheid van de informatie voor de politiediensten, op voet van gelijkheid, alsook voor de bevoegde gerechtelijke overheden. De naleving van de bepalingen van de Wet van 8 december 1992 tot bescherming van de persoonlijke levenssfeer ten opzichte van de verwerking van persoonsgegeven $5^{244}$ en haar uitvoeringsbesluit staat dan ook centraal.

Krachtens de artikelen 44/4, 44/6 en 44/7 WPA dient alle door de politiediensten verzamelde informatic aan de algemene nationale gegevensbank te worden gezonden. De wet voorziet de mogelijkheid voor de politiediensten om in bijzondere omstandigheden gegevensbanken te creëren, met voorafgaande mededeling aan het controleorgaan. De creatie van bijzondere gegevensbanken door de politiediensten is tijdens de overgangsperiode waarin de uitvoeringsteksten van de wet worden opgesteld evenwel aan een zogeheten moratorium (tijdelijke opschorting) onderworpen, met uitzondering van overleg met de Directie van de nationale gegevensbank (DSB).

Ter concretisering van de informatieverwerking is de algemene nationale gegevensbank er voor en door de politiemensen op het betreffende terrein. Zij vormen de belangrijkste betrokken partij als leveranciers en eindgebruikers van de informatie. De verantwoordelijken voor deze gegevensbank zijn de Directeur-generaal van de Algemene Directie van de Operationele Ondersteuning en zijn medewerkers belast met het beheer op functioneel (Directie van de nationale gegevensbank - DSB) en technisch vlak (Directie van de Telematica - DST). In de logica van de integratie is de Directeur-generaal van de operationele ondersteuning onder de coördinatie van de Commissaris-generaal verantwoordelijk voor de organisatic van het informatiebeheer ten overstaan van de Ministers. De algemene nationale gegevensbank wordt beheerd in een dienst die onder leiding staat van een diensthoofd en een adjunct-diensthoofd. Eén van beide behoort tot de federale politie en de andere behoort tot de lokale politie.

244. Wet van 8 december 1992 tot bescherming van de persoonlijke levenssfeer ten opzichte van de verwerking van persoonsgegevens, B.S., 30 december 1993. 
Door de Belgische lokale politie is het Informatiesysteem Lokale Politie (ISLP) in gebruik genomen. Dit systeem biedt enkele bijkomende functionaliteiten, bijvoorbeeld de toevoeging van navolgende processen-verbaal, een eenvormige toegang tot het Rijksregister en beheer van personeel. Alle politiezones hebben een nieuwe server ontvangen en 161 politiezones werken nu daadwerkelijk met ISLP. Dit gebeurt ook op de erkende provinciale scholen.

Alle Belgische politiezones en alle diensten van de federale politie hebben een rechtstreekse toegang tot de algemene nationale gegevensbank ANG. Er zullen binnenkort (2003/2004) 450 servers (waarvan 80 procent bestemd is voor de lokale politie) worden aangekocht en geleverd. Zij zijn nodig voor complexe opzoekingen op lokaal en arrondissementeel niveau van informatie uit de ANG. Medio 2003 voeden 125 politiezones rechtstreeks de ANG. ${ }^{245}$ De informatie van de overige zones wordt, als overgangsmaatregel (zie verderop), door het arrondissementele informatiekruispunt AIK geregistreerd.

Er is een overgangsreglement voor het beheer van politiële informatie, dat de regels bevat voor de werking van de algemene nationale gegevensbank.

Dit reglement is als volgt georganiseerd. Het bevat vier boeken:

- Boek 1: de verwerking van de informatie inzake gerechtelijke politie;

- Boek 2: de verwerking van de informatie inzake bestuurlijke politie;

- Boek 3: de verwerking van de informatie inzake de politie van het wegverkeer;

- Boek 4: de richtlijnen inzake de bescherming van de persoonlijke levenssfeer.

Boek 4 is nog niet verspreid. Elk van deze boeken is op dezelfde wijze gestructureerd. $\mathrm{Zij}$ bevatten een algemene nota die de grote lijnen van de inzameling en verwerking van politiële informatie beschrijft. Deze uitleg verwijst tevens naar een reeks fiches. Daarnaast zijn er fiches per onderwerp die de precieze richtlijnen aangeven die de politieambtenaren moeten volgen. Dit 'handboek' zal geleidelijk aangepast worden en bevat thans de meest dringende richtlijnen, die op korte termijn onontbeerlijk waren. Aangezien het document uit modules is samengesteld, volstaat het om, indien nodig, nieuwe fiches toe te voegen ter vervanging van de verlopen fiches.

\section{Omzendbrief internationale politiesamenwerking met gerechtelijke finaliteit}

Hoe het Belgische juridische kader omtrent de uitwisseling van gegevens - en dus ook van zachte gegevens - met het buitenland eruit ziet, is neergelegd in een gezamenlijke omzendbrief van de Minister van Justitie en het College van Procureurs-Generaal betref- 
fende de internationale politiesamenwerking met een gerechtelijke finaliteit. ${ }^{246} \mathrm{Er}$ is gekozen voor de vorm van een omzendbrief omdat er onvoldoende nationale wet- en regelgeving terzake aanwezig is. De omzendbrief beschrijft een uniforme werkwijze op federaal vlak voor de internationale gegevensuitwisseling. Tevens heeft zij als doel de toelaatbaarheid en de rechtmatigheid van de internationale politiesamenwerking met een gerechtelijke finaliteit door de Belgische politiediensten te toetsen. De gebruikte terminologie 'met een gerechtelijke finaliteit' ziet op het feit dat de omzendbrief alleen betrekking heeft op de internationale politiesamenwerking van gerechtelijke aard (recherche) en niet op de politiesamenwerking die louter en alleen betrekking heeft op opdrachten van de administratieve of bestuurlijke politie (OOV). ${ }^{247}$ In Belgiē zijn de zogeheten Nationale Magistraten, die onder toezicht en onder de leiding staan van een lid van het College van Procureurs-Generaal, belast met de coördinatie van de uitoefening van de strafvordering, alsmede met het vergemakkelijken van de internationale samenwerking. Dit gebeurt in overleg met één of meer Procureurs des Konings. ${ }^{248}$ Op grond van de SUO en de Europol-Overeenkomst dient één nationaal contactpunt belast te zijn met de internationale samenwerking (zie ook hoofdstuk 8). Op grond van artikel $4 \$ 1$ sub $1^{\circ}$ Koninklijk Besluit (KB) op de Algemene Politiesteundienst van 11 juli 1994 was dat contactpunt in België voor de buitenlandse diensten en organisaties de Afdeling internationale politiesamenwerking (IPS). In de nieuwe structuur van de Belgische geïntegreerde politie, is de Directie beleid inzake internationale politiesamenwerking dit

246. De omzendbrief is van 14 februari $2000 \mathrm{en}$ is in werking getreden op 1 maart 2000. $\mathrm{Zij}$ is verspreid door het College van Procureurs-Generaal in de Omzendbrief nr. COL. 2/2000 van het College van Procureurs-Generaal bij de Hoven van beroep. Brussel, 18 februari 2000. Deze omzendbrief vervangt de omzendbrief van 22 september 1997 inzake de "Internationale uitwisseling van gegevens met gerechtelijke finaliteit door Belgische politiediensten aan het buitenland."

247. De gerechtelijke politiele finaliteit wordt gedefinieerd door artikel 15 WPA, dat als volgt luidt:

"Bij het vervullen van hun opdrachten van gerechtelijke politic, hebben de politiediensten als taak:

1" de misdaden, de wanbedrijven en de overtredingen op te sporen, de bewijzen ervan te verzamelen, daarvan kennis te geven aan de bevoegde overheden, de daders ervan te vatten, aan te houden en tet beschikking te stellen van de bevoegde overheid, op de wijze en in de vorm bepaald door de wet;

$2^{\circ}$ de personen in wier aanhouding door de wet wordt voorzien, op te sporen, te vatten, aan te houden en ter beschikking te stellen van de bevoegde overheden;

$3^{\circ}$ de voorwerpen waarvan de inbeslagneming voorgeschreven is, op te sporen, in beslag te nemen en ter beschikking te stellen van de bevoegde overheden;

$4^{\circ}$ het verslag van hun opdrachten en de inlichtingen die zij naar aanleiding ervan hebben ingewonnen aan de bevoegde overheid bezorgen."

248. Zie artikel 144 bis $\$ 3$ sub $1^{\circ} \mathrm{GWb}$, zoals ingevoegd door artikel 5 van de wet van 4 maart 1997 tot instelling van het College van Procureurs-Generaal en tot instelling van het ambe van Nationaal Magistraat. 
contactpunt. ${ }^{249}$ Deze Directie valt onder het Commissaritaat-Generaal van de federale politie. De afkorting die voor het nationale contactpunt wordt gehanteerd is het CGI. ${ }^{250}$ Het CGI dient te waken over de rechtmatigheid van elke verwerking van informatie, zowel de harde als de zachte informatie. Tevens dient zij te waken over de naleving van de procedures bij het uitvoeren van grensoverschrijdende politicoperaties. Op basis van artikel 39 lid 3 en 46 lid 2 SUO mag in Belgiē alleen rechtstreekse uitwisseling met het buitenland plaatsvinden door politiediensten in dringende gevallen. Dringende gevallen zijn gevallen waarin het verzoek via het nationaal contactpunt niet tijdig kan worden gedaan. Het CGI dient van het rechtstreekse contact en de uitgewisselde gegevens onverwijld schriftelijk in kennis te worden gesteld. Op grond van artikel 39 lid 4 en 5 en artikel 46 lid 2 SUO vormt het zogeheten OIPG het contactpunt voor de gegevensuitwisseling in de grensgebieden. Op grond van de omzendbrief dienen de OIPG's en het nationaal contactpunt binnen én gemeenschappelijk netwerksysteem te zijn opgenomen. Dit is met het EMMI /PALMA-netwerk reeds gerealiseerd. Wat Europol betreft (zie hoofdstuk 8) dient de gegevensuitwisseling enkel via het nationale contactpunt te geschieden, ook in dringende gevallen.

\section{Twee categorieèn gegevens}

De gegevens die voor uitwisseling met het buitenland in aanmerking komen, worden in de omzendbrief internationale politiesamenwerking met een gerechtelijke finaliteit opgedeeld in twee categorieën. De eerste categorie betreft gegevens die door de politiediensten autonoom en zelfstandig mogen worden uitgewisseld. De tweede categorie betreft gegevens die slechts door de politiediensten mogen worden uitgewisseld na voorafgaande toestemming van de Belgische gerechtelijke autoriteiten.

De gegevens van de eerste categorie staan op een lijst in een bijlage A bij de omzendbrief. Voor het inwinnen van de gegevens van de eerste categorie mogen geen dwangmiddelen worden ingezet. Bij doorgifte van deze informatie naar het buitenland dient op de gegevensdrager de vermelding 'enkel voor politionele doeleinden' te worden aangebracht. Indien de betreffende buitenlandse politiedienst de gegevens wil gebruiken als bewijs in strafzaken, dient zij eerst de toestemming te verkrijgen van hetzij de Nationaal Magistraat, hetzij van de magistraat van het lokale parket, in functie van de door de wet voorziene bevoegdheidsregeling. Als niet duidelijk is of de verzochte informatie in het kader van een verzoek tot politiële samenwerking valt of eigenlijk betrekking heeft op een

249. Zie hieromtrent het Koninklijk besluit met berrekking tot de commissaris-generaal en de algemene directies van de federale politic van 3 september 2000, B.S. 23 september 2000.

250. CG staat naar alle waarschijnlijkheid voor Commissariaat-Generaal en de I voor Internationale politiesamenwerking. 
rechtshulpverzoek, dient het buitenlandse verzoek voor advies te worden voorgelegd aan de Nationaal Magistraat.

De Belgische bevoegde rechterlijke autoriteiten kunnen met betrekking tot de gegevens van de eerste categorie te allen tijde met betrekking tot specifieke onderzoeken hetzij beperkende voorwaarden, hetzij een volledig 'embargo' opleggen aan de gegevensuitwisseling. In het laatste geval kan enkel informatie worden doorgegeven na toestemming van de bevoegde gerechtelijke autoriteit.

De lijst van bijlage A van de omzendbrief kan natuurlijk bijgewerkt worden met betrekking tot de gerechtelijke evaluaties. De eventuele officiële aanpassingen dienen aan het CGI ter kennis te worden gebracht door de tussenkomst van de Nationaal Magistraat.

Gegevens van de tweede categorie, dus gegevens die door de politiediensten slechts kunnen worden uitgewisseld na voorafgaande toestemming van de rechterlijke autoriteiten, zijn alle gegevens die buiten de gegevens op de lijst van bijlage A van de omzendbrief vallen. Voor deze gegevens van de tweede categorie is uitwisseling met het buitenland dus slechts mogelijk na voorafgaande toestemming van een magistraat, hetzij de Nationaal Magistraat, hetzij de lokale parketmagistraat. De magistraat die door de betreffende Belgische politiedienst wordt geraadpleegd kan twee dingen doen. Ofwel geeft de magistraat toestemming om de gevraagde gegevens aan de verzoeker door te geven, ofwel geeft de magistraat de opdracht om aan de verzoeker ter kennis te brengen dat een rechtshulpverzoek vereist is. In spoedeisende gevallen kan in het laatste geval toestemming worden gegeven om de gevraagde gegevens voorlopig door te geven, op voorwaarde dat de vraag zal worden bevestigd door een rechtshulpverzoek. Onder meer in de volgende gevallen zal steeds een rechtshulpverzoek worden geëist:

- informatie die moet worden verstrekt door financiële instellingen en door administratieve overheden, zoals de Cel voor Financiële Informatieverwerking (art. 11 en volgende van de wet van 11 januari 1993 tot voorkoming van het gebruik van het financiële stelsel voor het witwassen van geld);

- informatie waarvan de opsporing een dwangmaatregel of een schending van individuele rechten en vrijheden inhoudt (inclusief de inbeslagneming);

- informatie die betrekking heeft op het gerechtelijke gevolg dat aan een bepaald feit werd gegeven (veroordeling, opschorting, internering, ontzetting ouderlijke macht en maatregelen jeugdbescherming, minnelijke schikking et cetera), alsmede informatie met betrekking tot de tenuitvoerlegging van deze uitspraken (gratie, eerherstel, voorwaardelijke invrijheidstelling, et cetera);

- wanneer voor het inzamelen van de informatie krachtens de nationale wet of een interne circulaire een vordering of de instemming van een magistraat is vereist, bijvoorbeeld bij de identificatie van een telefoonnummer of van een abonnee met de noodzakelijke medewerking van een operator van een telecommunicatienetwerk of 
van een verstrekker van een telecommunicatiedienst (art. 46bis Sv) of bij toepassing van de bijzondere opsporingstechnieken (circulaire van de Minister van Justitie van 22 april 1990).

Naar Belgisch recht heeft de opsporingsbevoegdheid van de politiediensten als doel de vervolging van strafbare feiten. De leiding van de vervolging ligt bij het $\mathrm{OM}$. Daardoor behoort het 'beschikkingsrecht' over alle informatie die betrekking heeft op de opsporing en de vervolging van strafbare feiten tot de uitsluitende bevoegdheid van de gerechtelijke autoriteiten.

Het beheer van het nationale gedeelte van de internationale informatiesystemen, met name EMMI en het informatiesysteem van Europol (en Interpol), in het domein van de politiesamenwerking wordt uitgeoefend door het CGI. Het CGI is verantwoordelijk voor de communicatie met de internationale informatiesystemen en voor de analysebestanden inzake politiesamenwerking. Zij voert ter zake, onder toezicht van de Nationaal Magistraat, de rechtmatigheidcontrole uit.

De (toekomstige) nadere richtlijnen inzake de invoer, de wijziging, het gebruik en de verwijdering van de Belgische gegevens in internationale gegevensbanken, onder voorbehoud van de toepasselijke bepalingen inzake bescherming van de persoonsgegevens, dienen aan de voorafgaande goedkeuring van het College van Procureurs-Generaal onderworpen te worden.

De deelname van het CGI aan strategische analyses in het gerechtelijk domein valt onder het toezicht van de Nationaal Magistraat. Het CGI en dé betrokken politiedienst dienen ieder voorstel uitgaande van Belgische diensten of van een internationale organisatie werkzaam in het domein van de internationale samenwerking tussen rechtshandhavingdiensten aan het voorafgaand advies van de Nationaal Magistraat te onderwerpen. Bij negatief advies dient het dossier ter beslissing overgemaakt te worden aan de Minister van Justitie en, in voorkomend geval, aan de Minister van Binnenlandse Zaken.

Het CGI mag de deelname van België aan grensoverschrijdende projecten binnen het toepassingsgebied van de proactieve recherche (zoals gedefinieerd in artikel $28 \mathrm{bis} \$ 2 \mathrm{~Sv}$ ) slechts goedkeuren na de voorafgaande schriftelijke toestemming van de Nationaal Magistraat die bevoegd is voor de uitwisseling van algemene gerechtelijke informatie die bij verschillende parketten aanwezig is. De Nationaal Magistraat dient de lokaal bevoegde Procureur des Konings te informeren over specifieke projecten. De deelname van België aan zaakgebonden operationele criminaliteitsanalyses is aan de voorafgaande goedkeuring van de Nationaal Magistraat onderworpen. Specifiek met betrekking tot de werking van Europol is de Belgische vertegenwoordiger binnen de Raad van Bestuur 
gebonden door deze beslissing bij het goedkeuren van het bestandsreglement (zie over Europol nader hoofdstuk 8).

\section{Bevoegdheidsverdeling bij de afhandeling van internationale rechshulpverzoeken}

Inzake de bevoegdheidsverdeling bij de afhandeling van internationale rechtshulpverzoeken, wordt in Belgię een onderscheid aangebracht tussen nieuwe onderzoeken en lopende onderzoeken. Nieuwe onderzoeken die krachtens de omzendbrief internationale politiesamenwerking met een gerechtelijke finaliteit niet door de politiediensten autonoom mogen worden afgehandeld, dienen met het oog op de toewijzing van de zaak door het CGI aan de voorafgaande beslissing van de Nationaal Magistraat of de lokaal bevoegde magistraat te worden onderworpen. Het CGI dient vooraf middels consultatie van de beschikbare documentatie te verifiëren of er geen enkel verband bestaat met een reeds door een politiedienst gevoerd onderzoek. $\mathrm{Zij}$ meldt het resultaat van deze opzoeking aan de Nationaal Magistraat of de lokaal bevoegde magistraat. Deze bepaling is tevens van toepassing op de informatie-uitwisseling door de OIPG's. Indien een OIPG krachtens de omzendbrief niet autonoom informatie mag verstrekken, dient deze het verzoek over te dragen aan het CGI. Het CGI handelt dan volgens de procedure zoals hiervoor beschreven.

Bij lopende onderzoeken is de bevoegdheidsverdeling als volgt. Het opsporingsonderzoek wordt gevoerd onder de leiding en het gezag van de bevoegde Procureur des Konings en strekt zich mede uit over de zogeheten proactieve recherche. De Nationaal Magistraat vergemakkelijkt de internationale samenwerking in overleg met één of meer Procureurs des Konings. Het gerechtelijk onderzoek wordt gevoerd onder de leiding en het gezag van de onderzoeksrechter. Het CGI dient de opdrachten opgedragen door de onderzoeksrechter onverwijld uit te voeren en dient de Nationaal Magistraat hiervan in kennis te stellen. De politiedienst die belast wordt met de uitvoering van opdrachten van gerechtelijke politie en die een beroep wil doen op Europol, dient op het verzoek tot tussenkomst uitdrukkelijk de door de bevoegde magistraat gevraagde handelingen van gerechtelijke politie te vermelden. Het CGI dient hiervan onverwijld de Nationaal Magistraat op de hoogte te stellen door het overmaken van een kopie van het verzoek. De officieren of agenten van gerechtelijke politie die op eigen initiatief handelen en de medewerking van Europol verzoeken zijn onderworpen aan de specifieke regelgeving inzake de rechtspleging in het stadium van het opsporingsonderzoek en het gerechtelijk onderzock. De tussenkomst van Europol bij zaakgebonden grensoverschrijdende operaties dient aan het voorafgaandelijk akkoord van de Nationaal Magistraat te worden onderworpen. Het optreden van vertegenwoordigers van Europol ter ondersteuning van de specifieke onderzoeksacties door de bevoegde autoriteiten van de lidstaten dient door het $\mathrm{CGI}$ aan de voorafgaande toestemming te worden onderworpen van de Nationaal Magistraat, overeenkomstig de nationale regelgeving. 


\section{Registratie van de politiële rechtshulp en controle}

Het CGI dient op basis van de omzendbrief internationale politiesamenwerking met een gerechtelijke finaliteit een indexsysteem bij te houden om de grensoverschrijdende verwerking van gegevens door deze dienst, door de OIPG en in dringende gevallen door de politiediensten te registreren op basis van gemeenschappelijk met het College van Procureurs-Generaal bepaalde parameters. De OIPG's zijn met het indexsysteem verbonden. De Nationaal Magistraat is gerechtigd dit indexsysteem te raadplegen. Alle diensten die betrokken zijn bij de internationale doorgifte van gegevens (het CGI, de OIPG's en de politiediensten in gevallen van hoogdringendheid), waarop de omzendbrief betrekking heeft, zijn ertoe gehouden deze gegevensuitwisseling nauwkeurig te registreren volgens het bijgevoegd registratiemodel in bijlage B van de omzendbrief. De CBPL is in gelijke mate gerechtigd dit indexsysteem voor controledoeleinden te raadplegen op grond van artikel 32 van de Wet van 8 december 1992 tot bescherming van de persoonlijke levenssfeer ten opzichte van de verwerking van persoonsgegevens. Het CGI houdt toezicht op de wijze waarop de OIPG's en de politiediensten de richtlijnen van de omzendbrief naleven. De Nationaal Magistraat is belast met het toezicht op de controle uitgevoerd door het CGI. Deze controle is onder meer gericht op de naleving van de wetgeving inzake de bescherming van de persoonlijke levenssfeer bij de geautomatiseerde verwerking van persoonsgegevens. De registratie vindt feitelijk plaats in de EMMI/PALMA-omgeving. Gezien het praktische belang van de bijlagen A en B van de omzendbrief internationale politiesamenwerking met een gerechtelijke finaliteit geven wij deze integraal weer in Appendix C respectievelijk Appendix D.

Omdat de richtlijn enkel over gerechtelijke informatie gaat, doet de vraag zich voor of de internationale uitwisseling van bestuurlijke informatie ook is toegelaten. De taken van de bestuurlijke politie zich vooral op het beschermen van de openbare orde, het voorkomen van misdrijven en het beschermen van personen in nood. ${ }^{251} \mathrm{Er}$ is geen richtlijn bekend die nadere regels geeft voor het uitwisselen van bestuurlijke informatie op een internationaal niveau. Het doel van zo'n uitwisseling is ook onduidelijk. Indien het gegevens betreft die puur de bestuurlijke politie raken, conform het finaliteitsbeginsel, dan kan men zich afvragen in hoeverre uitwisseling op internationaal vlak nodig is. Voor zover uitwisseling van gegevens toch nodig blijkt, kan men zich wellicht beroepen op het gerechtelijke doel. Denk hierbij bijvoorbeeld aan een demonstratie waaraan mogelijk gewelddadige activisten deelnemen. 


\section{Protocolakkoord OIPG's}

Ingevolge een zogenaamd Protocolakkoord OIPG's, ${ }^{252}$ dat gebaseerd is op de voornoemde wetgeving en richtlijnen, moet een OIPG een groot aantal dingen doen, onder meer:

- op verzoek of op initiatief beschikbare informatie en documentatie over de werking, de opdracht en de statistieken van de diensten van administratieve en gerechtelijke politie aan haar buitenlandse pendant verstrekken, 'en omgekeerd';

- 'zich gereedhouden' om op verzoek van een buitenlandse politiedienst informatie te geven en om de contacten met de gerechtelijke, politiële en/of bestuurlijke autoriteiten of met een andere bevoegde dienst te vergemakkelijken; dit moet de opdracht van de buitenlandse politiedienst bevorderen;

- informatie verspreiden inzake grensoverschrijdende politiesamenwerking onder alle betrokken diensten, teneinde de samenwerking te bevorderen;

- het hoofd van de plaatselijke dienst/gebruiker informeren, indien die daarom verzoekt, over het gebruik van de informatie die hij of zij aan het OIPG heeft meegedeeld;

- ten bate van de politiediensten de grensverschijnselen registreren die betrekking hebben op de Schengenproblematiek; dit moet de politiediensten toestaan hun operationele werkzaamheden in de strijd tegen de grensoverschrijdende criminaliteit aan te passen;

- op een vraag van de Procureurs-Generaal de bevoegde (gerechtelijke) autoriteiten informeren over alles wat te maken heeft met grensoverschrijdende criminaliteit.

De politiediensten in de grenszones moeten volgens het Protocolakkoord OIPG's het OIPG-kanaal gebruiken voor de uitwisseling van informatie en van verzoeken om bijstand met de politiediensten in de grenszones van de 'vreemde landen'. Rechtstreekse grensoverschrijdende contacten tussen politiediensten zijn met name toegestaan:

- in dringende gevallen;

- om praktische details te regelen in zaken die reeds zijn toegewezen; en

- indien het OIPG niet beschikbaar is.

Nochtans moet dan de grensoverschijdende informatie wel worden meegedeeld aan het OIPG als de informatie nuttig blijkt voor alle politiediensten, en voor zover deze mededeling het goede verloop van het onderzoek niet schaadt. De informatie die door de OIPG's wordt gegeven of ontvangen, mag slechts dienen voor politiële doeleinden. Ze mag slechts gebruikt worden als bewijsmiddel in strafzaken indien de bevoegde gerechtelijke overheid daar een schriftelijke machtiging toe geeft.

252. Dit akkoord is opgesteld door "de vertegenwoordigers van de politiediensten met algemene bevoegdheid". 
Een politiedienst die aan een OIPG een inlichting verstrekt die bestemd is voor een buitenlandse politiedienst blijft de eerstgerechtigde ${ }^{253}$ tot die informatic. De verzending door het OIPG van die informatie en van de bijkomende inlichtingen waartoe het de aanzet heeft gegeven aan een andere politiedienst is slechts toegestaan met de instemming van de eerstgerechtigde tot die informatie.

Het OIPG moet de informatie registreren in een doorlopend register. Ze moet ook alle schriftelijke informatie en de formulieren waarop de mondelinge informatie is opgenomen, klasseren volgens het registratiemodel in de Omzendbrief van de Procureur-Generaal.

Alle informatie kan ter plaatse van het OIPG worden geraadpleegd door zogenaamde OIPG-contactofficieren die door de politiediensten zijn aangewezen.

Als een inlichting dringend ten nutte moet worden gemaakt, kan een OIPG, indien de politiedienst die eerstgerechtigde is tot de informatie is niet bereikbaar is, de inlichting versturen naar de politiedienst die het best in staat is de inlichting ten nutte te maken. Het OIPG moet de dienst die eerstgerechtigde is tot de informatie of alle diensten met algemene bevoegdheid daarvan op de hoogte brengen. Een inlichting wordt als dringend beschouwd wanneer de verlenging van de termijn ${ }^{254}$ van verzending aan de plaatselijke dienst, wegens de onmogelijkheid om er onmiddellijk mee in contact te treden, de mislukking van de 'preventie- of opsporingsacte' met zich mee dreigt te brengen.

ledere politiedienst kan bij een gerichte actie waarvan hij belanghebbende partij is, worden vertegenwoordigd in een OIPG door een verbindingsofficier die hiertoe door die dienst wordt aangesteld. De politiediensten moeten samênwerken met een OIPG 'in een geest van neutraliteit en gezonde samenwerking, en vice versa'.

Op vraag van de Procureurs-Generaal moeten de OIPG's de bevoegde (gerechtelijke) autoriteiten, en in voorkomende gevallen de Nationaal Magistraat, informeren over de beslissing die werd genomen evenals over de redenen die de uitvoering van een uitzonderlijke procedure, als hierboven beschreven, rechtvaardigen.

253. Het Protocolakkoord OIPG's gebruikt de term "eigenaar" van de informatic. Het gebruik van dergelijke privaatrechtelijke begrippen in dit verband lijkt ons niet juist.

254. Grensoverschrijdende informatic moet worden meegedeeld "indien ze nutrig blijkt voor alle politiediensten en voor zover deze mededeling het goede verloop van het onderzock niet schaadt". 


\section{Verhouding politie, OM, controleorgaan en rechtstreekse toegang in België}

Uit meerdere bepalingen blijkt dat de Belgische opsporing gebeurt onder de bevoegdheid en het gezag van het OM. De wet vermeldt nadrukkelijk dat de politieambtenaren de plicht hebben om zowel hun collega's als de Procureur op de hoogte te houden. ${ }^{255} \mathrm{Er}$ wordt in de toelichtende teksten veelvuldig gesproken over een 'absolute informaticplicht'. Dit geldt zowel als er een onderzoek loopt als wanneer die ambtenaren op andere manieren aan de noodzakelijke informatic komen. ${ }^{256}$

In de relatie tussen politie en het $\mathrm{OM}$ heeft de laatste nadrukkelijk het primaat. ${ }^{257}$ Artikel 22 van het Belgische Wetboek van Strafvordering benadrukt dat de Procureurs ${ }^{23 t}$ zijn belast met de opsporing en vervolging van misdrijven. Het OM dient dit gezag over de politie wel te delen met het Ministerie van Justitie. Dit wordt mede bevestigd in de artikelen 9 en 279 van het Belgische Wetboek van Strafvordering, dat aangeeft dat politieambtenaren onder het toezicht staan van de Procureur-Generaal. Om in de praktijk invulling te geven aan dit gezag dient door het $\mathrm{OM}$ een duidelijk opsporings- en vervolgingsbeleid ontwikkeld te worden. De Procureur, die de leiding heeft over de opsporing en vervolging, dient zijn gezag te delen met het College van Procureurs-Generaal. ${ }^{259} \mathrm{Dit}$ College kan door middel van richtlijnen specifieke instructies geven aan politieambtenaren. ${ }^{260}$ Het College beroept zich in haar richtlijnen op de autoriteit van het Ministerie van Justitie, onder wiens verantwoordelijkheid zij valt. Dit verklaart waarom de richtlijnen officieel 'ministeriële richtlijnen' heten.

Sinds enkele jaren worden er experimenten gedaan met de zogeheten autonome politionele afhandeling (APA). Dit is een vorm van onderzoek waarbij de politie zelf in belangrijke mate de loop van een relatief eenvoudig onderzoek bepaalt. Het $\mathrm{OM}$ dient de afhandeling dan enkel nog te bekrachtigen, al heeft de Procureur steeds de bevoegdheid

255. Voorbeelden hiervan zijn de artikelen 28 bis en 28 ter van het (Belgische) Wetboek van Strafvordering.

256. Het betreffende wetsvoorstel drukte het als volgt uit: "Alle relevante informatie, wasrvan zij in het kader van hun opdrachten kennis krijgen, dient effectief en zonder enige restrictie ter beschikking gesteld te worden van de bevoegde gerechtelijke overheden, overeenkomstig de richtlijnen van deze laatsten." Zie het wetsvoorstel tot organisatie van een geintegreerde politiedienst, gestructureerd op twee niveaus, Belgische Kamer van Volksvertegenwoordigers, gewone zitting 1997-1998, 15 juli 1998, 1676/1-97-98, p. 96.

257. Zie bijvoorbeeld artikel 40 WPA, dat aangeeft dat de politieambtenaar alle processen-verbaal aan de bevoegde gerechtelijke autoriteiten (het $\mathrm{OM}$ ) dient over te maken.

258. Dit zijn de Belgische tegenhangers van de Officieren van Justitie in Nederland.

259. Zie bijvoorbeeld artikel S/3 WPA, dat aangeeft dat de politieambtenaren voor hun taken van gerechtelijke politie relaties dienen te onderhouden met dit College en de Procureur.

260. Een voorbeeld hiervan is omzendbrief Col 6/99 van het College van ProcureursGeneraal bij de hoven van beroep, betreffende een ministeriele richtiijn tot regeling van de samenwerking, de coördinatie en de taakverdeling tussen de lokale politie en de federale politie inzake de opdrachten van gerechtelijke politie. 
om de afhandeling alsnog op zich te nemen indien hij of zij daartoe reden ziet. APA's worden met name in relatief veel voorkomende en eenvoudige zaken gebruikt. ${ }^{261} \mathrm{Het}$ voordeel van een APA is dat de politie een gedeelte van het werk van het OM kan overnemen. Enkele jaren geleden werd in bepaalde arrondissementen voorzichtig geëxperimenteerd met APA's, maar de verwachting is dat deze procedure op termijn landelijk wordt ingevoerd. Opvallend aan deze APA's is dat het de politie is die in beginsel over de vervolging beslist, wat dus ook inhoudt dat het primaat van het $\mathrm{OM}$ bij het vervolgingsproces minder absoluut is dan het lijkt.

Zoals eerder al vermeld worden er in de WPA strikte voorwaarden gesteld aan elke verstrekking van informatie. Met de invoering van een eenheidspolitie werden ook de databases van de drie grote politiediensten samengevoegd. ${ }^{262}$ Aan dit aspect is bij de politiehervorming grote aandacht besteed. Uiteindelijk is besloten om alle politie-informatie onder te brengen bij de federale politie. ${ }^{263} \mathrm{Om}$ de lokale politie niet al te afhankelijk te maken van de federale politie, is besloten om de dienst die deze gegevensbank beheert onder het gezag te stellen van zowel een federale als een lokale politieambtenaar.

De politie is dus de beheerder van de databank. Alle onderzoeksinformatie die de politie vergaart moet doorgegeven worden aan het OM. De vraag doet zich voor of het OM ook zelfstandig de nationale gegevensbank kan bevragen. Dit kan inderdaad. De wettekst geeft aan dat bij KB regels kunnen worden gesteld omtrent de gevallen waarin de 'gerechtelijke overheden' toegang hebben tot de databank. ${ }^{264}$ Hierbij worden wel enkele voorwaarden gesteld. Los van de te bepalen regels dient de bevraging te gebeuren in het kader van de uitvoering van hun opdrachten. $\mathrm{Bij}$ het bepalen van de nadere regels dient daarbij eerst de CBPL gehoord te worden. Zo'n KB is tót dusverre nog niet uitgevaardigd.

De centrale databank is gekoppeld aan een aantal andere databanken. Zo wordt direct doorverwezen naar het centrale strafregister en het centrale gedetineerdenbestand. ${ }^{265}$ Opvallend is dat het desbetreffende wetsvoorste ${ }^{266}$ ook melding maakt van het feit dat er

261. Het gaat hier bijvoorbeeld om bedreiging, vernieling, vandalisme, diefstal en heling. Zie ook Fijnaut, Van Daele \& Parmentier 2000, p. 22.

262. Zie arrikel 44/4 WPA. Er wordt hier gesproken over een "algemene nationale gegevensbank".

263. Dit hangt vermoedelijk samen met de "ondersteunende functie" van de federale politie, waartoe ook het beheer van de informatic wordt gerekend.

264. Zie artikel 44/4 lid 2 WPA. Hierin staat dat de Koning de voorwaarden bepaalt waaronder de nationale gegevensbank en de indexsystemen toegankelijk zijn voor de bevoegde gerechtelijke overheden en de politiediensten.

265. Beide gegevensbanken staan nadrukkelijk onder de controle van het Ministerie van Justitic.

266. Zie wetsvoorstel gewone zitting 1997-1998, 15 juli 1998, 1676/1-97-98. 
koppeling kan plaatshebben met internationale gegevensbestanden, zonder dat hierbij voorbeclden worden gegeven.

Uit artikel 44/7 WPA blijkt dat de algemene gegevensbank onder controle staat van een orgaan dat wordt voorgezeten door een federale magistraat en samengesteld is uit een lid van de lokale politie, de federale politie en een deskundige. Dit orgaan is dus niet hetzelfde als de CBPL. De leden worden aangewezen door de Ministers van Binnenlandse Zaken en Justitie. Het orgaan dient vooral de naleving van de regels en de toegankelijkheid van de gegevensbank te bewaken.

Elke oprichting van een andere databank door de politie dient gemeld te worden aan het controleorgaan. Dit betekent echter niet dat de politiediensten geen 'eigen' databanken meer mogen opzetten. Voor specifiek lokale toepassingen (bijvoorbeeld een 'vakantiebestand'van burgers die op vakantie gaan en die de politie vragen een oogje in het zeil te houden) is dit toegelaten, mits het controleorgaan daar toestemming voor geeft. Het orgaan dient te allen tijde volledige toegang tot de gegevens te hebben. Ook dienen de bestanden opvraagbaar te zijn door de andere relevante diensten, in overeenstemming met de plicht om andere politiediensten (en bestuurlijke overheden) op de hoogte te houden. Ten slotte dient het bestaan van zo'n lokale gegevensbank ook gemeld te worden binnen de algemene databank, zodat de andere diensten weten van het bestaan en indien nodig een bevraging kunnen doen.

Wie is nu verantwoordelijk voor deze nationale gegevensbank? De wettekst gaat expliciet op deze vraag in. Artikel 44/3 WPA bepaalt dat het verzamelen en verwerken van gegevens van bestuurlijke politie gebeurt onder de verantwoordelijkheid van de Minister van Binnenlandse Zaken. Gegevens van gerechtelijke politie daarentegen worden verzameld en verwerkt onder auspiciën van de Minister van Justitie. Daarbij komt dat de voorzitter van het controleorgaan zowel door de Minister van Binnenlandse Zaken als de Minister van Justitie wordt benoemd. Samenvattend kan gesteld worden dat de algemene gegevensbank onder de verantwoordelijkheid valt van beide ministers.

Omtrent de rechtstreekse toegang vermeldt artikel 16 par 2 sub $2^{\circ}$ WVP ten slotte dat de verantwoordelijke voor de verwerking of, in voorkomend geval, zijn vertegenwoordiger in België ervoor dient te zorgen dat voor de personen die onder zijn gezag handelen, de toegang tot de gegevens en de verwerkingsmogelijkheden, beperkt blijven tot hetgeen die personen nodig hebben voor de uitoefening van hun taken of tot hetgeen noodzakelijk is voor de behoeften van de dienst. De genoemde personen dienen zich er tevens van te vergewissen of programma's voor de geautomatiseerde verwerking van persoonsgegevens in overeenstemming zijn met de vermeldingen van de aangifte op grond van artikel 17 WVP en dat er geen wederrechtelijk gebruik van wordt gemaakt (art. 16 par 2 sub $4^{\circ}$ WVP). 


\section{Koppeling van gegevens en bestanden in België}

De WVP verbiedt noch in de private sector, noch in de publieke sector de koppeling van bestanden. Op grond van een over het algemeen permissieve grondhouding van België kan gesteld worden dat koppeling van gegevens daarom is toegestaan. Van de koppeling zal op grond van artikel 17 melding dienen te worden gemaakt in de aangifte van de verwerking aan de CBPL. De WVP machtigt in artikel 17 bis en artikel 44 WVP de Koning op voorstel of advies van de CBPL de materie van de koppeling nader te regelen of te verbieden bij een in Ministerraad overlegd besluit. Er zijn echter tot op heden nog geen wettelijke waarborgen geformuleerd voor koppelingen in het kader van de Belgische politiële gegevensverwerking. Kijkend naar het finaliteitsbeginsel kan in ieder geval opgemerkt worden dat koppeling enkel is toegelaten indien daar een duidelijk omschreven (politie)taak aan ten grondslag ligt. De voorwaarden die aan de verwerking worden gesteld zijn ook van toepassing indien een politiebestand wordt gekoppeld aan een nietpolitiebestand. Aangezien de privacybescherming van het politicbestand zwaarder is, profiteert het niet-politiebestand hiervan onder het beschermingsbeginsel en valt dus ook onder de zwaardere voorwaarden die gelden voor politiegegevens.

Wij merken ten slotte nog op dat artikel 16 par. 4 WVP een uitdrukkelijke beveiligingseis stelt. Er moeten passende technische en organisatorische maatregelen worden getroffen om de bestanden te beschermen tegen toevallige of ongeoorloofde vernietiging, tegen toevallig verlies, evenals tegen wijziging van of toegang tot en iedere andere niet toegelaten verwerking van persoonsgegevens. Deze maatregelen moeten een passend beveiligingsniveau verzekeren, rekening houdend met de stand van de techniek en de kosten voor het toepassen van de maatregelen. Ook moet rekening worden gehouden met de aard van de te beveiligen gegevens en de potentiële risicô's. ${ }^{267}$

\subsubsection{Duitse wetgeving}

In deze subsectie behandelen wij de Duitse wetgeving met betrekking tot de informatieve politiesamenwerking. Na een inleiding in deze paragraaf in het Duitse gegevensbeschermingsrecht, gaan wij achtereenvolgens in op (1) Duitse politiële databanken en zachte informatie, (2) doelbinding en het legaliteitsbeginsel, (3) internationale politiële gegevensuitwisseling in Duitsland, (4) uitzonderingen op gegevensuitwisseling door de Duitse politie, (5) de bevoegde Duitse politiële autoriteiten, (6) toezicht en controle op de Duitse internationale gegevensuitwisseling, (7) de verhouding tussen de politie, het $\mathrm{OM}$ en rechtstreekse toegang in Duitsland en ten slotte (8) koppeling van gegevens en bestanden in Duitsland.

267. Op advies van de CBPL kan de Koning voor alle of voor bepaalde categorieèn van verwerkingen aangepaste normen inzake informaticaveiligheid uitvaardigen. 
Wat het gegevensbeschermingsrecht betreft heeft Duitsland altijd voorop-gelopen. De eerste nationale gegevensbeschermingswet is de Datenschutzwet van de Duitse deelstaat Hessen. ${ }^{268}$

In 1983 veroorzaakte het Duitse Constitutionele Hof, het Bundesverfassungsgericht, een enorme verandering in het Duitse gegevensbeschermingsrecht. In het censusarrest of Volkszahlungsurteil oordeelde het Hof dat de combinatie van de constitutionele rechten van de individuele waardigheid van $\$ 1$ lid 1 GG en de individuele vrijheid van $\$ 2$ lid 1 GG een onderliggend constitutioneel recht op individuele zelfbeschikking impliceert. ${ }^{269}$ De burger heeft cen informationeel zelfbeschikkingsrecht. Het individu heeft de bevoegdheid in beginsel zelf te beslissen over het prijsgeven en het gebruik van zijn persoonlijke gegevens. Als gevolg van genoemd arrest moesten vanaf dat moment alle handelingen, waarbij de Duitse staat of zijn organen zonder de expliciete toestemming van het betreffende individu omgaan met persoonsgegevens, worden gebaseerd op een wet in formele zin. Omdat politiewerk hoofdzakelijk een kwestie is van het verzamelen, registreren, combineren en verwerken van informatie over individuele burgers, heeft het arrest de politięle sector meer geraakt dan enig ander onderdeel van de Duitse samenleving. Elke vorm van politieoptreden waarbij persoonsgegevens betrokken zijn, dient zijn eigen specifieke wettelijke basis te hebben.

Gegevensbescherming maakt in Duitsland in de eerste plaats onderdeel uit van de taak van de wetgever van de deelstaten. Dit komt doordat gegevensbescherming een kwestie is van bestuurlijke aard. Bijgevolg bestaan er voor de gehele Duitse politie maar liefst zestien gegevensbeschermingswetten van de deelstaten, de zogenaamde Landesdatenschutzgesetze. ${ }^{270}$ Verder is er een federale gegevensbeschermingswet (Bundesdatenschutzgesetz; BDSG). ${ }^{271}$ Meer specifieke regelingen voor het gebruik van politiegegevens staan in de wetgevingen voor de politiediensten van de deelstaten en van de Bondsstaat. Deze politiewetten bevatten gedetailleerde bepalingen over het verzamelen, registreren, verzenden, tegenhouden, veranderen, combineren en vernietigen van persoonsgegevens. Zij bevatten ook de voorwaarden voor deze vormen van politieel gegevensbeheer. Zolang geen van deze specifieke bepalingen van toepassing is, moet de Duitse politie de algemene gegevensbeschermingswetgeving respecteren. De algemene gegevensbeschermingswet-

268. Hessischer Datenschuregesets, 7 oktober 1970, GVBI, I, S 625. Deze wet heeft een grondmodel geleverd voor veel Europese databeschermingswetten.

269. BVerfG, 15 december 1983, BVerfGE 65, 1.

270. Zie bijvoorbeeld het Datenschutzgesetz Nondrhein-Westfalen (DSG NRW), Wet van 15 maart 1988, laatstelijk gewijzigd bij wet van 9 juni 2000, alsmede het Niedersalchsische Datenschutzgesetz (NDSG), Wet van 17 juni 1993, laatstelijk gewijzigd bij wet van 21 juni 2001.

271. Wet van 20 december 1990 (BGBL. I, S.2954), zoals laatstelijk gewijzigd door $\$ 2$, Abs. 5 des Begleitgesetzes sum Telekommanikationgeserz (BegleirG) van 17 december 1997 (BGBl. I S, 3108). 
geving houdt ook de bevoegdheid in van de controle-instantie van de deelstaten (Landesdatenschutzbeauftragter) of, voor de federale politiediensten, van de federale controleinstantie (Bundesdatenschutzbeauftragter) om de registratic en het gebruik van persoonsgegevens door de politie te controleren.

Het beheer en de regulering van politiële gegevens onder Duits recht worden gedomineerd door de tweedeling die de Duitse politietaken in het algemeen karakteriseert. Het betreft de scheiding tussen enerzijds de strafrechtshandhaving en anderzijds de loutere politietaken zijnde de voorkoming van gevaar en het proactief politieoptreden. Bijgevolg moet voor de internationale uitwisseling van politiële gegevens rekening worden gehouden met verschillende niveaus en soorten van wetgeving. Voor de uitwisseling van informatie in strafzaken zijn regelingen te vinden in het BKAG, in het Gesetz über die internationale Rechtshilfe in Strafsachen (IRG), alsmede in gezamenlijke Richtlijnen van de Bondsstaat en de deelstaten betreffende contacten met het buitenland bij strafzaken (Richtlinien für den Verkehr mit dem Ausland in strafrechtlichen Angelegenbeiten RiVASt). ${ }^{272}$ Het onderwerp van de internationale uitwisseling van gegevens voor pure (preventieve en proactieve) politietaken komt aan de orde in de meeste politiewetten van de deelstaten en in de federale politiewet. Deze politiewetten geven ook bijzondere regels ten aanzien van politieregisters, bijvoorbeeld in de $\$ \$ 9-33$ van de Politiewet van Noordrijn-Westfalen, het PolGNRW.

\section{Duitse politiële databanken en zachte informatie}

Duitsland kent verschillende soorten politiedatabanken. Dit komt deels door de federale organisatie van de Duitse politie en door de specialisatie, maar voor een belangrijk deel ook door de strikte wettelijke scheiding tussen pure politietaken en opsporing. Sommige databanken worden gezamenlijk beheerd en gebruikt door de politiediensten van de Bondsstaat en de deelstaten; andere databanken worden of door de politiediensten van de Bondsstaat of door die van de deelstaten beheerd en gebruikt. Ook merken wij op dat sommige databanken worden gebruikt voor typisch preventieve taken, terwijl andere databanken hoofdzakelijk proactieve of opsporingsdoeleinden dienen. Weer andere databanken bevatten enkel informatie over (voorlopige) hechtenis of grenscontroles. Kortom, het loopt nogal door elkaar.

Een strikte scheiding tussen 'harde' en 'zachte' informatie kan in Duitsland niet worden gemaakt. De politiewetten maken geen onderscheid tussen harde en zachte informatie. Dit heeft wellicht te maken met de Duitse cultuur waarin zachte gegevens in de politiepraktijk veel gemakkelijker uitgewisseld worden dan in de Nederlandse of de Belgische

272. Gepubliceerd in Grützner \& Pötz (losbladig). 
cultuur. ${ }^{273}$ Sommige databases bevatten echter wel meer vage, ongeverifieerde en daatom zachte informatie dan andere. Voorbeelden van databases met 'zachte' informatie zijn de zogenaamde PIOS-274 en SPUDOK-databases, ${ }^{275}$ die opsporingsinformatie en proactieve informatie bevatten over verdachten, mogelijke verdachten en hun contacten. Voorbeelden van databases met 'harde' informatie zijn databases die informatie bevatten over gedetineerden en ongewenste vreemdelingen.

Men zou daarom kunnen concluderen dat er in Duitsland in feite een verschil bestaat tussen informatie in het algemeen en inlichtingen in het bijzonder. Juridisch wordt er evenwel geen onderscheid gemaakt in harde en zachte informatie in de Duitse politiewetten.

\section{Doelbinding en legaliteitsbeginsep 76}

De registratie van informatie is in het algemeen slechts toegelaten voor die doeleinden waarvoor de gegevens werden of konden zijn verzameld. $\$ 9$ PolGNRW geeft als generale regel dat gegevens slechts verzameld mogen worden als dit dienstbaar is aan een bepaalde politieactiviteit. Het doorgeven van geregistreerde persoonsgegevens mag op grond van $\$ 26$ PolGNRW slechts ten behoeve van het doel waarvoor ze verzameld zijn. Dit is het finaliteitsprincipe dat in zijn algemeenheid voortvloeit uit de \$\$13 en 14 BDSG. Verder is er een centrale rol toegekend aan de beginselen van proportionaliteit en subsidiariteit. Als bijzondere regel stelt $\$ 27$ lid 1 PolGNRW dat uitwisseling van gegevens tussen twee politiediensten slechts toegestaan is voorzover dat noodzakelijk is voor de vervulling van de dienst. In dat geval mogen gegevens ook doorgegeven worden met een ander doel dan waarvoor zij verzameld zijn. Dit kan op voorwaarde dat die gegevens verzameld hadden mogen worden door de ontvangende dienst. Het verzamelen van gegevens kan dus ook met behulp van reeds bestaande registers.

Een algemene basis voor het verzamelen en registreren van gegevens voor opsporingsdoeleinden (dus na de ontdekking van een strafbaar feit) staat in $\$ 163 \mathrm{StPO},{ }^{27}$ Alle methoden van proactieve of preventieve gegevensvergaring worden echter beheerst door

273. Deze vaststelling is mede gebaseerd op overleg hieromtrent met $R$. Mokroz, Coördinator Internationale Samenwerking/Euregionale Zaken, Polizeipräsidium Aachen. Mokroz is notoir deskundige en auteur op het gebied van de Duitse internationale politięle gegevensuitwisseling (zie Mokroz 2001). Hoewel Belgiē zoals gezegd een permissieve cultuur kent, betekent dit niet dat zachte gegevens gemakkelijk worden uitgewisseld met het buitenland. Hiervoor bestaat zoals gezegd een controlemechanisme in Belgię en is nieuwe wetgeving in voorbereiding.

274. PIOS staat voor Personen, Institutionen, Objekte, Sachen.

275. SPUDOK staat voor Spurendokumentationsostem.

276. Zie hieromtrent nader Tak 1973.

277. Deze algemene bepaling betreft alleen opsporing waarvoor geen specificke wettelijke basis bestaat of is vereist. 
politiewetten. Het PolGNRW regelt bijvoorbeeld slechts de bevoegdheden van de politie voor zover het de taak van de Gefahrenabuehr (preventie) betreft ( $\$ 1$ PolGNRW). Vanaf het moment dat er sprake is van strafvervolging zijn de bondswetten van toepassing. Voor de verzending van de gegevens en het gebruik van deze gegevens door de buitenlandse politiedienst aan wie zij worden verstrekt, moet het finaliteitsprincipe ook nageleefd worden. Hierop bestaan echter enkele uitzonderingen. \$26 lid 1 PolGNRW bepaalt bijvoorbeeld dat het finaliteitsprincipe moet worden nageleefd, tenzij de verzending:

1. een expliciete wettelijke basis heeft; of

2. noodzakelijk is voor de voorkoming van gevaar en het onmogelijk of onevenredig moeilijk is voor de verzoekende autoriteit om de informatie elders te verzamelen.

Het zogenaamde legaliteitsbeginsel speelt een centrale rol in het Duitse strafvorderingsrecht. Het beginsel houdt de algemene verplichting in om elk aan de politie gemeld strafbaar feit te vervolgen. Vanwege dit legaliteitsbeginsel moet de politie op grond van $\$ 163$ lid 2 StPO alle informatie over een concreet begaan strafbaar feit doorzenden naar de justitiële autoriteiten. De politie mag echter wel kopieën bewaren van informatic voor politieel gebruik. Het enkel en alleen doorsturen van een dossier naar de justitiële autoriteiten betekent ook niet dat het politiewerk voor de betreffende zaak is afgerond of moet worden stopgezet. Bij Nederlandse en Belgische politiediensten veroorzaakt het legaliteitsprincipe soms een zekere terughoudendheid in het verstrekken van informatie aan hun Duirse collegae. Van bepaalde informatie willen de politiediensten namelijk niet dat die gebruikt wordt voor vervolgingsdoeleinden. $\mathrm{Zij}$ hebben echter een praktische oplossing uitgewerkt voor dit probleem. Buitenlandse politiediensten die inlichtingen aan hun Duitse collegae verstrekken, verzekeren zich ervan dat de verstrekte informatie onvoldoende is om daarop een officiële verdenking te baseren.

\section{Internationale politiële gegevensuitwisseling in Duitsland}

In verschillende politiewetten van de deelstaten is een onderscheid gemaakt tussen de verstrekking van informatie op verzoek van een buitenlandse politiedienst en de spontane grensoverschrijdende verstrekking van informatie. Dit onderscheid is gerelateerd aan de doeleinden waarvoor informatie mag worden verstrekt. Spontane verstrekking is alleen toegestaan indien die noodzakelijk is voor de uitoefening van taken van de verstrekkende politiedienst.

Wat de toepasselijkheid van het IRG betreft, stellen we vast dat deze wet alle vormen van internationale rechtshulp in strafzaken beoogt te regelen. De meeste bepalingen van het IRG regelen onderwerpen als uitlevering en de executie van buitenlandse straffen. Een klein aantal bepalingen is echter gewijd aan 'andere vormen van hulp' in strafzaken, zoals de uitwisseling van bewijs of informatie. Hoewel dit regime volgens de tekst van art 59 IRG enkel ziet op de rechtshulp op verzoek, verhindert de wet niet om spontaan infor- 
matie te verstrekken aan andere staten, op voorwaarde dat achteraf een verzoek om informatie wordt ingediend. \$59 IRG ziet ook op politiesamenwerking, voor zover deze strikt strafrechtelijke aangelegenheden betreft. Preventief en proactief politieoptreden vallen hierbuiten. Als eenmaal een buitenlands verzoek om rechtshulp is ontvangen, moet het verzoek breed en op een flexibele manier worden geïnterpreteerd. Als bijvoorbeeld een getuige die op verzoek verhoord wordt geen essentiële informatie geeft maar een andere persoon noemt die een succesvollere getuige zou kunnen zijn, kan het verhoor van die andere getuige noodzakelijk worden geacht in de context van hetzelfde verzoek.

Volgens $\$ 59$ IRG is de uitwisseling van strafrechtelijke informatie niet onderworpen aan specifieke territoriale restricties. De uitwisseling van pure politiële informatie zal hoofdzakelijk afhangen van de bepalingen daarover in de wetten van de deelstaten. Bovendien moeten in het algemeen de gegevensbeschermingsstandaards van het ontvangende land worden geverifieerd. In het geval de informatie verstrekt zal worden aan een andere Schengenpartner, kan worden aangenomen dat deze standaards afdoende zijn. Uitwisseling met Belgiè en Nederland zal dus niet aan deze verificatie-eis behoeven te voldoen.

De grensoverschrijdende verstrekking van informatie door een Duitse politiedienst is toegestaan volgens diverse regels. Sommige regels vinden hun oorsprong aan Duitse zijde, andere aan buitenlandse zijde. In de eerste plaats mag politiële informatie worden verstrekt aan een buitenlandse politiedienst als dit noodzakelijk is voor de taakuitoefening van de Duitse verstrekker. Deze regel is onder andere neergelegd in $₫ 28$ lid 1 PolGNRW. In de tweede plaats kunnen politiële gegevens ook worden uitgewisseld indien dit noodzakelijk is voor de taakuitoefening van de buitenlandse politiedienst. ${ }^{278}$ Deze soort van uitwisseling is meestal beperkt tot hulp waarom verzocht is. Dit wordt expliciet tot uitdrukking gebracht in bijvoorbeeld $\$ 28$ lid 4 PolGNRW. Omstandigheden die de verstrekking van politiële gegevens op verzoek rechtvaardigen, zijn: de noodzaak van de voorkoming van een ernstig gevaar (bijvoorbeeld $\$ 28$ lid 4 PolGNRW) of van ernstige strafbare feiten in het ontvangende land, alsmede omstandigheden waarbij de verstrekking is voorgeschreven of geregeld door internationale akkoorden. Bovendien verbiedt het finaliteitsprincipe dat de verstrekte gegevens worden gebruikt voor andere doeleinden dan waarvoor ze werden verstrekt (bijvoorbeeld $\$ 26$ PolGNRW). Om na te kunnen gaan of aan dit principe wordt voldaan, moet een verzoek voldoende informatie bevatten over de zaak en de doeleinden van de verzoekende politiedienst.

278. 928 lid 3 PolGNRW zegt hierover: "Die Polizei kann auf Ersuchen personenbezogene Daten an öffentlichen Stellen übermitteln, soweit dies 1. zur Abwehr einer Gefahr durch den Empfanger, 2, in besonders gelagerten Einzelfallen zur Wahrnehmung einer sonstigen Gefahrenabwehraufgabe durch den Empfänger, 3. zur Abwehr erheblicher Nachteile für das Gemeinwohl oder zur Abwehr einer schwerwiegenden Becinträgtigung der Rechte einer Person erforderlich ist." 
Voorts wordt in $\$ 27$ lid 2 PolGNRW de Minister van Binnenlandse Zaken gemachtigd om via een amvb te verordonneren dat het doorgeven van gegevens aan het buitenland toegestaan is als dat noodzakelijk is ten behoeve van de internationale politiesamenwerking. Een voorwaarde hiervoor is dat er geen reden is om aan te nemen dat de doorgegeven gegevens gebruikt zullen worden op een wijze die niet strookt met de Duitse wetgeving.

In een op $\$ 74$ lid 2 IRG gebaseerd akkoord, de zogenoemde Zuständigkeitsvereinbarung $1993,{ }^{279}$ hebben de regeringen van de Bondsstaat en van de deelstaten hun bevoegdheden gescheiden wat de wederzijdse rechtshulp in strafzaken betreft. Op basis van dit akkoord is de meeste wederzijdse rechtshulp gedelegeerd aan de regeringen van de deelstaten, die het mogen subdelegeren aan de lokale autoriteiten. De meeste deelstaten hebben gedetailleerde regelingen ingevoerd met betrekking tot deze subdelegatie. Deze regelingen voorzien in een specificatie van zaken waarin de politie, met name het LKA, onafhankelijk mag antwoorden op verzoeken om politiële gegevens.

\section{Uitzonderingen op gegevensuitwisseling door de Duitse politie}

In het algemeen beschouwt de Duitse wetgeving het politieke, militaire of fiscale karakter van een zaak niet als een obstakel voor de verstrekking van de verzochte rechtshulp. Ook het risico van het mogelijk opleggen of uitvoeren van de doodstraf, een vervolging in het buitenland van een Duits staatsburger, of een vervolging van dezelfde persoon voor dezelfde feiten (bis in idem) worden daarvoor niet als obstakel gezien. Dit soort factoren kan echter wel consequenties hebben voor het uitvoeringsniveau waarop het verzoek moet worden behandeld. De verzoeken betreffende politieke of militaire strafbare feiten nemen een centrale positie in bij zaken waarin de beslissingsbevoegdheid om een buitenlands verzoek te beantwoorden uitgesloten is van delegatie aan de lokale autoriteiten (vergelijk $\$ 4$ sub b Zuständigkeitsvereinbarung). Indien bovendien een bepaald verzoek om politieke, feitelijke of wettelijke redenen een bijzonder belang vertegenwoordigt, dan moeten in ieder geval de Bondsregering of de federale autoriteiten worden geraadpleegd op grond van $\$ 7$ Zuständigkeitsvereinbarung. Dat is in het bijzonder het geval wanneer er redenen zijn om aan te nemen dat de doodstraf opgelegd zal worden of zal worden uitgevoerd, of wanneer basisbeginselen van de Duitse publieke orde zouden worden genegeerd (nr. 13.1 RiVASt). De verstrekking van gegevens is niet toegelaten indien dit daadwerkelijk in zou kunnen druisen tegen doeleinden van het Duitse recht. Volgens $₫ 73$ IRG moet namelijk een rechtshulpverzoek worden geweigerd indien de rechtshulp in zou gaan tegen de Duitse rechtsorde of de publieke orde. Dit zou enkel het

279. Vereinbarung zwischen der Bundesregierung und den Landesregierungen (...) über die Zuständigkeit im Rechtshilfeverkehr mit dem Ausland in strafrechtlichen Angelegenheiten, 1 juli 1993, gepubliceerd in Grützner \& Pötz (losbladig). 
geval zijn indien er een risico is van strijd met door alle democratische staten erkende beginselen, waaronder de standaards van het EVRM. Hoewel deze uitzonderingen oorspronkelijk zijn geschreven voor verzoeken om uitlevering, zijn ze tot op zekere hoogte ook van toepassing op andere rechtshulp, waaronder de informatieve samenwerking.

Bij wederzijdse rechtshulp in strafzaken (kleine rechtshulp) is dubbele strafbaarheid van de opgespoorde strafbare feiten niet vereist, tenzij het verzoek het gebruik van dwangmiddelen inhoudt. In het algemeen moeten verzoeken die inhouden dat originelen van politiebestanden naar het buitenland gestuurd moeten worden, behandeld worden door de hoogste justitiële of uitvoerende autoriteiten. Dit is echter niet verplicht in het geval van een verzoek van België, Nederland, Luxemburg, Frankrijk en andere West-Europese buurstaten van Duitsland (nr. 83 RiVASt). Ten slotte kunnen ook redenen van disproportionaliteit leiden tot een afwijzing van rechtshulp in het geval het betreffende strafbare feit te licht is volgens de Duitse standaards.

In tegenstelling tot het vroegere BDSG 1977 schrijft het huidige BDSG geen specifieke behandeling voor wanneer het gaat over bijzonder gevoelige gegevens betreffende politieke, religieuze, seksuele of andere intieme aspecten van het privé-leven. In plaats daarvan beoogt $₫ 31$ BDSG alle gegevens over een individu te beschermen; daaronder vallen ook de gegevens die zouden kunnen worden geïndividualiseerd. De juiste graad van bescherming kan vervolgens worden gewaarborgd door de beginselen van proportionaliteit en subsidiariteit.

Het concept van 'dwang' in het Duitse gegevensbeschermingsrecht is bijzonder breed. Het verwijst naar iedere vorm van gegevensbeheer die plaatsvindt zonder de toestemming van het betreffende individu. Zonder toestemming van het individu is uitwisseling van informatie door de politie slechts geoorloofd op grond van een expliciete wettelijke basis (zie hierboven) of met de medewerking van het individu, bijvoorbeeld door een vrijwillig verhoor. In het algemeen mogen de gegevens verzocht door en verstrekt aan de buitenlandse autoriteit resultaten bevatten van opsporingsonderzoeken, verhoren of onderzoeken van eigen of buitenlandse rapporten, registers en gegevens (nr. 77 RiVASt). In hun uitwerkingen van de Zuständigkeitsvereinbarung hebben de wetgevers van de deelstaten ook het beantwoorden van buitenlandse verzoeken om politiële gegevens door hun politiediensten beperkt tot verzoeken die geen gebruik van strafrechtelijke dwangmiddelen in de zin van het Duitse Wetboek van Strafvordering inhouden.

\section{De bevoegde Duitse politiële autoriteiten}

Het federale constitutionele systeem van Duitsland veroorzaakt continu hevige discussies over de vraag welke autoriteiten bevoegd moeten zijn voor de internationale politiële samenwerking, inclusief de gegevensuitwisseling. De Bondsregering en het BKA benadrukken dat een centralisering van dergelijke taken praktischer is en een beter overzicht 
van de activiteiten garandeert. Bovendien zijn internationale zaken een federale taak. Verscheidene deelstaten die hun LKA een belangrijke rol willen laten spelen, beweren daarentegen dat een gedecentraliseerde samenwerking sneller is en in overeenstemming is met de Constiturie. Volgens de Duitse Constitutie is de politie in de breedste zin des woords in de eerste plaats een taak van de deelstaten. $\$ 10$ BKAG vertrouwt de internationale communicatie op het gebied van de strafrechtshandhaving voornamelijk toe aan het BKA. Niettemin kunnen de federale Minister van Binnenlandse Zaken en de hoogste autoriteiten in de deelstaten op grond van $\$ 10$ BKAG uitzonderingen voor de internationale communicatie in grensgebieden maken. De politieautoriteiten van de deelstaten kunnen dan met hun directe buurstaten de internationale communicatie onderhouden. In deze context bepalen de Zustandigkeitsvereinbarung en de uitwerkingen daarvan in de wetgeving van de deelstaten dat in het algemeen de LKA's bevoegd zijn voor internationale aangelegenheden. Dit leidt tot een uitzondering als het BKA exclusief bevoegd is. Dit laatste is bijvoorbeeld het geval voor de samenwerking in de zin van artikel 39 leden 1 tot en met 3 SUO, waarvoor de Bondsregering exclusief het BKA in Wiesbaden heeft aangewezen, dat ook het Nationaal Centraal Bureau van Interpol in Duitsland is, alsmede het nationale contactpunt voor Europol. Voor de spontane uitwisseling van informatie in de zin van artikel 46 SUO geldt dit niet, omdat het gaat over informatie-uitwisseling voor preventieve en proactieve doeleinden en opsporingsonderzoeken in principe uitsluit. Derhalve is deze taak toevertrouwd aan de politiediensten van de deelstaten en niet aan de federale politiediensten.

In $\$ 3$ lid 2 BKAG is bepaald dat de informatieverstrekking die verder reikt dan de grensstreek verzorgd moet worden door het BKA. Dit is althans de grondregel. Op deze regel geldt echter een aantal uitzonderingen geformuleerd in $\$ 3$ lid 3 BKAG. Dit artikellid bepaalt dat de bevoegdheidstoedeling betreffende het grensoverschrijdend dienstverkeer zoals bepaald in de eerste zin van $\$ 3$ lid 2 BKAG $^{280}$ niet geldt voor het dienstverkeer tussen de politiediensten van de deelstaten en de bevoegde autoriteiten van de buurlanden en de overige landen van de EU voorzover:

- het dienstverkeer betrekking heeft op criminaliteit van regionale betekenis, of

- er sprake is van een nog plaatsvindende bedreiging van de rechtsorde (Gefahr im Verzug).

Indien de politie op deelstaatniveau, gebruikmakend van de uitzonderingen, zelfstandig het dienstverkeer uitvoert, dan is het zaak het BKA onverwijld dienaangaande in te lichten ( $\$ 3$ lid $3,2^{e}$ zin BKAG). In een dergelijke situatie is dus sprake van een inlichten

280. Deze zin luidt: "Der zur Verhütung oder Verfolgung van Straftaten erforderliche Dienstverkehr der Polizeien des Bundes und der Länder mit den Polizei- und Justizbebörden sowie sonstigen insoweit zuständigen öffentlichen Stellen anderer Staaten obliegt dem Bundeskriminalamt." 
achteraf. Het is echter ook mogelijk dat reeds vooraf overeenstemming wordt bereikt aangaande het door de deelstaatspolitie uit te voeren dienstverkeer. Deze overeenstemming kan worden bereikt indien sprake is van een binnen het speerpuntenbeleid vallende afgebakende casus. De betreffende deelstaatpolitie kan dan met instemming van het BKA zelfstandig het dienstverkeer met de buitenlandse autoriteiten onderhouden. ${ }^{281}$

Niet-strafrechtelijke gegevens mogen dus volgens de betreffende wetgevingen in het algemeen internationaal worden uitgewisseld door de politie van de deelstaten, alsook door de Bundesgrenzschutz, voor proactieve en preventieve doeleinden. Sommige wetgevers van de deelstaten hebben deze regels uitgewerkt in meer gedetailleerde regelingen. Op basis van bijvoorbeeld \$ 27 lid 2 PolGNRW heeft de Minister van Binnenlandse Zaken van Nordrhein-Westfalen een ministeriële regeling uitgevaardigd voor de politie in deze deelstaat, het PoIDUVNW. Deze verordening regelt de gegevensuitwisseling tussen de vier Polizeipräsidium-gebieden langs de Duitse grens en die met de aangrenzende Nederlandse politieregio's en de Belgische politiezones. Bepaalde gegevens mogen ook worden uitgewisseld tussen de hoogste politieautoriteiten in de grens-Kreisen, de zogenaamde Oberkreisdirektoren, en hun collegae in Nederland en België. Par. 3 van de genoemde verordening belast het LKA in Düsseldorf met de uitwisseling van gegevens die niet direct mogen worden uitgewisseld door lagere politieautoriteiten. De verordening is op 7 januari 1998 gewijzigd. ${ }^{282}$ Sinds 10 februari 1998 mogen op grond van deze wijziging gegevens in normale gevallen rechtstreeks door de Polizeibehörden (politiediensten) en politiebureaus in het grensgebied meegedeeld worden aan de politiediensten aan de andere zijde van de grens. Tot 10 februari 1998 was dit slechts in spoedgevallen mogelijk. De op de RVST's gerichte regeling werd ten behoeve van decentrale gegevensuitwisselingen veranderd. De bundeling van gegevensuitwisselingstaken bij de RVST's van de Polizeipräsidien Münster, Krefeld, Mönchengladbach en Aken wordt daardoor gereduceerd. De Bezirksregierung (de districtspolitie en de Autobahnpolizei) van Münster, Düsseldorf en Keulen, alsmede het Präsidium van de Wasserschutzpolizei mogen daarenboven ook gegevens uitwisselen in de grensgebieden.

Volgens par. 1 jo. par. 2 van de verordening mogen in het kader van de politiële samenwerking met Nederland en België persoonsgegevens worden uitgewisseld overeenkomstig $\$ 27$ lid 1 PolGNRW. Welke Duitse politiedienst met welke Nederlandse of Belgische politiedienst iets mag uitwisselen is per politieregio precies omschreven (zie par. 1 sub 2 en par. 2 PolDUUNW). Het doel van de gegevensuitwisseling mag Gefahrenabwehr zijn, inclusief de preventieve bestrijding van strafbare feiten. Gegevens mogen worden uitge- 
wisseld wanneer dit is vereist voor de rechtmatige vervulling van taken die vallen onder de bevoegdheid van de verstrekkende Duitse politiediensten, of van taken die vallen onder de bevoegdheid van de ontvangende Nederlandse of Belgische politiediensten. In par. 1 sub 1 PolDUVNW staat gespecificeerd welke gegevens uitgewisseld mogen worden. Het betreft vijf categorieën van gegevens:

1. overzichtsbeelden inclusief dagjournaals over actuele gebeurtenissen, bijvoorbeeld manifestaties en bijeenkomsten;

2. uitspraken inzake strafbare feiten, voor zover die voor de voorkoming en opheldering van toekomstige strafbare feiten van belang kunnen zijn;

3. observatie- en vaststellingsjournaals over verdachte gebeurtenissen en personen;

4. opsporingsgegevens over door de politie gezochte personen; en

5. uitspraken over in hechtenis genomen personen.

Par. 4 PolDOVNW bepaalt ten slotte dat gegevensuitwisseling achterwege dient te blijven wanneer er reden is om aan te nemen dat de gegevens door de buitenlandse politiediensten zouden worden gebruikt in strijd met de bedoeling van de Duitse wetgeving. In het bijzonder wordt gelet op strijd met de voorschriften inzake de registratie, het gebruik en de beperkingen inzake de uitwisseling van de gegevens.

\section{Toezicht en controle op de Duitse internationale gegevensuitwisseling}

Toezicht en controle op wederzijdse rechtshulp die door de Duitse politie is verleend, zijn weer onderworpen aan de tweeledigheid van het Duitse politiewerk. In het geval van informationele politiesamenwerking in strafrechtelijke aangelegenheden moet een rapport van het verzoek worden verzonden naar de justitiële en bestuurlijke autoriteiten volgens nr. 11 en 12 RiVASt. Bovendien schrijven de meeste uitwerkingen door de deelstaten van de Zuständigkeitsvereinbarung voor dat de uitwisseling moet worden opgetekend in een register, zoals dat is gerealiseerd in de EMMI/PALMA-omgeving. Aanleiding, inhoud, ontvangende partij en datum van verzending moeten ook worden geregistreerd in geval van uitwisselingen van gegevens voor preventieve en proactieve doeleinden.

\section{Verhouding politie, OM en rechtstreekse toegang in Duitsland}

Uit $\$ 163$ lid 1 StPO blijkt overduidelijk dat de politie een zelfstandige bevoegdheid heeft. Anders dan in Nederland, vindt het strafrechtelijk onderzoek niet plaats onder leiding van een OvJ. De Duitse StA heeft geen directe zelfstandige toegang tot de politieregisters, noch kan hij of zij bevelen hem die toegang te verschaffen. Slechts ter aanvulling van een strafdossier kan hij of zij van de politie verlangen hem gegevens te verstrekken.

De bevoegdheid van de Duitse politie is een bevoegdheid die niet is afgeleid van andere bevoegdheden en bovendien onder eigen gezag wordt toegepast. Dit wordt ook wel een originaire bevoegdheid genoemd. De politie is zelfs verplicht deze bevoegdheid toe te passen. Ten aanzien van het strafrechtelijk optreden geldt op grond van $\$ 163$ StPO het 
legaliteitsprincipe. ${ }^{283}$ Het zogenaamde 'politiesepot' zoals dat in Nederland wel wordt gehanteerd, is voor de Duitse politie met betrekking tot strafrechtelijk optreden een ongekend fenomeen. De uit dat politieonderzoek voortspruitende stukken dienen onverwijld aan de StaatsAnwalt (StA) te worden toegezonden ( $\$ 163$ lid 2 StPO). Indien tijdens het opsporingsonderzoek, naar het oordeel van de politie, een spoedige aanvang van rechterlijk handelen nodig is, dan kan de politie de betreffende stukken direct aan het Amtsgericht ${ }^{294}$ zenden, dus zonder tussenkomst van de StA.

Met het voorgaande is niet gezegd dat de StA geen bemoeienis zou hebben met een strafrechtelijk onderzoek. Indien de StA, op welke wijze dan ook, ${ }^{285}$ kennis krijgt van een strafbaar feit, dan is het zijn plicht de zaak te onderzoeken teneinde een beslissing te kunnen nemen over de vervolgbaarheid (\$ 160 lid 1 StPO). Ten aanzien van het dossieronderzoek dat de StA uitvoert betreffende de vervolgbaarheid geldt dus het legaliteitsbeginsel. Op basis van de resultaten van dat onderzoek beslist de StA omtrent het daadwerkelijk vervolgen. Bij dit beslissen gelden de $\$ 153$ tot en met $154^{\mathrm{e}}$ StPO.

De StA heeft met betrekking tot strafrechtelijk onderzoek een originaire bevoegdheid, naast die van de politic. Ter vervulling van deze taak heeft de StA de bevoegdheid om van alle overheidsorganen informatic te verlangen en onderzoekshandelingen van welke aard dan ook zelf uit te voeren dan wel te laten uitvoeren door politieautoriteiten of politieambtenaren. De politie is verplicht aan het verzoek of de opdracht van de StA te voldoen en in een dergelijk geval is de politie bevoegd om van alle overheidsorganen informatie te verlangen ( $\$ 161$ lid $1 \mathrm{StPO}$ ). Het is dit laatstgenoemde artikellid op basis waarvan samenwerking tussen StA en politie inzake strafrechtelijk onderzoek tot stand komt. Slechts indien sprake is van de taakuitvoering als bedoeld in $\$ 160$ StPO kan op basis van $\$ 161$ lid 1 StPO gesproken worden van een gezagsverhouding tussen Staatsanwaltschaft en politie die in tijdsduur beperkt wordt door de duur van de concrete casus.

Op het moment dat sprake is van een Anfangsverdacht, is het Wetboek van Strafvordering van toepassing. In geval van de meest voorkomende situatie, doet de politie haar onderzoek en levert het dossier na afsluiting in bij de StA. Deze handeling is op zichzelf een verstrekking van persoonsgegevens uit politieregisters. Het is een verstrekking waartoe de politie op grond van de StPO verplicht is ( $\$ 163$ lid 2 StPO).

283. Knemeyer 2000, p. 36.

284. Met betrekking tot strafzaken, is het Amtsgericht qua positie vergelijkbaar met een combinatie van de Nederlandse RC en de politierechter. Zie $\$ 25$ Gerichtsverfassungsgesetz (GVG), wet van 12 september 1950, BGBl 1950, nt. 455, 512 . 513: laatstelijk gewijzigd bij wet van 10 december 2001, $\$ 12$.

285. De StA kan bijvoorbeeld kennis omtrent een strafbaar feit verkrijgen door een aangifte, in geval van een klachtdelict door een klacht (\$ 158 StPO), door eigen waarneming of door de ontrangst van een politiedossier. 
De StA bepaalt aan de hand van het dossier of hij of zij voldoende gegevens heeft om tot vervolging over te gaan. Op het moment dat vastgesteld wordt dat nog gegevens ontbreken, kan de StA informatie verlangen van de politie ter aanvulling van het dossier. Indien de verlangde gegevens bij de politie reeds bekend en geregistreerd zijn, dan resulteert dat verlangen van de StA uiteraard direct in een verstrekking.

$\mathrm{Na}$ verkrijging van de persoonsgegevens uit de betreffende politieregisters, kan sprake zijn van een verder doorgeven door de Staatsanwaltschaft of door andere partijen die bij het strafproces betrokken zijn, doch deze verstrekking valt onder de vigeur van de StPO, in het bijzonder $\$ 474$ tot en met $\$ 482$.

Het zogenaamde proactieve optreden van de politie blijft buiten de taakstelling van de StA. Dit proactieve optreden vindt immers plaats op basis van de politiewet, een wet waaraan de StA geen bevoegdheden ontleent. Daarnaast blijkt dat een opdracht tot onderzoek een gevolg kan zijn van een door de politie aangeleverd onderzoeksresultaat. De StA moet immers op basis van de ontvangen stukken bepalen of vervolging zal worden ingesteld ( $\$ 160$ lid 1 StPO). Het gaat hier met name om de vraag of een vervolging enige kans van slagen heeft. Indien naar de mening van de StA het dossier incompleet is, kan de StA informatie verlangen van de politieautoriteiten of een verzoek richten dan wel opdracht geven aan de politie tot het verrichten van verder onderzoek ( $\$ 161$ lid 1 StPO).

De verschillende registers worden strikt gescheiden van elkaar gevoerd. De inzagerechten van ambtenaren worden allereerst in het algemeen bepaald aan de hand van de plaats binnen de totale politieorganisatie en vervolgens aan de hand van de taakstelling binnen de organisatie. De aldus in abstracto bepaalde inzagerechten krijgen hun concrete uitwerking in toegangsrechten die logistiek en geautomatiseerd verwerkelijkt worden. Het is de taakstelling die bepalend is voor de doelstelling waarmee een bepaalde registratie wordt aangelegd.

Aan buitenlandse opsporingsambtenaren wordt geen directe geautomatiseerde toegang verleend door de Duitse wetgeving en deze is derhalve verboden.

\section{Koppeling van gegevens en bestanden in Duitsland}

Uit de eis van transparantie vloeit voort dat een wettelijke bepaling die de verwerking van persoonsgegevens mogelijk maakt, ook eenduidig aangeeft welke wettelijke overheidsopdracht daarmee behartigd wordt. De inbreuk op het grondrecht moet dus een specifiek doel behartigen. Primair geldt een specifieke vorm van het doelbindingsprincipe: gegevens mogen slechts verstrekt worden voor het doel waarvoor zij ook verzameld of geregistreerd werden. Hiervan mag slechts worden afgeweken: 
- ten eerste voor zover de wet dat toestaat, dit geldt voor Noordrijn-Westfalen, of voor zover $\$ 39$ leden 1, 2 of 7 NdsGefAG dit toestaan ( $\$ 40$ lid 1 NdsGefAG).

- ten tweede voor zover dit noodzakelijk is ter afweer van een gevaar en de ontvanger de gegevens niet of niet tijdig op andere wijze kan verkrijgen zonder buitensporige moeite (Noordrijn-Westfalen).

Indien de ontvanger een politiedienst is, dan geldt een andere regeling. De politiediensten mogen in principe onderling gegevens vrij uitwisselen. Het verstrekken van gegevens is dan slechts toelaatbaar, indien de betreffende gegevens door de ontvanger ontvangen mogen worden ter vervulling van zijn taak. Deze regel is het spiegelbeeld van de regel, dat de politie slechts gegevens mag verzamelen voor zover dat nodig is ter vervulling van de politietaak.

Het interne gebruik van politiegegevens omvat tevens een regeling van een geautomatiseerde vergelijking van politieregisters. De wetgeving hanteert de termen 'bestand' (Datei) en persoonsgegeven (personenbezogene Daten). De politiewetten geven elk een regeling op grond waarvan, onder bepaalde omstandigheden, de gegevens van een bepaalde persoon vergeleken kunnen worden met gegevens in politieregisters. Het betreft hier dus een casusgericht opzoeken en niet een ter vergelijking naast elkaar leggen van bestanden. De Duitse wettelijke term in dezen is dan ook 'Datenabgleich' en niet 'Dateienabgleich'. Het gaat dan om het vergelijken van bepaalde gegevens van een persoon met hetgeen reeds geregistreerd is in de betreffende politieregisters. De (beperkte) verzameling persoonsgegevens die men dan heeft van een persoon worden blijkens de wettekst niet gezien als een bestand, maar als losse gegevens. De gegevens van een staandegehouden persoon, kunnen vergeleken worden met bestanden die de politie ter vervulling van haar taak heeft aangelegd ( $\$ 25$ lid 1 PolGNRW en $\$ 45$ lid 1 NdsGefAG). Indien deze vergelijking niet afgerond is binnen de tijd gedurende welke een persoon rechtmatig staande gehouden kan worden, dan kan die persoon verder opgehouden worden gedurende de tijd die nodig is om zijn gegevens te vergelijken met het 'Fahndungsbestand, een bestand met gezochte personen ( $\$ 25$ lid 2 PolGNRW en $\$ 45$ lid 2 NdsGefAG). Deze Datenabgleich is dus strikt casusgebonden.

In de opsporingsfase zijn met name $\$ \$ 98 \mathrm{a}$ en $98 \mathrm{~b}$ StPO van belang. Zij betreffen de mogelijkheid tot een gegevensvergelijking in het kader van de Rasterfahndung. Die vindt plaats op basis van rechterlijke toestemming. Slechts indien sprake is van een nog plaatsvindend strafbaar feit, de Duitse wettelijke term is Gefabr im Verzug, dan zijn zowel de StA alsook de hulpofficieren bevoegd tot uitvoeren van de betreffende handeling. In dat geval moet echter wel binnen drie dagen een rechterlijke goedkeuring zijn verleend.

In verband met het doelbindingsprincipe is een koppeling van zelfstandige bestanden voor het Duitse recht uit den boze, met name vanwege de dreiging van een bevoegd- 
heidsdoorbreking. De politie mag slechts persoonsgegevens verwerken voor zover dit is toegestaan door de toepasselijke wet. Aangezien de betreffende wet met het verlenen van bevoegdheden tevens de grenzen aangeeft waarbinnen de politie persoonsgegevens mag verwerken, moet geconcludeerd worden dat alle handelingen die verricht kunnen worden met persoonsregistraties en die niet gedekt worden door de toepasselijke wetgeving niet zijn toegestaan. De bevoegdheid tot het koppelen van bestanden en systemen of tot het uitvoeren van een bestandsvergelijking, wordt niet uitdrukkelijk gegeven in de Duitse wetgeving en is derhalve niet toegestaan.

\subsubsection{Conclusies omgaan met zachte gegevens}

In deze sectie formuleren wij onze conclusies ten aanzien van de eerste aanvullende onderzoeksvraag: "Hoe worden zachte politiële gegevens in de Nederlandse, Belgische en Duitse rechtsorde juridisch beschermd en hoe dient ermee omgegaan te worden in het kader van de grensregionale politiële gegevensuitwisseling?" De navolgende paragraaf bevat onze conclusies ten aanzien van het omgaan met zachte gegevens door de politiediensten van Nederland, België en Duitsland in grensregionaal verband. In de daaropvolgende paragraaf formuleren wij onze mening ten aanzien van het omgaan met zachte gegevens in grensregionaal verband.

\section{Conclusies omgaan met zachte gegevens}

Hieronder geven wij een hoofdconclusie en vier gewone conclusies.

De hoofdconclusie is dat zachte gegevens alleen in de Nederlandse rechtsorde een duidelijk juridisch beschermingsregime kennen in artikel 5a WPolr, aangaande informatie betreffende onverdachte personen, en $\$ 3$ a WPolr, aangaande de bijzondere politieregisters. De opslagtermijnen van de zachte gegevens zijn enkel in Nederland duidelijk wettelijk geregeld.

In het buitenland kent men het Nederlandse systeem van gecodeerde 'zachte' informatie veelal niet. Het is daarom al voorgekomen dat niet operationeel te gebruiken informatie in een zaaksdossier is beland. Onze eerste conclusie is dan ook dat bij het omgaan met uit het buitenland afkomstige informatie steevast wordt gehandeld naar het vertrouwensbeginsel. Dat wil zeggen dat er (al dan niet terecht) van uitgegaan wordt dat de informatie rechtmatig is verkregen door de buitenlandse autoriteit, alsmede dat de informatie gebruikt zal worden voor geen ander doel dan het doel waarvoor zij is verstrekt. ${ }^{286}$ De Nederlandse parlementaire Enquêtecommissie opsporingsmethoden constateerde in 1996 dat zelden wordt gecontroleerd of uit het buitenland verkregen informatie rechtmatig is verkregen. ${ }^{287} \mathrm{Het}$ is 
volgens haar denkbaar dat bijvoorbeeld informatic verkregen door uitlokking al dan niet van landen, zoals Duitsland, waar uitlokking onder omstandigheden is toegestaan, gebruikt wordt in een Nederlandse rechtszaak. De uit het buitenland verkregen CIE-informatie krijgt doorgaans de evaluatie A1. Dit wil zeggen dat de informatie afkomstig zou zijn uit zeer betrouwbare bron, alsmede dat de informatie door de bron zelf is waargenomen en er een bevestiging uit andere bron is. Wij pleiten ervoor dat er een zodanige voorafgaande controle komt op de uitwisseling van zachte gegevens, dat het vertrouwensbeginsel ook daadwerkelijk inhoud krijgt.

Omdat er sprake is van zachte, dus onbewijsbare nog niet vaststaande, gegevens is onze tweede conclusie dat controle vooraf van de internationale verstrekking van deze gegevens door de politiediensten in de grensregio's van groot belang is. In Nederland is duidelijk in de wetgeving vastgelegd dat voor de verstrekking van CIE-informatic de toestemming van de (landelijke) CIE-OvJ nodig is. Voor de verstrekking van informatie uit de tijdelijke registers is ook de tussenkomst van het $\mathrm{OM}$ vereist. De tussenkomst van de NCIE (Nationale Criminele Inlichtingeneenheid) is tevens vereist voor de verstrekking van CIE-informatie. Dit geldt op basis van artikel 13 lid 12 BPolr en artikel 8 Regeling criminele inlichtingeneenheden van 5 oktober 2000. De politie kan de verstrekking van dergelijke gegevens dus niet zelfstandig afhandelen. Wij stellen vast dat er voor België en Duitsland nog geen transparante wettelijke bepalingen bestaan die een dergelijke controle vooraf op de internationale verstrekking van zachte gegevens expliciet regelen.

Volgens het derde beginsel van de Recommendation R (87) 15 van de Raad van Europa ${ }^{288}$ moeten de verschillende soorten politiële gegevens die worden opgeslagen, zoveel mogelijk worden onderscheiden naar hun mate van precisie of betrouwbaarheid. In het bijzonder dienen gegevens gebaseerd op feiten gescheiden te worden van gegevens berustend op meningen of persoonlijke beoordelingen. Dit nu is enkel in de Nederlandse wet- en regelgeving voldoende uitgewerkt. $W_{i j}$ stellen in onze derde conclusie vast dat de Belgische wetgeving enkel een algemene regeling geeft in de artikelen 44/1 tot en met 44/11 WPA en de daarbij behorende omzendbrief van 14 juni 2002, die betrekking hebben op het politiële informatiebeheer. Specifieke wettelijke uitvoeringsbepalingen zijn er vooralsnog niet in Belgiê. Hoe het Belgische juridische kader omtrent de uitwisseling van gegevens met het buitenland eruit ziet, is in algemene termen, zonder specifieke aandacht voor zachte gegevens, neergelegd in de omzendbrief van 14 februari 2000 betreffende de internationale politiesamenwerking met een gerechtelijke finaliteit. De Nationaal Magistraat ziet toe op de rechtmatige gegevensuitwisseling. 
Onze vierde en laatste conclusie is dat er in Duitsland geen strikte scheiding tussen 'harde' en 'zachte' informatie wordt gemaakt. De politiewetten maken geen onderscheid tussen harde en zachte informatie. Dit heeft wellicht te maken met de Duitse cultuur waarin zachte gegevens in de politiepraktijk veel gemakkelijker uitgewisseld worden dan in de Nederlandse of de Belgische cultuur. Sommige databases bevatten echter in de praktijk wel meer vage, ongeverifieerde en daarom zachte informatie dan andere.

\section{Standpuntbepaling over het omgaan met zachte gegevens}

Hieronder formuleren wij drie eigen gezichtspunten omtrent het omgaan met zachte gegevens bij de informatieve politiesamenwerking tussen Nederland, België en Duitsland.

In de Europese verhoudingen van de grensregionale politiële gegevensuitwisseling achten wij het in de eerste plaats wenselijk, dat in andere Europese lidstaten, zoals in België en Duitsland, een controle vooraf door de gerechtelijke (justitiële) autoriteiten van de internationale uitwisseling van zachte gegevens wettelijk wordt vastgelegd. Op deze manier is er een betere garantie aanwezig dat de uitgewisselde informatie inderdaad rechtmatig verkregen is door de verstrekkende staat.

In de tweede plaats zijn wij de mening toegedaan dat de convenanten en akkoorden in de grensgebieden tussen Nederland, België en Duitsland op grond van de artikelen 39 lid 4 en 5 SUO en artikel 46 lid 2 SUO meer rekening dienen te houden met de zeer verschillende nationale wet- en regelgeving op het gebied van zachte gegevens.

In de derde plaats vinden wij het wenselijk dat België en Duitsland een goed wettelijk kader uitwerken voor het omgaan met (inclusief de opslagtermijnen) en de (internationale) uitwisseling van zachte gegevens; dit geldt mede in het licht van het derde beginsel van Recommendation R (87) 15 van de Raad van Europa. De nationale en internationale rechtspraktijk dient zich daar vervolgens bij aan te sluiten. 



\section{Koppelen van gegevens en rechtstreekse toegang}

In dit zesde hoofdstuk behandelen wij achtereenvolgens de technieken van koppeling (sectie 6.1), de Nederlandse juridische visie op koppeling (sectie 6.2), rechtstreekse geautomatiseerde toegang (sectie 6.3) en de mogelijke wegen van verstrekkingen van gegevens (sectie 6.4). Sectie 6.5 gaat in op multimediale gegevens in de EMMI-omgeving. In sectie 6.6 gaan wij ten slotte kort in op de voorgenomen herziening van de WPolr.

\subsection{Koppeling en de bijbehorende technieken}

De voortschrijdende informatietechnologie biedt tegenwoordig buitengewoon interessante mogelijkheden voor het opslaan en gebruiken van gegevens. In de jaren tachtig van de vorige eeuw werden daartoe de eerste stappen gezet. Steeds meer gegevens werden verzameld en een steeds grootschaliger opslag van gegevens werd gerealiseerd. De jaren negentig stonden in het teken van nieuwe methoden die aan de grote hoeveelheden gegevens belangwekkende informatic konden onttrekken. Tegenwoordig is het mogelijk om computersystemen en gegevensbestanden zodanig te koppelen dat de opgeslagen informatie efficiënt en effectief nieuwe informatie voortbrengt. Koppeling van systemen en bestanden kan worden omschreven als het leggen van relaties tussen gegevens.

Ook bij de politie is een koppelingstendens zichtbaar. Een kenmerkend voorbeeld is het feit dat informatiesystemen van verschillende politieorganisaties met elkaar in verbinding staan door middel van speciaal daarvoor ontwikkelde relationele databases, de BedrijfsProcessenSystemen (BPS). Op deze manier is integrale administratieve verwerking van aangiften van misdrijven en registratie alsmede afhandeling van incidenten mogelijk. Een ander voorbeeld waarvoor koppeling bij de politie gebruikt wordt, is het zogenaamde fenomeenonderzoek. Fenomeenonderzoek is onderzoek dat gericht is op het in beeld brengen van de criminaliteitsgevoeligheid van een groep van personen of van bepaalde situaties in de samenleving. ${ }^{289}$

289. $\mathrm{Vgl}$. het verkennend onderzoek van artikel $126 \mathrm{gg} \mathrm{Sv}$. 
In subsecties 6.1.1 tot en met 6.1.6 gaan wij in op zes verschillende technische vormen van koppeling die in het algemeen - dus niet beperkt tot de politiële sector - te onderscheiden zijn.

In de literatuur ${ }^{290}$ worden nog meer technieken van koppeling van persoonsgegevens alsmede van het 'grasduinen' in gekoppelde databases onderscheiden. Voor ons doel - het geven van inzicht aan de lezer in de diverse technische mogelijkheden - zijn de onderstaande zes technieken voldoende.

\subsubsection{Computer matching}

Computer matching van persoonsgegevens omvat het vergelijken van twee of meer gegevensverzamelingen met als doel individuen te zoeken die in meer dan één bestand voorkomen of juist in één van die bestanden ontbreken. Een gelukte match wordt aangemerkt als een 'hit', Bij matching kan het uitgangspunt zijn dat een persoon slechts in één van de bestanden mag voorkomen ${ }^{291}$ of juist in meerdere bestanden moet voorkomen. ${ }^{292}$

\subsubsection{Computer-assisted front-end verification}

Computer-assisted front-end verification wordt gebruikt om de juistheid en volledigheid vast te stellen van individuele persoonsinformatie door deze te vergelijken met gelijkwaardige informatie uit andere bestanden, meestal van derden. Er vindt een toetsing (en screening) van een persoon plaats op individuele basis. De toetsing geschiedt vooraf, bijvoorbeeld voordat een uitkering wordt toegekend. Een voorbeeld is de toetsing bij het Bureau Krediet-Registratie om na te gaan of iemand elders al een krediet heeft lopen.

\subsubsection{Computer profiling}

Bij computer profiling wordt in een of meer computerbestanden gezocht naar een specifieke combinatie van gegevenselementen. Deze specifieke combinatie is het profiel. Er wordt gebruik gemaakt van inductieve logica, waarbij wordt geredeneerd van het bijzon-

290. Schreuders \& Van Kralingen 1998; Gardeniers, Van Kralingen \& Schreuders 1996; Van Duivenboden 1994: U.S. Congress 1986. Zie in her bijzonder Meij 2002 over de vele verschillende vormen van datamining.

291. Een voorbeeld is marching op basis van een SOFI-nummer tussen enerzijds registraties met inkomens en uitkeringen en anderzijds de studiefinancieringsregistratie. Van een 'hit' kan sprake zijn als iemand in meer dan éen registratie voorkomt. Dit kan erop wijzen dat de betrokkene fraudeert.

292. Een voorbeeld is matching op basis van autokentekens. Het kenteken moet voorkomen in zowel het kentekenregister als in de registraties van de wegenbelasting. autoverzekering en verrichte APK-keuringen. Het ontbreken in eetn van de bestanden kan erop wijzen dat de betrokkene niet aan alle verplichtingen heeft voldaan. Van een 'hit' kan sprake zijn als iemand in eén van de bestanden ontbreekt. 
dere naar het algemene. Zo worden kenmerkende karakteristieken of gedragspatronen vastgesteld die een correlatie vertonen met een bepaald gedrag. ${ }^{293}$

\subsubsection{Integratie van bestanden}

Bij integratic worden twee of meer (delen van) bestanden samengevoegd tot één of meer nieuwe bestanden. Het is mogelijk dat de originele bestanden blijven bestaan, maar het is ook denkbaar dat een deel van de gegevens integraal wordt toegevoegd aan een andere gegevensverzameling en zelf ophoudt te bestaan. Er ontstaat een meerwaarde aan informatie door het doel waarvoor de integratie wordt uitgevoerd en de interpretatie van de samengevoegde gegevens. De genoemde BPS bij de politie vormen een voorbeeld van geïntegreerde systemen.

\subsubsection{Combinaties}

De vier hierboven beschreven vormen van koppeling kunnen ook in combinatie voorkomen. De ene vorm loopt dan over in een andere. Een heel bekend voorbeeld van een combinatie zijn opsporingshypotheses of -profielen. De Duitse politie en veiligheidsdiensten maakten daarvan gebruik bij de opsporing van terroristen. De hypotheses hielden in dat terroristen hun eigen elektriciteitsrekeningen niet betalen, dat ze in de wintermaanden een zomerhuisje huren en dat ze vaak gebruik maken van een vliegtuig. Op basis van deze profielen werden de registraties van elektriciteitsbedrijven, verhuurders van zomerhuisjes en vliegtuigmaatschappijen onderzocht. Zo wilden de Duitse diensten op het spoor komen van personen die aan de kenmerken van een van de gegeven profielen voldeden. De uitkomsten van de selectieprocedures werden later met andere bestanden en met elkaar gecombineerd ('gematcht'). De overgebleven personen werden daarna benaderd met het verzoek opheldering te geven over de niet-normale situatie. Het selecteren van personen op basis van een dergelijke profilering staat in Duitsland bekend onder de naam 'Rasterfahndung'. Hoewel het bij de grensregionale gegevensuitwisseling vooral om het 'gewone politiewerk' gaat, kan de uitwisseling van gegevens over terroristen wel degelijk aan de orde zijn in de Europese grensregio's.

293. Er zijn twee vormen van profiling. De eerste vorm bestaat uit het onderscheiden naar bepaalde kenmerken of activiteiten. Dit wordt het 'enkelvoudig' profileren genoemd (de theoretische analyse). Als de kenmerken in een bepaalde volgorde in een record (een 'kaartje' met gegevens ingedeeld in gegevensvelden) voorkomen. dan wordt dat record gemarkeerd en is er sprake van een 'hit'. Bij de tweede vorm wordt gezocht naar de frequentic waarin de geselecteerde kenmerken zich manifesteren bij en tussen de records. Deze vorm wordt 'globaal' profileren genoemd (de empirische analyse). 


\subsubsection{Knowledge Discovery in Databases}

Een recente nieuwe methode om grote hoeveelheden gegevens te gebruiken, is Knowledge Discovery in Databases (KDD). Bij KDD gaat het om het ontdekken van zinvolle, eerder onbekende, of zelfs onverwachte (strategische) informatie. Het gaat om verbanden, profielen en indicatoren. KDD is een verfijning van de hierboven beschreven technieken. Met behulp van speciale computerprogrammatuur wordt door analyse nieuwe kennis afgeleid van in omvangrijke databases opgeslagen gegevens. 'Verborgen' informatie komt zo te voorschijn. Het doel van KDD is dus als het ware het delven van verborgen informatic. Vandaar dat ook wordt gesproken van 'datamining' of 'informatiemijnbouw'. De analyse van data ten behoeve van de bestrijding van de (georganiseerde) misdaad, fenomeenonderzoek, ${ }^{294}$ alsmede het opstellen van risicoprofielen in verband met het opsporen van fraude zijn mogelijke toepassingen van informatiemijnbouw. Informatiemijnbouw kent drie fases: datawarehousing, datamining en interpretatie. In de eerste fase wordt een bestand aangelegd dat is toegespitst op het verrichten van breed opgezette analyses. Deze fase is soms overbodig, maar meestal wel aangewezen. Zo'n bestand wordt een datawarehouse genoemd. Het aanleggen ervan wordt datawarehousing genoemd. Datawarchousing bestaat uit het verzamelen, verrijken, opschonen en coderen van gegevens. Een datawarehouse bestaat meestal uit gegevens die uit meerdere bronnen afkomsvig zijin en die een of meendere bewerkingen hebben ondergaan. Controle op de juistheid van de gegevens is hierbij essentieel, want als de input van slechte kwaliteit is, is de output dat ook. De tweede fase, het eigenlijke datamining, bestaat uit het geautomatiseerd analyseren van de in het datawarehouse opgeslagen gegevens. ${ }^{295}$ In de fase van de interpretatie worden op basis van de uit de analyse voortgekomen informatie conclusies getrokken. Dit kan nieuwe kennis opleveren.

\subsection{Koppeling en de Nederlandse juridische visie}

In deze sectie behandelen wij de visie van de Nederlandse wetgever op de problemariek van de koppeling van systemen en bestanden in de politiële sector. De nadruk ligt daarbij op de koppeling van persoonsgegevens en de bedreiging die een dergelijke koppeling kan betekenen voor de persoonlijke levenssfeer van betrokken individuen en groepen van personen.

Het segmenteren, categoriseren en labelen van (groepen) personen met behulp van de in sectie 6.1 beschreven technieken heeft een nauw verband met de juridische positie van personen. De nieuwe mogelijkheden van de informatietechnologie om gebruik te maken van gegevens kunnen inbreuk maken op de informationele privacy van personen. De in

294. Zie hierover bijwoorbeeld Goos \& Vugts 1996, p. 12-14.

295. Voor de analyse worden verschillende nieuwe zoektechnieken gebruikt zoals genetische algoritmen, bepaalde boombeslisstructuren en neurale nerwerken. De nieuwe zocktechnicken gaan bij het analyseren uit van het principe van inductie (het algemene wordt afgeleid vanuit het bijzondere). 
sectie 6.1 beschreven instrumenten zijn verschijningsvormen van wat in brede zin als het koppelen van gegevensbestanden (en systemen) kan worden aangeduid. Het gaat namelijk om technieken die zich lenen voor vanuit privacyoogpunt gezien mogelijk inbreukmakende handelingen op de rechten van personen. Daarbij zijn verschillende juridische vragen aan de orde. Wij noemen er drie.

- Wanneer is er sprake van persoonsgegevens?

- Is het samenvoegen en combineren van uit verschillende bronnen afkomstige gegevens toelaatbaar?

- Welke eisen dienen te worden gesteld aan de juistheid en betrouwbaarheid van de verkregen en te gebruiken gegevens?

Het verstrekken, verkrijgen en gebruiken van gegevens gebeurt in de maatschappelijke context van de politie. Voor het verstrekken, verkrijgen en gebruiken van politiële gegevens is in Nederland een bijzonder rechtsbeschermingsregime van toepassing, dat is neergelegd in de WPolr en het BPolr. Hierin zijn ook specifieke regelingen met betrekking tot koppeling opgenomen. België en Duitsland kennen een dergelijke regeling voor de koppeling van politiegegevens niet.

De politie houdt echter ook registraties die onder de Wet Bescherming Persoonsgegevens $(\mathrm{Wbp})^{296}$ vallen. Hieronder maken wij eerst enkele algemene opmerkingen over persoonsgegevens (subsectie 6.2.1). Daarna geven wij een uiteenzetting van de wettelijke regeling voor de koppeling van bestanden en systemen in de Nederlandse politiële context (subsecties 6.2.2 tot en met 6.2.5). Ten slotte gaan wij in op het gebruik van datamining in een politieel-juridische context (subsecties 6.2.6 en 6.2.7). In subsectie 6.2.8 trekken wij onze conclusies met betrekking tot het koppelen van gegevens en bestanden en formuleren wij enkele aanvullende opmerkingen.

\subsubsection{Het begrip 'persoonsgegeven'}

De Nederlandse privacywetgeving is - evenals de Belgische en Duitse privacywetgeving - alleen van toepassing op persoonsgegevens. Een persoonsgegeven wordt - in overeenstemming met het Europees Databeschermingsverdrag - in artikel 1 sub a Wbp omschreven als elk gegeven betreffende een geïdentificeerde of identificeerbare natuurlijke persoon. ${ }^{297}$ Het gaat het erom of een gegeven relevante informatie verschaft over een identificeerbare persoon. In veel gevallen, bijvoorbeeld bij NAW-gegevens of persoonsnummers, is het duidelijk wanneer er sprake is van persoonsgegevens. In andere gevallen moet gekeken worden naar de context waarin het gegeven wordt vastgelegd of

296. Het betreft de opvolger van de WPR.

297. Deze definitic geldt thans op grond van het gewijzigde artikel 1 sub $i$ WPolr ook voot politiegegevens. 
gebruikt. Van belang is dan of het gegeven bepalend kan zijn voor de wijze waarop de betrokken persoon in het maatschappelijk verkeer wordt beoordeeld of behandeld. Volgens de Registratiekamer (thans het CBP) kunnen zodoende bijvoorbeeld postcodes met huisnummers en gegevens over een zaak persoonsgegevens zijn. ${ }^{298}$ Ook de via PALMA uitgewisselde voertuiggegevens zijn dus persoonsgegevens. Wat de identificeerbaarheid van een persoon betreft, gaat het om de vraag of de identiteit van een persoon redelijkerwijs kan worden vastgesteld zonder onevenredige inspanning. Hierbij wordt uitgegaan van de mogelijkheden die een redelijk toegeruste houder van (persoons)gegevens heeft om dat te doen. In concrete gevallen moet daarbij rekening gehouden worden met bijzondere expertise of technische faciliteiten. ${ }^{299}$

De vraag of er sprake is van persoonsgegevens, is afhankelijk van de fase van het proces van informatiemijnbouw (zie subsectie 6.1.6). ${ }^{300}$ De vraag of de in een datawarehouse opgenomen gegevens persoonsgegevens zijn, is op zijn beurt afhankelijk van de beantwoording van de vraag uit welke bestanden de gegevens die in het datawarehouse zijn opgenomen afkomstig zijn. Vaak zijn de gegevens afkomstig uit bestanden met persoonsgegevens. Het vanuit deze bestanden overhevelen van gegevens naar een datawarehouse komt neer op het verstrekken van gegevens in de zin van artikel 1 sub $\mathrm{n}$ Wb. De definitie van verstrekken van gegevens in de Wbp is heel ruim. ${ }^{301}$ Het kan daarbij gaan om intern gebruik of om derdenverstrekkingen. Voor politiegegevens geldt op grond van de WPolr mutatis mutandis hetzelfde. ${ }^{302}$ Hiermee staat echter niet vast dat gegevens die in een datawarehouse zijn opgeslagen altijd als persoonsgegevens zijn aan te merken. Het is mogelijk dat aggregatic en eventuele andere bewerkingen, bijvoorbeeld verregaande anonimisering, van dien aard zijn dat de in het datawarehouse opgeslagen gegevens niet meer, of alleen met onevenredige inspanning, te herleiden zijn tot de individuele personen waarop de gegevens oorspronkelijk betrekking hadden. In de gevallen waarin de in een datawarehouse opgeslagen gegevens wel als persoonsgegevens zijn aan te merken, kan

298. Registratiekamer 1996.

299. Registratickamer 1993.

300. Gardeniers, Van Kralingen \& Schreuders 1996.

301. Het verstrekken van persoonsgegevens is in artikel 1 sub n Wbp omschreven als het bekend maken of ter beschikking stellen van persoonsgegevens. De te verstrekken gegevens kunnen als zodanig in een persoonsregistratie zijn opgenomen. $\mathrm{Zij}$ kunnen echter ook het resultaat zijn van een verwerking waardoor nieuwe informatic wordt verkregen. Onder het verstrekken valt dan ook niet alleen het nauwkeurig weergeven van de uit de registratie verkregen informatie maar ook het in iets andere vorm doorgeven van in wezen dezelfde gegevens.

302. In artikel 1 sub h WPolr wordt het 'verstrekken van gegevens uit een politieregister' omschreven als: "het bekend maken of ter beschikking stellen van persoonsgegevens, voorzover zulks geheel of grotendeels steunt op gegevens die in dat politieregister zijn opgenomen, of die door verwerking daarvan, al dan niet in verband met andere gegevens, zijn verkregen", Met de omschrijving van het verstrekkingsbegrip is aangesloten bij de definitie in de WPR (oud), thans de Wbp. 
het zijn dat in de fase van de datamining het karakter van 'persoonsgegevens' alsnog verloren gaat. De gevonden verbanden en de presentatie daarvan zijn vaak niet meer als persoonsgegevens aan te merken. Als de door datamining gevonden verbanden of profielen vervolgens worden gebruikt, herleeft het karakter van persoonsgegevens vaak wel. Voor het benaderen van de doelgroepen zal immers weer gebruik gemaakt worden van bijvoorbeeld adressenbestanden. Aannemelijk is dus dat zowel in het begin van het proces van informatiemijnbouw (het verzamelen van gegevens voor het datawarehouse) als aan het eind van dit proces (het gebruiken van de gevonden kennis) er veelal sprake zal zijn van persoonsgegevens. ${ }^{303}$

\subsubsection{Koppeling in de WPolr en bet BPolr}

De WPolr besteedt in artikel 6 aandacht aan de koppeling van cen politieregister met enige andere verzameling van persoonsgegevens. De verzameling van persoonsgegevens kan zowel een politieregister zijn als een andere bij de politie of elders in beheer zijnde verzameling van persoonsgegevens. ${ }^{304}$ In artikel 1 sub $\mathrm{d}$ WPolr wordt het begrip 'koppeling' omschreven als "het treffen van technische of organisatorische voorzieningen, waardoor verschillende verzamelingen van persoonsgegevens systematisch met elkaar kunnen worden vergeleken". De wetgever stond dus blijkbaar hoofdzakelijk het in subsectie 6.1.1 beschreven computer matching voor ogen: het leggen van relaties tussen twee of meer gegevensbestanden om te zoeken naar individuen die in meer dan één bestand voorkomen. De normering van de koppelingshandelingen is hierop afgestemd. Wellicht heeft de wetgever nog even gedacht aan computer profiling, doch aan de andere beschreven technische vormen van koppeling wordt door de wetgever nog geen of althans onvoldoende aandacht besteed. De wetgever zal hieraan onzes inziens op korte termijn toch aandacht moeten schenken, teneinde de nieuwe technische mogelijkheden aan adequate en proportionele normen te binden. ${ }^{305}$

Een koppeling is slechts geoorloofd indien dit:

a. noodzakelijk is voor een goede uitvoering van de politietaak (art. 6 lid 1 WPolr); en

b. gebeurt overeenkomstig het voor het register geldende reglement (art. 6 lid 2 WPolr).

Een koppeling is dus in beginsel slechts geoorloofd indien en voorzover het reglement voor dat register dat bepaalt. Het Nederlandse Reglement Internationale Rechtshulp Politie (Reglement IRP) bepaalt ter zake niets, zodat een koppeling van het register Internationale Rechtshulp Politie (register IRP) met een ander register vooralsnog niet geoorloofd is. Het register IRP is het register waarin alle gegevens omtrent internationale

303. Gardeniers, Van Kralingen \& Schreuders 1996.

304. Kamerstukken $I 1,1985 / 1986,19589$, nr. 3 (MvT), par. 2, onder C (de inhoud van de registers).

305. Zie hieromtrent Sietsma, Verbeek \& Van den Herik 2002. 
politiële rechtshulp worden opgeslagen, conform de registratieplicht van de SUO. Voor de grensregiokorpsen is dit de (lokale) PALMA-registratiedatabase. Als de politie dit register in de toekomst zou willen koppelen met een andere verzameling van persoonsgegevens, dan zal hierover een bepaling moeten worden opgenomen in het Reglement IRP. Over die bepaling zal, alvorens deze wordt vastgesteld, het CBP moeten worden gehoord (art. 6 lid 2 WPolr). De MvT merkt op dat er in het algemeen minder bezwaren kleven aan het koppelen van gegevensbestanden met een verwant doel dan aan het koppelen van gegevensbestanden die met een geheel ander oogmerk zijn aangelegd. ${ }^{306}$ Op grond van artikel 6 lid 4 WPolr staat in uitzonderingsgevallen de mogelijkheid open dat koppeling plaatsvindt ook zonder dat het reglement daarin voorziet. De Minister van Justitie kan daarvoor in bijzondere gevallen toestemming geven, indien dit noodzakelijk is voor de opsporing van een misdrijf waardoor de rechtsorde ernstig is geschokt. Wanneer het gaat om zeer ernstige misdrijven weegt het belang van de opsporing zwaar en kan dit een inbreuk rechtvaardigen op regels die uit oogpunt van privacy zijn gesteld. Dit is in overeenstemming met de beperkingsclausule van artikel 8 lid 2 EVRM en de daarop gebaseerde jurisprudentie van het EHRM. Aan de toestemming kunnen beperkingen en voorschriften worden verbonden. Het CBP dient hierover zo mogelijk vooraf te worden gehoord. Vanwege het spoedeisend karakter van de opsporing kan het CBP niet altijd vooraf worden gehoord, doch de toestemming dient in ieder geval zo spoedig mogelijk aan het CBP te worden meegedeeld. De regeling van artikel 6 lid 4 WPolr ten behoeve van de opsporing van zeer ernstige misdrijven is dus een beperkte ontsnappingsmogelijkheid. Hoewel het Reglement IRP ter zake van koppeling geen regeling inhoudt, zou het register IRP in dit geval nu reeds kunnen worden gekoppeld met een andere verzameling van persoonsgegevens.

Volgens de MvT is het oogmerk van koppeling in de regel het verkrijgen van nieuwe informatie over een in beginsel onbepaalde groep van personen. De informatie kan dan niet worden ontleend aan een van de betrokken registers afzonderlijk. ${ }^{307} \mathrm{Er}$ is dus geen koppeling in de zin van de WPolr als omtrent bepaalde op voorhand bekende personen gerichte informatie wordt verzameld uit verschillende gegevensbestanden, ook al gebeurt dit langs geautomatiseerde weg en tegelijkertijd. ${ }^{308}$ Gelijktijdige raadpleging van gegevens omtrent een bepaalde persoon uit meerdere bestanden is geen koppeling in juridische zin, ook niet als de gegevens uit de betrokken bestanden op hetzelfde beeldscherm worden getoond. ${ }^{309}$

306. Kamentukken II, 1985/1986, 19589 , nx. 3 (MvT), par. 2, onder C (de inhoud van de registers).

307. Kamensukken II, 1985/1986, 19 589, nr. 3 (MvT), artikelsgewijze toelichting op artikel 1.

308. In gelijke zin: de NvT bij het BPolr, Stt. 1991, 56, p. 16.

309. Goos \& Vuges 1996, p. 64. 
Wij lopen nu de in sectie 6.1 genoemde vormen van technische koppeling langs en gaan $\mathrm{na}$ in hoeverre daarbij sprake is van koppeling in juridische zin.

- Bij normale bevragingen via de PALMA-formulieren van het systeem voor internationale grensregionale politiële gegevensuitwisseling PALMA, wordt in verschillende gegevensbestanden informatie verzameld over bepaalde op voorhand bekende personen. Er is dan geen sprake van koppeling van bestanden in de juridische zin van de WPolr en het BPolr.

- On-linetoegang tot externe gegevensverzamelingen door medewerkers van de IRC's ${ }^{310}$ is voornamelijk gericht op het snel opvragen van gegevens over een bepaalde persoon of object. Omdat daarbij geen groepsgewijze bevraging plaatsvindt, is er ook dan geen sprake van koppeling in wettelijke zin. Als een on-lineverbinding echter zodanig is opgezet dat naast bevragingen op individuele basis ook selecties van meerdere personen in het externe bestand kunnen worden gemaakt, kunnen de geselecteerde gegevens eenvoudig (groepsgewijs) worden vergeleken met gegevens in andere bestanden. On-linetoegang tot externe bestanden maakt het aldus eenvoudig koppelingen in wettelijke zin uit te voeren. ${ }^{311}$

- Bij computer-assisted front-end verification is sprake van gelijktijdige raadpleging van gegevens omtrent een bepaalde persoon uit meerdere bestanden en derhalve niet van koppeling in wettelijke zin.

- Wanneer sprake is van computer profiling of KDD lijkt er - in de fasen waarin sprake is van persoonsgegevens - een koppeling in wettelijke zin te zijn, omdat nieuwe informatie wordt verkregen over een in beginsel onbepaalde groep van personen.

- Ook datawarehousing kan worden beschouwd als het treffen van een voorziening ten bate van vergelijking van de betrokken bronregistraties. ${ }^{312} \mathrm{Er}$ is ook daarbij dus in beginsel sprake van koppeling in wettelijke zin. ${ }^{313}$

- Bij geïntegreerde politiële BedrijfsProcessenSystemen kan met behulp van standaard databasebevragingsinstrumenten een vergelijking van verschillende onderdelen van het systeem plaatsvinden. Omdat vergelijkingsvoorzieningen aanwezig zijn, is ook hierbij sprake van koppeling in wettelijke zin. ${ }^{314}$

- Ook bij geografische informatiesystemen is sprake van koppeling in wettelijke zin. Er vindt dan een bevraging plaats van verschillende registraties op basis van locatiekenmerken. Daarbij wordt een vergelijking van deze registraties uitgevoerd voor een onbepaalde groep van personen.

310. In de toekomst wellicht via de multimediakiosk van de EMMI-omgeving.

311. Goos \& Vugts 1996, p. 65.

312. Goos \& Vugts 1996, p. 66.

313. Anders: Schreuders 2001, p. 119.

314. Kamerstukken II, 1988/1989, 19589 , nr. 11, p. 13 (Nota naar anleiding van het Eindverslag WPolr): "Bij het opstellen van de reglementen voor de registers die in een geīntegreerd politie-informatiesysteem zijn opgenomen, dient met dit koppelingsbegrip rekening te worden gehouden." 
- Bij integratie houden de samengevoegde gegevensverzamelingen op te bestaan als zelfstandige gegevensverzamelingen. Uit de nieuw gevormde verzameling kan blijken omtrent welke personen gegevens voorkwamen in een of meer van de samengevoegde bestanden. Fysieke integratic kan daarom ook aangemerkt worden als koppeling in wettelijke zin.31s

- Wij merken ten slotte op dat ook de onderlinge vergelijking van handmatige bestanden onder het koppelingsbegrip valt.

\subsubsection{Commentaar op de wet}

Als wij de wettelijke definitie in artikel 1 sub $\mathrm{d}$ WPolr van koppelen nader beschouwen, vallen twee dingen op. ${ }^{316}$ Ten eerste acht de wet reeds een koppeling aanwezig als er voorzieningen zijn getroffen die vergelijking van gegevensverzamelingen mogelijk maken. Niet de daadwerkelijke vergelijkingshandeling is bepalend, maar de voorbereidingshandelingen zijn reeds bepalend. Ten tweede spreekt de wet niet over een vergelijking van 'registraties' maar over een vergelijking van 'verzamelingen van persoonsgegevens'. De wetgever heeft met deze terminologie waarschijnlijk willen bewerkstelligen dat het vergelijken van delen van registraties die geen nieuwe registraties vormen ook onder het wettelijk koppelingsbegrip zou vallen. Het begrip 'verzamelingen van persoonsgegevens' wordt in de wetsgeschiedenis echter niet nader gedefinieerd.

\subsubsection{Nadere regels omtrent koppeling}

Ter bescherming van de persoonlijke levenssfeer van de geregistreerden zijn in de artikelen 4 en 5 BPolr nadere regels omtrent koppeling gesteld krachtens artikel 6 lid 3 WPolr. Artikel 4 lid 1 BPolr bepaalt dat koppeling alleen is toegestaan van een politieregister met een ander politieregister of met een persoonsregistratie die is aangelegd binnen de overheid. ${ }^{317}$ Koppelingen met registers in de particuliere sector krachtens een reglement van een politieregister zijn dus uitgesloten. De NvT ${ }^{318}$ motiveert dit door te stellen dat de noodzaak dergelijke koppelingen tot stand te brengen zich nauwelijks voordoet. Verder zou de daaruit voortvloeiende inbreuk op de persoonlijke levenssfeer nog groter zijn dan bij registraties binnen de overheid. Wij merken op dat in bijzondere gevallen, wanneer het gaat om de opsporing van een misdrijf waardoor de rechtsorde ernstig is geschokt, de Minister van Justitie wél bijzondere toestemming tot een dergelijke koppeling kan geven op grond van artikel 6 lid 4 WPolr. Als een koppeling met een Wbp-register wordt overwogen, dan geldt voortaan artikel $43 \mathrm{Wbp}$, dat enkele uitzonderingen kent op de hoofdregel dat de verwerking van persoonsgegevens in overeenstemming dient te

315. Goos \& Vugts 1996, p. 66.

316. Goos \& Vugts 1996, p. 64.

317. Als bedoeld in artikel 17 anhef en sub $a$ WPR (oud). Artikel 4 lid 1 BPols dient nog te worden aangepast aan de Wbp.

318. Stb. 1991, 56, p. 17. 
zijn met de doeleinden waarvoor zij zijn verkregen en de mededelingsplicht aan de betrokkene. De koppeling leidt immers tot verstrekking van gegevens. De verantwoordelijke kan deze bepalingen buiten toepassing laten indien dit noodzakelijk is voor de voorkoming, opsporing en vervolging van strafbare feiten (art. 43 onder $b$ Wbp). ${ }^{319}$

De NvT ${ }^{320}$ gaat in op het resultaat van een koppeling van verzamelingen van persoonsgegevens. Het resultaat van een koppeling kan zijn dat gegevens worden verstrekt. Koppeling kan immers leiden tot verstrekking van gegevens aan degene ten behoeve van wie de koppeling wordt uitgevoerd. In geval van een koppeling met een politieregister moet dan tevens bezien worden of is voldaan aan het gesloten verstrekkingsregime van de WPolr en het BPolr. Het resultaat van een koppeling kan eventueel leiden tot een nieuw tijdelijk register in de zin van artikel 13 WPolr. Dit is volgens de NvT in ieder geval zo indien bij vergelijking van gekoppelde registers gegevens worden aangetroffen over meerdere personen die in meer dan één register voorkomen. Het tijdelijk register is dan aangelegd voor hetzelfde doel waartoe ook de koppeling plaatsvond. Van de aanleg van dit nieuwe register moet ingevolge artikel 13 lid 3 WPolr binnen een week het CBP in kennis worden gesteld. Tevens moet ingevolge artikel 8 lid 2 BPolr binnen dezelfde termijn het gezag dat verantwoordelijk is voor de uitvoering van de politietaak waarvoor het register is aangelegd, in kennis worden gesteld van het nieuwe register. Deze twee voorschriften van de WPolr en het BPolr zijn niet van toepassing indien het register in de tussentijd is vernietigd.

Koppeling behoeft echter niet te leiden tot een nieuw register. Volgens de NvT is er bijvoorbeeld geen sprake van een nieuw register wanneer een vergelijking van de bij de koppeling betrokken registers leidt tot het resultaat dat geen van de persoonsgegevens in enig register wordt teruggevonden in een ander bij de koppeling betrokken register. Het is ook mogelijk dat een of enkele personen worden gevonden op zo'n wijze dat niet kan worden gesproken van een nieuwe samenhangende verzameling van op verschillende personen betrekking hebbende persoonsgegevens. Dit is volgens de NvT bijvoorbeeld het geval indien de aangetroffen gegevens niet bijeen worden gehouden in een afzonderlijk register maar terstond blijken te kunnen worden opgenomen in bestaande duurzame registers. Ingevolge artikel 5 lid 1 sub f BPolr dient dit dan vermeld te worden in het ter zake van de koppeling opgemaakte proces-verbaal (zie hierna).

\footnotetext{
319. Deze regeling is in de plaats gekomen van de artikelen 11 en 18 WPR. Voor de andere taken van de politie, namelijk de handhaving van de openbare orde en de hulpverlening, biedt de genoemde uitzondering op de hoofdregel van de Wbp geen soclazs.

320.Stb. 1991, 56, p. 16-17.
} 
Art. 4 lid 2 BPolr stelt vervolgens dat de koppeling van een tijdelijk politieregister (art. 13 lid 1 WPolr) met een ander register alleen plaats mag vinden voorzover dit noodzakelijk is voor het doel waarvoor het tijdelijk politieregister is aangelegd.

Art. 5 lid 1 BPolr stelt de eis dat van elke koppeling een proces-verbaal wordt opgemaakt. ${ }^{321}$ Hierin moet zo nauwkeurig mogelijk worden vermeld:

a. het doel van de koppeling (om te kunnen toetsen of deze noodzakelijk was voor de goede uitvoering van de politietaak in verband met de naleving van artikel 6 lid 1 WPolr en artikel 4 lid 2 BPolr);

b. de datum van de koppeling (om de koppeling te kunnen identificeren);

c. degene in wiens opdracht de koppeling plaatsvond (om te kunnen vaststellen wie verantwoordelijk is voor de koppeling);

d. de registraties die zijn gekoppeld, alsmede de naam van de beheerder of de houder van die registraties (om te kunnen vaststellen wie verantwoordelijk is voor de koppeling);

e. of de koppeling heeft geleid tot nieuwe persoonsgegevens en zo ja, welke (voor het geval de koppeling achteraf onrechtmatig zou worden geoordeeld: de gegevens die als resultaat daarvan zijn opgeslagen, kunnen dan worden achterhaald en verwijderd);

f. of de nieuwe persoonsgegevens zijn opgenomen in een register en zo ja, in welk (voot het geval de koppeling achteraf onrechtmatig zou worden geoordeeld: de gegevens die als resultaat daarvan zijn opgeslagen, kunnen dan worden achterhaald en verwijderd);

g. eventuele bijzonderheden.

321. Als er sprake is van opsporing, is ook artikel $152 \mathrm{~Sv}$ van toepassing. Dit artikel ziet slechts op het door het WvSv bestreken opsporingsonderzoek. Opsporingsambtenaren moeten ten spoedigste een proces-verbaal opmaken van het door hen opgespoorde strafbare feit of van hetgeen door hen tot opsporing is verricht of bevonden. Volgens de Hoge Raad is artikel 152 Sv niet van toepassing op proactief onderzock, het onderzoek waarin door opsporingsambtenaren met het oog op cen mogelijk opsporingsonderzoek informatie wordt vergaard terwijl er nog geen sprake is van een verdenking van een strafbaar feit. Verslaglegging mag in de proactieve fase echter niet geheel achterwege blijven. Als immers een opsporingsonderzoek volgt, moet bij het opmaken van een proces-verbaal op grond van artikel 152 Sv kunnen worden teruggegrepen op hetgeen voorafgaand aan het opsporingsonderzoek is verricht en bevonden. Bovendien moet kunnen worden voldaan aan een verzoek van de rechter in het eindonderzoek tot nadere opheldering omtrent bepaalde feiten en omstandigheden. De gedragslijn die bij de verslaglegging van de proactieve fase wordt gevolgd, moet worden getoetst door de Officier van Justitie (Ovj). Op grond van artikel 13 Politiewet 1993 komt immers aan de Ovj ook in de proactieve fase het gezag toe over de verrichting van opsporingsambtenaren. Daarbii dient volgens de Hoge Raad uitgangspunt te zijn dat de rechter in het eindonderzock - overeenkomstig de aan een eerlijk proces te stellen eisen - in staat moet zijn de rechtmatigheid van het onderzock te toetsen en zich een oordeel te vormen over de betrouwbaarheid van de resultaten van dat onderzock. Zie HR 19 december 1995, NJ 1996, 249. 
Ingevolge artikel 5 lid 2 BPolr moet de korpsbeheerder het proces-verbaal gedurende twee jaar bewaren. ${ }^{322} \mathrm{Hij}$ moet dat doen op zodanige wijze dat het desgevraagd onmiddellijk aan de daartoe bevoegde organen ter inzage kan worden gegeven. ${ }^{323}$ Deze regeling inzake het koppelingsproces-verbaal strekt ertoe dat de uitoefening van controle op een uitgevoerde koppeling door bijvoorbeeld het CBP mogelijk is.

Ingevolge artikel 5 lid 3 kan bij reglement van deze regeling inzake het koppelingsproces-verbaal worden afgeweken voorzover dat met het oog op een goede uitvoering van de politietaak onvermijdelijk is. Blijkens de $\mathrm{NvT}^{324}$ is hierbij gedacht aan de mogelijkheid dat koppeling een zo alledaagse praktijk is - bijvoorbeeld in het kader van misdaadanalyse - dat vastlegging van alle in artikel 5 lid 1 genoemde gegevens een onevenredige administratieve werklast tot gevolg zou hebben. ${ }^{325}$ Ingevolge artikel 6 lid 2 WPolr moet het CBP over een dergelijke afwijkende bepaling in een reglement vooraf advies geven.

\subsubsection{Commentaar op nadere regels}

Uit de regeling in de artikelen 6 WPolr en 4 en 5 BPolr blijkt dat de wetgever er in beginsel vanuit is gegaan dat koppelen een ad hoc handeling is. In de wettelijke definitie in artikel 1 sub d WPolr wordt daarentegen een koppeling reeds aanwezig geacht als er voorzieningen voor het vergelijken van gegevensverzamelingen zijn aangebracht, ook al is de daadwerkelijke vergelijking niet of nog niet uitgevoerd. De inhoudelijke regeling en de definitie lijken dus niet geheel met elkaar in overeenstemming. Verder is het zo dat de toepassing van bepaalde in de vorige sectie beschreven innovatieve technieken kan leiden tot min of meer voortdurende bestandsvergelijking. De procedurele regeling inzake het opmaken van processen-verbaal is hierop praktisch gesproken niet goed toepasbaar. Ten aanzien van datawarehouses is bijvoorbeeld niet helemaal duidelijk of alleen bij de eerste opbouw sprake is van koppeling of dat dit ook het geval is als ten behoeve van actualisering de inhoud van een bestaand datawarehouse periodiek wordt vergeleken met de inhoud van de betrokken bronbestanden. ${ }^{326}$

322. Eventueel zal het proces-verbaal bij strafrechtelijk onderzoek echter langer moeten worden bewaard. De hele regeling van het strafrechtelijk onderzoek gaat immers uit van het bewaren van gegevens die nog van betekenis zijn voor het onderzoek.

323. Aan de bevoegde organen wil zeggen: aan de OvJ bij de strafrechtelijke handhaving van de rechtsorde en aan de burgemeester bij de handhaving van de openbare orde en bij de hulpverlening (arr. 1 sub e BPolr).

324. Stb. 1991, 56, p. 18.

325. In artikel $126 \mathrm{gg} \mathrm{Sv}$ is een rechtsbasis gecreēerd voor dergelijk onderzoek met als doel de voorbereiding van opsporing, het zogeheten verkennend onderzoek. Dit onderzoek valt niet helemaal samen met het zogeheten fenomeenonderzoek. Het laatste type onderzoek is gericht op het onderzocken van risico's en dreigingen en niet primair op opsporing.

326. Goos \& Vugts 1996, p. 72. Zie hierover nader Sietsma, Verbeek \& Van den Herik 2002 . 


\subsubsection{Datamining in juridische zin $^{32}$}

Het begrip datamining is bij de parlementaire behandeling van het voorstel tot wijziging van artikel $13 \mathrm{Gw}$ in verband met de onschendbaarheid van het brief-, telefoon- en telegraafgeheim aan de orde gekomen. ${ }^{328}$ Ook bij de parlementaire behandeling van de nieuwe Telecommunicatiewet kwamen de mogelijkheden van datamining naar voren. ${ }^{329}$ Het ging daarbij om een discussie over de juridische bescherming van zogenaamde verkeersgegevens (bijvoorbeeld gegevens over waarvandaan en waarnaartoe gebeld wordt). De grote mogelijkheden die datamining in een digitale omgeving aan inlichtingen- en opsporingsdiensten biedt, werden daarbij onderkend. In geen van beide gevallen werd echter een omschrijving van datamining gegeven. Datamining wordt slechts in verband gebracht met het analyseren van gegevens. ${ }^{330} \mathrm{Er}$ wordt wel een omschrijving van datamining gegeven in de Kabinetsnota Wetgeving voor de elektronische snelweg., ${ }^{331}$ Deze omschrijving luidt: "analyse van gegevens in een database met speciale programmatuur die naar anomalieèn, trends of bepaalde kenmerken zoekt". In het kader van de opsporing en vervolging van strafbare feiten wordt het begrip datamining echter beperkt tot het elektronisch zoeken op onbepaalde groepen van personen. Hiermee wordt aan het begrip datamining ongeveer dezelfde betekenis gegeven als aan het begrip koppeling in de artikelen 1 en 6 WPolr en de artikelen 4 en 5 BPolr. In de toelichting op deze artikel wordt ook over 'een onbepaalde groep van personen' gesproken.

\subsubsection{Categoriale privacy}

Bij het hanteren van informatie over groepen van personen en het daarbij creëren van digitale virtuele (niet overeenkomstig de werkelijkheid zijnde) evenbeelden komt een nieuwe vorm van potentiële schending van de privacy om de hoek kijken: de zogenaamde categoriale privacy. Er moet voor worden gewaakt dat het individu individueel beoordeeld blijft worden en niet wordt behandeld op basis van eigenschappen van groepen waartoe het, vaak toevallig, behoort. ICT mag door het maken van profielen ${ }^{332}$ niet haar eigen waarheden omtrent individuen gaan creëren en die vervolgens als beoordelingsmaatstaf en ten behoeve van beleidsvorming gebruiken. ${ }^{333}$ Een afzonderlijke individucle toets blijft onzes inziens daarvoor noodzakelijk, ${ }^{344}$ naast de eventuele toepassing van ICT en dataminingtechnieken. Het gebruik van profielen zal wettelijk nader moeten worden geregeld, omdat de gegevensbeschermingsregelingen niet zonder meer van toe-

327. Zie hieromtrent Sietsma, Verbeek \& Van den Herik 2002.

328. Handelingen II, 1997/1998, p. 43-3466 en 73.

329. Kamerstukken II, 1997/1998, 25.533, nr. 4, p. 44.

330. Schreuders \& Van Kralingen 1998.

331. Kamerstukken II, 1997/1998, 25880 , nr. 1-2.

332. Hieronder vallen virtuele evenbeelden en door mensen bedachte beelden.

333. Vergelijk Schreuders \& Van Kralingen 1998, par. 7.4.3.

334. Met het oog op het verdenkingsbegrip van artikel 27 Sv of het betrokkenheidsbegrip van artikel 132 a Sv. 
passing zijn op het gebruik van profielen. Er is immers, zoals gezegd, vaak geen sprake meer van persoonsgegevens in de zin van deze regelingen. Desalniettemin kan de privacy van personen in het geding zijn bij het gebruik van profielen. De wetgever en eventueel het openbaar bestuur zullen daarom zorgvuldigheidseisen voor het gebruik van profielen moeten opstellen. De beginselen van het Databeschermingsverdrag en de beginselen van behoorlijk (straf)procesrecht kunnen daarvoor als leidraad dienen. ${ }^{335}$

\subsubsection{Conclusies en aanvullende opmerkingen ${ }^{336}$}

De politie en de KMAR zullen in de praktijk gebruik (willen) maken van met behulp van geautomatiseerde middelen opgestelde beslisregels in het kader van de opsporing en het verkennend onderzoek van artikel $126 \mathrm{gg}$ Sv. Als voor het opstellen van dergelijke beslisregels in het kader van de uitvoering van de politietaak cen datawarehouse wordt angelegd, dan is dat een politieregister. Het vullen ervan en het gebruik ervan zal bijgevolg aan de voorwaarden van de WPolr dienen te voldoen. Voor zover de gebruikte beslisregels zelf geen persoonsgegevens zijn, is de bevoegdheid bij het toepassen van die beslisregels te ontlenen aan artikel 4 lid 3 WPolr. Hierin wordt bepaald dat de beheerder de nodige voorzieningen dient te treffen ter bevordering van de juistheid en de volledigheid van de opgenomen persoonsgegevens, evenals dit voor Wbp-registers bepaald is in artikel 11 lid $2 \mathrm{~Wb}$. In een politieregister, zoals genoemd datawarehouse, opgenomen gegevens mogen gebruikt worden voor de goede uitvoering van de politietaak. Zij staan ter beschikking van alle politietaken die dienen te worden uitgevoerd door de gehele Nederlandse politie (art. 14 sub a en b WPolr en artikel 14 lid 1 sub a BPolr. Het feit dat voor bepaalde politieregisters beperkingen gelden in het verstrekkingsregime, behoeft niet het aanleggen en vullen van een datawarehouse in de weg te staan. De WPolr kent geen niet-onverenigbaarheidstoets zoals dit wel bij een Wbp-register het geval is op grond van artikel $9 \mathrm{Wbp} .^{337}$ Een datawarehouse kan een gewoon politieregister zijn (art. 1 WPolr) of een bijzonder politieregister in de zin van paragraaf $3 \mathrm{a}$ WPolr. In een bepaald geval kan een tijdelijk register aangelegd worden. Dit tijdelijk register heeft dan

335. Vergelijk Schreuders \& Van Kralingen 1998, par. 7.5; Zie over de beginselen van behoorlijk strafprocesrecht: Cleiren 1989 en Corstens 1995.

336. Zie nader Schreuders 2001.

337. Persoonsgegevens uit een register dat valt onder de Wbp mogen niet verder worden verwerkt op een wijze die onverenigbaar is met de doeleinden waarvoor de persoonsgegevens zijn verkregen (art. 9 lid $1 \mathrm{Wbp}$ ). Bij de beoordeling of een verwerking onverenigbaar is, dient de verantwoordelijke in elk geval rekening te houden met: (a) de verwantschap tussen het doel van de beoogde verwerking en het doel waarvoor de gegevens zijn verkregen; (b) de aard van de betreffende gegevens; (c) de gevolgen van de beoogde verwerking voor de betrokkene; (d) de wijze waarop de gegevens zijn verkregen; en (e) de mate waarin jegens de betrokkene wordt voorzien in passende waarborgen (art. 9 lid 2 Wbp). Indien het evenwel noodzakelijk is voor de uitvoering van het verkennend onderzoek van artikel $126 \mathrm{gg}$ Sv kan de OvJ bepalen dat artikel 9 lid 1 Wbp niet van toepassing is op daarbij nader aan te geven openbare registers die bij wet zijn ingesteld (art. 126gg lid $2 \mathrm{~Sv}$ ). 
de analyse van gegevens in een bepaalde zaak ten doel in het kader van een goede uitvoering van de politietaak (art. 1 sub j en 13 lid 1 WPolr).

In een politieregister mogen gegevens worden opgenomen en (verder) worden gebruikt als de opname van de gegevens noodzakelijk is voor het doel van het register (art. 4 lid 2 WPolr) en het gebruik noodzakelijk is voor een goede uitvoering van de politietaak (art. 14 sub a WPolr en artikel 14 lid 1 sub a BPolr). Een politieregister mag worden aangelegd als het een bepaald doel heeft dat noodzakelijk is voor de goede uitvoering van de politietaak (art. 4 lid 1 WPolr). De inhoudelijke norm voor een toetsing bij het opstellen en toepassen van beslistegels is daarom gericht op de goede uitvoering van de politietaak. Het gaat derhalve om de vraag of de politie bevoegd is de gegevens te analyseren en of de politie bevoegd is bepaalde beslisregels toe te passen. Deze bevoegdheid dient te kunnen worden ontleend aan het WvSv of aan de Politiewet 1993. In zijn algemeenheid bestaat evenwel een dergelijke bevoegdheid nog niet in het Nederlandse recht. De WPolr zelf stelt nagenoeg geen inhoudelijke grenzen aan het aanleggen van een gegevensverzameling die is bedoeld voor het opstellen en toepassen van beslisregels. ${ }^{338}$

Het is ten slotte te verdedigen dat de koppelingsbepalingen van artikel 1 en 6 WPolr en artikel 4 en 5 BPolr niet van toepassing zijn als een specifiek register aangelegd en gevuld wordt ten behoeve van de analyse van gegevens en voor het opstellen van beslisregels. ${ }^{339}$ De koppelingsbepalingen zien, zoals gezegd, enkel op de situatie dat (tegelijkertijd) gegevens uit verschillende verzamelingen van persoonsgegevens systematisch met elkaar (kunnen) worden vergeleken. Het valt te verdedigen dat dit bij het enkele vullen van een politieregister dat als datawarehouse dienst doet niet het geval is, omdat er dan geen sprake is van 'vergelijken'. Op het moment dat de in het datawarehouse opgenomen gegevens worden geanalyseerd, is het te verdedigen dat er toch in juridische zin geen sprake is van koppeling, omdat er dan geen sprake meer is van 'verschillende verzamelingen van persoonsgegevens'. Overigens heeft de koppelingsregeling van de WPolr en het BPolr geen invloed gehad op de praktijk van het uitwisselen van gegevens. De precieze strekking van de koppelingsbepalingen is onduidelijk. Normerende werking is er niet vanuit gegaan. ${ }^{340}$ De wetgever zal onzes inziens naar nieuwe wetgevende instrumenten op

338. In de gevallen van artikel 12 lid 1 sub a en lid 2 BPolr dient opname van de betreffende gegevens in de gegevensverzameling echter geweigerd te worden. Artikel 11 BPolr bevat gevallen waarin kan worden geweigerd. Artikel 12 lid 1 sub a betreft registers die uitsluitend voor de hulpverlening zijn aangelegd. Artikel 12 lid 2 BPolr betreft het verstrekken van gegevens over de uitoefening van geregistreerden van het recht op kennisneming of verbetering. Artikel 11 BPolr betreft het verstrekken van gegevens over informanten en het verstrekken van gegevens uit een register waarbij er, mede gelet op de bijzondere aard van het register, direct gevaat voor de geregistreerde of derden zou zijn.

339. In de literatuur is dit standpunt verdedigd door Schreuders 2001, p. 119.

340. Schreuders 2001, p. 33. 
zoek moeten gaan voor het regelen van de besproken technische vormen van koppeling van gegevens en gegevensbestanden en voor het verlenen van de bevoegdheid aan politie en justitie om gegevens te mogen analyseren en om bepaalde beslisregels toe te mogen passen.

Voor de koppeling van registers die onder de Wbp vallen, wordt de normering teruggevoerd tot de toepassing van de algemene normen van de Wbp. Er is geen afzonderlijke regeling voor de koppeling van Wbp-registers onderling of met andere registers. Met name de in subsecties 6.1 .4 respectievelijk 6.1 .5 besproken integratic van bestanden en de combinaties van koppelingsvormen maken het heel lasting om in de praktijk niet te scheiden vormen wettelijk te regelen. ${ }^{341}$

\subsection{Rechtstreekse geautomatiseerde toegang}

Bij de technische koppeling van de EMMI-omgeving voor de grensregionale politiële gegevensuitwisseling aan de Nederlandse nationale politiële computernetwerken (de integratie van bestanden via on-linekoppeling) gaat het in juridische zin voornamelijk om verstrekking van gegevens en niet zozeer om koppeling van gegevensverzamelingen. De belemmeringen voor de technische koppeling van computersystemen blijken voornamelijk te zijn gelegen in het feit dat directe verstrekking van politic̈le gegevens langs geautomatiseerde weg noch aan buitenlandse politieambtenaren noch aan het Nederlandse OM mag plaatsvinden. De artikelen 17 lid 1 BPolr en 15 lid 1 sub a WPolr vormen hiervoor een juridische barrière. De juridische oplossing zal dus in ieder geval betrekking moeten hebben op het gesloten verstrekkingsregime inzake gegevens voor de politiële rechtshulp. Het juridische koppelingsbegrip speelt bij het zoeken naar een werkbare juridische oplossing slechts een ondergeschikte rol. Hier zij uitdrukkelijk vermeld dat vooraleer de genoemde juridische barrière eventueel uit de weg geruimd kan worden, een grondige afweging dient plaats te vinden tussen enerzijds het recht op de bescherming op de persoonlijke levenssfeer van de burger en anderzijds het belang bij een geautomatiseerde opsporing in de grensgebieden (zie hiervoor in het bijzonder sectie 9.12). In verband met de problematiek van de rechtstreekse geautomatiseerde toegang behandelen we hieronder in subsectie 6.3.1 de protocolplicht en in subsectie 6.3.2 de mogelijke verstrekkingen van gegevens.

\subsubsection{De protocolplicht}

Het register IRP heeft als voornaamste doel (in de zin van artikel 4 WPolr) controle door het OM (en eventueel het CBP) op de naleving van de protocolplicht voor gegevens inzake politiële rechtshulp mogelijk te maken. Gegevens uit het register kunnen ook worden gebruikt ten behoeve van de interne bedrijfsstatistiek, interne bedrijfsvoering en 
interne ontwikkeling van beleid met betrekking tot de uitvoering van de politietaak (vergelijk artikel 2 Reglement IRP). Het betreft dus wel degelijk een politieregister dat (mede) is aangelegd ten dienste van de uitvoering van de politietaak. De registratiedatabase of het register IRP is in juridische zin tevens een protocolregister. Een protocolregister is een register waarin op grond van een wettelijke verplichting aantekening wordt gehouden van gegevensverstrekkingen. Dit aantekening houden of vastleggen van verstrekkingen wordt protocolleren genoemd. ${ }^{342}$ De in het register IRP opgenomen gegevens over gegevensverstrekkingen zijn derhalve protocolgegevens. Voor elk politieregister geldt een protocolplicht op grond van artikel 19 WPolr jo. Artikel 16, 17 en 18 BPolr. ${ }^{343}$ artikel $552 i$ lid $3 \mathrm{~Sv}$ vormt daarnaast een speciale wettelijke protocolplicht voor de uitwisseling van gegevens over de politiële rechtshulp. Op deze bijzondere protocolplicht kan door de WPolr en het BPolr geen afbreuk worden gedaan (lex specialis derogat legi generali: de bijzondere regeling gaat in beginsel vóor de algemene regeling). Er kan ook geen vrijstelling of ontheffing worden verleend van de verplichtingen die in deze bijzondere strafvorderlijke bepaling, alsmede in de artikelen 126 lid 3 sub e jo. 127 lid 1 SUO, zijn opgenomen. ${ }^{344}$ Het begrip 'protocolgegeven' dekt bij het register IRP dus een dubbele lading. Enerzijds worden er de gegevens mee bedoeld die ingevolge artikel $552 i$ lid 3 Sv moeten worden geregistreerd, anderzijds betreft het de gegevens omtrent gegevensverstrekkingen uit het register IRP in de zin van de WPolr en het BPolr. Dit inzicht is voor een goed begrip van het navolgende van groot belang.

De protocolplicht is ingevoerd in het licht van de controle op de integriteit van het gegevensverkeer binnen het gesloten verstrekkingsregime van de WPolr en de daaraan gekoppelde geheimhoudingsplicht van artikel 30 WPolr. De geheimhoudingsplicht van artikel 30 WPolr houdt in dat, wanneer aan een persoon of instantie een gegeven uit een politieregister is verstrekt, deze het gegeven in beginsel geheim dient te houden. ${ }^{345}$ Ook de protocolverplichtingen in de SUO zijn met het oog op de controle van verstrekkingen opgenomen. ${ }^{346}$ Naast dit beheersmatige karakter heeft protocollering ook de effectuering

342. Registratiekamer 1994, p. 3. Het begrip protocol, dat overigens geen wettelijke term is, wordt bij politieregisters dus in een andere betekenis gebruikt dan bij automatisering gebruikelijk is. Daar wordt het begrip veelal gebruikt om een bepaalde procedure of een procedureel voorschrift over datacommunicatie aan te duiden. In de MvT bij de WPolt wordt de vastlegging van gedane verstrekkingen aangeduid als protocolplicht; Kamerstuken II, 1985/1986, 19 589, nr. 3, p. 10 (MvT).

343. Op grond van artikel 17 lid 5 BPolr is verder de Regeling vrijstelling protocolplicht vastgesteld; Stert. 1991, 158 en Stert. 1992, 32. Artikel 3 van deze regeling is op 17 februari 1995 komen te vervallen.

344. Registratiekamer 1994, p. 5.

345. Verdere verstrekking is alleen toegestaan indien een op de WPolr gebaseerd voorschrift mededeling toelaat, of indien de uitvoering van de taak met het oog warop de gegevens zijn verstrekt tot bekendmaking noodzaakt.

346. Aldus de MvT bij de Goedkeuringswet SUO; Kamenstukten II, 1990/1991, 22 140, ne. 3, p. 55. 
van de rechten van de geregistreerden op mededeling, verbetering, aanvulling en verwijdering van de gegevens op het oog. ${ }^{307}$

De algemene protocolverplichtingen voor gegevensverstrekkingen zijn omschreven in de artikelen 16 lid 2 en 17 lid 5 BPolr. Op grond van artikel 17 lid 5 BPolr moet in beginsel in alle gevallen van elke verstrekking langs geautomatiseerde weg aantekening worden gehouden. ${ }^{348}$ Indien niet rechtstreeks langs geautomatiseerde weg gegevens uit een politieregister worden verstrekt, moet daarvan op grond van artikel 16 lid 2 BPolr ook aantekening worden gehouden, tenzij overeenkomstig het doel van het register is verstrekt aan personen die blijkens het reglement behoren tot de vaste gebruikers van het register. Als gegevens worden verstrekt aan de vaste gebruikers van het register IRP - blijkens artikel 11 lid 3 Reglement IRP de personen die geautoriseerd zijn tot rechtstreekse toegang en het $\mathrm{OM}$ - behoeft daarvan derhalve geen aantekening te worden gehouden. Van een verstrekking die niet rechtstreeks langs geautomatiseerde weg geschiedt, behoeft op grond van artikel 16 lid 3 BPolr ook geen antekening te worden gehouden als de verstrekking het resultaat is van een koppeling en van de koppeling ingevolge artikel 5 lid 1 BPolr een proces-verbaal is opgemaakt. Ten slotte behoeft van een verstrekking geen aantekening te worden gehouden indien dit zich niet verdraagt met het belang van de veiligheid van de staat. In de aantekening van de verstrekking moeten ingevolge artikel 18 lid 1 BPolr de identiteit van de verzoeker, de datum van de verstrekking en een omschrijving van de verstrekte gegevens worden vastgelegd. Bij een verstrekking die niet rechtstreeks langs geautomatiseerde weg plaatsvindt, moet ingevolge artikel 18 lid 2 BPolr tevens het doel van de verstrekking worden vastgelegd. Indien de uitvoering van de taak met het oog waarop de gegevens zijn verstrekt, noodzaakt tot bekendmaking aan derden, moet hiervan ingevolge artikel 18 lid 3 BPolr apart aantekening worden gehouden. Dit is bijvoorbeeld het geval als bij de ondervraging van een getuige van een strafbaar feit gegevens uit het register IRP worden bekendgemaakt. Ook is dit, behoudens de anonieme getuigenregeling in artikel $226 a \mathrm{~Sv}$, het geval bij stukken van de strafzaak waarvan kennisneming an de verdachte niet kan worden onthouden (art. 33 en $34 \mathrm{~Sv}$ ). De regeling van artikel 18 lid 3 BPolr is in overeenstemming met artikel 30 WPolr. ${ }^{349}$

347. Registratiekamer 1994, p. 6.

348. Enkele uitzonderingen hierop zijn neergelegd in de Regeling vrijstelling protocolplicht (zie de artikelen 1 en 2).

349. Stb. 1991, 56, p. 32. Artikel 30 lid 1 WPolr bepaait: "Een ieder die krachtens deze wet de beschikking krijgt over gegevens met betrekking tot een derde, is verplicht tot geheimhouding daarvan, behoudens voorzover een bij of krachtens deze wet gegeven voorschrift mededelingen toelaat, dan wel de uitvoering van de taak met het oog waarop de gegevens zijn verstrekt tot het ter kennis brengen daarvan noodzaakt." 


\subsubsection{Mogelijke verstrekkingen}

Bij de verstrekkingen die vastgelegd dienen te worden in het register IRP als bedoeld in artikel $552 i$ lid $3 \mathrm{~Sv}$, gaat het om een vorm van verstrekking die in de huidige protocolregeling niet als een afzonderlijke categorie wordt onderscheiden. Het gaat namelijk om verstrekkingen waarbij de uiteindelijke ontvanger (de politiemedewerker op de werkvloer) geen rechtstreekse toegang heeft tot het register IRP. De gegevens worden verstrekt door een IRC-medewerker die rechtstreekse toegang heeft, aan een politiemedewerker die geen rechtstreekse toegang heeft. Deze verstrekkingen gebeuren mondeling of schriftelijk en in de toekomst via e-mail. Ook het verstrekken van een diskette of tape met gegevens is mogelijk. Bij deze verstekkingen worden de gegevens door degene die rechtstreekse toegang heeft (de IRC-medewerker) niet opgevraagd om ze - primair - zelf te gebruiken, maar om ze 'door te verstrekken'. ${ }^{350}$ Dit soort verstrekkingen vinden rechtstreeks langs geautomatiseerde weg plaats, maar de uiteindelijke ontvanger heeft hierbij geen rechtstreekse toegang tot het politieregister waaruit de gegevens afkomstig zijn.

\subsection{Twee wegen van verstrekkingen}

In de hierna volgende subsecties 6.4 .1 en 6.4 .2 beschrijven wij twee wegen die bewandeld kunnen worden om aan de gesignaleerde problemen tegemoet te komen: de weg van de WPolr en die van de Wbp. De problemen hebben betrekking op de verstrekking van gegevens uit het register IRP aan het OM en de verstrekking van gegevens uit de nationale politièle databases aan buitenlandse politieambtenaren. Noch het $\mathrm{OM}$ noch buitenlandse politieambtenaren mogen namelijk rechtstreekse geautomatiseerde toegang hebben tot het register IRP. De weg via de WPolr verdient de voorkeur boven die via de Wbp. De weg via de Wbp lijkt ons nogal gekunsteld en nodeloos gecompliceerd. Subsectie 6.4.3 behandelt het hergebruik van protocolgegevens.

\subsubsection{De weg via de WPolr}

In de eerste plaats is de opmerking van de Ministers van Justitic en Binnenlandse Zaken in de NvT bij het BPolr van belang, namelijk dat de beperkingen in het verstrekkingsregime van de WPolr en het BPolr geen afbreuk kunnen doen aan de plicht van opsporingsambtenaren om krachtens het $\mathrm{W} v \mathrm{v} v$ informatie aan de rechterlijke macht te verschaffen. ${ }^{351}$ De politie zal het $\mathrm{OM}$ dus in ieder geval in de gelegenheid moeten stellen zijn controlefunctie ingevolge artikel $552 i$ leden 2 en 3 Sv en zijn rechtshulptaak uit te oefenen, ondanks de bestaande beperkingen in het wettelijke verstrekkingsregime.

In de tweede plaats zou in het geval van de directe verstrekking langs geautomatiseerde weg van politiële gegevens uit het register IRP (de registratiedatabase) aan het Neder- 
landse $\mathrm{OM}$ of aan buitenlandse politiediensten met name artikel 18 lid 5 WPolr uitkomst kunnen bieden. Dit artikel houdt een ontsnappingsclausule in. In afwijking van het gesloten verstrekkingsregime van de WPolr en het BPolr kan de Minister van Justitie (voor een justitieel belang) of de Minister van Binnenlandse Zaken (voor een bestuurlijk belang) op grond van deze bepaling namelijk in bijzondere gevallen toestemming of opdracht geven tot het verstrekken van nauwkeurig omschreven gegevens uit een politicregister. De toestemming of opdracht is een beschikking. Van deze beschikking moet de betreffende minister mededeling doen aan het CBP via een afschrift van het besluit. Op deze wijze wordt het CBP op de hoogte gesteld van de toepassing van de bepaling en wordt ze in staat gesteld het gevoerde beleid te beoordelen. Bij zijn besluitvorming moet de minister er dan natuurlijk wel rekening mee houden dat niet onnodig aan het belang van de beperkte verspreiding van de politiegegevens afbreuk wordt gedaan. ${ }^{352}$ Tot op heden heeft artikel 18 lid 5 WPolr zijn rol als ontsnappingsclausule nog nauwelijks vervuld. ${ }^{33}$ Door een beschikking op grond van artikel 18 lid 5 WPolr zou de Minister van Justitic evenwel meer duidelijkheid kunnen verschaffen omtrent hetgeen is toegelaten in het kader van de internationale uitwisseling van politiële gegevens. De problemen bij de verstrekking langs geautomatiseerde weg aan het Nederlandse $\mathrm{OM}$ en aan buitenlandse politiediensten moeten immers op de een of andere manier worden ondervangen. Ook zou de materie betreffende de koppeling van bestanden en systemen, zowel nationaal als internationaal, in het kader van de politiële rechtshulp door middel van een dergelijke beschikking nader kunnen worden gereguleerd. Hierbij moet worden opgemerkt dat blijkens de $\mathrm{MvT}^{354}$ de ontsnappingsclausule van artikel 18 lid 5 WPolr uitsluitend is bedoeld voor incidentele beslissingen in bijzondere gevallen. Groepen van gevallen dienen eigenlijk bij amvb te worden geregeld, dat betekent op grond van artikel 18 lid 1 WPolr dus in het BPolr. Hoewel uiteindelijk een regeling in het BPolr of wijziging van het BPolr de voorkeur geniet, kan artikel 18 lid 5 wellicht voorlopig voor het bijzondere geval van de politiële rechtshulp op korte termijn reeds uitkomst bieden, zij het strikt genomen alleen in incidentele gevallen.

In de derde plaats zou artikel 30 WPolr een grondslag kunnen vormen voor verstrekking van gegevens uit het register IRP aan het OM. In het kader van de uitvoering van de rechtshulptaak zou de politie gegevens uit het register IRP kunnen verstrekken aan het OM. Dit kan ingevolge artikel 30 WPolr indien de uitvoering van de taak met het oog waarop de gegevens eerder zijn verstrekt (door het buitenland) tot het ter kennis brengen daarvan aan het OM noodzaakt. Op grond van artikel 30 WPolr kan gegevensverstrekking plaatsvinden naar aanleiding van een daartoe tot de politie gericht verzoek van een 
niet in het gesloten verstrekkingsregime opgenomen persoon of instantie, zoals het OM. ${ }^{35}$ Het artikel ziet echter vooral op omstandigheden waarin het initiatief tot het verstrekken bij de politie ligt. ${ }^{356}$ Het geheimhoudingsartikel 30 WPolr is in de loop der tijd een zelfstandige grondslag voor gegevensverstrekking geworden, naast het gesloten verstrekkingsregime. De wettelijkheid daarvan is discutabel.

Het gebruik van artikel 30 WPolr als zelfstandige grondslag voor het verstrekken van gegevens komt op gespannen voet te staan met de bedoeling van die bepaling en de uitgangspunten en achtergronden van het gesloten verstrekkingsregime van de WPolr. Artikel 30 WPolr is bedoeld voor gegevensverstrekkingen in bijzondere gevallen en niet als basis voor systematische informatie-uitwisseling en informatiestromen. Onder omstandigheden kan verstrekking in zich herhaaldelijk voordoende en ook met elkaar vergelijkbare gevallen zijn toegestaan. Het moet dan gaan om verstrekkingen die in individuele gevallen op grond van artikel 30 WPolr toelaatbaar zijn maar waarbij de omstandigheden die tot de verstrekking leiden zich (tijdelijk) niet of nauwelijks lenen voor een regeling in een wet of besluit. De gevallen waarin verstrekking kan plaatsvinden, zullen dan nauwkeurig moeten worden omschreven. ${ }^{357}$ Of de verstrekking in het kader van de politiële rechtshulp aan het $\mathrm{OM}$ aan deze criteria kan voldoen, is discutabel. Er zal bij de verstrekking aan het OM sprake zijn van structurele verstrekkingen in het kader van de controle- en rechtshulptaak van het OM. Daarvoor dient bij voorkeur een structurele regeling in het gesloten verstrekkingsregime zelf getroffen te worden. Bij een verstrekking op verzoek van het OM op grond van artikel 30 WPolr moet in ieder geval voldaan zijn aan de voorwaarde dat de verstrekking noodzakelijk is ter uitvoering van de politietaak als bedoeld in artikel 2 Politiewet 1993: de justitiële taken (waaronder de rechtshulptaak) en de openbare ordetaken van de politie, alsmede hulpverlening. Anders zou sprake kunnen zijn van een niet toegelaten vorm van 'serviceverlening' door de politie. ${ }^{358}$

Ook moeten de eisen van subsidiariteit en proportionaliteit in de gaten worden gehouden. Verder speelt een rol dat artikel 18 lid 3 WPolr voor de verstrekking aan instanties die met een publieke taak zijn belast (zoals het $\mathrm{OM}$ ) uitdrukkelijk geen subdelegatie tocstaat. ${ }^{359}$ Er mag ook geen strijd ontstaan met de internationale regelgeving, die duidelijke, heldere en toegankelijke wetgeving vereist indien de persoonlijke levenssfeer in het geding komt. Artikel 18 lid 5 WPolr vormt onzes inziens daarom een sterkere basis dan artikel 30 WPolr om - in afwachting van een eventuele aanpassing van het BPolr -

355. Schreuders 1995, p. 5.

356. Vergelijk Schreuders 1995, p. 29.

357. Schreuders 1995, p. 4.

358. Schreuders 1995, p, 5.

359. Anders zou het niet "in accordance with the law" (een wet in formele zin) in de zin van artikel 8 lid 2 EVRM zijn. 
geautomatiseerde verstrekking an zowel het $\mathrm{OM}$ als aan buitenlandse politiediensten nader te laten reguleren door de Minister van Justitie en eventueel de Minister van Binnenlandse Zaken. Een nieuwe specifieke regeling in het BPolr verdient echter sterk de voorkeur vanwege het feit dat artikel 18 lid 5 WPolr uitsluitend bedoeld is voor incidentele gevallen.

Ten slotte merken wij op dat spontane verstrekking door de politie aan een OvJ in zijn functies van eerstgenoemde opsporingsambtenaar in de zin van artikel $141 \mathrm{~Sv}$, leider van de opsporing (art. 148 lid 2 Sv) en leider van de vervolging (art. 9 Sv) eigenlijk niet afdoende is geregeld. Hiervoor zou in artikel 14 WPolr een spontane verstrekkingsmogelijkheid voor de politie aan de Ovj die in deze functies optreedt, kunnen worden ingevoegd. ${ }^{360}$ Dit behelst dus een aanpassing van de WPolr. Ten tijde van de concipiëring van de WPolr werd een dergelijke verstrekkingsmogelijkheid wellicht niet nodig geacht omdat er toen nog niet veel gegevens met behulp van computersystemen werden uitgewisseld.

\subsubsection{De weg via de Wbp}

De politie, inzonderheid de IRC's, zou, met het oog op de periodieke verstrekking aan het $\mathrm{OM}$, een apart $\mathrm{Wbp}$-register voor de controle van de naleving van de protocolplicht aan kunnen leggen. Op grond van artikel $9 \mathrm{Wbp}$ zou dit register alleen persoonsgegevens mogen bevatten die noodzakelijk zijn voor het doel van de registratie, namelijk controle van de protocolplicht ingevolge artikel $552 i$ lid $3 \mathrm{~Sv}$. Hieruit kan de politie dan op grond van artikel 43 sub b en $d$ Wbp langs geautomatiseerde weg rechtstreeks gegevens aan het $\mathrm{OM}$ verstrekken voorzover dit noodzakelijk is voor een goede taakuitoefening van het OM. Een dergelijk Wbp-register is dan geen register dat is aangelegd ten dienste van de uitoefening van de politietaak, maar één dat exclusief is aangelegd om controle door het OM mogelijk te maken. Dit zou een alternatieve juridische 'sluiproute' kunnen zijn. Een nadeel voor het $\mathrm{OM}$ is dat het in het Wbp-register gegevens kan missen die het wel wil controleren. De politie behoeft de gegevens die zij uit het Wbp-register heeft verwijderd echter niet meteen te vernietigen. $\mathrm{Zij}$ kunnen desgewenst worden gearchiveerd. Op dat moment is de Archiefwet van toepassing ${ }^{361}$ Deze situatie is dus een andere dan die waarin uit een politieregister verwijderde gegevens ingevolge artikel 10 lid 2 sub d WPolr zo snel mogelijk na de verwijdering moeten worden vernietigd. ${ }^{362}$ Vernietiging wil zeggen dat de betreffende gegevens ook in eventuele duplicaatbestanden, bijvoorbeeld backups, moeten worden gewist. Gegevens die uit een politieregister zijn verwijderd, mogen niet overgebracht worden naar een archiefbewaarplaats. De reeds verwijderde maar nog

\footnotetext{
360. Vergelijk Schreuders 1995, p. 14. Een OvJ is ook geen opsporingsambtenaar in de zin van artikel 14 sub c WPolr.

361. Archiefwet 1995, Stb. 1995, 276.

362. Kamerstukken $I I, 1988 / 1989,19589$, nr. 6. p. 5 en 6 (MvA).
} 
niet vernietigde gegevens mogen enkel worden gebruikt om te controleren of verwijdering terecht heeft plaatsgevonden. ${ }^{363}$

Een optimale controle door het OM lijkt ons via de weg van een apart Wbp-register echter niet mogelijk. Er zou in deze situatie sprake zijn van een autorisatie van het OM op het niveau van de gegevens en niet op het niveau van de hele registratiedatabase. Dit zou leiden tot opslag van de geautoriseerde gegevens in een aparte Wbp-database. De inhoud van de $\mathrm{Wbp}$-database voor het $\mathrm{OM}$ zou dan verschillen van de inhoud van de registratiedatabase voor de politic. Er zou dan dus sprake zijn van een dubbele opslag ${ }^{364}$ en autorisatie van het $\mathrm{OM}$ op gegevensniveau.

Verder zou het $\mathrm{OM}$ ook een Wbp-register kunnen aanleggen met het oog op de verstrekking van gegevens aan het buitenland in het kader van de politiële samenwerking, eventueel gevuld met de inhoud van de gegevens die zij aangeleverd krijgt van de politie. Dan zouden gegevens wel rechtstreeks langs geautomatiseerde weg aan buitenlandse politiediensten kunnen worden verstrekt. Een dergelijke weg lijkt echter toch enigszins op gespannen voet te staan met de strekking van artikel 18 lid 1 WPolr en de bedoeling van de wetgever wat de verstrekking van politielle (operationele) gegevens aan het buitenland betreft. Daárvoor had de wetgever het open verstrekkingsregime van de WPR en thans de Wbp niet bedoeld. Een andere vraag is met welke gegevens het OM een dergelijk specifiek Wbp-register zou vullen. De gegevens die het van de politie aangeleverd krijgt voor de controle van de protocolplicht (via artikel 15 lid 1 sub a sub 1 WPolr) of voor de vervulling van zijn rechtshulptaak (via artikel 15 lid 1 sub a sub 2 WPolr) kunnen bezwaarlijk worden gebruikt om een database te vullen met het oog op de politiële samenwerking. Als het $\mathrm{OM}$ aan derden informatie uit de politieregisters gaat verstrekken, krijgen wij te maken met een omstandigheid die niet in overeenstemming is met het gesloten verstrekkingsregime van de WPolr en het BPolr. ${ }^{365}$ De inhoud van de registratiedatabase en de Wbp-databases kunnen ook uiteen gaan lopen en de Wbp-databases zijn wellicht niet meer up-to-date. Het probleem dat aan de wetgever voorgelegd dient te worden is dat protocolregisters op de beschreven wijze een zelfstandige bron van informatie worden. De wetgever zal over de wenselijkheid en rechtmatigheid van dergelijke mogelijke praktijken het laatste woord moeten spreken. 


\subsubsection{Hergebruik van protocolgegevens}

In de praktijk hebben de IRC's de wens geuit om hergebruik van de gegevens die zijn vastgelegd in de PALMA-logdatabase respectievelijk de registratiedatabase mogelijk te maken (zie subsectie 4.4.4). Hergebruik is onder voorwaarden juridisch toelaatbaar. De in het IRP-register, dat een politieregister is, opgeslagen gegevens kunnen binnen de reguliere politie in beginsel vrij worden verstrekt en gebruikt. De WPolr gaat namelijk in principe uit van actieve informatieverstrekking binnen de politie (art. 14 sub a en b WPolr). Daarbij geldt in beginsel geen doelbinding voor de verstrekking. Bij een voorgenomen hergebruik van de protocolgegevens door de IRC-medewerkers zal echter wel uitdrukkelijk rekening moeten worden gehouden met het doelbindingsbeginsel. Deze belangrijke eis van onder andere het vijfde beginsel van Aanbeveling R (87) 15 (vergelijk subsectie 5.3.2) houdt daar in dat gegevens die door het buitenland aan de Nederlandse politie verstrekt zijn voor geen ander doel gebruikt mogen worden dan aangegeven is in het verzoek om inlichtingen. Gebruik van de gegevens voor andere doeleinden moet afhankelijk worden gesteld van goedkeuring door de verstrekkende instantie. Dit wordt de eis van doelbinding of beperkt gebruik genoemd. Nederland stelt op grond van artikel 13 lid 5 BPolr deze algemene voorwaarde ook aan het buitenland (vergelijk subsectie 5.4.3). Het hergebruik van de protocolgegevens mag dus niet in strijd komen met de doeleinden waarvoor de gegevens door het buitenland zijn verstrekt. Ingevolge artikel 11 lid 2 BPolr kan verstrekking van de betreffende gegevens aan onder andere de reguliere politie, de Koninklijke marechaussee, bijzondere opsporingsambtenaren en aan het $\mathrm{OM}$ onder omstandigheden achterwege worden gelaten. Dit kan namelijk indien de gegevens slechts konden worden verkregen onder de voorwaarde dat zij alleen voor een bepaald doel zouden worden gebruikt en de verstrekking een ander doel zou betreffen. ${ }^{366} \mathrm{Bij}$ verstrekking van de gegevens kunnen ingevolge artikel 11 lid 3 BPolr beperkingen aan het gebruik van de gegevens worden opgelegd. De IRC-medewerkers zullen in ieder geval henzelf en andere politieambtenaren de beperking moeten opleggen dat zonder voorafgaande toestemming van de buitenlandse verstrekkende instantie de protocolgegevens niet voor een ander doel mogen worden (her)gebruikt dan voor het doel waarvoor de gegevens door het buitenland zijn verstrekt. Wil men de gegevens voor een ander doel gebruiken, dan zal om toestemming van de verstrekkende instantic moeten worden verzocht of zal een nieuw politieel rechtshulpverzoek uit moeten gaan. Voor degenen op wie de gegevens betrekking hebben, houdt dit de waarborg in dat over hen geen beslissingen worden genomen op basis van gegevens die niet up-to-date zijn.

366. Het bestaan van een dergelijke voorwaarde kan ingevolge artikel 11 lid 2 BPolr slechts worden aangenomen indien van de voorwarde blijkt uit een proces-verbaal en van het bestaan van een dergelijke voorwaarde aantekening is gehouden in het betreffende politieregister. 
Het is echter wel zo dat gegevens die louter zijn vastgelegd met het oog op de controle op de naleving van het verstrekkingsregime van het register IRP, dus de protocolgegevens in de zin van de WPolr en het BPolr (vergelijk subsectie 6.1.3), niet zomaar door de politie mogen worden gebruikt. De NvT bij artikel 18 lid 4 BPolr stelt daaromtrent namelijk dat, hoewel dergelijke gegevens nuttige informatie voor de politie kunnen opleveren, zij niet voor dat doel zijn vastgelegd. Een gebruik voor operationele doeleinden van deze protocolgegevens moet daarom als oneigenlijk worden afgewezen en is ingevolge artikel 18 lid 4 BPolr verboden. ${ }^{367}$ De mogelijkheid bestaat wel dat de Minister van Justitic of de Minister van Binnenlandse Zaken op grond van artikel 6 lid 4 of 18 lid 4 WPolr toestemming geeft om deze protocolgegevens in bijzondere gevallen wel voor operationele doeleinden te gebruiken. Te denken valt aan de opsporing van misdrijven waardoor de rechtsorde ernstig geschokt is. ${ }^{360}$

Een belangrijk probleem vanuit juridisch oogpunt is dat het volgens de Schengenregels en de daarbij behorende uitvoeringsregels, met name artikel 6 lid 1 Reglement IRP, niet toegestaan is een exacte kopie te bewaren van de volledige inhoud van de gegevens die zijn uitgewisseld. Dit komt neer op het dubbel opslaan van gegevens, terwijl dat niet nodig is voor het doel van het register en ook niet noodzakelijk is voor een goede uitvoering van de politietaak (vergelijk artikel 4 lid 1 WPolr). Er mag op grond van artikel 6 lid 1 Reglement IRP alleen een omschrijving van de verstrekte gegevens worden vastgelegd en niet de gehele inhoud van de gegevens zelf. Het is duidelijk dat het voor de politic erg moeilijk en tijdrovend is een omschrijving te geven van de verstrekte gegevens die vervolgens kan worden opgeslagen. Om die reden is in het oorspronkelijke PALMA-systeem toch gekozen voor de volledige opslag van alle velden in de centrale PALMA-logdatabase en het overbrengen van bepaalde velden hiervan, waaronder de complete inhoud van het bericht, in de lokale registratiedatabases die bij de IRC's zijn ondergebracht. Bij het ontwerp van een nieuw PALMA-systeem is het belangrijk te wijzen op het gevaar van het hergebruik van een op deze wijze ontstaan archief voor het afhandelen van nieuwe aanvragen en eventueel voor analysedoeleinden. Wij zijn van mening dat het voor de effectuering van de rechten van de geregistreerde met betrekking tot verbetering, aanvulling en verwijdering van gegevens, wellicht toch te verdedigen is om de gehele inhoud van de gegevens te bewaren. Deze opslag voor dit specifieke doel dient dan wel duidelijk wettelijk te worden geregeld en in ieder geval te worden afgestemd met het $C B P$ en de buitenlandse controleautoriteiten. In ieder geval dient de volledige inhoud van de verstrekte gegevens voor de betrokken IRC-medewerkers niet langer toegankelijk te zijn dan redelijkerwijs nodig voor een goede internationale gegevensuitwisseling. Het archief zou anders een zelfstandige bron van informatic worden voor hergebruik ter verstrekking bij 
een nieuwe aanvraag en eventueel voor misdaadanalyse en dat is niet de bedoeling van de Schengenregels hieromtrent.

Er dient evenwel op gewezen te worden dat het hier om een interpretatiekwestie gaat. Artikel $552 i$ lid $3 \mathrm{~Sv}$ met het bijbehorend model ${ }^{369}$ spreken over "het register moet in ieder geval de volgende gegevens bevatten" en de SUO zegt niet meer dan hetgeen artikel 126 lid 3 sub e aangeeft: "van de verstrekking en de ontvangst van persoonsgegevens dient in de registratie waaruit zij worden verstrekt en waarin zij worden opgenomen aantekening te worden gehouden." Het is desalniettemin duidelijk dat de wetgever niet een nieuwe zelfstandige bron van informatie heeft willen creëren voor operationeel gebruik naast de bestaande politieregisters waaruit de informatie wordt onttrokken en waarin de verkregen informatie wordt opgeslagen. ${ }^{370}$

Met betrekking tot openbare orde-informatic is de situatie aangaande de registratiefunctie van PALMA nogal gecompliceerd. Op grond van de artikelen 39 en 46 SUO mogen deze gegevens wel verstrekt worden, doch het register IRP is er niet op van toepassing, daar het niet gaat om strafvordering. Het register IRP is van toepassing op strafvorderlijke gegevens, in principe aangaande verdachte personen (of overige betrokkenen zoals getuigen en slachtoffers). Voor openbare orde-gegevens geldt dat het eigenlijk niet de bedoeling is dat die worden opgeslagen in de PALMA-registratiedatabase. Ook voor die gegevens dient het archief geen zelfstandige bron van informatie te worden voor hergebruik. Hetzelfde geldt in principe voor de overige categorieën van gegevens, niet zijnde strafvorderlijke gegevens, bijvoorbeeld informatie over verdwenen personen. Dir kan er in verband met artikel 5a sub b WPolr toe leiden dat gegevens over onverdachte personen slechts vier maanden mogen worden bewaard, als het doel van het archiveren van openbare orde-informatie de strafrechtelijke handhaving van de rechtsorde is. Te betogen valt evenwel dat het doel van het archief in dit geval is de controle van het register door de burgemeester (omdat het OOV betreft en het gezag derhalve bij de burgemeester berust).

Het archief mag wel gebruikt worden om te kijken of er al eerder een aanvraag is geweest over het betreffende onderwerp. Het archief dient echter eigenlijk slechts een omschrijving van de op het betreffende geval betrekking hebbende gegevens te bevatten en niet de concrete inhoud van de gegevens zelf. De IRC-medewerker zal voor de afhandeling van een verzoek altijd terug moeten gaan naar de bron van de gegevens, het oorspronkelijke register waarin de gegevens zijn opgeslagen. Eigenlijk schrijft artikel 126 lid 3 sub e

369. Besluit van 28 december 1993, Stcrt. 1993, 252.

370. Een vergelijkbare problematiek doet zich voor bij de infodesks van de recherche.

Het is ook nooit de bedoeling geweest dat deze infodesks zelfstandige bronnen van

informatic zouden worden. 
SUO voor dat "van de verstrekking en de ontvangst van persoonsgegevens dient in de registratie waaruit zij worden verstrekt en waarin zij worden opgenomen aantekening te worden gehouden." Daar dit in de praktijk onuitvoerbaar is gebleken, is deze regel niet toegepast en protocolleren de IRC's alleen in de registratiedatabase, aansluitend bij artikel $552 i$ lid $3 \mathrm{~Sv}^{371}$

Gegevens die door een CIE worden verstrekt, mogen alleen worden opgeslagen door de CIE zelf en niet door de IRC's. Het opslaan van CIE-gegevens door de IRC's gebeurt op dit moment ook niet.

\subsection{Multimediale gegevens}

Het feit dat het in de EMMI-omgeving gaat om de uitwisseling van multimediale gegevens is voor wat de juridische bescherming van de gegevens betreft niet van wezenlijk onderscheidend belang. De via de PALMA-formulieren en de multimediakiosk uitgewisselde plaatjes, foto's en videobeelden zijn, ingevolge de ruime definitie van persoonsgegevens in onder meer het Databeschermingsverdrag, persoonsgegevens als de gegevens met een bepaalde persoon in verband kunnen worden gebracht (zie subsecties 5.3.1, 5.4.3 en 6.1.2). Dat zal meestal het geval zijn. Ook de Registratiekamer geeft in haar jaarverslag 1997 een ruime invulling aan het begrip persoonsgegeven. ${ }^{372}$ Van een persoonsgegeven is sprake als een gegeven herleidbaar is tot een individuele natuurlijke persoon. Daarvoor moet aan twee eisen voldaan worden:

- het gegeven heeft betrekking op of verschaft informatie over een bepaalde persoon; en - de identiteit van de betrokkene kan redelijkerwijs worden vastgesteld.

De Registratiekamer boog zich reeds in 1997 over de vraag of videobeelden als persoonsgegeven zijn aan te merken en beantwoordde deze vraag positief. ${ }^{373}$ De Registratiekamer is van oordeel dat een video-opname van een persoon die daarop duidelijk is afgebeeld altijd betrekking op hem heeft en bovendien informatie over deze persoon verschaft. Voor de vraag of op een video-opname ook de identiteit van iemand redelijkerwijs kan worden vastgesteld, zijn volgens de Registratiekamer twee factoren van belang: de aard van het gegeven en de mogelijkheden die degene die de beschikking over de beelden heeft ten dienste staan om de beelden te herleiden. De Registratiekamer komt tot de slotsom dat naast gegevens als naam en adres, vingerafdruk en DNA-profiel, ook videobeelden van een persoon in het maatschappelijk verkeer als identificerend kunnen worden beschouwd. Hiervoor is het volgens haar niet noodzakelijk dat de afgebeelde persoon met naam bekend is bij degene die de beschikking heeft over de videobeelden. Deze 
omstandigheid kan volgens de Registratiekamer veranderen als sprake is van minder scherpe afbeeldingen van personen. Of het dan om een persoonsgegeven gaat, wordt bepaald door de vraag of er binnen redelijke grenzen een mogelijkheid tot indirecte identificatie bestaat. Het kan daarbij gaan om bekendheid van de betrokkene bij degene die de beschikking heeft over de beelden of om de beschikbaarheid van aanvullende informatie.

\subsection{Voorgenomen herziening WPolr}

In Nederland bestaat het voornemen om de WPolr te herzien. ${ }^{374}$ De herziening van de WPolr is onder andere gericht op verruiming van de wettelijke mogelijkheden tot opslag, verstrekking en gebruik van persoonsgegevens door de politie. Onder andere zal het verstekken van persoonsgegevens door de politie aan derden worden verruimd. Wij beperken ons in deze subsectie tot de punten van de verwerking van persoonsgegevens over onverdachte personen en de aanpassing van de WPolr aan de Wbp.

De huidige wet kent voor de opslag van gegevens over onverdachte personen voor de strafrechtelijke handhaving van de rechtsorde een beperking. Deze gegevens mogen in beginsel niet langer dan vier maanden worden opgeslagen, tenzij zij verwerkt worden binnen het regime van de bijzondere politieregisters (zie subsectie 5.4.3). In de praktijk blijkt de termijn van vier maanden erg kort voor de dagelijkse uitvoering van de politietak. Om die reden wordt overwogen deze termijn te verlengen.

Daarnaast blijkt in de praktijk dat de verwerking van gegevens betreffende onverdachte personen noodzakelijk kan zijn om zicht te krijgen op bepaalde maatschappelijke verschijnselen die samenhangen met criminaliteit. Het regime van de bijzondere registers is hierop volgens de Minister van Justitie niet voldoende toegesneden. De problematiek van overlast door groepen jongeren in een wijk, het wapenbezit in bepaalde stadswijken, signalen over op handen zijnde terroristische aanslagen et cetera vergen volgens de Minister van Justitie meer ruimte voor de opslag en verdere verwerking van gegevens van ook onverdachte personen zonder concrete verdenking. Daarom wordt voorgesteld te komen tot ruimere mogelijkheden tot verwerking van gegevens van onverdachte personen voor specifieke doelen binnen de politietaak. Dit voorstel betekent dat gegevens over onverdachte personen langdurig kunnen worden opgeslagen indien de verwerking van gegevens van deze personen nodig is voor dit doel. Gegevens over personen die op grond van de handelingen die zij verrichten, betrokken kunnen zijn bij de maatschappelijke problematiek die wordt aangepakt, moeten kunnen worden verwerkt. Door verbanden te leggen tussen verschillende gegevens kan een probleem beter in kaart worden gebracht en

374. Kamerstukken II, 2002/2003, 28600 VI, nr. 134 (Brief van de Minister van Justitie). 
beter worden aangepakt, aldus de Minister van Justitie. De maatschappelijke problematiek dient de langduriger opslag van gegevens te rechtvaardigen. Het dient te gaan om maatschappelijke problemen die noodzakelijke aandacht van de politie vergen en waarvoor verwerking van relevante gegevens nodig is, zodat gekomen kan worden tot een beter inzicht en een betere aanpak. Deze aanpak behoeft niet te bestaan uit (de voorbereiding van) opsporing of het treffen van strafrechtelijke maatregelen. Deze kan ook bestaan uit het preventief optreden langs de weg van bestuurlijke maatregelen. Het voorstel houdt in dat in de wet criteria zullen worden opgenomen voor de verwerking van gegevens voor een dergelijk specifiek doel en voor de termijn gedurende welke opslag is toegestaan. Het voorstel sluit mede aan op het voorstel betreffende themaregisters in het rapport van de werkgroep Gegevensuitwisseling en terrorismebestrijding. ${ }^{375}$ Met behulp van themaregisters kan een bepaald strafrechtelijk relevant thema worden onderzocht, bijvoorbeeld terrorisme. In het themaregister kunnen gegevens worden opgeslagen over groepen van onverdachte personen ten aanzien van wie aanknopingspunten bestaan dat zij betrokken kunnen zijn bij het beramen, voorbereiden of plegen van misdrijven die verband houden met het te onderzoeken thema. Men dient zich hierbij onzes inziens af te vragen of het uitvoerig registreren van onverdachte personen rond een thema wel een taak is van de politie. De politie mag onzes inziens geen verkapte inlichtingendienst worden.

Het voorstel van de Minister van Justitie ziet ook op het verdere interne gebruik van persoonsgegevens over onverdachte personen door de politie. De huidige WPolr laat, behoudens uitzonderingen, niet toe dat gegevens over onverdachte personen die ten behoeve van een bepaald strafrechtelijk onderzoek zijn verzameld ook worden gebruikt voor een ander strafrechtelijk onderzoek. In de praktijk bestaat er een behoefte om in bepaalde gevallen gegevens over onverdachte personen uit een bepaald strafrechtelijk onderzoek te kunnen gebruiken voor andere strafrechtelijke onderzoeken. Voorgesteld wordt te komen tot een verruiming in die zin dat gegevens over personen uit de ene zaak ook voor een andere zaak kunnen worden verwerkt indien daartoe een concrete aanleiding bestaat. Daartoe zullen er criteria nodig zijn voor het verwerken van persoonsgegevens, in afwijking van het specifieke doel waarvoor deze zijn verzameld.

De herziening van de WPolr strekt mede tot een aanpassing aan de systematiek van de Wbp in die zin dat de verwerking van persoonsgegevens voor een bepaald doel centraal staat, in plaats van, zoals in de huidige wet, het registerbegrip. Thans wordt hieromtrent een wetsvoorstel voorbereid. De inhoud daarvan is nog niet openbaar zodat we er hier niet verder op ingaan. 


\title{
7 Digitale expertise in internationaal perspectief
}

In dit hoofdstuk behandelen wij de tweede aanvullende onderzoeksvraag:

\begin{abstract}
"Welke juridische keuze dienen de Raad van Europa en de Europese Unie te maken met betrekking tot het vraagstuk van de rechtstreekse geautomatiseerde grensoverschrijdende toegang van buitenlandse opsporingsambtenaren tot nationale (politiele) databases en computernetwerken, mede in het licht van de internationale juridische ontwikkelingen betreffende digitale expertise?"
\end{abstract}

In sectie 7.1 geven wij een kort overzicht van de internationale ontwikkelingen betreffende grensoverschrijdende bevoegdheden. Vervolgens bespreken wij in sectie 7.2 het Cybercrimeverdrag van de Raad van Europa en in sectie 7.3 de Overeenkomst betreffende de wederzijdse rechtshulp in strafzaken van de EU. In sectie 7.4 gaan we in op het juridische vraagstuk van de directe toegang in relatie tot EMMI. Sectie 7.5 behandelt de visie van de Raad van Europa omtrent directe toegang. In sectie 7.6 bezien wij het Nederlandse recht met betrekking tot directe toegang. Sectie 7.7 behandelt de directe toegang in België en Duitsland. Sectie 7.8 bevat onze conclusies met betrekking tot een deugdelijke regeling voor de directe toegang en sectie 7.9 bevat onze standpuntbepaling terzake. De reden om het onderzoek met het Cybercrimeverdrag van de Raad van Europa (sectie 7.2) te beginnen is gelegen in het feit dat dit het eerste internationale verdrag van die aard is.

\subsection{Internationale grensoverschrijdende bevoegdheden}

Hierbij formuleren wij een extra doel van ons onderzoek, te weten het aantonen dat in internationaal verband steeds meer bevoegdheden ontstaan die een grensoverschrijdend karakter hebben. Op Europees en internationaal vlak is er een ontwikkeling gaande warbij binnen de grenzen van subsidiariteit en proportionaliteit soms eindelijk iets wordt prijs gegeven dat voorheen te vuur en te zwaard verdedigd werd. Het gaat om de territoriale soevereiniteit van de betrokken staten. ${ }^{376}$ Deze ontwikkeling kan onzes

376. Zie hieromtrent ook Klip 2000. 
inziens positieve gevolgen hebben voor het vraagstuk van de rechtstreekse geautomatiseerde toegang tot politiële computernetwerken en computerbestanden door politieambtenaren van andere staten. Het kan een inspiratiebron zijn om tot internationaal aanvaardbare oplossingen te komen voor dit vraagstuk. De fora waarin tot dit soort oplossingen kan worden gekomen zijn de Raad van Europa en de EU.

\subsection{Het Cybercrimeverdrag}

Het Cybercrimeverdrag van de Raad van Europa ${ }^{377}$ is het eerste internationale verdrag dat betrekking heeft op strafbare feiten die gepleegd zijn via het Internet of andere computernetwerken, zowel publiek als privaat. Het verdrag bevat zowel bepalingen van materieel strafrecht (strafrechtelijke bepalingen) als van formeel strafrecht (strafvorderlijke bepalingen). De strafrechtelijke bepalingen zien onder meer op inbreuken op auteursrechten, computergerelateerde fraude, kinderpornografie en schending van de beveiliging van computernetwerken. Het formele strafrecht heeft betrekking op een geheel van bevoegdheden en procedures, zoals het doorzoeken van computernetwerken en interceptie van communicatie. Wij leggen in deze sectie de nadruk op de strafvorderlijke aspecten van het Cybercrimeverdrag en gaan in het verlengde daarvan in het bijzonder in op de grensoverschrijdende aspecten ervan. In subsectie 7.2.1 gaan wij nader in op het doel van het Cybercrimeverdrag en in subsectie 7.2.2 behandelen wij de inhoud van het verdrag.

\subsubsection{Doel van bet Cybercrimeverdrag}

Het hoofddoel van het Cybercrimeverdrag is het bereiken van een gemeenschappelijk internationaal opsporings- en vervolgingsbeleid teneinde de samenleving te beschermen tegen cybercrime (voorheen aangeduid met de term computercriminaliteit). Het verdrag wil dat hoofddoel bereiken door op dit onderwerp toegesneden internationale wetgeving vast te stellen en door internationale politiële en justitiële samenwerking op dit terrein te bevorderen.

Het Cybercrimeverdrag is niet louter een Europees instrument, maar vertoont mondiale trekken, aangezien ook de Verenigde Staten, Canada, Japan en Zuid-Afrika, mee hebben gewerkt aan de totstandkoming ervan en het verdrag mede hebben ondertekend. Het is op 23 november 2001 te Budapest ondertekend door eenendertig staten. Het verdrag treedt in werking na ratificatie door vijf staten, waarvan er ten minste drie lid zijn van de Raad van Europa. Dit zal geschieden op 1 juli 2004, aangezien het verdrag geratificeerd is door Litouwen op 18 maart 2004, door Hongarije op 4 december 2003, door Estland op 12 mei 2003, door Kroatiè op 17 september 2002 en door Albanië op 20 juni 2002. In verband met de bijzondere positie van de Verenigde Staten aangaande de vrijheid van meningsuiting, is het verdrag aangevuld met een Additioneel Protocol dat elke publicatie

377. Convention on Cybencrime, Council of Europe, ETS, na. 185, Nourmber 23, 2001. 
van racistische of xenofobische propaganda via computernetwerken tot strafbaar feit bestempelt.

Het verdrag is totstandgekomen doordat de lidstaten van de Raad van Europa zich bewust werden van de diepgaande veranderingen die het gevolg zijn van de digitalisering, de convergentie en de voortdurende globalisering van computernetwerken. Het gat de Raad van Europa daarbij om het risico dat (1) computernetwerken en elektronische informatie ook gebruikt worden voor het begaan van strafbare feiten en dat (2) bewijs met betrekking tot zulke strafbare feiten opgeslagen kan zijn in en overgedragen kan worden door computernetwerken. Voor de strijd tegen cybercrime is volgens de Raad van Europa een verbeterde, snelle en goed functionerende internationale samenwerking in strafzaken nodig. Het verdrag is in dit opzicht aanvullend ten opzichte van bestaande samenwerkingsverdragen, teneinde (1) opsporing en vervolging met betrekking tot strafbare feiten in verband met computersystemen en computergegevens effectiever te maken dan nu het geval is en (2) het verzamelen van bewijs in elektronische vorm van een strafbaar feit mogelijk te maken. De Raad van Europa heeft getracht hierbij de juiste balans aan te brengen tussen enerzijds de opsporingsbelangen en anderzijds het respecteren van (a) de fundamentele rechten van de mens zoals die zijn neergelegd in het EVRM van 1950 en (b) het IVBPR van 1966. De fundamentele rechten betreffen bijvoorbeeld het recht op privacy, de vrijheid van meningsuiting en de vrijheid van informatievergaring (de vrijheid om allerlei informatie en ideeën te zoeken, te ontvangen en mede te delen, ongeacht grenzen). In het bijzonder wordt rekening gehouden met het recht op gegevensbescherming, zoals neergelegd in het Databeschermingsverdrag uit 1981 van de Raad van Europa. Dit is ook het basisverdrag met betrekking tot de internationale politiële gegevensuitwisseling voor de lidstaten van de Raad van Europa.

Het verdrag werd voorafgegaan door enkele specifieke aanbevelingen van de Raad van Europa. Wij noemen hieronder de drie belangrijkste: Recommendation No. $R(87) 15$, met betrekking tot het gebruik van persoonsgegevens in de politiesector; Recommendation No. $R$ (89) 9, met betrekking tot computergerelateerde criminaliteit met aanwijzingen voor de nationale wetgever aangaande de definitie van computercriminaliteit (het betreft derhalve aanbevelingen met betrekking tot het materieel strafrecht van de lidstaten van de Raad van Europa); en Recommendation $R$ (95) 13, met betrekking tot strafvorderlijke problemen aangaande informatietechnologie. In twee resoluties uit $1997 \mathrm{en}$ 2000 heeft ook de Europese Raad van Ministers van Justitie het belang van de totstandkoming van het Cybercrimeverdrag onderstreept.

\subsubsection{Inhoud van het Cybercrimeverdrag}

Bij de bespreking van de inhoud van het Cybercrimeverdrag onderscheiden we drie zaken, te weten: het materieel strafrecht, het formeel strafrecht en de vereiste formeel strafrechtelijke voorwaarden en waarborgen. 


\section{Materieel strafrecht}

Het materieel strafrechtelijk gedeelte (art. 2 tot en met 11) van het Cybercrimeverdrag ziet op:

- strafbare feiten gericht tegen de vertrouwelijkheid, de integriteit en de beschikbaarheid van computergegevens en -systemen (wederrechtelijke toegang en interceptie, gegevens- en systeeminterferentic, misbruik van apparatuur);

- computergerelateerde vervalsing en fraude;

- kinderpornografie;

- inbreuken op copyright en gerelateerde rechten; alsmede

- poging en helpen of medeplichtig zijn bij genoemde strafbare feiten.

Het verdrag voorziet verder in de verplichte aansprakelijkheidsstelling van rechtspersonen (art. 11 Cybercrimeverdrag). Sancties dienen effectief, proportioneel en afschrikwekkend te zijn (art. 12 Cybercrimeverdrag).

De partijen bij het verdrag dienen in hun nationale wetgeving de genoemde feiten strafbaar te stellen, voor zover dat nog niet is gebeurd.

\section{Formeel strafrecht}

De in het Cybercrimeverdrag neergelegde bevoegdheden en procedures dienen door de nationale staten in hun nationale recht te worden toegepast op:

1. de strafbare feiten die van kracht zijn overeenkomstig de artikelen 2 tot en met 11 van het Cybercrimeverdrag;

2. andere strafbare feiten begaan door middel van een computersysteem;

3. de bewijsgaring in elektronische vorm van een strafbaar feit (art. 14 Cybercrimeverdrag).

De volgende bevoegdheden dienen te worden ingevoerd in de nationale wetgeving van de verdragspartijen.

- Het bevelen of op gelijkaardige wijze verkrijgen van een zogenoemde 'expedited preservation' (een spoedconservering) van opgeslagen computergegevens, inclusief verkeersgegevens, tot maximaal negentig dagen, om de bevoegde autoriteiten in staat te stellen deze gegevens te ontsluiten. Bij wederzijdse rechtshulp is de termijn van het bevelen of op gelijkaardige wijze verkrijgen van een spoedconservering niet minder dan zestig dagen (art. 16 en 17 Cybercrimeverdrag; en artikel 29 en 30 Cybercrimeverdrag in geval van wederzijdse rechtshulp). Hierbij geldt het beginsel van vertrouwelijkheid. Er is geen dubbele strafbaarheid van het betreffende feit in de betrokken landen vereist. 
- Het bevelen van de uitlevering van computergegevens (de 'production order'). Het bevel ziet op gespecificeerde computergegevens die in het bezit zijn of onder de controle staan van een persoon of op abonneegegevens (art. 18 Cybercrimeverdrag). ${ }^{378}$

- Het zoeken en vastleggen van opgeslagen computergegevens, ook in computernetwerken (art. 19 Cybercrimeverdrag; en artikel 31 Cybercrimeverdrag in geval van wederzijdse rechtshulp). Daarbij hoort ook het eventueel ontoegankelijk maken van de computergegevens en het bevel tot het verkrijgen van informatie van personen die kennis hebben van het functioneren van de beveiliging.

- Het real-time vergaren van verkeersgegevens (art. 20 Cybercrimeverdrag; en artikel 33 Cybercrimeverdrag bij wederzijdse rechtshulp). Hierbij speelt het beginsel van vertrouwelijkheid en gaat het zowel om publieke als om private telecommunicatic.

- Interceptie van de inhoud van de gegevens met betrekking tot een reeks ernstige delicten (art. 21 Cybercrimeverdrag; en artikel 34 Cybercrimeverdrag bij wederzijdse rechtshulp). Het gaat hierbij zowel om publieke als private telecommunicatie.

- Grensoverschrijdende toegang tor opgeslagen computergegevens met toestemming of zonder toestemming indien de gegevens publick beschikbaar zijn (art. 32 Cybercrimeverdrag).

\section{Vereiste formeel strafrechtelijke voorwaarden en waarborgen}

Art. 15 Cybercrimeverdrag noemt een aantal belangrijke voorwaarden en waarborgen die de verdragspartijen in acht dienen te nemen bij het invoeren van de bevoegdheden in hun nationale wetgeving. De bevoegdheden en procedures zijn onderworpen aan de voorwaarden en waarborgen van het nationale recht, die adequaat de mensenrechten en vrijheden dienen te beschermen.

Speciale nadruk ligt ten eerste op de proportionaliteit. Zo dient rekening gehouden te worden met de aard en omstandigheden van het betreffende misdrijf. Interceptiemaat-

378. De Europese Commissie heeft op 14 november 2003 een Voorstel voor een kaderbesluit van de Raad betreffende het Europees bewijsverkrijgingsbevel ter verkrijging van voorwerpen, documenten en gegevens voor gebruik in strafprocedures ingediend (COM/2003/0688 def. - CNS 2003/0270). Dit voorstel, dat op 22 januari 2004 informeel is behandeld door de Raad, beoogt verder te gaan dan het Cybercrimeverdrag van 2001 . Het wil onder meer een aantal bevoegdheidsvraagstukken oplossen die zich voordoen in verband met het verkrijgen van computergegevens die worden bewaard op servers binnen de Europese Unie. Het stelt duidelijk dat de tenuitvoerleggingsstaat het recht heeft computergegevens te verkrijgen die op wetrige wijze toegankelijk zijn vanaf zijn grondgebied, zelfs indien deze zijn opgeslagen op het grondgebied van cen andere lidstaat. Het kaderbesluit doet geen uitspraak over andere bevoegdheidsvraagstukken in verband met computergegevens, met name wanneer er derde landen bij betrokken zijn. Het voorstel vindt een rechtsgrond in artikel 31 VEU, dat betrekking heeft op het gezamenlijk optreden inzake justitiële samenwerking in strafzaken. Zie over de juridische status van een kaderbesluit subsectie 7.8.2. 
regelen mogen bijvoorbeeld alleen plaatsvinden met betrekking tot een reeks ernstige misdrijven. In de tweede plaats ligt de nadruk op de impact van de bevoegdheden en procedures, alsmede op de rechten, verantwoordelijkheden en gerechtvaardigde belangen van derden.

De voorwaarden en waarborgen dienen, onder meer, in de volgende zaken te voorzien.

Zij moeten:

- een vorm van rechterlijke of andere onafhankelijke controle mogelijk maken;

- de gronden aangeven die de toepassing van de bevoegdheid of procedure rechtvaardigen;

- de scope en de duur van de bevoegdheid of procedure beperken;

- de standaards of minimumwaarborgen volgens de verplichtingen van bijvoorbeeld het EVRM en het IVBPR volgen; hierbij zijn onder meer van belang de zaken Klass, ${ }^{379}$ Kruslin en Hüvig, ${ }^{380}$ Malone, ${ }^{301}$ Halford ${ }^{362}$ en Lambert ${ }^{385}$ uit de jurisprudentie van het EHRM;

- mededeling doen aan de betrokkenen van de toepassing van de bevoegdheden of procedures;

- het beginsel toepassen dat niemand verplicht is mee te werken aan zijn eigen veroordeling. het zogenaamde nemo-tenerurbeginsel:

- verschoningsrechten waarborgen;

- individuen of plaatsen specificeren die het voorwerp zijn van de toepassing van de maatregel;

- zo weinig mogelijk leiden tot verstoring van gebruikersdiensten;

- bescherming bieden tegen aansprakelijkheid voor (het behulpzaam zijn bij) ontsleuteling van de inhoud van computergegevens;

- bescherming van eigendomsbelangen waarborgen; en

- het recht op vergoeding bij het meewerken met Justitie garanderen.

Op grond van artikel 23 Cybercrimeverdrag dient internationale samenwerking te bestaan op een zo breed mogelijke schaal voor de opsporing of vervolging van strafbare feiten met betrekking tot computersystemen of -gegevens of voor bewijsvergaring van een strafbaar feit in elektronische vorm.

379. EHRM 6 september 1978, Series $A$, nr. 28, alsmede AAe 28 (1979), p. 327-334. m.nt. E.A. Alkema, par. 42 (Klass e.a.).

380. EHRM 24 april 1990, NJ 1991, 523 alsmede Series A, nr. 176a en 176b (Kruslin en Hūvig).

381. EHRM 2 augustus 1984, Series $A$, nr. 82 (Malone).

382. EHRM 25 juni 1997, NJCM-bulletin 1997, 765 en volgende (Halford).

383, EHRM 24 augustus 1998, Reports of Judgments and Decisions (Reports) 1998-V (Lambert). 
Op grond van artikel 25 Cybercrimeverdrag is iedere verdragspartij bevoegd, in dringende omstandigheden, een verzoek tot wederzijdse rechtshulp te doen of daarover te communiceren met behulp van spoedcommunicatiemiddelen, waaronder fax of e-mail, in zoverre die middelen een afdoende niveau van beveiliging en authenticatie hebben. Waar nodig mogen hiervoor encryptietechnieken worden toegepast. Indien de aangezochte staat dit vereist, dient er wel een formele bevestiging te volgen. De aangezochte staat mag het verzoek accepteren en beantwoorden met behulp van dezelfde communicatiemiddelen.

Op basis van artikel 26 Cybercrimeverdrag is spontane informatievoorziening met betrekking tot cybercrime mogelijk, eventueel onder bepaalde voorwaarden of met een vertrouwelijke behandeling.

Op grond van artikel 27 Cybercrimeverdrag is rechtstreekse communicatic mogelijk door gerechtelijke autoriteiten, door Interpol, door de bevoegde nationale autoriteit of door andere bevoegde autoriteiten, indien er geen dwangmiddelen behoeven te worden toegepast.

Art. 35 Cybercrimeverdrag verplicht de verdragspartijen tot de inrichting van een zogenoemd 24/7 Netwerk voor technisch advies, de conservatie van gegevens op grond van artikel 29 en 30 Cybercrimeverdrag, de bewijsvergaring, het verstrekken van juridische informatie en het lokaliseren van verdachten. De idee is dat in elke verdragsstaat 24 uur per dag en 7 dagen per week een informatieknooppunt actief is, waarbij bevoegde ambtenaren heel snel de genoemde informatie kunnen geven cn de genoemde handelingen kunnen verrichten. Wellicht is hierbij in de toekomst een rol weggelegd voor de IRC's.

Een heel belangrijke constatering in het kader van ons onderzoek is dat de zogenoemde directe penetratie, de grensoverschrijdende toegang tot opgeslagen computergegevens, op grond van artikel 32 Cybercrimeverdrag na de inwerkingtreding ervan mogelijk is via personen die rechtmatig toegang hebben tot een grensoverschrijdend computernetwerk of zelfs anderszins indien de informatie publiek beschikbaar is.

\subsection{EU-Overeenkomst wederzijdse rechtshulp in strafzaken}

Op grond van Titel VI van het VEU aangaande de politiële en justitiële samenwerking in strafzaken (zie sectie 5.2), inzonderheid de artikelen 34 lid 2 sub d en 31 sub a VEU, is bij Akte van de Raad van de Europese Unie van 29 mei $2000^{384}$ de EU-Overeenkomst

384. Akte van de Raad van 29 mei 2000 tot vaststelling, overeenkomstig artikel 34 van het Verdrag betreffende de Earopese Unie, van de Overeenkomst betreffende de wederzijdse rechtshulp in strafzaken tussen de lidstaten van de Europese Unie, PbEG 2000/C197/1, 12 juli 2000. 
betreffende de wederzijdse rechtshulp in strafzaken tussen de lidstaten van de Europese Unie aangenomen. ${ }^{305}$ Dit verdrag is een aanvulling op het Europese Rechtshulpverdrag van 20 april $1959^{386}$ en daarbij behorende aanvullende protocollen ${ }^{387}$ en verdragen ${ }^{388}$. De overeenkomst ziet op justitiële en politiële rechtshulp, doch niet op de handhaving van de openbare orde en de bescherming van de binnenlandse veiligheid ${ }^{399}$.

Hieronder behandelen wij de gegevensuitwisseling (subsectie 7.3.1), grensoverschrijdende videoconferentie en telefoonconferentie (subsectie 7.3.2), gemeenschappelijke onderzoeksteams (subsectie 7.3.3), het aftappen van telecommunicatie (subsectie 7.3.4) en gegevensbescherming (subsectie 7.3.5). In subsectie 7.3.6 bespreken wij de Nederlandse uitvoeringswetgeving.

\subsubsection{Gegevensuitwisseling}

Interessant voor de grensregionale informatieve samenwerking is dat deze recente EU. rechtshulpovereenkomst 2000 (hierna EU-RHO) in artikel 7 lid 1 jo. Artikel 6 lid 1, 4, 5 en 6 eigenlijk herbevestigt (mede tegen de achtergrond van artikel 39 lid 4 en 5 en artikel 46 lid 2 SUO; zie hoofdstuk 5) dat de bevoegde autoriteiten van de EU-lidstaten binnen de grenzen van het nationale recht (bijvoorbeeld in Nederland op grond van arti. kel 13 BPolr; zie hoofdstuk 5) zonder een daartoe strekkend verzoek gegevens mogen uitwisselen. Indien dit zo is geregeld (bijvoorbeeld in de daartoe bestemde grensregionale convenanten en akkoorden), mag de gegevensuitwisseling rechtstreeks tussen de bevoegde autoriteiten geschieden. Dit dient op grond van artikel 6 lid 1 EU-RHO schriftelijk te gebeuren, dan wel op zodanige wijze dat het verzoek schriftelijk kan worden vastgesteld en de ontvangende lidstaat de echtheid ervan kan vaststellen. Dit laatste is het geval in de EMMI-omgeving. Op grond van artikel 7 lid 2 EU-RHO mag de autoriteit die de gegevens verstrekt overeenkomstig het betreffende nationale recht voorwaarden verbinden aan het gebruik van de verstrekte gegevens door de ontvangende autori-

385. De overeenkomst is gepubliceerd in Trb. 2000, 96.

386. Europees Verdrag aangaande de wederzijdse rechtshulp in strafzaken, 20 april 1959 (ERV); Tr6. 1965, 10: ETS No. 30. Dit verdrag is tot stand gekomen in het kader van de Raad van Europa.

387. In het bijzonder het aanvullend protocol bij het ERV, 17 maart 1978 (AP-ERV); Trb. 1979, 121; ETS No. 99.

388. In het bijzonder de Schengen Uitvoeringsovereenkomst (SUO) van 19 juni 1990; Overeenkomst ter uitvoering van het op 14 juni 1985 te Schengen gesloten Akkoord betreffende de geleidelijke afschaffing van de controles aan de gemeenschappelijke grenzen; Schengen, 19 juni 1990, Tr6. 1990, 145; alsmede de bilaterale Overeenkomst tussen het Koninkrijk der Nederlanden en de Bondsrepubliek Duitsland betreffende de aanvulling en het vergemakkelijken van het ERV, 30 augustus 1979; Tr6. 1979, 143: dit is het zogeheten Verdrag van Wittem bij het ERV.

389. Op grond van artikel $33 \mathrm{VEU}$ is het aan de Europese lidstaten om te bepalen op welke wijze zij de openbare orde zullen handhaven en de binnenlandse veiligheid zullen beschermen. 
teit. Deze laatste is op grond van artikel 7 lid 3 EU-RHO gebonden aan de gestelde voorwaarden.

\subsubsection{Grensoverschrijdende videoconferentie en telefoonconferentie}

Art. 10 EU-RHO is een noviteit: het verhoor van getuigen of deskundigen en eventueel een verdachte mag onder voorwaarden plaatsvinden door middel van grensoverschrijdende videoconferentie. Nederland past de eerste alinea van het negende lid van artikel 10 EU-RHO niet toe, waardoor het grensoverschrijdende verhoor per videoconferentie van een persoon tegen wie een strafvervolging is ingesteld, door Nederland niet wordt toegestaan. ${ }^{390}$ Artikel 11 EU-RHO ziet op de mogelijkheid van het grensoverschrijdende verhoor van getuigen en deskundigen per telefoonconferentie, evenwel met hun instemming.

\subsubsection{Gemeenschappelijke onderzoeksteams}

Art. 13 EU-RHO is in het bijzonder relevant voor ons extra doel in dit hoofdstuk, namelijk het aantonen dat in internationaal verband steeds meer bevoegdheden ontstaan die een grensoverschrijdend karakter hebben. Het artikel heeft namelijk betrekking op gemeenschappelijke grensoverschrijdende onderzoeksteams. Op grond van artikel 13 lid 1 EU-RHO mogen de bevoegde autoriteiten van twee of meer EU-lidstaten onderling overeenkomen om een zogeheten gemeenschappelijk onderzoeksteam in te stellen, voor een bepaald doel en voor een beperkte periode. Dit team mag strafrechtelijke onderzoeken uitvoeren in één of meer van de lidstaten die het team instellen. Hiertoe wordt een overeenkomst opgesteld die tevens de samenstelling van het team dient te vermelden. Het team mag in het bijzonder worden ingesteld wanneer:

a. het onderzoek van een lidstaat naar strafbare feiten moeilijke en veeleisende opsporingen vergt die ook andere lidstaten betreffen;

b. verscheidene lidstaten onderzoeken uitvoeren naar strafbare feiten die wegens de omstandigheden van de zaak een gecoördineerd en gezamenlijk optreden in de betrokken lidstaten vergen.

Een verzoek om instelling van een gemeenschappelijk onderzoeksteam mag van elk van de betrokken lidstaten uitgaan. Het team dient te worden ingesteld in een van de lidstaten waar het onderzoek naar verwachting zal worden uitgevoerd.

Op grond van artikel 13 lid 3 EU-RHO mag een gemeenschappelijk onderzoeksteam onder de volgende algemene voorwaarden actief zijn op het grondgebied van de lidstaten die het team hebben ingesteld: 
a. de leider van het team dient een vertegenwoordiger te zijn van de aan strafrechtelijke onderzoeken deelnemende bevoegde autoriteit van de lidstaat waar het team actief is; hij dient te handelen binnen de grenzen van zijn bevoegdheid krachtens het nationale recht;

b. het team dient op te treden in overeenstemming met het recht van de lidstaat waarin het actief is; de teamleden dienen hun taken te verrichten onder leiding van de teamleider, met inachtneming van de voorwaarden die hun eigen autoriteiten hebben vastgelegd in de overeenkomst tot instelling van het team;

c. de lidstaat op het grondgebied waarvan het team optreedt, dient de voor het functioneren van het team noodzakelijke organisatorische voorzieningen te treffen.

De leden die afkomstig zijn uit andere lidstaten dan de lidstaat waar het team optreedt, zogeheten gedetacheerde leden, kunnen op grond van artikel 13 lid 6 EU-RHO door de teamleider worden belast met de uitvoering van bepaalde onderzoekshandelingen. Dit dient te gebeuren in overeenstemming met het recht van de lidstaat waar het team optreedt. Overigens is dit alleen toegestaan voor zover de bevoegde autoriteiten van (1) de lidstaat waar wordt opgetreden en (2) de detacherende lidstaat dit hebben goedgekeurd. Wanneer het gemeenschappelijk onderzoeksteam het noodzakelijk acht dat in een van de lidstaten die het team hebben ingesteld, onderzoekshandelingen plaatsvinden, kunnen op grond van artikel 13 lid 7 EU-RHO de door die lidstaat bij het team gedetacheerde leden hun eigen bevoegde autoriteiten vragen die handelingen te verrichten.

Een lid van het gemeenschappelijk onderzoeksteam mag op grond van artikel 13 lid 9 EU-RHO, in overeenstemming met zijn of haar nationale recht en binnen de grenzen van zijn of haar bevoegdheid, het team gegevens verstrekken, die beschikbaar zijn in de lidstaat die hem of haar heeft gedetacheerd. Gegevens die een lid of gedetacheerd lid rechtmatig verkrijgt terwijl hij of zij deel uitmaakt van een gemeenschappelijk onderzoeksteam en die niet op een andere wijze voor de bevoegde autoriteiten van de betrokken lidstaten beschikbaar zijn, mogen op grond van artikel 13 lid 10 EU-RHO voor de volgende doeleinden worden gebruikt:

a. voor het doel waarvoor het team is ingesteld;

b. behoudens voorafgaande toestemming van de lidstaat waar de informatie vandaan komt, voor het opsporen, onderzoeken en vervolgen van andere strafbare feiten; de toestemming kan worden geweigerd in gevallen waarin dergelijk gebruik strafrechtelijk onderzoek in de betrokken lidstaat in gevaar brengt, of ten aanzien waarvan die lidstaat rechtshulp mag weigeren;

c. ter voorkoming van een onmiddellijke en ernstige bedreiging van de openbare veiligheid, onverminderd het bepaalde onder b, indien vervolgens een strafrechtelijk onderzock wordt geopend;

d. voor andere doeleinden, voor zover dat tussen de lidstaten die het team hebben ingesteld is overeengekomen. 
Op grond van artikel 13 lid 12 EU-RHO kunnen, onder welbepaalde voorwaarden, ook andere personen dan vertegenwoordigers van de bevoegde autoriteiten van de lidstaten die cen gemeenschappelijk onderzoeksteam instellen, deelnemen aan de activiteiten van het team. Dat kunnen bijvoorbeeld de ambtenaren van Europol zijn of andere bij het VEU ingestelde instanties. Hun rechten zijn in beginsel niet gelijk aan de rechten van de leden of gedetacheerde leden van het team.

\subsubsection{Aftappen van telecommunicatie}

De artikel 17 tot en met 22 EU-RHO hebben betrekking op specifieke gevallen van het grensoverschrijdend aftappen van telecommunicatie. Deze regeling vormt eveneens een mooie demonstratie van het feit dat in internationaal verband steeds meer bevoegdheden ontstaan die een grensoverschrijdend karakter hebben. Het gaat blijkens artikel 18 lid 1 EU-RHO om grensoverschrijdende verzoeken tot (a) het aftappen van telecommunicatic en het rechtstreeks doorgeleiden daarvan naar de verzoekende lidstaat en (b) het aftappen en opnemen van telecommunicatie en het aansluitend doorgeleiden van de opname naar de verzoekende lidstaat. Deze verzoeken kunnen op grond van artikel 18 lid 2 EURHO worden gedaan met betrekking tot het gebruik van telecommunicatiemiddelen door de af te tappen persoon, wanneer deze persoon zich bevindt in:

a. de verzoekende lidstaat, en de verzoekende lidstaat technische bijstand van de aangezochte lidstaat nodig heeft om de communicatie van de betrokkene af te tappen;

b. de aangezochte lidstaat, en de communicatie van de betrokkene in die lidstaat kan worden afgetapt;

c. een derde lidstaat, die daarvan in kennis is gesteld, en de verzoekende lidstaat de technische bijstand van de aangezochte lidstaat nodig heeft om de communicatie van de betrokkene af te tappen.

De leden 3 tot en met 9 van artikel 18 EU-RHO zien op de formele vereisten van zo een rechtshulpverzoek tot het aftappen van telecommunicatie.

Art. 19 EU-RHO bevat een regeling voor het aftappen van telecommunicatie op het eigen grondgebied van EU-lidstaten door tussenkomst van dienstenverstrekkers. Indien telecommunicatienetwerken op het grondgebied van een andere lidstaat niet rechtstreeks toegankelijk zijn voor het rechtmatig aftappen van communicatie van een persoon die zich in die andere lidstaat bevindt, bepaalt artikel 19 lid 1 EU-RHO, dat de EU-lidstaten ervoor dienen te zorgen dat die telecommunicatienetwerken die via een zogeheten toegangspoort op hun grondgebied worden geëxploiteerd, rechtstreeks toegankelijk kunnen worden gemaakt voor het rechtmatig aftappen door de andere lidstaat. Dit geschiedt via de tussenkomst van een daartoe aangewezen dienstenverstrekker op het grondgebied van de andere lidstaat die rechtmatig wil aftappen. Bij het aftappen behoeft dan, blijkens artikel 19 lid 2 EU-RHO de lidstaat die de telecommunicatienetwerken met toegangspoort exploiteert niet meer betrokken te worden. Dit geldt eveneens voor het geval van artikel 18 lid 2 sub b EU-RHO met betrekking tot het gebruik van telecommunicatie- 
middelen door de af te tappen persoon, wanneer deze persoon zich bevindt in de aangezochte lidstaat, en de communicatie van de betrokkene in die lidstaat kan worden afgetapt (art. 19 lid 3 EU-RHO).

Art. 20 EU-RHO regelt de situatie waarin het aftappen van telecommunicatie gewenst is zonder technische bijstand van een andere EU-lidstaat. Wanneer in het kader van een strafrechtelijk onderzoek het aftappen van telecommunicatie is bevolen en het telecommunicatieadres in gebruik is op het grondgebied van een andere lidstaat, dient de aftap. pende lidstaat op grond van artikel 20 lid 2 de andere lidstaat in kennis te stellen van het aftappen. Hij dient dit te doen vóór het aftappen indien hem reeds bij het geven van het aftapbevel bekend is dat de persoon zich op het grondgebied van de in kennis gestelde lidstaat bevindt. Deze kennisgevingsregeling is eveneens van toepassing op artikel 18 lid 2 sub c, indien wel technische bijstand van een andere derde EU-lidstaat is gewenst. In andere gevallen dient de aftappende staat de kennisgeving te doen aan de andere staat onmiddellijk nadat hem bekend is geworden dat de persoon zich op het grondgebied van de andere lidstaat bevindt. De procedureregels zijn te vinden in artikel 20 lid 3 tot en met 7. Artikel 20 lid 4 sub d vermeldt dat de lidstaten de nodige maatregelen dienen te treffen om ervoor te zorgen dat binnen een termijn van 96 uur kan worden geantwoord op een rechtshulpverzoek betreffende het aftappen van telecommunicatie zonder technische bijstand van een andere EU-lidstaat. Hiertoe dienen contactpunten aangewezen te worden die 24 uur per dag beschikbaar zijn. Wellicht zijn de IRC's in de toekomst als contactpunt aan te wijzen.

Art. 22 EU-RHO vermeldt bovendien dat niets de lidstaten belet bilaterale of multilaterale regelingen te treffen die het gebruik van huidige en toekomstige technische mogelijkheden voor het rechtmatig aftappen van telecommunicatie vergemakkelijken.

\subsubsection{Gegevensbescherming}

Art. 23 bevat enige bepalingen inzake gegevensbescherming in het kader van de EURHO. Het eerste lid bepaalt dat persoonsgegevens die uit hoofde van de EU-RHO worden meegedeeld, gebruikt mogen worden door de lidstaten waaraan zij zijn verstrekt:

a. ten behoeve van de procedures waarop de EU-RHO van toepassing is;

b. voor andere gerechtelijke en administratieve procedures die rechtstreeks verband houden met de onder a) bedoelde procedures;

c. ter voorkoming van een onmiddellijke en ernstige bedreiging van de openbare veilig. heid;

d. voor enig ander doel, alleen na voorafgaande toestemming van de verstrekkende lidstaat, tenzij de ontvangende lidstaat de toestemming van de betrokkene heeft verkregen. 
De gegevensbescherming is ook van toepassing op gegevens die weliswaar niet zijn meegedeeld, maar anderszins zijn verkregen met toepassing van de EU-RHO (art. 23 lid 2 EU-RHO). Ingevolge artikel 23 lid 3 EU-RHO kan de verstrekkende lidstaat, gelet op de omstandigheden van het geval, aan de lidstaat waaraan de persoonsgegevens zijn medegedeeld, verzoeken om informatie over het gebruik dat van die gegevens is gemaakt.

\subsubsection{Nederlandse uitvoeringswetgeving EU-RHO}

De Nederlandse Staten-Generaal hebben de EU-RHO goedgekeurd. ${ }^{391}$ De inwerkingtreding kan elk ogenblik volgen. Bij gelegenheid van de goedkeuring van de EU-RHO wordt Titel X, boek IV Sv nogal gewijzigd, evenals artikel $13 \mathrm{~d}$ WPolr. ${ }^{392}$ De wijziging van artikel 13d WPolr houdt rechtstreeks verband met de in artikel 13 EU-RHO voorziene samenwerking in het kader van gemeenschappelijke onderzoeksteams. Het bepaalde in het tiende lid van artikel 13 EU-RHO (zie subsectie 7.3.3) noodzaakt tot anpassing van artikel $13 \mathrm{~d}$ WPolr. De voorgestelde wijziging van artikel $13 \mathrm{~d}$ WPolr ziet uitsluitend op gemeenschappelijke teams die in Nederland zijn gevestigd. Indien een team in het buitenland is gevestigd zullen de aldaar geldende regels voor registratie van toepassing zijn. In artikel $13 \mathrm{~d}$ WPolr wordt, onder vernummering van het derde lid tot vierde lid een nieuw derde lid ingevoegd, dat luidt:

"Uit een tijdelijk register kunnen verder gegevens worden verstrekt:

a. ter voorkoming van een onmiddellijke en ernstige bedreiging van de openbare veiligheid, of

b. indien dat is overeengekomen bij de instelling van een gemeenschappelijk onderzoeksteam als bedoeld in artikel 552qa van het Wetboek van Strafvordering dat in Nederland is gevestigd."

Art. 13d WPolr lid 3 sub a ziet op artikel 13 lid 10 sub c EU-RHO (zie subsectie 7.3.3).

De gegevensuitwisseling in het kader van een gemeenschappelijk onderzoeksteam dat in Nederland is gevestigd wordt aldus in de WPolr verankerd. Het nieuwe artikel $552 q d \mathrm{~Sv}$ stelt verder in het eerste lid dat stukken van overtuiging en gegevensdragers waarop gegevens zijn opgenomen die in Nederland in beslag zijn genomen of zijn vergaard met gebruikmaking van enige strafvorderlijke bevoegdheid ten behoeve van het onderzoek van het gemeenschappelijk onderzoeksteam, bedoeld in artikel $552 \mathrm{qa} \mathrm{Sv}$, dat buiten Nederland is gevestigd, onmiddellijk voorlopig ter beschikking kunnen worden gesteld

391. Kamerstukken II, 2001/2004, 28350 , nr. 1-7 en nr. A-C.

392. Kamerstukken II, 2001/2003, 28351 , nr. 1-5. Zo worden de artikelen $126 \mathrm{~m}$ en $126 t$ Sv gewijzigd in verband met de artikelen 18 en 20 EU-RHO, alsmede de artikelen $552 n$ en 5520 Sv in verband met artikel 10 EU-RHO. Er worden twee nieuwe artikelen $5520 b$ en $552 o c$ Sv ingevoerd in verband met artikel 18 respectievelijk artikel 20 EU-RHO. De nieuwe artikelen 552 ga tot en met 552 ge Sv zien op het gemeenschappelijke onderzoeksteam ingevolge artikel 13 EU-RHO. 
van het onderzoeksteam. Op grond van het tweede lid verbindt de OvJ die betrokken is bij het gemeenschappelijk onderzoeksteam aan de voorlopige terbeschikkingstelling, bedoeld in het eerste lid, de voorwaarden dat het Nederlandse recht onverkort blijft gelden ten aanzien van die stukken en gegevensdragers en dat het gebruik daarvan als bewijsmiddel pas mogelijk is, nadat deze definitief ter beschikking worden gesteld. $\mathrm{O}_{\mathrm{p}}$ grond van het derde lid kan de OvJ de stukken en gegevensdragers, bedoeld in het eerste lid, definitief ter beschikking stellen van het gemeenschappelijk onderzoeksteam dat in het buitenland is gevestigd, voor zover de rechtbank daartoe verlof heeft verleend.

\section{Directe toegang}

De vraag of directe geautomatiseerde toegang aan de tot het gemeenschappelijk onderzoeksteam behorende buitenlandse opsporingsambtenaren dient te worden toegestaan is een politieke en juridische vraag die het wetsvoorstel nog niet beantwoordt. Empirisch onderzoek zal dienen uit te wijzen of dit gewenst is. De privacywaarborgen voor de burger dienen evenwel optimaal gewaarborgd te blijven (zie nader sectie 9.12). Verstrekking dient in ieder geval plaats te vinden in overeenstemming met het nationale recht van het teamlid en binnen de grenzen van zijn of haar bevoegdheid (art. 13 lid 9 EU-RHO). Gegevens die een lid of gedetacheerd lid rechtmatig verkrijgt terwijl hij of zij deel uitmakkt van een gemeenschappelijk onderzoeksteam en die niet op een andere wijze voor de bevoegde autoriteiten van de betrokken lidstaten beschikbaar zijn, mogen op grond van artikel 13 lid 10 EU-RHO alleen voor de in dit artikellid genoemde doeleinden worden gebruikt (zie subsectie 7.3.3).

\subsection{EMMI en directe toegang}

De doelstelling van het EMMI-project was, zoals gezegd in hoofdstuk 4: (1) het ontwikkelen van een hecht samenwerkingsverband tussen politie, universiteiten en telecommunicatiebedrijven, in dit verband is het blikveld gericht op geheel Europa; (2) het bereiken van doelstelling (1) via groeikernen, zowel organisatorisch, als politieel, alsook softwarematig gezien; en (3) het ontwikkelen van een beveiligde communicatieomgeving, waarbinnen de politie zowel gebruik kan maken van gewone informatiediensten als van kioskdiensten.

De EMMI-omgeving beoogt uiteindelijk te komen tot een integratie van alle nationale netwerken in de grensregio's met EMMI. De realisatie van rechtstreekse geautomatiseerde grensoverschrijdende toegang door buitenlandse opsporingsambtenaren tot nationale (politiële) bestanden, databases en computernetwerken in een ander EMMI-land is technologisch geen groot probleem meer. Op die manier kan veel dubbel werk worden voorkomen en kunnen allerhande controlemechanismen worden ingebouwd in de 
software. ${ }^{393}$ Men zou ook PALMA geautomatiseerde toegang kunnen geven tot de nationale politiele informatiesystemen van de EMMI-landen. PALMA kan dan gegevens geheel automatisch ophalen uit de betreffende nationale databanken. De IRC-medewerker behoeft het versturen van die gegevens dan alleen maar te bevestigen en ze eventueel aan te vullen met gegevens die niet met het programma opgezocht kunnen worden. Met andere woorden, hetgeen nu door een IRC-medewerker gedaan wordt, kan eigenlijk voor een deel ook door een programma gedaan worden, vooral voor veel voorkomende aanvragen. Als voorbeeld noemen we dat het programma ziet dat er voertuiggegevens moeten worden opgezocht; het programma kan zo geìnstrueerd worden dat het zelf die gegevens opzoekt in het kentekenregister. Tevens ziet het programma dat er persoonsgegevens moeten worden opgezocht en vervolgens zoekt het die op in de GBA. Andere gegevens, voor het opzoeken waarvan het programma door de IRC-medewerkers niet geautoriseerd is, kunnen dan alsnog handmatig worden opgezocht en worden toegevoegd in het reactieformulier. Controle van het gehele proces is achteraf nog steeds verzekerd met behulp van de registratiedatabase. De werklast van de IRC-medewerker bij het zoeken in de nationale databanken kan dan verminderd worden. Tevens wordt vierentwintiguursbevraging voor veel gevraagde gegevens mogelijk met controle achteraf. Om de gedachten verder te bepalen, werken we bovengenoemd voorbeeld nader uit. Het programma zou bijvoorbeeld een Nederlands programma kunnen zijn waarin Nederland bepaalt welke gegevens en databanken wel en niet op deze geautomatiseerde manier te bevragen zijn. Als extra controle wordt er een menselijke controle aan toegevoegd. Het is evenwel duidelijk dat, als de invoering van een dergelijk systeem wenselijk wordt geacht, de wetgeving aangepast dient te worden. Technisch gesproken is de EMMI-architectuur klaar voor een uitbreiding van de gebruikersmogelijkheden in de aangegeven zin. Zoals het vaak gaat in de wereld van de ICT gaat het ook hier: als men ziet dat iets mogelijk is, wil men het ook gerealiseerd zien. Dat geldt voor een groot aantal IRC's. Of dat ook gebeurt, hangt echter af van de wettelijke belemmeringen en mogelijkheden en van de politieke wil van de betrokken EMMI-landen. In Nederland is op grond van een interpretatie van artikel 17 BPolr rechtstreekse geautomatiseerde grensoverschrijdende toegang van buitenlandse opsporingsambtenaren tot het Nederlandse politiële netwerk wettelijk niet toegestaan. In België en Duitsland bestaat er geen specifieke wetgeving ter zake, maar heeft de politiek tot op heden een dergelijke technologische ontwikkeling niet toegestaan.

393. Dit is mogelijk met behulp van de inzet van agenttechnologie, intelligent handelende computerprogramma's die zo geprogrammeerd kunnen worden dat zij bijvoorbeeld op zoek gaan naar alleen die nationale gegevens over de grens die een bepaalde IRC-medewerker op grond van zijn of haar bevoegdheid rechtmatig mag inzien. Dit is momented nationaal en internationaal wettelijk echter nog niet mogelijk. 


\subsection{Directe toegang en de Raad van Europa}

Zoals besproken in sectie 5.3.2 is het vijfde beginsel van Aanbeveling $R$ ( 87 ) 15 is van cruciaal belang voor het vraagstuk van de rechtstreekse geautomatiseerde grensoverschrijdende toegang van buitenlandse opsporingsambtenaren tot nationale (politiële) bestanden, databases en computernetwerken. Dit vijfde beginsel legt namelijk een normering aan voor de koppeling van bestanden en de directe toegang tot bestanden.

In één van de twee volgende gevallen mag een bestand gekoppeld worden aan een ander bestand dat een ander doel dient:

1. de controleautoriteit (bijvoorbeeld voor Nederland het CBP) heeft in verband met een onderzoek naar een bepaald strafbaar feit machtiging gegeven;

2. de koppeling geschiedt op grond van een uitdrukkelijk wettelijk voorschrift (in Nederland neergelegd in de WPolr en het BPolr).

Directe (on line) toegang tot een bestand is volgens het vijfde beginsel slechts toegestaan in overeenstemming met nationale wetgeving die de beginselen 1 tot en met 6 van Aanbeveling $R$ (87) 15 respecteert. De uitwerking hiervan is in Nederland te vinden in artikel 17 BPolr. Belgiě en Duitsland hebben geen specifieke wetgeving terzake. Dit betekent concreet gesproken, dat er op grond van deze aanbeveling van de Raad van Europa nationale wetgeving tot stand gebracht zou dienen te worden in de EMMI-landen Nederland, België en Duitsland, die bepaalt dat voor de grensregionale politiële gegevensuitwisseling directe (on line) toegang tot bestanden door buitenlandse politieambtenaren is toegestaan. De wetgeving zou dan ook dienen te bepalen onder welke voorwaarden dit dan mogelijk is en door welke buitenlandse ambtenaren. Deze wetgeving dient bovendien in overeenstemming te zijn met de beginselen 1 tot en met 6 van Aanbeveling $\mathrm{R}$ (87) 15 (zie voor deze beginselen subsectie 5.3.2).

\subsection{Directe toegang in het Nederlandse recht}

In Nederland geldt een impliciet wettelijk verbod op rechtstreekse geautomatiseerde grensoverschrijdende toegang voor buitenlandse politieambtenaren en voor het $\mathrm{OM}$ tot nationale politiële bestanden, databases en computernetwerken, op grond van een interpretatie van artikel 17 BPolr. In dat artikel is bepaald dat rechtstreekse verstrekking uit een politieregister, dat wil zeggen verstrekking zonder menselijke tussenkomst, langs geautomatiseerde weg alleen is toegestaan aan personen die daartoe een schriftelijke autorisatie hebben gekregen. Deze autorisatie mag op grond van artikel 17 lid 1 BPolr alleen worden verleend aan bepaalde Nederlandse politieambtenaren die belast zijn met opsporingstaken. ${ }^{394}$ Belgische of Duitse politieambtenaren zijn derhalve nooit bevoegd tot het raadplegen van de Nederlandse politieregisters zonder tussenkomst van een

394. Het betreft de personen genoemd in artikel 14 sub a en b WPolr en artikel 14 lid 1 sub a BPolr. 
Nederlandse geautoriseerde persoon. De beheerder van het politieregister moet op grond van artikel 17 lid 4 BPolr de nodige voorzieningen van technische en organisatorische aard treffen om te voorkomen dat ongeautoriseerde verstrekkingen plaatsvinden. Het is deze bepaling die de grondslag vormt voor de beschreven praktijk van de Nederlandse IRC's. Een Nederlands IRC mag op grond van deze bepaling niet via een on-lineverbinding rechtstreeks toegang tot Nederlandse politieregisters verlenen aan buitenlandse politiediensten en dat doet zij dan ook niet. Elke gegevensverstrekking geschiedt via de tussenkomst van een Nederlandse IRC-medewerker. Artikel 17 BPolr is daarmee een echt juridisch knelpunt voor de praktijk van de IRC's. De Nederlandse Minister van Binnenlandse Zaken wees daar de verantwoordelijke Korpsbeheerders van de politieregio's Ijsselland, Groningen, Drenthe en Twente reeds bij brief van 9 februari $1996^{395}$ op, alsmede de Korpschefs van de genoemde politieregio's bij brief van 24 mei $1996 .{ }^{396}$ In verband met de toegenomen grensoverschrijdende politiële informatic-uitwisseling tussen de Nederlandse grensregio's en de Duitse grensLänder was de Minister van Binnenlandse Zaken op de hoogte gebracht van het voornemen om de vier regionale HKD-systemen van de vier genoemde politieregio's rechtstreeks toegankelijk te maken voor enkele daartoe opgeleide IRC-medewerkers van de RVST in Lingen (deelstaat Niedersachsen), ${ }^{397}$ In de brief van 24 mei 1996 wordt in beginsel een efficiëntieverbetering toegejuicht door de Minister van Binnenlandse Zaken, maar wordt gesteld dat niet in strijd met de wet gehandeld mag worden. In de brief wordt tevens aangeven dat zowel de Minister van Binnenlandse Zaken als de Minister van Justitie verantwoordelijk zijn voor de grensoverschrijdende politiële informatie-uitwisseling.

Hieronder bespreken wij drie geheel verschillende situaties, te weten: geen directe toegang voor het OM (subsectie 7.6.1), een bepaald omschreven doel (subsectie 7.6.2) en Wbp-registers (subsectie 7.6.3).

\subsection{Geen directe toegang voor het $O M$}

De autorisatie tot rechtstreekse toegang langs geautomatiseerde weg mag evenmin als aan buitenlandse politieambtenaren aan het OM worden gegeven. Het OM valt namelijk niet in de categorie personen waaraan op grond van artikel 17 lid 1 BPolr rechtstreeks (on line) politiële gegevens verstrekt mogen worden langs geautomatiseerde weg. De personen aan wie rechtstreeks langs geautomatiseerde weg verstrekt mag worden, moeten namelijk deel uitmaken van de reguliere politie of de Koninklijke marechaus-

395. Kenmerk EA95/U3739, directie politie.

396. Kenmerk EA96/985, directie politic.

397. Zie de brief van 19 maart 1996, kenmerk 96/01271, waarin de Hoofdcommissaris van de politieregio IJsselland, mede namens zijn collega's van de politieregio's Groningen, Drenthe en Twente; dit voornemen meldt aan de Minister van Binnenlandse Zaken. 
see. ${ }^{398}$ On-lineconsultatie is een uitzondering op het uitgangspunt van de menselijke verstrekking en is alleen bedoeld voor de meest voorkomende verstrekkingen en dus niet voor de verstrekking aan het $\mathrm{OM}$.

Aan het OM mogen dus op grond van artikel 17 lid 1 BPolr uit de PALMA-registratiedatabase geen gegevens langs geautomatiseerde weg worden verstrekt. De gegevens mogen ter controle van de naleving van artikel $552 i$ lid $2 \mathrm{~Sv}$ of voor de uitvoering van de aan het OM opgedragen rechtshulptaak, slechts 'op verzoek' aan het $O M$ worden verstrekt op grond van artikel 15 lid 1 WPolr. ${ }^{399}$ Dat wil zeggen dat een on-lineverbinding met de PALMA-registratiedatabase, zoals men die in de toekomst ten behoeve van het $\mathrm{OM}$ in gebruik wil stellen, op dit moment wettelijk niet is toegestaan. Politiële gegevens mogen slechts incidenteel op verzoek van het $\mathrm{OM}$ ter controle van de naleving van artikel $552 i$ lid 2 en $3 \mathrm{~Sv}$ uit de registratiedatabase worden verstrekt. Het is niet de bedoeling dat het $\mathrm{OM}$ continu over alle met het buitenland uitgewisselde persoonsgegevens beschikt. Dit is in de praktijk niet te ondervangen door de betreffende functionaris van het $\mathrm{OM}$ ter uitoefening van de controlefunctic een zogenaamde commissie (toelating) van onbezoldigd opsporingsambtenaar te geven via de Procureur-Generaal. Dan zou de OM-functionaris immers een buitengewoon opsporingsambtenaar zijn in de zin van artikel 142 lid 1 sub a Sv. ${ }^{400}$ Dit zijn opsporingsambtenaren in de zin van artikel 14 sub c WPolr. Aan hen kan op grond van artikel 17 lid 1 BPolr ook niet rechtstreeks langs geautomatiseerde weg uit de registratiedatabase worden verstrekt. Er manifesteert zich hier dus een juridisch obstakel als het OM rechtstreekse toegang zou willen krijgen tot de politiële gegevens die zich in de registratiedatabase bevinden. Het periodiek, bijvoorbeeld wekelijks, aan het OM verstrekken van de integrale inhoud van de registratiedatabase is op grond van artikel 15 WPolr ook niet mogelijk. Een dergelijke afspraak treedt aanzienlijk buiten de mogelijkheden en grenzen van de voorwaarde 'op verzoek'. ${ }^{401}$ Dit is

398. Ook opsporingsambtenaren van bijzondere opsporingsdiensten zoals de FIOD (in de zin van artikel 14 sub c WPolr) mogen op grond van artikel 17 lid 1 BPolr niet geautoriseerd worden tot rechtstreekse geautomatiseerde toegang.

399. Uit een politieregister worden "op hun verzoek" gegevens verstrekt aan leden van her $\mathrm{OM}$, voorzover zij deze behoeven:

1) in verband met hun gezag en zeggenschap over de politie (...): artikel 15 lid 1 sub a sub 1 WPolr; hieronder valt de controle door het $O M$ op grond van artikel $552 i$ lid 2 en 3 Sv; of

2) voor de uitvoering van andere bij of krachtens wet opgedragen taken: artikel 15 lid 1 sub a sub 2 WPolr; hieronder valt in het algemeen de rechtshulptaak van het $\mathrm{OM}$.

400. Op basis van een op naam gestelde akte ("een individuele aanwijzing") kan opsporingsbevoegdheid worden verleend aan een zogenaamde buitengewone opsporingsambtenaar. De akte wordt verleend door de Minister van Justitie of de ProcureurGeneraal. Zie verder het Besluit buitengewoon opsporingsambtenaar van 11 november 1994, Stb. 825, dat op grond van artikel 442 lid 4 Sv nadere regels stelt.

401. Vergelijk Schreuders 1995, p. 9, met verwijzing naar het Jaarverslag van de Registratickamer 1992-1993, p. 24. 
wellicht ook een juridisch obstakel voor de voorziene koppeling van LURIS aan PALMA.

\subsubsection{Bepaald omscbreven doel}

De autorisatie tor rechtstreekse geautomatiseerde toegang aan bevoegden, waaronder de RCIE, kan slechts worden gegeven voor een bepaald omschreven doel. Daarbij wordt ervan uitgegaan dat de terminals vanwaaraf politieregisters kunnen worden geraadpleegd door de beheerder ingevolge artikel 7 lid 2 WPolr afdoende beveiligd zijn tegen raadpleging door onbevoegden. ${ }^{402}$ Ingevolge artikel 17 lid 5 BPolr dient van iedere verstrekking langs geautomatiscerde weg aantekening te worden gehouden. ${ }^{403}$

\subsubsection{Wbp-registers}

Rechtstreekse geautomatiseerde toegang van buitenlandse politicambtenaren is juridisch echter alleen mogelijk - onder bepaalde juridische randvoorwaarden - voor bestanden en databases die onder de ( $\mathrm{Wb}$ ) vallen. In de $\mathrm{Wb}$ zijn namelijk geen nadere voorwaarden genoemd voor internationale verstrekking aan politieambtenaren of andere personen. Een buitenlandse politieambtenaar wordt wat de verstrekking betreft uit een persoonsregistratie waarop de Wbp van toepassing is, gelijkgesteld aan een Nederlandse politieambtenaar. Politiële bestanden en databases die onder de WPolr en het BPolr vallen, mogen daarentegen niet rechtstreeks langs geautomatiseerde weg door buitenlandse politieambtenaren worden benaderd.

\subsection{Rechtstreekse toegang in België en Duitsland}

Zoals gezegd, bestaat er in België en Duitsland geen expliciet wettelijk verbod tot rechtstreekse geautomatiseerde grensoverschrijdende toegang van buitenlandse politieambtenaren tot de nationale politiële bestanden en computernetwerken. Politiek is het evenwel geen haalbare kaart gebleken om buitenlandse opsporingsambtenaren directe toegang te verlenen tot Belgische of Duitse politiële bestanden, databases of computernetwerken. In België kan in de toekomst op grond van artikel 44/4 lid 2 WPA wel aan het OM rechtstreekse geautomatiseerde toegang worden verleend tot de Belgische politieregisters door middel van een KB (zie subsectie 5.6.1). De Duitse StA heeft daarentegen geen directe zelfstandige toegang tot de Duitse politieregisters, noch kan hij of zij bevelen hem die

402. Stb. 1991, 56, p. 31 (NvT).

403. Een uitzondering op deze vastleggingsplicht is ingevolge artikel 17 leden 6 en 7 BPolr mogelijk indien naar het oordeel van de Minister van Justitic of de Minister van Binnenlandse Zaken (naargelang het taken onder het gezag van de Ovj respectievelijk de burgemeester betreft) vergelijkbare waarborgen anderszins anwezig zijn om het verstrekkingenregime te handhaven. Hierbij wordt blijkens de NvT gedacht aan kleine systemen op posten waar slechts enkele politieambtenaren rechtstreeks langs geautomatiseerde weg van de opgesiagen gegevens kennis kunnen nemen (Stb. 1991, 56, p. 32; NvT). 
toegang te verschaffen. Slechts ter aanvulling van een strafdossier kan hij of zij van de politie verlangen hem gegevens te verstrekken (zie subsectie 5.6.2).

\subsection{Conclusies: regelen directe toegang}

Het impliciete Nederlandse verbod tot rechtstreekse geautomatiseerde grensoverschrijdende toegang door buitenlandse opsporingsambtenaren tot nationale politiēle bestanden, databases en politienetwerken veroorzaakt tezamen met de Belgische en Duitse politiek terzake, dat een fysieke koppeling van de EMMI-omgeving met de betrokken nationale politiële computernetwerken momenteel nog niet tor de mogelijkheden behoort. Als de betrokken landen een dergelijke directe toegang in het leven zouden willen roepen, zal de nationale en /of de internationale wetgever zich hierover moeten uitspreken. De behoefte van de IRC's aan mogelijkheden voor directe toegang van buitenlandse politieambtenaren tot nationale bestanden en databases is ingegeven door de toegenomen werkdruk van de IRC's sinds de effectuering van de politiēle informatieve samenwerking in de grensgebieden. Voor de uitwisseling van zogeheten bulkinformatie $^{404}$ met het buitenland is een juridische mogelijkheid tot rechtstreekse bevraging van nationale bestanden en databases erg welkom. De werklast van de IRC-medewerkers bij het zoeken in de nationale bestanden en databases kan dan worden verminderd. Tevens zou een vierentwintiguursbevraging voor veel gevraagde gegevens mogelijk worden, met controle achteraf.

In deze sectie beantwoorden wij de tweede aanvullende onderzoeksvraag: "Welke juridische keuze dienen de Raad van Europa en de Europese Unie te maken met betrekking tot het vraagstuk van de rechtstreekse geautomatiseerde grensoverschrijdende toegang van buitenlandse opsporingsambtenaren tot nationale (politiële) databases en computernetwerken, mede in het licht van de internationale juridische ontwikkelingen betreffende digitale expertise?" Wij behandelen vier mogelijke wegen om tot een goede regeling van de problematiek omtrent de directe toegang te komen: de weg van de Raad van Europa (subsectie 7.8.1), de weg van de EU (subsectie 7.8.2), maar ook de weg van de grensregionale convenanten en akkoorden (subsectie 7.8.3) en de weg van de regeling in het nationale recht van de betrokken staten (subsectie 7.8.4). In subsectie 7.8.5 onderzoeken wij de juridische haalbaarheid van de automatisering van directe toegang in het algemeen. Subsectie 7.8.6 beschrijft de invloed van het ontwerp-kaderbesluit Europees bewijsverkrijgingsbevel van de EU op het vraagstuk van de rechtsteekse geautomatiseerde grensoverschrijdende toegang tot registers.

404. Bij bulkgegevens ter ondersteuning van her dagelijkse operationele werk op straat gaat het vooral om gegevens over kentekens, rijbewijzen, naamsverificaties, signaleringen, voertuigen, antecedenten van personen en vreemdelingen. Het aantal gegevensaanvragen varieert van enige duizenden tot enige tienduizenden per IRC per jaar. Het aantal groeit nog steeds. 


\subsubsection{Raad van Europa}

Het juridisch probleem van de directe grensoverschrijdende toegang tot nationale politéle netwerken en van het grensoverschrijdend gebruik van (multimediale) bestanden en databases zou bij voorkeur op het niveau van de Raad van Europa moeten worden behandeld. Rechtstreekse geautomatiseerde toegang van politieambtenaren tot (multimediale) databases van een ander land zou hoog op de agenda van de Raad van Europa moeten (komen te) staan. Koppeling van een internationaal politieel Intranet als EMMI aan de Europese nationale politicle netwerken is realiseerbaar als de Raad van Europa duidelijke regels formuleert voor de rechtstreekse toegang. Adequaat internationaal overleg en gedegen besluitvorming hieromtrent zouden plaats kunnen vinden in gelijke zin als dit is gebeurd in het kader van het Cybercrimeverdrag. De Raad van Europa kan het Comité van Ministers van de Raad van Europa opgedragen cen verdragstekst tot stand te brengen over grensoverschrijdende directe toegang in een digitale internationale politiële netwerkomgeving. Een comité van experts, waarin de betrokken landen zijn vertegenwoordigd, kunnen onderhandelen over een deugdelijke verdragstekst. Net zoals binnen de Raad van Europa in het kader van het Cybercrimeverdrag is geworsteld met de vraag in hoeverre opsporingsambtenaren grensoverschrijdend computernetwerken van burgers mogen doorzoeken en gegevens uit het buitenland mogen aftappen, kan er ook worden onderhandeld over de vraag of er internationaal juridisch een grensoverschrijdende rechtstreekse toegang tot nationale politiële bestanden, databases en politienetwerken voor buitenlandse politieambtenaren (en voor het $\mathrm{OM}$ ) gerealiseerd zou kunnen worden. De juridische netwerkproblematiek van de rechtstreekse geautomatiseerde toegang tot gegevens en computersystemen speelt zowel op het terrein van de opsporing van strafbare feiten op grond van het Cybercrimeverdrag als bij de grensregionale politiële gegevensuitwisseling. In het Cybercrimeverdrag gaat het om de rechtstreekse geautomatiseerde en grensoverschrijdende toegang van buitenlandse opsporingsambtenaren tot computergegevens en -systemen van verdachten en van derden. Bij de politiële gegevensuitwisseling gaat het om de rechtstreekse geautomatiseerde en grensoverschrijdende toegang van politieambtenaren tot buitenlandse politiële computernetwerken en gegevens. Beide vormen van rechtstreekse toegang spelen een belangrijke rol in de hedendaagse bestrijding van de grensoverschrijdende criminaliteit. Uitbreiding van de onderhandelingen binnen de Raad van Europa tot het terrein van de internationale informatieve politiële samenwerking is derhalve aangewezen. Het zou nog mooier zijn wanneer bij deze onderhandelingen ook aandacht wordt besteed aan juridische mogelijkheden voor internationale koppeling van politiegegevens. ${ }^{405}$

405. Zie hieromtrent hoofdstuk 6. 


\subsubsection{Europese Unie}

De onderwerpen van de rechtstreekse geautomatiseerde toegang en de koppeling van politiegegevens zouden daarnaast ook op de agenda van de EU geplaatst moeten worden. Dit kan gebeuren in het kader van de zogeheten Derde Pijler van de EU. De rechtsgrondslag hiervoor is te vinden in Titel VI VEU (zie sectie 5.2). Op grond van art 34 lid 2 VEU dient de Raad van de EU maatregelen te nemen en samenwerking te bevorderen, in een passende vorm en volgens passende procedures zoals bepaald in Titel VI. Daartoe kan de Raad van de EU met eenparigheid van stemmen op initiatief van elke lidstaat of van de Europese Commissie onder meer overeenkomsten vaststellen, waarvan de Raad de aanneming door de lidstaten overeenkomstig hun onderscheiden grondwettelijke bepalingen aanbeveelt. De lidstaten dienen de toepasselijke procedures dan te beginnen binnen een door de Raad te bepalen termijn. Tenzij in de overeenkomsten anders wordt bepaald, treden zij, zodra zij door ten minste de helft van de lidstaten zijn aangenomen, ten aanzien van deze lidstaten in werking. De maatregelen ter uitvoering van de overeenkomsten worden in de Raad van de EU aangenomen met een meerderheid van tweederde van de stemmen van de verdragsluitende partijen. Op grond van deze procedure van artikel 34 lid 2 sub d zou een EU-Overeenkomst aangaande de rechtstreekse geautomatiseerde grensoverschrijdende toegang van buitenlandse politieambtenaren tot nationale bestanden, databases en politienetwerken gesloten kunnen worden, met passende bepalingen inzake de bescherming van persoonsgegevens, in het licht van de voortschrijdende ICT. Eventueel zou deze materie ook geregeld kunnen worden in een kaderbesluit of een besluit, zoals genoemd in artikel 34 lid 2 sub b respectievelijk sub c VEU. Dit zou een aanzienlijke tijdswinst betekenen, aangezien er dan geen ratificaties op nationaal niveau meer plaats dienen te vinden. Er zou ook sneller kunnen worden ingespeeld op actuele ontwikkelingen. De regelingen zouden sneller kunnen worden aangepast indien daartoe een noodzaak bestaat. Deze instrumenten uit Derde Pijler zijn weliswaar bindend maar hebben geen directe werking, hetgeen betekent dat burgers zich voor de rechter niet op afzonderlijke bepalingen van de instrumenten kunnen beroepen. Een kaderbesluit is het equivalent van een communauraire richtlijn op grond van artikel 249 derde alinea EGverdrag. Zij zijn dus verbindend voor de lidstaten ten aanzien van het te bereiken resultaat, doch aan de nationale instanties wordt de bevoegdheid gelaten om vorm en middelen te kiezen. Een kaderbesluit kan gehanteerd worden voor de onderlinge aanpassing van de wettelijke en bestuursrechtelijke bepalingen van de lidstaten. Een besluit kan gehanteerd worden voor andere dan harmonisatiedoeleinden.

\subsubsection{Grensregionale convenanten en akkoorden}

Een derde mogelijkheid voor het regelen van de problematiek betreffende de directe toegang is het treffen van een regeling in de convenanten en akkoorden die op basis van artikel 39 lid 4 en 5 en artikel 46 lid 2 SUO tot stand zijn gekomen, met betrekking tot de grensregionale uitwisseling van politiële gegevens. Deze artikelen bepalen namelijk dat de samenwerking in de grensgebieden nader kan worden geregeld in afspraken tussen 
de bevoegde Ministers van de Schengenlanden. Van deze mogelijkheid is gebruik gemaakt in de Euregio's. Daar zijn namelijk allerlei bilaterale Convenanten en Akkoorden van toepassing tussen voornamelijk Nederland en België, en Nederland en Duitsland. De akkoorden regelen specifiek voor de betreffende Euregio de rechtstreekse politiēle gegevensuitwisseling in de grensregio's. Die afspraken mogen verder gaan dan de algemene procedures van gegevensuitwisseling. Met name de spoedeisendheid van rechtstreekse gegevensuitwisseling tussen betrokken politiediensten en de tussenkomst van de centrale autoriteiten zijn in deze akkoorden niet langer vereist voor de gegevensuitwisseling in de Euregio. Volgens artikel 39 lid 5 SUO mogen de bilaterale akkoorden tussen an elkaar grenzende Schengenlanden ook verder gaan. Bij 'Besluit van de Raad van 20 mei 1999 tot vaststelling in overeenstemming met de desbetreffende bepalingen van het Verdrag tot oprichting van de Europese Gemeenschap en het Verdrag betreffende de Europese Unie, van de rechtsgrondslag van elk van de bepalingen of besluiten die het Schengen-acquis vormen 1999/346/EG' ${ }^{406}$ zijn als rechtsgrondslag van artikel 39 SUO de artikelen 34 en $30 \mathrm{VEU}$ vastgesteld en van artikel 46 SUO de artikelen 34 en 30 lid 1 VEU,

\subsubsection{Regeling in het nationale recht}

Een vierde mogelijkheid voor het regelen van directe grensoverschrijdende toegang van buitenlandse opsporingsambtenaren tot nationale politiële bestanden, databases en politienetwerken, is het in het leven roepen van nationale wettelijke bepalingen hieromtrent door de betrokken landen. Dit is op grond van het vijfde beginsel van Recommendation R (87) 15 van de Raad van Europa de eerst aangewezen weg, maar verdient onzes inziens niet de voorkeur, vanwege het internationaal grensoverschrijdend karakter van een dergelijke regeling. Een internationale (Europese) overeenkomst lijkt ons voor dit doel een beter en voor de politiële praktijk transparanter juridisch instrument. Er bestaan dan namelijk geen (geheel) verschillende nationale regelingen meer in de betrokken lidstaten.

\subsubsection{Juridische haalbaarheid van automatisering}

Het nationale normatieve kader van Nederland, België en Duitsland blijkt vooralsnog niet te zijn ingericht op een fysieke koppeling van de EMMI-omgeving aan de nationale politiële databases. Het rechtstreeks wederzijds bevragen van Euregionale multimediale politiële databases door politiediensten van verschillende landen is op dit moment (januari 2004) niet mogelijk binnen de bestaande nationale wetgeving en politiek. Buitenlandse politieambtenaren mogen volgens het nationale recht en het nationale beleid namelijk geen rechtstreekse geautomatiseerde toegang tot politieregisters hebben. Menselijke controle door de verstrekkende staat is op dit moment eveneens een hard juridisch en politiek vereiste. 
Er kan derhalve nu niet tegemoet worden gekomen aan de wensen van bepaalde IRC. medewerkers om de volgende vier stappen geheel te automatiseren:

- het controleren van de aanvraag;

- het geven van toestemming;

- het zoeken van de informatie; en

- het autoriseren van het beschikbaar stellen van de informatie.

De vier stappen kunnen ook niet uit de automatiseringsketen worden gehaald. Daarvoor zijn zij te essenticel. Zoals eerder gezegd, geldt bij al deze stappen dat menselijke controle juridisch of in ieder geval politiek vereist is. Het automatiseringsproces kan derhalve zonder nieuwe nationale of internationale (Europese) wetgeving niet minder omslachtig gemaakt worden.

Ter uitoefening van zijn controlefunctie kan het $\mathrm{OM}$ technisch gesproken rechtstreekse geautomatiseerde toegang worden verleend tot de PALMA-registratiedatabase. Juridisch is dit echter nog niet toegestaan in België. In Duitsland heeft het OM geen controlefunctie ten aanzien van politieregisters. Feitelijk is er daarom voor het $\mathrm{OM}$ ook nog geen rechtstreekse toegang gerealiseerd tot de registratiedatabase.

De bevoegdheid tot directe (on line) roegang van buitenlandse politieambrenaren tor nationale politiële databases dient onzes inziens als eerste geregeld te worden, als daartoe daadwerkelijke een noodzaak bestaat, zoals aangegeven door de IRC's. Pas daarna kan men overgaan tot de internationale (juridische) koppeling van de verschillende nationale computernetwerken en gegevens. Als de wetgever mocht beslissen dat directe toegang van buitenlandse politieambtenaren niet wenselijk is, zal de directe grensoverschrijdende koppeling van gegevens feitelijk niet uitvoerbaar zijn, hoewel een dergelijke koppeling formeel wel is toegestaan onder welbepaalde voorwaarden. Als de koppeling bij wet is voorzien of als de nationale controleautoriteiten er goedkeuring aan verlenen, is koppeling namelijk toegestaan volgens het internationale recht, met name het vijfde beginsel van Recommendation R (87) 15. Juridisch is koppeling - het komen tot nieuwe informatic over een vooraf onbepaalde groep van personen - volgens het internationale recht dus toegestaan. De uitvoering ervan wordt echter gefrustreerd door het feit dat volgens het nationale recht en de nationale politiek aan buitenlandse politieambtenaren geen rechtstreekse geautomatiseerde toegang tot politieregisters wordt toegestaan.

Wij geven nu een overzicht van de juridische haalbaarheid van vier technologische niveaus (in volgorde van opklimmende geavanceerdheid) binnen de EMMI-omgeving waarop grensoverschrijdende bevraging van (multimediale) politiële databases kan plaatsvinden. 
niveau 1: Het situisselen van informatie geschiedt volgens de huidige stand wan zaken: zowel in het aanvragende als in het verstrekkende land overleggen speciaal daarvoor aangestelde politiefunctionarissen, eventueel na inschakeling van het $\mathrm{OM}$, of en welke gegevens worden uitgewisseld. Het zoeken in de nationale databases gebeurt uitsluitend door de IRC-medewerkers van het verstrekkende land zelf, alsmede door de agent op de werkvloer die hiervoor door de IRC-medewerkers is benaderd. Deze huidige werkwijze is juridisch toegestaan en gečigend voor politieregisters zolang geen rechtstreekse geautomatiseerde toegang van buitenlandse politieambtenaren is toegestaan. Menselijke tussenkomst van de bevoegde nationale politieambtenaren is op dit moment nog een absoluut wettelijk en politiek vereiste.

niveau 2: Het zoeken in de nationale databases wondt uitgevoend door computerprognammas' in het informatieverstrekkende IRC. Op de uitkomst van die geautomatiseerde zoekactie vindt controle plaats door de daarvoor aangestelde IRC-medewerkers. Daarna worden de gegevens al dan niet verzonden naar het buitenlandse IRC. Deze technische stap is op dit moment juridisch niet toegestaan voor het zoeken in politieregisters, omdat de wetgever uitgaat van de menselijke uitvoering van de gegevensuitwisseling. Bij Wbp-registers ligt het iets gemakkelijker. Voor het grensoverschrijdend zoeken in Wbp-registers zou dit tweede niveau een reële mogelijkheid kunnen zijn. Menselijke controle is vooralsnog vereist.

niveau 3: Het wordt de IRC-medewerker mogelijk gemaakt om via computerprogramma's rechtstreeks in buitenlandse databases te zoeken en de gevonden informatie op te halen. Controle kan achteraf plaatsvinden door de inhoud van de PALMA-registratiedatabase of de PALMA-logdatabase na te trekken. Het is niet erg waarschijnlijk dat deze optie in de nabije toekomst gerealiseerd zal worden op nationaal wetgevend niveau, omdat de menselijke controle te beperkt is op dit niveau. Voor Wbpregisters zou dit automatiseringsniveau wellicht wel gehaald kunnen worden.

niveau 4: Politieambtenaren mogen 'op de werkvloer', bijvoorbeeld via de browser van de multimediakiosk, rechtstreeks in de buitenlandse databases kijken en de gegevens ophalen, zonder dat er nog sprake is van enige vorm van firewall. Dit niveau van gegevensuitwisseling lijkt vooralsnog een utopie, omdat de internationale politiële gegevensuitwisseling een zeer specialistisch terrein is dat bij voorkeur wordt uitgeoefend door ter zake goed opgeleide politiefunctionarissen. Daarbij komt dat het weghalen in de automatiseringsketen van de schakel van de IRC's in strijd is met de bestaande wet- en regelgeving en de daarop gebaseerde richtlijnen. Dit automatiseringsniveau is dus juridisch onhaalbaar, misschien op een aantal uitzonderingen na waarin rechtstreekse contacten tussen agenten op de werkvloer juridisch toegelaten zijn. Zo zijn op grond van de van kracht zijnde convenanten tussen de 
Nederlandse politie Limburg-Zuid en de politie van het Belgische Genk en Eupen informatie-uitwisselingscontacten tussen politiediensten in het grensgebied zonder tussenkomst van het IRC toegestaan. Dit is het geval in concrete opsporingsonderzoeken of samenwerkingsverbanden. Daarbij moet dan wel een werkdossier of werkregister worden bijgehouden.

\subsubsection{Invloed ontwerp-kaderbesluit Europees bewijsverkrijgingsbevel}

In deze subsectie bespreken wij kort het ontwerp-kaderbesluit van de EU betreffende het Europees bewijsverkrijgingsbevel ter verkrijging van voorwerpen, documenten en gegevens voor gebruik in strafprocedures. ${ }^{407}$ Wij onderzoeken de invloed die dit nieuwe juridische instrument kan hebben op het vraagstuk van de grensoverschrijdende geautomatiseerde toegang tot registers. Momenteel (begin 2004) is genoemd ontwerp-kaderbesluit in behandeling bij de Raadswerkgroep samenwerking in strafzaken van de Raad van Justitie en Binnenlandse Zaken (de JBZ-Raad).

\section{Doelstelling van het voorstel ${ }^{\text {sos }}$}

Het doel van het kaderbesluit is het bewerkstelligen van een snellere, efficiëntere strafrechtelijke samenwerking tussen de lidstaten op het gebied van het vergaren en overdragen van bestaand bewijs. Hoewel in het voorstel steeds wordt gesproken over 'bewijs', gaat het strikt genomen om voorwerpen, documenten en gegevens ten behoeve van de waarheidsvinding, die tot bewijs in een strafzaak kunnen dienen. Het is immers de rechter in de berechtende staat die uiteindelijk bepaalt welke informatie in het strafproces als bewijs wordt aangemerkt. Het genoemde doel dient te worden bereikt door het invoeren van een uniform Europees bewijsverkrijgingsbevel dat door de justitiële autoriteit van de uitvaardigende lidstaat kan worden afgegeven en door de lidstaat op wiens grondgebied de voorwerpen, documenten of gegevens zich bevinden dient te worden uitgevoerd. Op welke wijze de uitvoerende lidstaat uitvoering geeft aan het bevel wordt aan die lidstaat overgelaten, zolang het resultaat (het vergaren en overdragen van het gevraagde materiaal) maar wordt bereikt. Het kaderbesluit ziet op het verkrijgen en overdragen van bestaand 'bewijs'. Het heeft derhalve geen betrekking op de inzet van bevoegdheden om nieuwe informatie te vergaren, zoals het afluisteren van telecommunicatie, het observeren van verdachten of het monitoren van bankrekeningen. Ook ziet het niet op het verhoren van verdachten, getuigen of deskundigen of het afnemen en onderzoeken van DNA-materiaal.

407. Datum Raadsdocument: 25 november 2003; nt. Raadsdocument: $15221 / 03$ COPEN 119; nt. Commissiedocument: COM (2003) 688 definitief.

408. Bron: Ministerie van Buitenlandse Zaken, document nr. 22112, 306 fiche 5, DIE68/04 [bnc-fiche]. 


\section{Gevolgen voor Nederland}

Voor Nederland gaat het om bevoegdheden als inbeslagneming van voorwerpen, het geven van een bevel uitlevering stukken, het vorderen van gegevens (onder andere over bankrekeningen), doorzoeking ten behoeve van inbeslagneming en de overdracht van het aldus verkregen materiaal. Voorts ziet het kaderbesluit op de verstrekking van informatie die zich bevindt in politieregisters en andere registers. Dit betekent dat informatic over DNA-onderzoeken of informatic afkomstig uit telefoontaps die reeds hebben plaatsgevonden voor het Europees bevel werd afgegeven en die zich in politieregisters bevindt, wel weer onder de reikwijdte van het kaderbesluit kan vallen. Ten slotte ziet het kaderbesluit op het verstrekken van justitiële documentatie (strafbladen).

Op een aantal punten is het voorstel verstrekkend van aard. Zo behelst het voorstel niet de mogelijkheid om tenuitvoerlegging te weigeren indien het bevel betrekking heeft op een strafbaar feit dat op Nederlands grondgebied is gepleegd. Ook wordt voorgesteld om na een overgangsperiode van vijf jaar de mogelijkheid af te schaffen om tenuitvoerlegging te weigeren op grond van het ontbreken van dubbele strafbaarheid (dat wil zeggen wel strafbaarheid in een andere lidstaat en niet in Nederland). Voorts gaan de bevoegdheden tot het grensoverschrijdend vergaren van computergegevens die zich bevinden op het grondgebied van een andere lidstaat verder dan diegene die zijn neergelegd in het Cybercrimeverdrag van de Raad van Europa (zie subsectie 7.2.2). Het voorstel raakt in zijn algemeenheid belangrijke aspecten van het strafprocesrecht en daarmee aan verschillende strafrechtsstelsels van de lidstaten. De rechtsbasis van het voorstel betreft de artikelen 31 en 34 lid 2 sub b VEU.

Het kaderbesluit zal naar verwachting tot gevolg hebben dat meer opsporingscapaciteit moet worden ingezet ten behoeve van in het buitenland lopende strafzaken. In welke mate dit het geval zal zijn, is thans niet aan te geven. Het voorstel kan een extra administratieve belasting opleveren voor politie en justitie in verband met registratie- en informatieverplichtingen.

\section{Nederlandse opstelling 409}

Nederland stelt zich in verband met het Europese subsidiariteitsbeginsel positief op. Afspraken van dit karakter en met deze reikwijdte over justitiële samenwerking tussen de lidstaten dienen op EU-niveau te worden gemaakt. In verband met de proportionaliteit heeft Nederland twijfels bij het voorliggende ontwerp-kaderbesluit. Op onderdelen hebben de voorstellen verstrekkende gevolgen en bestaat er aanleiding te bezien of met minder vergaande voorstellen hetzelfde doel kan worden bereikt.

409. Bron: Ministerie van Buitenlandse Zaken, document nr. 22112, 306 fiche 5. DIE68/04 [bnc-fiche]. 
De Europese Commissie stelt in het ontwerp-kaderbesluit 1 januari 2005 als implementatiedatum voor. Deze datum is niet reëel. Gelet op de veelomvattendheid van het ontwerp-kaderbesluit zal volgens het Nederlandse Ministerie van Buitenlandse Zaken op zijn minst geheel 2004 besteed dienen te worden aan de onderhandelingen over dit ontwerp-kaderbesluit. Voor dit soort kaderbesluiten is een implementatietermijn van twee jaar na vaststelling van het besluit gebruikelijk.

\section{Nederlandse belangen en eerste algemene standpuntbepaling}

Nederland hecht belang aan een vlotte en doelmatige strafrechtelijke samenwerking tussen de lidstaten. Een Europees bewijsverkrijgingsbevel kan hieraan bijdragen en wordt vanuit dat oogpunt positief beoordeeld. Het kaderbesluit raakt echter aan elementaire onderdelen van het strafprocesrecht. Een grondige bespreking en bestudering van het voorstel is daarom noodzakelijk. Nederland acht het dan ook van belang dat het kaderbesluit een goed evenwicht tot stand brengt tussen enerzijds het verbeteren van de strafrechtelijke samenwerking en anderzijds het behoud van een consistent en werkbaar straf. procesrecht met inbegrip van belangrijke strafprocessuele waarborgen.

\section{Grensoverschrijdende toegang}

Wat de invloed van het Europees bewijsverkrijgingsbevel is op het vraagstuk van de grensoverschrijdende toegang van buitenlandse opsporingsambtenaren tot Nederlandse registers, is nu nog niet geheel duidelijk. In ieder geval zullen op grond van een Europees bewijsverkrijgingsbevel van een justitiële autoriteit van de uitvaardigende lidstaat gegevens uit Nederlandse registraties dienen te worden verstrekt aan andere Europese lidstaten. Of hiervoor rechtstreekse geautomatiseerde grensoverschrijdende toegang wenselijk is, vereist een nadere zorgvuldige afweging van het privacybelang van de burger tegenover het opsporingsbelang van de Europese lidstaten. Het enkele feit dat het nieuwe juridische instrument een extra administratieve belasting kan opleveren voor politie en justitie in verband met registratie- en informatieverplichtingen is onvoldoende voor het invoeren van een rechtstreekse geautomatiseerde grensoverschrijdende toegang voor buitenlandse politieambtenaren (zie nader sectie 9.12).

\subsection{Standpuntbepaling directe toegang}

In deze sectie formuleren wij in drie punten onze visie op het juridische vraagstuk van de grensoverschrijdende directe toegang en doen wij een suggestie tot uitbreiding van het takenpakket van de IRC's.

In de eerste plaats achten wij het wenselijk dat voor het juridische kernprobleem van de rechtstreekse geautomatiseerde toegang duidelijke juridische normen en heldere formele procedures worden opgesteld. Dit dient bij voorkeur te gebeuren op het internationaalrechtelijk niveau van de Raad van Europa en van de EU. De normen kunnen worden aangevuld door de meer specifieke nationale wetgeving. Het Cybercrimeverdrag en de EU- 
Overeenkomst betreffende de wederzijdse rechtshulp in strafraken kunnen een inspiraticbron zijn om tot internationaal aanvaardbare oplossingen te komen voor dit vraagstuk.

In de rweede plaats vinden wij het raadzaam dat de ratio van de huidige regeling voor en het beleid aangaande de rechtstreekse geautomatiseerde toegang tot politieregisters heroverwogen worden. De wetgevers van de betrokken landen dienen zich er over uit te spreken of aan buitenlandse politieambtenaren en aan leden van het $O M$ rechtstreekse geautomatiseerde toegang tot bepaalde politieregisters moet worden gegund. Bij een verlening van rechtstreekse toegang dient dan ook te worden bepaald onder welke juridische en technische randvoorwaarden dit dient te geschieden.

In de derde plaats bevatten de huidige bilaterale convenanten en verdragen die tussen Nederland, Belgiě en Duitsland onderling van kracht zijn, geen regeling omtrent de rechtstreekse geautomatiseerde toegang tot de nationale politiêle gegevens en computernetwerken door buitenlandse politieambtenaren. Zij bepalen ook niets over koppeling van gegevens, bestanden of systemen. Naar onze mening zouden de partners bij de internationale politiële gegevensuitwisseling hierover tot overeenstemming moeten komen, bij voorkeur via een bi- of trilateraal verdrag of convenant, via een verdrag in het kader van de Raad van Europa of via een EU-Overeenkomst. Wellicht kunnen in een dergelijk internationaal juridisch instrument ook afspraken worden gemaakt of en in hoeverre juridisch gesproken koppeling van internationaal uitgewisselde (persoons)gegevens mogelijk dient te zijn. Het respecteren van het doelbindingsbeginsel zal hierbij een cruciale rol spelen. Men dient zich evenwel te realiseren dat de inzet van verdragswetgeving voor de genoemde doeleinden een zwaar middel is, dat eakel mag worden toegepast als het echt noodzakelijk is.

Hieronder volgt een concrete suggestie tot uitbreiding van het takenpakket van de IRC's.

Art. 20 lid 4 sub d EU-RHO vermeldt dat de lidstaten de nodige maatregelen dienen te treffen om ervoor te zorgen dat binnen een termijn van 96 uur kan worden geantwoord op een rechtshulpverzoek betreffende het aftappen van telecommunicatie zonder technische bijstand van een andere EU-lidstaat. Hiertoe dienen contactpunten aangewezen te worden die 24 uur per dag beschikbaar zijn. Artikel 35 Cybercrimeverdrag verplicht de verdragspartijen tot de inrichting van een zogenoemd 24/7 Netwerk voor technisch advies, de conservatie van gegevens op grond van artikel 29 en 30 Cybercrimeverdrag, de bewijsvergaring, het verstrekken van juridische informatie en het lokaliseren van verdachten. In elke verdragsstaat dient 24 uur per dag en 7 dagen per week een informatieknooppunt actief te zijn, waarbij bevoegde ambtenaren heel snel de genoemde informatie kunnen geven en de genoemde handelingen kunnen verrichten. Wij denken dat het goed zou zijn om in de toekomst hiervoor een rol toe te kennen aan de IRC's door de IRC's als een dergelijk contactpunt aan te wijzen. 



\section{Juridische grenzen tussen Europol en de IRC's}

In dit hoofdstuk behandelen wij de derde aanvullende onderzoeksvraag:

"Waar liggen de juridische grenzen tussen de werkzaamheden van Europol en de werkzaambeden van de IRC's?"

In sectie 8.1 bespreken wij de werking en de ontstaansgeschiedenis van de Europese politiedienst Europol. In sectie 8.2 gaan we dieper in op de informatie-uitwisseling in het kader van Europol en behandelen we enkele voorwaarden voor informatieverwerking. In sectie 8.3 vergelijken wij Europol en de IRC's. Wij formuleren daar ook onze conclusies ten aanzien van de relatie tussen Europol en de IRC's.

\subsection{De politiedienst Europol}

Europol is een Europese politiële rechtshandhavingsorganisatie, die gevestigd is in Den Haag en die zogeheten 'criminele inlichtingen' behandelt. Het doel van de organisatie is het bevorderen van de effectiviteit van het optreden van, en de samenwerking tussen, de bevoegde (politiële) instanties van de EU-lidstaten met betrekking tot het voorkomen en bestrijden van ernstige internationaal georganiseerde misdaad. Europol heeft als taak een wezenlijke bijdrage te leveren aan de rechtshandhavingsacties van de EU tegen georganiseerde misdaad. Europol richt zich in het bijzonder op de criminele organisaties.

In deze sectie behandelen wij eerst de juridische basis van Europol (subsectie 8.1.1). Daarna gaan wij in op de taakvelden van Europol, ook wel het Europolmandaat genoemd (subsectie 8.1.2). In subsectie 8.1.3 bespreken wij het beheer van Europol. Subsectie 8.1.4 ziet ten slotte op het toezicht op de werkzaamheden van Europol.

\subsubsection{Juridische basis Europol}

Op 7 februari 1992 werd in het Verdrag van Maastricht betreffende de Europese Unie (VEU) besloten tot oprichting van Europol. ${ }^{410}$ Op 3 januari 1994 gingen, in de vorm 
van de Europol-Drugseenheid (EDE), enkele beperkte werkzaamheden van Europol van start. Het betrof de strijd tegen illegale drugs. Dit geschiedde op basis van een Ministeriële Overeenkomst. "11 In deze overeenkomst was vastgelegd, dat de mogelijkheden tot informatie-uitwisseling in concrete strafzaken zouden worden voorgeschreven door de nationale wettelijke bepalingen van de EU-lidstaten. ${ }^{612}$

De juridische basis van Europol is de Europol-Overeenkomst (EO) ${ }^{413}$ van 26 juli 1995. Deze overeenkomst werd door alle lidstaten geratificeerd en trad op 1 oktober 1998 in werking. Na een aantal rechtshandelingen, betrekking hebbend op de Overeenkomst, is Europol op 1 juli 1999 gestart met zijn volledige activiteiten. ${ }^{414}$ De EO voorziet voor het eerst in een duidelijke verdragsbasis voor een multinationaal samengestelde politiedienst.

Art. 2 lid 1 EO formuleert de doelstelling van Europol als volgt: "Europol heeft ten doel, in het kader van de samenwerking tussen de Lid-Staten overeenkomstig artikel K.1, punt 9, van het Verdrag betreffende de Europese Unie, door de in deze Overeenkomst genoemde maatregelen het optreden van en de samenwerking tussen de bevoegde instanties van de Lid-Staten met betrekking tot het voorkomen en bestrijden van terrorisme, de illegale handel in verdovende middelen en andere ernstige vormen van internationale criminaliteit doeltreffender te maken voor zover er concrete aanwijzingen zijn voor het bestaan van een criminele structuur of organisatie en twee of meer Lid-Staten betrokken zijn bij de genoemde vormen van criminaliteit op een wijze die, gelet op de omvang, de ernst en de gevolgen van de strafbare feiten, een gemeenschappelijk optreden van de LidStaten noodzakelijk maakt." In artikel K.1, punt 9 (oud) VEU werd met het oog op de verwezenlijking van de doelstellingen van de EU, met name het vrije verkeer van personen, een aantal aangelegenheden genoemd die van algemeen belang zijn. Het gaat hierbij onder meer om de politiële samenwerking met het oog op het voorkomen en bestrijden van terrorisme, de illegale drugshandel en andere ernstige vormen van internationale criminaliteit. ${ }^{415}$ Europol dient in dit kader de samenwerking tussen politieorganisaties van de EU-lidstaten doeltreffender te maken. Europol doet dit met name door uitwisseling van informatie en het maken van analyses met betrekking tot internationale criminaliteit in de EU.

411. Zie Kamesstukken II, 1993/1994, 23 401, nr. 1-2, p. 15. De Ministeriële overeenkomst op basis waarvan de Europol-Drugseenheid als eerste fase van Europol ging functioneren is ondertekend op 2 juni 1993.

412. Zie Kamerstukken II, 1993/1994, 23 815, nr. 1, p. 3 en 23490 , nr. 7.

413. Overeenkomst tot oprichting van een Europese Politiedienst, Tr6. 1995, 282; PbEG 1995/C316, 2, 27 november 1995.

414. Zie hieromtrent het Algemeen Politicblad $(A P B)$, nt. 17 van 28 augustus 1999, p. 3 en 4.

415. Vgl. MvT bij de Nederiandse Goedkeuringswet van de EO, Kamerstukken II. 1996/1997, 25339 , nr. 3, p. 13. 


\subsubsection{Het Europolmandaat}

Om de doelstelling van Europol te bereiken noemt artikel 2 lid 2 en 3 EO een aantal juridisch vastgestelde taakvelden voor Europol. Wij noemen het geheel van taakvelden voor Europol het Europolmandaat. Het gaat vooreerst om de voorkoming en bestrijding van illegale handel in verdovende middelen en nucleaire en radioactieve stoffen, alsmede om de voorkoming en bestrijding van illegale immigratic, mensenhandel en handel in gestolen voertuigen. Uiterlijk twee jaar na de inwerkingtreding van de EO diende Europol tevens de volgende strafbare feiten te behandelen: strafbare feiten die zijn gepleegd of wellicht zullen worden gepleegd in het kader van terroristische activiteiten die gericht zijn tegen het leven, de lichamelijke integriteit en de persoonlijke vrijheid, alsmede tegen goederen. Bij Besluit van de Raad van 3 december 1998 werd Europol daadwerkelijk belast met de behandeling van deze strafbare feiten. ${ }^{416}$

De Raad van de EU kan met eenparigheid van stemmen aan Europol opdragen zich ook te belasten met andere in de bijlage bij de EO vermelde vormen van criminaliteit of specificke uitingsvormen daarvan. Alvorens daarover een besluit te nemen, dient de Raad van Bestuur ${ }^{417}$ van Europol dit besluit voor te bereiden en met name de gevolgen daarvan voor de begroting en het personeel van Europol uiteen te zetten. De bevoegdheid van Europol met betrekking tot een vorm van criminaliteit of met betrekking tot specifieke aspecten van een vorm van criminaliteit omvat blijkens artikel 2 lid 3 EO tevens: - het witwassen van geld in verband met deze vormen van criminaliteit of specificke aspecten ervan;

- de daarmee samenhangende strafbare feiten, namelijk (1) strafbare feiten die zijngepleegd om zich de middelen te verschaffen om daden te plegen die onder de werkingssfeer van Europol vallen; (2) strafbare feiten die zijn gepleegd om daden die onder de werkingssfeer van Europol vallen, te vergemakkelijken of uit te voeren; en (3) strafbare feiten die zijn gepleegd om ervoor te zorgen dat daden die onder de werkingssfeer van Europol vallen, ongestraft blijven.

De samenwerking van de EU-lidstaten in het kader van Europol bij de bestrijding van criminaliteit, vindt uit het oogpunt van doelmatigheid alleen plaats wanneer het om zware criminaliteit gaat en daarbij twee of meer lidstaten daadwerkelijk betrokken zijn. Nationaal georiënteerde criminaliteit dient nationaal te worden bestreden en opgelost en niet via Europol. Verder is het zo dat bepaalde vormen van grensoverschrijdende criminaliteit die zich tussen twee lidstaten afspelen vaak efficiënter kunnen worden aangepakt door middel van bilaterale samenwerking. Hierbij is dan ook geen rol weggelegd voor Europol.418 
Hieronder bezien wij het mandaat van Europol nader. Wij bezien achtereenvolgens het mandaat van artikel 2 , het mandaat volgens artikel 3 , en de verdere bijdrage van Europol.

\section{Mandaat volgens artikel 2}

Uit artikel 2 EO blijkt dat de informatie-uitwisseling via Europol beperkt is tot gepleegde of te plegen strafbare feiten. Het dient daarbij dan ook nog te gaan om de zwaardere vormen van criminaliteit die onderdeel uitmaken van het Europolmandaat. Via de artikelen 29 en 30 VEU, die betrekking hebben op de Europese samenwerking op het terrein van politic en justitie, werd het Europolmandaat reeds uitgebreid op het tijdstip van de intwerkingtreding van het Verdrag van Amsterdam, per 1 mei 1999, nog voordat de in de EO genoemde taken volledig werden vervuld. Artikel 29 lid 1 VEU bepaalt dat er een nauwere samenwerking tussen de politiediensten, douaneautoriteiten en andere bevoegde autoriteiten, zowel rechtstreeks als via Europol, dient te komen. Op grond van artikel 29 lid 2 sub a VEU dient Europol binnen vijf jaar na 1 mei 1999 in staat te worden gesteld tot het vergemakkelijken en ondersteunen van de voorbereiding en het aanmoedigen van de coördinatie en uitvoering van specifieke onderzoeksacties door de bevoegde autoriteiten van de lidstaten; deze opdracht is inclusief operationele acties van gezamenlijke teams waarvan vertegenwoordigers van Europol ter ondersteuning deel uitmaken. Op grond van artikel 29 lid 2 sub b VEU dient Europol binnen vijf jaar na 1 mei 1999 de bevoegde autoriteiten van de lidstaten te kunnen vragen om (1) hun onderzoek in specifieke zaken te mogen verrichten en (2) dit onderzoek te mogen coördineren en (3) specifieke expertise te mogen ontwikkelen die ter beschikking van de lidstaten kan worden gesteld om hen te assisteren bij het onderzoeken van zaken betreffende de georganiseerde criminaliteit. De Raad van Ministers dient op grond van artikel 29 lid 2 sub c binnen vijf jaar na 1 mei 1999 verbindingsregelingen te bevorderen tussen functionarissen die zijn belast met opsporing en vervolging, die zich specialiseren in de bestrijding van de georganiseerde criminaliteit in nauwe samenwerking met Europol. Op grond van artikel 29 lid 2 sub d dient de Raad van Ministers binnen vijf jaar na 1 mei 1999 een netwerk op te richten voor onderzoek, documentatie en statistiek met betrekking tot grensoverschrijdende criminaliteit. Bij Besluit van de Raad van 29 april $1999^{419}$ is het Europolmandaat uitgebreid met de bestrijding van valsemunterij en de vervalsing van betaalmiddelen met het oog op de Euro. Op 30 november 2000 heeft de Raad zijn goedkeuring gehecht aan de akte waarbij op basis van artikel 43 lid 1 EO, een protocol wordt opgesteld tot wijziging van artikel 2 en de bijlage bij de overeenkomst. ${ }^{420}$ Uit hoofde van die akte is de bevoegdheid van Europol uitgebreid tot het witwassen van geld 
in het algemeen, ongeacht het soort misdrijf waarvan de witgewassen opbrengsten afkomstig zijn. Op 30 november 2000 heeft de JBZ-Raad zijn goedkeuring gehecht aan een aanbeveling aan de lidstaten betreffende de steun die Europol verleent aan door de lidstaten opgerichte gemeenschappelijke onderzoeksteams. De Raad beschrijft in dit document de wijze waarop Europol de gemeenschappelijke onderzoeksteams kan steunen en beveelt de lidstaten aan ten volle van deze mogelijkheden gebruik te maken.

Ingevolge artikel 2 lid $4 \mathrm{EO}$ zijn alle in de lidstaten bestaande overheidsinstanties, die krachtens het nationale recht bevoegd zijn op het gebied van het voorkomen en bestrijden van strafbare feiten, nationaal bevoegde autoriteiten in de zin van de EO. ${ }^{421}$ De informatieverstrekking in concrete strafzaken alsmede in geval van zachte gegevens (CIEgegevens, gegevens van de Criminele Inlichtingen Eenheid) in het kader van Europol valt darmee voor Nederland volledig onder de verantwoordelijkheid van het $O M$.

\section{Mandaat volgens artikel 3}

Op grond van artikel 3 lid 1 EO verricht Europol de volgende taken en werkzaamheden in het kader van zijn doelstelling.

1. Het vergemakkelijken van de uitwisseling van informatie tussen de lidstaten.

2. Het verzamelen, compileren en analyseren van informatie en inlichtingen.

3. Het via de zogeheten nationale eenheden aan de bevoegde autoriteiten van de lidstaten onverwijld geven van informatie die voor hen van belang is, alsmede het hen onmiddellijk geven van informatie over de verbanden tussen strafbare feiten die aan het licht zijn gekomen.

4. Het ondersteunen van het opsporingsonderzoek in de lidstaten door aan de nationale eenheden alle relevante informatie te verstrekken.

5. Het bijhouden van geautomatiseerde gegevensbestanden waarin gegevens als bedoeld in de artikelen 8,10 en 11 EO zijn opgeslagen.

Art. 3 lid 2 voegt hieraan nog de volgende taken en werkzaamheden toe in het kader van de doelstelling van Europol.

1. Het vergroten van de vakkennis die in het kader van de onderzoeksactiviteiten van de bevoegde autoriteiten van de lidstaten wordt gebruikt, alsmede het van advies dienen van opsporingsonderzoekers.

421. Het gaat hierbij voor Nederland niet alleen om het OM en de politie, maar ook om diensten als de douane, de FIOD, de Economische Controledienst (ECD) en de Algemene Inspectiedienst (AID), voor zover zij met het bestrijden of voorkomen van bepaalde vormen van criminaliteit zijn belast, alsmede om de Algemene Inlichtingen-en Veiligheidsdienst (AIVD), voor zover deze dienst mede tot taak heeft bepaalde vormen van criminaliteit te voorkomen. 
2. Het verstrekken van strategische inlichtingen om een doeltreffende en rationele besteding op nationaal niveau van de voor operationele taken beschikbare middelen te vergemakkelijken en te bevorderen.

3. Het opstellen van algemene verslagen over de verrichte werkzaamheden.

\section{Verdere bijdrage van Europol}

Ten slotte kan Europol, in het kader van zijn doelstelling, afhankelijk van zijn personele en budgettaire mogelijkheden en binnen de door de Raad van Bestuur van Europol bepaalde grenzen, de lidstaten met raad en onderzoek bijstaan op de volgende gebieden.

1. Opleiding van de leden van hun bevoegde autoriteiten.

2. Organisatie en uitrusting van de bevoegde autoriteiten.

3. Methoden van misdaadpreventie.

4. Methoden van criminalistiek en forensische technologie en methoden van opsporings. onderzoek.

Europol is dus met andere woorden te zien als een Europees orgaan voor de veredeling en uitwisseling van gegevens die een bijdrage kunnen leveren aan het voorkomen en bestrijden van bepaalde vormen van grensoverschrijdende georganiseerde criminaliteit. Europol heeft op grond van de EO geen operationele taken of opsporingsbevoegdheid, doch heeft slechts ondersteunende, informerende en coördinerende taken. ${ }^{422}$ Met de inwerkingtreding van het Verdrag van Amsterdam heeft Europol evenwel toch beperkte operationele taken gekregen. In het kader van artikel 30 lid 2a VEU betreft dit het deelnemen aan gezamenlijke onderzoeksteams. Een dergelijk gezamenlijk onderzoeksteam dient evenwel altijd te werken onder de verantwoordelijkheid van de lokaal bevoegde autoriteiten. De wetgeving van de lidstaat waar zo een team functioneert is bepalend voor de wettelijke mogelijkheden.

Geleidelijk aan werden andere belangrijke gebieden van criminaliteit aan de competentie van Europol toegevoegd. Zo werd met ingang van 1 januari 2002 het mandaat van Europol uitgebreid om te kunnen optreden tegen ernstige vormen van internationale misdaad, zoals beschreven is in de bijlage bij de EO.

Europol ondersteunt momenteel (januari 2004) rechtshandhavingsactiviteiten van de EU-lidstaten die voornamelijk betrekking hebben op:

- illegale handel in verdovende middelen;

- illegale immigratienetwerken;

- terrorisme;

422. Vgl. MvT bij de Goedkeuringswet Europol-Overeenkomst; Kameritukken II. $1996 / 1997,25339$, nr. 3, p. 4. 
- illegale handel in motorvoertuigen;

- mensenhandel met inbegrip van kinderpornografie;

- valsemunterij (in het bijzonder vervalsing van de Euro) en vervalsing van andere betaalmiddelen;

- handel in radioactieve en nucleaire stoffen; en

- witwasactiviteiten.

Tot de voornaamste prioriteiten van Europol behoren verder misdrijven tegen personen, financiële misdrijven en computercriminaliteit.

Europol is bevoegd tot ondersteuning van bovengenoemde rechtshandhavingsactiviteiten indien een georganiseerde criminele structuur bestaat en twee of meer EUlidstaten betrokken staten zijn.

De ondersteuning van de EU-lidstaten door Europol geschiedt praktisch gesproken hoofdzakelijk op de volgende vier wijzen.

1. Het vergemakkelijken van de uitwisseling van gegevens, in overeenstemming met nationale wetgeving, tussen Europol-verbindingsofficieren (Europol Liaison Officers; ELO's). ELO's zijn door de lidstaten als vertegenwoordigers van hun nationale rechtshandhavingsorganen afgevaardigd naar Europol.

2. Het verstrekken van operationele analyses ter ondersteuning van onderzoeken in de lidstaten.

3. Het genereren van strategische verslagen (zoals de beoordeling van bedreigingen) en misdaadanalyses op basis van door de lidstaten verstrekte, door Europol gegenereerde of uit nadere bronnen afkomstige informatie en inlichtingen.

4. Het leveren van expertise en het verlenen van technische ondersteuning aan lopende onderzoeken in de EU, onder toezicht en wettelijke verantwoording van de betrokken lidstaten.

Europol zet zich verder in voor het bevorderen van misdaadanalyses en de harmonisatie van onderzoekstechnieken in de EU-lidstaten.

Europol heeft zijn internationale samenwerking op het gebied van de rechtshandhaving versterkt door de ondertekening van bilaterale overeenkomsten met onder meer de volgende niet-EU lidstaten en Internationale Organisaties: Estland, de Europese Centrale Bank, het Europees Waarnemingscentrum voor Drugs en Drugsverslaving (EWDD), Hongarije, ICPO/Interpol, IJsland, Noorwegen, Polen, Slovenië, de Verenigde Staten en de Wereld Douane Organisatie (WDO). Verder heeft Europol een bureau voor zijn verbindingsofficieren geopend in de Verenigde Staten (Washington D.C.). 


\subsubsection{Het beheer van Europol}

De Directie van Europol bestaat uit een directeur en twee adjunct-directeuren. $\mathrm{Zij}$ worden benoemd door de Raad van de EU (in casu de Ministers van Justitie en Binnenlandse Zaken).

Europol wordt gefinancierd door bijdragen van de lidstaten. Deze bijdragen worden vastgesteld naar rato van het Bruto Nationaal Product (BNP) van een lidstaat. De Europol-begroting voor 2003 bedroeg $€ 55,5$ miljoen. ${ }^{423}$ Tijdens de de Raad van Ministers van Justitie en Binnenlandse Zaken van 5 en 6 juni 2003 werd de begroting voor 2004 goedgekeurd. ${ }^{424}$ De Europol begroting voor 2004 bedraagt - exclusief de kosten die door het gastland worden gedragen voor huisvesting en beveiliging - $€ 58,8$ miljoen. ${ }^{425}$

Een financieel controleur is verantwoordelijk voor (1) de controle op het aangaan van betalingsverplichtingen en op de betalingen en (2) de controle op de vaststelling en de inning van ontvangsten van Europol. Deze controleur wordt, met eenparigheid van stemmen, benoemd door de Raad van Bestuur van Europol. ${ }^{426}$

De jaarrekeningen van Europol worden gecontroleerd door een gemeenschappelijk controlecomité, dat is samengesteld uit drie leden die door de Rekenkamer van de Europese Gemeenschappen worden aangewezen.

In januari 2003 telde Europol 386 medewerkers, die uit alle lidstaten afkomstig waren. Hieronder vallen 59 verbindingsofficieren (ELO's), die verschillende opsporingsdiensten vertegenwoordigen (politie, douane, federale politie of marechaussee, immigratiediensten, enzovoorts). De overige medewerkers zijn Europol-officieren, analisten en andere deskundigen. Zij verlenen samen 24 uur per dag een effectieve, snelle en meertalige ondersteuning. De verwachting van Europol was dat eind 2003 het totale aantal Europolwerknemers, waarbij inbegrepen de ELO's en het bewakingspersoneel, zou stijgen tot ongeveer 460 werknemers. ${ }^{427}$

423, Zie PbEG 2002/C179, 1, 27 juli 2002 en PbEG 2003/C152, 16, 28 juni 2003 voor de gewijzigde begroting.

424. Deze werd op 28 juni 2003 gepubliceerd in PbEG C152/04.

425. De begroting stijgt uitsluitend door de $€ 7$ miljoen aan kosten ten gevolge van de uitbreiding van de EU uit boven de begroting voor 2003, die dus $€ 55,5$ miljoen bedroeg. De verhoging van de begroting ten opzichte van 2003 bedraagt 6,2\%. De uitgaven voor ICT zijn maxima, ze kunnen lager uitvallen afhankelijk van beslissingen op ICT terrein in de komende tijd. De Nederlandse Eerste Kamer heeft op 27 mei 2003 ingestemd met de begroting. De Nederlandse Tweede Kamer heeft op 3 juni 2003 ingestemd. (Bron: Europees Bureau Eerste Kamer; www.europapoort.nl)

426. Zie met betrekking tot de Raad van Bestuur van Europol subsectie 4.1.4.

427. Of deze verwachting uit is gekomen, is in januari 2004 nog niet bekend. Zie www.europol.eu.int. 


\subsubsection{Toezicht op werkzaamheden Europol}

Europol legt vetantwoording af aan de Raad van Ministers van Justitie en Binnenlandse Zaken. De Raad is verantwoordelijk voor de begeleiding van en het toezicht op Europol. De Raad benoemt, zoals gezegd, de directeur en de adjunct-directeuren. Verder keurt de Raad de begroting goed. De Raad van Ministers is samengesteld uit vertegenwoordigers uit alle lidstaten. Voor besluiten door de Raad van Ministers is eenparigheid vereist. De eenparigheid van stemmen bij besluiten draagt bij tot een democratische controle van Europol. De Raad van Bestuur van Europol telt één afgevaardigde per lidstaat van de EU en is belast met het algemene toezicht op de werkzaamheden van de organisatic. $\mathrm{Zij}$ heeft een controlerende en sturende rol (art. 28 EO). De Raad van Bestuur heeft beheerstaken en bereide de vergaderingen van de Raad van Ministers voor.

Europol dient op basis van artikel 34 EO jaarlijks ter verantwoording ook een verslag an het Europees Parlement toe te zenden.

Een zogenoemd gemeenschappelijk controleorgaan met twee deskundigen per lidstaat op het gebied van de bescherming van gegevens, houdt toezicht op de inhoud en aanwending van alle door Europol beheerde persoonsgegevens op grond van artikel 24 EO. Op 17 oktober 2000 heeft de Raad zijn goedkeuring gehecht aan een besluit tot oprichting van een secretariaat ten behoeve van de gemeenschappelijke controleorganen voor gegevensbescherming. ${ }^{428}$ In het Nederlandse stelsel dient vóór verstrekking aan het buitenland en dus ook vóór verstrekking aan Europol van CIE-gegevens toestemming te worden gegeven door de Officier van Justitie. Dit is een vorm van controle vooraf. Een nationaal controleorgaan (in Nederland het CBP) ziet toe op de rechtmatige verstrekking van gegevens aan Europol door de nationale eenheden en verbindingsofficieren (art. $23 \mathrm{EO})$.

Uiteindelijk valt de informatie-uitwisseling in het kader van Europol natuurlijk ook onder de justitiële controle van de nationale rechter in een concrete strafzaak waarin informatie-uitwisseling via Europol heeft plaatsgevonden.

\subsection{Informatie-uitwisseling in het kader van Europol}

In deze sectie behandelen wij eerst de juridische structuur van de informatie-uitwisseling in het kader van Europol (subsectie 8.2.1). Daarna gaan we in op het gegevensbeschermingskader van Europol (subsectie 8.2.2) en de bescherming bij informatieverwerking (subsectie 8.2.3). 


\subsubsection{De juridische structuur van informatie-uitwisseling}

De informatic-uitwisseling in het kader van Europol (de informatiestroom van en naar Europol) mag op grond van artikel 4 lid 2 EO alleen plaatsvinden via door elke lidstaat daarvoor aangewezen nationale eenheden. Deze eenheden dienen het enige contact te zijn tussen Europol en de bevoegde autoriteiten van de lidstaten. In Nederland is de Dienst Internationale Netwerken (DIN) van het KLPD de aangewezen nationale eenheid. De betrekkingen tussen de nationale eenheid en de bevoegde autoriteiten worden beheerst door het nationale recht. Op grond van artikel 4 lid $3 \mathrm{EO}$ dienen de lidstaten wel alle nodige maatregelen te treffen om ervoor te zorgen dat hun nationale eenheid haar taken kan uirvoeren en in het bijzonder om de toegang van deze eenheid tot de betrokken nationale gegevens te verzekeren. Dit laatste is natuurlijk heel belangrijk, omdat anders de door Europol in het kader van zijn mandaat benodigde informatie niet aan Europol kan worden bezorgd.

De werkzaamheden binnen Europol zijn nauwkeurig vastgelegd in de EO. Wij bespreken de belangrijkste werkzaamheden zoals die zijn vastgelegd in artikel 4, artikel 5, de artikelen 6 en 7 , artikel 8, en artikel 9 EO.

\section{Art. 4: nationale eenheden}

Ingevolge artikel 4 lid $4 \mathrm{EO}$ heeft de nationale eenheid de volgende taken.

1. Europol uit eigen beweging voorzien van informatie en inlichtingen die Europol nodig heeft voor zijn taakvervulling.

2. Het ingaan op verzoeken van Europol om informatie, inlichtingen en adviezen.

3. Het actualiseren van informatie en inlichtingen.

4. Informatie en inlichtingen overeenkomstig het nationale recht ten behoeve van de bevoegde autoriteiten evalueren en onder deze autoriteiten verspreiden.

5. Verzoeken om adviezen, informatie, inlichtingen en analyses aan Europol voor leggen.

6. Informatie voor invoering in de geautomatiseerde bestanden aan Europol verstrekken.

7. Zorgdragen voor de rechtmatigheid van elke uitwisseling van informatie met Europol.

De nationale eenheden verzorgen derhalve enerzijds de informatievoorziening ten behoeve van Europol (taken 1, 2, 3 en 6) en anderzijds die ten behoeve van de nationale autoriteiten. De rechtmatigheid van de informatie-uitwisseling dient te worden getoetst aan zowel de EO als aan het nationale recht van de betreffende nationale eenheid.

Alle bevoegde nationale diensten (zie hieromtrent subsectie 8.1.2) verstrekken informatie aan Europol via de nationale eenheid en ontvangen informatie van Europol eveneens via de nationale eenheid. De Officieren van Justitie van het zogeheten Landelijk Parket zijn in Nederland aangewezen als bevoegd nationaal gezag voor de bevoegde nationale diensten. Zij dienen voor alle politie- en justitiediensten in Nederland borg te staan dat de verstrekte informatic in ieder geval in Nederland rechtmatig is verkregen. 
Op grond van artikel 4 lid $5 \mathrm{EO}$ is een nationale eenheid in afzonderlijke gevallen niet verplicht de in lid 4, punten 1, 2 en 6, alsmede de in de artikelen 8 en 10 EO bedoelde informatic en inlichtingen te verstrekken indien:

1. wezenlijke nationale veiligheidsbelangen daardoor worden geschaad; of

2. het welslagen van lopende opsporingsonderzoeken of de veiligheid van een persoon daardoor in gevaar wordt gebracht; of

3. het informatic betreft die afkomstig is van specifieke inlichtingendiensten of -activiteiten op het gebied van de Staatsveiligheid.

Het betreft hier weigeringsgronden die ervoor zorgen dat er geen vrees behoeft te bestaan dat nationale onderzoeksbelangen door de informatie-uitwisseling via Europol geschaad worden.

Op grond van artikel 4 lid $6 \mathrm{EO}$ zijn de kosten die de nationale eenheid maakt voor communicatie met Europol nationale kosten en mogen zij met uitzondering van de verbindingskosten niet aan Europol worden doorberekend.

Door middel van de informatie-uitwisseling via Europol kan eventueel informatie afkomstig van her buitenland worden gebruikt in een nationaal onderzoek. In dat geval kan later de verstrekkende lidstaat benaderd worden om de verstrekte informatie door middel van getuigenverklaringen of schriftelijke bewijsstukken in bruikbaar bewijs om te zetten. De noodzaak hiervan is gelegen in de artikelen 31 en 32 EO. Op basis van deze artikelen kunnen de organen en het personeel van Europol zich namelijk beroepen op geheimhouding.

\section{Art. 5: verbindingsofficieren}

De informatie-uitwisseling van de nationale eenheden met Europol geschiedt via door de lidstaten afgevaardigde verbindingsofficieren op grond van artikel $5 \mathrm{EO}$. Zij zijn, behoudens bijzondere bepalingen van de EO, onderworpen aan het nationale recht van de afvaardigende lidstaat. De verbindingsofficieren behartigen binnen Europol de belangen van hun nationale eenheid. Zij geven (1) informatie van hun nationale eenheid aan Europol door, (2) de van Europol afkomstige informatic aan hun nationale eenheid door en (3) werken samen met de Europolambtenaren door middel van het doorgeven van informatie en het geven van advies bij de analyse van de informatie die de afvaardigende lidstaat aangaat. $\mathrm{Zij}$ hebben daartoe toegang tot diverse bestanden, voor zover dat voor hun taakvervulling nodig is.

\section{Art. 6 en 7: geautomatiseerde gegevensbestanden en aanleggen informatiesysteem}

In de artikelen 6 en 7 Europol-overeenkomst is vastgelegd dat Europol een geautomatiseerd systeem dient op te zetten en te onderhouden voor het inbrengen, opvragen en analyseren van gegevens. Europol beheert geautomatiseerde gegevensbestanden, die uit 
de volgende bestanddelen bestaan: (1) een informatiesysteem met cen beperkte, nauwkeurig vastgelegde inhoud waarmee snel kan worden nagegaan welke gegevens bij de lid. staten en bij Europol voorhanden zijn, (2) de in artikel 10 EO bedoelde werkbestanden met uitgebreide informatic, die zijn aangelegd voor een variabele tijd met het oog op analyse en (3) een indexsysteem dat uitsluitend elementen uit de werkbestanden met uitgebreide informatie bevat.

Op grond van artikel 6 lid 2 EO mogen de door Europol beheerde geautomatiseerde gegevensbestanden onder geen beding worden verbonden met andere systemen voor geautomatiseerde gegevensverwerking, met uitzondering van het systeem voor geautoma. tiseerde gegevensverwerking van de nationale eenheden. Een rechtstreekse verbinding met bijvoorbeeld PALMA/EMMI is dus op grond van deze bepaling uit den boze.

Om zijn taken te vervullen, dient door Europol een geautomatiseerd informatiesysteem aangelegd en beheerd te worden, waarin de lidstaten, vertegenwoordigd door de nationale eenheden en de verbindingsofficieren, met inachtneming van hun nationale procedures, rechtstreeks gegevens invoeren en Europol de door derde Staten en instanties verstrekte gegevens alsmede de uit analyses voortvloeiende gegevens invoert. Het informatiesysteem kan rechtstreeks worden geraadpleegd door de nationale eenheden, de verbindingsofficieren, de directeur, de adjunct-directeuren en de daartoe gemachtigde personeelsleden van Europol.

\section{Art. 8: inboud informatiesysteem}

De directe toegang van de nationale eenheden tot het informatiesysteem dient voor de in artikel 8 lid 1 punt 2 EO vermelde categorie van personen te worden beperkt tot de in artikel 8 lid 2 bedoelde persoonsgegevens (zie de volgende twee alinea's voor een precieze opsomming van de bedoelde personen en persoonsgegevens). Met andere woorden, de nationale eenheden mogen geen directe toegang hebben tot aanvullende gegevens (die zijn opgesomd in artikel 8 lid $3 \mathrm{EO}$ ) over de personen ten aanzien van wie bepaalde ernstige feiten gelet op het nationale recht het vermoeden rechtvaardigen dat zij een strafbaar feit zullen begaan ten aanzien waarvan Europol bevoegd is. Zij mogen alleen directe toegang hebben tot de basisgegevens over deze personen, die staan opgesomd in artikel 8 lid 2 EO. Op verzoek krijgen de nationale eenheden via de verbindingsofficieren toegang tot alle gegevens indien dat voor een bepaald onderzoek noodzakelijk is (art. 7 lid 1 EO). Europol dient het beheer van het informatiesysteem te verzekeren en is verantwoordelijk voor de goede werking van het informatiesysteem in technisch en operationeel opzicht (art. 7 lid 2 EO). In de lidstaten is de nationale eenheid verantwoordelijk voor de communicatie met het informatiesysteem op grond van artikel 7 lid 3 EO.

In het informatiesysteem van Europol mogen op grond van artikel 8 lid 1 EO uitsluitend worden opgeslagen, gewijzigd en gebruikt de voor de taakvervulling van Europol beno- 
digde gegevens, met uitzondering van de gegevens betreffende samenhangende strafbare feiten, met betrekking tot:

1. personen die, gelet op het nationale recht van de betrokken lidstaat, verdacht worden van het plegen van of deelnemen aan een strafbaar feit ten aanzien waarvan Europol bevoegd is, of die veroordeeld zijn voor een dergelijk strafbaar feit;

2. personen ten aanzien van wie bepaalde ernstige feiten gelet op het nationale recht het vermoeden rechtvaardigen dat zij een strafbaar feit zullen begaan ten aanzien waarvan Europol bevoegd is.

De gegevens over de onder 1 en 2 bedoelde personen mogen op grond van artikel 8 lid 2 slechts betrekking hebben op:

1. achternaam, meisjesnaam, voornamen en eventuele bijnamen of valse namen;

2. geboortedatum en -plaats;

3. nationaliteit;

4. geslacht;

5. voor zover nodig, andere voor identificering geschikte kenmerken, in het bijzonder niet aan verandering onderhevige objectieve lichamelijke kenmerken.

Er mag in het informatiesysteem verder melding worden gemaakt van Europol of de nationale eenheid die de gegevens heeft ingevoerd. Op grond van artikel 8 lid 3 EO mogen met betrekking tot de in art 8 lid 1 EO bedoelde personen ook de volgende bijkomende gegevens in het informatiesysteem worden opgeslagen, gewijzigd en gebruikt: 1. strafbare feiten, belastende feiten, tijd en plaats van het strafbare feit;

2. middelen waarmee het strafbare feit (vermoedelijk) is begaan;

3. de diensten die het dossier hebben aangelegd en de dossiernummers;

4. de verdenking deel uit te maken van een misdaadorganisatie;

5. veroordelingen, voor zover deze betrekking hebben op strafbare feiten ten aanzien waarvan Europol bevoegd is.

Deze gegevens mogen ook worden ingevoerd wanneer er nog geen verband met een bepaalde persoon wordt gelegd. Indien Europol de gegevens zelf invoert, dient het aan het dossiernummer een extra aantekening toe te voegen om aan te geven of de gegevens door derden zijn verstrekt dan wel het resultaat zijn van een eigen analyse.

De door de nationale eenheden en door Europol verkregen aanvullende informatie over de in artikel 8 lid 1 EO bedoelde personen kan op verzoek worden verstrekt aan elke nationale eenheid en aan Europol. Wat de nationale eenheden betreft, geschiedt dit met inachtneming van hun nationale recht. Indien deze aanvullende informatie betrekking heeft op een of meer samenhangende strafbare feiten worden de in het informatiesysteem opgeslagen gegevens voorzien van een aantekening om het bestaan van samenhangende strafbare feiten te signaleren, opdat de nationale eenheden en Europol de informatie over 
de daarmee samenhangende strafbare feiten kunnen uitwisselen (art. 8 lid 4 EO). Wanneer een procedure tegen de betrokkene definitief wordt beëindigd of wanneer de betrokkene wordt vrijgesproken, dienen alle gegevens die op deze beslissing betrekking hadden, te worden verwijderd op grond van artikel 8 lid 5 EO.

\section{Art. 9: recht van toegang tot informatiesysteem}

Op grond van artikel 9 lid 1 EO hebben alleen de nationale eenheden, de verbindingsofficieren, de directeur, de adjunct-directeuren en de daartoe gemachtigde personeelsieden van Europol het recht om rechtstreeks gegevens in het informatiesysteem van Europol in te voeren en daaruit op te vragen. Het opvragen van gegevens is toegestaan voor zover dit noodzakelijk is voor de vervulling van een bepaalde taak en vindt plaats in overeenstem. ming met de wettelijke en bestuursrechtelijke bepalingen en procedures van de opvragende eenheid, voor zover de $\mathrm{EO}$ geen stringentere bepalingen bevat.

Ingevolge artikel 9 lid $2 \mathrm{EO}$ is alleen de eenheid die de gegevens heeft ingevoerd, bevoegd om deze te wijzigen, te verbeteren of te verwijderen. Indien een eenheid aanwij. zingen heeft dat de in artikel 8 lid 2 EO bedoelde gegevens (de basisgegevens; zie hierboven) onjuist zijn of indien zij deze gegevens wil aanvullen, dient zij dit onverwijld mee te delen aan de invoerende eenheid, die dan vervolgens de plicht heeft om deze mededeling onmiddellijk te toetsen en om de gegevens indien nodig onmiddellijk te wijzigen, aan te vullen, te verbeteren of te verwijderen. Indien in artikel 8 lid 3 EO bedoelde gegevens over personen (de aanvullende gegevens; zie hierboven) zijn opgeslagen, kan elke eenheid nadere gegevens als bedoeld in artikel 8 lid 3 bij wijze van aanvulling invoeren. Indien deze gegevens elkaar duidelijk tegenspreken, dienen de betrokken eenheden overleg te plegen. Indien een eenheid voornemens is de door haar ingevoerde persoonsgegevens als bedoeld in artikel 8 lid 2 volledig te verwijderen en indien er door andere eenheden met betrekking tot deze persoon gegevens als bedoeld in artikel 8 lid 3 zijn ingevoerd, gaan de wettelijke aansprakelijkheid voor de gegevensbescherming als bedoeld in artikel 15 lid $1 \mathrm{EO}$ en het recht om gegevens te wijzigen, aan te vullen, te verbeteren en te verwijderen als bedoeld in artikel 8 lid 2 over op de eenheid die als eerstvolgende gegevens over deze persoon als bedoeld in artikel 8 lid 3 heeft ingevoerd. De eenheid die gegevens wil verwijderen, dient de eenheid die de wettelijke aansprakelijkheid voor de gegevensbescherming overneemt, daarvan in kennis te stellen.

Op grond van artikel 9 lid 3 EO ligt de verantwoordelijkheid voor de rechtmatigheid van het opvragen uit en het invoeren en wijzigen van gegevens in het informatiesysteem van Europol bij de eenheid die de gegevens opvraagt, invoert of wijzigt. Er dient te kunnen worden vastgesteld welke eenheid deze handeling verricht. De uitwisseling van informatie tussen de nationale eenheden en de bevoegde autoriteiten van de lidstaten vindt plaats overeenkomst het nationale recht. 


\subsubsection{Gegevensbescherming in bet kader van Europol}

De Europol-overeenkomst geeft strikte regels voor de bescherming van de mensenrechten, waronder strikte regels voor het omgaan met gegevens. Verder zijn er specifieke regels voor controle en toezicht en voor de beveiliging van de gegevens. Wij bespreken in deze subsectie de belangrijkste bepalingen terzake, te weten artikel 10, artikel 11, artikel 12, en artikel 24 EO.

Art. 10: verzameling, verwerking en gebruik van persoonsgegevens

Art. 10 EO ziet op de verzameling, de verwerking en het gebruik van persoonsgegevens in het kader van Europol. Voor zover dit noodzakelijk is voor de verwezenlijking van de doelstelling van Europol mag Europol, naast niet-persoonsgebonden gegevens, in andere bestanden gegevens opslaan, wijzigen en gebruiken in verband met strafbare feiten ten anzien waarvan Europol bevoegd is, met inbegrip van de gegevens betreffende de zogenoemde samenhangende strafbare feiten ten behoeve van specifieke analysewerkzaamheden. Deze gegevens hebben betrekking op:

1. personen als bedoeld in artikel 8 lid 1 (zie subsectie 8.2.1);

2. personen die wellicht als getuige moeten optreden bij onderzocken naar de betrokken strafbare feiten of bij daaropvolgende strafvervolgingen;

3. personen die het slachtoffer zijn geworden van een van de betrokken strafbare feiten of ten aanzien van wie zich bepaalde omstandigheden voordoen die doen vermoeden dat zij het slachtoffer van een dergelijk strafbaar feit kunnen worden;

4. contact- en begeleidende personen; alsmede

5. personen die informatie kunnen verschaffen over de betrokken strafbare feiten.

Het verzamelen, de verwerking en de opslag (als verbijzondering van gebruik) van de gegevens betreffende ras, politieke overtuiging, godsdienstige of andere levensbeschouwingen, gezondheid, seksueel gedrag en strafrechtelijke veroordelingen is slechts toegestaan voor zover dit absoluut noodzakelijk is voor het met het betrokken bestand beoogde doel en voor zover deze gegevens een aanvulling vormen op andere in hetzelfde bestand opgeslagen persoonsgegevens. Het is verboden om in strijd met bovengenoemde voorwaarden een specifieke categorie personen te selecteren uitsluitend aan de hand van de genoemde gegevens.

De bestanden met persoonsgegevens worden aangelegd voor analysedoeleinden omschreven als het compileren, verwerken of gebruiken van gegevens ter ondersteuning van het strafrechtelijk onderzoek. Voor elk analyseproject dient op grond van artikel 10 lid 2 EO een analysegroep ingesteld te worden waarin de volgende deelnemers overeenkomstig de omschreven taken en opdrachten nauw met elkaar samenwerken:

1. de door de directie van Europol aangewezen analisten en andere personeelsleden van Europol (uitsluitend de analisten zijn gemachtigd in het betrokken bestand gegevens in te voeren en op te zoeken); en 
2. de verbindingsofficieren of de deskundigen van de lidstaten die de informatie hebben verstrekt of die als partij bij de analyse betrokken zijn.

Op grond van artikel 10 lid 3 EO verstrekken de lidstaten de betreffende persoonsgegevens slechts wanneer zij ook volgens het desbetreffende nationale recht verwerkt mogen worden met het oog op het voorkomen, bestrijden of analyseren van strafbare feiten. Afhankelijk van de mate van gevoeligheid, kunnen de van de nationale eenheden afkomstige gegevens rechtstreeks en met alle passende middelen, al dan niet via de betrokken verbindingsofficieren, aan de analysegroepen worden verstrekt.

Indien Europol in het kader van andere overeenkomsten het recht heeft verkregen om andere informatiesystemen geautomatiseerd te raadplegen, kan Europol op deze wijze persoonsgegevens opzoeken indien dat noodzakelijk is voor zijn taakvervulling inzake het verzamelen, compileren en analyseren van informatie en inlichtingen (art. 10 lid 5 EO).

Indien het om een algemene strategische analyse gaat, krijgen alle lidstaten via verbindingsofficieren of deskundigen het volledige resultaat van de werkzaamheden, in het bijzonder door toezending van de door Europol opgestelde verslagen (art. 10 lid 6 EO).

Indien de analyse betrekking heeft op bijzondere gevallen die niet alle lidstaten aangaan en een rechtstreekse operationele bedoeling heeft, nemen op grond van artikel 10 lid 7 EO de vertegenwoordigers van de volgende lidstaten daaraan deel:

1. de lidstaten van wie de informatie afkomstig is die geleid heeft tot het besluit om het analysebestand aan te leggen of die daarbij rechtstreeks betrokken zijn, alsmede de lidstaten welke de analysegroep in een later stadium uitnodigt mee te werken omdat zij eveneens daarbij betrokken raken;

2. de lidstaten die op grond van raadpleging van het (hierna te behandelen) indexsysteem weten dat zij kennis moeten kunnen nemen van bedoelde gegevens en die dit overeenkomstig de voorwaarden van artikel 10 lid 7 EO hebben medegedeeld.

Overeenkomstig artikel 10 lid $8 \mathrm{EO}$ kan de lidstaat die informatie verstrekt aan Europol, als enige oordelen over de mate van en de verandering in de gevoeligheid van die informatie. Over elke verstrekking en elk operationeel gebruik van analysegegevens dient tussen de deelnemers aan de analyse overleg plaats te vinden. Elke lidstaat die als deelnemer wordt ingeschakeld bij een analyse die al gaande is, mag de gegevens niet verspreiden of gebruiken zonder voorafgaande toestemming van de lidstaten die reeds daarbij betrokken waren. 


\section{Ant. 11: indexsysteem}

Op grond van artikel 11 EO dient Europol van de overeenkomstig artikel 10 lid 1 in bestanden opgeslagen gegevens een indexsysteem aan te leggen. De directeur, de adjunctdirecteuren en de gemachtigde personeelsleden van Europol alsmede de verbindingsoffcieren zijn bevoegd het indexsysteem te raadplegen. Uit het indexsysteem moet de raadplegende verbindingsofficier, aan de hand van de geraadpleegde gegevens, duidelijk kunnen opmaken of in de in artikel 6 lid 1 punt 2 en artikel 10 lid 1 EO bedoelde bestanden (dus in werkbestanden met uitgebreide informatic, die zijn aangelegd voor een variabele tijd met het oog op analyse) gegevens zijn opgeslagen die van belang zijn voor de lidstaat die hem of haar heeft afgevaardigd.

De toegang tot het indexsysteem is zodanig geregeld dat de verbindingsofficieren kunnen vaststellen of bepaalde gegevens al dan niet opgeslagen zijn. Er mogen geen verbanden worden gelegd of conclusies getrokken kunnen worden met betrekking tot de inhoud van de bestanden.

\section{Ant. 12: bestandsreglement}

Overeenkomstig artikel 12 EO dient Europol voor elk bij Europol voor zijn taakvervulling overeenkomstig artikel $10 \mathrm{EO}$ bijgehouden geautomatiseerd bestand met persoonsgegevens in een door de Raad van Bestuur van Europol goedgekeurd reglement het volgende vast te leggen: (1) de omschrijving van het bestand; (2) het doel van het bestand; (3) de categorieën personen over wie gegevens worden opgeslagen; (4) de aard van de gegevens die worden opgeslagen en eventueel de absoluut noodzakelijke gegevens betreffende ras, politieke overtuiging, godsdienstige of andere levensbeschouwingen, gezondheid, seksueel gedrag en strafrechtelijke veroordelingen; (5) de aard van de persoonsgegevens die ertoe dienen om het bestand toegankelijk te maken; (6) het aanleveren of invoeren van de voor opslag bestemde gegevens; (7) de voorwaarden waaronder de in het bestand opgeslagen persoonsgegevens mogen worden verstrekt, aan welke ontvangers en volgens welke procedure; (8) de controletermijnen en de duur van de opslag; en (9) de vastlegging van de verstrekking.

\section{Art. 24: gemeenschappelijk controleorgaan}

Op grond van artikel $24 \mathrm{EO}$ is een gemeenschappelijk controleorgaan opgericht, dat bestaat uit afgevaardigden uit de nationale controleorganen (bijvoorbeeld in Nederland het (BP). Dit gemeenschappelijk controleorgaan dient door de directeur van Europol onmiddellijk op de hoogte te worden gebracht van het ontwerpreglement voor een dergelijk bestand en ontvangt het dossier, opdat het de opmerkingen die het noodzakelijk acht onder de aandacht van de Raad van Bestuur kan brengen. 


\subsubsection{Bescherming bij informatieverwerking}

In deze subsectie geven wij een aantal voorwaarden voor informatieverwerking in het kader van Europol. Zij zijn gebaseerd op artikel 16, artikel 17, artikel 19 en 20, artikel 21 , artikel 22, en artikel $25 \mathrm{EO}$. We vermelden tevens hoe het uiteindelijke computersysteem van Europol eruit zal zien.

\section{Voorwaarden op grond van artikel 16: vastlegging verstrekking}

Op grond van artikel 16 EO dient Europol gemiddeld ten minste elke tiende opvraging c.q. verstrekking van persoonsgegevens vast te leggen en elke opvraging van persoonsgegevens in het kader van het informatiesysteem als bedoeld in artikel $7 \mathrm{EO}$, om na te gaan of deze toelaatbaar is. De vastgelegde gegevens mogen alleen voor dit doel door Europol en de controleorganen voor de gegevensbescherming worden gebruikt en moeten na zes maanden worden verwijderd, tenzij zij in het kader van een lopende controle vereist blijven.

\section{Voorwaarden op grond van artikel 17: gebruik van de gegevens}

Persoonsgegevens die worden opgevraagd uit het informatiesysteem, het indexsysteem of de voor analysedoeleinden aangelegde bestanden en de gegevens die op enige andere passende wijze zijn meegedeeld mogen op grond van artikel 17 lid 1 EO door de bevoegde autoriteiten van de lidstaten slechts worden verstrekt en gebruikt ter voorkoming en bestrijding van de tot de bevoegdheid van Europol behorende criminaliteit en van andere ernstige vormen van criminaliteit. Het gebruik van deze gegevens geschiedt met inachtneming van het recht van de lidstaat waaronder de diensten die de gegevens gebruiken, ressorteren. Europol kan de gegevens alleen maar gebruiken met het oog op de vervulling zijn taken.

Indien de verstrekkende lidstaat voor afzonderlijke gegevens beperkingen voor het gebruik ervan meedeelt die voor deze gegevens in de betrokken lidstaat gelden, dienen deze beperkingen in beginsel ook door de gebruiker te worden nageleefd op grond van artikel 17 lid 2 EO.

Gegevens kunnen op grond van artikel 17 lid 3 EO slechts voor andere doeleinden of door andere dan de bevoegde nationale autoriteiten worden gebruikt na voorafgaande toestemming van de lidstaat die de gegevens heeft verstrekt en voor zover het nationale recht van deze lidstaat dat toelaat.

Voorwaarden op grond van artikel 19 en 20: kennisneming, verbetering en verwijdering Eenieder heeft recht op kennisneming van de bij Europol opgeslagen op hem of hasr betrekking hebbende gegevens volgens de procedure van artikel $19 \mathrm{EO}$, alsmede op verbetering en verwijdering van gegevens volgens de procedure van artikel $20 \mathrm{EO}$. 
Verwasanden op grond van artikel 21: opslag- en verwijderingstermijnen Op grond van artikel 21 lid 1 EO mogen gegevens niet langer bij Europol in bestanden worden opgeslagen dan voor de taakvervulling van Europol noodzakelijk is. Uiterlijk drie jaar na invoering dient de noodzaak van verdere bewaring getoetst te worden. Het toetsen en verwijderen van in het informatiesysteem opgeslagen gegevens geschiedt door de invoerende eenheid. Het toetsen en verwijderen van de in de overige bestanden bij Europol opgeslagen gegevens geschiedt door Europol. Europol dient de lidstaten drie maanden van tevoren automatisch in kennis te stellen van het aflopen van de termijn warbinnen de door hen ingevoerde gegevens moeten worden getoetst.

Bij de toetsing kunnen de invoerende eenheid en Europol besluiten de opslag van de gegevens te verlengen tot de volgende toetsing indien het opslaan voor de taakvervulling van Europol nodig blijft. Blijft een besluit over verdere opslag uit, dan worden de gegevens automatisch verwijderd (art. 21 lid 2 EO).

Het opslaan van de persoonsgegevens in verband met strafbare feiten ten aanzien waarvan Europol bevoegd is, met inbegrip van de gegevens betreffende de zogenoemde samenhangende strafbare feiten ten behoeve van specifieke analysewerkzaamheden, welke gegevens betrekking hebben op personen als bedoeld in artikel 8 lid 1 EO (zie subsectie 8.2.1) mag in totaal niet langer dan drie jaar duren (art. 21 lid 3 EO). Deze termijn begint telkens opnieuw op de dag dat een feit plaatsvindt dat aanleiding geeft tot het opslaan van gegevens over de betrokkene. Jaarlijks wordt getoetst of verdere opslag nodig is. Deze toetsing dient schriftelijk te worden vastgelegd.

Wanneer een lidstaat uit zijn nationale bestanden gegevens verwijdert die aan Europol zijn verstrekt en die in de overige bestanden van Europol opgeslagen zijn, dient hij dit aan Europol mee te delen op grond van artikel 21 lid 4 EO. In dit geval verwijdert Europol de gegevens, tenzij Europol verder belang hecht aan deze gegevens op grond van uitvoeriger informatie over de betrokkene dan de verstrekkende lidstaat bezit. Europol stelt de betrokken lidstaat in kennis van de voortgezette opslag van deze gegevens.

Op grond van artikel 21 lid 5 EO mag niet tot verwijdering worden overgegaan indien dit schade zou berokkenen aan de gerechtvaardigde belangen van de betrokkene. In dat geval mogen de gegevens alleen nog worden gebruikt met toestemming van de betrokkene.

\section{Voorwaarden op grond van artikel 22: bewaren en verbeteren gegevens in dossiers} Indien blijkt dat een geheel dossier of gegevens in dit dossier van Europol niet meer nodig zijn voor de taakvervulling van Europol, of indien deze inlichtingen in hun geheel strijdig zijn met de bepalingen van de EO, moeten het dossier of de betrokken gegevens worden vernietigd op grond van artikel 22 lid $1 \mathrm{EO}$. Zolang het dossier of de betrokken gegevens niet daadwerkelijk zijn vernietigd, moet een aantekening worden aangebracht 
waaruit blijkt dat dit dossier of deze gegevens niet mogen worden gebruikt. Een dossier mag niet worden vernietigd indien er redenen zijn om aan te nemen dat de gerechtvaardigde belangen van de betrokkene daardoor zouden worden geschaad. In dat geval moet dezelfde aantekening worden gemaakt waaruit blijkt dat dit dossier niet mag worden gebruikt.

Indien blijkt dat gegevens in dossiers van Europol onjuistheden bevatten, dient Europol deze gegevens te verbeteren (art. 22 lid 2 EO). Elke bij een dossier van Europol betrokken persoon kan jegens Europol een recht op verbetering, de vernietiging van het dossiet, of het opnemen van een aantekening uitoefenen op grond van artikel 22 lid 3 EO.

\section{Voorwaarden op grond van artikel 25: gegevensbeveiliging}

Art. 25 EO ziet op de beveiliging van de gegevens in het kader van Europol. Op grond van het eerste lid dient Europol de technische en organisatorische maatregelen te treffen die nodig zijn om de tenuitvoerlegging van de EO te waarborgen. Maatregelen zijn slechts dan nodig als de kosten ervan in verhouding tot het doel van de bescherming staan. Het tweede lid eist dat elke lidstaat en Europol met het oog op de geautomatiseerde verwerking van gegevens door Europol passende maatregelen treffen om:

1. te verhinderen dat onbevoegden toegang krijgen tot installaties voor de verwerking van persoonsgegevens (controle op de toegang tot de installatie);

2. te verhinderen dat onbevoegden de gegevensdragers lezen, kopiëren, wijzigen of meenemen (controle op de gegevensdragers);

3. te verhinderen dat onbevoegden gegevens in het bestand invoeren of opgeslagen persoonsgegevens lezen, wijzigen of verwijderen (opslagcontrole);

4. te verhinderen dat onbevoegden de systemen voor geautomatiseerde gegevensverwerking gebruiken met behulp van datatransmissieapparatuur (gebruikscontrole);

5. te waarborgen dat diegenen die bevoegd zijn tot het gebruik van een systeem voor geautomatiseerde gegevensverwerking uitsluitend toegang krijgen tot de gegevens waarvoor hun recht van toegang geldt (toegangscontrole);

6. te waarborgen dat kan worden nagegaan en vastgesteld aan welke eenheden persoonsgegevens met behulp van datatransmissieapparatuur verstrekt kunnen worden (transmissiecontrole);

7. te waarborgen dat achteraf kan worden nagegaan en vastgesteld welke persoonsgegevens in de systemen voor geautomatiseerde gegevensverwerking zijn ingevoerd, alsook wanneer en door wie de gegevens zijn ingevoerd (invoercontrole);

8. te verhinderen dat bij de overdracht van persoonsgegevens of bij het vervoer van gegevensdragers onbevoegden gegevens lezen, kopiëren, wijzigen of verwijderen (transportcontrole);

9. te waarborgen dat de gebruikte systemen in geval van storing onverwijld opnieuw ingezet kunnen worden (herstel); en 
10.te warborgen dat de functies van het systeem foutloos verlopen, dat eventuele functionele storingen onmiddellijk gesignaleerd worden (betrouwbaarheid) en dat opgeslagen gegevens niet door verkeerd functioneren van het systeem vervalst kunnen worden (echtheid).

\section{Het witeindelijke systeem}

Het feitelijke Europol Computersysteem heet TECS (The Europol Computer System). Het zal uiteindelijk bestaan uit drie hoofdbestanddelen:

- een informatiesysteem;

- een analysesysteem; en

- een indexsysteem.

De analyse- en indexsystemen zijn reeds gereed. Een voorlopige versie van het informatiesysteem is op 1 januari 2002 operationeel geworden. Er zullen geavanceerdere versies volgen, die uiteindelijk alle (momenteel vijftien) lidstaten met elkaar zullen verbinden en toegang tot het systeem in alle officiële talen van de EU zullen bieden.

\subsection{Conclusies Europol versus IRC's}

In deze sectie beantwoorden wij de derde aanvullende onderzoeksvraag van deze studie. Wij doen dit in de vorm van de belangrijkste conclusies van dit hoofdstuk.

De derde aanvullende onderzoeksvraag luidde: "Waar liggen de juridische grenzen tussen de werkzaamheden van Europol en de werkzaamheden van de IRC's?" De werkzaamheden van de IRC's voorzien in een nieuwe 'samenwerkingsmarkt' voor informatie-uitwisseling in grensregio's van de EU. Het gaat daarbij om de behoefte aan snelle grensoverschrijdende informatie-uitwisseling voor het 'gewone' politiewerk, zijnde voornamelijk ordehandhaving, verkeerstoezicht en de zogenoemde kleinere criminaliteit. ${ }^{429}$ Het internationale gegevensuitwisselingsnetwerk EMMI wordt hiervoor thans gebruikt door twintig (grensregionale) politiekorpsen in vier landen: Nederland, België, Duitsland en Frankrijk. De grensregionale politiële gegevensuitwisseling geschiedt binnen de juridische grenzen van internationale wet- en regelgeving en convenanten, die onder bepaalde voorwaarden rechtstreekse gegevensuitwisseling tussen de IRC's van de verschillende landen mogelijk maken.

Europol is een Europees orgaan voor de veredeling en uitwisseling van gegevens die een bijdrage kunnen leveren aan het voorkomen en bestrijden van bepaalde vormen van grensoverschrijdende georganiseerde criminaliteit. De informatie-uitwisseling verloopt nationaal op centraal niveau via de nationale eenheden en verbindingsofficieren bij 
Europol. Europol is bevoegd tot ondersteuning van in het Europolmandaat bepaalde rechtshandhavingsactiviteiten indien een georganiseerde criminele structuur bestaat en twee of meer EU-lidstaten betrokken staten zijn.

Op grond van het internationaal juridisch verankerde beginsel dat de registraties van de IRC's geen nieuwe zelfstandige bron van informatie mogen vormen, mogen de gegevens die in de lokale registratiedatabase en de centrale logdatabase van PALMA zijn opgeslagen, niet gebruikt worden voor de veredeling of uitwisseling van gegevens via Europol. Er dient voor die veredeling of uitwisseling teruggegrepen te worden op de (geüpdate) gegevens uit de oorspronkelijke registraties. De gegevens uit de PALMA-databases kunnen immers verouderd zijn en daardoor niet meer betrouwbaar. De gegevens uit de wettelijk verplichte registratie in de PALMA-databases kunnen dus ook niet gebruikt worden voor operationele misdaadanalyses binnen of buiten Europol. Hetzelfde geldt voor de gegevens die opgeslagen worden bij de infodesks van de regiopolitie, voor zover die gegevens niet afkomstig zijn uit de oorspronkelijke registraties.

Een koppeling tussen de EMMI/PALMA-omgeving en Europol is op grond van artikel 6 lid 2 EO eveneens niet toegestaan.

De Europese Raad en de Raad van Ministers van de EU dienen onzes inziens te bevorderen dat Europol en de IRC's op de hoogte zijn van elkaars werkzaamheden, van de raakvlakken van hun werkzaamheden en van de juridische grenzen tussen beide instanties. ${ }^{40}$

430. IKAT heeft reeds bijgedragen aan deze kennisverspreiding door de organisatie van nationale en internationale workshops, bijvoorbeeld de conferentic Police and Intranet. Universiteit Leiden, Poortgebouw Leiden, 24 september 1999 (in samenwerking met het E.M. Meijers Instituut van de Universiteit Leiden). Hier waren nagenocg alle IRC's alsmede Europol vertegenwoordigd. Bij de Europese Raad blijkt overigens de kennis omtrent de werkzaamheden van de IRC's nog niet erg groot te zijn. 


\section{Conclusies: de techniek aan juridische banden}

In dit hoofdstuk formuleren wij onze conclusies met betrekking tot de probleemstelling van dit onderzoek uit sectie 1.3, die luidde als volgt.

"Kan er een juridisch kader worden ontwikkeld dat een beveiligde koppeling tussen nationale politienetwerken mogelijk maakt in het kader van de Europese grensregionale informatieve samenwerking?"

Deze hoofdvraag is beantwoord in de hoofdstukken 5 en 6 . Wij geven onze conclusies terzake in de secties 9.1 aangaande de juridische mogelijkheden, 9.2 betreffende de juridische eisen, 9.3 met betrekking tot de technische mogelijkheden voor de juridische eisen, 9.4 omtrent de samenwerking van organisaties en 9.5 over de legitimiteit binnen de bestaande wet- en regelgeving.

Met betrekking tot onze probleemstelling hebben wij ook twee deelvragen geformuleerd in sectie 1.3.

De eerste deelvraag luidde:

"Voldoet de bestaande nationale en internationale wet-en regelgeving aan de voorwaarden die gesteld worden aan een adequate geautomatiseerde (multimediale) politiële gegevensuitwisseling?"

De conclusies met betrekking tot deze vraag formuleren wij in het bijzonder in sectie 9.1. Het gaat daarbij om de vraag (1) hoe het EMMI-concept ingepast kan worden binnen de bestaande wet- en regelgeving, en (2) op welke gebieden nadere regulering noodzakelijk is, wil het EMMI-concept zonder wettelijke belemmeringen geïmplementeerd kunnen worden in de Europese grensregio's. 
De tweede deelvraag luidde:

"Welke sechnische randvoorwaarden en juridische waarborgen zijn vereist voor de betrouwbaarheid van gebruik en gebruiker, als ook ten aanzien van de bescherming van de persoonlijke levenssfeer, in het bijzonder wanneer het om gevoelige (persoons)gegevens gaat?"

De conclusies met betrekking tot deze vraag formuleren wij in het bijzonder in sectie 9.6. In deze sectie bespreken wij de juridische randvoorwaarden voor een betrouwbaar gebruik van de EMMI-omgeving alsmede de beginselen van behoorlijk ICT-gebruik.

In sectie 9.7 formuleren wij onze conclusies met betrekking tot de eerste aanvullende onderzoeksvraag, in sectie 9.8 de conclusies met betrekking tot de tweede aanvullende onderzoeksvraag en in sectie 9.9 de conclusies met betrekking tot de derde aanvullende onderzoeksvraag. In de betreffende secties herhalen wij voor de overzichtelijkheid de aanvullende onderzoeksvragen. In sectie 9.10 formuleren wij onze persoonlijke visie op het gewenste juridische kader van de internationale informatieve politiesamenwerking tussen de grensregio's van Nederland, België en Duitsland. Sectie 9.11 bevat een concrete suggestie over de totstandbrenging van een EMMI-beheersorganisatic. In sectie 9.12 behandelen wij ten slotte standpunten pro en contra de invoering van een bevoegdheid tot directe geautomatiseerde grensoverschrijdende toegang tot registers door buitenlandse politicambtenaren.

\subsection{Juridische mogelijkheden voor gegevensuitwisseling}

Voor de Nederlandse grensregionale praktijk van de politiële gegevensuitwisseling bestaat een wettelijk kader dat wij hieronder kort samenvatten. Wij bespreken: rechtshulpverzoeken, spontane verstrekking, convenanten, de Schengen Handleiding en specifieke regelingen. In subsectic 9.1.1 besteden wij aandacht aan de koppeling (wel of niet toegestaan) en in subsectie 9.1.2 aan geautomatiseerde toegang.

\section{Rechtshulpverzoeken}

Wanneer er, in verband met een strafzaak, sprake is van rechtshulpverzoeken uit het buitenland waarbij slechts om inlichtingen wordt gevraagd en er voor het verkrijgen daarvan geen dwangmiddelen, bijzondere opsporingsbevoegdheden artikel $126 \mathrm{~g}$-126ua Sv), bijstand aan de opsporing door burgers (art. 126v-126z Sv), verkennend onderzoek (art. $126 \mathrm{gg} \mathrm{Sv}$ ) of doorlating (art. 126ff Sv) nodig zijn, dan is de politie bevoegd tot zelfstandige afdoening van dat verzoek (art. $552 i$ lid $2 \mathrm{~Sv}$ ). In de richtlijn inzake de toepassing van artikel $552 i \mathrm{~Sv}$ is vervolgens aangegeven in welke gevallen daarentegen doorzending van het verzoek aan het $\mathrm{OM}$ dient plaats te vinden. Als het gaat om verstrekking van 
gegevens uit een politieregister dan moet tevens voldaan zijn aan de voorwaarden van artikel 13 BPolr. ${ }^{431}$

\section{Spontane verstrekking}

Wanneer er sprake is van spontane verstrekking van gegevens uit een politieregister dient er te worden getoetst aan de voorwaarden van artikel 13 BPolr en aan de voorwaarden van de richtlijn inzake de toepassing van artikel $552 i$ Sv. Hoewel artikel 552i Sv slechts ziet op rechtshulpverzoeken kan volgens het College van Procureurs-Generaal ook spontane bijstand worden verleend, maar alleen onder dezelfde voorwaarden die gelden voor een rechtshulpverzock. Zowel bij een verstrekking van gegevens op verzoek als bij een spontane gegevensverstrekking dient een registratie te worden gevoerd conform artikel $552 i$ lid 3 Sv en artikel 126 lid 3 sub e SUO. De geciteerde zinsnede uit de richtlijn inzake de toepassing van artikel $552 i \mathrm{~Sv}$ houdt ook in dat voor de spontane verstrekking van inlichtingen die niet afkomstig zijn uit politieregisters de weigeringsgronden van het Wv $S_{v}$ van toepassing zijn. Verder geldt voor gegevens die niet afkomstig zijn uit een politieregister het 'open' regime van de Wbp. Wij merken nog op dat opsporingsambtenaren op grond van artikel $552 i$ lid 2 Sv onder omstandigheden bevoegd zijn om zonder tussenkomst van de RC personen te horen, hetgeen in de Euregionale praktijk ook gebeurt.

\section{Convenanten}

De grensoverschrijdende gegevensuitwisseling steunt verder op convenanten, een Schengen Handleiding en specifieke regelingen. Door middel van goedgekeurde convenanten, die gebaseerd zijn op modelconvenanten, zijn specifieke, afspraken gemaakt met België en Duitsland voor de samenwerking in de grensgebieden. Dit is in overeenstemming met artikel 39 lid 4 en artikel 46 lid 2 SUO en met artikel 13 lid 7 BPolr. Deze afspraken gaan in sommige gevallen verder dan de bepalingen van de SUO voorschrijven, hetgeen toegestaan is op grond van artikel 39 lid 5 SUO. Voor de positie van Nederland als verzoekende staat is vooral de nationale wetgeving van de door Nederland aangezochte staat bepalend. Er zijn verder ook een aantal Belgische en Duitse grensakkoorden en twee Benelux-grensakkoorden van kracht. Over koppeling van gegevens en systemen en over rechtstreekse geautomatiseerde toegang tot gegevens en computersystemen met betrekking tot de politiële rechtshulp bepalen de convenanten evenwel niets. 


\section{Schengen Handleiding}

Naast de convenanten bestaat er een Schengen Handleiding over de samenwerking en de politiële handhaving inzake de openbare orde en veiligheid van het Uitvoerend Comité van Schengen (dat op grond van het Verdrag van Amsterdam is vervangen door de Raad van de $\mathrm{EU})$.

\section{Specifieke regelingen}

In België en Duitsland zijn eveneens specifieke regelingen van toepassing op de internationale politiële gegevensuitwisseling. Het valt op dat in Duitsland is bepaald welke soorten gegevens met het buitenland uitgewisseld mogen worden. Dit geldt tevens voor Belgiè. Uit de Nederlandse regelingen blijkt niet duidelijk welke soorten van gegevens uitgewisseld mogen worden. Afhankelijk van de omstandigheden mogen, zoals het er staat, alle soorten gegevens aan het buitenland worden verstrekt. Verder valt op dat er in Belgiê en Duitsland in tegenstelling tot Nederland geen (duidelijke) wettelijke regimes bestaan voor het omgaan met 'zachte informatie'. Zodoende kan bijvoorbeeld informatie die niet operationeel gebruikt mag worden toch in een buitenlands zaaksdossier belanden. Hierover zullen nadere afspraken met het buitenland moeten worden gemaakt (zie sectie 9.7). Koppeling van gegevens is op grond van het Belgische recht in beginsel wel toegestaan, doch dient verder uitgekristalliseerd te worden. De bevoegdheid tot het koppelen van bestanden en systemen of tot het uitvoeren van een bestandsvergelijking, wordt in de Duitse wetgeving evenwel niet uitdrukkelijk gegeven en is derhalve in Duitsland niet toegestaan. Rechtstreekse geautomatiseerde toegang van buitenlandse politieambtenaren en het OM tot politieregisters is in België in beginsel wel toegestaan, doch onvoldoende wettelijk uitgekristalliseerd. Rechtstreekse geautomatiseerde toegang van buitenlandse opsporingsambtenaren is in het geheel niet geregeld. In Duitsland is rechtstreekse geautomatiseerde toegang van buitenlandse politieambtenaren en het OM verboden, want niet wettelijk toegestaan.

\subsubsection{Is koppeling verboden of toegestaan?}

Bij het ontwerpen van EMMI gingen de EMMI-partners ervan uit dat de Schengenwetgeving koppeling van de EMMI-omgeving aan de nationale politiële netwerken verbiedt. Deze zienswijze moet op grond van het onderhavige onderzoek enigszins bijgesteld worden. De SUO zegt niets specifieks over de koppeling van bestanden en systemen. De enige internationale regeling die hierover iets zegt, is de Aanbeveling R (87) 15 van de Raad van Europa. In deze aanbeveling zijn de basisbeginselen van het Databeschermingsverdrag nader uitgewerkt. De aanbeveling dient ook in het kader van de SUO te worden nageleefd. Zij dient als leidraad voor nationale wetgeving en zelfregulering. Het vijfde beginsel van de aanbeveling legt een normering aan voor de koppeling van bestanden en de directe toegang tot bestanden. Een bestand mag volgens dit beginsel met een ander bestand dat een ander doel dient, worden gekoppeld in éen van de twee volgende gevallen: 
1. de controleautoriteit voor de gegevensbescherming heeft in verband met een onderzoek naar een bepaald strafbaar feit een machtiging gegeven; of

2. de koppeling geschiedt op grond van een uitdrukkelijk wettelijk voorschrift.

Koppeling van bestanden is dus toegestaan als het volgens het nationale recht is toegestaan. In Nederland is de koppeling van gegevens geregeld in de WPolr en het BPolr voor gegevens uit een politieregister en aanvullend in de Wbp met betrekking tot andere persoonsgegevens. De Wbp hanteert niet de terminologie van 'koppeling', maar ziet koppeling als een vorm van 'verwerking' van persoonsgegevens en beschouwt een koppeling als een al dan niet onverenigbaar gebruik van de gegevens met de doeleinden waarvoor zij zijn verkregen. Hoewel de wetgever nog niet heeft stilgestaan bij allerlei nieuwe technieken voor de koppeling van gegevens, kan toch worden geconcludeerd dat die koppeling niet het grootste knelpunt voor de internationale uitwisseling van politiegegevens vormt. Koppeling van gegevens en systemen mag onder welbepaalde wettelijke voorwaarden van het land waar de koppeling geschiedt wel degelijk plaatsvinden.

\subsubsection{Geautomatiseerde toegang}

De cruciale juridische belemmering voor het fysiek koppelen van de EMMI-omgeving an de nationale politiële netwerken wordt gevormd door de nationale wettelijke regeling van de rechtstreekse geautomatiseerde toegang tot gegevens uit de nationale politieregisters.

Directe on-linetoegang tot een bestand mag volgens het vijfde beginsel van Aanbeveling $R$ (87) 15 slechts worden toegestaan in overeenstemming met een nationale wetgeving die de beginselen 1 tot en met 6 van Aanbeveling R (87) 15 respecteert. In Nederland is de rechtstreekse geautomatiseerde toegang tot gegevens conform de genoemde beginselen geregeld in artikel 17 BPolr. Uit artikel 17 lid 1 BPolr vloeit voort dat buitenlandse politieambtenaren alsook het Nederlandse OM geen rechtstreekse geautomatiseerde toegang mogen hebben tot gegevens uit een politieregister. Deze en soortgelijke regelingen in het buitenland dan wel het ontbreken van een regeling omtrent rechtstreekse geautomatiseerde toegang in het buitenland veroorzaken dat een fysieke koppeling van de EMMI-omgeving met de nationale politiële computernetwerken momenteel nog niet tot de mogelijkheden behoort. Aan het OM mogen ingevolge artikel 15 lid 1 sub a WPolr alleen incidenteel en op verzoek gegevens uit een politieregister worden verstrekt.

Wij kunnen concluderen dat de bestaande nationale en internationale wet- en regelgeving voldoet aan de voorwaarden die kunnen worden gesteld aan een adequate geautomatiseerde en multimediale gegevensuitwisseling. Het enige werkelijke knelpunt blijkt te liggen in de rechtstreekse geautomatiseerde toegang. Hierover zal de nationale en de internationale wetgever żich moeten uitspreken (zie nader sectie 9.7). De behoefte van de IRC's aan mogelijkheden voor directe toegang van buitenlandse politieambtenaren tot 
nationale databases is ingegeven door de toegenomen werkdruk van de IRC's sinds de effectuering van de politiële informatieve samenwerking in de grensgebieden. Voor de doorgifte van zogeheten bulkinformatie aan het buitenland is een juridische mogelijkheid tot rechtstreekse bevraging van nationale databases erg welkom. De werklast van de IRC-medewerkers bij het opzoeken in de nationale databases kan dan worden verminderd. Tevens zou een vierentwintiguursbevraging voor veel gevraagde gegevens mogelijk worden, met controle achteraf. Rechtstreekse geautomatiseerde toegang van buitenlandse politieambtenaren is juridisch echter alleen mogelijk - onder bepaalde juridische randvoorwaarden - voor databases die onder de Wbp vallen. In de Wbp zijn namelijk geen nadere voorwaarden genoemd voor internationale verstrekking aan politieambtenaren of andere personen. Een buitenlandse politieambtenaar wordt wat de verstrekking betreft uit een persoonsregistratic waarop de Wbp van toepassing is, gelijkgesteld aan een Nederlandse politieambtenaar. Politięle databases die onder de WPolr en het BPolr vallen, mogen daarentegen niet rechtstreeks langs geautomatiseerde weg door buitenlandse politieambtenaren worden benaderd.

\subsection{Juridische eisen aan gegevensuitwisseling}

De hoofdvraag die we vanuit juridisch oogpunt in dit onderzoek moeten beantwoorden, is of er een juridisch kader kan worden ontwikkeld dat een beveiligde koppeling tussen nationale politienetwerken mogelijk maakt. In de hoofdstukken 5 en 6 is een inventarisatie gemaakt van het bestaande juridisch kader. Dit normatieve kader blijkt echter nog niet te zijn ingericht op een fysieke koppeling van de EMMI-omgeving aan de nationale politiële databases. Het wederzijds bevragen van Euregionale multimediale politiële databases door politiediensten van verschillende landen is vooralsnog niet mogelijk binnen de bestaande nationale wetgeving. Buitenlandse politieambtenaren mogen volgens het nationale recht namelijk geen rechtstreekse geautomatiseerde toegang tot politieregisters hebben. Menselijke controle door de verstrekkende staat is vooralsnog een hard juridisch vereiste.

Er kan derhalve op dit moment niet tegemoet worden gekomen aan de wensen van bepaalde IRC-medewerkers om de volgende vier stappen geheel te automatiseren:

- het controleren van de aanvraag,

- het geven van toestemming,

- het zoeken van de informatic, en

- het autoriseren van het beschikbaar stellen van de informatie.

Deze stappen kunnen niet uit de automatiseringsketen worden gehaald, omdat, zoals gezegd, bij al deze stappen menselijke controle juridisch vereist is. Het automatiseringsproces kan derhalve niet minder omslachtig gemaakt worden. Hieronder bespreken wij in subsectie 9.2.1 de internationale juridische eisen en in subsectic 9.2.2 de internationale gegevensbeschermingsbepalingen. 


\subsubsection{Internationale juridiscbe eisen}

Een heel belangrijke juridische eis wordt gesteld in het cerste beginsel van Aanbeveling $\mathbf{R}$ (87) 15 van de Raad van Europa. De onafhankelijke controleautoriteiten voor de gegevensbescherming van Nederland, België en Duitsland - respectievelijk het CBP, de CBPL en de Datenschutzbeaufinagte - moeten telkens vooraf geraadpleegd worden wanneer de invoering van automatische verwerkingsmethoden juridische vragen opwerpt over de gegevensbescherming. Over de problematiek van de koppeling van gegevens en de rechtstreekse geautomatiseerde toegang zal dus overleg gevoerd moeten worden met de nationale controleautoriteiten.

Verder stelt vooral het vijfde beginsel van Aanbeveling R (87) 15 nog een aantal stringente eisen met betrekking tot de registratie van de internationale politiële gegevensuitwisseling. Deze eisen zijn nader uitgewerkt in de nationale wet- en regelgeving. Verzoeken tot het verstrekken van gegevens dienen in beginsel aan te geven wie de verzoekende instantie of persoon is, welke redenen deze voor het verzoek heeft en wat met de gegevens wordt beoogd. Voor zover mogelijk dient uiterlijk ten tijde van de verstrekking de deugdelijkheid van de gegevens te worden geverifieerd. Zo mogelijk dienen bij elke verstrekking van gegevens rechterlijke uitspraken en besluiten tot ontslag van rechtsvervolging te worden opgegeven. Tevens dienen gegevens die berusten op opinies of persoonlijke beoordelingen vóór de verstrekking aan de bron te worden gecontroleerd. Daarbij dient de mate van nauwkeurigheid en betrouwbaarheid van de gegevens te worden aangegeven. Wanneer wordt geconstateerd dat gegevens niet langer juist of up-to-date zijn, mogen zij niet worden verstrekt. Indien toch niet langer juiste of niet bijgewerkte gegevens verstrekt zijn, dient de verstrekkende instantie zovęel mogelijk alle ontvangers attent te maken op het feit dat de gegevens niet de juiste status hebben.

Een andere belangrijke eis van het vijfde beginsel is dat gegevens die verstrekt zijn aan buitenlandse instanties (of aan overheidslichamen en particulieren) voor geen ander doel gebruikt mogen worden dan aangegeven in het verzoek om inlichtingen. Gebruik van de gegevens voor andere doeleinden dient afhankelijk te worden gesteld van goedkeuring door de verstrekkende instantie. Dit wordt de eis van doelbinding of beperkt gebruik genoemd. Voor gevoelige gegevens over ras et cetera dient er een aanduiding omtrent de betrouwbaarheid van het gegeven te worden vermeld en de verstrekking ervan moet onvermijdelijk zijn (art. 13 lid 6 BPolr). Er moeten technische en organisatorische maatregelen worden getroffen om ongeautoriseerde verstrekkingen te voorkomen (op grond van bijvoorbeeld artikel 17 lid 4 BPolr en het achtste beginsel van Aanbeveling R (87) 15). Aan al deze eisen wordt in de praktijk van de grensregionale en Euregionale gegevensuitwisseling in de meeste gevallen al voldaan. 


\subsubsection{Internationale gegevensbeschermingsbepalingen}

Uitwisseling van gegevens in het kader van de politiele samenwerking is verder gebonden aan de gegevensbeschermingsartikelen 126 tot en met 130 SUO. Zo moet er in beginsel binnen de doeleinden van de artt. 39 en 46 SUO gebleven worden, behalve wanneer er voorafgaande toestemming is van de verstrekkende Schengenstaat. De Schengenstaat die de gegevens verstrekt, dient erop toe te zien dat de gegevens juist zijn. Wij hebben geconstateerd dat dit in de grensregionale en Euregionale politiële gegevensuitwisselingspraktijk inderdaad op deze wijze gebeurt.

Het is van groot praktisch belang dat niet alleen de volledig geautomatiseerde verwerking en verstrekking (art. $126 \mathrm{SUO}$ ) onder de Schengengegevensbescherming vallen maar ook de verwerking en verstrekking van persoonsgegevens uit niet-geautomatiseerde doch gestructureerde bestanden (art. 127 lid 1 SUO). Hiervoor geldt dezelfde regeling als voor persoonsgegevens die volledig geautomatiseerd worden verwerkt. Verder vallen onder de bescherming ook de verwerking en verstrekking waarbij losse (niet-geautomatiseerde) ongestructureerde persoonsgegevens worden gebruikt, die niet in een registratie zijn opgeslagen (art. 127 lid $2 \mathrm{SUO}$ ). Hierbij kan worden gedacht aan losse inlichtingen, een (robot)foto of een ad hoc opgestelde persoonsbeschrijving. Voor deze groep gegevens gelden dezelfde regels als voor de eerste twee genoemde groepen persoonsgegevens, met uitzondering van de registratieplicht en enkele aanvullende regels. Van de verstrekking en de ontvangst van losse gegevens dient aantekening te worden gehouden. Deze verplichting geldt niet indien, gelet op het gebruik van de gegevens, aantekening niet nodig is. Dit geldt in het bijzonder wanneer de gegevens niet of slechts kortstondig worden gebruikt.

De privacycommissies in de Schengenlanden zijn bevoegd om alle gegevensuitwisselingen te toetsen, zelfs als het gaat om een losse mededeling (de derde groep gegevens).

Bij spontane gegevensverstrekking op grond van artikel 46 SUO dient ingevolge artikel 129 SUO de ontvangende Schengenstaat de verstrekkende Schengenstaat desgevraagd te informeren over het gebruik van de verstrekte gegevens en het op grond daarvan bereikte resultaat. Een dergelijke terugkoppeling geschiedt in de praktijk meestal niet.

In beginsel moeten de gegevens ingevolge artikel 8 lid 2 van het Reglement IRP in ieder geval uit het register IRP worden verwijderd na afloop van het tiende jaar na het jaar van het desbetreffende politiële rechtshulpverzoek.

\subsection{Technische mogelijkheden voor juridische eisen}

De EMMI-omgeving heeft alles in zich om te voldoen aan de juridische eisen en randvoorwaarden die gesteld worden aan de informatieve politiesamenwerking. De beschikbare technische mogelijkheden zijn juridisch heel goed toepasbaar. EMMI heeft geleid tot een vereenvoudiging en vermindering van het aantal vereiste handelingen. De toe- 
gangs- en gegevensbeveiliging zijn geoptimaliseerd en er zijn geautomatiseerde autorisatieprocedures. Hierop is (achteraf) controle mogelijk. De telefoon en fax zijn niet langer doorlopend bezet, waardoor de bereikbaarheid van de IRC's is verbeterd. Ook het genereren van managementinformatie is aanzienlijk eenvoudiger geworden. De kwaliteit en de kwantiteit van de gegevensuitwisseling kunnen aldus worden beoordeeld.

Van de gegevens die via de multimediakiosk beschikbaar worden gesteld wordt geen registratie bijgehouden. Daarom mogen via de multimediakiosk geen persoonsgegevens worden verstuurd. Voor de publicatie van procedures en voorschriften, organogrammen et cetera met niet persoonsgebonden informatie is de multimediakiosk van EMMI cen geweldig hulpmiddel ten behoeve van de buitenlandse politiepartners. De kennis van elkaars regels en werkwijzen wordt hierdoor aanzienlijk verhoogd.

Ook voertuiggegevens en multimediale gegevens als plaatjes, foto's en videomateriaal zijn, als zij met een bepaalde persoon in verband kunnen worden gebracht, persoonsgegevens. Zij dienen dan ook via de PALMA-software en niet via de multimediakiosk te worden uitgewisseld. Hieronder bespreken wij in subsectie 9.3.1 de koppeling van gegevens en in subsectie 9.3.2 de rechtstreekse geautomatiseerde toegang.

\subsubsection{Koppeling van gegevens}

Bij een technische koppeling van gegevens is de vraag of er sprake is van persoonsgegevens afhankelijk van de fase waarin het dataminingproces verkeert. Het is aannemelijk dat er zowel in het begin van het proces (bij het verzamelen van gegevens voor het datawarehouse) als aan het eind van dit proces (bij het gebruiken van de gevonden kennis) veelal sprake zal zijn van persoonsgegevens.

De hoofdvraag die het onderzoek vanuit technisch oogpunt wil beantwoorden, is hoe koppeling van het EMMI-netwerk aan de nationale politiële netwerken dient plaats te vinden binnen de daarvoor geldende regels. Omdat het EMMI-concept generiek is, kan het goed ingepast worden binnen de bestaande wet- en regelgeving.

De EMMI-omgeving is een uitstekend hulpmiddel om de juridische eisen met betrekking tot de internationale politiële gegevensuitwisseling beter te kunnen naleven. De uitwisselingsprocedure is geformaliseerd en er is sprake van een uitgebreide geautomatiseerde registratie conform artikel $552 i$ lid 3 Sv. EMMI heeft verder bewezen dat het technisch mogelijk is een beveiligde koppeling tussen nationale politiële computernetwerken tot stand te brengen. Een technisch goed beveiligde koppeling is een absolute voorwaarde om in de nabije toekomst rechtstreekse toegang en koppeling juridisch toelaatbaar te kunnen achten. Wij concluderen echter dat de huidige stand van de techniek een informatie-uitwisseling mogelijk maakt die verder gaat dan momenteel juridisch is toegestaan. Belemmeringen zijn er dus slechts op het juridische vlak en niet op het vlak 
van de techniek. Wellicht is het nog wel een uitdaging voor de techniek om de letter van artikel 126 lid 3 sub e SUO alsmede artikel 5 van het modelconvenant in praktijk te brengen door een registratie te realiseren in het register waaruit de gegevens worden verstrekt en waarin zij worden opgenomen. Artikel $552 i$ lid 3 Sv loopt wat dit betreft uit de pas met artikel 126 lid 3 sub e SUO.

Bij normale bevragingen via de PALMA-formulieren wordt in verschillende gegevensbestanden informatie verzameld over bepaalde op voorhand bekende personen. Er is dan geen sprake van koppeling van bestanden in de juridische zin van de WPolr en het BPolr.

\subsubsection{Rechtstreekse geautomatiseerde toegang}

Het IRC vormt de waterscheiding (of firewall) tussen de binnenlandse en de buitenlandse politiele computernetwerken. Alleen IRC-medewerkers hebben toegang tot het eigen nationale politięle netwerk en het EMMI-netwerk. Gebruikers van het nationale netwerk hebben geen toegang tot het EMMI-netwerk. De IRC-medewerkers beoordelen in alle gevallen of de gevraagde gegevens geschikt zijn om naar het buitenland te worden verstuurd. Zij controleren ook de gegeven antwoorden. Reactieformulieren zijn in de eigen landstaal opgesteld. Dit verhoogt de transparantie van de gegevensuitwisseling.

Ter uitoefening van zijn controlefunctie kan het OM technisch gesproken rechtstreekse geautomatiseerde toegang worden verleend tot de registratiedatabase van PALMA. Juridisch is dit echter niet toegestaan. Feitelijk is er daarom voor het OM ook nog geen rechtstreekse toegang gerealiseerd tot de registratiedatabase. Een deugdelijke controle door het OM vereist echter onzes inziens, onder nader te bepalen randvoorwaarden, wel degelijk rechtstreekse geautomatiseerde toegang. De wetgever zal zich over dit juridische probleem moeten buigen. Feitelijk deugdelijke controle strijdt met de uit het wettelijk systeem af te leiden norm dat aan het OM geen rechtstreekse geautomatiseerde toegang mag worden verleend. Ter wille van een vlotte uitwisseling met de RCIE heeft deze wel rechtstreekse toegang gekregen tot de registratiedatabase. Dit is juridisch ook toegestaan.

On-linetoegang tot externe gegevensverzamelingen door IRC-medewerkers is voornamelijk gericht op het snel kunnen opvragen van gegevens over een bepaalde persoon of object. Omdat daarbij geen groepsgewijze bevraging plaatsvindt, is er ook dan geen sprake van koppeling in wettelijke zin. Als een on-lineverbinding echter zodanig is opgezet dat naast bevragingen op individuele basis ook selecties van meerdere personen in het externe bestand kunnen worden gemaakt, kunnen de geselecteerde gegevens eenvoudig (groepsgewijs) worden vergeleken met gegevens in andere bestanden. On-linetoegang tot externe bestanden maakt het aldus eenvoudig koppelingen in wettelijke zin uit te voeren. 


\subsection{Samenwerking van organisaties}

Door de implementatie van EMMI in Nederland, België en Duitsland kunnen de geconstateerde verschillen in organisatiestructuur en automatiseringsgraad van de betrokken politiepartners overbrugd worden.

Wij hebben geconstateerd dat de kennis van de regels op het gebied van de internationale gegevensuitwisseling niet groot is (zie subsectie 2.1.1). Het geĭnventariseerde juridische kader geeft de bij de internationale gegevensuitwisseling betrokken politieambtenaren inzicht in de mogelijkheden van internationale gegevensuitwisseling, zoals het direct aan elkaar doorgeven van bepaalde gegevens. Hoewel scholing onontbeetlijk blijft om het betrokken politiepersoneel vertrouwd te maken en houden met de toepasselijke juridische normen en eisen, is de volgende vaststelling geruststellend te noemen. De Schengenwetgeving voor een betrouwbare en privacywaarborgende gegevensuitwisseling is in de EMMI-omgeving geformaliseerd via het gebruik van vaste sjablonen en een uitgebreide Schengenconforme registratic. De betrokken politieambtenaren behoeven daarom niet precies op de hoogte te zijn van alle in dit onderzoek geĭnventariseerde regels om toch rechtmatig gegevens te kunnen uitwisselen met het buitenland. De EMMI-omgeving is dus een enorm hulpmiddel om de naleving te verzekeren van de juridische normen en eisen voor een vlotte doch rechtmatige informatieve politiesamenwerking. Omdat de EMMI-omgeving generiek is, kunnen de in dit onderzoek besproken juridische regels en toekomstige afspraken vrij eenvoudig in de EMMI-omgeving worden geformaliseerd.

Controle is verzekerd tijdens en na de verstrekking. Ook de officieuze communicatielijnen kunnen in de EMMI-omgeving worden geregistreerd, zodat zij niet langer aan controle onttrokken zijn. Tevens kan over deze officieuze communicatielijnen voortaan managementinformatie worden gegenereerd door EMMI. Het inzicht in dit officieuze circuit zal daardoor vergroten. De politieorganisaties en/of de wetgever kunnen dan eventueel bijsturen. Op deze manier kunnen de noodzakelijke officieuze contacten op een gecontroleerde manier blijven bestaan.

Men kan zich afvragen of het gerechtvaardigd is dat de EMMI-parners in de praktijk de gegevensuitwisseling in de grensstreek alleen toevertrouwen aan de politieregio's die aan de binnengrens met België en Duitsland zijn gelegen. Politieregio's als Brabant-Noord, Zuid-Holland-Zuid en Rotterdam-Rijnmond liggen zo dicht bij de grens dat er goede redenen zijn om voor die regio's directe gegevensuitwisseling met buitenlandse politiediensten toe te staan. 


\subsection{Legitimiteit binnen bestaande regelgeving}

In deze sectie geven wij aan wat in de EMMI-omgeving zowel technisch als juridisch goed te realiseren is en wat niet.

Wat de koppeling van het EMMI-netwerk aan de verschillende nationale politiële netwerken betreft, hebben wij gezien dat, in verband met de eisen van de SUO en de nationale wetgevingen, geen directe koppeling is gerealiseerd in Belgiè en Duitsland. In verband met de privacy achtten deze politiepartners een koppeling politiek en juridisch op voorhand niet mogelijk. Nederland heeft met toestemming van het Ministerie van Binnenlandse Zaken gekozen voor een indirecte koppeling. Dit houdt in dat, hoewel er wel degelijk een fysieke koppeling aanwezig is tussen beide netwerken, er geen geautomatiseerde routing van gegevens van het ene naar het andere netwerk plaatsvindt. Verder beschikt elk werkstation in de Nederlandse IRC's over twee netwerkkaarten: één voor de verbinding met de EMMI-server en één voor de verbinding met het regionet PILZ. De IRC-medewerkers bepalen welke gegevens van de EMMI-omgeving naar het nationale politienetwerk gekopieerd worden voor voeding van de registratiedatabase en voor beantwoording van de vragen van en aan de medewerkers op de werkvloer. Omgekeerd bepalen de IRC-medewerkers ook welke gegevens van de nationale politiële databanken

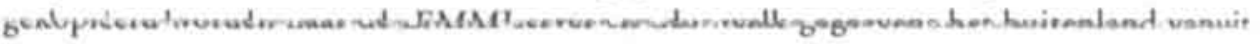
die nationale databanken verkrijgt. In België en Duitsland is er geen directe verbinding met het regionet. In Duitsland wordt alles nog in handmatige archieven bijgehouden en 's avonds in kasten opgeslagen.

De bevoegdheid tot directe on-linetoegang van buitenlandse politieambtenaren tot nationale politiële databases dient onzes inziens als eerste geregeld te worden. Pas daarna kan men overgaan tot de internationale (juridische) koppeling van de verschillende nationale computernetwerken en gegevens. Als de wetgever mocht beslissen dat directe toegang van buitenlandse politieambtenaren niet wenselijk is, zal de directe grensoverschrijdende koppeling van gegevens feitelijk niet uitvoerbaar zijn, hoewel een dergelijke koppeling formeel wel is toegestaan. Als de koppeling bij wet is voorzien of als de nationale controleautoriteiten er goedkeuring aan verlenen, is koppeling namelijk toegestaan volgens het internationale recht. Juridisch is koppeling - het komen tot nieuwe informatie over een vooraf onbepaalde groep van personen - volgens het internationale recht dus tocgestaan. De uitvoering ervan wordt echter gefrustreerd door het feit dat volgens het nationale recht aan buitenlandse politieambtenaren geen rechtstreekse geautomatiseerde toegang tot politieregisters wordt toegestaan.

Wij geven nu een concluderend overzicht van de juridische haalbaarheid van elk van de vier in hoofdstuk 4 beschreven (technische) niveaus waarop grensoverschrijdende bevraging van (multimediale) politie̋le databases kan plaatsvinden. 
niveau 1: Het wituisselen san informatie geschiedt volgens de buidige stand sun aaken zowel in het aanvragende als in het verstrekkende land overieggen speciaal daarvoor aangestelde politiefunctionarissen, eventueel na inschakeling van het $\mathrm{OM}$, of en welke gegevens worden uitgewisseld. Het zoeken in de nationale databases gebeurt uitsluitend door de IRC-medewerkers van het verstrekkende land zelf, alsmede door de agent op de werkvloer die hiervoor door de IRC-medewerkers is benaderd. Deze huidige werkwijze is juridisch toegestaan en geeigend voor politieregisters zolang geen rechtstreekse geautomatiseerde toegang van buitenlandse politieambtenaren is toegestaan. Menselijke tussenkomst van de bevoegde nationale politieambtenaren is op dit moment nog een absoluut wettelijk vereiste.

aiveau 2: Het zoeken in de nationale databases wondt uitgevoend door computerprognammas in het informatieverstrekkende IRC. Op de uitkomst van die geautomatiseerde zoekactie vindt controle plaats door de daarvoor aangestelde IRC-medewerkers. Daarna worden de gegevens al dan niet verzonden naar het buitenlandse IRC. Deze technische stap is op dit moment juridisch niet toegestaan voor het zoeken in politieregisters, omdat de wetgever uitgaat van de menselijke uitvoering van de gegevensuitwisseling. Bij Wbp-registers ligt het iets gemakkelijker. Voor het grensoverschrijdend zoeken in Wbp-registers zou dit tweede niveau cen recle mogelijkheid kunnen zijn. Menselijke controle zal, zoals het er nu naar uitziet, een absolute juridische eis blijven.

niveau 3: Het wordt de IRC-medewerker mogelijk gemaakt om via computerprogramma's rechtstreeks in buitenlandse databases te zoeken en de gevonden informatie op te halen. Controle kan achteraf plaatsvinden door de inhoud van de registratiedatabase na te trekken. Het is niet erg waarschijnlijk dat deze optie in de nabije toekomst gerealiseerd zal worden op nationaal wetgevend niveau, omdat de menselijke controle te beperkt is op dit niveau.

niveau 4: Politieambtenaren mogen 'op de werkvloer' rechtstreeks in de buitenlandse databases kijken en de gegevens ophalen, zonder dat er nog sprake is van enige vorm van firewall. Dit niveau van gegevensuitwisseling lijkt vooralsnog een utopie, omdat de internationale politiële gegevensuitwisseling een zeer specialistisch terrein is dat bij voorkeur wordt uitgeoefend door ter zake goed opgeleide politiefunctionarissen. Daarbij komt dat het weghalen in de automatiseringsketen van de schakel van de IRC's in strijd is met de bestaande wet- en regelgeving en de daarop gebaseerde richtlijnen. Dit automatiseringsniveau is dus juridisch onhaalbaar, misschien op een aantal uitzonderingen na waarin rechtstreekse contacten tussen agenten op de werkvloer juridisch toegelaten zijn. Zo zijn op grond van de van kracht zijnde convenanten tussen de Nederlandse politie Limburg-Zuid en de politie van het Belgische Genk en Eupen informatie-uitwisselingscontacten tussen politiedien- 
sten in het grensgebied zonder tussenkomst van het IRC toegestaan. Dit is het geval in concrete opsporingsonderzoeken of samenwerkingsverbanden. Daarbij moet dan wel een werkdossier of werkregister worden bijgehouden.

In de wetsgeschiedenis van artikel $552 i$ Sv wordt zoals gezegd benadrukt dat dit wetsartikel de Nederlandse politie niet bevoegd maakt tot het verrichten van bewijsvergaringshandelingen in het buitenland. De Nederlandse overheid mag in het buitenland alleen strafvordering plegen op basis van toestemming van de territorialiteitsstaat en met inachtneming van het recht ter plaatse.

Ten slotte stellen wij vast dat onderzocht zal moeten worden of uitwisseling van gegevens over onderwerpen als vermiste personen en ongeidentificeerde lijken zonder de tussenkomst van de IRC's mogelijk moet worden.

\subsection{Betrouwbaarheid van gebruik en gebruiker}

In deze sectie bespreken wij de juridische randvoorwaarden voor een betrouwbaar gebruik van de EMMI-omgeving (subsectie 9.6.1), alsmede de beginselen van behoorlijk ICT-gebruik (subsectie 9.6.2), Wij komen hiermee tot een concrete beantwoording van de tweede deelvraag van ons onderzoek die als volgt luidt.

"Welke technische randvoorwaarden en juridische waarborgen zijn vereist voor de betrouwbaarheid van gebruik en gebruiker, als ook ten aanzien van de bescherming van de persoonlijke levenssfeer, in het bijzonder wanneer het om gevoelige (persoons)gegevens gaat?"

\subsubsection{Juridische randvoorwaarden}

Uit de in voorgaande secties behandelde wetgeving, verdragen en internationale teksten vloeien rechtstreeks een aantal juridische randvoorwaarden voort voor een betrouwbaar gebruik van de EMMI-omgeving. Hieronder geven wij een opsomming van de randvoorwaarden aan de inzet van ICT.

Als het gaat om de bescherming van de persoonlijke levenssfeer, dient het primaat te liggen bij de wetgever en niet bij de systeemontwerper of de gebruiker van het systeem. ${ }^{62}$ Dit primaat is verwoord in het eerste beginsel van Aanbeveling $R$ (87) 15 van de Raad van Europa. Nieuwe technische middelen voor gegevensverwerking mogen pas worden ingevoerd als alle redelijke maatregelen zijn genomen om te bevorderen dat bij het gebruik daarvan gehandeld wordt in de geest van de bestaande gegevensbeschermingswetgeving. Artikel 7 Databeschermingsverdrag heeft betrekking op gegevensbeveiliging 
en roept de lidstaten van de Raad van Europa op passende veiligheidsmaatregelen te nemen om in geautomatiseerde bestanden opgeslagen persoonsgegevens te beschermen tegen toevallige of ongeoorloofde vernieling, tegen toevallig verlies en tegen ongeoorloofde toegang, wijziging of verstrekking. Ook het achtste beginsel van Aanbeveling $R$ (87) 15 handelt over de beveiliging van de gegevens. De beheerder van de gegevens dient alle mogelijke maatregelen te nemen om een behoorlijke fysieke en softwarebeveiliging van de gegevens te garanderen. Ongeoorloofde veranderingen, toegang of verstrekkingen moeten worden voorkomen. Daarbij dient rekening te worden gehouden met de verschillende kenmerken en met de inhoud van de bestanden.

De korpsbeheerder dient ingevolge artikel 7 lid 1 WPolr zorg te dragen voor de juiste werking van het register IRP. Dit is een algemene zorgverplichting. Artikel 7 lid 2 WPolr stelt een meer specifieke beveiligingsplicht. De korpsbeheerder dient zorg te dragen voor de nodige voorzieningen van technische en organisatorische aard ter beveiliging van het register tegen verlies of aantasting van de gegevens, alsmede tegen onbevoegde kennisneming, wijziging of verstrekking daarvan. Ook in de Wbp zijn dergelijke verplichtingen opgenomen.

In verband met de protocolverplichtingen van enerzijds artikel $552 i$ lid 3 Sv en de artikelen 126 lid 3 sub e jo. 127 lid 1 SUO, en anderzijds artikel 19 WPolr jo. De artikelen 16, 17 en 18 BPolr moeten technische en organisatorische voorzieningen worden getroffen. Ook het inloggen in systemen (hardware en software) dient te worden vastgelegd..$^{433}$

Door deze juridische randvoorwaarden kan het vertrouwen van het publiek in de politieorganisatie, haar taakuitvoering en werkzaamheden gewaarborgd worden. Het vertrouwen van het politiepersoneel in het computersysteem en de gegevens waarmee gewerkt wordt, zal daardoor ook groeien. Ten slotte wordt het vertrouwen tussen verschillende (onderdelen van) politiediensten eveneens versterkt.

\subsubsection{Beginselen van behoorlijk ICT-gebruik}

Naast de in subsectie 9.6.1 genoemde juridische randvoorwaarden voor een betrouwbaar gebruik van de EMMI-omgeving die rechtstreeks uit de verdragsrechtelijke en wettelijke normering kunnen worden gehaald, zijn door Franken ook een aantal zogenaamde algemene beginselen van behoorlijk ICT-gebruik geformuleerd. ${ }^{434}$ Deze beginselen zijn te omschrijven als oriëntatiepunten om in ICT-omgevingen zoals de EMMI-omgeving belangen af te wegen en bepaalde waarden te erkennen. De door Franken geformuleerde beginselen zijn vergelijkbaar met de algemene beginselen van behoorlijk bestuur in het 
bestuursrecht en met de onrechtmatigheidscriteria voor een actie uit onrechtmatige daad. Het zijn eisen die aan ICT te stellen zijn vanuit technisch, procedureel en materieel oogpunt. De criteria voor behoorlijk ICT-gebruik zijn concretiseringen van algemene rechtsbeginselen die in de samenleving gelden. Het zijn toepassingen van waarden als vertrouwen, zorgvuldigheid, informatievrijheid en vrijheid van meningsuiting. Met behulp van de beginselen van behoorlijk ICT-gebruik is volgens Franken een functionele benadering mogelijk, daar waar juridische begrippen en concepten tekortschieten.

In essentic gaat het om de volgende algemene beginselen van behoorlijk ICT-gebruik: beschikbaarheid, vertrouwelijkheid (exclusiviteit), integriteit, authenticiteit, flexibiliteit en transparantic. Deze beginselen worden hierna kort omschreven.

\section{Beschikbaarheid}

Het beschikbaarheidsbeginsel ziet op het feit dat informatie beschikbaar en toegankelijk moet zijn voor de burger. Vrijheid van informatie is immers een grondrecht dat door artikel 10 EVRM is gewaarborgd. De diverse componenten van elektronische communicatie moeten gestandaardiseerd zijn om de beschikbaarheid te waarborgen. Daartoe dienen normen te worden gedefinieerd voor de functies van de computersystemen en de wijze van interactie met en tussen de diverse systemen. GVer zowei 'ué geviurnile cean' niek, de procedure als de inhoud van het berichtenverkeer moet eenduidigheid bestaan.

\section{Vertrouwelijkheid (exclusiviteit)}

Het principe van vertrouwelijkheid of exclusiviteit biedt de mogelijkheid tot een beperking van de kennisneming van opgeslagen gegevens. Het is niet wenselijk dat onbevoegden kennisnemen van als vertrouwelijk of geheim aangemerkte gegevens. Verder wil men soms de exclusieve zeggenschap hebben over de wijze waarop en de personen door wie de geautomatiseerde middelen en gegevens mogen worden gebruikt. Dit kan worden gerealiseerd door de toegankelijkheid tot de informatie(systemen) slechts voor geautoriseerde gebruikers te laten gelden. De privacy van personen kan een reden zijn voor deze beperking. Onbevoegde bekendmaking van de gegevens kan de persoonlijke levenssfeer van burgers schaden. Het is duidelijk dat voor het waarborgen van de vertrouwelijkheid van informatie(systemen) een adequate beveiligingseis geldt, waarbij een afweging heeft plaatsgevonden tussen het te beveiligen belang en de genomen maatregelen.

\section{Integriteit}

Het integriteitsbeginsel ziet op de integriteit of de inhoudelijke kwaliteit van een informatiesysteem. Het systeem moet goed functioneren en de gegevens en computerprogramma's moeten correct en volledig zijn. De output van het computersysteem moet 'waar' zijn en men moet op de resultaten kunnen vertrouwen. Gegevens mogen niet ongemerkt verdwijnen of veranderen. Bovendien moeten de gegevens in databases actueel blijven en moet de input juist zijn. 


\section{Authenticiteit}

Omdat de partijen die aan elektronisch berichtenverkeer deelnemen niet zichtbaar zijn voor elkaar, moet vaststaan dat zij 'echt' zijn. De verzonden berichten moeten authentiek zijn. Ze moeten werkelijk afkomstig zijn van de verzender en terechtkomen bij de juiste geadresseerde.

\section{Flexibiliteit}

Toepassingen van ICT moeten flexibel zijn. $\mathrm{Zij}$ dienen gemakkelijk te kunnen worden aangepast aan nieuwe gebruikseisen.

\section{Tnansparantie}

Het transparantiebeginsel houdt in dat de werking van ICT-tocpassingen zichtbaar en begrijpelijk moet zijn voor zowel de gebruiker als de burger. Aldus blijft controle op de werking van ICT-toepassingen gewaarborgd. Als informatiesystemen heel complex zijn, mag worden volstaan met de eis dat de technische oplossingen de gestelde doeleinden realiseren. De transparantie kan dan niet volledig zijn en behoeft dat dan ook niet te zijn. De transparantic-eis speclt bij vermoede inbreuken op de privacy en strafvorderlijk optreden een heel belangrijke rol.

Wij merken op dat de genoemde algemene beginselen van behoorlijk ICT-gebruik niet altijd in overeenstemming zijn met elkaar. De vertrouwelijkheidseis vormt bijvoorbeeld een uitzondering op de beschikbaarheidseis. Flexibiliteit van informatiesystemen kan tot een hogere complexiteit van het informatiesysteem leiden waardoor de transparantie vermindert. Integriteit en authenticiteit liggen wel op één lijn met transparantie. In individuele gevallen zullen afwegingen per informatiesysteem dienen plaats te vinden over de vraag welk criterium doorslaggevend is.

\subsection{Conclusies eerste aanvullende onderzoeksvraag}

Hieronder formuleren wij in het kort onze conclusies ten aanzien van de eerste aanvullende onderzoeksvraag van dit onderzoek (zie subsectie 5.6.3 voor de uitgebreide conclusies). De vraag luidde als volgt.

\section{"Hoe worden zachte politiële gegevens in de Nederlandse, Belgische en Duitse rechtsorde juridisch beschermd en hoe dient ermee omgegaan te worden in het kader van de grens- regionale politiële gegevensuitwisseling?"}

De hoofdconclusie met betrekking tot het omgaan met zachte gegevens in grensregionaal verband is dat zachte gegevens alleen in de Nederlandse rechtsorde een duidelijk juridisch beschermingsregime kennen. Dit regime is neergelegd in artikel 5a WPolr, aangaande informatie betreffende onverdachte personen, en $₫ 3 \mathrm{a}$ WPolr, aangaande de bij- 
zondere politieregisters. De opslagtermijnen van de zachte gegevens zijn enkel in Nederland duidelijk wettelijk geregeld.

In het buitenland kent men het Nederlandse systeem van gecodeerde 'zachte' informatie veelal niet. Het is daarom al voorgekomen dat niet operationeel te gebruiken informatie in een zaaksdossier is beland. Bij het omgaan met uit het buitenland afkomstige informatie wordt steevast gehandeld naar het vertrouwensbeginsel. Dat wil zeggen dat ervan uitgegaan wordt dat de informatie rechtmatig is verkregen door de buitenlandse autoriteit, alsmede dat de informatie gebruikt zal worden voor geen ander doel dan het doel waarvoor zij is verstrekt.

Als er sprake is van zachte, dus onbewijsbare nog niet vaststaande, gegevens is controle vooraf van de internationale verstrekking van deze gegevens door de politiediensten in de grensregio's van groot belang. In Nederland is duidelijk in de wetgeving vastgelegd dat voor de verstrekking van CIE-informatie de toestemming van de (landelijke) CIE-OvJ nodig is. Voor de verstrekking van informatie uit de tijdelijke registers is ook de tussenkomst van het OM vereist. De tussenkomst van de NCIE (Nationale Criminele Inlichtingeneenheid) is tevens vereist voor de verstrekking van CIE-informatie. Dit geldt op basis van artikel 13 lid 12 BPolr en artikel 8 Regeling criminele inlichtingen eenheden van 5 oktober 2000. De politie kan de verstrekking van dergelijke gegevens dus niet zelfstandig afhandelen. Wij stellen vast dat er voor België en Duitsland nog geen transparante wettelijke bepalingen bestaan die een dergelijke controle vooraf op de internationale verstrekking van zachte gegevens expliciet regelen.

Volgens het derde beginsel van de Recommendation R (87) 15 van de Raad van Europa moeten de verschillende soorten politiële gegevens die worden opgeslagen, zoveel mogelijk worden onderscheiden naar hun mate van precisie of betrouwbaarheid. In het bijzonder dienen gegevens gebaseerd op feiten gescheiden te worden van gegevens berustend op meningen of persoonlijke beoordelingen. Dit nu is alleen in de Nederlandse wet- en regelgeving voldoende uitgewerkt. Wij stellen vast dat de Belgische wetgeving enkel een algemene regeling geeft in de artikelen 44/1 tot en met 44/11 WPA en de daarbij behorende omzendbrief van 14 juni 2002, die beide betrekking hebben op het politiële informatiebeheer. Specifieke wettelijke uitvoeringsbepalingen zijn er vooralsnog niet in België. Hoe het Belgische juridische kader omtrent de uitwisseling van gegevens met het buitenland eruit ziet, is in algemene termen, zonder specifieke aandacht voor zachte gegevens, neergelegd in de omzendbrief van 14 februari 2000 betreffende de internationale politiesamenwerking met een gerechtelijke finaliteit. De Nationaal Magistraat ziet toe op de rechtmatige gegevensuitwisseling.

In Duitsland wordt geen strikte scheiding tussen 'harde' en 'zachte' informatie gemaakt. De politiewetten maken zelfs helemaal geen onderscheid. Dit heeft wellicht te maken 
met de Duitse cultuur waarin zachte gegevens in de politiepraktijk veel gemakkelijker uitgewisseld worden dan in de Nederlandse of de Belgische cultuur. Sommige databases bevatten echter in de praktijk wel meer vage, ongeverifieerde en daarom zachte informatie dan andere.

\subsection{Conclusies tweede aanvullende onderzoeksvraag}

Hieronder formuleren wij in her kort onze conclusies ten aanzien van de tweede aanvullende onderzoeksvraag van dit onderzoek (zie sectie 7.8 voor de uitgebreide conclusies). De vraag luidde als volgt.

"Welke juridische keuze dienen de Raad van Europa en de Europese Unie te maken met betrekking tot bet vnaagstuk van de rechtstreekse geautomatiseende grensoversehrijdende tocgang van buitenlandse opsporingsambtenaren tot nationale (politiele) databases en computernetwerken, mede in bet licht van de internationale juridische ontwikkelingen betreffende digitale expertise?"

Het impliciete Nederlandse verbod tot rechtstreekse geautomatiscerde grensoverschrijdende toegang door buitenlandse opsporingsambtenaren tot nationale politiële bestanden, databases en politienetwerken is er tezamen met de Belgische en Duitse wetgeving en politiek terzake de oorzaak van, dat een fysieke koppeling van de EMMI-omgeving met de betrokken nationale politiële computernetwerken momenteel nog niet tot de mogelijkheden behoort. Als de betrokken landen een dergelijke directe toegang in het leven zouden willen roepen, zal de nationale en /of de internationale wetgever zich hierover moeten uitspreken.

Er zijn vier mogelijke wegen om tot een goede regeling van de problematiek omtrent de directe toegang te komen: de weg van de Raad van Europa, de weg van de EU, de weg van de grensregionale convenanten en akkoorden, en de weg van de regeling in het nationale recht van de betrokken staten.

De Raad van Europa kan het Comité van Ministers van de Raad van Europa opgedragen een verdragstekst tot stand te brengen over (1) grensoverschrijdende directe toegang in een digitale internationale politiële netwerkomgeving en (2) internationale koppeling van politiegegevens.

De onderwerpen van de rechtstreekse geautomatiseerde toegang en de koppeling van politiegegevens zouden ook op de agenda van de EU geplaatst moeten worden. Dit kan gebeuren in het kader van de zogeheten Derde Pijler van de EU: de intergouvernementele samenwerking op het gebied van politie en strafrecht. De rechtsgrondslag hiervoor is te vinden in Titel VI van het Verdrag betreffende de EU. Op grond van de procedure van artikel 34 lid 2 sub d VEU zou een EU-Overeenkomst aangaande de rechtstreekse geau- 
tomatiseerde grensoverschrijdende toegang van buitenlandse politieambtenaren tot nationale bestanden, databases en politienetwerken gesloten kunnen worden, met passende bepalingen inzake de bescherming van persoonsgegevens, in het licht van de voortschrijdende ICT. Deze materie zou eventueel ook geregeld kunnen worden in een kaderbesluit of een besluit op grond van artikel 34 lid 2 sub b respectievelijk sub c VEU.

Een derde mogelijkheid voor het regelen van de problematiek betreffende de directe toegang is het treffen van een regeling in de convenanten en akkoorden die op basis van artikel 39 lid 4 en 5 en artikel 46 lid 2 SUO tot stand zijn gekomen met betrekking tot de grensregionale uitwisseling van politiële gegevens. Een dergelijk convenant kan binnen de bestaande kaders van de BNPS en DNPS worden uitgewerkt.

Een vierde mogelijkheid voor het regelen van directe grensoverschrijdende toegang van buitenlandse opsporingsambtenaren tot nationale politiële bestanden, databases en politienetwerken, is het in het leven roepen van nationale wettelijke bepalingen hieromtrent door de betrokken landen. Dit is op grond van het vijfde beginsel van Recommendation R (87) 15 van de Raad van Europa de eerst aangewezen weg, maar verdient onzes inziens niet de voorkeur, vanwege het internationaal grensoverschrijdend karakter van een dergelijke regeling. Een internationale (Europese) overeenkomst lijkt ons voor dit doel een beter en voor de politiële praktijk transparanter juridisch instrument. Er bestaan dan namelijk geen (geheel) verschillende nationale regelingen meer in de betrokken lidstaten.

\subsection{Conclusies derde aanvullende onderzoeksvraag}

Hieronder formuleren wij in het kort onze conclusies ten aanzien van de derde aanvullende onderzoeksvraag van dit onderzoek (zie sectie 8.3 voor de uitgebreide conclusies). De vraag luidde als volgt.

"Waar liggen de juridiscbe grenzen tussen de werkzaambeden van Europol en de werkzaamheden van de IRC's?"

De werkzaamheden van de IRC's voorzien in een nieuwe 'samenwerkingsmarkt' voor informatie-uitwisseling in grensregio's van de EU. Het gaat daarbij om de behoefte aan snelle grensoverschrijdende informatie-uitwisseling voor het 'gewone' politiewerk, zijnde voornamelijk ordehandhaving, verkeerstoezicht en de zogenoemde kleinere criminaliteit. Het internationale gegevensuitwisselingsnetwerk EMMI wordt hiervoor thans gebruikt door twintig (grensregionale) politiekorpsen in vier landen: Nederland, België, Duitsland en Frankrijk. De grensregionale politiële gegevensuitwisseling geschiedt binnen de juridische grenzen van internationale wet- en regelgeving en convenanten, die onder bepaalde voorwaarden rechtstreekse gegevensuitwisseling tussen de IRC's van de verschillende landen mogelijk maken. 
Europol is een Europees orgaan voor de veredeling en uitwisseling van gegevens die een bijdrage kunnen leveren aan het voorkomen en bestrijden van bepaalde vormen van grensoverschrijdende georganiseerde criminaliteit. De informatic-uitwisseling verloopt nationaal op centraal niveau via de nationale eenheden en verbindingsofficieren bij Europol. Europol is bevoegd tot ondersteuning van in het Europolmandaat bepaalde rechtshandhavingsactiviteiten indien er een georganiseerde criminele structuur bestaat en twee of meer EU-lidstaten betrokken staten zijn.

Op grond van het internationaal juridisch verankerde beginsel dat de registraties van de IRC's geen nieuwe zelfstandige bron van informatic mogen vormen, mogen de gegevens die in de lokale registratiedatabase en de centrale logdatabase van PALMA zijn opgeslagen, niet gebruikt worden voor de veredeling of uitwisseling van gegevens via Europol. Er dient voor die veredeling of uitwisseling teruggegrepen te worden op de gegevens uit de oorspronkelijke registraties. De gegevens uit de PALMA-databases kunnen immers verouderd zijn en daardoor niet meer betrouwbaar. De gegevens uit de wettelijk verplichte registratie in de PALMA-databases kunnen dus ook niet gebruikt worden voor operationele misdaadanalyses binnen of buiten Europol. Hetzelfde geldt voor de gegevens die opgeslagen zijn bij de infodesks van de regiopolitie, voor zover die gegevens niet afkomstig zijn uit de oorspronkelijke registraties.

Een koppeling tussen de EMMI/PALMA-omgeving en Europol is op grond van artikel 6 lid 2 EO niet toegestaan.

\subsection{Standpuntbepaling ten aanzien van het juridische kader}

In deze sectie formuleren wij negenentwintig persoonlijke standpunten ten aanzien van het gewenste juridische kader van de internationale informatieve politiesamenwerking tussen de grensregio's van Nederland, België en Duitsland.

1. Voor het juridische kernprobleem van de rechtstreekse geautomatiseerde toegang achten wij het verstandig dat duidelijke juridische normen en heldere formele procedures worden opgesteld. Dit dient bij voorkeur te gebeuren op het internationaalrechtelijk niveau van de Raad van Europa (zie punt 2) en van de Europese Unie (zie punt 3). De normen kunnen worden aangevuld met de meer specifieke nationale wetgeving. Het Cybercrimeverdrag en de EU-Overeenkomst betreffende de wederzijdse rechtshulp in strafzaken kunnen een inspiratiebron zijn om tot internationaal aanvaardbare oplossingen te komen voor dit vraagstuk.

2. De in dit onderzoek centraal staande koppeling van nationale politiële netwerken en het grensoverschrijdend gebruik van (multimediale) databases zouden op het niveau van de Raad van Europa dienen te worden behandeld. Ter nadere ondersteuning van dit punt stellen wij-dat rechtstreekse geautomatiseerde toegang van politieambtenaren tot (multimediale) databases van een ander land hoog op de agenda van de Raad 
van Europa zou moeten komen te staan. Koppeling van een internationaal politicel Intranet als EMMI aan de Europese nationale politiële netwerken is het best realiseerbaar als de Raad van Europa duidelijke regels formuleert voor de rechtstreekse toegang. Het Cybercrimeverdrag regelt reeds grensoverschrijdende netwerkzoeking ter opsporing van strafbare feiten door buitenlandse opsporingsambtenaren. De Straatsburgse verdragstekst regelt onder meer dat (1) partijen elkaar grensoverschrijdende netwerkzoekingen toestaan en (2) de voorwaarden voor het ter beschikking krijgen en gebruiken van elektronisch bewijs. Het gaat daarbij om de vraag in hoeverre opsporingsambtenaren grensoverschrijdend netwerken mogen doorzoeken en gegevens mogen aftappen en opnemen in het buitenland. Rechercheurs hebben een soort elektronisch achtervolgingsrecht als er geen tijd is om op toestemming van het buitenland te wachten. De verdragstekst heeft vooralsnog geen betrekking op internationale uitwisseling van politiële gegevens. De Raad van Europa zou zich dit onderwerp evenwel ook dienen aan te trekken. De juridische netwerkproblematiek van de rechtstreekse geautomatiseerde toegang tot gegevens en computersystemen speelt zowel op het terrein van de opsporing van strafbare feiten als bij de politiële gegevensuitwisseling. In het Cybercrimeverdrag gaat het om de rechtstreekse geautomatiseerde en grensoverschrijdende toegang van buitenlandse opsporingsambtenaren tot computergegevens en -systemen van verdachten en van derden. Bij de politiële gegevensuitwisseling gaat het om de rechtstreekse geautomatiseerde en grensoverschrijdende toegang van politieambtenaren tot buitenlandse politiële computernetwerken en gegevens. Beide vormen van rechtstreekse toegang spelen een belangrijke rol in de hedendaagse bestrijding van de grensoverschrijdende criminaliteit. Uitbreiding van de werkzaamheden van de Raad van Europa in dezen tot het terrein van de informatieve politiesamenwerking is derhalve aangewezen. Het zou nog mooier zijn wanneer bij deze werkzaamheden ook aandacht wordt besteed aan juridische mogelijkheden voor internationale koppeling van politiegegevens. Daarbij dient dan acht te worden geslagen op de in dit onderzoek beschreven moderne koppelingstechnieken.

3. De onderwerpen van de rechtstreekse geautomatiseerde toegang en de koppeling van politiegegevens zouden daarnaast ook op de agenda van de EU geplaatst dienen te worden. Dit kan gebeuren in het kader van de zogeheten Derde Pijler van de EU: de intergouvernementele samenwerking op het gebied van politie en strafrecht. De rechtsgrondslag hiervoor is te vinden in Titel VI VEU. Aldus kan een betrouwbare en tevens privacywaarborgende fysieke koppeling van de nationale politiěle computernetwerken in Europa worden bereikt.

4. Wij geven de nationale wetgever in overweging de ratio van de huidige regeling voor de rechtstreekse geautomatiseerde toegang tot politieregisters en het beleid dienaangaande te heroverwegen. De wetgevers van de betrokken landen dienen zich er over uit te spreken of aan buitenlandse politieambtenaren en aan leden van het $O M$ rechtstreekse geautomatiseerde toegang tot bepaalde politieregisters dient te worden 
gegund. Bij een verlening van rechtstreekse toegang dient ook te worden bepaald onder welke juridische en technische randvoorwaanden dit dient te geschieden.

5. Het juridische koppelingsbegrip dient onzes inziens aangepast te worden aan de huidige stand van de techniek. De wetgever had destijds alleen een systematische vergelijking van twee of meer gegevensverzamelingen voor ogen (computer matching) en wellicht ook nog computer profiling, waarbij in een of meer computerbestanden wordt gezocht naar een specifieke combinatie van gegevenselementen. Hij zal nu evenwel ook aandacht dienen te schenken aan de meest recente technieken (onder andere datamining) teneinde hiervoor passende juridische waarborgen te formuleren.

6. De huidige bilaterale convenanten en verdragen die tussen Nederland, Belgiè en Duitsland onderling van kracht zijn, bevatten geen regeling omtrent de rechtstreekse geautomatiseerde toegang tot de nationale politiele gegevens en computernetwerken door buitenlandse politieambtenaren. Zij bepalen ook niets over koppeling van gegevens, bestanden of systemen. Wij vinden het wenselijk dat de partners bij de internationale politiēle gegevensuitwisseling hierover tot overeenstemming komen, bij voorkeur via een bi- of trilateraal verdrag of convenant, via een verdrag in het kader van de Raad van Europa of via een EU-Overeenkomst (of wellicht een kaderbesluit of besluit). Wellicht kunnen in een dergelijk internationaal juridisch instrument ook afspraken worden gemaakt of en in hoeverre, juridisch gesproken, koppeling van internationaal uitgewisselde (persoons)gegevens mogelijk dient te zijn. Het respecteren van het doelbindingsbeginsel zal hierbij een cruciale rol spelen. Men dient zich evenwel te realiseren dat de inzet van verdragswetgeving voor de genoemde doeleinden een zwaar middel is, dat enkel mag worden toegepast als het echt noodzakelijk is.

7. Art. 3 lid 1 van het modelconvenant dient te worden afgestemd op artikel 13 lid 12 BPolr en artikel 8 Regeling criminele inlichtingen eenheden van 5 oktober 2000. De tussenkomst van de NCIE en de CIE-OvJ dient bij dergelijke verstrekkingen namelijk te zijn gewaarborgd.

8. In de Europese verhoudingen van de grensregionale politiële gegevensuitwisseling geven wij er de voorkeur aan, dat in andere Europese lidstaten, zoals in België en Duitsland, een controle vooraf door de gerechtelijke (justitiële) autoriteiten van de internationale uitwisseling van zachte gegevens wettelijk wordt vastgelegd. Op deze manier is er een betere garantie aanwezig dat de uitgewisselde informatie inderdaad rechtmatig verkregen is door de verstrekkende staat.

9. Wij menen dat het goed zou zijn om in de convenanten en akkoorden in de grensgebieden tussen Nederland, België en Duitsland op grond van artikel 39 lid 4 en 5 SUO en artikel 46 lid 2 SUO meer aandacht te schenken aan afstemming tussen de zeer verschillende nationale wet- en regelgeving op het gebied van zachte gegevens.

10. Wij achten het wenselijk dat België en Duitsland een goed wettelijk kader uitwerken voor het omgaan met zachte gegevens (inclusief de opslagtermijnen) en de (interna- 
tionale) uitwisseling van zachte gegevens; dit geldt mede in het licht van het derde beginsel van Recommendation R (87) 15 van de Raad van Europa. De nationale en internationale rechtspraktijk dient zich daar vervolgens bij aan te sluiten.

11. Het Reglement IRP dient op grond van artikel 6 lid 2 WPolr de koppeling van de gegevens uit het register IRP met gegevens uit een ander register te regelen. Zolang dat niet is gebeurd is koppeling van het register IRP met een andere verzameling van persoonsgegevens wettelijk nog niet mogelijk. Over een dergelijke regeling dient het CBP te worden gehoord. Wel is op grond van artikel 6 lid 4 WPolr in uitzonderingsgevallen koppeling van het register IRP met andere gegevensverzamelingen mogelijk zonder dat het Reglement IRP daarin voorziet. Hiervoor moet de Minister van Justitie toestemming geven. Een dergelijke koppeling dient noodzakelijk te zijn voor de opsporing van een misdrijf waardoor de rechtsorde ernstig is geschokt.

12. De toepassing van bepaalde innovatieve technieken kan leiden tot een min of meer voortdurende bestandsvergelijking. De procedurele regeling inzake het opmaken van processen-verbaal is hierop niet goed toepasbaar. Wij geven de wetgever in overweging hiervoor praktische regels uit te werken.

13. Er dient onzes inziens voor te worden gewaakt dat het individu individueel beoordeeld blijft worden en niet wordt behandeld op basis van eigenschappen van groepen waartoe het, vaak toevallig, behoort. Daarom zijn wij de mening toegedaan dat het gebruik van profielen nader dient te worden geregeld voor de politiële sector in zijn geheel.

14. De tekst van artikel 5 van het modelconvenant dient enigszins aangepast te worden. Het onderscheid tussen de verschillende regimes van niet-geautomatiseerde doch gestructureerde gegevens en niet-geautomatiseerde ongestructureerde gegevens wordt daarin niet helemaal helder gemaakt. Bepaalde regels die alleen gelden voor losse gegevens zijn ten onrechte van toepassing verklaard op alle niet-geautomatiseerde gegevens.

15. Wij achten het wenselijk dat de eis van artikel 129 SUO dat de ontvangende staat de verstrekkende staat (desgevraagd) dient te informeren over het gemaakte gebruik van de gegevens, strikter wordt nageleefd. Dan kan het hergebruik van de verstrekte gegevens beter worden gecontroleerd.

16. Wij zijn van mening dat technische en organisatorische maatregelen dienen te worden getroffen met betrekking tot de eis van artikel 8 lid 2 Reglement IRP dat de gegevens na tien jaar uit het register IRP moeten worden verwijderd. De EMMIomgeving is op deze juridische eis nog niet ingericht.

17. Wij achten het verstandig om in de multimediakiosk de standaardrubriek met 'hot news' over operationele aangelegenheden periodiek te onderzoeken op de aanwerigheid van persoonsgegevens. Persoonsgegevens dienen vervolgens op de geformaliseerde wijze via de PALMA-software verzonden te worden, zodat wordt voldaan aan de Schengeneisen. 
18. Naar onze mening dienen ook de officieuze communicatielijnen te worden geregistreend in de EMMl-omgeving, zodat zij niet langer aan controle onttrokken zijn.

19. De Europese wetgever dient onzes inziens te onderzoeken of het wenselijk is in de toekomst ook tussen niet-grensregio's van de EU-lidstaten rechtstreeks gegevens uit te wisselen zonder tussenkomst van de centrale autoriteiten.

20. De juridische oplossing voor de rechtstreekse geautomatiseerde toegang zal naar onze mening voor Nederland in ieder geval betrekking dienen te hebben op aanpassing van het gesloten verstrekkingsregime inzake gegevens voor de politiele rechtshulp. Wij hebben hiervoor twee wegen aangegeven: de weg van de WPolr en de weg van de Wbp.

21. De beste juridische oplossing voor Nederland aangaande de rechtsteekse geautomatiscerde toegang bestaat er volgens ons in om de bestaande regeling van artikel 17 lid 1 BPolr te heroverwegen. De regeling dient in overeenstemming te worden gebracht met de technische mogelijkheden in zoverre die noodzakelijk zijn voor de bestrijding van de grensoverschrijdende criminaliteit.

22. Wij zijn de mening toegedaan dat een beschikking van de Ministers van Binnenlandse Zaken en van Justitie waarin de rechtstreekse toegang van buitenlandse politieambtenaren en het $\mathrm{OM}$ geregeld wordt een iets minder fraaie oplossing voor de regeling van rechtstreekse geautomatiseerde toegang in Nederland zou zijn. Deze regeling is namelijk alleen bedoeld voor incidentele beslissingen in bijzondere gevallen, terwijl in casu sprake is van gestructureerde gegevensuitwisseling.

23. Wij benadrukken dat artikel 30 WPolr slechts een provisoire oplossing voor verstrekking aan het OM zou kunnen vormen. Op grond van dit artikel mogen gegevens worden verstrekt indien de uitvoering van de taak met het oog waarop de gegevens eerder zijn verstrekt tot het ter kennis brengen daarvan noodzaakt. Ook dit artikel is evenwel niet voor structurele gegevensuitwisseling bedoeld.

24. Het verdient onze voorkeur de spontane verstrekking door de politie aan een OvJ in zijn functies van eerstgenoemde opsporingsambtenaar in de zin van artikel $141 \mathrm{~Sv}$, leider van de opsporing (art. 148 lid 2 Sv) en leider van de vervolging (art. 9 Sv) nader te regelen. Hiervoor zou in artikel 14 WPolr een spontane verstrekkingsmogelijkheid voor de politie aan de OvJ die in deze functies optreedt, kunnen worden ingevoegd. Dit komt dus neer op een aanpassing van de WPolr. Ten tijde van de concipiëring van de WPolr werd een dergelijke verstrekkingsmogelijkheid wellicht niet nodig geacht omdat er toen nog niet veel gegevens met behulp van computersystemen werden uitgewisseld. Een aanpassing van de WPolr en eventueel het BPolr achten wij hiervoor de beste juridische oplossing.

25 . Wij achten het wenselijk het probleem van hergebruik van gegevens uit de protocolregisters aan de Nederlandse wetgever voor te leggen. Protocolregisters worden bij hergebruik een zelfstandige bron van informatie. De wetgever dient onzes inziens over de wenselijkheid en rechtmatigheid van dergelijke mogelijke praktijken het laatste woord te spreken. Hergebruik van de gegevens uit het register IRP door de 
IRC-medewerkers is juridisch toegestaan, mits het doelbindingsbeginsel in acht wordt genomen. De gegevens mogen niet voor een ander doel worden gebruikt dan waarvoor zij aanvankelijk door het buitenland verstrekt zijn, behoudens toestemming van de verstrekkende staat. Gegevens die louter zijn vastgelegd met het oog op de controle op de naleving van het verstrekkingsregime van het register IRP, dus de protocolgegevens in de zin van de WPolr en het BPolr, mogen echter niet zomaar door de politie worden gebruikt. De mogelijkheid bestaat wel dat de Minister van Justitie of de Minister van Binnenlandse Zaken op grond van artikel 6 lid 4 of 18 lid 4 WPolr toestemming geeft om deze protocolgegevens in bijzondere gevallen wel voor operationele doeleinden te gebruiken. Te denken valt aan de opsporing van misdrijven waardoor de rechtsorde ernstig geschokt is.

26. Het lijkt ons verstandig bij de totstandbrenging van de nadere normering betreffende de kernproblemen van de rechtstreekse toegang en de koppeling van politiegegevens rekening te houden met de zogeheten algemene beginselen van behoorlijk ICT-gebruik. Met behulp van deze concretiseringen van de algemene rechtsbeginselen die in de samenleving gelden, kunnen normen worden opgesteld die de betrouwbaarheid van gebruik en gebruiker in de EMMI-omgeving waarborgen.

27. Art. 20 lid 4 sub d EU-RHO vermeldt dat de lidstaten de nodige maatregelen dienen te treffen om ervoor te zorgen dat binnen een termijn van 96 uur kan worden geantwoord op een rechtshulpverzoek betreffende het aftappen van telecommunicatie zonder technische bijstand van een andere EU-lidstaat. Hiertoe dienen contactpunten aangewezen te worden die 24 uur per dag beschikbaar zijn. Artikel 35 Cybercrimeverdrag verplicht de verdragspartijen tot de inrichting van een zogenoemd 24/7 Netwerk voor technisch advies, de conservatie van gegevens op grond van artikel 29 en 30 Cybercrimeverdrag, de bewijsvergaring, het verstrekken van juridische informatic en het lokaliseren van verdachten. In elke verdragsstaat dient 24 uur per dag en 7 dagen per week een informatieknooppunt actief te zijn, waarbij bevoegde ambtenaren heel snel de genoemde informatie kunnen geven en de genoemde handelingen kunnen verrichten. Wij doen hierbij de suggestie om in de toekomst hiervoor een rol toe te kennen aan de IRC's door de IRC's als een dergelijk contactpunt aan te wijzen.

28. De Europese Raad en de Raad van Ministers van de Europese Unie zouden onzes inziens dienen te bevorderen dat Europol en de IRC's op de hoogte zijn van elkaars werkzaamheden, van de raakvlakken van hun werkzaamheden en van de juridische grenzen tussen beide instanties.

29. Wij zijn de mening toegedaan dat menselijke controle op de grensregionale informatieve politiesamenwerking leidend dient te blijven. Wij achten het evenwel wenselijk dat de nationale en internationale wetgevers zich erover uitspreken in hoeverre zij de inzet van kennis- en agenttechnologie ter ondersteuning van de taken van de IRC's toelaatbaar achten. 


\subsection{Op weg naar een EMMI-beheersorganisatie}

In deze laatste sectie formuleren wij een concrete suggestie over de totstandbrenging van een EMMl-beheersorganisatie.

Voor de participatie aan EMMI bestaan geen specifieke toelatingsregels. Wij achten een regeling gewenst waarin de verschillende deelnemers afspreken hoe zij aan EMMI meedoen en op welke wijze de partners met elkaar omgaan. Het belangrijkste lijkt hier te zijn: het afspreken dat de betrokken politiediensten zich aan de voorgeschreven protocollen en standaarden houden, en dat iedere deelnemer de eigen 'nationale' kosten draagt. Naast deze nationale kosten zijn er de centrale kosten. Deze centrale kosten lijken niet te zien op personeel of materieel. Dat is immers in beginsel allemaal nationaal. Het verdient overigens de voorkeur om EMMI geen eigen personeel of middelen in eigendom te geven. Dat leidt tot lastige arbeidsrechtelijke, privaatrechtelijke en overige problemen. Wel zijn er ontwikkelkosten en kan eventueel een deel van het onderhoud van het systeem gecentraliseerd worden.

Voor deze afspraken lijken noch de Europese regels (Derde Pijler, dus intergouvernementeel), noch de Schengenregels een afdoende aanknopingspunt te bieden. Mede gelet op de aspecten van soevereiniteit, die met name bij politiēle en justitiële gegevensuitwisseling en internationale rechtshulp in strafzaken spelen, verdient een regeling op 'nationaal' niveau de voorkeur. Het gaat dan in feite om een afspraak tussen de deelnemende landen (staten en Länder). Deze afspraak kan publiekrechtelijk gemaakt worden door middel van de installatie van een publiekrechtelijke rechtspersoon in de nationale wetgeving van een of meer deelnemende landen, doch dit zou een langdurige wetgevingsprocedure tot gevolg hebben. Een andere internationaal publiekrechtelijke mogelijkheid is het sluiten van een verdrag met als onderwerp de EMMI-beheersorganisatie. De betrokkenen zijn dan de Ministers van Binnenlandse Zaken en/of Justitic. Een convenant, te ondertekenen door deze ministers, is eveneens een mogelijke, doch langdurige weg. De derde en onzes inziens beste mogelijkheid is de oprichting van een privaatrechtelijke stichting 'EMMI-beheersorganisatie' naar Nederlands recht.

\section{Het beheer over EMMI}

De regeling van het beheer zelf is ook belangrijk. Het gaat dan bijvoorbeeld om de volgende vragen. Wie is bevoegd om de verplicht te volgen protocollen vast te stellen, om de technische standaarden vast te stellen en om opdracht te geven tot 'centrale' ontwikkeling van nieuwe softwareversies en tot onderhoud? Wie beschikt over een daartoe strekkend budget? Een bij de regeling van de EMMI-beheersorganisatie in te stellen beheersraad lijkt het aangewezen orgaan. Deze raad krijgt een aantal algemene bevoegdheden, een budget en een verantwoordingsplicht aan de ondertekenaars van de regeling van de EMMI-beheersorganisatie. Daarnaast kan de beheersraad een eigen regeling van werkzaamheden opstellen. 
Uiteraard is de samenstelling van de beheersraad een punt voor de regeling van de EMMI-beheersorganisatie. Een eerste optie hiervoor is één afgevaardigde uit de deelnemende landen met een roulerend voorzitterschap en een ambtelijk secretaris/secretariaat. Wellicht kan het secretariaat in de eerste fase gevoerd worden door een universiteit. Dat waarborgt onafhankelijkheid en daarbij zijn de secretariaatskosten eenvoudiger om te slaan over de deelnemers dan het geval is bij een secretariaat dat gevoerd wordt door één van de deelnemende EMMI-landen. De centrale kosten worden daarbij als het ware geheel vormgegeven in de cofinanciering van een deels wetenschappelijk project.

Bovenstaande is nog vrij algemeen van opzet, maar een eerste stap zal zijn dat onderzocht wordt of de deelnemende landen en betrokken ministers, iets in een dergelijke regeling zien, en dat een voorstel voot een dergelijke regeling kan worden voorbereid. Wellicht is een voorlopige overeenkomst na te streven met daarin de kernpunten. In een eerste stadium behoeven dan niet alle onderdelen 'uitonderhandeld' te worden. Een regeling waarin besloten wordt mee te doen en waarin een beheersraad wordt opgericht, gecombineerd met de cofinanciering van het hiervoor genoemde deels wetenschappelijke project, lijkt het beste te realiseren. In het onderhavige voorstel is er in feite sprake van een getrapte regeling. De hoofdlijnen kunnen worden geregeld door de deelnemende landen en de uitvoeringsregeling door de beheersraad. Daarbij kan er voor worden gekozen dat de uitvoeringsregeling de goedkeuring behoeft van de deelnemende landen, zij het dat dat een vertragende factor kan zijn.

Overigens is een regeling waarbij de regie geheel centraal bij én land (bijvoorbeeld Nederland) ligt ook mogelijk, maar dat lijkt niet direct snel politiek haalbaar. In die visie besluiten de deelnemers aan EMMI (in feite de politiekorpsen) eigen middelen beschikbaar te stellen. Iedere deelnemer verricht dan zijn eigen onderhoud en bijdrage aan de 'eigen' communicatielijnen. Er wordt een bedrag ter beschikking gesteld voor een centraal punt voor de ontwikkeling van het systeem, de protocollen en de standaarden. Ook in deze opzet kan een beheersraad gevormd worden en kan een project voorzien worden van cofinanciering.

\section{De stichting 'EMMI-beheersorganisatie'}

Voor een publiekrechtelijke rechtspersoon voor het beheer van de centrale PALMA-logdatabase en eventucel een deel van de centrale infrastructuur, zijn geen aanknopingspunten te vinden in:

- de EU-Verdragen (het gaat immers om Derde-Pijleractiviteiten);

- de Europol- en de Schengenregelingen;

- de Politiewet 1993 of de WPolr;

- de Algemene wet bestuursrecht en de Wet gemeenschappelijke regelingen. 
Ook artikel 2:1 BW biedt geen mogelijkheid om zelfstandig een publickrechtelijke rechtspersoon op te richten. Volgens het tweede lid van dit artikel kan dat (voor zover het EMMI betreft) enkel bij of krachtens de wet geschieden. Andere lichamen dan de Staat, de provincies, de gemeenten, de waterschappen, alsmede alle lichamen waaraan krachtens de Grondwet verordenende bevoegdheid is verleend, waaraan een deel van de overheidstaak is opgedragen, bezitten namelijk slechts rechtspersoonlijkheid, indien dit uit het bij of krachtens de wet bepaalde volgt.

Met uitzondering van de WPolr verzetten de genoemde regels zich onzes inziens niet tegen de oprichting van een privaatrechtelijke rechtspersoon, mits deze enkel beheerstaken heeft. Er kan wel een probleem zijn met de WPolr. In de woorden van de Wbp zou een dergelijke beheersinstantie een deel van de apparatuur onder zich hebben waarmee een politieregister wordt gevoerd. In termen van de Wbp zou de EMMI-beheerorganisatie dan waarschijnlijk ook een bewerker zijn. En daar zit het probleem. De WPolr kent het begrip 'bewerker' niet. Voor een politieregister is het dus niet mogelijk om een deel van de persoonsregistratie of om een deel van de apparatuur onder te brengen bij een derde partij. Strikt gezien verzet de WPolt zich dan ook tegen een 'zelfstandige' EMMIbeheersorganisatie. Dit hoeft evenwel geen onoverkomelijk probleem te zijn. Enerzijds is de keuze om in de WPolr de 'bewerker' niet op te nemen, ingegeven door de gedachte dat de politie zelf zorg dient te dragen voor de eigen informatievoorziening en voor het beheer van de apparatuur waarmee politieregisters worden gevoerd. Het is bij een EMMI-beheersorganisatie goed te onderbouwen dat een dergelijke organisatie geen echte 'bewerker' is, omdat die EMMI-beheersorganisatie, voor zover Nederlandse politiegegevens verwerkt worden, geheel onder de verantwoordelijkheid van de politie zal blijven vallen (een extra argument dus om de EMMI-beheersorganisatie enkel een beheersorganisatie te laten zijn). Anderzijds lijkt er niet zo'n probleem omdat het niet opnemen van de 'bewerker' eigenlijk geen principiële keuze was, maar meer een praktische, vooral verband houdende met eventuele beveiligingsrisico's.

Een stichting naar Nederlands recht (Boek 2 Titel 6 BW) lijkt een goede mogelijkheid om een privaatrechtelijke rechtspersoon op te richten voor een EMMI-beheersorganisatie (zie artikel 2:3 BW). Dat zou dan een beheersstichting zijn. Het bestuur van de stichting kan dan bestaan uit een Raad van bestuur (beheersraad). Het is waarschijnlijk het beste om het bestuur te laten bestaan uit de deelnemende politiekorpsen zelf. Ook dan kan een soort 'Raad van bestuur' worden gecreëerd (zie artikel 2: 292 lid 4 BW).

De stichting kan door een Nederlands regionaal politiekorps worden opgericht. Wellicht kunnen alle deelnemende korpsen bij de oprichting betrokken worden. Dit is voor de oprichting echter niet noodzakelijk. Er lijkt geen strikte noodzaak te bestaan om te vereisen dat de nationale staten zelf de oprichting verrichten. De oprichters dienen in het eigen land wel rechtspersoonlijkheid te hebben. Het oprichten van een stichting is 
immers een rechtshandeling (art. 2:285 lid 1 BW). Wat Nederland betreft hebben de regionale politiekorpsen dat ook. Ook als de 'buitenlandse' deelnemers niet aan EMMI meedoen, kunnen zij onzes inziens nog wel in het bestuur van de stichting plaatsnemen.

De stichting dient statuten te bezitten waarin het doel, het beheer van de EMMI-infrastructuur, wordt vermeld. Met behulp van een daartoe bestemd vermogen wordt dit doel verwezenlijkt. Het bestuur van een privaatrechtelijke stichting als de onderhavige kan publiekrechtelijke rechtshandelingen verrichten als haar feitelijke handelingen duidelijk een publiekrechtelijk rechtsgevolg beogen. In voorkomende gevallen kan dit getoetst worden aan de interpretatie van de rechter. De procedure kan vergeleken worden met het Centraal Bureau Rijvaardigheidsbewijzen.

\section{Conclusie}

Er lijken twee reële mogelijkheden te zijn voor de oprichting van een EMMI-beheersorganisatic, waarvan de tweede mogelijkheid de eenvoudigste en minst tijdrovende is.

Mogelijkheid 1. De deelnemende staten sluiten onderling een internationale overeenkomst of verdrag.

Mogelijkheid 2. De deelnemende korpsen (of een deel van de korpsen) richten bij notariële akte (art. 2:286 BW) een stichting op naar Nederlands recht. De akte bevat de statuten van de stichting (met de naam en het doel van de stichting alsmede de wijze van benoeming en ontslag van de bestuurders en een gemeente in Nederland als statutaire zetel; verder ook nog de bestemming van het overschot na vereffening van de stichting in geval van ontbinding, of de wijze waarop de bestemming zal worden vastgesteld). Inschrijving in het handelsregister is verplicht (art. 2:289 BW). De stichting kan enkel beheerstaken hebben ten aanzien van de infrastructuur, en niet ten aanzien van het verwerken van persoonsgegevens. Het bestuur van de stichting 'EMMI-beheersorganisatie' kan bestaan uit de deelnemende korpsen. Er kan tevens een soort dagelijks bestuur worden aangewezen (zie artikel 2:292 lid 4). Dit dient allemaal bij notariële akte te geschieden. Als dit gebeurt is de grensregionale politiële gegevensuitwisseling in Europa een feit en kan de politie met behulp van de nieuwe internationale informatiemarkt de haar opgedragen taken in Europa adequaat uitoefenen. Het is een toekomstbeeld dat niet erg ver weg behoeft te zijn.

\subsection{Pro of contra invoering directe toegang?}

In deze sectie maken wij enige evaluerende opmerkingen over de vraag of directe geautomatiseerde grensoverschrijdende toegang tot registers geboden dient te worden aan buitenlandse politieambtenaren. Wij stellen voorop dat dit een politiek en juridisch vraagstuk is dat door de lidstaten van de Raad van Europa en de Europese Unie dient te worden opgelost. 


\section{Niet per definitie ongebinderde grensoverschrijdende toogang}

Het uitgangspunt is dat wij een instrumentalistische kijk op het recht afwijzen, waarbij het impliciete verbod op grensoverschrijdende toegang als obstakel voor de grensregionale opsporingspraktijk wordt gezien. De nationale en internationale wetgever heeft zich tot op heden niet expliciet uitgesproken over de ratio achter dit impliciete verbod. Het opsporingsbelang van een effectieve opsporing van de grensoverschrijdende criminaliteit in de Europese grensregio's dient onzes inziens zorgvuldig te worden afgewogen tegen het recht op de bescherming van de persoonlijke levenssfeer van de betrokkenen. Het moge zo zijn dat bepaalde politieregio's die bij de grensregionale gegevensuitwisseling betrokken zijn, van mening zijn dat directe grensoverschrijdende toegang noodzakelijk is voor de grensregionale opsporingspraktijk. Deze observatie is evenwel onvoldoende om tot de invoering van een zo ingrijpende bevoegdheid voor buitenlandse opsporingsambtenaren over te gaan. Wij zijn van mening dat op basis van empirisch onderzoek door het $\mathrm{OM}$ en de nationale gegevensbeschermingsautoriteiten dient te worden vastgesteld in hoeverre de grensregionale opsporingspraktijk daadwerkelijk gehinderd worde door het impliciete verbod op directe grensoverschrijdende toegang door buitenlandse politieambtenaren. Als de grensregionale opsporingspraktijk in aanzienlijke mate wordt gehinderd, dient de mogelijkheid te worden onderzocht om directe grensoverschrijdende toegang voor buitenlandse politieambtenaren tot registers onder voorwaarden mogelijk te maken. Hierbij dient de privacy van de burger evenwel zo goed mogelijk gewaarborgd te blijven. Daarvoor dienen minimumnormen te worden vastgesteld. Dergelijke minimumnormen voor het recht op bescherming van de persoonlijke levenssfeer liggen besloten in de bestaande internationale gegevensbeschermingswetgeving evenals in de besproken algemene beginselen van behoorlijk ICT-gebruik.

\section{Minimumnormen}

Beginselen voor gegevensbescherming zijn neergelegd in het Databeschermingsverdrag van de Raad van Europa ter bescherming van personen met het oog op de geautomatiseerde verwerking van persoonsgegevens (zie subsectie 5.3.1). Het betreft principes die inhouden dat gegevens (1) rechtmatig moeten zijn verkregen, ${ }^{45}$ (2) alleen voor specifieke en legitieme doeleinden mogen worden opgeslagen, (3) evenredig moeten zijn in relatie tot het doel waarvoor zij zijn opgeslagen, en (4) niet langer mogen worden bewaard dan vereist voor het doel waarvoor zij zijn opgeslagen. Het vereiste van doelbinding houdt in dat persoonsgegevens alleen mogen worden gebruikt voor het doel waarvoor zij verzameld zijn. Bij doelbinding hoort logischerwijze een omschrijving van dat doel. Het doel moet welbepaald, uitdrukkelijk omschreven en gerechtvaardigd zijn. Gebruik van de gegevens voor een ander doel is alleen aanvaardbaar voor zover dat gebruik niet onver-

435. Dit dient internationaal gecontroleerd te worden door de gegevensbeschermingsautoriteiten, her $\mathrm{OM}$ en de nationale rechter. 
enigbaar is met het doel waarvoor de gegevens zijn verzameld. Gevoelige persoonsgegevens (ras, politieke opvatting, geloof, en dergelijke) mogen niet geautomatiseerd worden verwerkt, behalve wanneer de nationale wetgeving voorziet in de nodige waarborgen.

Afwijking van het principe van doelbinding is mogelijk indien dit noodzakelijk is in een democratische samenleving in het belang van (onder meer) de bestrijding van strafbare feiten. Artikel 7 Databeschermingsverdrag vereist passende veiligheidsmaatregelen om in geautomatiseerde bestanden opgeslagen persoonsgegevens te beschermen tegen toevallige of ongeoorloofde vernieling, toevallig verlies alsmede tegen ongeoorloofde toegang, wijziging of verstrekking. Het betreft maatregelen tegen menselijke en niet-menselijke factoren. Deze eisen zijn onverkort van toepassing bij een mogelijke invoering van grensoverschrijdende directe toegang tot registers. Het uitgangspunt van artikel 12

Databeschermingsverdrag is dat er vrij gegevensverkeer dient te bestaan tussen lidstaten van het verdrag en met staten die een gelijkwaardige gegevensbescherming kunnen garanderen. Er kan een uitzondering worden gemaakt voor bepaalde categorieën van gegevens waarvoor de nationale wetgeving een speciale behandeling voorschrijft.

Het Databeschermingsverdrag geeft uitwerking aan artikel 8 EVRM op het terrein van de gegevensverwerking. Voor de uitleg van het verdrag en voor de uitwerking van bepaalde begrippen in het verdrag, is de uitleg die gegeven wordt aan artikel 8 EVRM van belang (zie subsectie 5.3.4).

Artikel 8 EVRM en de daarop gebaseerde jurisprudentie stellen eisen aan de kwaliteit van de mogelijke wettelijke regeling. Deze eisen houden in dat de wettelijke regeling voor de burger voldoende toegankelijk en kenbaar moet zijn. Dit brengt met zich mee dat de regeling voldoende precies moet zijn geformuleerd, zodat de burger vooraf kan weten onder welke omstandigheden en voorwaarden persoonsgegevens mogen worden verwerkt. De regeling moet bovendien waarborgen bieden tegen willekeurige inmenging van de overheid in het persoonlijke leven van de burger en tegen misbruik van de bevoegdheid. ${ }^{436}$ Dit betekent dat de wet moet omschrijven in welke gevallen en voor welke doelen persoonsgegevens verwerkt mogen worden. Ook de aanwijzing van de bevoegde autoriteit en voorzieningen voor transparantie en controleerbaarheid, zoals voorschriften voor verslaglegging en registratie zijn van belang.

Een heel belangrijk criterium dat uit het Databeschermingsverdrag voortvloeit is dat de verwerking van gegevens door de politie noodzakelijk moet zijn voor een goede uitvoering van de politietaak. Dit criterium sluit aan bij het criterium in artikel 8 lid 2 van het Land). 
EVRM. Het houdt in dat beperking van het recht op eerbiediging van de persoonlijke levenssfeer alleen is toegestaan voor zover dit 'in een democratische samenleving noodzakelijk is' in het belang van enkele met name genoemde doelen, waaronder het voorkomen van strafbare feiten. Het noodzaakcriterium wordt in de Straatsburgse rechtspraak nader ingevuld met het vereiste van een 'pressing social need' (er moet een dringende maatschappelijke behoefte bestaan om het legitieme doel te vervullen). Dit begrip wordt nader ingevuld door de vereisten van proportionaliteit (staat het belang van de verwerking in verhouding tot de beperking van de persoonlijke levenssfeer) en subsidiariteit (zijn andere, minder in de persoonlijke levenssfeer van de burger ingrijpende maatregelen redelijkerwijs mogelijk en voldoende doeltreffend). De beoordeling van de noodzakelijkheid tot uitoefening van een bevoegdheid als de onderhavige brengt een beoordelingsmarge met zich mee, die ergens ligt tussen 'onmisbaar' als bovengrens en 'normaal', 'nuttig', 'redelijk' en 'wenselijk' als ondergrens. Wij kunnen stellen dat vooralsnog de 'pressing social need' voor de invoering van directe geautomatiseerde grensoverschrijdende toegang tot registers voor buitenlandse politieambtenaren niet is komen vast te staan.

Verder is de Aanbeveling R (87) 15 van de Raad van Europa van belang (zie subsectie 5.3.2). Directe (on line) toegang tot een bestand is volgens het vijfde beginsel van de Aanbeveling slechts toegestaan in overeenstemming met nationale wetgeving die de beginselen 1 tot en met 6 van Aanbeveling R (87) 15 respecteert (zie subsectie 5.3.2 voor alle beginselen). Als de invoering van directe grensoverschrijdende toegang tot registers wordt overwogen, dienen de gegevensbeschermingsautoriteiten op grond van het eerste beginsel van de Aanbeveling vooraf te worden geraadpleegd. Een dergelijk nieuw technisch middel voor gegevensverwerking mag pas worden ingevoerd als alle redelijke maatregelen zijn genomen om te bevorderen dat het gebruik van dat middel geschiedt in de geest van de bestaande gegevensbeschermingswetgeving. Op grond van het vierde beginsel van de Aanbeveling mogen de betreffende persoonsgegevens alleen voor politiedoeleinden (en dus niet voor bewijsdoeleinden) worden gebruikt. De doorgifte van gegevens aan het buitenland mag niet gepaard gaan met een vermindering aan gegevensbescherming. Als de gegevens worden doorgegeven aan landen met een vergelijkbaar gegevensbeschermingsniveau (zoals België, Duitsland en Frankrijk) wordt aan deze eis voldaan. Wanneer de gegevens echter worden doorgegeven aan landen zonder adequate gegevensbescherming, zullen ad hoc afspraken gemaakt moeten worden over de na te leven voorwaarden. Op grond van het vijfde beginsel geldt vervolgens dat verzoeken tot het verstrekken van gegevens in beginsel dienen aan te geven wie de verzoekende instantie of persoon is, welke redenen deze voor het verzoek heeft en wat met de gegevens wordt beoogd. Voor zover mogelijk dient uiterlijk ten tijde van de verstrekking de deugdelijkheid van de gegevens te worden geverifieerd. Zo mogelijk dienen bij elke verstrekking rechterlijke uitspraken en besluiten tot ontslag van rechtsvervolging te worden opgegeven. Tevens dienen gegevens die berusten op opinies of persoonlijke beoordelingen vóór 
de verstrekking aan de bron te worden gecontroleerd. Daarbij dient de mate van nauwkeurigheid en betrouwbaarheid van de gegevens te worden aangegeven. Wanneer wordt geconstateerd dat gegevens niet langer juist zijn of up-to-date zijn, mogen zij niet worden verstrekt. Indien toch niet langer juiste of niet bijgewerkte gegevens verstrekt zijn, dient de verstrekkende instantie zoveel mogelijk alle ontvangers erop attent te maken dat de gegevens niet langer aan de werkelijkheid beantwoorden. Deze vereisten blijven bij een mogelijke invoering van de bevoegdheid tot directe grensoverschrijdende toegang onverkort van toepassing.

Een heel belangrijke eis van het vijfde beginsel is dat gegevens die verstrekt zijn aan buitenlandse instanties (of aan overheidslichamen en particulieren) voor geen ander doel gebruikt mogen worden dan aangegeven in het verzoek om inlichtingen. Gebruik van de gegevens voor andere doeleinden moet afhankelijk worden gesteld van goedkeuring door de verstrekkende instantie. Dit is de reeds genoemde eis van doelbinding of beperkt gebruik die onverkort van toepassing blifft indien er sprake zou zijn van directe geautomatiseerde grensoverschrijdende toegang door buitenlandse opsporingsambtenaren.

Op grond van het zesde beginsel dient het recht van toegang tot de eigen gegevens van de betrokkene gegarandeerd te blijven.

Er dient bij de mogelijke invoering van een bevoegdheid tot directe grensoverschrijdende toegang tot registers ook acht te worden geslagen op de in subsectie 9.6 .2 behandelde algemene beginselen van behoorlijk ICT-gebruik: beschikbaarheid, vertrouwelijkheid (exclusiviteit), integriteit, authenticiteit, flexibiliteit en transparantie.

\section{Wederzijdse erkenning in EU-verband}

De mogelijke invoering van een bevoegdheid tot directe grensoverschrijdende toegang van buitenlandse politieambtenaren tot registers raakt aan de toenemende betekenis van de wederzijdse erkenning van de nationale rechtsstelsels in EU-verband. De Europese Raad bijeen in het Finse Tampere op 15 en 16 oktober $1999^{437}$ heeft de wederzijdse erkenning van gerechtelijke beslissingen ingeschreven als hoeksteen van de gerechtelijke samenwerking. Het Europese aanhoudingsmandaat (European Arrest Warrant; goedgekeurd door de Europese Raad bijeen in Laken in december 2001) dat het toepassingsgebied van het nationale aanhoudingsmandaat uitbreidt tot de totaliteit van het grondgebied van de EU, vormt een belangrijk precedent voor de wederzijdse erkenning. Een tweede precedent ten faveure van wederzijdse erkenning vormt een kaderbesluit dat in februari 2002 werd goedgekeurd betreffende de bevriezing van vermogensbestand- 
delen. ${ }^{45}$ De vraag van een rechter in lidstaat $\mathrm{A}$ om goederen te bevriezen in lidstaat B gebeurt via een eenvoudig certificaat. In de Raad wordt er voorts gewerkt aan cen kaderbestuit voor de wederzijdse erkenning van geldboeten. Het huidige lerse voorzitterschap (eerste helft 2004) legt de nadruk op de samenwerking op het gebied van confiscatie. Verder kunnen wij ook wijzen op het in voorbereiding zijnde Europees bewijsverkrijgingsbevel (zie subsectie 7.8.6). Grondslag voor de genoemde precedenten voor de wederzijdse erkenning van strafrechtelijke beslissingen voor de Europese lidstaten is de Derde Pijler van de Europese Unie (zie sectie 5.2). Dit systeem van tendensen tot het op elkaar afstemmen van regels voor opsporing en vervolging kan worden benoemd als 'formele harmonisatic'. 499 De strafprocesrechtelijke autonomie van de lidstaten wordt gerespecteerd, maar die vormt tegelijkertijd geen beletsel voor een zo onbelemmerd mogelijke samenwerking. ${ }^{40}$ Ten aanzien van de staten die rechtshulpverdragen sluiten geldt het vertrouwensbeginsel als basis van de wederzijdse erkenning. Het vertrouwensbeginsel houdt in dat de betrokken staten er wederzijds op moeten kunnen vertrouwen dat zij zich aan de beginselen van een eerlijk proces houden. Slechts in gevallen van een flagrante rechtsschending door de staat die om rechtshulp verzoekt, zal het EVRM onder omstandigheden kunnen worden ingeroepen als grondslag voor de weigering van het verzoek. ${ }^{41}$

Dit ontslaat de rechtshulpverlenende staat evenwel niet van het onderzoek naar de vraag of rechten en vrijheden effectief beschermd worden in de andere staat. ${ }^{442}$

\section{Wederzijdse erkenning en directe toegang}

Als wij het beginsel van de wederzijdse erkenning en het vertrouwensbeginsel toepassen op het vraagstuk van de directe grensoverschrijdende toegang tot registers, zou dit kunnen betekenen dat bij invoering van deze bevoegdheid bijvoorbeeld Poolse en wellicht later ook Turkse politieambtenaren daarvan gebruik zouden kunnen maken. Vanaf het moment dat deze landen deel uitmaken van de EU (Polen vanaf mei 2004) verdienen deze landen ook wederzijdse erkenning en vertrouwen, omdat deze staten het EVRM ondertekend hebben en verder akkoord zijn gegaan met alle toetredingsvoorwaarden, ook op strafprocesrechtelijk en privacyrechtelijk terrein. Op dit moment zijn er politici

438. Kaderbesluit van de Raad van 26 juni 2001 inzake het witwassen van geld, de identificatie, opsporing, bevriezing, inbeslagneming en confiscatie van hulpmiddelen en van opbrengsten van misdrijven (2001/500/JBZ), PbEG 2001, L182, 5 juli 2001.

439. Sjöcrona \& Orie 2002, p. 336. In de gebruikelijke bespreking van het EU-recht wordt evenwel een onderscheid gemaakt tussen harmonisatie en wederzijdse erkenning. Wederzijdse erkenning aanvaardt het recht van de andere staat zoals het is maar verplicht de aangezochte staat vertrouwen te hebben dat het er in de verzoekende staat behoorlijk aan toe gaat.

440. Sjöcrona \& Orie 2002, p. 344.

441. Vgl. HR 9 april 1991, NJ 1991, 696.

442. Vgl. Sjöcrona \& Orie 2002, p. 208. De HR laat zoals gezegd minder ruimte voor bezwaren ontleend aan het EVRM. 
die menen dat in dergelijke gevallen toch aanleiding kan bestaan voor de vrees tot misbruik van een dergelijke vergaande bevoegdheid. Zo leert de ervaring uit de politiële praktijk dat de aan de uitgewisselde informatie verbonden kwalificatie 'uitsluitend voor politiedoeleinden bestemd' kan worden misbruikt om het eigenlijke rechtshulpkarakter van politiële samenwerking te verhullen. ${ }^{43}$ De ontvangende autoriteiten gebruiken de verschafte informatie ondanks een dergelijke kwalificatie toch soms als bewijs in een strafzaak. ${ }^{44}$ Gebruik voor politieke en andere oneigenlijke doeleinden van de informatie die aldus beschikbaar komt, vormt wellicht ook een belangrijk gevaar. Wij zijn evenwel van mening dat agenttechnologie (intelligent handelende software die bepaalde taken van de mens overneemt) ervoor kan zorgen dat dergelijke vormen van misbruik uitgebannen worden. De genoemde minimumnormen voor de bescherming van het recht op de persoonlijke levenssfeer van de betrokkenen dienen evenwel onverkort te worden gehandhaafd. Beveiligingsmaatregelen voor de directe grensoverschrijdende toegang en controle op misbruik van de bevoegdheid door middel van informatietechnologie ter ondersteuning van menselijke controle is cruciaal bij het invoeren van een zo vergaande bevoegdheid. Speciaal geautoriseerde opsporingsambtenaren dienen enkel toegang te krijgen tot de gegevens waartoe zij rechtmatig toegang mogen hebben op grond van het nationale en internationale gegevensbeschermingsrecht. Hergebruik van de gegevens evenals misbruik van de gegevens dient uitgesloten te zijn. Thans staat zoals gezegd de noodzaak tot invoering van de bevoegdheid tot grensoverschrijdende toegang tot registers door buitenlandse opsporingsambtenaren nog niet vast. Hiervoor dienen ten minste de afwegingen gemaakt te worden die in deze sectie zijn beschreven. Het is duidelijk dat de grensregionale politiële gegevensuitwisseling in Europa vanwege de nieuwe internationale informatiemarkt voor belangrijke uitdagingen staat. 


\section{Summary}

The setting and aim of the study

The research takes stock of the legal standard for the connection of several national police computer networks. Moreover, the cross-border use of (multimedia) databases over an international police Intranet is investigated.

The main research question is whether it is possible to develop a legal framework in which a secured connection can be established between national police networks within the framework of the international informative police co-openation in the bonder regions, in such a way that mutual queries of (multimedia) databases become possible, in compliance with the national and international legislation.

The research consists of three parts.

Firstly, an inventory has been made of (1) the relevant legal frameworks, (2) the legal bottlenecks that may arise out of these frameworks, and (3) the organisational implications in The Netherlands, Belgium, and Germany.

Secondly, an adequate proposal for a legal framework has been developed to support a reliable connection of national Intranets, which guarantees the privacy.

Finally, an inventory has been made of the technical achievements of the computer environment PALMA/EMMI.

The main research question is supplemented with three additional reseach questions. These questions fall fully within the scope of the main research question. They deal however with three specific subjects of the main research question. It entails the following three research questions.

1. "In what way are soft police data legally protected in the Dutch, Belgian, and German legal order, and how should they be treated within the framework of the police information exchange in the border areas?" (The question is answered in Chapter 5 and in particular subsection 5.6 .3 of the study). 
2. "Which legal choice should the Council of Europe and the European Union make with respect to the problem of direct automated cross-border access of foreign lawenforcement officers to national (police) databases and computer networks, seen in the light of the international legal developments on digital expertise?" (The question is answered in Chapter 7 of the study).

3. "Which are the legal boundaries between the activities of Europol and the activities of the IRCs?" (The question is answered in Chapter 8 of the study).

\section{The scope of the study}

The increasing need for international exchange of police data within the European border regions has been a great stimulus for this study. In particular, the opening of the European inner borders since 1992 and the rise in cross-border crime rates resulting from it have encouraged the international exchange of information by computer communication.

In order to realise a quick and effective information exchange several international contact points were established along the various borders of The Netherlands, Belgium, and Germany. These contact points are called International Legal Assistance Centres (in Dutch: Internationale Rechtshulp Centra, IRCs).

In the Euregion Aachen-Liege-Maastricht, two major projects were conducted in the years 1995 to 1998: PALMA and EMMI (PALMA stands for Police connections Aachen Liège MAastricht and EMMI stands for Euregional MultiMedia Information exchange). These projects and their positive results have led to the present study.

After PALMA and EMMI, i.e. around 2000, the state of affairs was the existence of an EMMI environment in which an automated and secured exchange of police data could take place. The essence was an international, closed police Intranet, which operated separately from other networks. The computer network is closed because only authorised police officials have access to it. The network is (obviously) separate because a direct connection with other national networks may not be realised for political and legal reasons. The present study deals in particular with the question how a connection of the EMMI environment with the national police networks of The Netherlands, Belgium, and Germany should be arranged in order to comply with the national and international legal requirements. The EMMI environment has been designed to work within the framework of the Schengen legislation, the result of which is examined in our study. Moreover, we focus on the compatibility of the environment with the national legislations and regulations of The Netherlands, Belgium, and Germany. 
Within the EMMI environment a distinction has been made between two types of communication: (1) direct multimedia communication and (2) communication via a multimedia kiosk.

1. Multimedia communication takes place between two (or more) identities (person or authority). For this type of communication the so-called PALMA software is used. Personal data are exchanged between the national and foreign IRCs via templatebased and secured e-mail facilities. All exchanges are registered in so-called registration databases and a central logdatabase. Furthermore, video conferencing and filetransfer facilities are provided.

2. The multimedia kiosk contains all kinds of information which is not personal data, which may be exchanged between the national and foreign IRCs via electronic publication by means of browser software. In the future this browser software could be used to establish a connection with all the available databases within the national police networks. Whether this is possible depends mainly on the legal requirements for such a connection.

In the thesis the following approach has been followed after the introduction in Chapter 1.

Chapter 2 describes how data are exchanged in the police practice in the border regions at this moment. Among other things, the organisations and agencies involved are discussed. In Chapter 3 the PALMA concept is described and in Chapter 4 the EMMI concept.

After the description of the usual practice, Chapter 5 investigates how the mutual legal assistence in criminal affairs in The Netherlands, Belgium, and Germany is regulated. A distinction is made between judicial and police legal assistence. The last type of legal assistence is examined in detail. The international legislation on the exchange of police data and the various national legislations and instructions of The Netherlands, Belgium, and Germany are discussed. We also describe the way soft data should be handled within the framework of the police information exchange in the border areas. Soft data are nonconclusive and non-established data, which may not yet be used for evidentiary purposes.

Chapter 6 describes the connection of data as seen from two essentially distinct angles: a technical one and a legal one. It appears that the legislator merely has envisaged the simple connection of databases via computer matching or computer profiling. However, modern techniques give rise to several other ways of tracking down relevant information. Legally speaking many obstacles concerning connection still have to be incorporated into regulations. The chapter formulates multiple proposals with respect to this issue. 
Chapter 7 leads us into the domain of digital expertise of the police conducting criminal investigation throughout the physical borders of countries and the virtual borders of cyberspace. We discuss the Cybercrime Convention from 2001 and the EU Agreement on mutual legal assistance in criminal matters from 2000. This adjacent research domain learns us about the necessity (or at least the wish of certain European police services) to draft adequate legislation for the central problem of the direct cross-border access of foreign police officers to national computer networks, files, and databases.

Chapter 8 deals with the legal boundaries between the activities of Europol and the activities of the IRCs.

In Chapter 9 conclusions are formulated through a synthesis of the existing practice and the legal standard. We consider especially what is legally desirable as well as technically realisable. The focus is on an adequate legal framework for a reliable connection of the national police computer networks of The Netherlands, Belgium, and Germany. The main issue is guaranteeing the citizen's privacy.

\section{Main results}

The main results of our study are summarised below.

- For the international exchange of police data, in particular the following Articles have to be taken into account: the Articles 39, 46, and 126-130 SUO, the Article 552i Sv, and the Articles 13 and 17 BPolr.

- The international law allows connection of police data provided that a legal basis in the national law exists or that the national data protection authorities have given their consent. In The Netherlands a legal basis for the connection of police data is incorporated in domestic law. In Belgium and Germany such clear connection rules still have to be incorporated in the privacy legislation.

- The connection of data, as legally envisaged so far, is not the main legal bottleneck for the informative police co-operation in the border areas. In addition to simple connections of data the legislator should focus on other existing connection techniques such as data mining.

- A predominant legal problem is direct automated access to police registers, which is prohibited for foreign police officials as well as for the national Public Prosecution. The latter group has the duty to control the exchange of police data and the IRP register (the registration database) under the Article 552i Sv.

- At this moment, mutual cross-border queries of (multimedia) databases in national police networks are only possible through human intervention. Then the control is in compliance with the national and international legislation. To achieve a connection without human intervention, e.g., only with human inspection afterwards, the national (and preferably also international) legislation has to be revised. Until then human intervention and human control by the members of the IRCs remain strict 
legal demands for the international exchange of police data. It should be stressed that these strict legal demands do not fully apply with respect to direct automated access to registers that fall under common privacy regulations.

- EMMI fulfils the needs of an effective informative police co-operation. The implemented automated information exchange has the following benefits:

- easier access to cross-border information;

- standardised information exchange;

- faster exchange of diverse (multimedia) information;

- automated registration with management facilities;

- maintaining, formalising, and controlling informal contacts; and

- a better understanding of cultural and organisational differences.

- The implicit Dutch prohibition of direct automated cross-border access of foreign law-enforcement officers to national police registers, databases, and police networks, as well as the Belgian and German policy in this respect, make a physical link of the EMMI environment with the national police computer networks involved impossible for the moment.

- There are four possible ways towards an adequate regulation of the problem of direct access: via (a) the Council of Europe, (b) the European Union, (c) covenants and agreements in the border areas, and (d) regulation in the national legislation of the states involved.

- Only in the Dutch legal order soft data have a definite legal protection regime within Article $5 \mathrm{a}$ and $\$ 3 \mathrm{a}$ WPolr (Police registers Act). The storage terms of soft data are only competently regulated within The Netherlands.

- Soft, non-conclusive and non-established data require supervision of the Public Prosecutor before they are internationally exchanged with police services in the border areas. For the moment, such supervision is only properly regulated in Dutch legislation; not in Belgian and German legislation.

- The activities of the IRCs provide a new 'co-operation market' for the information exchange in the border regions of the European Union. This entails the need for a swift cross-border information exchange for the 'ordinary' police work, being maintaining order, traffic control, and the so-called smaller crime. The international information exchange network EMMI is at present being used for this purpose by twenty police forces in the border regions of four countries: The Netherlands, Belgium, Germany, and France. The international police data exchange in the border regions takes place within the legal boundaries of international legislation and covenants, which allow under certain conditions and legal safeguards the direct exchange of data between the IRCs of the states involved.

- Europol is a European body for the refinement and exchange of data, which may contribute to preventing and fighting certain forms of cross-border organised crime. The information exchange takes place on a central national level via national units and Europol Liaison Officers (ELOs). Europol is competent to support certain law- 
enforcement activities, which are laid down in the Europol mandate, if there exists an organised criminal structure and two or more EU member states are involved.

- On the basis of the international legal principle that the registrations of the IRCs may not constitute a new independent source of information, the data, which are stored on the local registration databases and the central log database of PALMA, may not be used for the refinement or the exchange of data via Europol.

- On the basis of Article 6 section 2 of the Europol Convention, a link between the EMMI/PALMA environment and Europol is not allowed.

\section{Leading recommendations}

The study formulates twenty-nine implicit recommendations for both the national and international legislators with respect to the international informative police co-operation between the border areas of The Netherlands, Belgium, and Germany. We also give one specific recommendation with respect to the establishment of an EMMI management organisation. The following fourteen implicit recommendations are the most important ones.

- The rationale behind the existing regulation of direct automated access to police registers has to be reconsidered.

- Legal solutions for direct automated access and for legal connection have to be dealt with by: (1) the Council of Europe, (2) the European Union, and (3) the national leg. islator. The latter has to adapt Article 17, paragraph 1 BPolr.

- According to Article 6, paragraph 2 WPolr the IRP regulations should control the connection of data when taken from the IRP register and any other register.

- Article 8, paragraph 2 of the IRP regulations states that the data stored in the registration database must be removed after a period of ten years. To ensure this both technical and organisational measures have to be taken.

- The unofficial communication lines should also be registered within the EMMI environment.

- The legislator has to take into account that the registration databases and the central logdatabase have become an autonomous source of information.

- The legal notion of connection has to be adjusted in such a way that it complies with the existing modern connection techniques.

- When creating standards for a reliable connection, the legislator should obey the common principles of appropriate ICT use.

- We strongly recommend the constitution of unambiguous legal norms and transparent formal procedures with respect to the core legal problem of direct automated access to data, files, and computer systems. Preferably, this task should be executed on the level of the Council of Europe and the European Union. National legislation could then be employed to regulate the set of norms in greater detail. The Cybercrime Treaty of 2001 and the EU Agreement on mutual assistance in criminal matters of 
2000 may be a source of inspiration in order to come to internationally acceptable solutions for this legal problem.

- The legislators of the countries involved in the international exchange of police data need to express formally whether members of the Public Prosecutor and foreign police officers should have direct automated access to certain police registers. If direct automated access is given, the legal and technological preconditions need to be determined too.

- The present bilateral treaties and covenants, which are in force between The Netherlands, Belgium, and Germany, do neither contain a regulation on the direct automated access by a foreign police officer, nor do they contain anything on the linking of data, files or computer systems. Hence, the parties involved in the international police data exchange need to reach an agreement on these points, preferably by means of a bilateral or trilateral treaty or covenant. Perhaps, in such a treaty or covenant agreements could be made whether, from a legal point of view, the linking of exchanged (personal) data should be possible, and if so, to what extent. In such a treaty or covenant respect for the finality principle will continue to play a crucial part. One might consider that the use of a treaty to achieve the aforementioned purposes is rather severe, since a treaty should only be used if all other means fail.

- Within the covenants and agreements in the border areas between The Netherlands, Belgium, and Germany, on the basis of Article 39 sections 4 and 5 and Article $46 \mathrm{sec}-$ tion 2 of the Schengen Executive Agreement, more tuning should take place between the completely different national legislation with respect to soft data.

- Belgium and Germany should constitute an adequate legal framework for handling soft data (including the storage terms) and the (international) exchange of soft data.

- The European Council and the Council of Ministers of the European Union should stimulate that Europol and the IRCs are informed about each others activities, the common grounds of their activities, and the legal boundaries between both bodies. 



\section{Appendix A: De Duitse politiële \\ organisatiestructuur}

De Duitse politiēle organisatiestructuur

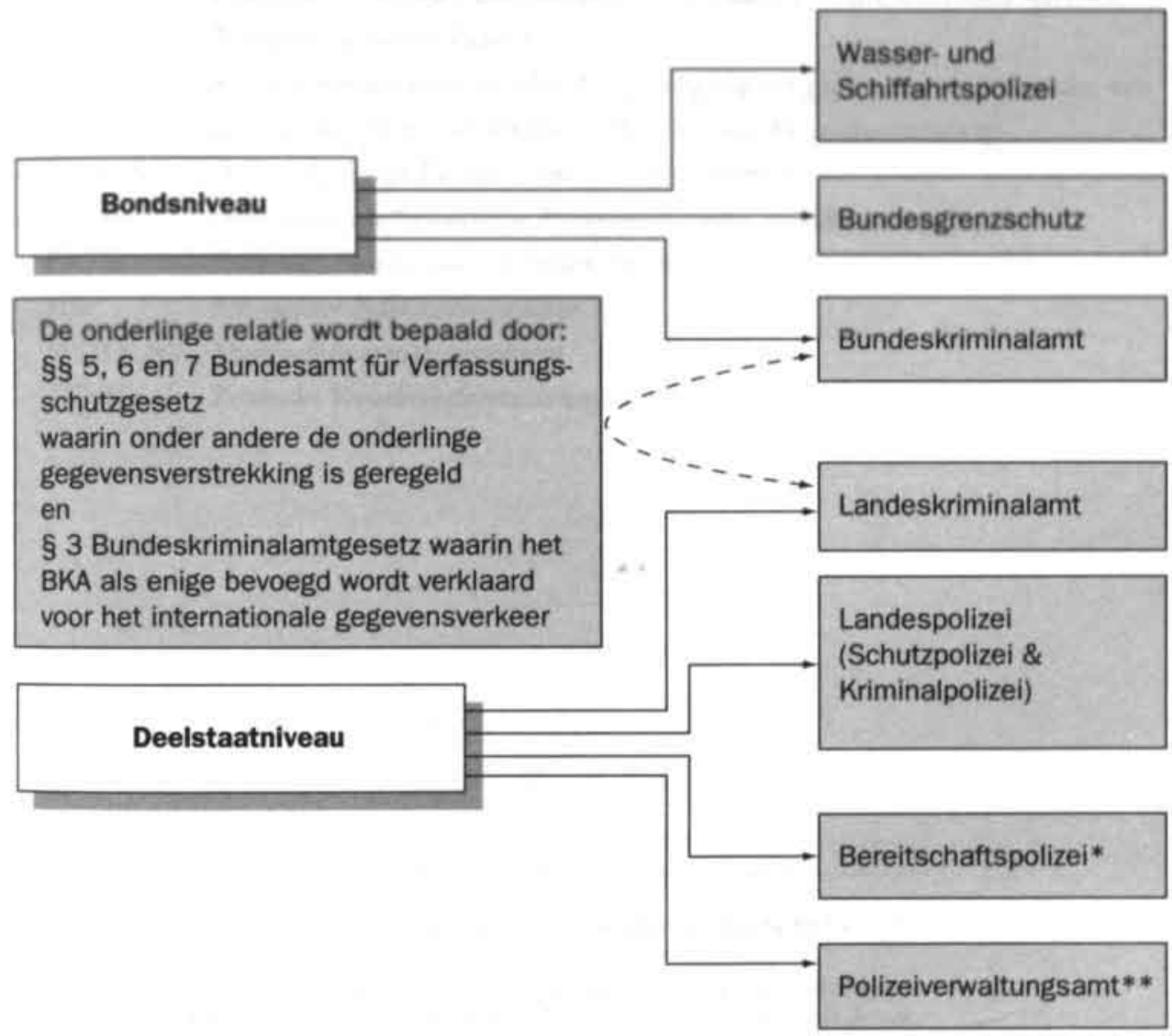

(Ontleend aan Verbeek, Claus, Van den Eshof \& Van den Herik 2002) Het schema zoals het hier is weergegeven is niet dekkend. Sommige deelstaten hebben bijvoorbeeld ook een eigen grenspolitie, maar dergelijke bijzonderheden zijn hier niet relevant.

("Mobiele Eenheid * De administratieve organisatie ten behoeve van de politie) 



\section{Appendix B: Duitse politieregisters}

Kort overzicht van enkele voorhanden zijnde (politie)registers in Duitsland 4 4s

- AZR: Ausländerzentnalrogister (centrale registratie van buitenlanders die niet slechts tijdelijk binnen de Bondsrepubliek Duitsland verblijven $)^{4+6}$

- CEBIUS: Computer, Einsates, Bearbeitungs, Informations und Untentätzungsystem

- INPOL: Informationsystem Polizei

- KBA: Knafffahrtbundesamt (te Flensburg; toegang tot gegevens van de houder van een motorvoertuig in verband gebracht met dat motorvoertuig)

- PALMA: Polizei Auskunft Lüttich-Maastricht-Aachen

- PIKAs: Polizeiliches Informations- Kommunikations- und Ausuertungsystem

- PIOS: Personen, Institutionen, Objekse, Sachen ${ }^{40}$

- SIS: $\quad$ Schengener Informationsystem

- SPUDOK: Spurendokumentationssystem

- ZEVIS: Zentrales Verkehrsinformationssystem

445. Dit overzicht is mede aangeleverd door Dhr. E.-J. Zwingmann, hoofd RVST Aachen, waarvoor onze dank.

446. Dit register wordt gevoerd op basis van het Geserz über das Ausländerzentralregister (AZRG), wet van 2 september 1994, BGBl 1994, 2265. Bij deze wet hoort de volgende uitvoeringsregeling: Verordnung zur Durchführung des Gesetzes ïber das Ausländerzentralregister, verordening van 17 mei 1995, BGBl 1995, nr. 695. laatstelijk gewijzigd 9 januari 2002. Voor de politie is dit register van belang voor zover gegevens verstrekt kunnen worden op basis van \$16 AZRG jo. \$2 lid 2, nr. 6 en 7 AZRG.

447. Dit register is een fahndungregister (opsporingsregister) specifiek voor politicke misdrijven. Toegang tot dit register wordt slechts verleend indien men bijzondere bevoegdheden heeft, vergelijkbaar met de in Nederland opererende Regionale Inlichtingendienst (RID). 



\section{Appendix C: Lijst zelfstandige politiële gegevensuitwisseling België}

\section{Bijlage A: lijst met gegevens die autonoom en zelfstandig door de Beigische politie mogen worden uitgewisseld}

\begin{tabular}{|c|c|c|}
\hline Soort informatie & $\begin{array}{l}\text { Zelfstandige } \\
\text { doorglfte }\end{array}$ & Opmerkingen \\
\hline \multicolumn{3}{|c|}{ 1. Informatie over natuurlijke personen } \\
\hline $\begin{array}{l}1.1 \text { Naam, geboorte-, voor-, roep-, bijnamen } \\
\text { aliassen }\end{array}$ & Ja & \\
\hline 1.2 Geboorteplaats en -datum & Ja & \\
\hline 1.3 Geslacht & Ja & \\
\hline 1.4 Burgerlijke staat & Ja & \\
\hline 1.5 Nationaliteit/verblijfstatus & Ja & \\
\hline 1.6 Beroep & $\mathrm{Ja}=$ & \\
\hline $\begin{array}{l}1.7 \text { Gepubliceerde telefoon-, fax-en GSM- } \\
\text { nummers }\end{array}$ & Ja & \\
\hline $\begin{array}{l}1.8 \text { Niet gepubliceerde telefoon-, fax-en } \\
\text { GSM-nummers }\end{array}$ & Neen & \\
\hline 1.9 Adres en woon-/verblijfplaats & Ja & \\
\hline 1.10 Nummer rijksregister & Neen & \\
\hline $\begin{array}{l}\text { 1.11 Persoonsgegevens inzake verdachten } \\
\text { of gekende personen* }\end{array}$ & Ja & $\begin{array}{l}\text { Met uitsluiting van de } \\
\text { gegevens openbare } \\
\text { orde, veiligheid van de } \\
\text { staat en de dienst } \\
\text { vreemdelingenzaken }\end{array}$ \\
\hline
\end{tabular}




\begin{tabular}{|c|c|c|}
\hline Soort informatie & $\begin{array}{l}\text { Zeifstandige } \\
\text { doorglfte }\end{array}$ & Opmerkingen \\
\hline $\begin{array}{l}1.12 \text { Relatie tussen gekende personen, fei- } \\
\text { ten, verdachte plaatsen en voorwerpen }\end{array}$ & $\begin{array}{l}\text { Ja, beperkt tot de } \\
\text { gegevens opgenomen } \\
\text { in manuele of geauto- } \\
\text { matiseerde politie- } \\
\text { bestanden }\end{array}$ & 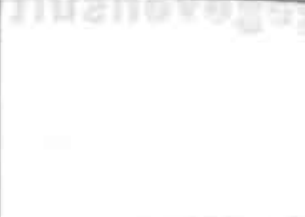 \\
\hline 1.13 Penitentiaire gegevens ** & Ja & \\
\hline 1.14 Antecedenten & $\begin{array}{l}\text { Ja, voor zover het } \\
\text { gegevens betreft } \\
\text { beschikbaar in } \\
\text { manuele of } \\
\text { geautomatiseerde } \\
\text { politiebestanden }\end{array}$ & 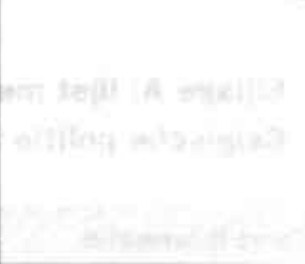 \\
\hline 1.15 Veroordelingen & Neen & . \\
\hline 1.16 Vermiste personen & Ja & \\
\hline $\begin{array}{l}\text { 1.17 Niet geidentificeerde stoffelijke over- } \\
\text { schotten }\end{array}$ & Ja & \\
\hline \multicolumn{3}{|c|}{ 2. Rechtspersonen } \\
\hline 2.1 Benaming/handelsnamen & Ja & \\
\hline 2.2 Rechtsvorm & Ja & \\
\hline $\begin{array}{l}2.3 \text { Zetel, exploitatieadres, vestigingsadres- } \\
\text { sen }\end{array}$ & Ja & \\
\hline 2.4 Datum vestiging & Ja & \\
\hline 2.5 Beheerders, bestuurders, vennoten & Ja & \\
\hline $\begin{array}{l}2.6 \text { Ingeschreven aantal werkzame perso- } \\
\text { nen }\end{array}$ & Ja & \\
\hline $\begin{array}{l}2.7 \text { Maatschappelijk doel/bedrijfsactivitei- } \\
\text { ten/bedrijfsomschrijving }\end{array}$ & Ja & \\
\hline 2.8 Bedrijfsbalansen & $\begin{array}{l}\text { Ja, voor zover gepubli- } \\
\text { ceerd }\end{array}$ & 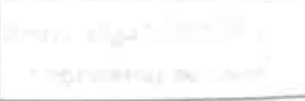 \\
\hline
\end{tabular}




\begin{tabular}{|c|c|c|}
\hline Soort informatie & $\begin{array}{l}\text { Zelfstandige } \\
\text { doorgifte }\end{array}$ & Opmerkingten \\
\hline \multicolumn{3}{|c|}{ 3. Voorwerpen - voertuigen uitgezonderd } \\
\hline 3.1 Geseinde voorwerpen & 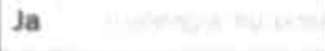 & 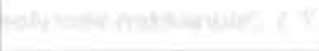 \\
\hline $\begin{array}{l}3.2 \text { Voorwerpen gelieerd aan personen, fei- } \\
\text { ten of verdachte plaatsen }\end{array}$ & $\begin{array}{l}\text { Ja, voor zover beschik. } \\
\text { baar in manuele of } \\
\text { geautomatiseerde poll- } \\
\text { tiebestanden }\end{array}$ & 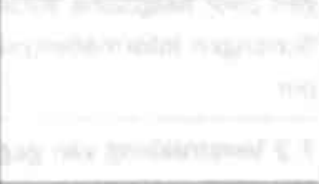 \\
\hline 3.3 Vertoren voorwerpen & Ja & 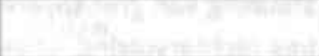 \\
\hline 3.4 Gegevens uit het wapenregister & Ja & 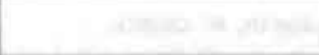 \\
\hline \multicolumn{3}{|c|}{ 4. Feiten } \\
\hline 4.1 Plaats en tijdselement & Ja & \\
\hline 4.2 Modus operandi & Ja & 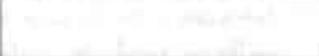 \\
\hline $\begin{array}{l}\text { 4.3 Relaties feiten, personen, plaatsen, } \\
\text { sporen, voorwerpen }\end{array}$ & $\begin{array}{l}\text { Ja, voor zover beschik- } \\
\text { baar in geautomati- } \\
\text { seerde of manuele } \\
\text { politiebestanden }\end{array}$ & \\
\hline \multicolumn{3}{|c|}{ 5. Voertuigen } \\
\hline 5.1 Categorie, merk, type & Ja & \\
\hline 5.2 Kenmerken & Ja & \\
\hline 5.3 Chassisnummer & Ja & \\
\hline 5.4 Relaties met personen & $\begin{array}{l}\text { Ja, tenzij beschermde } \\
\text { nummerplaat }\end{array}$ & \\
\hline 5.5 Relaties met feiten & Ja & \\
\hline 5.6 Relaties met plaatsen & Ja & \\
\hline \multicolumn{3}{|c|}{ 6. Locaties $* * *$} \\
\hline 6.1 Aard feiten/voorvallen & Ja & \\
\hline 6.2 Omschrijving locatie & Ja & \\
\hline 6.3 Relevante personen & Ja & \\
\hline 6.4 Relevante voertuigen & Ja & \\
\hline
\end{tabular}




\begin{tabular}{|l|l|l|}
\hline Soort informatie & $\begin{array}{l}\text { Zelfstandige } \\
\text { doorgifte }\end{array}$ & Opmerkingen \\
\hline \multicolumn{2}{|c|}{ 7. Opdrachten uitgaande van rechterijke autoriteiten } \\
\hline $\begin{array}{l}\text { 7.1 Opdrachten voorvloeiend uit signalerin- } \\
\text { gen door Belgische autoriteiten middels het } \\
\text { Schengen Informatiesysteem (SIS) en Inter- } \\
\text { pol }\end{array}$ & Ja & \\
\hline $\begin{array}{l}\text { 7.2 Verstrekking van gegevens ter onder- } \\
\text { steuning van grensoverschrijdende opera- } \\
\text { ties (achtervolging, observaties, politie- } \\
\text { alarm, et cetera) }\end{array}$ & Ja & \\
\hline
\end{tabular}

- Persoonsgegevens opgenomen in automatische of manuele bestanden ter beschikking van de Belgische politiediensten (IB, foto, vingerafdrukbladen, et cetera).

*. Detenties, verloven, permissies, detentiercgime, reden van detentic.

*.. Informatic die locaties aanduidt, waar frequent feiten/voorvallen plaatsvinden. welke de aandacht verdienen van de politie. 


\section{Appendix D: Het OIPG-register}

\section{Bijlage B: register van de OIPG's}

Het register van de OIPG's dient te bestaan uit de volgende zeven velden.

\begin{tabular}{|l|l|l|l|l|l|l|}
\hline $\mathbf{1}$ & $\mathbf{2}$ & $\mathbf{3}$ & $\mathbf{4}$ & $\mathbf{5}$ & $\mathbf{6}$ & $\mathbf{7}$ \\
\hline EUP/21 & 221330 Sep & $\begin{array}{l}\text { Van OIPG } \\
\text { Eupen aan } \\
\text { Recherche } \\
\text { Breda }\end{array}$ & $\begin{array}{l}\text { P } \\
\text { NP }\end{array}$ & $\begin{array}{l}\text { Opsporingsbericht } \\
\text { hold-up Eupen van } \\
221315 \text { Sep } \\
96\end{array}$ & $\begin{array}{l}\text { Map X } \\
\text { Doc Y }\end{array}$ & $\begin{array}{l}\text { HU } \\
\text { ASLK } \\
\text { Eupen } \\
220996\end{array}$ \\
\hline
\end{tabular}

\section{Volgnummer}

2. Datum/uur

3. Van ... Aan

4. Persoonsgegevens: P; Niet-persoonsgegevens: NP

5. Soort informatie

6. Classificatiereferentie bij archivering

7. Opsporingsreferentie:

- kwalificatie van het feit;

- gegevens betreffende de personen (naam, voornaam, adres, geboortedatum);

- gegevens betreffende de voertuigen;

- gegevens betreffende de voorwerpen. 



\section{Appendix E: Huidige softwareonderdelen van}

\section{PALMA}

\section{Overzicht huidige softwareonderdelen PALMA}

Het huidige PALMA-systeem is een groot samenwerkingsverband tussen een reeks softwarepakketten die deels ontwikkeld zijn door IKAT, deels commercieel verkrijgbaar zijn en deels public domain zijn. Wij geven hieronder een opsomming van de pakketten in de drie genoemde klassen.

\section{Ontwikkelde software}

Hieronder volgt een lijst van negen door IKAT ontwikkelde software-onderdelen.

\section{PALMA.exe (en PALMA.dIl) 'PALMA Protocol Server'}

Dit is de kern van het PALMA-systeem. Het is een in Visual Basic (VB) 3.0 geschreven Win-CGI-applicatie die, door middel van MS-IIS (MicroSoft Internet Information Server), met de gebruikers communiceert op basis van HTML. De extensie PALMA.dll is een (public domain) koppeling tussen het Win-CGI-protocol en de MS-IIS-server. In 2001 is dit PALMA-onderdeel herschreven in Delphi 5.0 in het project PALMA Stability Update.

\section{ESTOFexe 'Extremely Simple Transfer Of Files'}

ESTOF zorgt voor de communicatie tussen palma-servers. In 2001 is dit PALMA-onderdeel herschreven van VB 3.0 in Delphi 5.0 in het project PALMA Stability Update.

\section{PALMAConfig.exe}

Een VB 3.0 applicatie voor het beheer van PALMA. Deze applicatie is niet volledig en wordt momenteel nauwelijks gebruikt.

\section{PALMAdm.exe (en PALMAdm.dll) 'PALMA Administrator'}

Win-CGI applicatie in VB 3.0 die het mogelijk makt om een applicatie op afstand (via de MS-IIS) te beheren. Dit pakket wordt alleen gebruikt vanuit Maastricht door IKAT. Met PALMAdm kan palma.ini worden beheerd (gebruikers, organisaties) en kunnen eenvoudige bestandsoperaties worden uitgevoerd (view, copy, delete, edit). 


\section{ICC97.mdb (Mutatieformulier)}

Een Access '97/2000-applicatie voor het werken met de registratiedatabase.

\section{Autopalma.mdb}

Een Access '97-applicatie die informatie van de PALMA-logdatabase naar de registratiedatabase overzet.

\section{Uploader.exe}

Een CGI-Bin-applicatie (in Delphi geschreven) die speciaal bedoeld is om bestanden naar de PALMA server te sturen en in een persoonlijke data-directory van gebruikers te stoppen. Dit gebeurt wanneer gebruikers bij het mededelingenformulier in PALMA een aantal documenten willen meesturen. Uploader communiceert via HTML met de gebruiker en staat een eenvoudig beheer van de documenten toe. Het programma is alleen in het Nederlands beschikbaar. Uploader.exe is op alle PALMA-servers geinstalleerd.

\section{Update.exe}

Dit is een klein VB 3.0-programma dat in samenwerking met ESTOF.exe op afstand aanpassingen kan doen aan een PALMA server. Het programma is alleen bedoeld voor gebruik door het IKAT. Update.exe wordt niet geïnstalleerd, maar met behulp van ESTOF naar een server getransporteerd en uitgevoerd.

\section{PALMAMail.class}

Dit is een Java-servlet die in staat is om automatisch e-mail te versturen. Dit pakket wordt alleen in het PALMA op de Werkplek-experiment gebruikt.

\section{Commerciële pakketten}

Hieronder volgt een lijst van zes commercieel verkrijgbare pakketten die in het PALMAsysteem geïmplementeerd zijn.

\section{Microsoft Internet Explorer (vanaf versie 4.x) (MIE)}

Wordt gebruikt als WWW-browser op de gebruikersmachines.

2. Microsoft Access (versie ' 97 en incidenteel versie 2000)

Voor raadpleging van de lokale registratiedatabase.

3. Microsoft Internet Information Server (MS-IIS)

WWW-server die op alle PALMA-servers draait.

\section{Microsofi SQL-server (versie 6.5)}

Database-server op de PALMA-server in Driebergen 


\section{Microsoft $O D B C$-drivers voor $S Q L$-server}

Te installeren op machines in Nederland die Autopalma draaien.

\section{Scansofruare, photo-paint sofruare}

Software om foto's en documenten te scannen en te bewerken alvorens ze met PALMA mee te sturen.

\section{Public-domain pakketten}

Hieronder volgt een opsomming van zes public-domain pakketten die in het PALMAsysteem geïmplementeerd zijn.

\section{Visual Basic 3.0 runtime}

Dit pakket is nodig om alle VB 3.0-programma's te draaien. Het is alleen op de PALMAservers geinstalleerd.

\section{IpDeamon, vbx en IpPort.vbx}

Deze pakketten verzorgen de TCP/IP-communicatie van ESTOF.exe. Zij zijn alleen op PALMA-servers geïnstalleerd. Deze modules zijn eigenlijk shareware, maar registratie/ betaling bleek niet mogelijk. Ze worden daarom als public-domain beschouwd.

\section{WINCGI2ISAPI.dIl}

Dit is een pakket om CGI op een MS-IIS server te draaien. Het vertaalt ISAPI naar Win$\mathrm{CGI}$ en vice versa. Om het te kunnen gebruiken, moet dit document dezelfde naam krijgen als de WIN-CGI-applicatie en in dezelfde directory (../scripts) staan.

\section{WinSQL}

Dit is een tool om op afstand de SQL-server te bevragen en te beheren.

\section{IWS}

Dit is een WWW-server die in staat is om Java-servlets te draaien. Deze webserver wordt alleen gebruikt bij het PALMA op de Werkplek-experiment in Zuid-Limburg. IWS wordt gebruikt om PALMAMail.class te kunnen draaien.

\section{Iproxy}

Dit is een public-domain proxy-server die vanaf PolitieNet beschermd toegang geeft tot de buitenlandse webservers (kiosken). 



\section{Appendix F: EMMI-netwerksituatie}

\section{Overzicht netwerksituatie EMMI}

In deze appendix geven wij het overzicht van de huidige netwerksituatie (in januari 2004) aan met behulp van een aantal figuren. ${ }^{46}$ Figuur 7 geeft aan welke machines meedoen aan PALMA, welke software erop draait en hoe de machines onderling zijn verbonden. Figuur 8 geeft aan hoe de software die op de verschillende machines is geìnstalleerd onderling communiceert in de Nederlandse situatie. Vervolgens geven wij een overzicht van de stappen die plaatsvinden bij een gegevensaanvraag. 


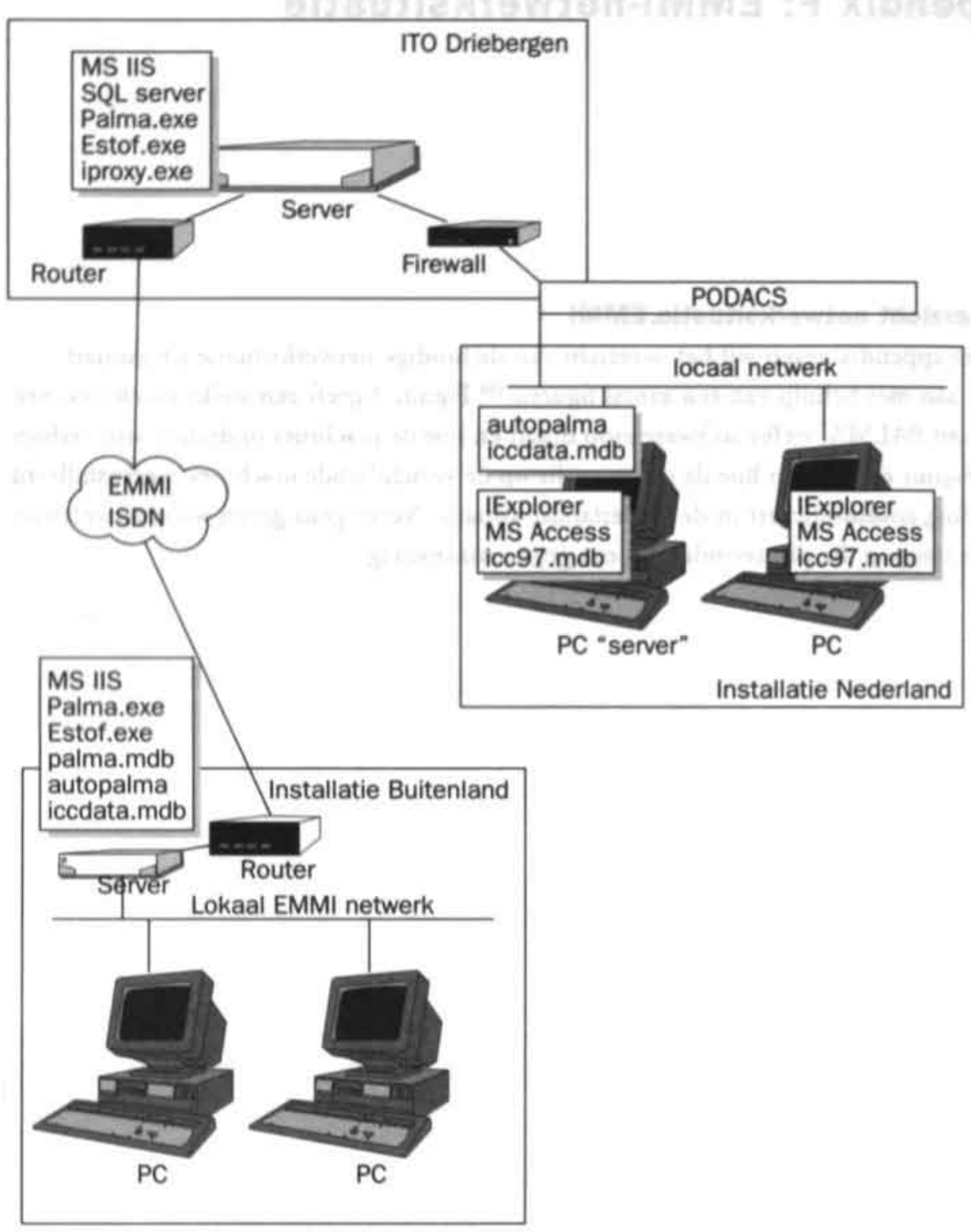

Figuur 7 Het huidige PALMA: de machines, de software en de onderlinge verhoudingen 


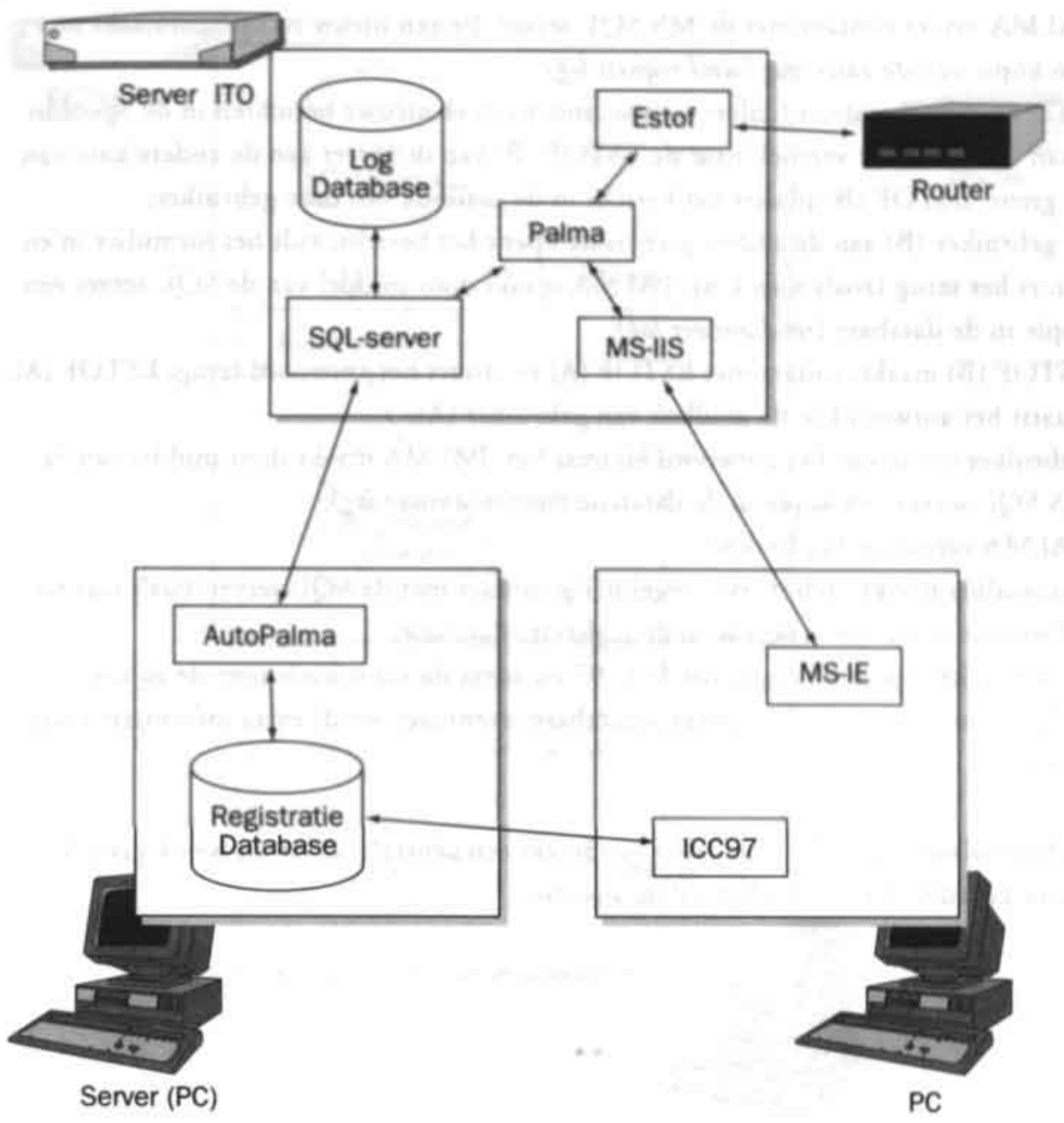

Figuur 8 Huidige PALMA-communicatie voor de Nederlandse situatie

Stap-voor-stap gebeurt er in de huidige PALMA-omgeving het volgende tijdens en na het afhandelen van een aanvraag:

1. een gebruiker (A) stuurt een aanvraagverzoek naar MS IIS via de browser (MS IE);

2. IIS start de palma.exe (palma.dII) op, PALMA genereert een invulformulier;

3. IIS stuurt het in te vullen formulier naar de gebruiker;

4. de gebruiker (A) stuurt het ingevulde formulier terug naar de IIS;

5. de IIS maakt contact met de PALMA-protocolserver. PALMA maakt een verzendklaar bericht van de aanvraag en zet het bericht in de zogenoemde Spool directory (Spooldir) voor ESTOF; 
6. PALMA maakt contact met de MS-SQL-server die een nieuw record aanmaakt met een kopie van de aanvraag (send request log);

7. ESTOF (A) controleert (iedere tien seconden) of er nieuwe berichten in de Spooldir staan en stuurt het verzoek naar de ESTOF (B) van de server aan de andere kant van de grens; ESTOF (B) plaatst het bericht in de mailbox van deze gebruiker;

8. de gebruiker (B) aan de andere grenszijde opent het bericht, vult het formulier in en stuurt het terug (zoals stap 1-4); PALMA maakt door middel van de SQL-server een kopie in de database (send answer log);

9. ESTOF (B) maakt contact met ESTOF (A) en stuurt het antwoord terug; ESTOF (A) plaatst het antwoord in de mailbox van gebruiker (A);

10.gebruiker (A) opent het antwoord en leest het; PALMA maakt door middel van de MS SQL-server een kopie in de database (receive answer log);

11.PALMA vernietigt het bericht;

12.Autopalma maakt ondertussen regelmatig contact met de SQL-server, haalt nieuwe informatic op en verwerkt die in de registratiedatabase;

13.de gebruiker opent de applicatie ICC'97 en zoekt de informatie over de zojuist gedane aanvraag op in de registratiedatabase; eventueel wordt extra informatie toegevoegd.

In de buitenlandse EMMI-installaties ontbreekt een centrale server en is ook geen SQLserver in gebruik. Figuur 9 schetst deze situatie. 


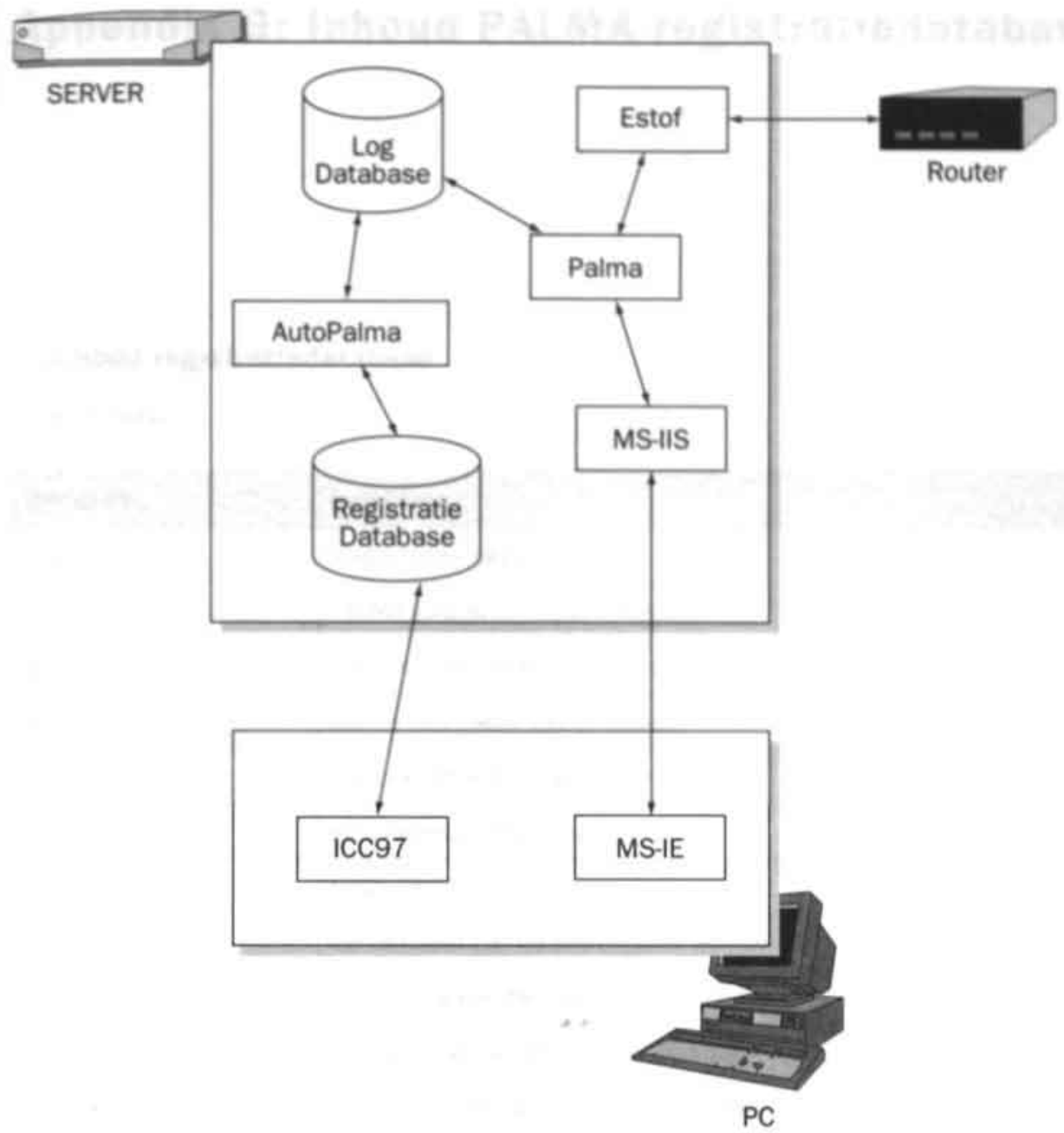

Figuur 9 De huidige EMMI-omgeving in het buitenland

De 'server' wordt in het buitenland vaak ook als PC gebruikt. De plaats van de SQL-server wordt in het buitenland overgenomen door PALMA zelf dat rechtstreeks logs aanmaakt in de logdatabase. Het is overigens mogelijk dat de registratiedatabase en autopalma op een derde machine zijn ondergebracht. 



\section{Appendix G: Inhoud PALMA-registratiedatabase}

\section{Inhoud registratiedatabase}

\section{Tabel: iccdata}

\begin{tabular}{|c|c|}
\hline Veldnaam & Betekenis \\
\hline volgnr & volgnummer (automatisch) \\
\hline jobid & PALMA volgnummer (automatisch) \\
\hline pv_nt & nummer van het proces-verbaal \\
\hline datum & datum van invoer (automatisch) \\
\hline doel & doel van de aanvraag \\
\hline instantie & aanvragende instantie \\
\hline Basiseenh & basiseenheid \\
\hline naam & achternaam van de betreffende persoon \\
\hline voort & voorletters van de betreffende persoon \\
\hline gesl & geslacht van de betreffende persoon \\
\hline voornamen & voornamen van de betreffende persoon \\
\hline gebdat & geboortedatum van de betreffende persoon \\
\hline gebplaats & geboorteplaats van de betreffende persoon \\
\hline gebland & land van geboorte van de betreffende persoon \\
\hline nat & nationaliteit van de betreffende persoon \\
\hline adres & huidige adres van de betreffende persoon \\
\hline postcode & postcode van de betreffende persoon \\
\hline woonplaats & woonplaats van de betreffende persoon \\
\hline woonland & land van verblijf van de betreffende persoon \\
\hline telefoon & telefoonnummer van de betreffende persoon \\
\hline ipdossier & Interpol-dossiernummer \\
\hline
\end{tabular}




\begin{tabular}{|l|l|}
\hline Veldnaam & Betekenis \\
\hline memo & vrije tekstruimte \\
\hline dat_delikt & datum van het delict \\
\hline tijd & tijdstip van het delict \\
\hline land & aanvragend land \\
\hline plaats & plaats waarvoor door de instantie de aanvraag wordt gedaan \\
\hline voor & land waar de informatie wordt gehaald \\
\hline merk & merk van het motorvoertuig \\
\hline type & type van het motorvoertuig \\
\hline kleur & kleur van het motorvoertuig \\
\hline sign & (3-karakter) signaalcode \\
\hline kenteken & kenteken van het motorvoertuig \\
\hline chassienr & chassisnummer van het motorvoertuig \\
\hline ktr, hkd, nsis, bev, vis & diensten \\
\hline tel, aig, rhv, vrz, rib & diensten \\
\hline afh_datum & datum van afhandeling \\
\hline Tijdsduur & tijdsindicatie voor de duur van de infoaanvraag \\
\hline afhandel & geeft aan of de aanvraag is afgehandeld \\
\hline betr_ambt & betrokken ambtenaar van het aanvragende land \\
\hline teinr & telefoonnummer van de betrokken ambtenaar \\
\hline initialen van de verbalisant (IRC) \\
\hline
\end{tabular}




\section{Appendix H: SIKS Dissertatiereeks}

\section{8}

1998-1 Johan van den Akker (CWI)

DEGAS - An Active, Temporal Database of Autonomous Objects

1998-2 Floris Wiesman (UM)

Information Retrieval by Graphically Browsing Meta-Information

1998-3 Ans Steuten (TUD)

A Contribution to the Linguistic Analysis of Business Conversations within the Language/Action Perspective

1998-4 Dennis Breuker (UM)

Memory versus Search in Games

1998-5 E.W. Oskamp (RUL)

Computerondersteuning bij Straftoemeting

1999

1999-1 Mark Sloof (VU)

Physiology of Quality Change Modelling; Automated modelling of Quality

Change of Agricultural Products

1999-2 Rob Potharst (EUR)

Classification using decision trees and neural nets

1999-3 Don Beal (UM)

The Nature of Minimax Search

1999-4 Jacques Penders (UM)

The practical Art of Moving Physical Objects 
1999-5 Aldo de Moor (KUB)

Empowering Communities: A Method for the Legitimate User-Driven

Specification of Network Information Systems

1999-6 Niek J.E. Wijngaards (VU)

Re-design of compositional systems

1999-7 David Spelt (UT)

Verification support for object database design

1999-8 Jacques H.J. Lenting (UM)

Informed Gambling: Conception and Analysis of a Multi-Agent Mechanism for

Discrete Reallocation

2000

2000-1 Frank Niessink (VU)

Perspectives on Improving Software Maintenance

2000-2 Koen Holtman (TUE)

Prototyping of CMS Storage Management

2000-3 Carolien M.T. Metselaar (UvA)

Sociaal-organisatorische gevolgen van kennistechnologie; een procesbenadering en actorperspectief

2000-4 Geert de Haan (VU)

ETAG, A Formal Model of Competence Knowledge for User Interface Design

2000-5 Ruud van der Pol (UM)

Knowledge-based Query Formulation in Information Retrieval

2000-6 Rogier van Eijk (UU)

Programming Languages for Agent Communication

2000-7 Niels Peek (UU)

Decision-theoretic Planning of Clinical Patient Management

2000-8 Veerle Coupé (EUR)

Sensitivity Analyis of Decision-Theoretic Networks 
2000-9 Florian Waas (CWI)

Principles of Probabilistic Query Optimization

2000-10 Niels Nes (CWI)

Image Database Management System Design Considerations, Algorithms and Architecture

2000-11 Jonas Karlsson (CWI)

Scalable Distributed Data Structures for Database Management

2001

2001-1 Silja Renooij (UU)

Qualitative Approaches to Quantifying Probabilistic Networks

2001-2 Koen Hindriks (UU)

Agent Programming Languages: Programming with Mental Models

2001-3 Maarten van Someren (UvA)

Learning as problem solving

2001-4 Evgueni Smirnov (UM)

Conjunctive and Disjunctive Version Spaces with Instance-Based Boundary Sets

2001-5 Jacco van Ossenbruggen (VU)

Processing Structured Hypermedia: A Matter of Style

2001-6 Martijn van Welie (VU)

Task-based User Interface Design

2001-7 Bastiaan Schonhage (VU)

Diva: Architectural Perspectives on Information Visualization

2001-8 Pascal van Eck (VU)

A Compositional Semantic Structure for Multi-Agent Systems Dynamics

2001-9 Pieter Jan ' $t$ Hoen (RUL)

Towards Distributed Development of Large Object-Oriented Models, Views of

Packages as Classes 
2001-10 Maarten Sierhuis (UvA)

Modeling and Simulating Work Practice BRAHMS: a multiagent modeling and simulation language for work practice analysis and design

2001-11 Tom M. van Engers (VUA)

Knowledge Management: The Role of Mental Models in Business Systems Design

2002

2002-01 Nico Lassing (VU)

Architecture-Level Modifiability Analysis

2002-02 Roelof van Zwol (UT)

Modelling and searching web-based document collections

2002-03 Henk Ernst Blok (UT)

Database Optimization Aspects for Information Retrieval

2002-04 Juan Roberto Castelo Valdueza (UU)

The Discrete Acyclic Digraph Markov Model in Data Mining

2002-05 Radu Serban (VU)

The Private Cyberspace Modeling Electronic Environments inhabited by Privacyconcerned Agents

2002-06 Laurens Mommers (UL)

Applied legal epistemology; Building a knowledge-based ontology of the legal domain

2002-07 Peter Boncz (CWI)

Monet: A Next-Generation DBMS Kernel For Query-Intensive Applications

2002-08 Jaap Gordijn (VU)

Value Based Requirements Engineering: Exploring Innovative E-Commerce Ideas

2002-09 Willem-Jan van den Heuvel (KUB)

Integrating Modern Business Applications with Objectified Legacy Systems

2002-10 Brian Sheppard (UM)

Towards Perfect Play of Scrabble 
2002-11 Wouter C.A. Wijngaards (VU)

Agent Based Modelling of Dynamics: Biological and Organisational Applications

2002-12 Albrecht Schmidt (UvA)

Processing XML in Database Systems

2002-13 Honging Wu (TUE)

A Reference Architecture for Adaptive Hypermedia Applications

2002-14 Wieke de Vries (UU)

Agent Interaction: Abstract Approaches to Modelling, Programming and

Verifying Multi-Agent Systems

2002-15 Rik Eshuis (UT)

Semantics and Verification of UML Activity Diagrams for Workflow Modelling

2002-16 Pieter van Langen (VU)

The Anatomy of Design: Foundations, Models and Applications

2002-17 Stefan Manegold (UvA)

Understanding, Modeling, and Improving Main-Memory Database Performance

\section{3}

2003-01 Heiner Stuckenschmidt (VU)

Ontology-Based Information Sharing in Weakly Structured Environments

2003-02 Jan Broersen (VU)

Modal Action Logics for Reasoning About Reactive Systems

2003-03 Martijn Schuemie (TUD)

Human-Computer Interaction and Presence in Virtual Reality Exposure Therapy

2003-04 Milan Petkovic (UT)

Content-Based Video Retrieval Supported by Database Technology

2003-05 Jos Lehmann (UvA)

Causation in Artificial Intelligence and Law - A modelling approach

2003-06 Boris van Schooten (UT)

Development and specification of virtual environments 
2003-07 Machiel Jansen (UvA)

Formal Explorations of Knowledge Intensive Tasks

2003-08 Yongping Ran (UM)

Repair Based Scheduling

2003-09 Rens Kortmann (UM)

The resolution of visually guided behaviour

2003-10 Andreas Lincke (UvT)

Electronic Business Negotiation: Some experimental studies on the interaction between medium, innovation context and culture

2003-11 Simon Keizer (UT)

Reasoning under Uncertainty in Natural Language Dialogue using Bayesian Networks

2003-12 Roeland Ordelman (UT)

Dutch speech recognition in multimedia information retrieval

2003-13 Jeroen Donkers (UM)

Nosce Hostem - Searching with Opponent Models

2003-14 Stijn Hoppenbrouwers (KUN)

Freezing Language: Conceptualisation Processes across ICT-Supported Organisations

2003-15 Mathijs de Weerdt (TUD)

Plan Merging in Multi-Agent Systems

2003-16 Menzo Windhouwer (CWI)

Feature Grammar Systems - Incremental Maintenance of Indexes to Digital

Media Warehouses

2003-17 David Jansen (UT)

Extensions of Statecharts with Probability, Time, and Stochastic Timing

2003-18 Levente Kocsis (UM)

Learning Search Decisions 
2004

2004-01 Virginia Dignum (UU)

A Model for Organizational Interaction: Based on Agents, Founded in Logic

2004-02 Lai Xu (UvT)

Monitoring Multi-party Contracts for E-business

2004-03 Perry Groot (VU)

A Theoretical and Empirical Analysis of Approximation in Symbolic Problem Solving

2004-04 Chris van Aart (UvA)

Organizational Principles for Multi-Agent Architectures

2004-05 Viara Popova (EUR)

Knowledge discovery and monotonicity

2004-06 Bart-Jan Hommes (TUD)

The Evaluation of Business Process Modeling Techniques

2004-07 Elise Boltjes (UM)

Voorbeeldig onderwijs; voorbeeldgestuurd onderwijs, een opstap naar abstract denken, vooral voor meisjes 



\section{Referenties}

\section{Geraadpleegde literatuur}

Baümler, Helmut (Hrsg.), Polizei und Datenschuts. Neupositionierung im Zeichen der Informationsgesellschaft; Neuwied; Kriftel: Luchterhand, 1999.

Bevers, H. \& Joubert, C., Politiële samenwerking in Europa, Arnhem: Gouda Quint 1994.

Block, L., Het beveiligingsbewustzijn bij de Nederlandse Politie, Een onderzoek naar de omgang met de beveiliging van geautomatiseende systemen, Lochem: van den Brink 1991. Bovenkerk, F. \& Yesilgöz, Y., De maffia van Turkije, 1998, p. 20, 21 en 169.

Brants, C.H., Mevis, P.A.M. \& Prakken, E. (red.), Legitieme strafuordering: rechten van de mens als inspinatie in de 21ste ceum, Antwerpen: Intersentia, 2001.

Bruinsma, G.J.N., 'Oost-Europa en het Interregionale Recherche Team', in: Bruinsma, G.J.N. (red.), Georganiseerde criminaliteit wit Oost-Europa en het IRT Noord- en OostNederland, 1998, p. 1.

Buruma, Y., Introductie internationaal strafrecht, Nijmegen: Ars Aequi Libri 1994.

Buruma, Y., 'Onrechtmatige opsporing', Delikt en Delinkwent, 2002, p. 198-208.

Busch, M., Grenzenloze Polizei. Neue Grencen und polizeiliche Zusammenarbeit in Europa, Münster: Westfalischer Dampfboot 1995.

Cleiren, C.P.M., Beginselen van een goede procesorde, Arnhem: Gouda Quint 1989.

Corstens, G.J.M., Het Nederlands strafprocesrecht, Arnhem: Gouda Quint 1995, p. 58-69 en 2002 (vierde druk).

Derey, M., 'Digitaal Voorlichtings Systeem', in-pactueel, 1997/2, p. 38-39.

Donkers, H.H.L.M., Verbeek, J.P.G.M., Herik, H.J. van den, Boers, G., Krogt, P.A.M. van der, Spronck, P.H.M. \& Wiesman, F.J., Reright: Een Fundamenteel Herontwerp van PALMA met Nieuwe Gebruikerswensen. Technical Reports in Computer Science, CS 01-07. Maastricht: IKAT, Universiteit Maastricht 2001.

Duivenboden, H. van, 'Achter de schermen van de overheid: beleid en recht inzake koppeling van persoonsregistraties', in: Zuurmond, A., Huigen, J., Frissen, P.H.A., Snellen, I.Th.M. \& Tops, P.W., Informatisering in het openbaar bestuur: technologie en sturing bestuurskundig beschouwd, Den Haag: VUGA 1994, p. 397-414.

Dumortier, J., 'Het Schengen Informatie Systeem en de bescherming van persoonsgegevens', in: Fijnaut, C., Stuyck, J. \& Wytinck, P. (red.), Schengen: Proeftuin voor de Europese Gem̌eenschap?, Arnhem: Gouda Quint 1992, p. 119-173. 
Elchingen, S. van (red.), Het informatiebeheer in het kader van de politiehervorming, Kessel-Lo: Centrum voor politiestudies v.z.w., 1999.

Enquêtecommissie opsporingsmethoden, Inzake opsporing, 's-Gravenhage: Sdu 1996, p. 292-302 en p. 458.

Fijnaut, C. (red.), The Internationalization of Police Cooperation in Western Europe, Arnhem: Gouda Quint 1993.

Fijnaut, C., Een kleine geschiedenis van de huidige organisatie van het Belgische politiewezen, Antwerpen: Kluwer rechtswetenschappen, 1995.

Fijnaut, C., De Ruyver, B. \& Goossens, F., (red.), De reorganisatie van het politiewezen, Samenleving Criminaliteit \& Strafrechtspleging nr. 17, Leuven: Universitaire Pers, 1999.

Fijnaut, C., Van Daele, D. \& Parmentier, S., Een openbaar ministerie voor de 21 ste ceuw, Samenleving Criminaliteit \& Strafrechtspleging nr. 21a, Leuven: Universitaire Pers, 2000.

Franken, H., 'Overheid, informatietechnologie en recht - een gevarendriehoek?', in:

Frissen, P.H.A., Koers, A.W. \& Snellen, I.Th.M. (red.), Orwell en Athene, Den Haag: NOTA 1992, p. 165-177.

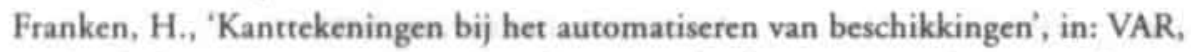
Beschikken en automatiseren, Pre-advies voor de algemene vergadering van de Vereniging voor Administratief Recht (VAR), Alphen a/d Rijn: Samsom H.D. Tjeenk Willink 1993, p. 11-50.

Franken, H., 'Juridisch theoretische achtergronden', in: Franken, H., Kaspersen H.W.K. \& Wild, A.H. de (red.), Recht en Computer, Deventer: Kluwer 1997, p. 52-55.

Franken, H., 'Beveiliging als maatschappelijke plicht', in: Herik, H.J. van den \& Roos Lindgreen, E. (red.), Bewaar me, liber amicorum voor Prof.dr. I.S. Herschberg, Delft: Van den Herik, 16 januari 1998.

Gardeniers, H.J.M., Kralingen, R.W. van \& Schreuders, E., 'Knowledge discovery in databases; privacyaspecten van informatiemijnbouw', in: Nouwt, S. \& Voermans, W. (red.), Privacy in het informatietijdperk, Den Haag: Sdu 1996, hoofdstuk 7.

Goos, M. \& Vugts, J., IT \& Privacy, cen onderzoek naar de kansen en bedreigingen van de toepassing van nieuwe informatietechnologie door de Nederlandse politie, Nijmegen: Inpact 1996.

Grützner, H. \& Pötz, P.-G. (red.), Internationaler Rechtshilfeverkehr in Strafsachen. Die für die Rechtsbeziehungen der Bundesrepublik Deutschland mit dem Ausland in Strafsachen maßgeblichen Bestimmungen, Heidelberg: R. v. Decker, losbladig.

Havelange, B. \& De Schutter, B., 'L'analyse criminelle et la protection de la vie privée', Custodes: analyse criminelle, Les cahiers thématiques de la police et de la justice, $2^{c}$ jaargang, nr. 3, p. 31-49.

Heimans, D., 'Internationale uitwisseling van politie-informatie: over het grensvlak tussen rechtshulp en privacybescherming, $D D$ 1994, p. 125-142. 
Herik, H.J. van den, Bakker, H. \& Schoo, P.N.A., Eindnapportage MultiMediale InformatieVoorziening in de politiengio Limburg Zuid. MMIV/20, Maastricht: MATRIKSInformatica 1993.

Herik, H.J. van den, Meulen, M. van der \& Schijf, M., Eindrapportage Haalbaarheidsstudie DVS, Maastricht: MATRIKS-Informatica 1994.

Herik, H.J. van den, Plugge, L.A., Donkers, J. \& Berghmans, J., PALMA (Politieverbindingen Aken-Luik-MAastricht) Eindnapport, Maastricht: MATRIKS-Informatica 1996.

Herik, H.J. van den, Plugge, L.A., Mathijsen, E.H.N., Donkers, H.H.L.M., Bosch, A.E.M. van den \& Klinkers, A., Palma en Multimedia, Politieverbindingen Aken-LuikMaastricht, PC-PC Fase II Eindnapport, Maastricht: MATRIKS-Informatica 1997.

Hert, P. De \& Vanderborght, J., Informatieve samenwerking over de grenzen been (2 delen), Brussel: Politeia 1996.

Heus, H.J.E. de, 'Een common market voor 'information exchange', Een nieuwe benadering van informatie-uitwisseling tussen Europese korpsen', $A P B$, nr. 5 van 26 februari 2000, p. 11-13.

Heus, H.J.E. de, 'Euregionale politiebureaus, Meer veiligheid langs de grens', $A P B$, nr. 22 van 16 november 2002, p. 18-20.

Hofstede, G., Twuyver, M., Kapp, B., Vries, H. de, Faure, M., Claus, F. \& Wel, J. van der, Grensoverschrijdende politiesamenwerking tussen Belgie, Duitsland en Nederland met speciale aandacht voor de Euregio Maas-Rijn, Maastricht: Universitaire Pers Maastricht 1993.

Janssen, D.J.T. \& Koning, M.B.J., Politie en veiligheid in Europa, 's-Gravenhage: NPI 1998.

Joubert, C. \& Bevers, H., Schengen Investizated, a comparative Interpretation of the Schengen Provisions on International Police Cooperation in the Light of the European Convention on Human Rights, Den Haag: Kluwer Law International 1996.

Kauss, Udo \& Narr, Wolf-Dieter, Der suspendierte Datenschutz bei Polizei und Geheimdiensten; Frankfurt: Campus Frankfurt, 1989.

Kempf, Eberhard, Moderne Datenverarbeitung und strafprozessuale Rechte von Beschuldigten, in: Baümler 1999, p. 60.

Klip, A.H., 'Soevereiniteit in het strafrecht', in: Corstens, G.J.M. \& Groenhuijsen, M.S., Rede en recht: opstellen ter gelegenheid van het afscheid van Prof. mr. N. Keijzer van de Katholieke Universiteit Brabant, Deventer: Gouda Quint, 2000, p. 139.

Klip, A.H., Swart, A.H.J. \& Wilt, H.G. van der (red.), Internationale en interregionale samenwerking in strafzaken, Deventer: Kluwer, losbladig.

Kloepfer, Michael, Datenschutz als Grundrecht: Verfassungsprobleme der Einfuihrung eines Grundrechts auf Datenschutz; Königstein: Athenäum Königstein, 1980.

Klunder, J. \& Adelhart Toorop, Y. de, Definitiestudie Luris, Driebergen: IT-organisatie 1997.

Koers, A.W. \& Schmidt, A.H.J., 'ICT en organisaties van Recht en Openbaar Bestuur', in: Franken, H., Prins, J.E.J., Esch, R.E. van, Quaedvlieg, A.A., Dommering, E.J., 
Koers, A.W., Schmidt, A.H.J., Koops, B.J. \& Lips, A.M.B., Zeven essays over informatietechnologie en recht, Den Haag: Sdu Uitgevers, 2003, p. $227-259$ (elektronisch te raadplegen via www.nwo.nl/iter).

Koers, J., Nederland als verzoekende staat bij de wederzijdse rechtshulp in strafzaken, Achtergronden, grenzen en mogelijkheden, Nijmegen: Wolf Legal Publishers, 2001.

Kowalczyk, Anneliese, Datenschutz im Polizeirecht, Reaktionen des Gesetzgeber auf das Volkszählungsgesetzurteil des Bundesverfassungsgerichts; Schriften zur öffentlichen Verwaltung, dl. 29; Keulen: Verlag W. Kohlhammer GmbH en Deutscher Gemeindeverlag $\mathrm{GmbH}, 1989$.

Knemeyer, Franz-Ludwig, Polizei- und Ordnungsrecht, 8. Auflage, München: Beck'sche Verlagsbuchhandlung, 2000.

Lambrecht, D., De bescherming van de privacy in de Belgische wetgeving: overzicht van de bestaande wetgeving en een blik vooruit naar de op handen zijnde veranderingen, Jura Falconis, het artikel is on line te vinden op de volgende website: www.law.kuleuven.ac.be/jura/37n $3 /$ lambrecht.htm

Levi, M., 'The extent of cross border crime in Europe', European Journal on Criminal Policy and Research, Amsterdam: Kugler Publications 1993.

Meij. J. (ed.), Dealing with the data flood, mining data, text and multimedia, dl. 65 uit de STT-reeks, Den Haag: STT 2002.

Melai: Groenhuijsen, M.S. (red.), Commentaar op het wetboek van strafvordering, artt. 552h-552q, Arnhem: Gouda-Quint, losbladig.

Mokroz, Reinhard, 'Polizeiliche Zusammenarbeit in Europa', in: Lisken, Hans \& Denniger, Erhard, Handbuch des Polizeirechts, München: C.H. Beck, derde druk, 2001, p. 1133-1230.

Montfort, B. van, 'Politie Intranet verbindt politiekorpsen', in-pactueel, 1997/2, p. $41-45$.

Nijboer, J.F., Strafrechtelijk bewijsrecht, Nijmegen: Ars Aequi Libri, 2000.

Outrive, L. van \& Vanderborght, J. (red.), Schengen en de Belgische politiediensten, Leuven: Centrum voor Politiestudies 1995.

Plugge, L.A., 'EMMI Euregionale Multimediale Informatie-uitwisseling', in-pactueel, 1997/2, p. 7-8.

Registratiekamer, Casusregisters in de geestelijke gezondheidszorg, Den Haag: Registratiekamer 9 juni 1993.

Registratiekamer, Politieregisters en protocol, Den Haag: Registratiekamer 29 december 1994.

Registratickamer, Credit Scoring Database, Den Haag: Registratiekamer 21 juni 1996. Registratiekamer, Jaarverslag 1997, Den Haag: Registratiekamer mei 1998.

Schreuders, E., Het gesloten verstrekkingenregime van de Wet politieregisters, Rijswijk: Registratiekamer 1995.

Schreuders, E. \& Kralingen, R.W. van, 'Klantenkaarten, chipcards en data-mining; een (juridische) verkenning', in: Kralingen, R.W. van, Lips, M. \& Prins, C. (red.), De 
kaarten op tafel; Een verkenning van de juridische en bestusurkundige aspecten van chipcands, Den Haag: Sdu 1998, hoofdstuk 7.

Schwarze, Thomas, Das Grundreche auf Datenschutz in der Verfassung des Landes Nondrhein-Westfalen (Art. 4 Abs.2 der Landesverfassung); Keulen: diss. Universităt zu Köln. Hohe rechtswissenschaftliche Fakultät; s. n. Köln, 1989.

Sietsma, R., Verbeek, J.P.G.M. \& Herik, H.J. van den, Datamining en opsporing, Toepassing van datamining ten behoeve van de opsporingstaak: strafprocesnecht versus recht op privacy, dl. 55 uit de ITeR-reeks, Den Haag: Sdu Uitgevers 2002.

Sjöcrona, J.M. \& Groot, S.K. de, 'Aantekeningen bij de eerste afdeling van Titel X Sv', in: Cleiren, C.P.M. \& Nijboer, J.F. (red.), Tekst $\alpha$ Commentaar Stnafuordering. Deventer: Kluwer 2003, p. 1385-1476.

Sjöcrona, J.M. \& Orie, A.M.M., Internationaal stnafrecht vanuit Nederlands perspectief. Deventer: Kluwer 2002.

Tak, P.J.P. Het vervolgingsbeleid in de Duitse Bondsrepubliek: een onderzoek naar de witzonderingen op het legaliteissbeginsel (par.153-154d StPO Strafprozessondnung), Zwolle: Tjeenk Willink, 1973.

Thomas, F., De Europese rechtshulpverdragen in strafzaken, Gent: E. Story-Scientia 1980.

Thomas, F., Internationale rechtshulp in stnafzaken, Antwerpen: Story-Scientia 1998.

U.S. Congress, Office of Technology Assessment, Fedenal Government Information Technology: Electronic Record Systems and Individual Privacy, Washington D.C.: U.S. Congress 1986.

Valckeneer, C. de, 'Le traitement des données sensibles au stade de l' instruction', Custodes: la protection des sources, Les cahiers thématiques de la police et de la justice, $2^{e}$ jaargang, nr. 4, p. 49-69.

Vanderborght, J., Over de grens, Internationale politiesamenwerking getoetst aan de praktijk, Brussel: Politeia 1997.

Van Dorp, C.A., Verbeek, J.P.G.M. \& Herik, H.J. van den, Euro-Info, Een onderzoek naar grensoverschrijdende informatie-uitwisseling vanuit Nederlands perspectief, Technisch Rapport CS 01-03, Maastricht: IKAT, Universiteit Maastricht 2001.

Vel, G. de, 'De rol van de Raad van Europa bij justitiële samenwerking', in: Integrale veiligheid in Europa: heden en toekomst, Mulder, E.B. \& Zuidhof, K.P., Den Haag: NPI 1999.

Verbeek, J.P.G.M., Claus, F.J.L.M., Eshof, G.L.M. van den \& Herik, H.J. van den, NORMA+, Normering van Netwerkkoppeling en Grensoverschrijdend Gebruik van Multimediale Databases op een Internationaal Politieel Intranet vanuit Belgisch en Duits Perspectief, Maastricht: IKAT, Universiteit Maastricht 2002.

Verbeek, J.P.G.M., Herik, H.J. van den, Plugge, L.A. \& Roos, Th.A. de, Politie en Intranet, Normering van netwerkkoppeling en grensoverschrijdend gebruik van multimediale databases op een internationaal politieel Intranet, dl. 19 uit de ITeR-reeks, Deventer: Kluwer 1999. 
Verbeek, J.PG.M., Claus, F.J.L.M. \& Herik, H.J. van den, EMMI-3, Euregionalel MultiMediale Informatie-uitwisseling, EMMI derde traject (enige juridische aspecten), Maastricht: IKAT, Universiteit Maastricht 2003.

Vermaas, P., 'Nationaal Schengen Informatie Systeem', APB, 1998, nr. 23, p. 12-13.

Vermeulen G., Wederzijdse rechtshulp in strafzaken in de Europese Unie: naar een volwaardige eigen rechtshulpruimte in de Lid-Staten, Gent: Universiteit Gent 1999.

Vermeulen, G., Vander Beken, T. \& Ruyver, B. de, Internationaal strafrecht, actuele ontwikkelingen in België en Europa, Brugge: Vanden Broele 1998.

Verstraeten, R. \& Daele, D. van, 'De verhouding tussen het federaal parket en de politicdiensten', De orde van de dag, maart 2001, p. 15-20.

Wyngaert, C. van den (red.), Criminal procedure systems in the European Community, Londen-Brussel-Dublin-Edinburgh: Butterworths 1993.

Zwaan, J.W. de \& Bultena, A.J., Ruimte van vrijheid, veiligheid en rechtvaardigheid, De samenwerking op het gebied van Justitie en Binnenlandse Zaken in de Europese Unie, 's-Gravenhage: Sdu 2002.

\section{Geraadpleegde jurisprudentie}

\section{A: Rechtbank}

Rb. Utrecht 16 juni 1987, NJ 1987, 922.

Rb. Utrecht 18 april 2001, LJN-nummer AB1866.

\section{B: Hoge Raad}

HR 4 november 1986, NJ 1987, 812.

HR 9 april 1991, NJ 1991, 696.

HR 19 december 1995, NJ 1996, 249.

HR 22 september 1998, NJ 1999, 104.

HR 6 april 1999, NJ 1999, 565.

\section{C: Bundesverfassungsgericht}

BVerfG, 15 december 1983, BVerfGE 65, 1.

D: Europese Hof voor de Rechten van de Mens

EHRM 6 september 1978, Series A, nr. 28, alsmede AAe 28 (1979), p. 327-334, m.nt.

E.A. Alkema, par. 42 (Klass e.a.).

EHRM 26 april 1979, NJ 1980, 146 (Sunday Times).

EHRM 2 augustus 1984, NJ 1988, 534, Series $A$, nr. 82 (Malone).

EHRM 26 maart 1987, NJCM 1988, 148 (Leander).

EHRM 24 april 1990, NJ 1991, 523 alsmede Series A, nr. 176a en $176 b$ (Kruslin en Hüvig).

EHRM 25 juni 1997, NJCM-bulletin 1997, 765 en volgende (Halford). 
EHRM 24 augustus 1998, Reports of Judgments and Decisions (Reports) 1998-V (Lambert).

EHRM, 25 maart 1998, Reports 1998-II, NJ 2001, 459 (Kopp a. Stvitserland).

\section{E. Europese Hof van Justitie}

HvJEG 8 september 1987 (80/86), Jur 1987, 3969; NJ 1988, 1029 en AAe 1988, 329

(Kolpinghuis).

\section{Wet- en regelgeving en parlementaire stukken ${ }^{49}$}

\section{A: Nederland}

Wetboek van Strafvordering; Wet van 15 januari 1921; in werking getreden op 1 januari 1926, zoals laatstelijk gewijzigd bij Wet van 31 oktober 2002, Stb. 2002, 539.

Kamerstukken II, 1984/1985, 19 095, nr. 1-3, p. 36.

Kamerstukken II, 1985/1986, 19589 , nr. 3 (Mv'T).

Wet persoonsregistraties (oud), Wet van 28 december 1988, houdende regels ter bescherming van de persoonlijke levenssfeer in verband met persoonsregistraties, Stb. 1988 , 665 , zoals laatstelijk gewijzigd bij Wet van 11 december 1997, Stb. 1997, 674.

Kamerstukken II, 1988/1989, 19 589, nr. 6, p. 4-6 (MvA).

Kamerstukken II, 1988/1989, 19589 , nr. 11, p. 13 (Nota naar aanleiding van het Eindverslag WPolr).

Handelingen $I I, 1989 / 1990$, p. 26-1123.

Wet politieregisters, Wet van 21 juni 1990, houdende regels ter bescherming van de persoonlijke levenssfeer in verband met politieregisters, zoals laatstelijk gewijzigd bij Wet van 20 juni 2002, Stb. 2002, 674.

Besluit politieregisters, Besluit van 14 februari 1991, houdende bepalingen ter uitvoering van de Wet politieregisters, zoals laatstelijk gewijzigd bij Besluit van 14 oktober 2002, Stb. 2002, 2002, 514.

NvT bij het BPolr, Stb. $1991,56$.

Kamerstukken II, 1990/1991, 22 083, nr. 3, p. 6 (MvT; 'Plukze internationaal').

Kamerstukken II, 1990/1991, 22 140, nr. 3, p. 55 (MvT op de Goedkeuringswet SUO). Kamerstukken II, 199/1992, 22 140, nr. 12, p. 84 (MvA).

Kamerstukken II, 1991/1992, 22 142, nr. 6, p. 26-28 (MvA).

Kamerstukken II, 22 142, 1991/1992, nr. 8, p. 10 en 11 (Nota naar aanleiding van het cindverslag). 
Kamerstukken II, 1991/1992, 22 142, nr. 17 (gewijzigd amendement van het lid Van Traa).

Regeling vrijstelling protocolplicht; Stcrt. 1991, 158 en Stcrt. 1992, 32.

Wet van 24 februari 1993 tot wijziging van de Vreemdelingenwet, het Wetboek van Strafrecht, het Wetboek van Strafvordering en de Uitleveringswet met het oog op de uitvoering van de op 19 juni 1990 te Schengen tot stand gekomen Overeenkomst ter uitvoering van het tussen de regeringen van de Staten van de Benelux Economische Unie, de Bondsrepubliek Duitsland en de Franse Republiek op 14 juni 1985 te Schengen gesloten Akkoord betreffende de geleidelijke afschaffing van de controle aan de gemeenschappelijke grenzen; Stb. 1993, 141.

Politiewet 1993, Wet van 9 december 1993 tot vaststelling van een nieuwe Politiewet; in werking getreden op 1 april 1994; zoals laatstelijk gewijzigd bij Wet van 23 januari 2003, Stb. 2003, 52 en 60.

Wet melding ongebruikelijke transacties, Wet van 16 december 1993, Stb. 1993, 705; in werking getreden 1 februari 1994; laatstelijk gewijzigd bij wet van 13 december 2001 , St6. 2001, 665.

Besluit van 28 december 1993, Stcrt. 1993, 252.

Kamerstukken II, 1993/1994, 23 401, nr. 1-2, p. 15.

Kamerstukken II, 1993/1994, 23 815, nr. 1, p. 3 en 23 490, nr. 7.

Besluit beheer regionale politiekorpsen, Besluit van 28 maart 1994, Stb. 1994, nr. 224;

in werking getreden 1 april 1994; laatstelijk gewijzigd bij Besluit van17 april 2002, Stb. 2002, 213.

Besluit buitengewoon opsporingsambtenaar van 11 november 1994, Stb. 825 .

Modelreglement Internationale rechtshulp politie, Stcrt. 1994, 133.

Richtlijn wederzijdse rechtshulp; Richtlijn van 23 november 1994, Stcrt. 242, inzake de toepassing van artikel $552 i \mathrm{WvSv}$ door het OM en de informatieverstrekking door de politic in het kader van de wederzijdse rechtshulp in strafzaken, vastgesteld door de vergadering van procureurs-generaal; Stcrt. 2000, 43.

CID-regeling 1995 (oud), Regeling van 31 maart 1995, Stcrt. 1995, 74, vervallen per 1 november 2000.

Archiefwet 1995, Stb. 1995, 276.

Kamerstukken II, 1995/1996, 24 072, nr. 14, p. 422-454.

MvT bij de Nederlandse Goedkeuringswet van de EO, Kamerstukken II, 1996-1997,

25339 , nr. 3, p. 13.

Kamerstukken 1997/1998, 25533.

Kamerstukken II, 1997/1998, 25 533, nr. 4, p. 44.

Kamerstukken II, 1997/1998, 25 880, nr. 1-2.

Kamerstukken II, 1997/1998, 25892 (Wetsvoorstel Wet bescherming persoonsgegevens).

Kamerstukken II, 1997/1998, 26 108, nr. 1-4.

Handelingen II, 1997/1998, p. 43-3466 en 73. 
Wet bijzondere politieregisters, Wet van 27 mei 1999 tot wijziging van de Wet politieregisters, houdende nadere regels voor bijzondere politieregisters ten behoeve van de politie, Koninklijke marechaussee en daartoe aangewezen diensten van publiekrechtelijke lichamen die met de opsporing van strafbare feiten zijn belast (bijzondere politicregisters), Stb. 1999, 244.

Wet bijzondere opsporingsbevoegdheden, Wet van 27 mei 1999, Stb. 1999, 245.

Wet van 6 juli 2000, houdende regels inzake de bescherming van persoonsgegevens (Wet bescherming persoonsgegevens), Stb. 2000, 302, zoals gewijzigd bij Wet van 5 april 2001 tot wijziging van bepalingen met betrekking tot de verwerking van persoonsgegevens, Stb. 2001, 180; laatstelijk gewijzigd bij wet van 7 februari 2002, Stb. 2002, 148.

Regeling Criminele inlichtingeneenheden, Regeling van 5 oktober 2000, Stert. 2000, 198 ; in werking getreden 1 november 2000.

Kamerstukken II, 2002/2003, 28600 VI, nr. 134 (Brief van de Minister van Justitie). Kamerstukken II, 2002/2003, 27 925, nr. 82.

Kamerstukken II, 2001/2004, 28 350, nr. 1-7 en nr. A-C.

Kamerstukken II, 2001/2003, 28 351, nr. 1-5.

\section{B: België}

Gerechtelijk Wetboek van 10 oktober 1967, B.S., 31 oktober 1967.

Circulaire betreffende speciale politietechnieken, 24 april 1990 (kenmerk 7/SDP/690/ MN NIX/RB6/6).

Gedrukte stukken 1990-1991, nr. 1610/1.

Gedrukte stukken 1990-1991, nr. 1637/1, p, 65 en 66.

Wet van 5 augustus 1992 op het Politieambt, B.S., 22 december 1992, zoals in werking getreden op 1 januari 2003.

Belgische privacywet, Wet van 8 december 1992 tot bescherming van de persoonlijke levenssfeer ten opzichte van de verwerking van persoonsgegevens, B.S., 30 december 1993.

Protocolakkoord tussen de Ministers van Binnenlandse Zaken en Justitie van 4 juli 1994 betreffende de bilaterale politiesamenwerking met de buurlanden.

KB van 11 juli 1994 over de algemene politiesteundienst, B.S., 30 juli 1994.

KB nr. 8 van 7 februari 1995, B.S., 28 februari 1995, p. 4453-4455.

Schengencirculaire, 16 maart 1995, B.S., 28 maart 1995.

Wetsvoorstel gewone zitting 1997-1998, 15 juli 1998, 1676/1-97-98.

Wet tot organisatic van een geïntegreerde politiedienst, gestructureerd op twee niveaus, van 7 december 1998, zoals bijgewerkt tot 23 mei 2003, B.S., 5 januari 1999.

Commissie voor bescherming van de persoonlijke levenssfeer, 'VICLAS'-systeem voor misdaadanalyse: advies, nr. RZ995A1_1, 10 mei 1999, te vinden op http://www.cass.be 
Omzendbrief Col 6/99 van het College van Procureurs-Generaal bij de hoven van beroep, betreffende een ministeriële richtlijn tot regeling van de samenwerking, de coördinatie en de taakverdeling tussen de lokale politie en de federale politie inzake de opdrachten van gerechtelijke politic.

Gezamenlijke omzendbrief van de Minister van Justitie en het College van Procureursgeneraal betreffende de internationale politiesamenwerking met een gerechtelijke finaliteit; de omzendbrief is van 14 februari $2000 \mathrm{en}$ is in werking getreden op 1 maart 2000; zij is verspreid door het College van Procureurs-generaal in de Omzendbrief nr. COL 2/2000 van het College van Procureurs-generaal bij de Hoven van beroep, Brussel, 18 februari 2000.

Koninklijk besluit met betrekking tot de commissaris-generaal en de algemene directies van de federale politie van 3 september 2000, B.S. 23 september 2000.

$K B$ van 27 december 2000 , houdende de indeling van het grondgebied van de provincie Limburg in politiezones, B.S. 251, 30 december 2000.

Gemeenschappelijke richtlijn MFO-3 van de Ministers van Justitie en van Binnenlandse Zaken betreffende het informatiebeheer inzake gerechtelijke en bestuurlijke politie, Brussel, 14 juni 2002, in werking getreden op 18 juni 2002.

\section{Duitsland}

Verfassung für das Land Nordrhein-Westfalen, Wet van 18 juni 1950, GVNRW 1950, p. 127, laatstelijk gewijzigd bij wet van 24 november 1992, GVNRW 1992, p. 448.

Strafprozeßordnung, Wet van 12 september 1950; BGBl 1950, 455, 512, 629, zoals laatstelijk gewijzigd bij wet van 25 juni 2001, BGBl 2001, 1206.

Gerichtsverfassungsgesetz, Wet van 12 september 1950, BGBl 1950, nr. 455, 512, 513 , zoals laatstelijk gewijzigd bij wet van 10 december 2001, artikel 12 .

Hessischer Datenschutzgesetz, 7 oktober 1970, GVBl, I, p. 625.

Niedersächsisches Gefahrenabwehrgesetz, Wet van 17 november 1981, Nds. GVBl, p. 347, laatstelijk gewijzigd bij Wet van 25 oktober 2001, Nds. GVBl, p. 664 .

Datenschutzgesetz Nordrhein-Westfalen, Wet van 15 maart 1988, zoals laatstelijk gewijzigd bij wet van 9 juni 2000.

Nordrhein-westfalisches Polizeigesetz van 24 februari 1990, GVNRWp. 70, zoals laatstelijk gewijzigd door het Gesetz van 9 mei 2000, GVNRW p. 452.

Niedersächsische Verfassung, Wet van 19 mei 1993, Nds. GVBl 1993, p. 107, zoals laatstelijk gewijzigd bij wet van 6 juni 1994, Nds. GVBl 1994, p. 229.

Niedersächsische Datenschutzgesetz, Wet van 17 juni 1993, zoals laatstelijk gewijzigd bij wet van 21 juni 2001.

Vereinbarung zwischen der Bundesregierung und den Landesregierungen (...) über die Zuständigkeit im Rechtshilfeverkehr mit dem Ausland in strafrechtlichen Angelegenheiten, 1 juli 1993, gepubliceerd in Grützner \& Pötz (losbladig).

Gesetz über das Ausländerzentnalregister, Wet van 2 september 1994, BGBl 1994, 2265. 
Verondnung äber die Zulassang der Datenübermittlung von der Polizei und auslandiscbe Polizeibehönden, 22 oktober 1994, GVNRW, 11 november 1994. p. 109, zoals laatstelijk gewijzigd bij verordening van 7 januari 1998, GVNRW, p. 109.

Verondnung zur Durchführung des Gesetzes aber das Auslanderzentnalregister, verordening van 17 mei 1995, BGBl 1995, nt. 695, laatstelijk gewijzigd 9 januari 2002.

Bundeskriminalamtgesetz, Gesers über das Bundeskriminalamt und die Zusammenarbeit des Bundes and der Länder in kriminalpolizeilichen Angelegenbeiten, BGBII 1997, 1650; laatstelijk gewijzigd bij artikel 2 Wet van 11 december 200113510.

Verordnung zu Anderung der Verordnung über die Zulassung der Datenübermittlung ven der Polizei an ausländische Polizeibebönden van 7 januari 1998, GVNRW, 9 februari 1998, nr. 47, p. 109; in werking getreden op 10 februari 1998.

Decreet Gem. RdErlaß d. Justizministeriums (9350-III A. 19) u. d. Innenministeriums IV A I-1431/3,0, Nondrhein-Westfalen (Düsseldorf), 10 maart 1999.

\section{D: Raad van Europa}

Europees Verdrag tot bescherming van de Rechten van de Mens en de fundamentele vrijheden, Verdrag van 4 november 1950, Tr6. 1990, 156.

Europees rechtshulpverdrag, Europees Verdrag aangaande de wederzijdse rechtshulp in strafzaken; Straatsburg, 20 april 1959, Trb. 1965, 10 met aanvullend protocol van 17 maart 1978, Trb. 1979, ETS No. 30.

Aanvullend protocol bij het ERV, 17 maart 1978 (AP-ERV); Trb. 1979, 121; ETS No. 99.

Verdrag van Wittem, Verdrag van 30 augustus 1979, Bilaterale Overeenkomst tussen het Koninkrijk der Nederlanden en de Bondarepubliek Duitsland betreffende de aanvulling en het vergemakkelijken van het ERV, Trb. 1979, 143, behorende bij het ERV voor de relatie Nederland/Bondsrepubliek Duitsland.

Verdrag tot bescherming van personen met betrekking tot de geautomatiseerde verwerking van persoonsgegevens, Straatsburg 28 januari 1981, Trb. 1988, 7.

Recommendation No. $R(87) 15$ of the Committee of Ministers to Member States regulating the use of personal data in the police sector.

Recommendation No. $R$ (95) 13 Concerning problems of criminal procedural law connected with information technology, aanvaard door het Comité van Ministers van de Raad van Europa op 11 september 1995.

\section{E: Benelux}

Benelux uitleverings- en rechtshulpverdrag, Verdrag tussen het Koninkrijk der Nederlanden, het Koninkrijk België en het Groothertogdom Luxemburg aangaande de uitlevering en de rechtshulp in strafzaken; Brussel, 27 juni 1962, Trb. 1962, 97 en Trb.

$1974,161$. 
Benelux Drugsconvenant van 21 december 1993: Convenant tussen Politie-autoriteiten van de BENELUX-staten in de grensregio MAASTRICHT betreffende de as MAASTRICHT-LUIK-LUXEMBURG.

Memorandum van overeenstemming inzake de samenwerking op het terrein van politie, justitie en immigratie tussen de ministers van Justitie van België, Nederland en Luxemburg, de ministers van Binnenlandse Zaken van België en Nederland en de minister van de Force Publique van Luxemburg, 4 juni 1996.

\section{F: Schengen}

Uitvoeringsovereenkomst Schengen, Overeenkomst ter uitvoering van het op 14 juni 1985 te Schengen gesloten Akkoord betreffende de geleidelijke afschaffing van de controles aan de gemeenschappelijke grenzen; Schengen, 19 juni 1990, Trb. 1990, 145 .

\section{G: Europese Unie}

Europese Asielzoekersovereenkomst, Overeenkomst van 15 juni 1990, neergelegd in artikel 15 van de Convention Determining the State Responsibility for Examining Applications Lodged in One of the Member States of the European Communities, ondertekend te Dublin op 15 juni 1990.

Verdrag betreffende de Europese Unie, Trb. 1992, 74; in Trb. 1998, 12 is de geconsolideerde versie van het verdrag opgenomen, na doorvoering van de wijzigingen uit het Verdrag van Amsterdam en in PbEG 2002/C 325/5, 24 december 2002 de geconsolideerde versie na doorvoering van de wijzigingen uit het Verdrag van Nice.

Richtlijn van de Europese Unie van 24 oktober 1995 betreffende de bescherming van natuurlijke personen in verband met de verwerking van persoonsgegevens en betreffende het vrije verkeer van die gegevens, PbEG L 281, 23 november 1995.

Europol-Overeenkomst, Overeenkomst tot oprichting van een Europese Politiedienst, Trb. 1995, 282; PbEG 1995/C316, 2, 27 november 1995.

Richtlijn 97/66/EG (oud) van het Europese Parlement en de Raad van 15 december 1997 betreffende de verwerking van persoonsgegevens en de bescherming van de persoonlijke levenssfeer in de telecommunicatiesector, PbEG L. 24, 30 januari 1998.

Weense Acrieplan van de Raad en Commissie over hoe de bepalingen van het Verdrag van Amsterdam inzake de totstandbrenging van een ruimte van vrijheid, veiligheid en rechtvaardigheid het best kunnen worden uitgevoerd, PbEG C $19 / 1$ van 23 januari 1999.

Besluit 99/C 26/06 van de Raad, PbEG C 26 van 30 januari 1999.

Besluit van de Raad van 29 april 1999, PbEG 1999/C149, 16, 28 mei 1999.

Besluit 1999/437/EG van de Raad van 17 mei 1999 inzake bepaalde toepassingsbepalingen van de door de Raad van de Europese Unie, de Republiek IJsland en het Koninkrijk Noorwegen gesloten Overeenkomst inzake de wijze waarop deze twee staten wor- 
den betrokken bij de uitvoering, de toepassing en de ontwikkeling van her Schengenacquis, PbEG L 176/31 van 10 juli 1999.

Besluit van de Raad van 20 mei 1999 tot vaststelling in overeenstemming met de desbetreffende bepalingen van het Verdrag tot oprichting van de Europese Gemeenschap en het Verdrag betreffende de Europese Unie, van de rechtsgrondslag van elk van de bepalingen of besluiten die het Schengen-acquis vormen 1999/346/EG, PbEG 1999/ L176/17, 10 juli 1999.

Besluit 1999/435/EG van de Raad van 20 mei 1999, PbEG L 176/1 van 10 juli 1999. Besluit 1999/436/EG van de Raad van 20 mei 1999, PbEG L 176/17 van 10 juli 1999. PbEG 1999/C229/14, 12 augustus 1999 met betrekking tot een rectificatic van artikel 2 EO.

Conclusies van de Europese Raad van 15 en 16 oktober 1999 in Tampere (Finland), Presidency Conclusions, Secretariaat-Generaal van de Europese Commissic, Brussel, 16 oktober 1999, kenmerk SI (1999) 800, SN 200/99.

Besluit van de Raad van 29 mei 2000 betreffende het verzock van het Verenigd Koninkrijk van Groot-Britannič en Noord-Ierland deel te mogen nemen aan enkele van de bepalingen van het Schengen-acquis (2000/365/EG), PbEG L 131/43 van I juni 2000.

Akte van de Raad van 29 mei 2000 tot vaststelling, overeenkomstig artikel 34 van het Verdrag betreffende de Europese Unie, van de Overeenkomst betreffende de wederzijdse rechtshulp in strafzaken tussen de lidstaten van de Europese Unie, PbEG 2000/ C197/1, 12 juli 2000.

EU-Overeenkomst betreffende de wederzijdse rechtshulp in strafzaken tussen de lidstaten van de Europese Unie, Trb. 2000, 96.

Protocol tot opneming van het Schengen-acquis in het kader van de Europese Unie, genoemd onder II.B.2 van de Slotakte van het Verdrag van Amsterdam. PbEG L 239, 22 september 2000 bevat het gehele Schengen-acquis.

Besluit van de Raad tot oprichting van een secretariaat ten behoeve van de gemeenschappelijke controleorganen voor gegevensbescherming, 2000/641/JBZ - PbEG L 271 van 24 september 2000.

Akte waarbij op basis van artikel 43 lid $1 \mathrm{EO}$, een protocol wordt opgesteld tot wijziging van artikel 2 en de bijlage bij de overeenkomst, PbEG 2001/C358, 13 december 2001.

Verordening (EG) nr. 2424/2001 betreffende de ontwikkeling van het SIS van de tweede generatie gebaseerd op artikel 66 van het Verdrag tot oprichting van de Europese Gemeenschap.

Kaderbesluit van de Raad van 26 juni 2001 inzake het witwassen van geld, de identificatie, opsporing, bevriezing, inbeslagneming en confiscatie van hulpmiddelen en van opbrengsten van misdrijven (2001/500/JBZ), PbEG 2001, L182, 5 juli 2001. 
Besluit 2001/886/JBZ van de Raad betreffende de ontwikkeling van het SIS van de tweede generatie gebaseerd op de artikelen 30, 31 en 34 van het Verdrag betreffende de Europese Unie.

Besluit van de Raad van 28 februari 2002 betreffende het verzoek van Ierland deel te mogen nemen aan bepalingen van het Schengen-acquis (2002/192/EG), PbEG L 164/20 van 7 maart 2002.

Richtlijn 2002/58/EG van het Europees Parlement en de Raad van 12 juli 2002 betreffende de verwerking van persoonsgegevens en de bescherming van de persoonlijke levenssfeer in de sector elektronische communicatie, PbEG L 201/37 van 31 juli 2002.

Europol-begroting 2003, PbEG 2002/C179, 1, 27 juli 2002 en PbEG 2003/C152, 16. 28 juni 2003 voor de gewijzigde begroting.

Voorstel voor een kaderbesluit van de Raad betreffende het Europees bewijsverkrijgingsbevel ter verkrijging van voorwerpen, documenten en gegevens voor gebruik in strafprocedures, COM/2003/0688 def. - CNS 2003/0270, 14 november 2003.

\section{H: OESO}

OECD-Guidelines Governing the Protection of Privacy and Transborder Data Flows of Personal Data van 23 september 1980.

\section{I: Convenanten en Akkoorden}

Overeenkomst tussen de Minister van Binnenlandse Zaken en de Minister van Justitie van Nederland en het Bondsministerie van Binnenlandse Zaken van de Bondsrepubliek Duitsland inzake politiële samenwerking in het grensgebied tussen Nederland en de Bondsrepubliek Duitsland, Den Haag, 17 april 1996.

Abkommen zwischen der Regierung der Bundesrepublik Deutschland und der Regierung des Königsreichs. Belgien über die Zusammenarbeit der Polizeibehörden und Zollverwaltungen in den Grenzgebieten, Brussel, 27 maart 2000.

Convenant ten behoeve van de verstrekking van informatic uit een politieregister, convenant tussen de korpsbeheerders van de politieregio's Zeeland, Midden- en WestBrabant, Brabant Zuid-Oost, Limburg-Noord en Limburg-Zuid en de Beheerders van de OIPG's te Gent, Antwerpen, Turnhout, Genk en Eupen, met bijbehorende werkinstructic, Gent, 24 oktober 2000.

Convenant ten behoeve van de verstrekking van informatie uit een politieregister, convenant tussen de korpsbeheerders van de politieregio's Limburg-Noord en LimburgZuid en de beheerders van de Verbindungsstellen Aachen en Mönchen-Gladbach, januari 2001. 


\section{Curriculum Vitae}

Joop Verbeek werd geboren in Nuenen, Gerwen en Nederwetten op 12 december 1969. Hij genoot zijn voorbereidend wetenschappelijke opleiding aan het St.-Hubertuscollege te Neerpelt (België) van 1982 tot 1988, met als hoofdvakken Klassieke Talen Latijn en Grieks en Wiskunde. In 1984 studeerde hij na een vijfjarige opleiding af in Notenleer, in de graad van uitmuntendheid, aan de Noord-Limburgse Muziekacademie te Overpelt en Neerpelt. Hij studeerde met genoegen Nederlands Recht (propedeuse en doctoraal), strafrechtelijke afstudeerrichting, aan de Katholieke Universiteit Brabant te Tilburg van 1988 tot 1994. In 1993 studeerde Verbeek af als kleinkunstenaar/klassick organist aan de Noord-Limburgse Muziekacademie te Overpelt en Neerpelt, na een tienjarige opleiding.

In 1995 was Verbeek als onderzoeker werkzaam bij de afdeling Computercriminaliteit van de divisie Centrale Recherche Informatiedienst van het Korps Landelijke Politiediensten. Van 1996 tot 1997 was hij als onderzoeker werkzaam bij de Faculteit der Rechtsgeleerdheid, Instituut voor Informatica en Recht van de Vrije Universiteit Amsterdam. Van 1997 tot 1999 werkte Verbeek als onderzocker bij de Faculteit der Rechtsgeleerdheid, Afdeling Recht \& Informatica van de Universiteit Leiden, met een korte tussentijdse aanstelling in 1998 als onderzoeker bij de Faculteit der Algemene Wetenschappen, capaciteitsgroep Informatica van de Universiteit Maastricht. Daar is hij sinds 1999 tot op heden als onderzoeker/hoofd van de Public Services Group bij het Instituut voor Kennis en Agent Technologie (IKAT) werkzaam.

Verbeek's hobby's zijn badminton (sinds 1988), het volgen van de ontwikkelingen in de ICT en het beluisteren en beoefenen van muziek. 
